\title{
O Ensino da Arquitetura e a Construção da Modernidade
}

Trabalho apresentado à Faculdade de Arquitetura e Urbanismo da Universidade de São Paulo para a obtenção

do título de Doutor em Arquitetura e Urbanismo

Área de Concentração: Projeto de Arquitetura

Orientadora: Prof. ${ }^{a}$ Dr. ${ }^{a}$ Marlene Yurgel 
Autorizo a reprodução e divulgação total ou parcial deste trabalho, por qualquer meio convencional ou eletrônico, para fins de estudo e pesquisa, desde que citada a fonte.

e-mail: vera@vdarquitetura.com.br

Domschke, Vera Lúcia

D673e O ensino da arquitetura e a construção da modernidade / Vera Lúcia Domschke. --São Paulo, 2007.

324 p.: il.

Tese (Doutorado - Área de Concentração: Projeto de Arquitetura) - FAUUSP.

Orientadora: Marlene Yurgel

1. Projeto de arquitetura (Estudo e ensino) 2. Arquitetura (Estudo e ensino) 3. Faculdade (Arquitetura) I. Título 


\section{Resumo}

O trabalho expõe e busca discutir experiências de ensino de projeto de arquitetura, tendo sido motivado pela minha vivência na Faculdade de Arquitetura e Urbanismo da Unisantos, como colaboradora na disciplina de Projeto Arquitetônico. Aborda inicialmente, de forma ampla, as condições do ensino da arquitetura e a conjunção entre essa situação e a construção do ofício de arquiteto até o século XX. Foi eleito como motivo de interpretação a instituição do ensino na França e os desdobramentos da industrialização e da instituição de métodos científicos elaborados ao longo do século XIX. A partir de então, esses métodos científicos instruíram o pensamento e a construção do conhecimento, superando as situações anteriores voltadas para a composição da obra arquitetônica no que dizia respeito à sua criação. Como a então moderna tecnologia industrial informa, as abordagens apoiadas no pensamento que buscava critérios e razões da produção industrial, seus princípios e seus produtos finais convergem na formação de duas escolas seminais - o Vkhutemas e a Bauhaus - para o ensino do projeto de arquitetura ao longo do século XX: na União Soviética, após a Revolução Bolchevique de 1917, e na Alemanha, durante o curto período da República de Weimar.

A institucionalização do ensino da engenharia em São Paulo deu-se em 1894 com a fundação da Escola Politécnica da Universidade de São Paulo, procedendo-se, então, à instituição do ensino de arquitetura no Brasil, gênese das faculdades de Arquitetura e Urbanismo em São Paulo, a partir de 1947/1948.

É relatado também o processo de integração horizontal introduzido nos primeiros anos da Faculdade de Arquitetura e Urbanismo da Universidade de São Paulo e da Unisantos, durante o período compreendido entre os anos de 2001 e 2006, e o estúdio vertical da Escola da Cidade. 


\section{Abstract}

This work puts forward teaching experiences in architectural design motivated by my practice in FAU of Unisantos as a collaborator in the subject Architecture Design. Initially, we discuss broadly the teaching conditions in Architecture and the connection between this situation and the construction of the profession of Architect up to the XX century. The learning institution in France was elected as a interpretation motive, as well as the evolution of industrialization and adoption of scientific methods during the XIX century. From then onwards, scientific methods commanded thought and building up of knowledge surmounting the previous situation focused on the composition of an architectonic work. As the modern technology informs the approaches supported by a reasoning which sought criteria and reasons of industrial production, its principals and final products converge to the formation of two seminal schools - Vkhutemas and Bauhaus - for the training in architectonic design during the XX century in the Soviet Union after the Bolshevik Revolution in 1917, and in Germany during the short period of Weimar Republic.

Institutional schooling in Engineering was instituted in 1894 with the foundation of Escola Politécnica in the University of São Paulo when the training in Architecture was instituted in Brazil, being the birthplace of the Architecture and Urbanism Colleges in São Paulo in 1947/48.

The process of horizontal integration during the first years in the Architecture and Urbanism College - University of São Paulo, Unisantos during the period 2001-2006 and the Vertical Studio in Escola da Cidade are described. 


\section{Agradecimentos}

À minha querida orientadora Prof. ${ }^{a}$ Dr. ${ }^{a}$ Marlene Yurgel, pela compreensão, apoio e estímulo que recebi durante esta fase de minha vida profissional.

Ao diretor da FAUUSP Prof. Dr. Sylvio de Barros Sawaya, pela gentileza com que sempre me atendeu na FAUUSP.

Ao amigo Júlio Camargo Artigas, sempre disposto a atender com benevolência aos meus chamados de socorro!!!

Ao amigo Antônio Cláudio Pinto da Fonseca,

que gentilmente cooperou comigo na realização deste trabalho.

Ao amigo Paulo Fernando von Poser,

pela amizade e fotos gentilmente cedidas.

Ao amigo Edgar Gonçalves Dente,

que nunca se negou a me auxiliar na elucidação de minhas dúvidas surgidas durante este processo.

Ao amigo Francisco Lúcio Mário Petracco,

de quem recebi atenção e carinho durante a realização de meu trabalho.

Ao amigo Renato Carrieri,

meu colega de doutorado e sempre um companheiro muito atento.

Ao colega Francisco Spadoni, pela feliz indicação da revisora.

À Biblioteca da FAUUSP,

na pessoa de Eliana de Azevedo Marques, pela demonstração de amizade.

À Universidade Católica de Santos,

pela Bolsa de Capacitação de Docentes que recebi para elaborar este trabalho durante o período de meu vínculo com essa escola.

À Neusa Caccese de Mattos, pela presteza na revisão desta tese.

À Adriana Caccese de Mattos, pela editoração deste trabalho. 
Aos meus queridos Mário, Carolina e Francisco, por terem me poupado tanto, sem, contudo, terem tido nada em troca. 
Ao inesquecível professor João Batista Vilanova Artigas. 


\section{Sumário}

$2.1 \quad$ A revolução industrial e a ciência . . . . . . . . . . . . 26

2.2 A necessidade de mudança no ensino da arquitetura . . . . 33

2.3 O ensino da arquitetura no Vkhutemas e na Bauhaus . . . . 49

3 O ensino da arquitetura no Brasil

3.1 A origem do ensino da arquitetura no Brasil . . . . . . . . 60

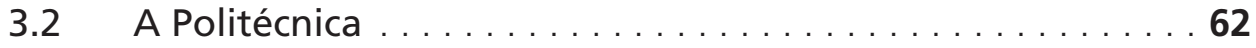

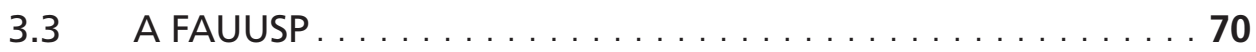

4 Experiências de ensino de projeto

4.1 FAUUSP: a AUP 608 - Fundamentos de Projeto . . . . . . . . 74

4.2 FAUS - Universidade Católica de Santos: a integração horizontal no primeiro ano . . . . . . . . . . 128

$4.3 \quad$ Escola da Cidade: o estúdio vertical . . . . . . . . . . 208

5 Conclusão . . . . . . . . . . . . . . . . . . . . . 246

$6 \quad$ Bibliografia . . . . . . . . . . . . . . . . . . . 250

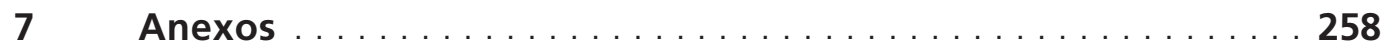

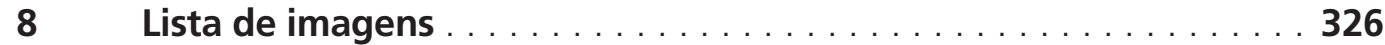


O projeto desta monografia nasceu de minha experiência docente, a partir da coleta de dados e informações sobre processos pedagógicos na área do ensino da arquitetura. Esse material foi selecionado na época em que fui aluna da Faculdade de Arquitetura e Urbanismo da Universidade de São Paulo - FAUUSP, em 1977, participando da integração horizontal no primeiro ano e do acompanhamento de atividades de ensino durante o ano de 2004 . Valime, também, do trabalho realizado, por dezesseis anos, para as disciplinas do primeiro ano da Faculdade de Arquitetura e Urbanismo da Unisantos e da experiência docente adquirida no curso de Arquitetura e Urbanismo da Universidade Anhembi Morumbi, durante dez anos, na FAU Braz Cubas, em Moji das Cruzes, por três anos, e, atualmente, na Escola da Cidade e FAU Mackenzie.

Foi na Faculdade de Arquitetura e Urbanismo da Unisantos que coordenei as atividades de ensino de projeto, visando realizar a integração horizontal entre as disciplinas do primeiro ano.

Para descrever as experiências realizadas em relação ao ensino de projeto, escolhi a Unisantos, onde trabalhei por dezesseis anos, a FAUUSP, onde fui aluna por cinco anos e trabalhei como monitora do Programa de Aperfeiçoamento de Ensino - PAE, e a Escola da Cidade (Associação de Ensino de Arquitetura e Urbanismo de São Paulo), onde trabalho como professora de projeto do primeiro e do quinto ano.

Minha formação na FAUUSP, escola que gerou o modelo essencial de ensino de forma significativa nas escolas de arquitetura do Estado de São Paulo, permitiu uma referência direta dos modelos adotados nas escolas que são objeto deste estudo, inclusive das modificações e interpretações diversas que 
cada uma delas foi aos poucos inserindo em sua estrutura de ensino.

A linha mestra deste trabalho foi o desenho, entendido como uma forma de pensar, ou seja, o desenho no sentido mais amplo, como forma de conduzir um raciocínio, como forma de expressão de uma idéia; portanto, o desenho mais do que um instrumento auxiliar da arquitetura: uma descoberta que revela uma idéia. Nesse sentido, o desenho como design e não como drawing e, como explicava o professor Flávio Motta, ${ }^{1}$ o desenho com intenção, como projeto.

Nessa experiência acadêmica de mais de uma década, pude perceber os vários caminhos possíveis para o desenho como forma de pensar, como estruturador do projeto enquanto elemento que persegue um desejo e um desígnio. Essa forma de pensar parte de uma reflexão teórica que busca em Vitruvius e Alberti as insinuações originais do desenho moderno, passando pela escola novecentista de procura das grandes composições, até desaguar na arquitetura do século $X X$, que terá na indústria e na produção em série baseada na tecnologia a sua conseqüência mais profunda.

As escolas de arquitetura do Estado de São Paulo buscaram, desde sua origem, a montagem de estruturas de ensino baseado nos diversos departamentos, que pudessem, desde sempre, produzir o espaço voltado para a grande cidade e para os grandes temas de um país industrializado e moderno.

O espírito de uma faculdade de arquitetura que é originária da Escola Politécnica de Engenharia, como a FAUUSP, tem um viés diferenciado daquelas originadas das escolas de belas-artes, sediadas no Rio de Janeiro principalmente. Esse caráter está ligado às técnicas e às artes, ao projeto e ao canteiro, utilizando o desenho como manifestação artística em si, mas também como instrumento de 
pesquisa do próprio espaço desejado. As referências para esse estudo baseiam-se nos trajetos que as escolas adotaram, ao longo dos últimos trinta anos, para consecução de seus respectivos projetos. Cada escola, à sua maneira, configurou suas diferenças a partir de suas especificidades e referências culturais e regionais.

Esta apresentação aborda estratégias de ensino de projeto adotadas pelas escolas de arquitetura e urbanismo do Estado de São Paulo nos últimos trinta anos, os vários momentos do pensar o ensino nesse período, as principais correntes de doutrina e os resultados concretos obtidos nas três décadas. Os trabaIhos das disciplinas de Projeto Arquitetônico oriundos de cada uma dessas escolas apoiou a pesquisa de maneira complementar, mesmo que de forma essencial.

Sendo o objeto deste trabalho o ensino da arquitetura explorado através da relação entre as várias formas de pensar o ensino de projeto e a qualidade do espaço produzido, buscou ele explicitar como a adoção de um enfoque mais voltado para a edificação e o lote em suas variadas formas foi aos poucos sendo substituída por um enfoque mais ligado ao ambiente construído e à cidade. Procuramos qualificar, sempre, o edifício como agregador ou desagregador do espaço da cidade, permitindo estabelecer diferenças entre o desejável como espaço do morar e o ambiente edificado realizado de forma genérica na cidade.

Enfatizamos o período delimitado entre o final dos anos de 1960, quando as conseqüências do golpe militar de 1964 e as mudanças do projeto econômico para o Brasil se alteram drasticamente, surgindo como conseqüência um projeto de ensino de terceiro grau baseado na universidade privada. Em fins da década de 1960 tínhamos no Estado de São Paulo duas escolas de arquitetura: a Faculdade de Arquitetura e Urbanismo da Universidade de São Paulo e a Faculdade de Arquitetura da Universidade Mackenzie. No meio da década seguinte já haviam aparecido as duas escolas de arquitetura de Moji 
das Cruzes e as escolas católicas de Santos e de Campinas. Hoje as escolas de arquitetura são mais de setenta em todo o território do Estado de São Paulo. Nesse período também acontece o processo final da privatização da estrutura majoritária do ensino superior. As crises por que passaram as universidades públicas, na época, decorrentes do golpe militar, contrastam com a proliferação das escolas privadas.

Ao analisar o modelo genérico utilizado por parte significativa dos segmentos que compõem o universo do ensino de arquitetura e urbanismo no Estado de São Paulo (entendendo como modelo tudo aquilo que, por um motivo específico, se generalizou e passou a ser adotado como paradigma), discutimos algumas técnicas pedagógicas específicas, que configuram tentativas que visam reintegrar, dentro dos limites possíveis, as questões que envolvem as disciplinas de projeto, revendo, especialmente, a fragmentação do ensino nas diversas especialidades. Essa releitura se deve à compreensão de que a fragmentação do conhecimento durante o período de aprendizagem dificulta a prática profissional.

Tal estudo ressalta a importância de ampliar o âmbito da reflexão sobre o ensino da arquitetura e urbanismo no Estado de São Paulo, rompendo a relação de distanciamento entre as escolas de arquitetura e as cidades onde estão inseridas. A dicotomia entre o ambiente construído em nossas cidades e as próprias propostas e programas urbanos formulados e implantados apresenta, na maior parte das vezes, um descomprometimento com as formulações e projetos desenvolvidos em nossas escolas.

Ao procurar entender os diversos planos teóricos desenvolvidos nas escolas e as condicionantes marcantes das escolhas e possibilidades de desenvolvimento prático que conduziram essas escolas, percebemos, em alguns casos, procedimentos e práticas muito distantes das formulações originais. 
Antecedentes históricos. Ressaltamos a importância dos trabalhos de Marcus Vitruvius Pollio, que viveu no século I a.C., compilados em dez livros, que tratam de temas que englobam da formação do arquiteto aos processos de construção, estudando desde hidrologia e hidráulica até engenharia mecânica. Em 1450 Leon Battista Alberti, em seu tratado De re aedificatoria, ressalta a importância do projeto e a diversidade tipológica do edifício segundo sua função. No final do século XVIII, com Jean-Nicolas-Louis Durand, professor da Escola Politécnica de Paris, o ensino da arquitetura tomou nova direção, com a criação de uma metodologia projetual, através do desenho da geometria descritiva, antecipando vários ideais do movimento moderno. A moderna tecnologia industrial converge na formação de duas escolas seminais para o ensino do projeto de arquitetura ao longo do século $X X$, na União Soviética e na Alemanha, com as escolas Vkhutemas e a Bauhaus.

Ensino da arquitetura no Brasil. O estudo da engenharia em São Paulo foi efetivado em 1894 com a fundação da Escola Politécnica da Universidade de São Paulo, que incluía o ensino da arquitetura no Brasil, gênese das faculdades de arquitetura e urbanismo a partir de 1947-1948 em São Paulo.

Experiências de ensino de projeto. Discutimos algumas técnicas pedagógicas específicas que visam reintegrar as questões que envolvem as disciplinas de projeto, revendo especialmente a fragmentação do ensino nas diversas especialidades. 


\section{$2 \quad$ Antecedentes históricos}

Marcus Vitruvius Pollio foi um escritor romano que viveu no século I a.C. e deixou como legado uma obra, em dez volumes, à qual deu o nome de De Architectura. Constitui o único tratado clássico europeu do período greco-romano sobre o tema que chegou aos nossos dias e, na época do Renascimento, serviu como fundamento das construções, influenciando a arquitetura realizada no período.

Logo no pri-

meiro volume, o

autor vê no ar-

quiteto uma pes-

soa que detém

conhecimentos

sobre as mais di-

versas ciências e

artes, como a geo-

metria, a história,

a matemática, a

música, a medici-

na; até mesmo a

astronomia deve-

ria ser conhecida
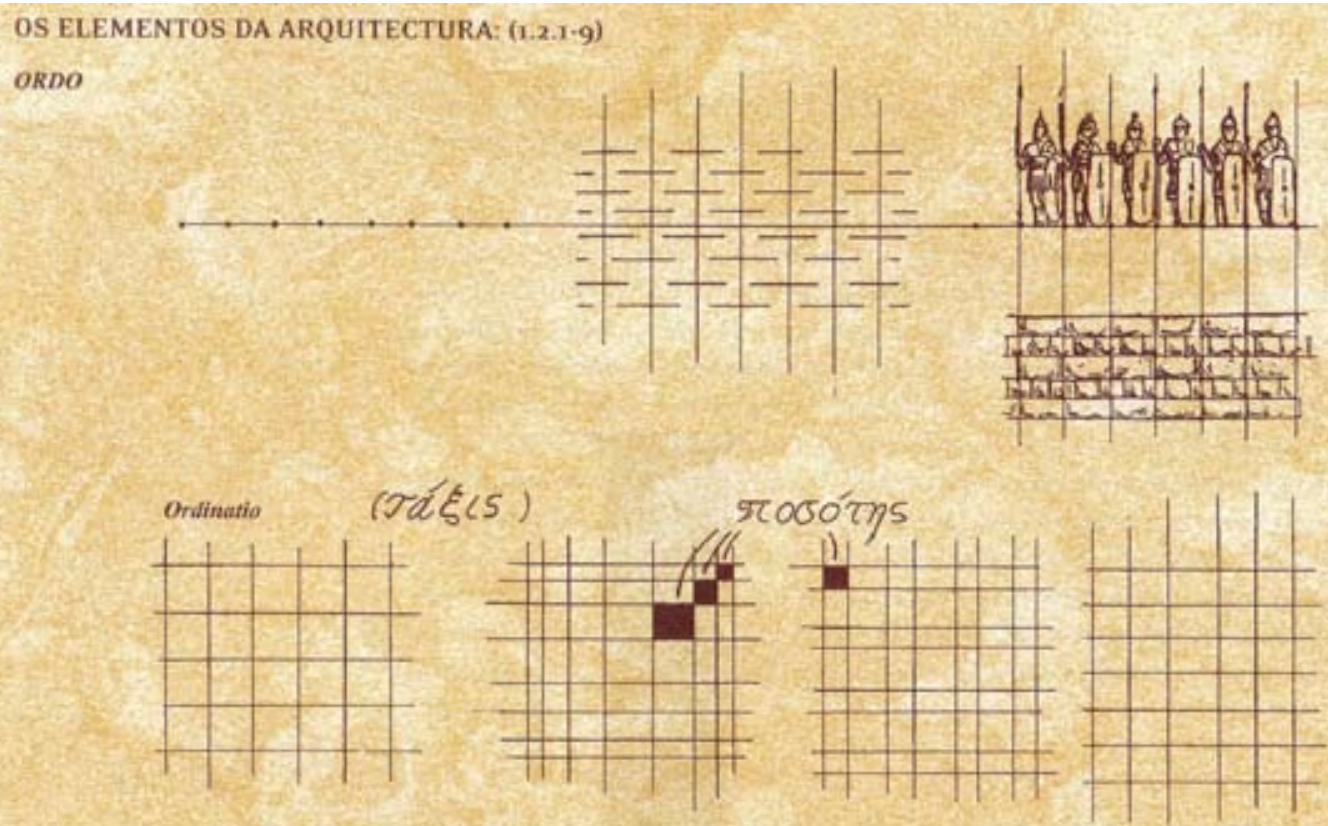

DISPosirio (sLáOGOLS)

Jchnographia

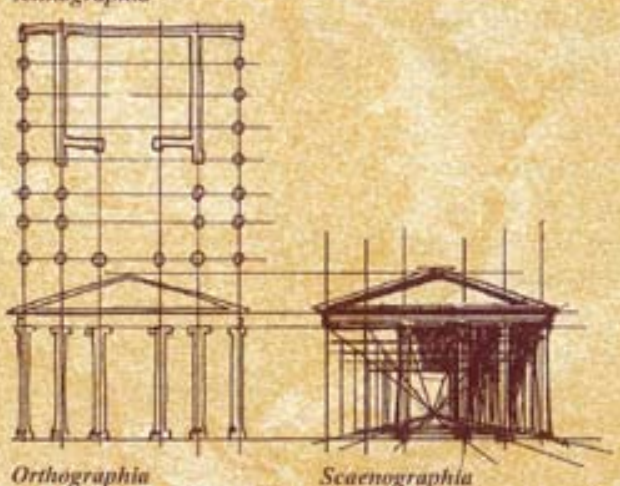

Membra

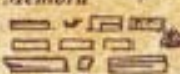
$\mathrm{Da}^{2} \mathrm{E}$

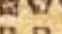

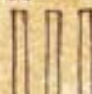

토르를

包皇

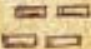

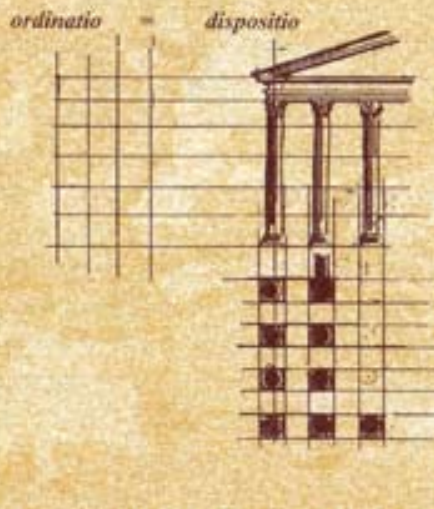

pelo arquiteto que, ao contrário do que ocorre em outras profissões, não

deveria se especializar em um único tema, mas sim abranger as diversas 
No segundo volume, Vitruvius refere-se aos materiais utilizados na construção de edifícios. Lista os tipos de materiais comumente usados na época, relacionando-os com sua ocorrência na natureza e com o nível de conhecimento científico do homem.

O terceiro e o quarto volumes

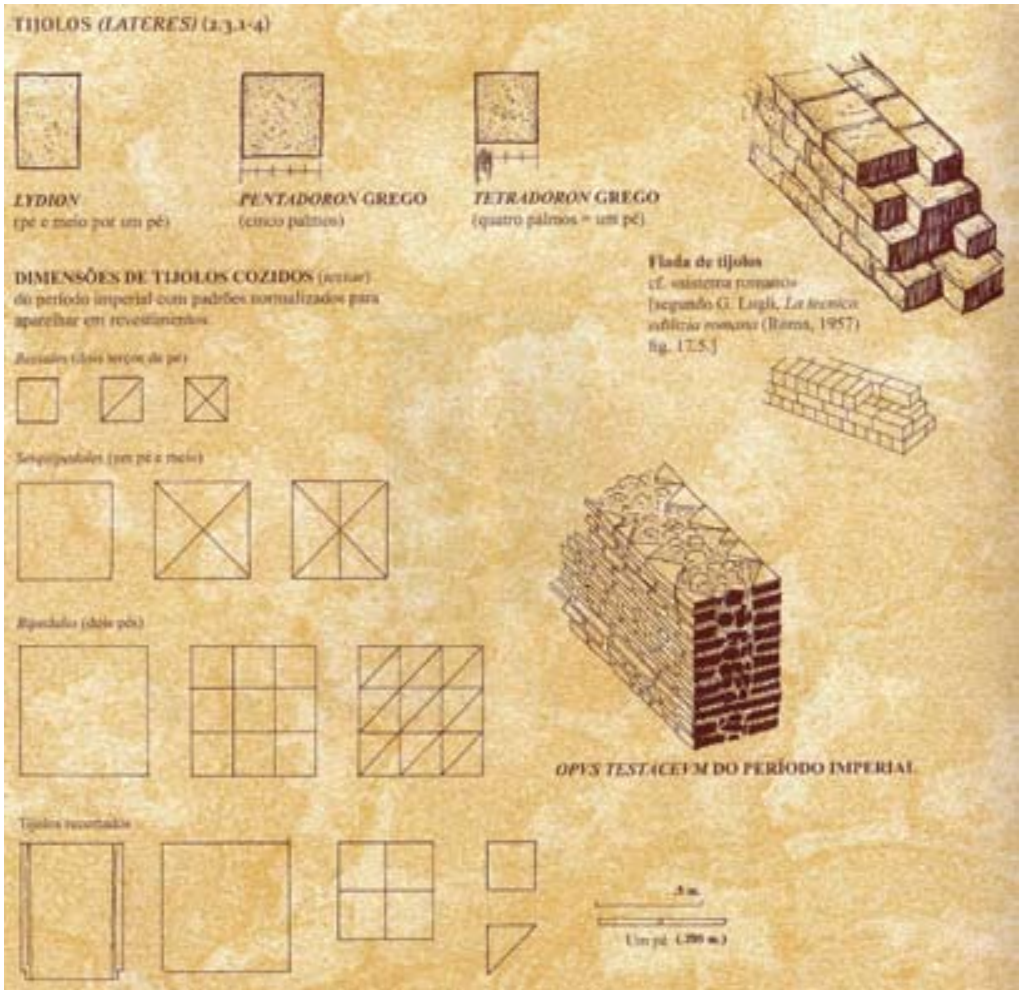
neles Vitruvius ressalta a importância da simetria tanto na arquitetura quanto no próprio ser humano.
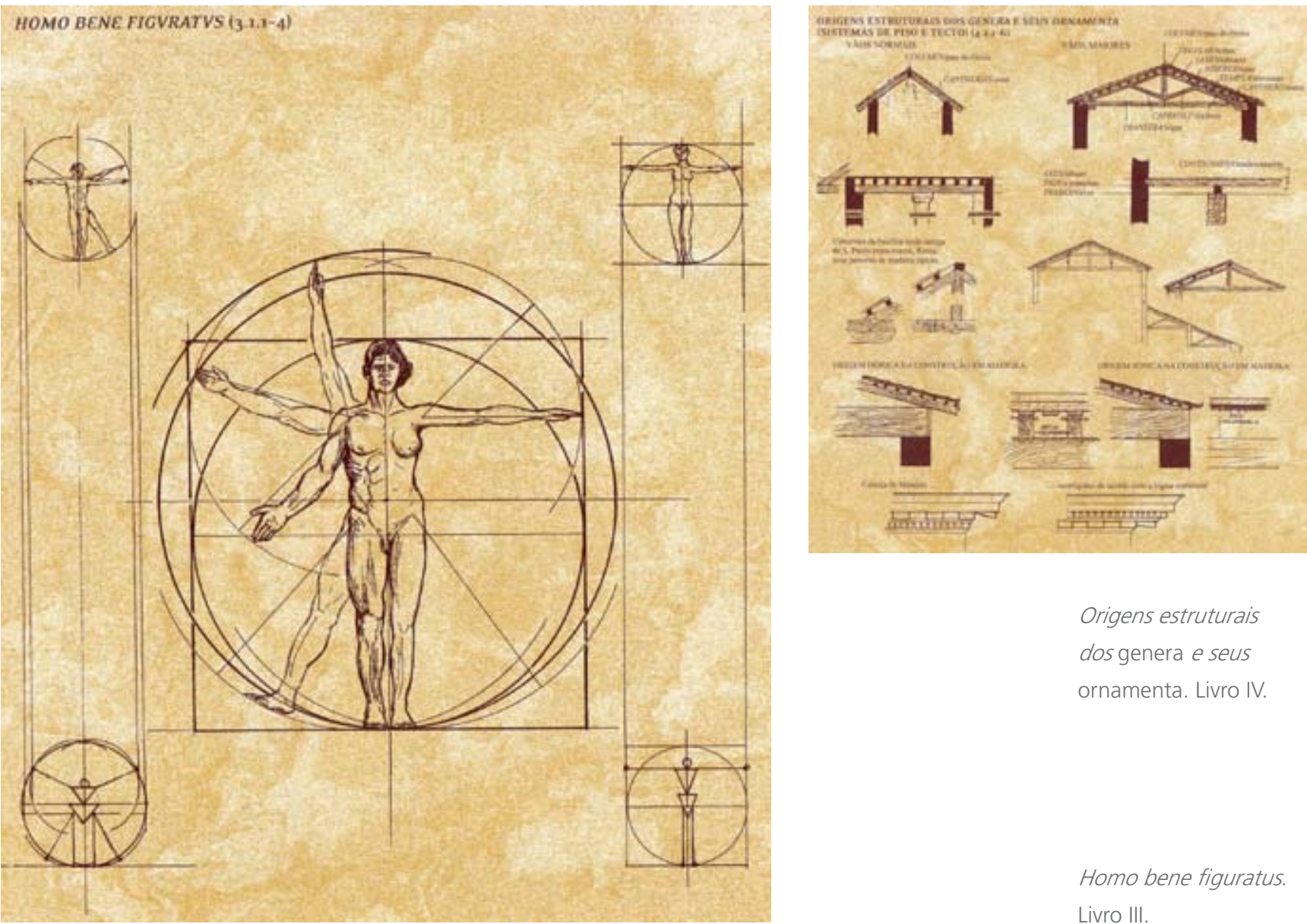

Origens estruturais dos genera e seus ornamenta. Livro IV.

No volume quinto, Vitruvius escreve a respeito dos diferentes tipos de prédios públicos: fóruns, basílicas, teatros, portos, quebra-mares e estaleiros. 


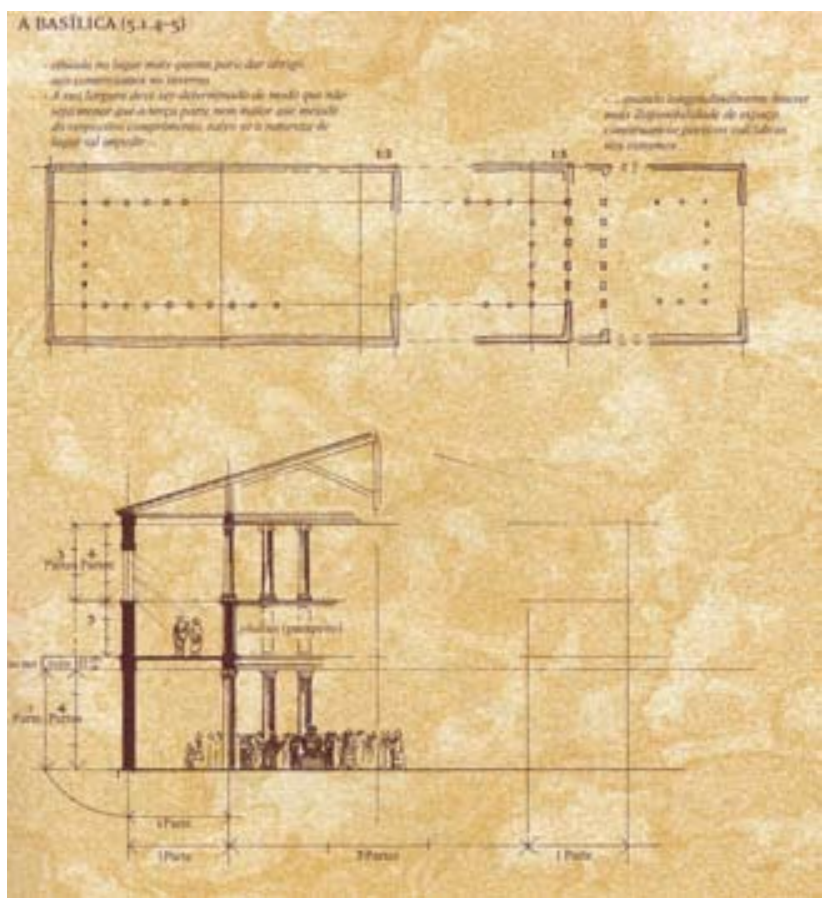

No volume sexto apresenta os edifícios privados, casas urbanas e rurais, focando, mais uma vez, as peculiaridades das construções gregas e romanas.

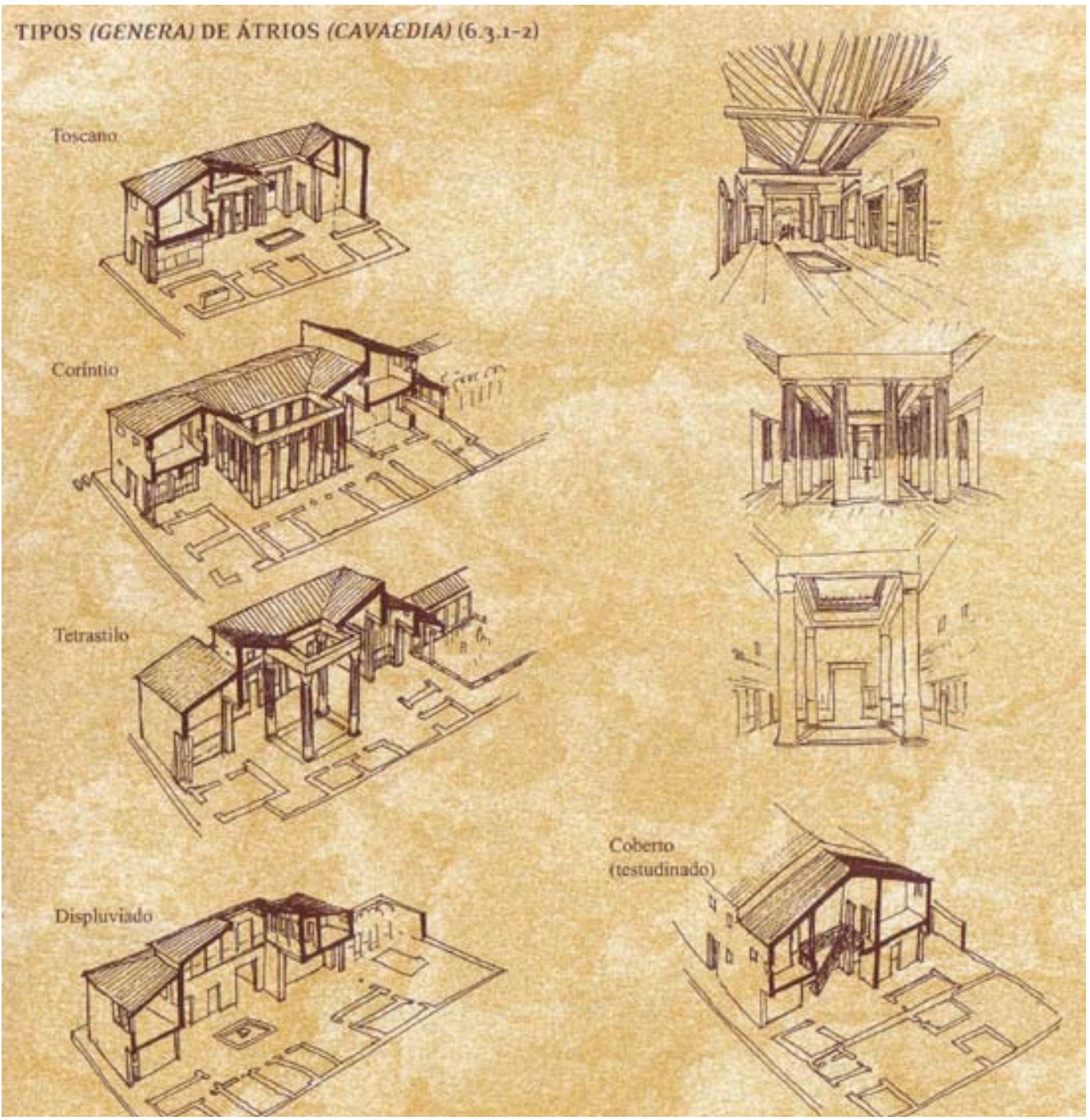




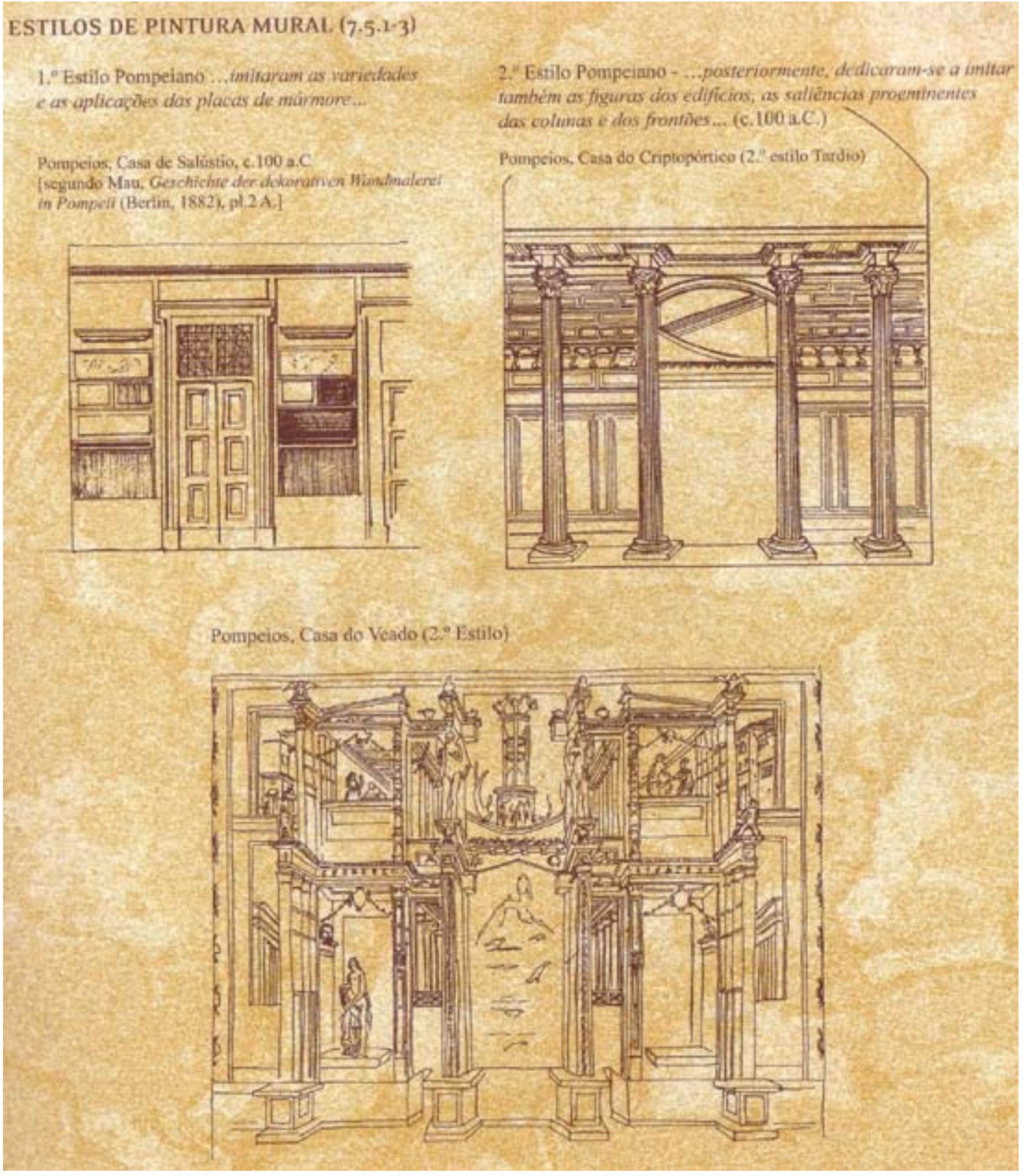

Estilos de pintura mural. Livro VII.

Nivelamento com a ajuda do coróbata. Livro VIII.

O volume sétimo é sobre a decoração interior das casas. No volume seguinte, o autor retoma os estudos sobre os processos de construção, estudando hidrologia e hidráulica, como relógios d'água, meios de se encontrar água, cisternas, etc.

O nono volume trata de assuntos ligados às fases da lua, o percurso do sol pelos doze signos, relógios de sol, constelações, etc.; no décimo volume, entre outros ensinamentos, descreve a engenharia mecânica.

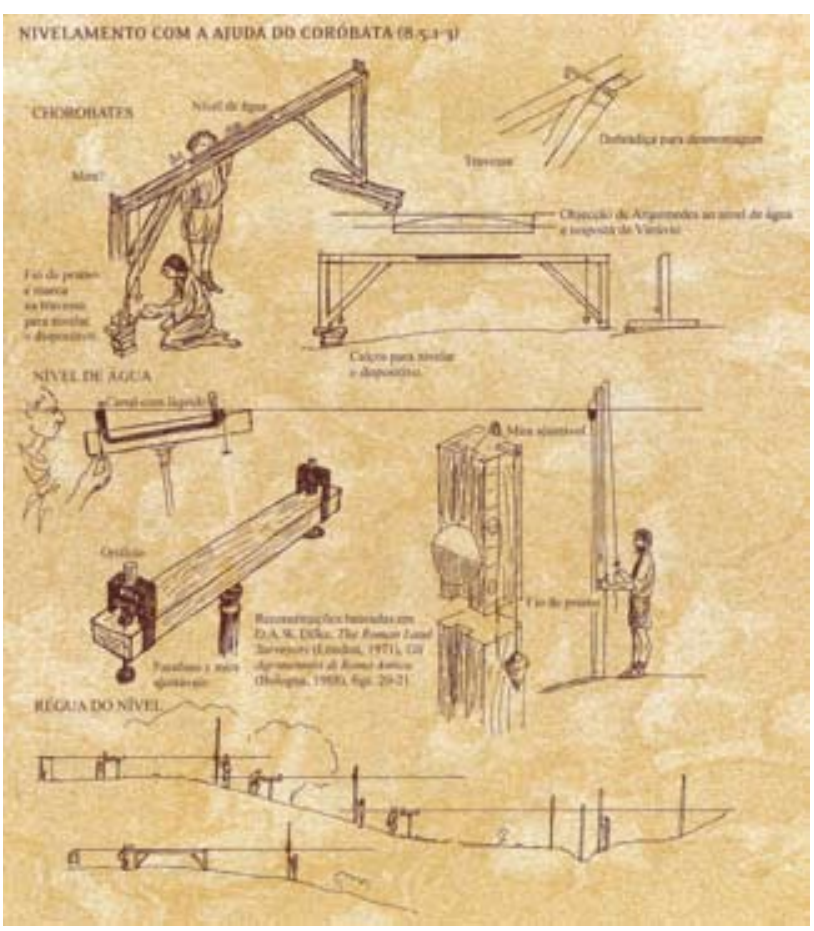



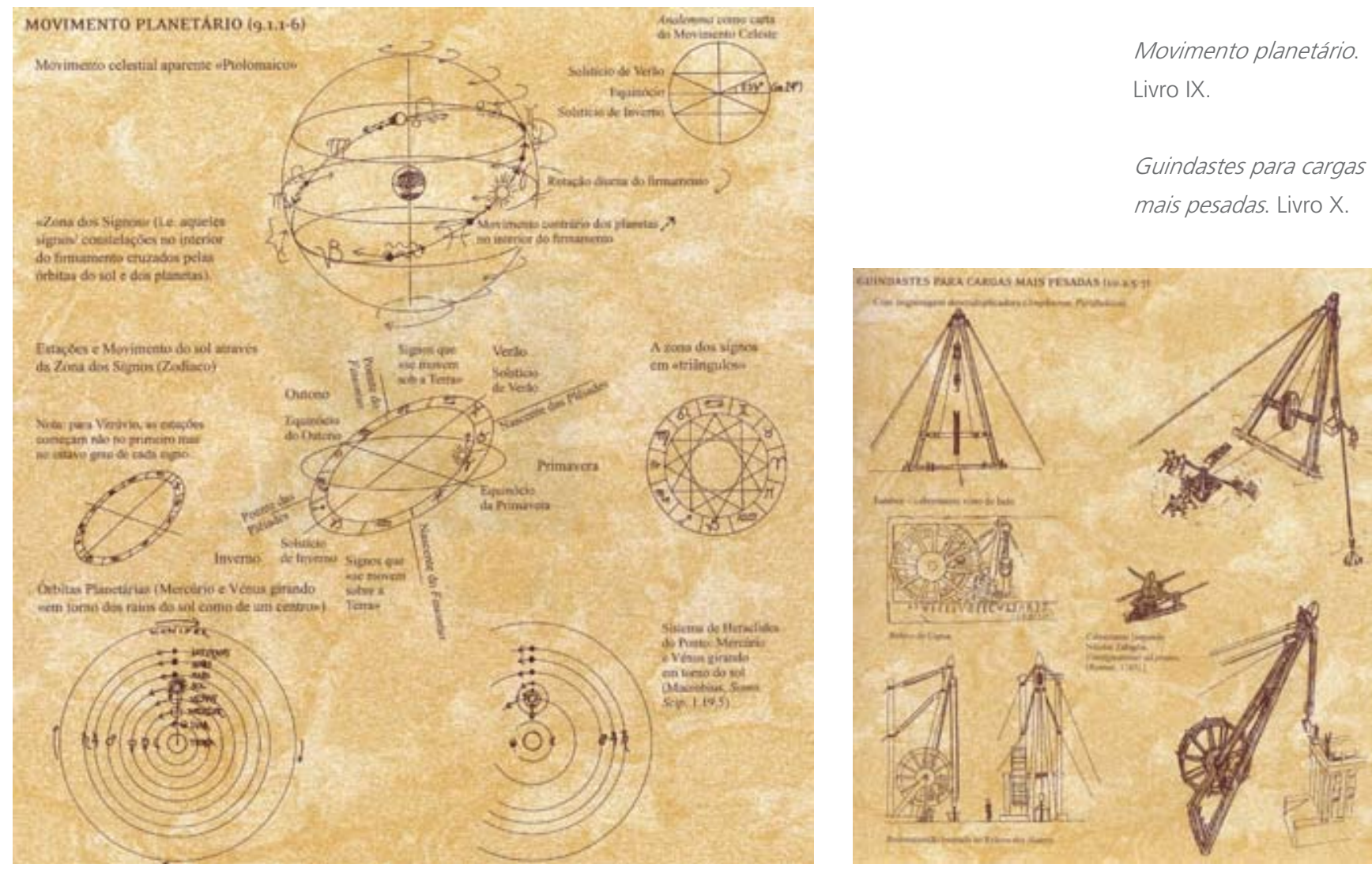

O livro de Vitruvius estabelece com clareza a questão essencial da formação do arquiteto. A idéia de um profissional generalista, capaz de entender e refletir os problemas de seu tempo a partir de vários enfoques, em contraponto com a necessidade do domínio das técnicas e do entendimento mais preciso dos valores culturais e plásticos de sua época. Como veremos adiante, essa questão também é posta por Leon Battista Alberti e pelos tratadistas dos séculos XVIII e XIX. É incrível perceber que, ao longo de vinte séculos, a essência da profissão e, como decorrência, da formação do arquiteto se explicita de modo coerente e contínuo. A formação do arquiteto é sempre pontuada pela dualidade existente entre o geral e o particular, entre a liberdade fundamental à concepção arquitetônica e o rigor e o método exigidos para o desenvolvimento material da arquitetura.

Cabe aqui uma explicação sobre o papel de Jean-Nicolas-Louis Durand na trajetória do ensino da arquitetura.

Durand nasceu em 1760. Estudou em Paris onde, com dezesseis anos, trabalhou no escritório de Boullée, como desenhista de arquitetura. Em 1778 
seguiu o exemplo de seu mestre nas especulações teóricas sobre arquitetura. Fez uma série de 168 desenhos a lápis reunidos no Rudimenta operis magni et disciplinae. Em 1794 tornou-se professor assistente na École Polytechnique e após três anos, professor de arquitetura dessa escola. Em 1799 escreve o Recueil et parallèle des édifices de touts genres, anciens et modernes. Em 1802/1805 apareceu a $1^{\text {a }}$ edição de Précis des leçons d'architecture donnés à l'École Polytechnique, trazendo Durand para a fase mais brilhante de sua carreira. Seus textos e projetos o fizeram a maior figura da cena arquitetônica francesa.

No final do século XVIII, com Durand, o ensino da arquitetura tomou uma nova direção, abandonando os conceitos absolutos que dominavam até então. Durand criou uma metodologia projetual através do desenho da geometria descritiva. Um método racional, que antecipou vários ideais do movimento moderno. Marcou o fim da arquitetura no que se refere a mito e a história, nas constantes e poéticas reinterpretações de Vitruvius.

O curso de Durand como professor na Escola Politécnica de Paris foi um sucesso, sempre lembrado por seus alunos, por ele ter procurado dar aos engenheiros uma formação ampla e generalista. Estruturava o curso em aulas, sessões de estudo e concursos. De 1806 a 1811, ocorreu uma diminuição do número de aulas teóricas com o aumento do número de aulas de projeto em estúdio.

Podemos estabelecer uma analogia com a lingüística, para a qual o que conta não é o tamanho do vocabulário, mas o estabelecimento de uma gramática. A sintaxe começa com as partes do edifício: varandas, vestíbulos, escadas, quartos, quintais. A manipulação desses elementos representa o primeiro estágio da composição. Nesse momento surge a modulação quadrada e, com ela, a padronização iniciada com os elementos, dando origem aos alinhamentos, eixos, que, mais tarde, se tornaram conceitos essenciais para a composição. 
Elementos dos edifícios

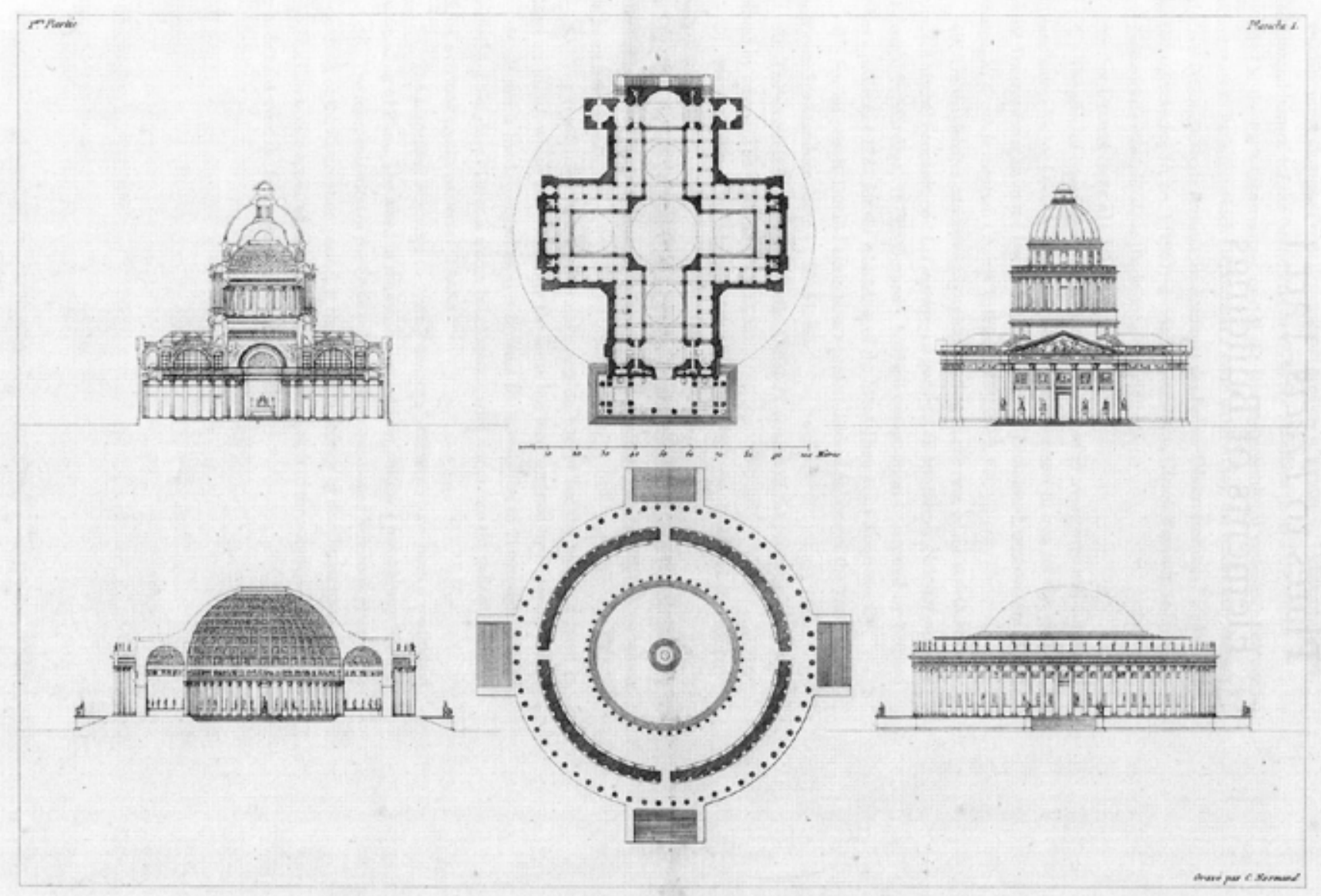

A modulação quadrada

tornou-se importante graças

a Durand, por ter se tornado

uma ferramenta metodoló-

gica. Ele fazia os estudantes

trabalharem as composições

sobre papel quadriculado,

uma prática coerente com o

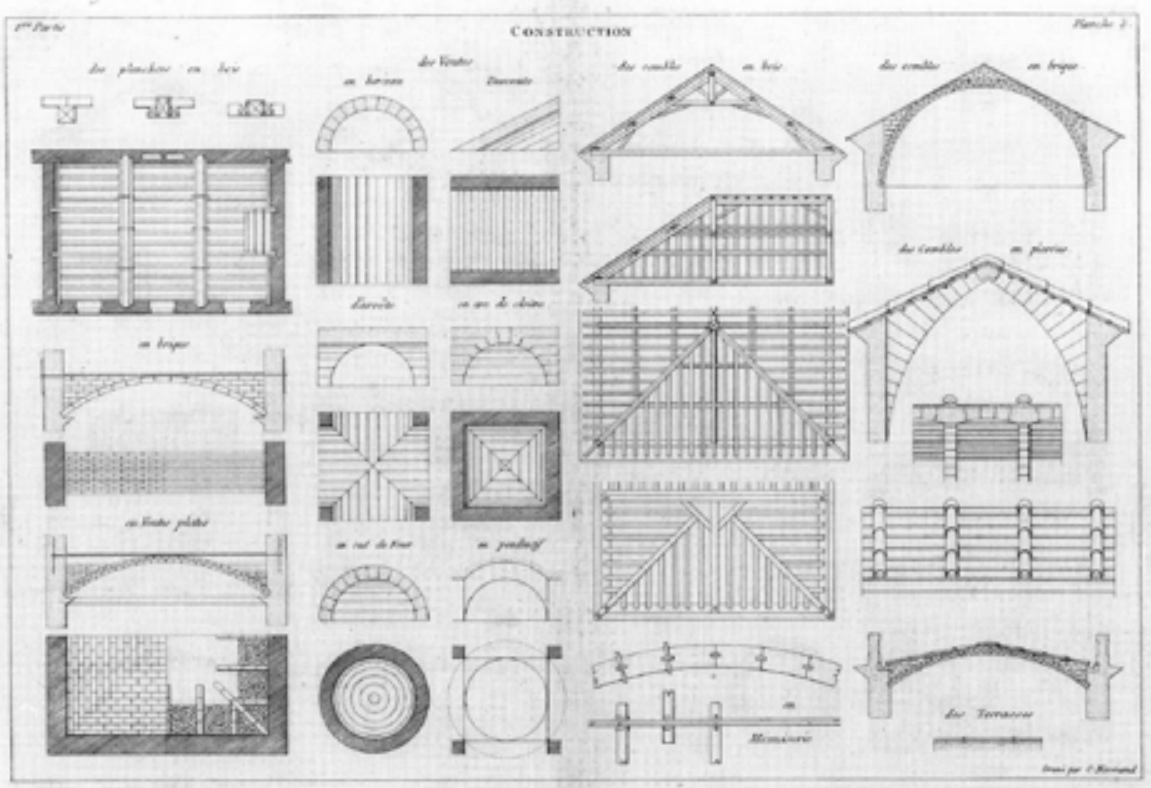

seu desenho, além da práti-

ca ilusionista das perspectivas e aguadas. Se "projetar um edifício é resolver

Construction

um problema", os estudantes devem ater-se ao dimensionamento e aban-

donar os efeitos pictóricos e ambíguos. 
Durand abriu novos caminhos para a imaginação arquitetural, seguindo seu mestre Étienne-Louis Boullée, com o objetivo de um exame metodológico da natureza do projeto arquitetônico. É provável que os mitos e sonhos dos arquitetos contemporâneos tenham se iniciado com Durand.

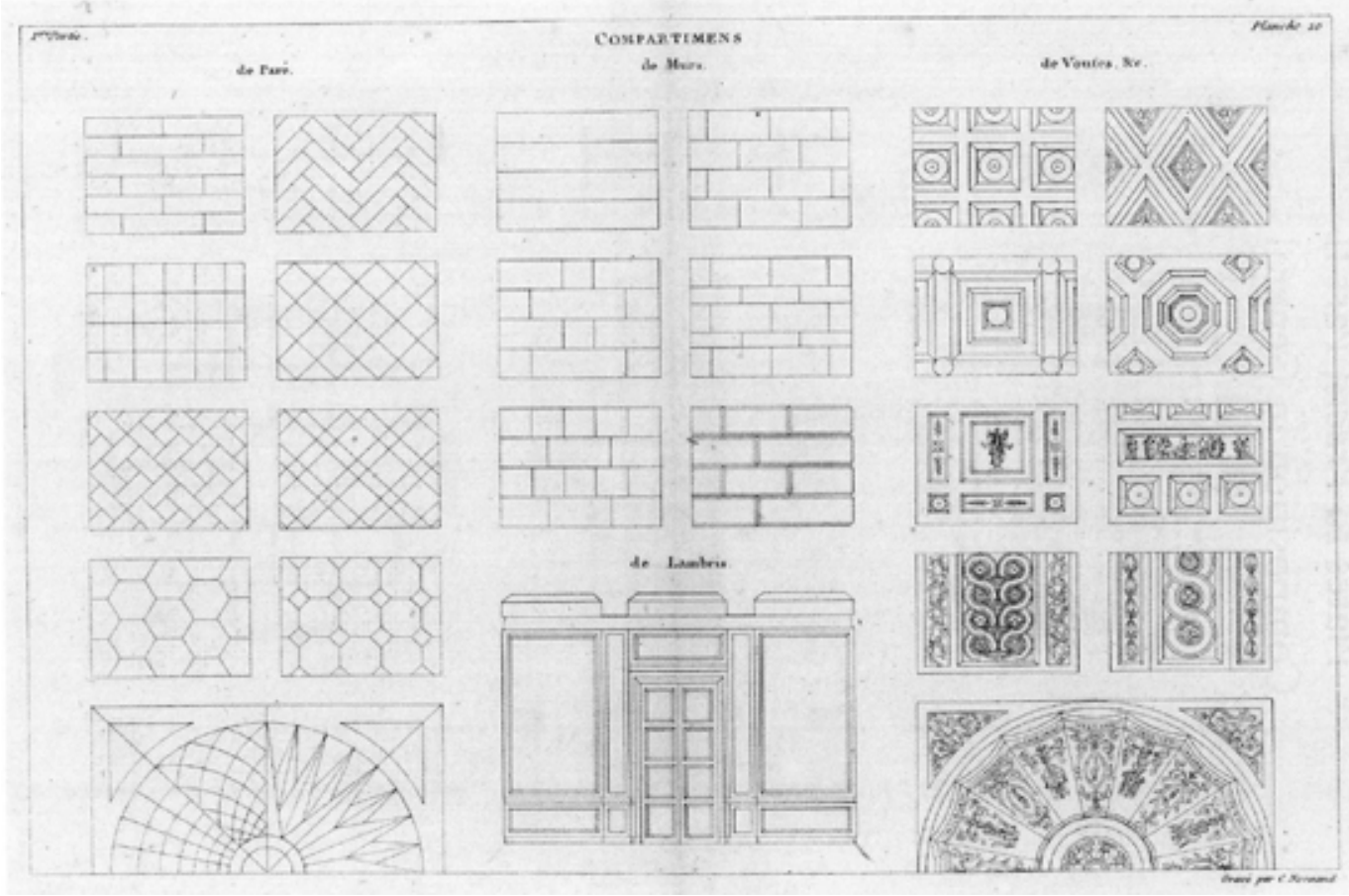

Composição

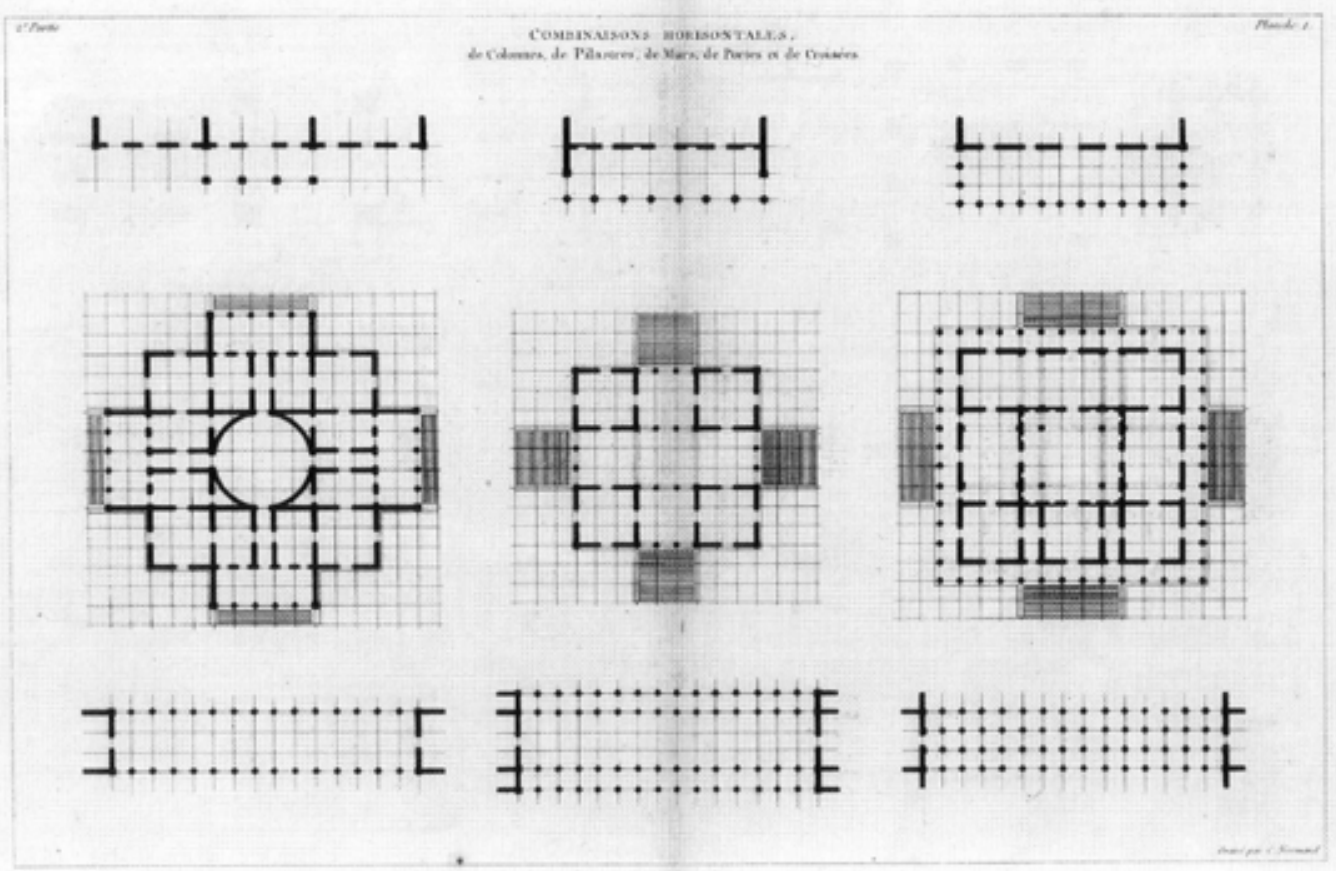



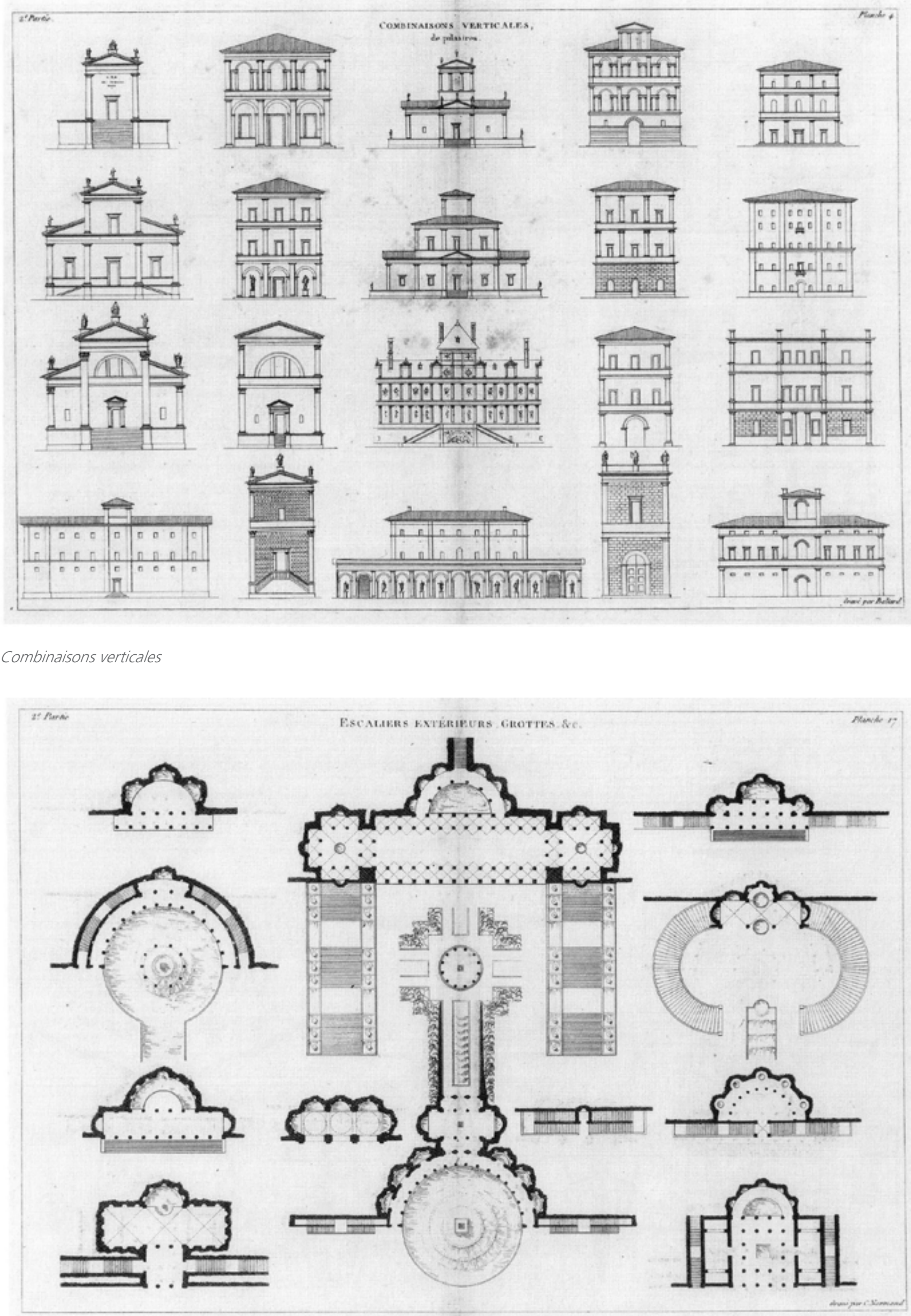


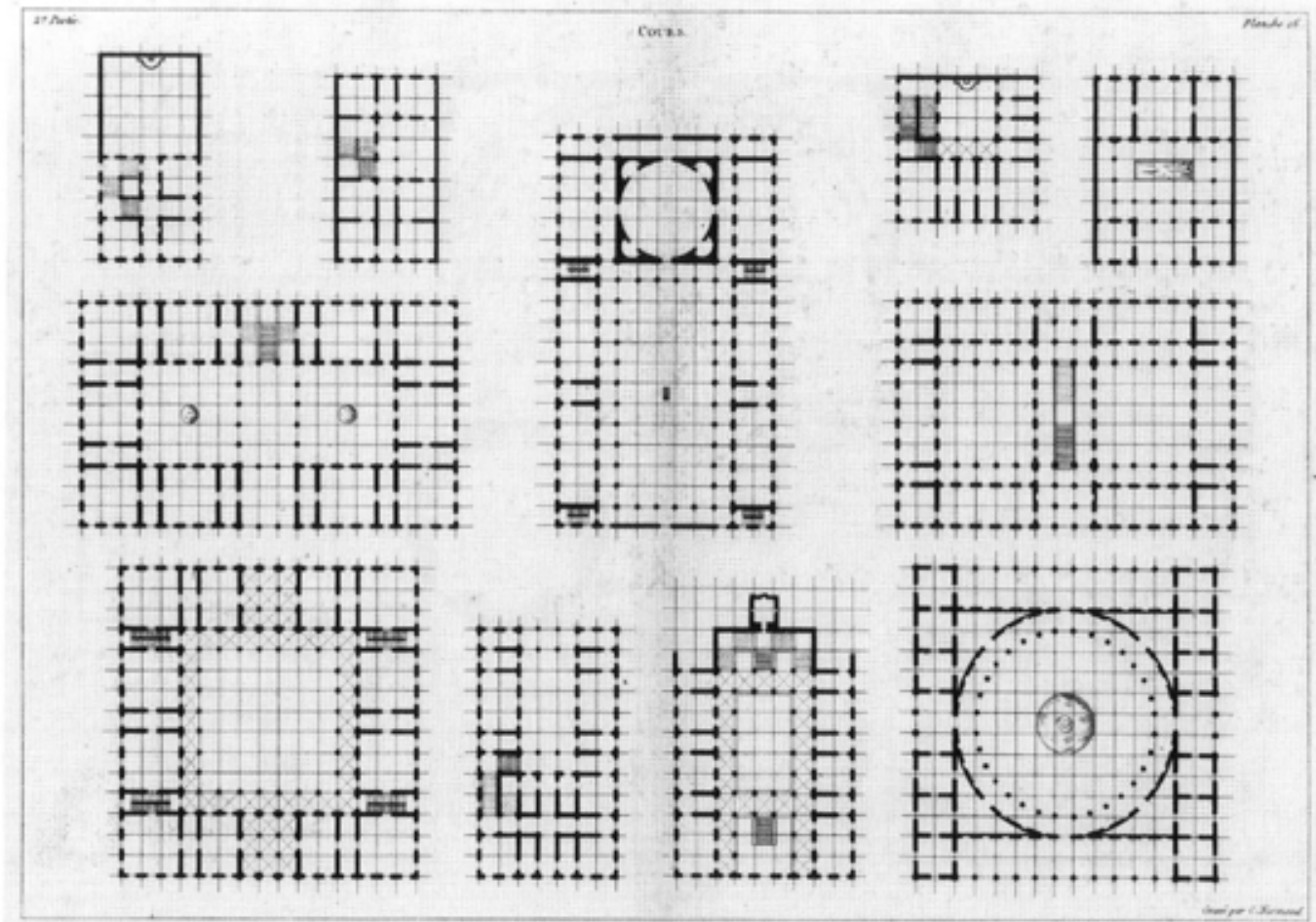

Tipos de edifícios
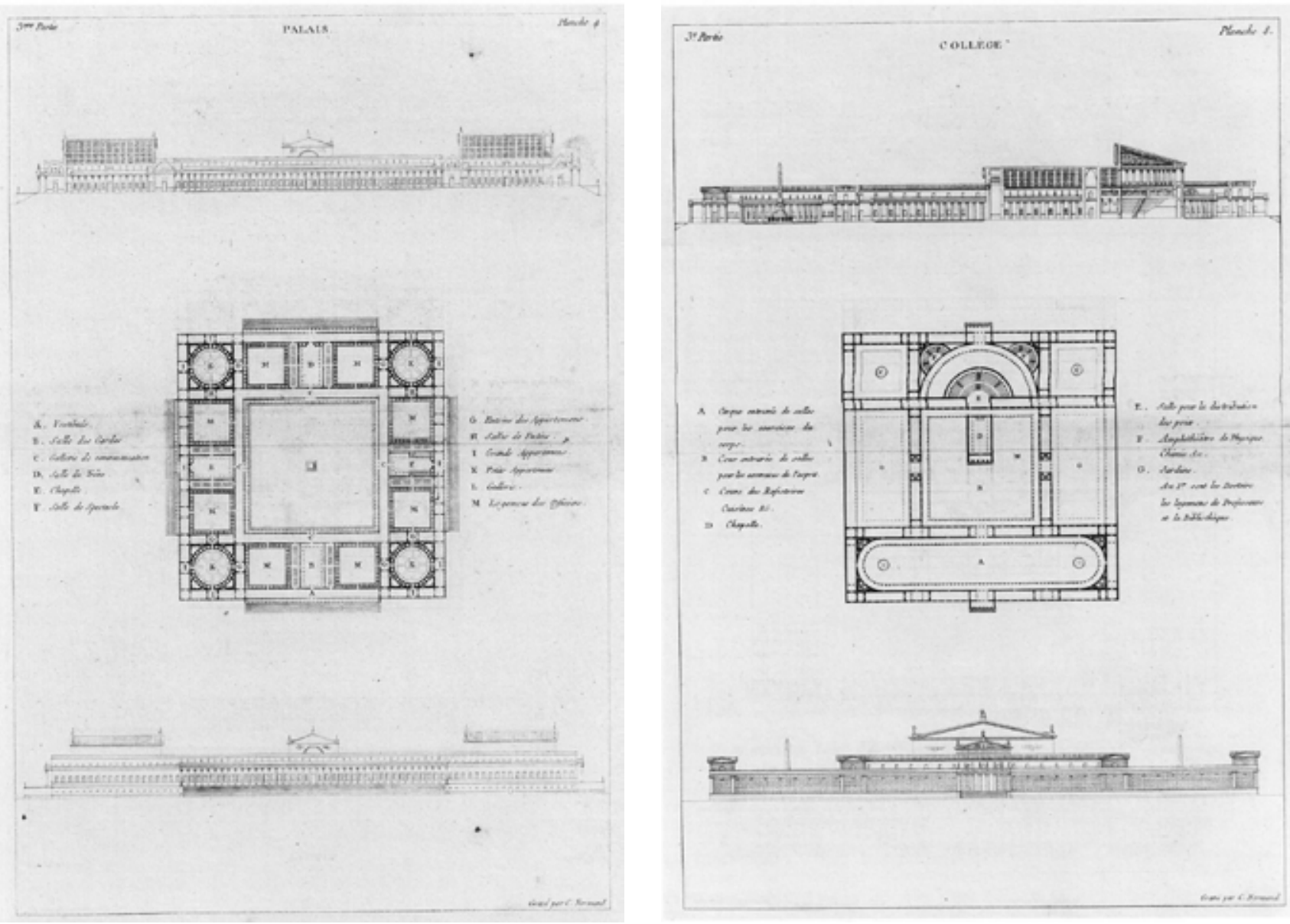

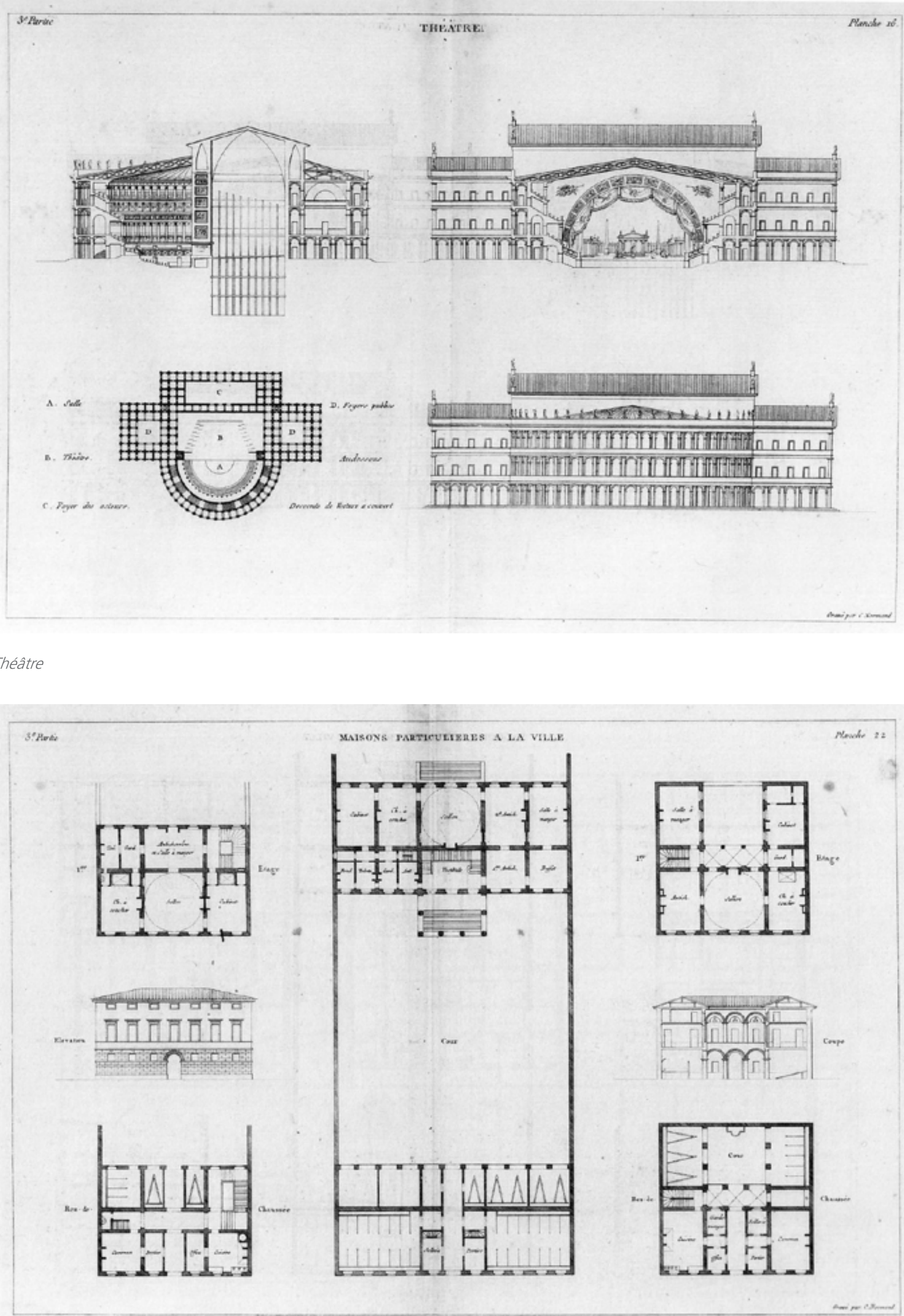


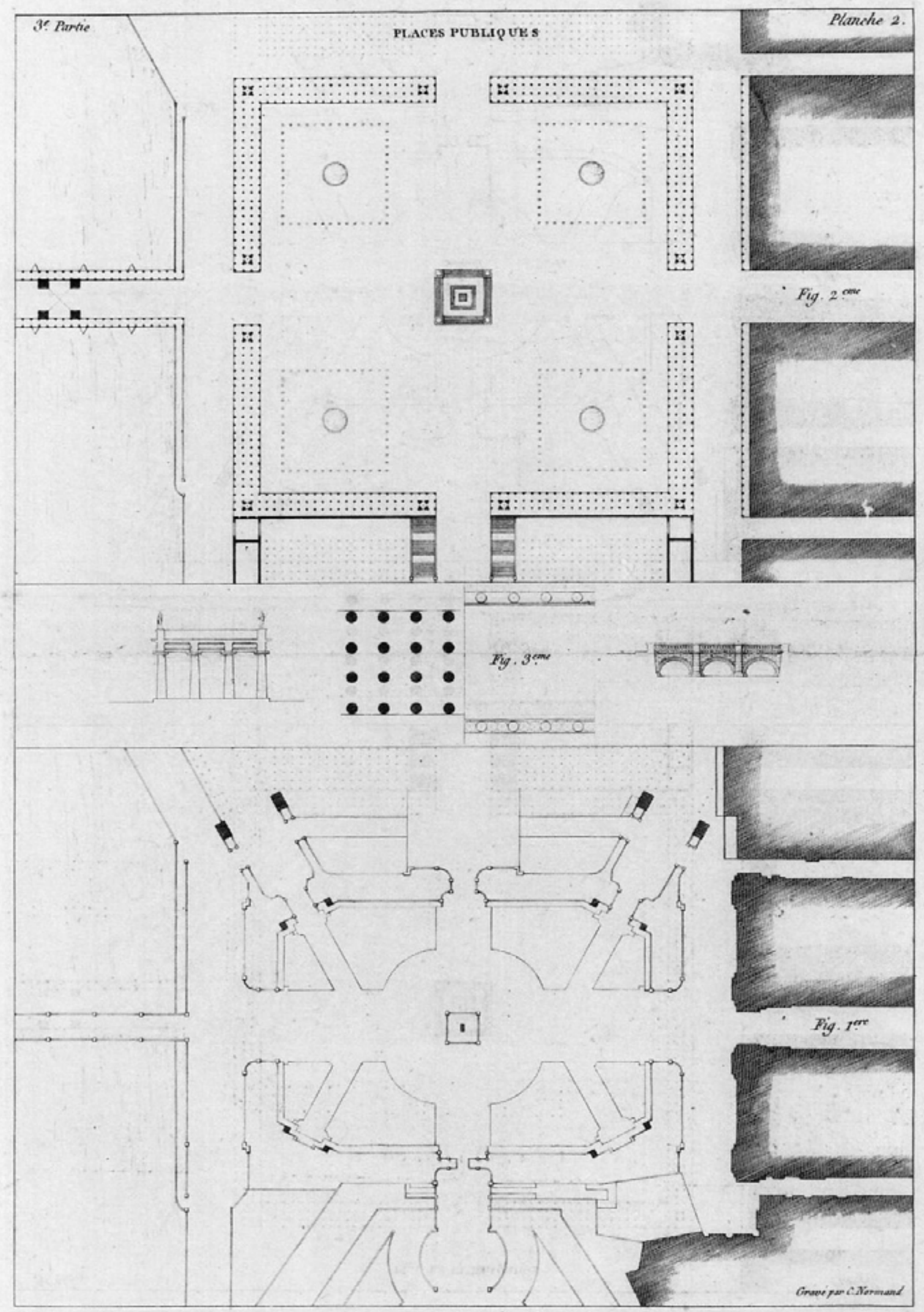


Graphic portion

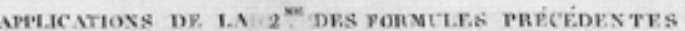
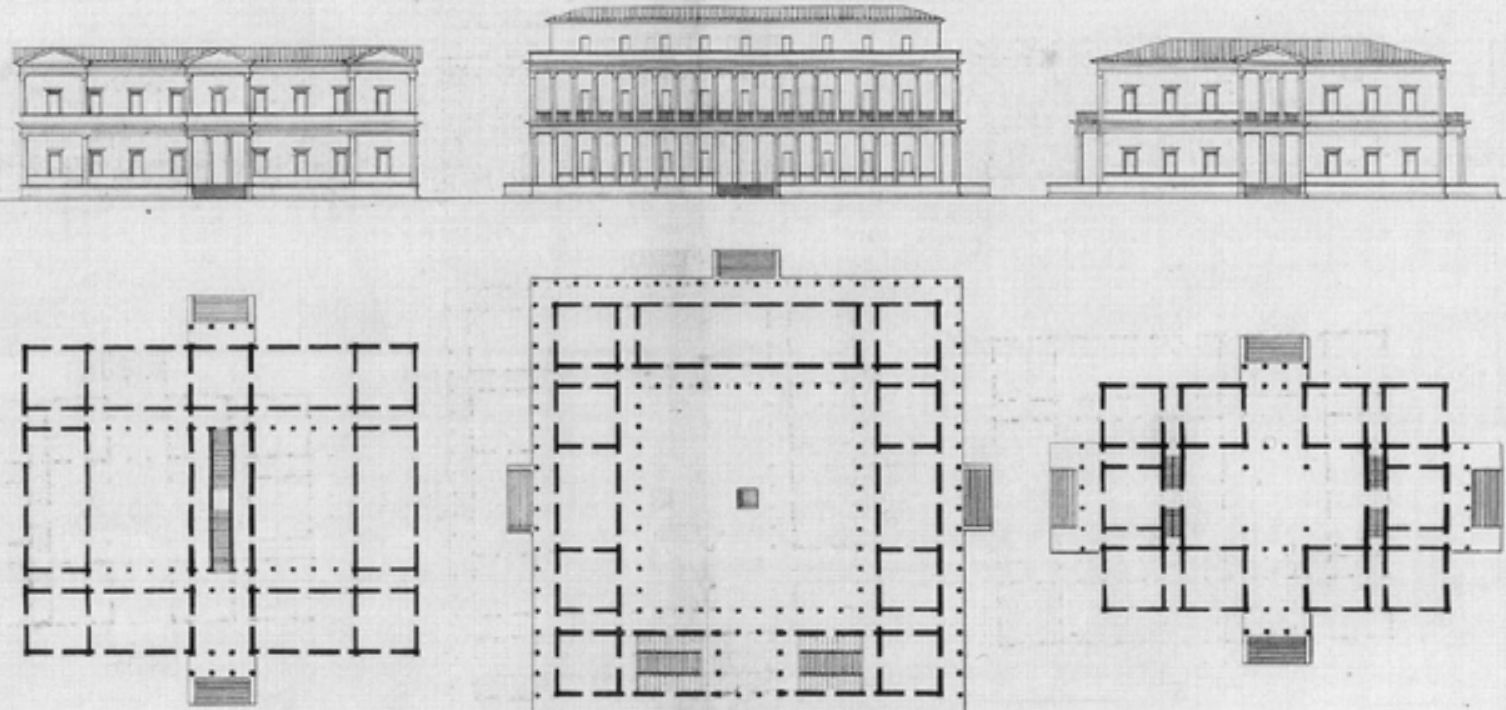

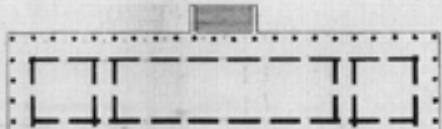

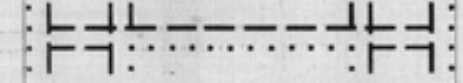

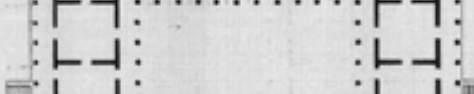

$: 11:$

$\therefore$ 1:

[ :1:-

$: \vdash \dashv:$ $: \vdash \neg:$

:ட」:

:ケフーー::ーートフ:

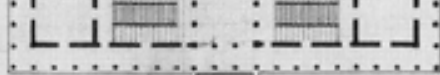

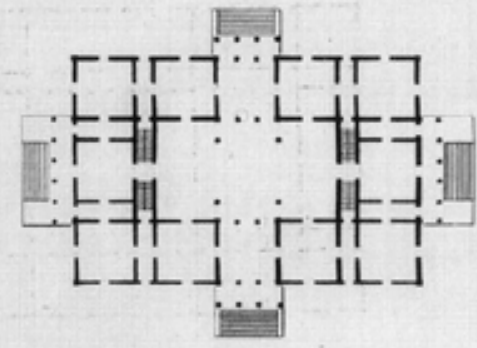

(1)
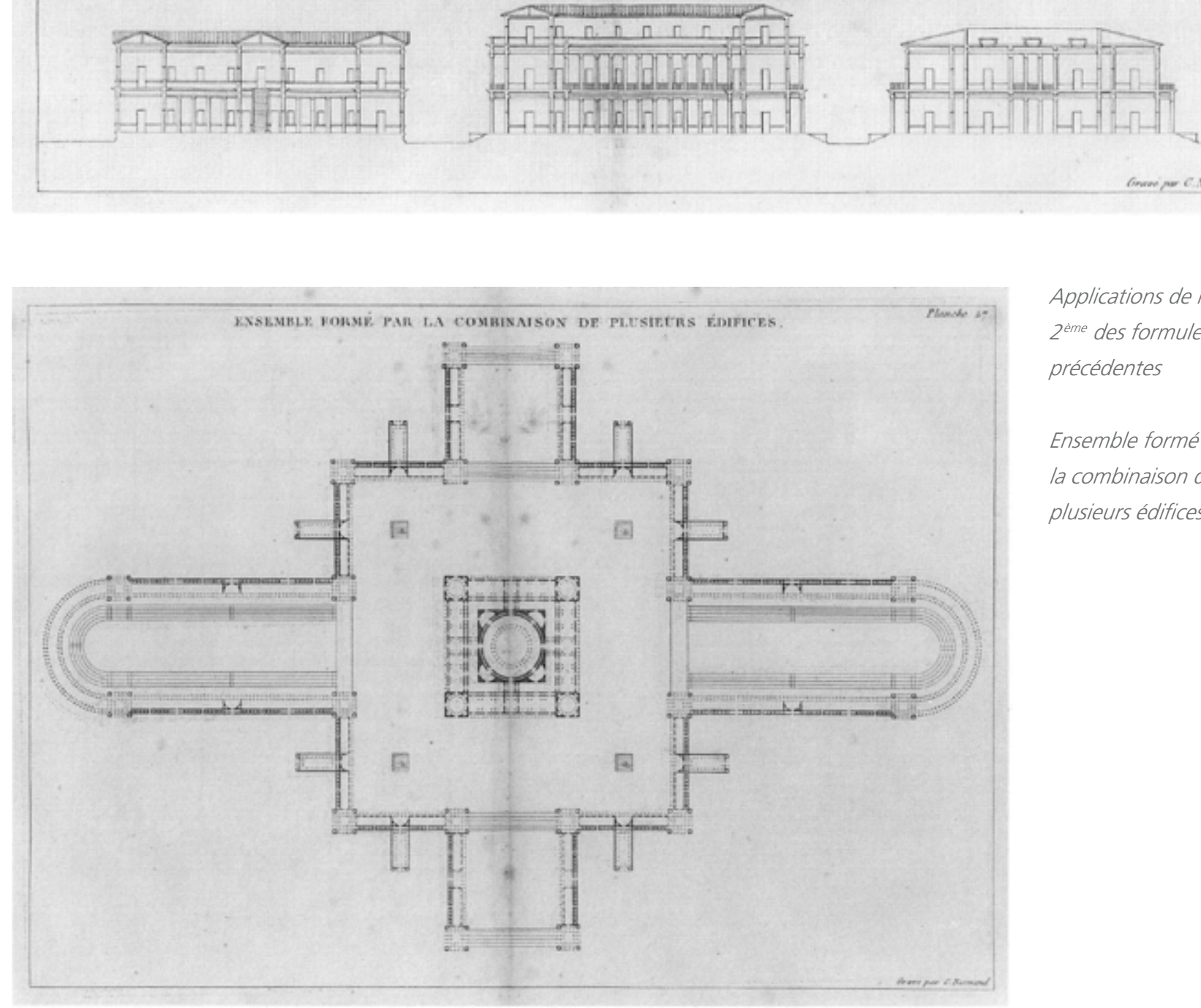

Applications de la

$2^{\text {ème }}$ des formules

précédentes

Ensemble formé par

la combinaison de

plusieurs édifices 


\subsection{A revolução industrial e a ciência}

O impacto da moderna tecnologia industrial pode ser observado em todos os âmbitos: na teoria, na prática, no produto final. Na esfera teórica seu efeito é mais claro e pungente. A tecnologia desenvolvida no século XIX iniciou, entre os arquitetos, especulação a respeito de seu significado, seu provável curso de desenvolvimento e as possíveis respostas da arquitetura. Essa especulação alastrou-se até envolver todos os teóricos dos últimos duzentos anos, todos eles ativados pelas ondas de choque do impacto. Essas especulações ainda não chegaram ao fim. Ao contrário, para a arquitetura, os impactos da tecnologia são, de muitas maneiras, mais agourentos e obscuros do que há cem anos.

As sucessivas ondas de especulação também são reveladas com muita clareza na arquitetura daquele período. É uma confusão sem paralelo, pois, embora a tecnologia, através da manipulação da natureza externa, tenha possibilitado avanços sem precedentes para a arquitetura, por ironia, também possibilitou mais "má" arquitetura do que jamais fora visto. A arquitetura, ao contrário das artes finas, é ao mesmo tempo príncipe e prisioneira do reino da necessidade. Nunca pôde escapar das rígidas garras das leis da física: de fato, seus melhores exemplos são justamente aqueles em que essas leis foram mais escrupulosamente respeitadas. A aceitação, e não a negação, das leis da estática foi a base de toda a arquitetura pré-industrial. Como a tecnologia moderna estendeu o poder do homem sobre a natureza, arquitetos modernos, muitas vezes, agiram como se essas leis tivessem sido rejeitadas. O resultado, talvez pela primeira vez na história, foi uma arquitetura de má qualidade: feia para os olhos e insatisfatória para o uso. 
gia, realizou grandes avanços no último século, o que é verdade em muitos aspectos. Mas a implicação é que esses avanços foram graduais e contínuos e que agora vivemos um auge de realizações. Infelizmente, para nosso desprazer, esse não é o caso. As grandes estruturas germinais dos últimos cem anos não estão distribuídas uniformemente ao longo desse período; ao contrário, acontecem de forma agrupada e mais no início do período do que no final.

Resumindo e simplificando o registro histórico, podemos considerar o Palácio de Cristal, de Joseph Paxton (1851), como marco inicial de nossa era. Essa foi a primeira estrutura no mundo ocidental que demonstrou claramente a chegada de uma nova era. Não somente usou os materiais da nova tecnologia - ferro e vidro - como os empregou de uma forma explicitamente nova, purgados de toda dependência historicamente determinada pela forma.

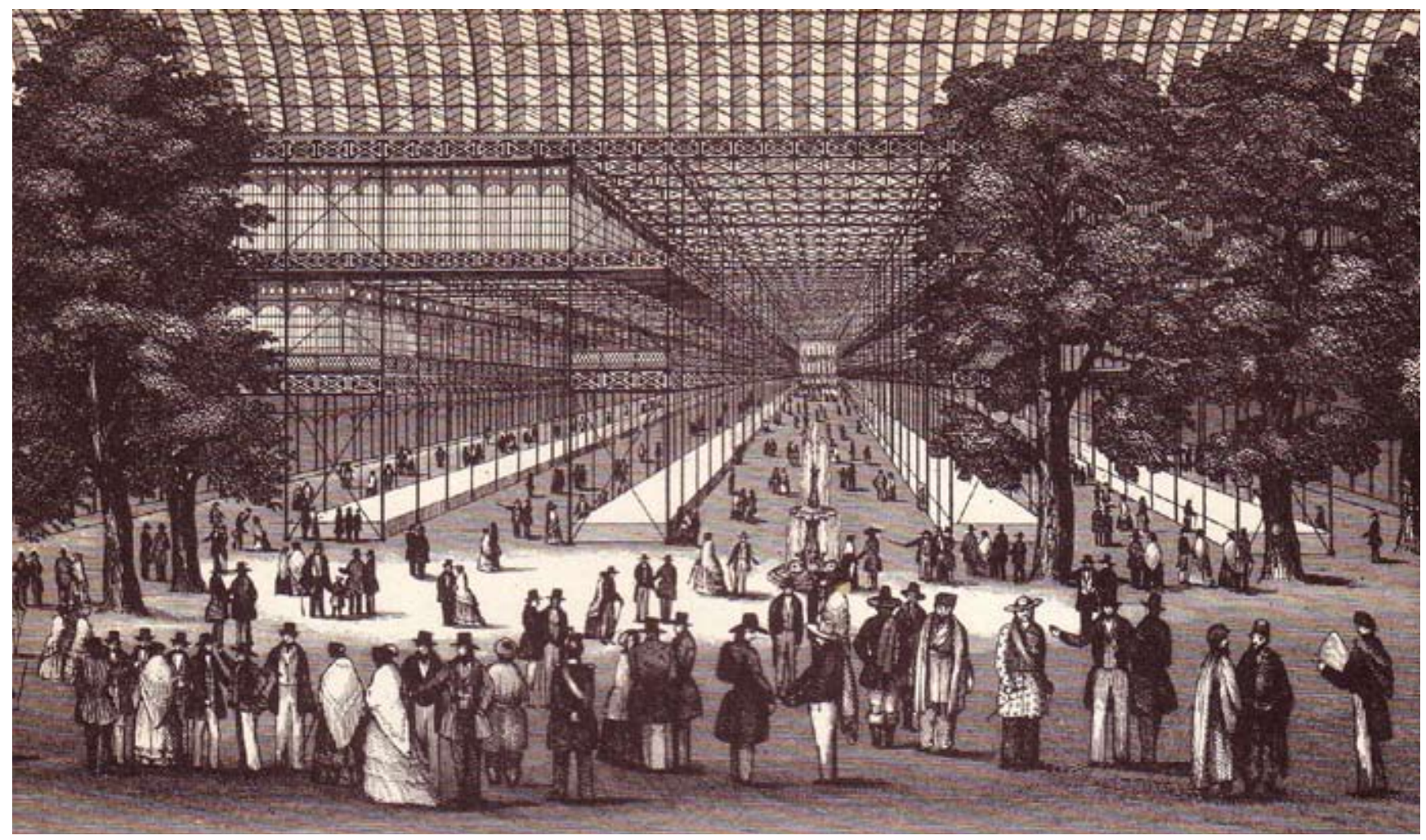

Essa nova frase arquitetônica não foi imediatamente adotada no OciPalácio de Cristal, 1851, Joseph Paxton.

dente. Ao contrário, quatro ou cinco décadas se passaram antes de encontrar- 
de múltiplos andares no Schlesinger

e Meyer Building, de 1899, de Louis

Sullivan. Nessa obra encontramos um

perfeito entendimento da constru-

ção de armação externa em aço bem

como, e talvez mais importante, da

expressão estética da sua qualidade

essencialmente estática. Quatro anos

mais tarde, em 1903, encontramos na

cité industrielle de Tony Garnier um

entendimento igualmente maduro

da natureza estrutural e do potencial

estético de um material ainda mais

recente - o concreto armado.
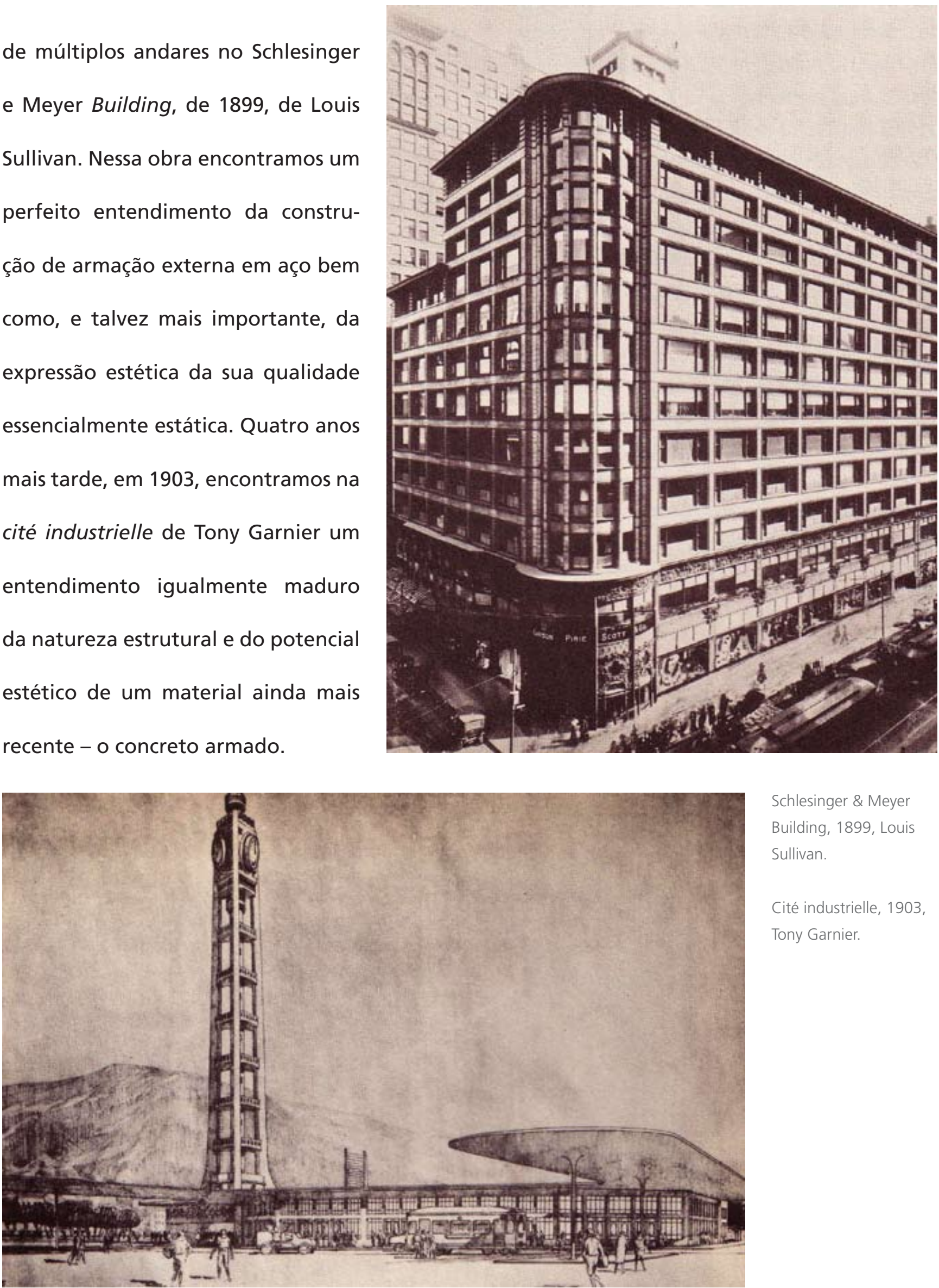

Schlesinger \& Meyer

Building, 1899, Louis

Sullivan.

Cité industrielle, 1903,

Tony Garnier.

Mas essas estruturas seminais não geraram descendentes imediatos. 
edifícios, como no Ministério da Educação e Saúde do Rio de Janeiro (1946) ou nos apartamentos de Mies van der Rohe em Chicago (1952). Assim, levou-se cerca de um século para estabilizar, refinar e adotar o uso geral de um idioma arquitetônico expressivo da nova tecnologia, embora fosse perfeito desde o começo.

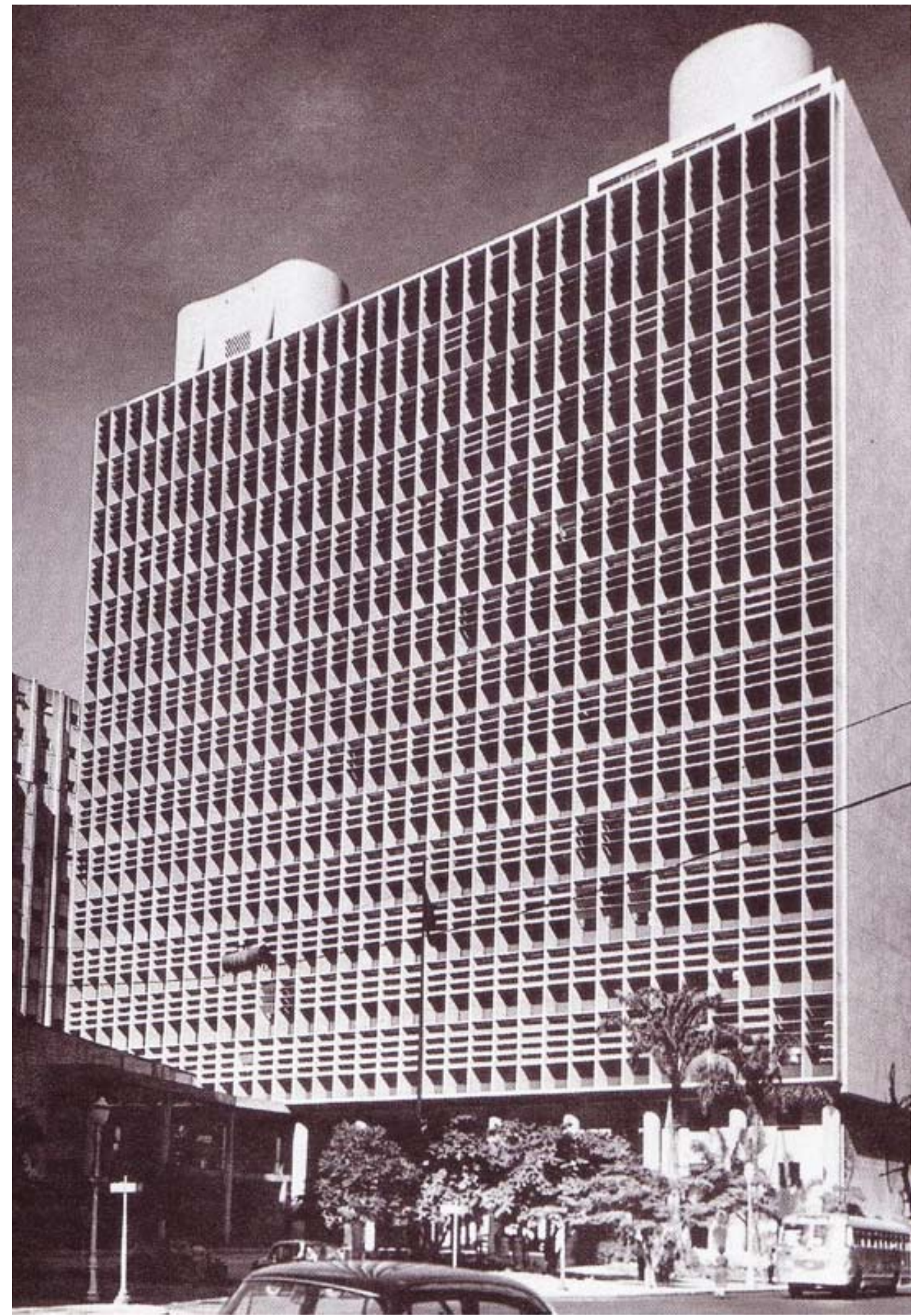

Edifício do Ministério da Educação e Saúde, 1946. 


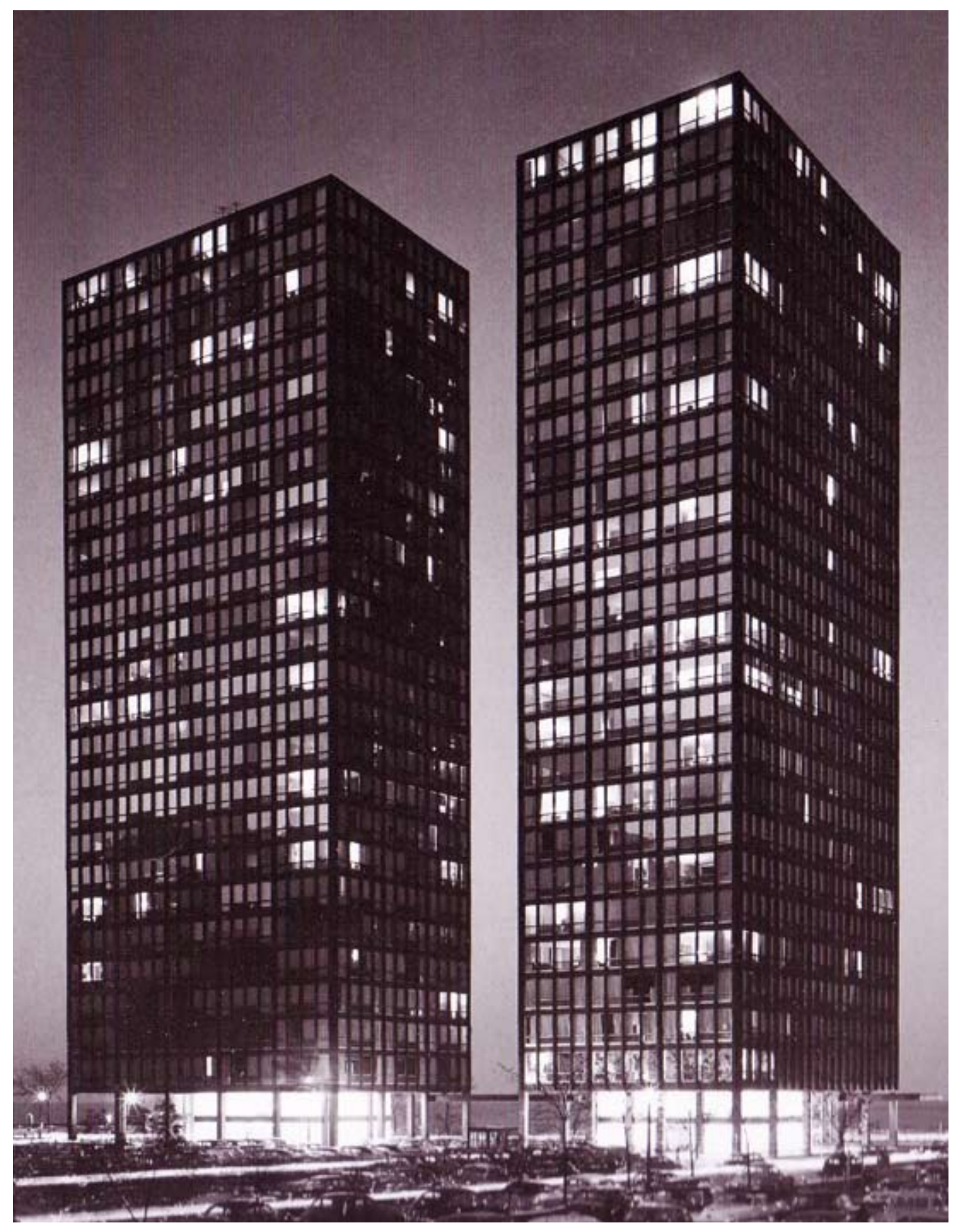

Embora a arquitetura tenha sido exposta ao impacto da tecnologia, tem

Salvo algumas notáveis exceções, os arquitetos sempre estiveram fora da tradição científica. Geralmente preocupados com problemas de estética, estavam completamente despreparados teoricamente para os desenvolvimentos trazidos pela industrialização. Seu único contato com a ciência era através da tecnologia, e os avanços nesse campo chegavam com tal rapidez e eram de tal magnitude, que ocupavam a total atenção dos arquitetos.

sido tocada apenas de forma oblíqua pelas ciências que estão por trás dela. 
Muitos dos avanços mais significativos estavam no campo da estrutura pura. Como a expressão da estrutura é sempre a geometria, tendiam a focar a atenção arquitetônica nessa que é a mais formal e abstrata das disciplinas científicas. Os arquitetos contemporâneos pagaram caro por isso.

É verdade que o avanço científico confirmou que existe ordem, ritmo e lei na natureza. Porém, como sistema, a natureza é infinitamente mais complexa do que parecia aos olhos do contemporâneo de Joseph Paxton, Charles Darwin. A geometria oferece uma representação inadequada para essa nova perspectiva da natureza. As qualidades essenciais da natureza - vida, movimento e tempo (a dimensão em que vida e movimento acontecem) - são precisamente as qualidades que e geometria não consegue descrever.

Não se pretende sugerir que o edifício possa prescindir da forma geométrica, nem que o tecido possa ser organizado sem a célula. Contudo, a geometria contém riscos inerentes aos quais os arquitetos devem estar, ao menos, atentos. O principal risco é o formalismo, isto é, o interesse pela forma com descuido do conteúdo e função. A ciência moderna nos ensina os perigos do formalismo. Um módulo nunca fez um avião decolar. E a seção áurea não ajudou a descobrir o arranjo das moléculas da penicilina. Da mesma forma, a arquitetura nunca conseguirá cumprir inteiramente sua missão enquanto a geometria das formas for considerada como um fim e não um meio.

Se, nos últimos cem anos, a arquitetura mostrou menos avanços do que geralmente assumimos, não se pode concluir que esse curso de desenvolvimento tenha sido "ruim", nem historicamente desnecessário. Qualquer avaliação deve reconhecer que há uma pequena diferença qualitativa entre o Edifício Reliance, de Burnham e Root, de 1890-1895, e nossos arranha-céus "avançados" de hoje. Devemos estudar o passado como homens, e não copiar formas como macacos. 
Felizmente, a teoria arquitetônica contemporânea está crescentemente sendo iluminada pelo conhecimento objetivo de campos adjacentes - história da arte, arqueologia e história cultural. Isso deve criar uma nova atitude perante a arte do passado e nos auxiliará a evitar tanto o ecletismo como o culto à antiguidade. Deve ser observado que a arquitetura contemporânea tem à sua disposição todos os recursos da pintura e escultura contemporâneas, que Burnham e Root, 1890,1895 são vastos; nunca houve na história um tempo em que arquitetos tivessem uma produção tão rica e tão variada em que se inspirar. É a essas artes, tão próximas de nós em espírito, que devemos solicitar ajuda.

Contudo, o restabelecimento de formas de arte na arquitetura moderna deve, também, se assentar no mais profundo entendimento dos potenciais estéticos da sua estrutura. Uma análise verdadeiramente científica indicará as linhas gerais desse desenvolvimento. Se a análise da parede e do homem que habita atrás dela revelar a complexidade da sua tarefa, então teremos as especificações para uma fachada rica e não pobre. Se a ciência indicar que a arquitetura, apesar de todos os avanços tecnológicos, não se afastou de sua relação umbilical com a paisagem e as forças naturais que agem sobre ela, então teremos as especificações para uma paisagem mais variada, colorida e estimulante. Se seguirmos as orientações dadas pela historiografia moderna, então nosso lidar com os monumentos do passado poderá evitar os extremos contemporâneos: por um lado, a mera cópia mecânica, evidente nos "coloniais e afins", e, por outro, a destruição de edifícios histórica e artisticamente significativos.

Para evitar o desastre de atitudes contemporâneas desavisadas, é necessário mudar o ensino da arquitetura. 


\subsection{A necessidade de mudança no ensino da arquitetura}

Os agitadores e realizadores do mundo moderno - pessoas como Einstein, Shaw, Matisse e Wright - passaram a vida sob condições históricas especiais. Viveram até uma idade avançada num mundo de mudanças sociais aceleradas. Diferentemente dos profetas de tempos passados, sobreviveram não apenas para presenciar a realização das suas previsões: viveram o suficiente para participar de um mundo onde seus trabalhos haviam se tornado lugar-comum, integrados ao cotidiano. O profeta sobreviveu à sua profecia.

Essa situação, tão nova nos afazeres humanos, cria um dilema tanto para eles como para nós, que tanto temos lucrado com seus esforços. Significa que, para nós, eles existem em duas esferas distintas: são ao mesmo tempo heróis legendários e colegas e contemporâneos normais. E isso complica enormemente a tarefa de pesar suas contribuições para a vida de hoje.

Walter Gropius, um dos criadores da arquitetura moderna e fundador da mundialmente famosa Bauhaus, foi o mais influente professor de arquitetura enquanto viveu; foi também um arquiteto praticante de sucesso, membro ativo e opinativo de uma profissão fortemente influenciada pelos padrões que ele mesmo ajudou a estabelecer, desde 1919, na Alemanha e depois nos Estados Unidos. Por mais de quatro décadas a profissão contou com centenas de seus alunos e centenas de admiradores, e milhares de outros que, sabendo disso ou não, foram afetados por seu exemplo. Gropius se moveu num mundo duplamente construído por ele: no passado europeu e, posteriormente, até a década de 1960, nos Estados Unidos da América.

No decorrer de uma vida longa e ativa na arquitetura internacional, Gropius desempenhou três papéis separados, porém interconectados: educador, 
projetista e crítico. Sua contribuição nas três áreas foi marcante, embora variasse em importância relativa ao longo de diferentes décadas. Os desastres da história moderna desempenharam importante papel nessa flutuação, dividindo sua vida em várias fases distintas. Mas Gropius nunca deixou de ser atuante em todos os níveis da área escolhida. Sempre foi um crítico franco e consistente dos aspectos sociais da arquitetura, da moradia e do planejamento urbano. Talvez essa crítica tenha sido mais afiada (provavelmente mais abrangente) durante os anos vividos na Alemanha (1919-1934), mas suas declarações sempre confirmaram a firmeza de suas convicções sociais. Foi sempre um arquiteto influente: iniciou a carreira como projetista de dois edifícios sensacionais; os anos intermediários foram marcados por projetos imensamente significativos, incluindo o projeto para o edifício da Bauhaus. O núcleo de sua fama e influência, a alavanca com a qual Gropius moveu o mundo, contudo, foi outro: a grande invenção educacional, a escola Bauhaus.

Edifício da Escola Bauhaus, 1919 Walter Gropius.

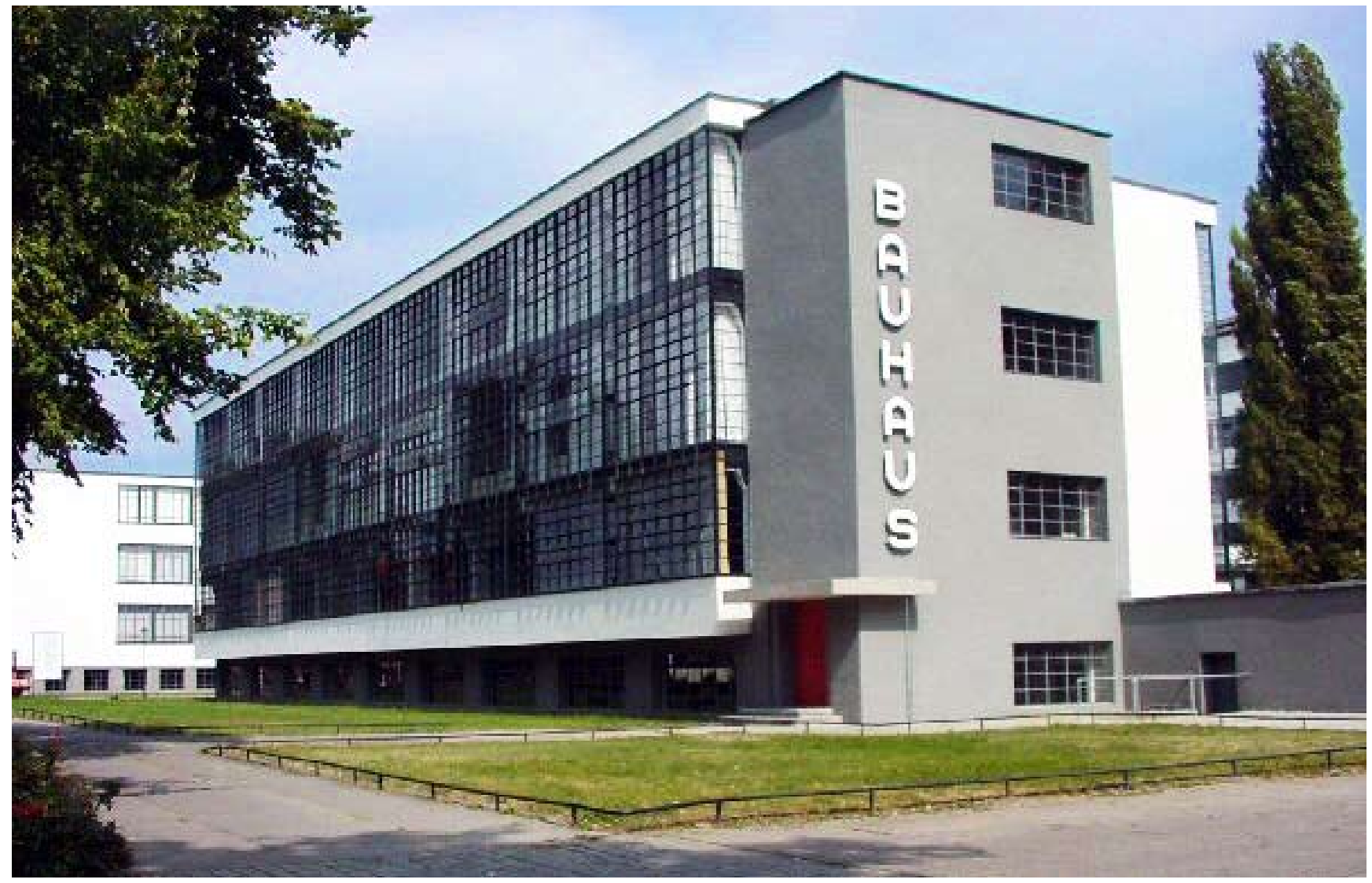


Naquele dia de abril em 1919 quando criou a Bauhaus, Gropius deflagrou um círculo de repercussões que não deixou um canto do mundo intocado. Quem adivinharia, quando ele assinou o contrato com o Escritório "Court Chamberlain, sob consentimento do Governo Republicano Provisório de Saxe-Weimar" (a ambigüidade da sentença reflete a revolução política que balançava a Alemanha), quem adivinharia que estavam em gestação teorias que, um dia, dariam forma a artefatos, tecidos e mobílias, nas ilhas do Japão, no Brasil e no vale quente do Tigre?

Se analisarmos as posições ideológicas demarcadas por Gropius, desde o início, para a Bauhaus, e se estudarmos o corpo do trabalho que cresceu durante as décadas subseqüentes, poderemos concluir que esses princípios nem estavam equivocados em 1919 nem obsoletos em 1970. Isso porque um dos principais aspectos de seu trabalho em educação é o entendimento dos perigos inerentes à separação entre cabeça e mão, teoria e prática, trabalhadores intelectuais e braçais, artistas e artesãos. Ele sempre tentou transpor a divisão arbitrária entre os dois extremos, procurando reuni-los para o enriquecimento de ambos.

O Staatliche Bauhaus, em Weimar, ofereceu a primeira e mais abrangente oportunidade de aplicar suas teorias à prática. Até mesmo as duas escolas existentes então, que ele mesclou para formar a nova instituição, simbolizam essa ambição: a Escola Grand Ducal de Artes Aplicadas e a Grand Ducal Academia de Artes. O currículo oriundo dessa combinação foi um esforço racional para mesclar o melhor do treinamento técnico com o mais válido da academia. Opunha-se à "arte pela arte", acreditando que, antes de tudo, o artista é um artesão: "apenas em alguns momentos de abençoada inspiração, momentos além do seu controle, seu trabalho pode florescer em 
arte". ${ }^{2}$ Assim, todo estudante da Bauhaus - não importando suas ambições ou habilidades - passava pelo mesmo treinamento nas oficinas. Ao mesmo tempo, Gropius cuidava para não vulgarizar a distinção entre competência e criatividade:

"De fato, a arte não é um ramo da ciência que pode ser aprendido, passo a passo, de um livro. Habilidade artística inata pode ser intensificada (não ensinada) pela influência do ser integral; (...) a habilidade para desenhar é muito freqüentemente confundida com a habilidade de produzir um projeto criativo. Assim, tal como a destreza em artesanato é, no entanto, nada mais do que uma perícia; (...) virtuosidade (...) não é arte". ${ }^{3}$

Gropius almejava evitar tanto o grosseiro analfabetismo do artesão moderno como a precocidade irresponsável do artista treinado em academia. Ele esperava recriar, na sociedade industrial moderna, o mesmo tipo de unidade orgânica e saudável que caracterizava as sociedades préindustriais em todas as fases de projeto.

A capacidade de Gropius em traçar um rumo entre esses dois extremos nos quais muitas teorias afundaram é uma medida de sua maturidade (bem como de seu círculo em geral). Os princípios específicos sobre os quais a Bauhaus foi fundada não são facilmente encapsulados. O próprio Gropius achou necessário ampliar e desenvolvê-los repetidamente após a publicação do primeiro manifesto. ${ }^{4}$ Na sua essência, esses princípios são:

1. "A Bauhaus acredita que a máquina é o meio moderno de projeto e busca chegar a um acordo com ele." 5

\footnotetext{
2 GROPIUS, Programm des Staatlichen Bauhauses (Weimar, 1919).

${ }^{3}$ Walter GROPIUS, Scope of total architecture (New York, Harper \& Brothers, 1955), p. 18-19.

${ }^{4}$ GROPIUS, Programm.

${ }^{5}$ Herbert BAYER; Ise GROPIUS; Walter GROPIUS, Bauhaus. 1919-1928 (New York, Museum of Modern Art, 1938), p. 27.
} 
2. Todo projeto deve reconhecer esse fato e dele extrair um novo conjunto de critérios estéticos. No caso da arquitetura, tal processo deveria levar a uma "forma clara e orgânica cuja lógica interna seja nua e radiante, livre de fachadas mentirosas e truques". ${ }^{6}$

3. A Bauhaus ensina "a cidadania comum de todas as formas de trabaIho criativo e a interdependência lógica entre elas". ${ }^{7}$

4. A escala e complexidade dos problemas modernos necessitam de projetos colaborativos. "Qualquer objeto industrialmente produzido é resultado de inúmeros experimentos, de pesquisas longas e sistemáticas." 8 A escola de projeto deve reconhecer esse dado e equipar o estudante com "as bases comuns sobre as quais serão capazes de, juntos, criar uma unidade superior de trabalho". ${ }^{9}$

5. A educação do projetista "deve incluir um treinamento manual intenso e prático em oficinas envolvidas em produção, acoplando a instrução teórica às leis de projeto". ${ }^{10}$

Esse foi o programa que lançou a Bauhaus à proeminência internacional, fazendo dela a mais importante força individual no mundo de projetos no período entre guerras. Todos os campos de projetos registraram sua influência: arquitetura, desenho de produtos, mobília; tecidos, utensílios de prata e cerâmica; artes gráficas, tipografia, pintura, propaganda; fotografia, cinema, cenografia, balé. Em todo lugar sua influência foi benigna. Como programa,

\footnotetext{
6 Ibid., p. 28.

7 Ibid., p. 127

8 Ibid., p. 30

9 Ibid., p. 28

10 Ibid., p. 24.
} 
sua capacidade de regenerar projetos vinha de sua análise essencialmente correta da relação entre projeto e produção num mundo industrial.

Em sua vida curta e conturbada, a Bauhaus treinou mais de quinhentos homens e mulheres em vários campos. Suas publicações, exibições e palestras preencheram um vácuo, com precisão, e sua influência extrapolou a proporção de seu tamanho, irradiando-se para toda a Europa Ocidental e Estados Unidos (depois da chegada de Gropius a Harvard, em 1937). Embora o currículo da Bauhaus não pudesse ser aplicado à Graduate School of Design, a filosofia de projeto de Gropius podia ${ }^{11}$ e fez de Harvard o líder mundial em estudos arquitetônicos, além de produtor de toda uma geração de projetistas que hoje emergem como líderes na profissão. A durabilidade do conceito de Bauhaus foi comprovada pelo fato de projetistas navegarem, por décadas, sobre o momentum gerado por aqueles anos iniciais em Weimar e Dessau (de 1919 a 1928). Por outro lado, a educação em projeto não seguiu o modelo da Bauhaus; parece ter adotado um caminho oposto. Escolas de arte e de profissionais proliferaram. Mas onde no mundo existe uma instituição que enfrenta os problemas tão de frente, com tanta profundidade como fez a Bauhaus?

Estaria esse programa obsoleto, como muitos críticos contemporâneos afirmam? A análise objetiva das condições revelaria alguma mudança fundamental que o torne menos valioso? É fato que as condições contra as quais Gropius reagiu em 1919 se tornaram gradativamente mais agudas no mundo ocidental, e ainda mais agudas nos Estados Unidos. A produção industrial fica cada vez mais complexa e domina todos os aspectos da vida. O projetista está

\footnotetext{
${ }^{11}$ O currículo da Bauhaus e seu método de ensino foram implantados com sucesso por Moholy-Nagy no mesmo ano, quando ele fundou a Nova Bauhaus, em Chicago. Foi reorganizada em 1939 como Escola de Design e, em 1944, como Instituto de Desenho. Atualmente é um departamento do Illinois Institute of Tecnology.
} 
cada vez mais distante do controle, ou mesmo do entendimento, do campo da ciência e da tecnologia. E o processo de projetar se deteriora para ser mero cosmético: desnudo de qualquer funcionalidade, tornou-se prisioneiro de modas e modismos. Em tal contexto, deve ficar claro que, longe de ter "amadurecido", superando a necessidade de um padrão de educação Bauhaus, precisamos dele ainda mais.

Duas acusações, ambas estéticas, são feitas contra a Bauhaus por seus críticos atuais. A primeira é que ela estabeleceu um estilo. A segunda é que esse estilo é "ruim". Essas acusações, embora relacionadas, não são a mesma coisa. Gropius sempre negou que tivesse qualquer ambição de estabelecer um estilo; sempre garantiu que, ao contrário, buscava uma metodologia básica para projetos. Na sua primeira declaração, ao chegar aos Estados Unidos em 1937, afirmou:

"Não é minha intenção introduzir (...) um 'Estilo Moderno' da Europa, mas sim introduzir um método de abordagem que permita lidar com o problema de acordo com suas condições específicas (...), uma atitude sem preconceitos, original e elástica, perante os problemas de nossa geração." 12

Um democrata, no seuíntimo, e incansável defensor do trabalho colaborativo, repetidamente rejeitou o que Ihe parecia ser as implicações ditatoriais na questão de estilo: "Sei que sou uma figura coberta de muitos rótulos (...); Estilo Bauhaus, Estilo Internacional, Estilo Funcional - que quase conseguiram esconder o núcleo humano por detrás disso tudo." Estava ansioso para escapar da caricatura da sua verdadeira posição. ${ }^{13}$ Há algo ao mesmo tempo

\footnotetext{
${ }^{12}$ GROPIUS, Scope of total architecture, p. 3. 
cômico e triste nas repetidas tentativas desse grande homem de se desvencilhar de uma armadilha semântica de pouca importância. Pois, quando um grupo de homens chega a um acordo sobre um método em comum para alcançar um resultado, acabará por surgir um sistema comum de expressão: um estilo. O final do século XX é o primeiro período na história a se envergonhar dessa certeza cultural.

Gropius é vítima da fantástica capacidade de imitar e multiplicar que a industrialização tem. Poderoso projetista comprometido com um estilo de expressão suprapessoal, sempre atraiu estudantes e discípulos; conforme sua influência e fama se espalhavam, foi elogiado com pirataria e paródia do que desenhava. O mesmo aconteceu com a Bauhaus. Deu ao mundo um novo conjunto de protótipos; vezes demais o mundo os transformou em estereótipos. Um terço de século mais tarde, esses protótipos podem ser inadequados ao gosto e sensibilidade vigente, mas isso não altera o fato de que a Bauhaus, no seu tempo, não foi um carcereiro, mas um libertador do projetista ocidental, oferecendo-lhe a primeira possibilidade de liberdade estilística desde o período medieval.

A outra acusação contra a Bauhaus é de ter criado um estilo que era ruim porque era frio, desumano, mecanicista, etc. Esses são julgamentos de uma geração que não participou das grande batalhas estéticas dos anos de 1920 e que, conseqüentemente, pode não estar em posição de compreender os termos daquele esforço revolucionário. O único modo pelo qual a forma moderna poderia ter evoluído do pântano do fin-de-siècle seria abandonar todo o passado: aqui o artístico traçou um paralelo com o político. Qualquer avaliação deve levar em conta esse fato histórico. A luta foi amarga, e as opiniões estavam polarizadas em posições extremas. Afinal, por razões "puramente" estéticas, a Bauhaus foi, por duas vezes, enxotada de casa (pelo reacionarismo 
da República de Weimar, em 1925; pelos nazistas em Dessau, em 1932). Foi denunciada como "artebolchevismo que deveria ser eliminado": o "espírito nacional alemão" foi conclamado a "salvar" a arte alemã dos modernistas, ${ }^{14}$ uma tarefa que Hitler estava prestes a cumprir com rigor sangrento.

Não falta inteligência, paixão e coragem entre os partidários da nova arquitetura; aqui Gropius não era o primeiro, nem estava sozinho. Antes mesmo da Primeira Guerra Mundial, Adolph Loos escreveu um ataque efetivo à ornamentação histórica (e, por extensão, ao ecletismo em geral). Em sua famosa monografia Ornamento e delito escreveu: "o artista representava, no auge da humanidade, força e saúde; mas o ornamento moderno é culturalmente preguiçoso ou é caso patológico". Loos defendeu que nenhum ornamento é permitido ao homem civilizado: por serem aborígines, os papauns podem ser perdoados se "tatuam suas peles, decoram seus barcos, seus remos - tudo o que tocam. Mas o homem moderno que se tatua... (é) ou um criminoso latente ou um aristocrata degenerado (...). A verdadeira grandeza da nossa era é que não pode mais avançar um ornamento. Eliminamos o ornamento", Loos vangloriava, "e adentramos um mundo sem ornamentação (...). Liberdade da ornamentação é sinal de força mental". ${ }^{15}$

O próprio Gropius, na primeira primavera da paz, escreveu um contundente chamado para a arquitetura "radiante e nua":

"Não é a arquitetura a expressão cristalizada dos pensamentos mais nobres do homem, seu ardor, sua humanidade, sua fé, sua religião? Costumava ser antes. Mas quem, nestes dias de maldita conveniência, ainda deixa-se

\footnotetext{
${ }^{14}$ BAYER; GROPIUS; GROPIUS, Bauhaus, p. 22. 
deslumbrar pela sua mensagem? Deveríamos nos revoltar contra esses desperdícios de feiúra quando andamos pelas ruas das nossas cidades! Encaremos o fato! Essas fraudes vazias, sem graça e sem significado nas quais vivemos e trabalhamos, deixarão um mortificante testemunho da pobreza espiritual da nossa geração." 16

László Moholy-Nagy define verbalmente essa atitude, esse tempo, num dos manifestos mais incandescentes, habituais naqueles dias: "a realidade do nosso século é a tecnologia: a invenção, construção e manutenção da máquina. Ser usuário da máquina é ter o espírito desse século. Substituiu o espiritualismo transcendental de eras passadas (...)". Disso tira o que parecia ser a conclusão para esse período: "Essa é a raiz do socialismo, a liqüidação final do feudalismo. (...) Façam suas pazes com isso". ${ }^{17}$ A maioria das grandes figuras de então compartilhava essa perspectiva geral. Poemas, pinturas, esculturas; balé, sonatas e cinema celebravam as formas, movimentos e promessas das máquinas. Assim, quando ecoaram as famosas frases de Le Corbusier ("a casa, uma máquina para viver") e de Gropius ("queremos uma arquitetura adequada ao nosso mundo de máquinas"), ambos falavam a linguagem do humanismo ocidental dos primeiros anos da década de 1920.

Entretanto, mesmo nesses anos de entusiasmo, Gropius não era cego adorador acrítico da tecnologia. "Trabalho mecanizado é sem vida, apropriado apenas à máquina sem vida" alertava. "Enquanto a economia pela máquina for um fim em si, ao invés de um meio para liberar o intelecto do fardo do trabalho mecanizado, o indivíduo permanecerá escravizado e a sociedade

\footnotetext{
${ }^{16}$ Extraído do catálogo da exposição UnbekannteArchitekten verastalten vom Arbeitsrat für Kunst (Berlin, April 1919). 
permanecerá desorganizada." Ele aspirava ao domínio da máquina pelo projetista, a fim de criar uma arquitetura anônima e serena, capaz de uma resposta flexível às demandas da vida. E esse esforço consciente de purificação foi exatamente o que forneceu incrível durabilidade ao idioma ${ }^{18}$ de Gropius e seus colegas na Bauhaus. O tempo tem seu método particular de separar o impudico e efêmero na arte e de expô-lo ao ridículo da simples distância. Nesse contexto, o desempenho da Bauhaus é admirável: poucos objetos daquele período sobreviveram tão bem quanto a Tribune Tower de Gropius, de 1922, ou o automóvel Adler, de 1931. Os quadros de Paul Klee, as cadeiras de Marcel Breuer, os têxteis de Anni Albers continuam a mostrar aquela durabilidade artística que é evidência interna de valor contínuo.

A reserva dos artistas e arquitetos modernos diante da própria palavra estilo é compreensível. Tem sua origem justamente no período Bauhaus e é resultado da experiência traumática de serem forçados a empregar estilos mortos para expressar conceitos artísticos vivos. No entanto, se a revolta contra estilos históricos viesse a ser, por extensão, a rejeição do próprio estilo em si, os resultados seriam uma anarquia visual, além de um absurdo intelectual. Gropius sempre esteve consciente desse paradoxo. Por um lado, ele argumentou corretamente que "a criação de padrões para o uso cotidiano é uma necessidade social". Para ele, a busca desse padrão "implica buscar o melhor, a separação do essencial e suprapessoal do pessoal e do acidental". Esse padrão torna-se, assim, "um título cultural de honra". ${ }^{19}$ Ao mesmo tempo, reconheceu também que a "sucessiva repetição de uma expressão que se sedimentou

\footnotetext{
18 Idiom: pode ser traduzido como idioma, frase, expressão, declaração. 
como denominador comum para o período inteiro" é justamente o que constitui estilo! Mesmo assim, o perigo reside na "tentativa de classificar, e assim congelar, arquitetura e arte vivas, quando ainda estão numa fase formativa, em um 'estilo' ou 'ismo'. Isso tende a sufocar mais do que estimular a atividade criativa". ${ }^{20}$ Essa distinção, embora sutil, sempre lhe pareceu extremamente importante e ele voltou a ela recentemente:

"Nem eu nem meus colaboradores na Bauhaus tínhamos a pretensão de chegar a um 'estilo'. Minha idéia era evitar o corriqueiro das escolas de arte, onde o diretor ou professor produz pequenas edições de si mesmo. Buscávamos um método de abordagem para dar ao aluno descobertas objetivas relacionadas com nosso modo de ver e experimentar fatos físicos e psicológicos. Isso é muito diferente de trabalhar conscientemente rumo a um estilo. De fato, é claro que o historiador, olhando o passado, perceberá certo estilo e expressão da Bauhaus."

Sua desconfiança em relação à verbalização prematura o leva a uma posição característica:

"Na minha opinião, estilos devem ser nomeados pelos historiadores apenas para períodos passados. No presente nos falta a atitude desapaixonada necessária para um julgamento impessoal do que está acontecendo. Por que não deixamos ao futuro historiador resolver a história do crescimento da arquitetura de hoje - e voltar ao trabalho e deixar crescer?"

Gropius, com seus antecedentes protestantes e educação prussiana, nunca estava ocioso. Acreditando na "cidadania comum de todas as formas de trabalho criativo", ele podia projetar uma maçaneta ou uma linha de mobília de produção em massa com a mesma concentração e ânimo que dedicaria a um 
grande teatro ou a um plano para uma cidade. Sua imaginação e versatilidade como projetista industrial já haviam sido definidas antes da guerra, quando projetou um vagão diesel de autopropulsão, o tecido para estofados para o vagão dormitório, mobília de aço para um couraçado e mobília de luxo para uma mansão. Seu domínio teórico dos problemas de projetos industriais fica claro nos artigos que escreveu para os anuários da Werkbund, associação da qual era membro ativo. Em 1913, estava saudando o "poder monumental" e "majestade não reconhecida" dos silos americanos para grãos: o trabalho anônimo de trabalhadores práticos poderia "suportar a comparação com as construções do Egito antigo". No ano seguinte, contribuiu com um artigo sobre o desenho de "automóvel e vagão de trem, navio a vapor e barco a vela, nave aérea e avião". ${ }^{21}$ Após 1919, literalmente não existia na Bauhaus nenhum projeto industrial, de colheres de prata a automóveis, que não contasse com a participação de Gropius, tanto como cabeça da escola, como projetista ativo.

Mas o projeto para a Bauhaus, quando ela mudou para Dessau, foi o maior desafio de toda a sua carreira. Talvez porque fosse o cliente com o qual tivesse mais intimidade e cujas necessidades melhor conhecesse: ele era o arquiteto da instituição, de sua filosofia e currículo, não só de sua carapaça física. O complexo Bauhaus é uma bela demonstração de sua convicção de que "arquitetos devem conceber os edifícios não como monumentos mas como receptáculos do fluxo de vida ao qual devem servir".22 Ele conhecia intimamente o fluxo de vida da Bauhaus; se hoje admiramos a facilidade com que os cinco elementos se encaixam - salas de aula, salas administrativas, oficinas,

\footnotetext{
${ }^{21}$ Siegfried GIEDION, Walter Gropius: work and teamwork (New York, Reinhold, 1954), p. 22. 
áreas sociais e dormitórios -, é porque as formas derivaram de suas funções. Nada pode ser adicionado a essa composição ou dela ser subtraído. É um clássico justamente porque abjurou qualquer indulgência pessoal, fazendo de si mesmo, podemos até dizer, o puro veículo ou meio do processo de projetar.

A qualidade que distinguiu sua carreira da de Wright ou Mies tem sido sua explícita responsabilidade social. Isso teve importantes conseqüências para a arquitetura, pois ele sempre a interpretou não meramente como uma solução, na arquitetura, para problemas sociais urgentes (e.g., moradia e planejamento urbano), mas como a expressão numa "linguagem da forma supra-individual e que pode ser ensinada". ${ }^{23} \mathrm{~A}$ atração da realidade social tal como a entropia que direciona a flor para o sol orientou Gropius para longe do íntimo, do pessoal, do subjetivo, o que, necessariamente, restringiu a cor e a paixão com que, como artista, poderia ter tingido seus trabalhos. É evidente que seu temperamento também desempenhou importante papel aqui: a racionalidade o teria impedido de cometer atos de subjetivismo como Taliesin ou Ronchamp.

Com tal atitude filosófica, Gropius ocupa uma posição exatamente oposta à de Wright, Mies ou Le Corbusier. Esses homens são, acima de tudo, arquitetos polêmicos. Seus edifícios devem ser entendidos como eles próprios os entendem - isto é, como as declarações mais contundentes e persuasivas que poderiam formular para uma convicção artística. Nenhum deles poderia aceitar a teoria do "instrumento impessoal" de Gropius.

A própria estrutura da mente de Gropius estimulava a especulação social. Diferentemente de Wright ou Mies, nunca foi capaz de focar sua atenção integral no projeto de um edifício particular, excluindo seu contexto social. 
Como Le Corbusier, sempre foi compelido a examinar o organismo maior do qual o edifício era apenas uma célula. Gropius escreveu:

"Minha idéia do arquiteto como coordenador - cujo negócio é unificar os vários problemas formais, técnicos, sociais e econômicos que surgem em relação a um edifício - me levou inevitavelmente, passo a passo, do estudo da função de uma casa ao da rua; da rua à cidade; e finalmente às implicações ainda mais vastas do planejamento regional e nacional." 24

Além de examinar, passo a passo, a tessitura da sociedade moderna, ele foi forçado a comentá-la. Embora isso o levasse a se expor, conta como crédito a seu favor o fato de ter sempre escolhido um curso de ação de princípios (e não meramente conveniente). Preferiu mudar a Bauhaus para Dessau, em 1925, a se submeter às demandas reacionárias do governo Weimar. Quando as diferenças fundamentais entre ele e o governo de estado emergiram em 1928, preferiu demitir-se a afundar a Bauhaus. E em 1934, melhor do que encarar a vida da Alemanha de Hitler, optou por deixar sua terra natal para sempre.

Num esforço para proteger (ou pelo menos isolar) a escola das convulsões políticas que a cercavam, Gropius proibiu qualquer atividade política por parte da equipe ou dos estudantes. No fim, porque o peso da ira direitista parecia ser direcionada contra ele, Gropius tentou desviá-la da Bauhaus ao pedir demissão como diretor. Mas nada disso a salvou dos nazistas. Embora o programa político da Bauhaus pudesse tender à esquerda (não mais do que um leve cooperativismo), seu programa estético era extremamente radical. E isso os fascistas loucos compreendiam. A Bauhaus representava a liberação total da personalidade criativa do ecletismo servil do passado. Apregoava o integral e livre exame 
dos fundamentos do projetar pela reconstrução de um mundo visual da forma. Assim, havia corajosa e consistentemente atraído alguns dos artistas mais avançados da Europa. Do ponto de vista prático, como apontou Giedion:

"(...) é mera loucura colocar em risco a reputação e posição pela indicação de artistas como Klee, Kandinsky, Feininger, Schlemmer e Moholy-Nagy como funcionários do governo em uma instituição do estado: artistas cujo significado era apreciado apenas por um círculo restrito e cujo trabalho incitava fortes expressões de afronta, abuso e abominação através da Alemanha"...25

Em suas publicações esposava movimentos como o cubismo e o nãosubjetivismo, artistas estrangeiros como Mondrian, van Doesburg e Malevitch. Essa política determinada trouxe em sua defesa tudo o que havia de mais saudável na cultura alemã: os arquitetos Beherns, Mies van der Rohe, Poelzig; os escritores Werfel, Sudermann, Hauptmann; o pintor Kokoschka; o compositor Schönberg; o produtor Reinhardt; o cientista Einstein. Em suma, Gropius colocava-se - como sempre - ao lado da vida; os nazistas entendiam isso e não podiam perdoar. 


\subsection{0 ensino da arquitetura no Vkhutemas e na Bauhaus}

No início do século XX surgiu na União Soviética o Instituto Vkhutemas como unificação de três escolas: Escola de Arquitetura de Moscou, uma academia que existia desde 1865; Seção de Arquitetura da Escola de Pintura e Escultura, fundada em 1918; e Estúdios Livres do Estado, criados a partir de 1918. O Instituto mantinha relações com a maioria dos grupos artísticos e culturais, como o Comissariado do Povo para a Educação (por meio da Izo) e o Instituto da Cultura Artística (Inhouk). Controvérsias a respeito da orientação pedagógica surgiram no âmago da escola e estouraram em 1924 contra a "reação artística que tinha retomado vigor no interior do Vkhutemas", confronto, a rigor, entre os produtivistas e os formalistas; a contradição entre forma e objeto firmava-se, mas desconectada das questões inerentes à planificação e produção artística e à arquitetura. O empirismo produtivista não bastava para estabelecer uma condução política e social que sintetizasse as relações entre objeto-casa-cidade e plano econômico e social.

O Instituto, contudo, contribuiu de forma positiva para a formação de artistas e para a discussão de vários problemas levantados a partir da arquitetura e, em seguida, do urbanismo. A crítica aos meios tradicionais e, principalmente, a supressão da dualidade artificiosa entre arquiteto e engenheiro contribuíram para uma discussão mais adequada da problemática do construir. A preocupação didática de fazer com que os estudantes absorvessem uma prática de canteiro constituiu um enorme avanço em relação ao passado. O ensino sociológico e político também contribuiu para ampliar o campo de visão dos alunos, incorporando a precisão econômica ao fazer artístico e cultural coerente. A formação dispensada nos cursos estribava-se em: 
1. Um curso fundamental de dois anos, no sentido de formar construtores e técnicos em edificação.

2. Um curso voltado para a arquitetura, de três anos, que buscava formar arquitetos-artistas.

3. Uma área de pesquisas.

O curso fundamental oferecia uma formação que se estendia por diversos domínios complementares como: sociologia, política, física, química, matemática e geometria, e principalmente uma formação de desenho e suas técnicas, uma iniciação ao domínio dos materiais. O curso de arquitetura ampliava as cadeiras político-sociais, ao mesmo tempo que aprofundava os estudos sobre a tecnologia e os materiais. A se destacar que o curso compreendia estudos sobre urbanismo, o que era raro na época. Pesquisavamse as questões do ambiente, da influência da forma arquitetônica sobre o psíquico. Perseguia-se o saber nas questões relativas à organização econômica e à padronização na produção da arquitetura. Por fim, as pesquisas no domínio das metodologias pedagógicas da arquitetura constituíam por si só um terceiro setor de investigação na escola.

Encontram-se nas preocupações e abordagens pedagógicas do Vkhutemas, e mesmo em suas realizações, paralelos e pontos comuns com a Bauhaus, tendo efetivamente ocorrido um certo intercâmbio entre a vanguarda européia e os arquitetos soviéticos nos anos de 1920. As experiências conduzidas pelos arquitetos e urbanistas nos países capitalistas industrializados tiveram repercussões sobre as idéias de seus confrades na União Soviética. Essa questão não deve ser subestimada, mas se L'Ésprit Nouveau na França, De Stijl, na Holanda, e a Bauhaus, na Alemanha, marcaram os arquitetos contemporâneos soviéticos, a influência destes últimos sobre todos esses grupos não foi 
menos importante. Resultado da fusão em um só organismo de diferentes estabelecimentos que, até a revolução, ensinavam arquitetura em Moscou segundo os métodos tradicionais, baseados na cópia do antigo e a habilidade do traçado que resultava em claro-escuro.

As semelhanças, particularmente com os métodos da Bauhaus, também aberta em 1920, são evidentes: criação de um ensino comum introdutório para todas as disciplinas artísticas; curso concebido não como um ensino didático, mas como uma série de experiências que orientavam o aluno para a pesquisa pessoal e a descoberta, rejeitando totalmente o academismo e suas receitas; tendência marcante para uma síntese das artes; abandono da pintura de cavalete em proveito de meios de expressão integrados à arquitetura, etc. Mas a Bauhaus instituiu-se definitivamente como uma escola de artes aplicadas adaptada à era industrial, e o ensino de arquitetura só foi introduzido ali, em 1927, por Hannes Meyer, nomeado professor de arquitetura pelo diretor da Bauhaus, Walter Gropius. No Vkhutemas a arquitetura era ensinada desde 1920. Nesse ensino, os métodos psicotécnicos denunciados como "idealistas" pelos críticos da Asnova (Associação de Novos Arquitetos) têm um papel fundamental. Como na Bauhaus, os alunos são incentivados a estudar a função da cor, dos volumes, das texturas, etc. e os fenômenos ligados à visão e à percepção. Escola e academia livre ao mesmo tempo, o Instituto mantém estúdios dos melhores artistas modernos e é freqüentado por cerca de quatro mil estudantes nos cursos de arquitetura, artes gráficas e tipografia, escultura, obras de madeira e metal, obras têxteis e pintura. Em 1924 é reorganizado, conforme já foi dito, com a implantação de um "ensino fundamental" dividido em dois cursos: um para o estudo da "disciplina do espaço e seus problemas abstratos", obrigatório para todas as oito áreas de 
concentração de conhecimento da escola, e outro exclusivamente orientado para as questões essenciais da criação arquitetônica. Esse método de ensino foi, em seguida, adotado e desenvolvido no âmbito da Bauhaus.

Diante do entusiasmo da implantação desses métodos então inteiramente novos, alguns imaginaram um sistema no qual seria possível provocar voluntariamente uma ou outra emoção pelo uso racional do vocabulário formal da arquitetura. Mas não é menos verdade que o Vkhutemas será uma das duas únicas escolas de arte do mundo fundadas sobre métodos novos de ensino e a única a ensinar uma nova arquitetura, até a abertura da seção de arquitetura da Bauhaus, em 1927.

Em 1924, quando apareceu em Moscou o livro Estilo e Época, do arquiteto Moisei Ginzburg, a situação da União Soviética era muito diferente daquela em que viviam os arquitetos da Europa Ocidental. Na União Soviética, o que não havia era, precisamente, as possibilidades técnicas para a renovação da arquitetura e do urbanismo. A obra de Ginzburg, que, a partir de 1926, foi um dos principais líderes do movimento de arquitetura contemporânea, foi a primeira manifestação de uma teoria da arquitetura na União Soviética. Foi a partir dessa obra e de um artigo publicado num dos primeiros números da revista SA (Arquitetura Contemporânea) que se pode discernir os traços comuns e as diferenças entre a nova arquitetura que se iniciava na União Soviética e aquela que durante muito tempo vinha traçando seu caminho na Europa Ocidental e nos Estados Unidos. O ponto comum entre elas era, sobretudo, o que se referia ao termo funcionalismo, novo na época, que se tornou universal. Mas esse funcionalismo que na Europa se apoiava sobre as realidades técnicas, na União Soviética estava somente na vontade de seus partidários e não nas experiências reais. Segundo as palavras de Lênin, citadas nos periódicos 
construtivistas, os arquitetos soviéticos acreditavam que "para conhecer realmente um objeto, é necessário compreender, estudar todos os seus aspectos; todas as suas conexões internas e externas". Referia-se ao problema do desenho como um complexo integrado e tendia a resolver o problema enquanto totalidade. Moisei Ginzburg escreveu: "A forma é uma função X, que o arquiteto tem que voltar a avaliar segundo as precondições em constante mudança determinantes do fazer da forma". No jargão moderno, que não está distante dos construtivistas, diríamos que aspiravam a modelar toda a resolução do espaço que envolve a forma. M. R. Savchenko, arquiteto e teórico soviético, retomando o debate histórico, em 1980, descreveu a "investigação arquitetônica" como uma investigação que tem "orientação dupla, na direção dos aspectos sociais e espaciais da arquitetura" e que essa orientação dupla se "repete em uma diferenciação entre os parâmetros de um edifício e suas propriedades".

As análises sistemáticas dos soviéticos dessas duas dimensões do problema do desenho e de suas infinitas relações têm origem diretamente no pensamento construtivista da década de 1920. "Os parâmetros" de Savchenko "são as medidas diretas de uma construção de seus espaços, dos consumidores envolvidos e das atividades que abriga. As propriedades são as medidas das reações dos consumidores diante dessa mesma construção. Portanto, tanto são medidas obtidas por meio de um 'intermediário', medidas de decisões tomadas, de situações simbólicas postas, na medida que o usuário 'penetre' o edifício real (...). As propriedades e os parâmetros refletem o objeto como um todo, mas o fazem através do prisma das atitudes sociais diante da arquitetura no contexto de certo corpus de valores arquitetônicos". Ginzburg insistia que "de nenhuma maneira o artista perde sua criatividade simplesmente porque sabe com clareza o que quer, o que busca e em que consiste o sentido de 
sua obra. A criatividade subconsciente, impulsiva, deve ser substituída por um método clara e distintamente organizado, que economize energia do arquiteto e que transfira o excedente dessa energia à invenção e à força do impulso criador". Nas palavras de outro membro fundador e mais jovem do grupo, Nikolai Krassilnikov: "A intuição não se elimina; simplesmente tem que ocupar seu lugar apropriado". O construtivismo se distinguiu pela negação em deixar que os problemas metodológicos ficassem à mercê da intuição.

Os construtivistas acreditavam que o modo de trabalhar do arquiteto soviético devia exibir a mesma tendência de construir totalidades dos mundos materiais e cognitivos nos quais esse arquiteto estava "construindo". Precisamente para "garantir" que no trabalho de desenho se preservasse uma integração monística dos aspectos materiais e cognitivos do mundo, formalizaram seu "método de criatividade funcional", ou, de forma mais abreviada, posteriormente, "método funcional". O método consistia num conjunto de procedimentos por meio dos quais seria apropriada objetivamente a totalidade dos fatores que, em sua opinião, incidem num projeto, "passando da primeira para a segunda prioridade", gerando um "organismo espacial básico" com grande refinamento técnico e formal. O corpo de conhecimentos concomitantes era objeto de "trabalho de laboratório". Como explicava Ginzburg em 1927: "Metodologicamente, para submeter tudo à avaliação, o construtivismo recorre a muitas outras disciplinas científicas e utiliza o método de laboratório, isolando uma reação, ou seja, tomando um processo na sua integridade" - nos termos atuais, um subsistema - "em isolamento temporal em relação aos outros, para obter as condições mais favoráveis de análise".

A exposição completa do método de trabalho dos arquitetos construtivistas foi divulgada no auge de sua atividade, em fins de 1927, num artigo 
que Ginzburg publicou em sua revista Arquitetura Contemporânea (SA). Intitulado "O construtivismo como método de laboratório e trabalho de ensino", o artigo era um "plano esquemático para o curso de teoria da arquitetura que o autor ensinava nos departamentos de arquitetura do Vkhutemas (Instituto Técnico Artístico de Moscou) e MTVU (Escola Técnica Superior de Moscou)". Assim os construtivistas ensinavam a projetar. Era como eles mesmos operavam o projeto e o padrão por meio do qual as diferentes "investigações de laboratório" realizadas por eles e por outros - em ciência da construção, em aspectos sociais, em psicologia visual, em desenvolvimento de linguagens formais, etc. - eram organizadas dentro do processo de projeto de novos edifícios para catalisar o processo de "construir o novo modo de vida".

Esse plano esquemático de cinco partes foi depois publicado no Diagrama 2. O Diagrama 1 apresenta o desenvolvimento das idéias desse esquema através dos primeiros escritos de Ginzburg, que datam dos anos anteriores à publicação da SA, 1927 e 1926, da formação do grupo arquitetônico construtivista OSA, em fins de 1925, e do "manifesto original" de Ginzburg sobre arquitetura construtivista no livro Estilo e Época, de 1924. 


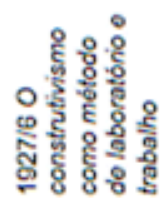
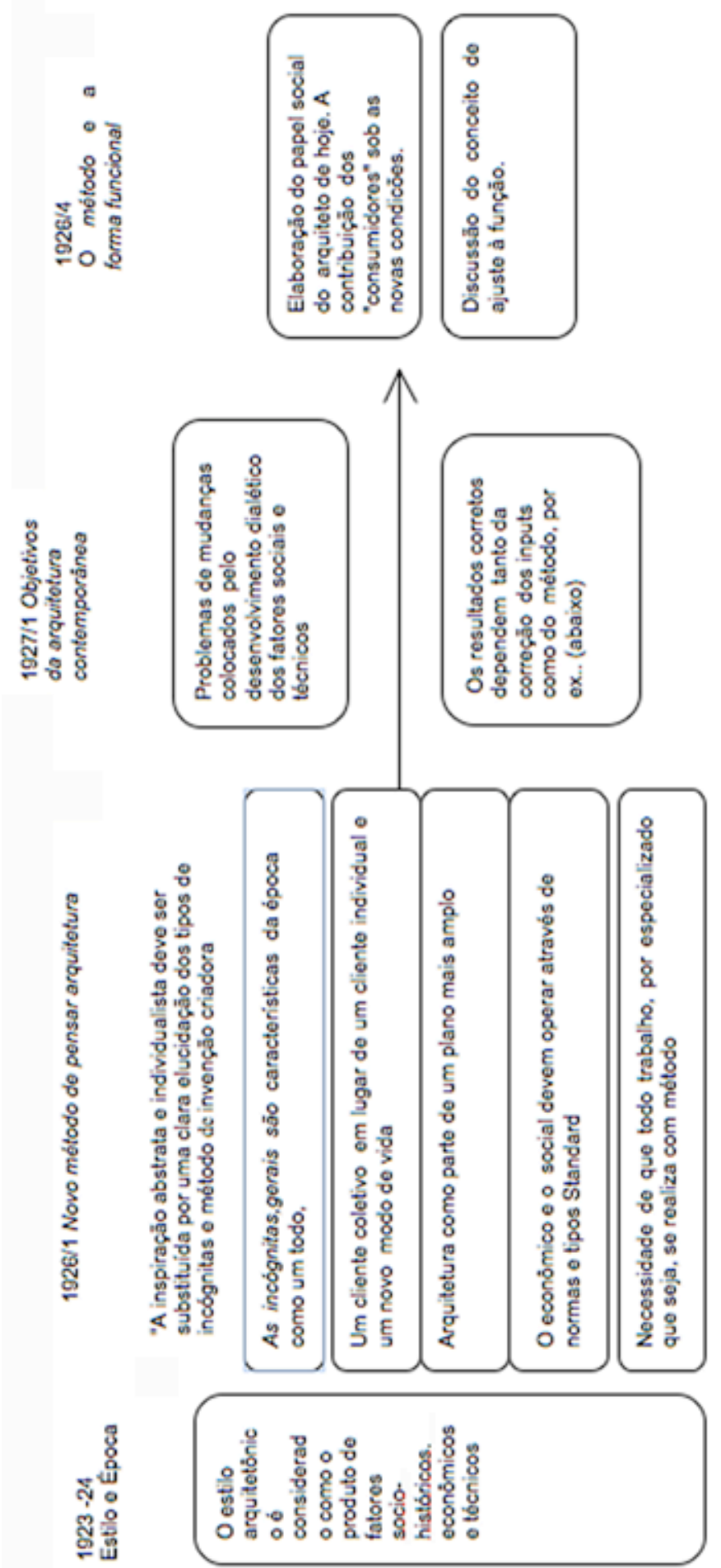

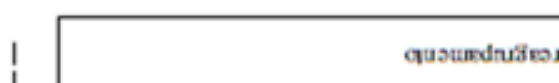

Guvtanduses

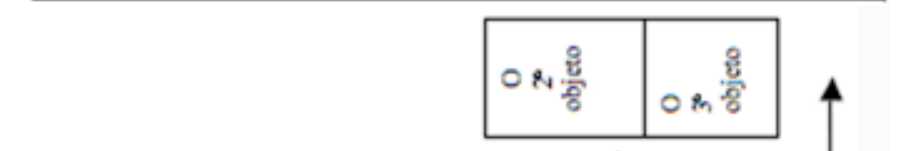

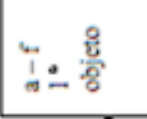

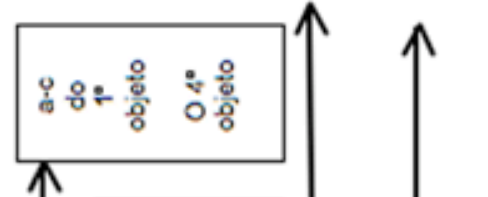

1

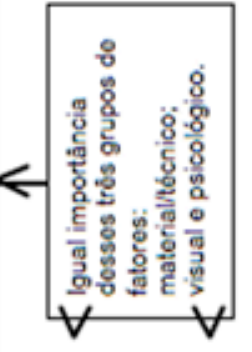

婙

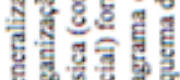

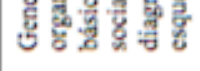

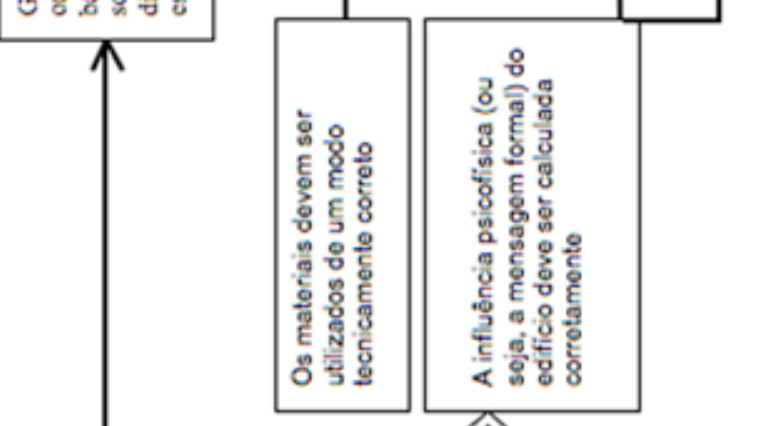


Consideração de todas as PRECONDICÕES tanto EXIGÊNCIAS COMO
taSS POSSIBILIDADES
Consideração da PERCEPÇÃO e da CLAREZA VISUAL

1. As precondições sociais e produtivas do plano

a. Um estudo de como estas podemmudarpor meio de mudançassociais e tecnológicas-destacandonãoas dimensões e sim a dinâmica, mudandoo uso dos espaços através dos tempos

b. Construir os DIAGRAMAS DE FLUXO - passando do particular para o geral, que é o PRIMEIRO DIAGRAMA ESPACIAL DO EDIFÍCIO

c. Estudar os esquemas do equipamento que os itens anteriores requerem

d. Estabelecer as dimensões desse equipamento junto com sua DISTRIBUIÇÃO ESPACIAL, correta.

e. Estudar as necessidades MEIO AMBIENTAIS das atividades e os processos implicados - temperatura, luz, acústica etc.

f. Construir o esquemas do CONDENSADOR SOCIAL sobre a base desse material estabelecendo um organismo integrado como um PROTÓTIPO ESPACIAL.

2. As pré condições técnicas e de construção da realização.

a. Estudo dos MATERIAIS DE CONSTRUÇÃo à disposição destacando o máximo possível seu papel inovador utilizando, quando possível os mais avançados (ou seja, com menor massa)

b. Estudo dos MÉTODOS E SOLUÇÕES ESTRUTURAIS que são apropriadas à luz das precondições do plano; estudar seu caráter e as possibilidades técnicas que possuem destacando os métodos mais RACIONAIS de construção segundo as possibilidades espaciais.

c. Estudas as condições e métodos de REALIZAÇÃO PRÁTICA implícitos em relação a cada detalhe e ao todo arquitetônico - os atuais MÉTODOS DE CONSTRUÇÃO, buscando o máximo de INDUSTRIALIZAÇÃO, com todas as conseqüências arquitetônicas que isso implica

O $2^{\circ}$ Objeto é observar as FORMAS MATERIAIS cristalizadas como condensador social, em função do PROBLEMA DA PERCEPÇÃO, de modo que a atividade útil do condensador seja aumentada pela clara percepção que o usuário tenha dessa atividade.

O construtivismo vê a FORMA como ATIVA e não como passiva. Busca a ORGANIZAÇÃo DA PERCEPÇÃo e isso é parte de sua tarefa tanto quanto a organização de fatores materiais.

Para isso existem os seguintes estágios:

A. O que se segue deve ser estudado EM ORDEM, desde as propriedades PARTICULARES do objeto particular até as questões GERAIS.

1. O CARÁTER FUNCIONAL do objeto, seupropósito

2. Seu ESTADO - "estático ou em movimento?

3. MATERIAL - suas propriedades e faktura, cor, etc.

4. As ESCALAS RELATIVAS das partes e o todo.

5. A ESTRUTURA TECTÔNICA do objeto

(Como está construído.Os vínculos entre as partes e o todo.)

6. FORMA COMO VÍNCULO um volume 3-D, um espaço definido

7. As principias marcas, distintivas do objeto enquanto ORGANIZAÇÃO ESPACIAL a) Percepção a respeito das características fundamentais do objeto

b) Como ORGANIZAR A PERCEPÇÃO para deixar CLARAS as relações dos elementos que compreendem o abjeto, seus TAMANHOS absolutos e relativos, a clareza de toda SUA FORMA ESPACIAL GERAL.

c) Percepção da UNIDADE E DO TODO

d) Percepção sobre as INTER-RELAÇÕES ESPACIAIS e do ESPAÇO em geral.

B. Em relação à percepção destas características, o segundo estágio de estudos AGRUPA COMO acima a-d

Consideração do USO RACIONAL dos ELEMENTOS FORMAIS da arquitetura.

Consideração das POSSIBILIDADES DE EDIFICAÇÃO INDUSTRIALIZA

Reordenação
O $3^{\circ}$ Objeto é estudar OS ELEMENTOS DE ARQUITETURA que são OBJETO DE PERCEPÇÃO, em ordem de complexidade, a saber:

\begin{tabular}{ll} 
A. SUPERFICIE & B. VOLUME, enquanto. Sistema de superfícies \\
\hline
\end{tabular}

C. A coexistência volumétrica de MUITOS CORPOS [intersectados, contíguos ou relacionados mas separados)

TEMPO E MOVIMENTO enquanto MÉTODOS DE ORGANIZAR O ESPAÇO; espaço enquanto interelaçãode volumes individuais ENTRE SI E CO COM O TODO; a LOCALIZAÇÃO de um objeto no espaço; o espaço enquanto fator isolante; o espaço como a ORGANIZAÇÃO de dimensões NÃO RELACIONADAS, OU PARCIALMENTE RELACIONADAS (espaço-rua-cidade, etc)

ATRAVÉS DESSE PROCESSO devem ser observados DOIS PRINCIPIOS IMPORTANTES:

1. Nessa desmontagem de laboratório não há que se preocupar com A EXPRESSÃO ARTíSTICA EM GERAL, pois oconstrutivismosó compreende a expressividade concretamente, em relação com OBJETIVOS E INTENÇÕES DEFINIDOS, como algo específico a seu contexto.

2. Todos os estudos comportam o perigo básico da CANONIZACC̃̃O de certas formas, de convertê-las em elementos fixos do vocabulário do arquiteto.O Construtivismo LIDERA A BATALHA contra esse fenômeno e estuda esses elementos básicos da arquitetura como algo CONTINUAMENTE EM MUDANÇA em conexão com as precondições mutantes da situação criadora das formas. Nunca admite, portanto, A FIXAÇÃO DAS FORMAS. A forma é uma incógnita, um X que sempre será aval pelo arquiteto. Portanto, DEVEMOS TAMBBÉM ESTUDAR não só os elementos da arquitetura mas também os MÉTODOS DE SUA TRANFORMAÇÃO. Temos que

estudar COMO ESSA FUNÇÃO ' $X$ ' MUDA; como uma mudança no plano afeta a forma.

Entre esses tipos de transformação podemos incluir.

1. mudanças externas do objeto

2. desmembramento vertical ou horizontal do objeto;

3. corte da superfície ou volumes a partir do interior (portas, janelas etc)

4. corte da superfície ou volume a partir do exterior (mudança de silhueta)

5 difererşas no material, cor ou feitura do objeto

6.mudança das relações espaciais de suas partes

7 introdução da mobilidade nas partes ou no todo.

8. introdução de novos elementos (operativos) etc.

Em tudo isso 3 coisas são vitais:

1. O método de transformação é PARTE DAS FERRAMENTAS PRÁTICAS, REAIS DO ARQUITETO.

2. Essa TRANSFORMAČ̃̃O IMPLICA NÃO SOMENTE A ESTÉTICA, mas também a reorganização dos ELEMENTOS CONSTRUTIVOS OPERATIVOS.

3. O que estamos mudando é o objeto material, mas isso se faz no CONTEXTO DE SEU PROPÓSITO ESSENCIAL e de sua PERCEPÇÃ́O PELO USUÁRIO.

O $4^{\circ}$ Objeto é o estudo dos PROCESSOS INDUSTRIAIS, não para IMITAR as formas industriais mas sim para identificar AS CARACTERÍSTICAS que serão AS DE INSDUSTRIALIZAÇÃO DA ARQUITETURA, Portanto estudamos.

1. De que modo a tecnologia industrial CRIA uma forma funcional

2. Os processos particulares e característicos da produção industrial que DEIXAM UMA MARCA NO CARÁTER DE SEUS PRODUTOS.

Isto deve se fazer com relação aos COMPONENTES INDIVIDUAIS do edifício EM RELAÇÃO COM TODOS OS ORGANISMOS (cozinhas etc)

Reordenação O $5^{\circ}$ Objeto é a RESTAURAÇÃO DA TOTALIDADE ORGÂNICA. Isto se aplica tanto se o método funcional foi utilizado para a ANÁLISE DE UM PRODUTO EXISTENTE, COmo para a CRIAÇÃO DE UM OBJETO NOVO ( Qualquer desses processo implica nas 4 seções anteriores) 
Antes, em 1922, quando os primeiros artistas construtivistas, como Alexei Gan e Alexander Rodchenko, formularam o perfil desse "artista construtor" que aspiravam formar por meio das disciplinas que ensinavam no Vkhutemas, não estavam falando de um khudozhnik-stroitel - um artista construtor, um herdeiro da tradição de Artes e Ofícios. Pensavam em um khudozhnikkonstruktor, um artista desenhista. O konstruktor é um especialista, um desenhista altamente qualificado na indústria, na engenharia ou na eletrônica, enfim, quem projeta, quem concebe. Para ele, dizainer seria insultante, como considerá-lo um estilista. Já os racionalistas russos do século XIX usavam o adjetivo konstruktivnyi como um grande elogio para uma arquitetura claramente "construída". O verbo konstruirovat apresenta-se com muitas alternativas: "construir, desenhar, formar, organizar" e os construtivistas eram Konstruktivisty. Estavam preocupados em entender como um arquiteto organiza ou estrutura seu pensamento; como organiza o trabalho.

Também estavam muito interessados na stroitelstvo em todas as suas dimensões. A palavra russa para construção social ou para construção de um edifício é stroitelstvo, considerada num espaço e tempo real; o stroitel é o construtor de uma obra real, com as botas cheias de barro. "Construção social", nesse sentido, pode ser um conceito estranho para nós, mas a compreensão desse conceito ilumina a forma pela qual o pensamento soviético enfoca as possibilidades nessa área. Como soviéticos leais, a construção social, e, em particular, a "construção do socialismo" eram a razão de ser, inquestionável, de seu trabalho. A construção material é o meio físico pelo qual a arquitetura pode existir; o materialista, em particular, deve sempre levar em conta os obstáculos e as possibilidades que oferecem todos os meios, mesmo que nos problemas de konstruktsiia as escolhas se baseiem mais em 
princípios filosóficos ou estéticos do que em princípios físicos. O princípio estético define as escolhas entre os sistemas possíveis de construção formal. Os problemas filosóficos da konstruktsiia são o enfoque geral da tarefa de projetar, o ordenamento dos dados e a prioridade dos objetivos, os métodos de síntese e os critérios de avaliação. 


\section{$3 \quad 0$ ensino da arquitetura no Brasil}

\subsection{A origem do ensino da arquitetura no Brasil}

A formação em arquitetura dos profissionais na Europa tem origem na relação de mestre e aprendiz, consolidada ao longo dos séculos através das corporações profissionais, com regras e sistemas de controle bastante eficazes e extremamente rígidos.

A estruturação da profissão de arquitetos e engenheiros em Portugal não foi diferente. As corporações montavam diversas estratégias de controle e manutenção tanto da qualidade da produção como do caráter freqüentemente monopolista da prestação de serviço. Uma das estratégias de garantia da qualidade era a organização de cursos teóricos e práticos ministrados por profissionais considerados habilitados (mestres-de-obras, engenheiros militares e arquitetos), que transformavam o canteiro de obras em local de aprendizado. O mais estruturado desses cursos foi montado por ordem de Felipe II, em 1594, com o nome de Aula de Risco do Paço da Ribeira. O responsável pelas obras reais em Portugal era intitulado Engenheiro-Mor do Reino, mesmo que fosse arquiteto por formação. Na origem dessas profissões, portanto, não há uma diferenciação clara entre engenheiro e arquiteto. A exceção foi a nomeação, em 1750, de João Ludovici como Arquiteto-Mor, ato que, para alguns estudiosos, marca, em Portugal, o início do processo de separação entre as duas profissões.

Várias escolas de arquitetura e engenharia militar vão sendo organizadas ao longo do reino, sendo uma das mais importantes a Aula de Artilharia e Esquadria, montada em 1641 sob o encargo do engenheiro militar Luís Serrão Pimentel, autor do primeiro livro editado em Portugal sobre o assunto, 
denominado Método lusitano de desenhar as fortificações. Esse curso deu origem à Academia Real da Marinha, que exerceu muita influência na montagem das escolas de engenharia em Portugal.

Em 1777, durante o reinado de D. José I, o Colégio dos Nobres, que recebia como estudantes a elite da nobreza portuguesa, instituiu em seu curso estudos de arquitetura civil, militar e de desenho. Esses cursos serão a base da criação da Real Sociedade Marítima Militar e Geográfica, que coloca com precisão a discussão científica sobre as questões da engenharia e da arquitetura.

A primeira notícia que se tem sobre o ensino da engenharia e arquitetura no Brasil remonta a 1699, quando, por meio de carta régia, se institui o ensino formal da arquitetura militar nas capitanias em que havia engenheiros. Um dos mais famosos engenheiros militares portugueses no Brasil foi José Fernandes Pinto Alpoim, autor do projeto do Palácio dos Governadores em Ouro Preto. Alpoim foi nomeado em 1738 por carta régia para responder pelo curso de Artilharia. Foi encarregado também do curso de Fortificação, tendo recebido proventos na qualidade de "mestre e lente da Academia Real". ${ }^{26}$

A soma desses esforços culminou com a montagem, em 1862, do Instituto Politécnico Brasileiro, que tem por objeto o estudo e a difusão dos conhecimentos teóricos e práticos dos diferentes ramos da engenharia e das ciências e artes acessórias. Como veremos, essa é uma das vertentes da fundação da Escola Politécnica, que terá papel fundamental na estruturação do ensino da arquitetura no Brasil.

${ }^{26}$ Nireu Oliveira CAVALCANTI, Arquitetos e engenheiros, p.42. 


\subsection{A Politécnica}

A efetivação do ensino institucional da engenharia em São Paulo deu-se em 1894 com a fundação da Escola Politécnica da Universidade de São Paulo. A Escola Politécnica de Engenharia se desenvolveu em diversas fases, que, de maneira geral, ocorrem em paralelo ao desenvolvimento da própria profissão. Talvez seja essa a razão pela qual a fundação da Escola de Engenharia da Universidade Mackenzie tenha ocorrido quase simultaneamente à da Politécnica, em 1896, sob forte influência norte-americana. Conforme veremos adiante, a coincidência de datas é uma constante: a separação das escolas de arquitetura ocorrerá em datas próximas e muitas de suas reformas também acontecerão em datas correlatas.

Em trabalho que resultou de sua tese de doutoramento, a arquiteta Sylvia Ficher delimita e explicita com clareza essa correlação, ao historiar o desenvolvimento da profissão de engenheiro, engenheiro-arquiteto e arquiteto, com os ritmos e mudanças ocorridas no processo e na estruturação do ensino dessas profissões. ${ }^{27}$

Na primeira fase da Politécnica, é praticamente impossível discernir entre uma profissão e outra, recebendo as duas atividades encargos semelhantes e muito imbricados quanto a seus conteúdos. O mesmo ocorrerá na Escola de Engenharia do Mackenzie. Alguma diferença já se estrutura desde o início nas duas instituições, quanto a objetivos e conceitos essenciais. O episódio da disputa entre Estado e Prefeitura, representados por Vitor Freire e Samuel das Neves, respectivamente, e que culminou com a vinda de Joseph-Antoine Bouvard a São Paulo, pode ser um indício dessa diversidade que, de algum modo, persiste até nossos dias.

27 Sylvia FICHER, Os arquitetos da Poli, p. 28. 
Entende-se o campo de atividades da engenharia e da arquitetura como implicitamente dividido entre obras públicas e obras particulares. Esse entendimento é importante porque explicitará, na fase seguinte dessas escolas e das duas profissões, a primeira divisão clara de atividades, estabelecendo como papel do engenheiro as obras relativas a infra-estrutura urbana, pontes, viadutos, etc. e aos arquitetos os trabalhos relativos à construção de edifícios. É importante salientar que a responsabilidade sobre a construção de edifícios inclui a obra e a administração da obra, sendo o projeto uma parte do processo, mas sem a importância que terá décadas depois. Essa situação ajuda a explicar, por exemplo, por que o engenheiro Ramos de Azevedo valorizava muito mais o papel de "administrador construtor" da edificação a ser realizada do que o papel de arquiteto projetista da obra.

Entretanto, desde os seus primórdios, as escolas ofereceram algumas possibilidades de escolha entre as várias modalidades da engenharia.

Conforme o primeiro regulamento da escola, os alunos aprovados para a Politécnica puderam escolher entre os cursos de engenheiro civil, industrial ou agrícola. Havia um curso anexo de artes mecânicas para formação de mãode-obra técnica. No projeto que veio a ser o segundo regulamento da escola, de 20 de novembro de 1894, além dos cursos de engenheiro civil, industrial e agrônomo, estava previsto um curso de engenheiro-arquiteto. Dessa forma, institucionaliza-se naquele ano o ensino da arquitetura em São Paulo.

O regulamento estabelece também uma estrutura didática que compreendia um curso fundamental (dividido em um ano de curso preliminar e dois anos de curso geral) e os cursos especiais: engenheiro civil, arquiteto, industrial e agrônomo. Essa nova estrutura foi mantida até 1931, quando foi extinto pelo oitavo regulamento. 
Na Politécnica seguia-se mais o sistema germânico de ensino, apesar da difusão da pioneira escola francesa ao longo do século XIX, que tinha a particular característica de unificar, em uma única escola, o ensino do curso fundamental e dos cursos especiais. Esse sistema havia sido o modelo adotado na Polytechnikum de Karlsruhe, em 1832, com algumas variações na organização do curso de Zurique em 1834. Foi adotado na Politécnica de São Paulo muito provavelmente porque o seu principal organizador e primeiro diretor, Antônio Francisco de Paula Sousa, havia estudado em Karlsruhe, onde se formara engenheiro civil, em 1868.

Essa origem alemã da Escola Politécnica coloca uma questão que será relevante num futuro próximo e que estabelece a possibilidade de que os engenheiros-arquitetos da Politécnica, que sabidamente eram, em boa parte, fluentes em alemão, tenham conhecido os ideais da arquitetura moderna via arquitetos alemães, por intermédio da Bauhaus. Essa questão traz uma incógnita que precisaria de estudo próprio, que poderia explicar a vertente fortemente ligada à tectônica, que desde sempre marcou a arquitetura moderna em São Paulo. Como se sabe, no Rio de Janeiro o aprendizado da arquitetura ocorre a partir da Escola de Belas-Artes, e a arquitetura moderna se desenvolve sob forte influência de Le Corbusier.

Diferentemente de Paris ou do Rio de Janeiro, onde os arquitetos eram formados em escola integrada ao ensino artístico, em São Paulo a arquitetura veio a ser estudada como uma das especialidades da engenharia. Ou seja, o curso de arquitetura da Politécnica visava formar engenheiros-arquitetos, preparados para projetar e construir edificações, em contraste com seus colegas, engenheiros civis, que deveriam projetar e construir obras de engenharia: pontes, viadutos, portos, cais, estradas de ferro, de rodagem. 
Seguiram-se vários regulamentos. Contudo, não obstante as mudanças que criaram e extinguiram cursos especiais e alteraram outros, o curso de engenheiro-arquiteto não foi afetado de modo expressivo até 1918, quando foi baixado o sexto regulamento, pois, com a morte de Maximiliano Emílio Hehl em 1916, em fevereiro de 1917 foi realizado um concurso para preencher a vaga de substituto da "Quarta Seção de Artes". O resultado foi a volta, para o curso de engenheiro-arquiteto, de seus diplomados, agora como professores. Como também no ano de 1917 começara a funcionar na escola de engenharia do Mackenzie College um outro curso de engenheiro-arquiteto, parece adequado entender o período de 1884 a 1917 como o da consolidação do ensino institucional da arquitetura em São Paulo.

Foi na década de 1920 que engenheiros e arquitetos diplomados se mobilizaram corporativamente para obter o controle legal do exercício da profissão. Foi na década de 1930, resultado também da especialização do mercado de trabalho na construção, que se iniciou a caracterização do arquiteto como profissional liberal; mas a definição de sua atribuição de urbanista ocorreu na década de 1940.

É nessa fase que o desenvolvimento da atividade projetual como atividade exclusiva começa a interessar a alguns profissionais. Alguns nomes tiveram papel de destaque nesse processo. Não há como deixar de citar os engenheiros-arquitetos Cristiano Stockler das Neves, Anhaia Melo e Alexandre Albuquerque. Sobre este último o arquiteto João B. V. Artigas comenta: "arquiteto, foi professor de construção na Politécnica, e foi exatamente o homem que fazia a ponte entre a arquitetura e a engenharia. Foi o homem que estudou a insolação, foi o homem que procurou as teorias humanísticas que se dirigem em torno da higiene dos edifícios, para aplicar no funcionalismo 
de hospitais e casas... Veja que figura interessante, o Alexandre". ${ }^{28}$

Nessa época, a partir dos esforços realizados por Lúcio Costa e o "grupo do Rio de Janeiro", a profissão do arquiteto passa a ser definida como a do idealizador de obras originais e diferenciadas, do profissional liberal ocupado com a elaboração do projeto de arquitetura que resultará na obra. Posteriormente, a gestão dos projetos complementares e a responsabilidade sobre o resultado de qualidade da obra começam a se estruturar de modo claro. É significativo nesse sentido o depoimento de Oscar Niemeyer em recente entrevista, em que afirma que o conjunto de quebra-sol colocado na Obra do Berço havia sido realizado de modo equivocado. Ao tomar conhecimento do erro, custeou do próprio bolso a correção do equívoco, numa demonstração de quanto se sentia responsável pela qualidade da edificação resultante de seu projeto arquitetônico. ${ }^{29}$

É importante notar que a década de 1930 marca o final de uma etapa para a Politécnica, que, ao ser incluída entre as escolas que comporão a Universidade de São Paulo, perderá muito de seu prestígio enquanto entidade, mormente aquele poder de influência que dispunha no governo estadual. ${ }^{30}$ É curioso notar que, por razões completamente diferentes, também a Escola de Engenharia Mackenzie perde muito prestígio nessa época, tendo, inclusive, sido cassado o reconhecimento de seus diplomas. Esse fato ocorre em face do enfrentamento político entre a elite paulistana ligada ao ex-governador Washington Luís e o presidente Getúlio Vargas. Alega-se, entretanto, defasagem entre o currículo estabelecido pela instituição e as diretrizes estabelecidas pelo governo federal.

\footnotetext{
28 J.B.V. ARTIGAS, A função social do arquiteto, São Paulo, 1984.

${ }^{29}$ Oscar NIEMEYER, depoimento no vídeo $A$ vida é um sopro. 
A década de 1930 aponta a institucionalização das profissões, tarefa que o governo federal levará a cabo por meio de várias disposições de caráter trabalhista, em que a linha mestra está explícita na consolidação da legislação trabalhista de 1938. Seguindo a tendência existente desde finais do século XIX, a idéia é restringir o mercado de trabalho que envolva responsabilidade técnica de obras e projetos aos portadores de diploma de engenheiro em suas várias aplicações. A municipalidade passa simultaneamente a exigir, de modo mais agudo, a apresentação de profissional diplomado para a função de cargos técnicos relativos a engenharia e arquitetura.

Até então, a cultura da profissão designava como tarefa da arquitetura a construção de edificações, entendida no sentido amplo, em que a elaboração do projeto é parte do processo, nem sempre a mais importante. Todo o trabalho desenvolvido por Ramos de Azevedo ao longo da primeira parte do século XX é baseado nessa compreensão; daí o engano de não considerá-lo um arquiteto no sentido pleno do termo. A partir dos anos de 1940, o entendimento da profissão de arquiteto vai mudar, e ela se estabelecerá fortemente sobre o conceito de profissional encarregado de produzir o projeto arquitetônico e gerir os projetos complementares que viabilizarão determinada obra. Nessa linha é sobejamente conhecida a posição do arquiteto Rino Levi, no sentido de que a peça gráfica produzida no escritório de arquitetura deve ser de tal modo consistente e detalhada, que a obra estará assegurada quanto à sua qualidade e economia.

É nessa época também que os órgãos de classe iniciam seu trajeto para proteger e explicitar os espaços concernentes à profissão. Configuram-se e fortalecem-se vários órgãos de organização profissional, sendo os mais destacados o Instituto de Engenharia e o Instituto de Arquitetos do Brasil. 
O final da década de 1930 aponta claramente a diferença entre a prática e a conceituação das profissões de engenheiros e arquitetos. Inicia-se aí o processo de separação entre o projeto de arquitetura e a edificação de determinada obra. A década de 1940 inicia-se com a necessidade de separar a formação profissional de engenheiros e arquitetos. Na visão de muitos engenheiros-arquitetos da época, não é mais possível manter os cursos de arquitetura dentro da Escola de Engenharia. Alguns engenheiros-arquitetos como Cristiano Stockler das Neves e Luís Anhaia Melo, entre outros, trabalham pela materialização dessa certeza. Argumentando nesse sentido, Cristiano Stockler das Neves afirma que arquitetura não só não pode ser um ramo da engenharia como se configura como uma atividade artística superior às demais.

A separação entre os dois cursos se efetivará em 1945 com a criação da Faculdade Nacional de Arquitetura, da Universidade do Brasil, no Rio de Janeiro. Embora em São Paulo o curso de engenheiro-arquiteto perdure até 1954, em 1947 o curso de Arquitetura da Escola Mackenzie se separa do curso de Engenharia, o mesmo ocorrendo com o curso de Arquitetura da Universidade de São Paulo, que, no ano seguinte, se separa da Escola Politécnica.

Como explicita a arquiteta Sylvia Ficher: "Assim como no final do século XIX, no espaço de dois anos haviam começado a funcionar duas escolas de engenharia na cidade, a Politécnica e o Mackenzie, meio século depois, no espaço de apenas um ano, os cursos de arquitetura dessas escolas davam origem a duas faculdades autônomas de arquitetura. E, como acontecera com aqueles dois cursos, essas duas faculdades teriam, desde sua origem, diferentes filosofias de ensino: 'Havia uma divergência de ideal quando foram criadas a Faculdade de Arquitetura Mackenzie e a Faculdade de Arquitetura e Urbanismo. O Anhaia tinha uma concepção e o Cristiano tinha outra: o Cristiano muito 
influenciado pela formação americana e o Anhaia muito influenciado pela francesa, mais humanista, mais culta (Prado, 1985). Na verdade a situação foi bem mais paradoxal, de vez que a formação americana de Stockler das Neves representava a manutenção dos ideais do ensino beaux-arts francês, enquanto que o humanismo francês de Anhaia resultava na assimilação da prática urbanística americana e na adoção da estética modernista para o ensino". ${ }^{31}$

É esse o contexto em que aparece a Faculdade de Arquitetura e Urbanismo da Universidade de São Paulo, que terá em João Batista Vilanova Artigas, discípulo direto de Luís Anhaia Melo, um de seus maiores idealizadores e instituidores. 


\subsection{A FAUUSP}

O surgimento de várias faculdades de arquitetura ocorre num período de tempo relativamente curto. Em menos de uma década - de meados de 1940 até meados de 1950 -, diversos cursos de arquitetura se estruturam independentemente. Em São Paulo esse fenômeno ocorrerá com a Faculdade de Arquitetura da Universidade Mackenzie e com a Faculdade de Arquitetura e Urbanismo da Universidade de São Paulo. Muitos estudiosos atribuem esse fato à dinâmica do exercício da profissão de arquiteto, que ganha clareza e dimensão e se afasta da engenharia enquanto prática profissional.

É importante estabelecer que, em São Paulo, as faculdades de arquitetura eram, originariamente, departamentos das escolas de engenharia, tendo, portanto, forte alicerce técnico, decorrente da origem de sua formulação. No caso da FAUUSP, sua gênese ocorre a partir da Escola Politécnica.

No Rio de Janeiro a escola de arquitetura, desenhada e reestruturada à luz da arquitetura moderna por Lúcio Costa, foi configurada pela Escola de Belas-Artes que a antecede e da qual se origina, dentro do espírito das beauxarts, do desenho e da estética como essência.

A estruturação original da escola de arquitetura do Rio Grande do Sul se dá pela fusão entre o Departamento de Arquitetura da Escola de Engenharia e da Escola de Belas-Artes, sinalizando, desde sua origem, um equilíbrio entre arte e técnica.

A FAUUSP, que se estrutura em 1948, carrega a herança da Escola Politécnica. Basicamente, sua configuração se pautava no sistema de cátedras isoladas, com a figura quase imperial do professor catedrático, resultando numa escola onde as diversas disciplinas ocorriam de modo isolado e sem 
qualquer compromisso entre si. Cabia aos estudantes trabalharem a síntese, organizando seus trabalhos de modo a harmonizarem os conhecimentos adquiridos de forma isolada. Outra questão relevante era o distanciamento entre o foco das disciplinas e os horizontes sociais, econômicos e políticos existentes no país. Acreditava-se, na época, que a universidade deveria formar um estudante generalista e culto nas ciências que cursava, sem nenhuma preocupação quanto a aspectos de ordem crítica.

O primeiro ajuste da FAUUSP ocorre apenas na modificação da seriação do curso, concentrando nos primeiros anos as disciplinas de teor mais técnico, de modo a fornecer ao estudante o instrumental necessário para o desenvolvimento das atividades de projeto, estas sim que deveriam ser a espinha dorsal da escola. Os grupos de disciplinas eram organizados por afinidade: as de formação científica, as de aplicação técnica, as de cultura e as de práticas de ateliê. Dava-se também grande importância à questão da composição, "que deveria ter dentro da escola a importância que ela tem no exercício da profissão". ${ }^{32}$

Será através dos fóruns ocorridos nos anos de 1962 e 1968 que a FAUUSP procurará superar a dicotomia entre arte, técnica e crítica, e que gerará uma nova articulação pedagógica que a estruturará por meio dos departamentos de Projeto, Tecnologia e História.

O processo de amadurecimento da escola sempre se fez pela articulação entre a prática dos escritórios e o ensino de projeto. Os profissionais que, de algum modo, se destacavam por sua prática profissional eram, com algumas exceções importantes, convidados a fazer parte do corpo docente da FAUUSP. 
Estava estabelecido que a aproximação entre prática profissional e ensino era um dos caminhos seguros em termos pedagógicos para a escola de arquitetura. O mote apregoava que "não se pode ensinar projeto de arquitetura a um estudante, mas se pode ensiná-lo a aprender".33

Esse modo de entender as questões de ensino parece bastar em relação ao ensino de projeto, até a grande reestruturação, que ocorrerá quando da mudança da Rua Maranhão para a Cidade Universitária. A mudança é vital para a estrutura dos cursos, porque altera de modo profundo o perfil de uma escola antes direcionada para turmas com cerca de trinta alunos, para uma escola de ensino de massa, com turmas iniciais de cem alunos, ampliando-se, mais tarde, as vagas para cento e cinqüenta alunos.

A estrutura formal deveria ser sistematizada em ciclos de análise e síntese, conforme proposto pelo relatório de Carlos Milan, de modo a repetir o processo de criação do arquiteto. Altera-se de modo radical a organização burocrática da instituição, tendo sido aumentado o número de funcionários. Altera-se, também, principalmente, a relação entre professores e estudantes.

A escola se organiza em departamentos, que teoricamente deveriam estabelecer uma relação de soma e reciprocidade. Entretanto, as dificuldades de integração estão nas raízes da criação da FAUUSP e não são fáceis de serem superadas. O grau de dificuldade da integração é expresso em texto de Carlos Milan: "De forma alguma o Ateliê pode ser considerado como um departamento auto-suficiente. É da maior importância, para a sua plena eficiência, uma colaboração direta e harmônica entre os outros departamentos que reúnem as cadeiras técnicas, as cadeiras de história e ciências sociais e o 
departamento de atividades curriculares". ${ }^{34}$ Conforme anota Roberto Portugal, duas questões se colocam: a primeira relativa à divisão das matérias em grupos; a outra, relativa à fusão dos conhecimentos a serem trabalhados em ateliê..$^{35}$

Como se pode notar, a estruturação da FAUUSP sempre se baseou na dicotomia entre teoria e prática, prática profissional de projeto e ensino de projeto. As tentativas de superá-la no âmbito mais geral da escola vêm ocorrendo ao longo desses cinqüenta anos, sendo os momentos mais intensos do debate os fóruns de 1962 e 1968 e as discussões ocorridas mais recentemente, geradas ainda por questões mais profundas ligadas à própria profissão.

${ }^{34}$ Carlos B. MILLAN, O atelier na formação do arquiteto, São Paulo, 1962.

${ }^{35}$ Roberto P. ALBUQUERQUE, São Paulo, 2004. 


\section{Experiências de ensino de projeto}

\subsection{FAUUSP: AUP-608 - Fundamentos de projeto}

AUP-608 - Fundamentos de Projeto, disciplina inicial do Departamento de Projeto, é uma das que surgiram em 1998, com o processo de reestruturação curricular desse Departamento. Ela alterou a estrutura de relacionamento entre as seqüências de disciplinas: Projeto de Edificações, Planejamento Urbano e Regional, Programação Visual, Paisagismo e Desenho Industrial, assumindo a responsabilidade de reunir os conceitos dessas várias seqüências. O professor Zanettini foi quem liderou o processo de fusão de conteúdos, contando com os demais professores do departamento: Rafael Perrone, Feres Khouri, Klara Kaiser, Marai Cristina da Silva Leme, Heliana Comin Vargas e Maria Cecília Loschiavo dos Santos. Mantendo a qualidade das contribuições, outros professores foram se revezando, para compor um grupo de professores nunca inferior a quatorze.

O conceito sobre ensino de projeto existente até 1998 na FAUUSP traduzia-se por um tronco de árvore que, com o passar do tempo, se ramificava nas suas especialidades. Para formular a disciplina AUP-608 foi necessário fazer o raciocínio inverso, isto é, fundir todas as disciplinas em um único tronco.

A intenção da disciplina Fundamentos de Projeto é fazer os alunos desenvolverem um único exercício por vez, com o acompanhamento diário dos professores em rodízio. Não assume um objeto de estudo com enfoques diferentes de acordo com as especificidades das diferentes disciplinas.

As características principais do modelo não formal podem ser claramente observadas no conceito adotado pela AUP-608, com a ênfase no aprendiza- 
do, nas atividades e nas habilidades do aluno, e não no ensinar, nas atividades do professor e nos conteúdos.

O fato de que os exercícios incluíam fundamentos das várias áreas do conhecimento relativas à Arquitetura e Urbanismo e eram ministrados conjuntamente obrigou o corpo docente a se reciclar para estar apto a discutir, entre outros temas, o desenvolvimento urbano, as intervenções urbanas, o desenho de observação, o projeto de arquitetura, a paisagem urbana.

A principal mudança em relação à integração é que o método de ensino é que trabalha com diversos focos sobre o mesmo objeto.

Seis anos depois de implantada a disciplina AUP-608, através do Programa PAE - Programa de Aperfeiçoamento de Ensino na pós-graduação tive a oportunidade de vivenciar a experiência como monitora da AUP-608, no primeiro semestre de 2004.

Nesse semestre, quinze professores e seis monitores participaram da disciplina Fundamentos de Projeto. Os cento e cinqüenta alunos que ingressaram na FAUUSP foram divididos em quinze grupos de dez alunos, assessorados todos os dias da semana pelos professores e monitores em sistema de rodízio. Cada professor era responsável por um desses grupos e os orientava dois dias da semana. Um dia da semana, quarta-feira, era reservado para atividades de pesquisa sem a presença dos professores e monitores. Nos outros dois dias, a equipe era orientada por outros professores.

As reuniões com todos os alunos, professores e monitores eram realizadas às segundas-feiras (dia em que todos compareciam), quando ocorria a explanação ou discussão dos resultados dos exercícios.

Esse sistema de rodízio tem a intenção de permitir que todos os alunos conheçam e tenham contato com todos os professores, possibilitando-lhes 
enfoques diferentes, no mesmo objeto de estudo, de acordo com as especificidades de cada professor.

\section{Universidade de São Paulo}

Faculdade de Arquitetura e Urbanismo

Departamento de Projeto

\section{AUP 608 - Fundamentos de Projeto}

$1^{\circ}$ Semestre de 2004

\section{DOCENTES}

Siegbert Zanettini / Coordenador

Maria Cristina da Silva Leme / Vice-Coordenadora

Anália Amorim

Andreína Nigriello

Antonio Carlos Sant'Anna

Clice de Toledo Sanjar Mazzilli

Feres Lourenço Khoury

Francisco Segnini

Heliana Comin Vargas

Joana Carla Soares Gonçalves

Klara Kaiser Mori

Maria Assunção Ribeiro Franco

Maria Cecília Loschiavo dos Santos

Minoru Naruto

Vladimir Bartalini 


\section{MONITORES}

Camila Faccioni Mendes / Coordenadora

Almiro Blumenschein Cruz

Antônio Takao Kanamaru

Larissa Garcia Campagner

Vera Lúcia Domschke

Rodrigo Boufleur

SECRETÁRIA RESPONSÁVEL

Eliane (GDPR)

\section{OBJETIVO GERAL}

Esta disciplina, que inicia o curso da FAUUSP, vem sendo ministrada desde 1998. Seu principal objetivo é introduzir o aluno no processo de elaboração do projeto de arquitetura e urbanismo, considerando a amplitude oferecida pelo Departamento de Projeto através de suas cinco principais áreas de conhecimento (projeto de edificações, planejamento, paisagismo, desenho industrial e programação visual). A disciplina visa fortalecer a capacidade crítica e propositiva dos alunos, como futuros arquitetos e cidadãos.

\section{ESTRUTURA DA DISCIPLINA}

A disciplina será desenvolvida em 5 (cinco) tardes por semana, através de 6 (seis) exercícios e contará com a participação 15 professores e 6 monitores. A apresentação dos exercícios, seminários e aulas expositivas será realizada nas segundas-feiras com a presença de todos os professores. Às terças, quintas e sextas-feiras os exercícios serão desenvolvidos no ateliê com a supervisão de professores. As quartas-feiras estão reservadas para aulas expositivas, realização de visitas de campo, pesquisa na biblioteca e desenvolvimento dos exercícios. 
Para o desenvolvimento dos trabalhos estão estabelecidos os seguintes procedimentos:

Os trabalhos deverão ser realizados durante o horário de aula, no estúdio, não sendo aí permitida a execução de trabalhos de outras disciplinas.

Deverá ocorrer discussão permanente do trabalho com os professores, monitores e colegas na própria prancheta do aluno, onde será possível para o professor acompanhar o processo de trabalho do aluno.

Todos os produtos finais deverão ser guardados na pasta, que poderá ser solicitada ao aluno a qualquer momento para análise, avaliação e orientação.

Ao final de cada exercício (vide calendário), será feita a escolha de alguns trabalhos para análise e comentários em seminários.

Ao final de cada exercício haverá entrega dos trabalhos para avaliação, conforme datas constantes dos calendários. Os desenhos deverão estar na pasta elaborada para todo o curso.

As avaliações levarão em conta não apenas o resultado do produto final, mas também a evolução no processo de trabalho, de acordo com o alcance dos objetivos estabelecidos para cada exercício.

Ao final do semestre (vide calendário) será organizada uma exposição geral dos exercícios. O aluno deverá entregar em papéis-cartão, tamanho de acordo com o exercício, fotos e desenhos dos exercícios, dispondo-os no sentido horizontal de observação, com identificação no canto direito inferior (nome e número do aluno, disciplina, ano e nome do professor).

Observação: Veja, no anexo, desenho da pasta onde deverão ser guardados todas as peças gráficas do semestre, e desenho da legenda que deverá constar em todas as pranchas a serem produzidas pelo aluno. 


\section{EXERCÍCIO 1}

\section{Desenho de Observação}

"O olho é aquilo que foi comovido por um certo impacto do mundo, e que o restitui ao visível pelos traços da mão. Seja qual for a civilização em que nasça, seja quais forem as crenças, os motivos, os pensamentos, as cerimônias de que se cerque, desde Lascaux até hoje, impura ou não, figurativa ou não, a pintura e o desenho jamais celebram outro enigma a não ser o da visibilidade." Merleau-Ponty

\section{Objetivos}

Considerando que o desenho de observação caracteriza-se, dentro da atividade de desenho, como um instrumento de conhecimento capaz de despertar através da sua abrangência, novos "olhares" sobre a realidade observada, registrados através da materialidade sutil da linha até a massa forte de matérias gráficas e que o desenho de observação não só provoca a investigação do que se olha mas provoca, também, a necessidade de ordenar uma linguagem que represente sua visibilidade, o presente exercício tem como objetivo específico:

- Mostrar ao aluno a importância do desenho como instrumento fundamental de investigação e compreensão da realidade observada, permitindo também, através do desenho, ordenar e escolher uma linguagem que a represente.

- O desenho de observação de modelo vivo objetiva a ampliação e a adoção de um repertório visual; a valorização do gesto e do registro dos desenhos.

\section{Material}

Papel-sulfite, canson ou papel-jornal, tamanho A3.

Grafite ou lápis, lápis de cor, carvão ou pastel seco ou oleoso. 
$1^{\text {a }}$ Aula - Desenho de Modelo Vivo (09/03)

Dois modelos femininos

Das $14 h 00$ às 15 h30 - Os alunos deverão realizar uma série de desenhos "rápidos", com o intuito de registrar impressões e aspectos importantes do modelo ou da sua composição. O aluno deve valorizar o gesto (a forma de atacar o registro gráfico), a tensão e a força dos registros (linhas, massa, etc.), realizando:

- Desenhos do corpo inteiro do modelo, sem referências exteriores (8 a 10 desenhos de 3 minutos);

- Desenhos de aproximação, enfoques específicos do detalhe (8 a 10 desenhos de 3 minutos).

Das $15 \mathrm{~h} 40$ às $17 \mathrm{~h} 00$ - Os alunos deverão realizar uma série de desenhos "Iongos" com a atenção voltada à construção do volume, visto através de tratamento de luz e sombras (valores tonais) e texturas que representem a natureza do modelo observado realizando:

- Desenhos do corpo inteiro do modelo, sem referências exteriores (25 a 30 minutos).

- Desenhos de aproximação, enfoques específicos do detalhe (25 a 30 minutos).

- Desenhos do modelo e do fundo, isto é, a relação do modelo com o lugar, a escala a dimensão e a indicação de um espaço ( 25 a 30 minutos).

\section{$2^{\text {a }}$ Aula - Desenho de Modelo Vivo (11/03)}

Procedimento igual à aula anterior

Três modelos masculinos 


\section{$3^{\text {a }}$ Aula - Desenho de Modelo Vivo com Figura - Fundo (12/03)}

Dois modelos femininos

Das 14 h00 às 15 h30 - Os alunos deverão realizar uma série de desenhos "rápidos", com o intuito de registrar impressões e aspectos importantes do modelo ou da sua composição. O aluno deve valorizar o gesto (a forma de atacar o registro gráfico), a tensão e a força dos registros (linhas, massa, etc.), realizando:

- Desenhos do corpo inteiro do modelo com referências do entorno (8 a 10 desenhos de 3 minutos).

- Desenhos de aproximação, enfoques específicos do detalhe com referências ao entorno (8 a 10 desenhos de 3 minutos).

- Desenhos do modelo em movimento com representação linear. Procurando não a cópia da forma observada, mas as pegadas, o ritmo de uma forma em movimento. Deve-se valorizar mais a sugestão, a invenção do gesto do que a aparência do modelo, podendo incluir de 8 a 10 movimentos em uma ou mais folhas, com sobreposição ou não, dependendo do que o aluno decidir como terminado (8 a 10 desenhos de 3 minutos).

Das $15 \mathrm{~h} 30$ às $17 \mathrm{~h} 00$ - Os alunos deverão realizar uma série de desenhos "Iongos" com a atenção voltada à construção do volume, figura e fundo, escala, visto através do tratamento de luz e sombras (valores tonais) e texturas que representem a natureza do modelo observado:

- Desenhos do corpo inteiro do modelo, com referências do entorno (25 a 30 minutos).

- Desenhos de aproximação, enfoques específicos do detalhe (25 a 30 minutos). 
- Desenhos do modelo e o fundo, isto é, a relação do modelo com o lugar, a escala a dimensão e a indicação de um espaço ( 25 a 30 minutos).

Ao final de cada aula de modelo vivo, os alunos deverão expor um desenho de sua escolha de cada item previsto no exercício. Esses desenhos deverão permanecer expostos até o final do exercício, pois serão discutidos coletivamente, no seminário de conclusão deste primeiro exercício.

\section{Entrega}

Caderno espiralado contendo 20 desenhos

Desenvolvimento do desenho de observação através de desenhos de modelo vivo, realizados em três dias consecutivos com diferentes modelos e a orientação de todos os professores.

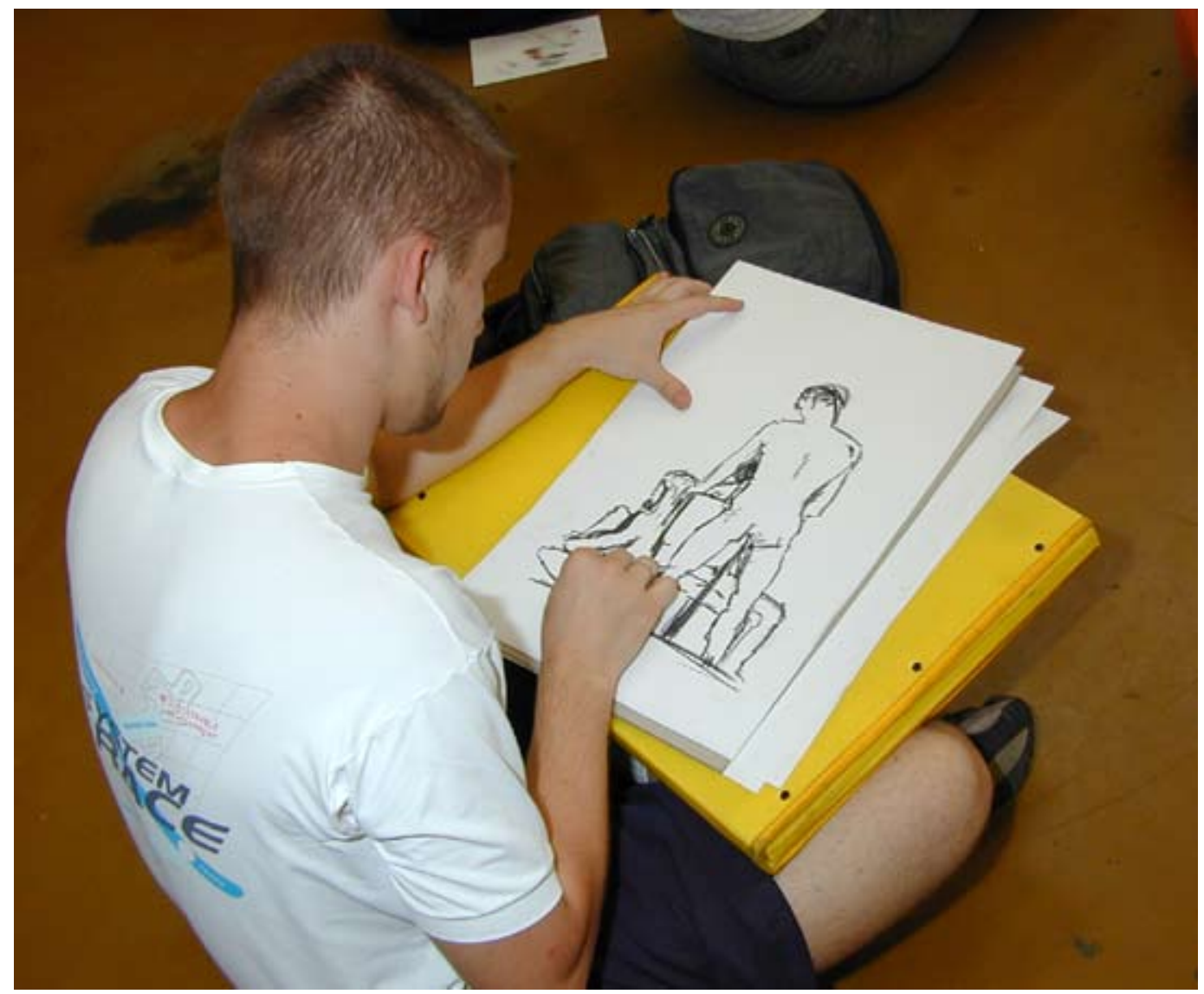



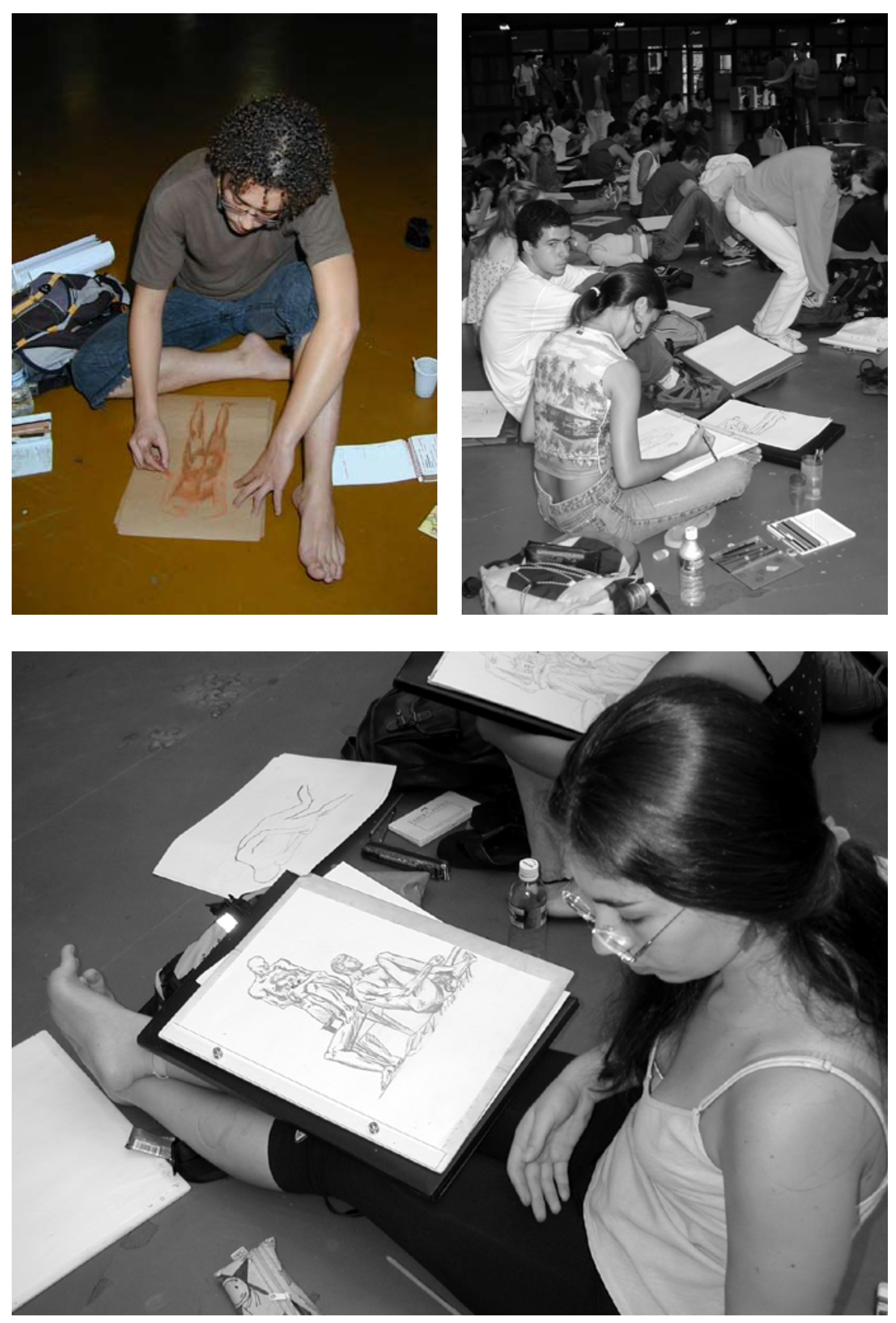

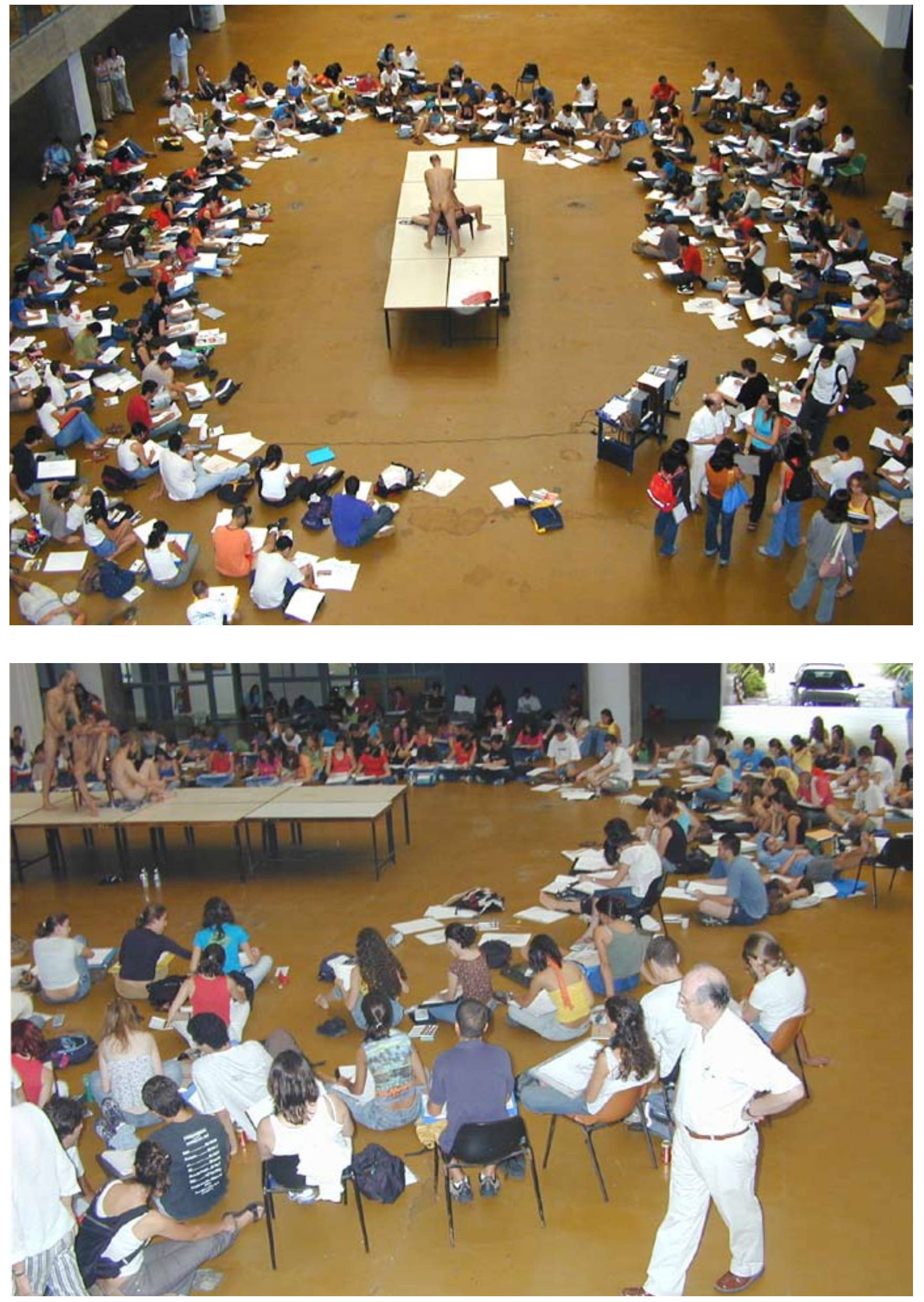


\section{EXERCÍCIO 2}

Percepção Ambiental: o Desenho da Paisagem Urbana

\section{Objetivos}

Despertar no aluno a percepção ambiental da paisagem urbana enfocando:

- A paisagem como espaço e o desenho como forma de pensamento.

- A exploração da questão gramatical do espaço urbano nas suas diversas escalas.

- A questão espaço-tempo traduzida no desenho seqüencial.

- A questão histórica: a leitura dos vários tempos da paisagem urbana no desenho da trama urbana e na leitura de seus monumentos referenciais.

- A natureza na cidade: o suporte físico e suas manifestações visíveis (topografia, recortes de céu e da paisagem distante, solo descoberto, massas de vegetação, insolação, varreduras de sombra, etc.) e invisíveis (rede hídrica, drenagem, túneis de vento, etc.).

Este exercício visa também preparar o aluno para futuras intervenções projetuais, em diversas escalas (edifício, largo, praça, rua).

\section{Objeto de Estudo}

Centro Histórico da Cidade de São Paulo, tendo como focos principais os seguintes percursos:

10 Percurso: A "grande caixa" do Vale do Anhangabaú (entre Viaduto Santa Efigênia e Viaduto do Chá, Teatro Municipal e o seu lado oposto constituído por edifícios que ladeiam a Rua Líbero Badaró - ver planta anexa).

2 Percurso: Rua paralela ao Anhangabaú: percurso ligando o Largo de São Bento ao Largo de São Francisco onde a Rua São Bento liga as cinco "pequenas caixas" - o Largo de São Bento, Praça Antônio Prado, o Largo do Café, a Praça 
Patriarca e o Largo de São Francisco.

$3^{\circ}$ Percurso: Rua transversal ao Anhangabaú: percurso ligando a Praça Patriarca ao Pátio do Colégio, a ser percorrido ou pela Rua Direita ou pela Rua da Quitanda - ver planta anexa.

Observação: Os percursos descritos estão destacados no mapa anexo.

\section{Material}

Papel-sulfite, canson ou papel-jornal, tamanho A4.

Grafite ou lápis, lápis de cor, carvão ou pastel seco ou oleoso.

Prancheta de mão

ETAPA 1 - VALE DO ANHANGABAÚ (16, 17 E 18/03)

\section{$1^{\circ}$ Percurso}

Os alunos deverão fazer o reconhecimento do centro da cidade de São Paulo, em duas fases, tomando ciência do espaço construído e de seu suporte físico (topografia, geomorfologia, rede hídrica, etc.)

Na grande caixa do Anhangabaú, o aluno deverá através de seus desenhos e suas anotações identificar a relação entre a escala urbana e a humana. Também deverá o aluno observar o sentido espacial do vale, sua perspectiva e sua arquitetura (é um exercício de reconhecimento do espaço construído sobre o suporte físico original do vale do ribeirão Anhangabaú). Como estratégia de trabalho o aluno deverá desenvolver uma visão de fora para dentro e vice-versa, numa seqüência de giro de $360^{\circ}$, e deslocar seu ponto de vista, até abarcar todo o espaço.

O exercício deverá ser traduzido em desenhos (mínimo de 20) em perspectiva e à mão livre, em traços rápidos, dando idéias de síntese do espaço e contendo referências de escala. 
ETAPA 2 - CENTRO HISTÓRICO (23, 24 E 25/03)

\section{$2^{\circ}$ Percurso}

Rua paralela ao Anhangabaú: percurso ligando o Largo de São Bento ao Largo de São Francisco onde a Rua São Bento liga as cinco "pequenas caixas" - o Largo de São Bento, Praça Antônio Prado, o Largo do Café, a Praça Patriarca e o Largo de São Francisco.

\section{$3^{\circ}$ Percurso}

Rua transversal ao Anhangabaú: percurso ligando a Praça Patriarca ao Pátio do Colégio percorrido ou pela Rua Direita ou pela Rua da Quitanda.

A partir do Pátio do Colégio, o aluno perceberá a abertura de outra grande caixa que é a do vale do Tamanduateí, onde se insere o Parque Dom Pedro, tendo como "pano de fundo" o Bairro do Brás e parte da Zona Leste da Cidade de São Paulo - ver planta anexa.

Os desenhos deverão expressar novamente as questões anteriormente citadas, observando mudanças na escala do percurso, que se constitui pela visão seriada da rua e suas dilatações espaciais representadas pelas cinco pequenas caixas (largos). Como estratégia de trabalho o aluno deverá desenvolver uma visão seriada linear ao longo das linhas transversais ao Anhangabaú e deslocar seu ponto de vista, até finalizar os trajetos.

Os alunos deverão apresentar no mínimo 20 desenhos de cada percurso alusivos aos trajetos acima citados, dando idéia de síntese em perspectivas seriadas, as quais deverão traduzir as sensações do encaixe e do dinamismo daqueles corredores. Na abordagem do Pátio do Colégio, mostrar o enquadramento do Pátio entre os prédios do entorno e a idéia de vazamento do lado leste, olhando para o Parque Dom Pedro. 


\section{Calendário - Exercícios 1 e 2}

\begin{tabular}{|c|c|c|}
\hline Dias & Etapas & Local \\
\hline $08 / 03$ & Apresentação do curso & Sala 801 \\
\hline 09/03 & Desenvolvimento do Exercício 1 & Caramelo \\
\hline $10 / 03$ & $\begin{array}{l}\text { Aula Inaugural } 2004 \text { - "Os Desafios do Século XXI. Arquitetura } \\
\text { sem Adjetivos" (14-16 h). Prof. Dr. Siegbert Zanettini }\end{array}$ & $\begin{array}{l}\text { Auditório } \\
\text { Ariosto Mila }\end{array}$ \\
\hline $10 / 03$ & Aula Prof. Feres - "Exposição de Diapositivos" (16-18 h) & Sala 801 \\
\hline $11 / 03$ & Desenvolvimento do Exercício 1 & Caramelo \\
\hline $12 / 03$ & Desenvolvimento do Exercício 1 & Caramelo \\
\hline $15 / 03$ & $\begin{array}{l}\text { Discussão do Exercício } 1 \text { e apresentação do Exercício } 2 \\
\text { Aula Prof. Feres - "O Desenho da Paisagem" }\end{array}$ & Sala 801 \\
\hline $16 / 03$ & $\begin{array}{l}\text { Entrega do Exercício } 1 \text { das } 9 \text { às } 11 \text { h30 (GDPR) } \\
\text { Desenvolvimento da Etapa } 1 \text { - Exercício } 2\end{array}$ & \\
\hline $17 / 03$ & Desenvolvimento da Etapa 1 - Exercício 2 & \\
\hline $18 / 03$ & Desenvolvimento da Etapa 1 - Exercício 2 & \\
\hline $19 / 03$ & Seleção, edição e montagem da exposição dos desenhos & Estúdio 1 \\
\hline $22 / 03$ & 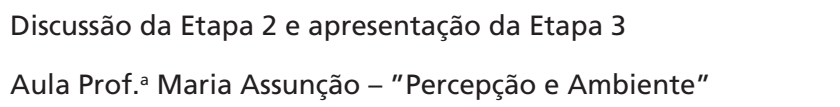 & \\
\hline $23 / 03$ & Desenvolvimento da Etapa 2 - Exercício 2 & \\
\hline $24 / 03$ & Desenvolvimento da Etapa 2 - Exercício 2 & \\
\hline $25 / 03$ & Desenvolvimento da Etapa 2 - Exercício 2 & \\
\hline $26 / 03$ & Desenvolvimento da Etapa 2 - Exercício 2 & \\
\hline
\end{tabular}

Este segundo exercício consta de desenhos de observação da paisagem. Foram escolhidos três sítios no centro da cidade de São Paulo para serem retratados através de desenhos. Os alunos foram divididos em três grupos, com o acompanhamento de professores. 

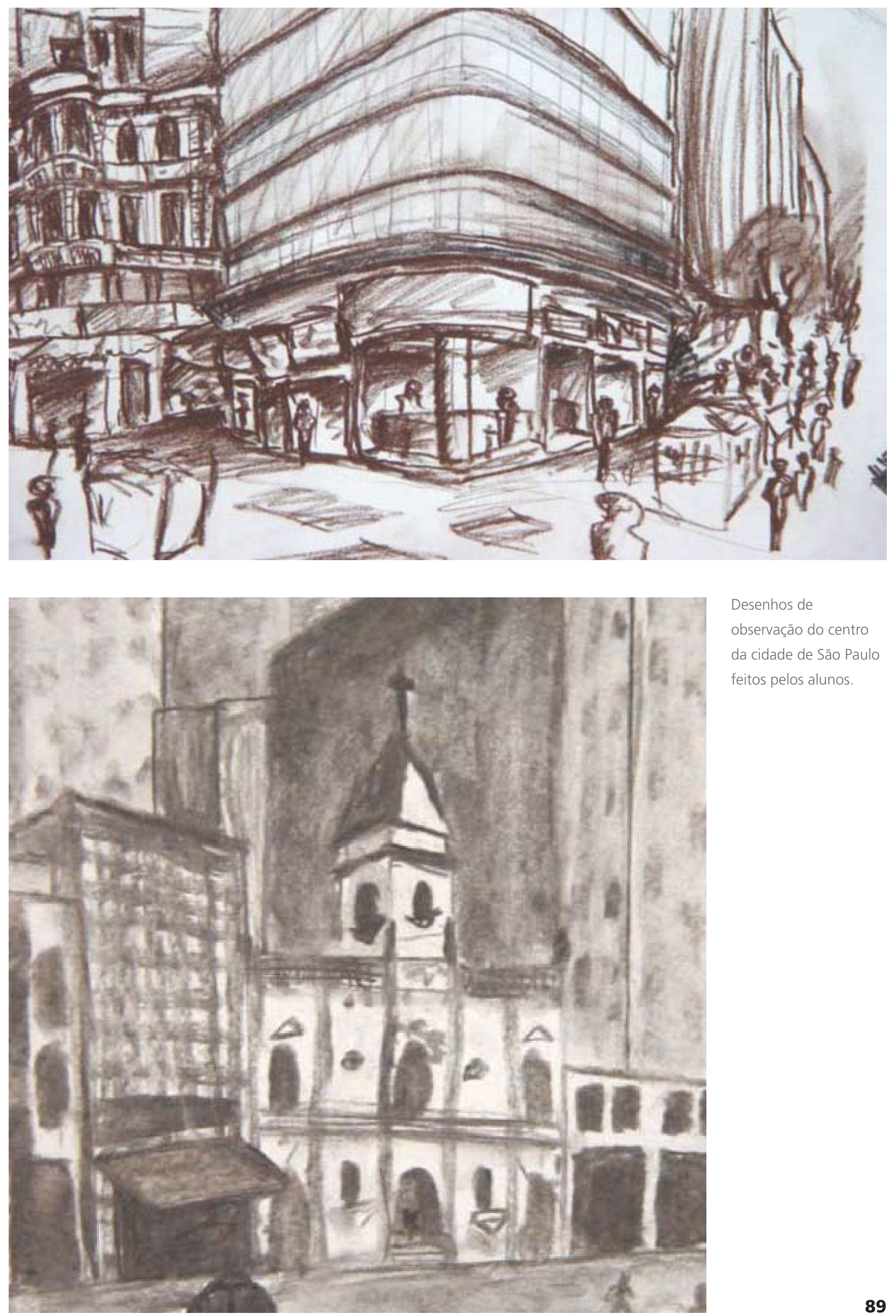

Desenhos de

observação do centro

da cidade de São Paulo

feitos pelos alunos. 

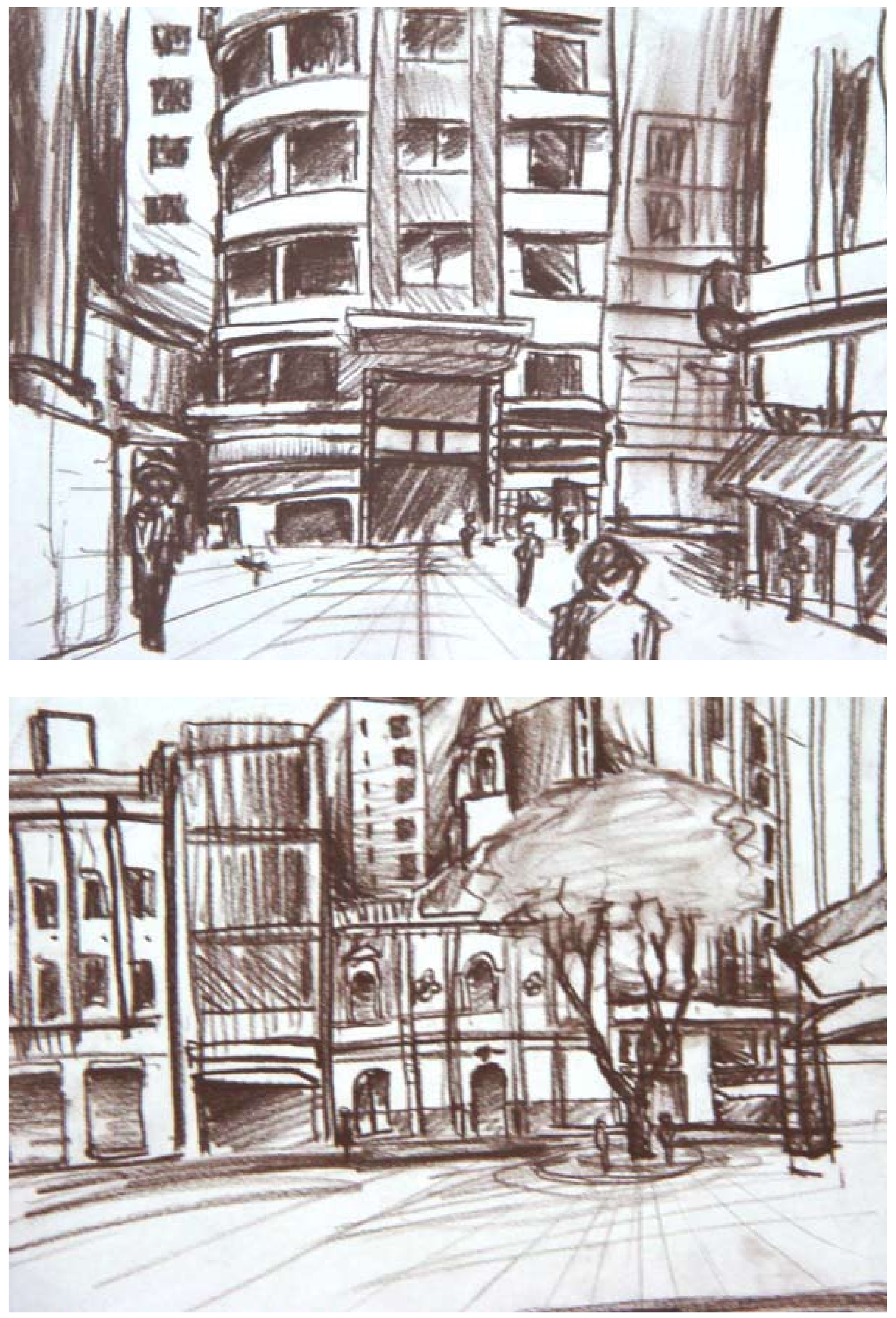

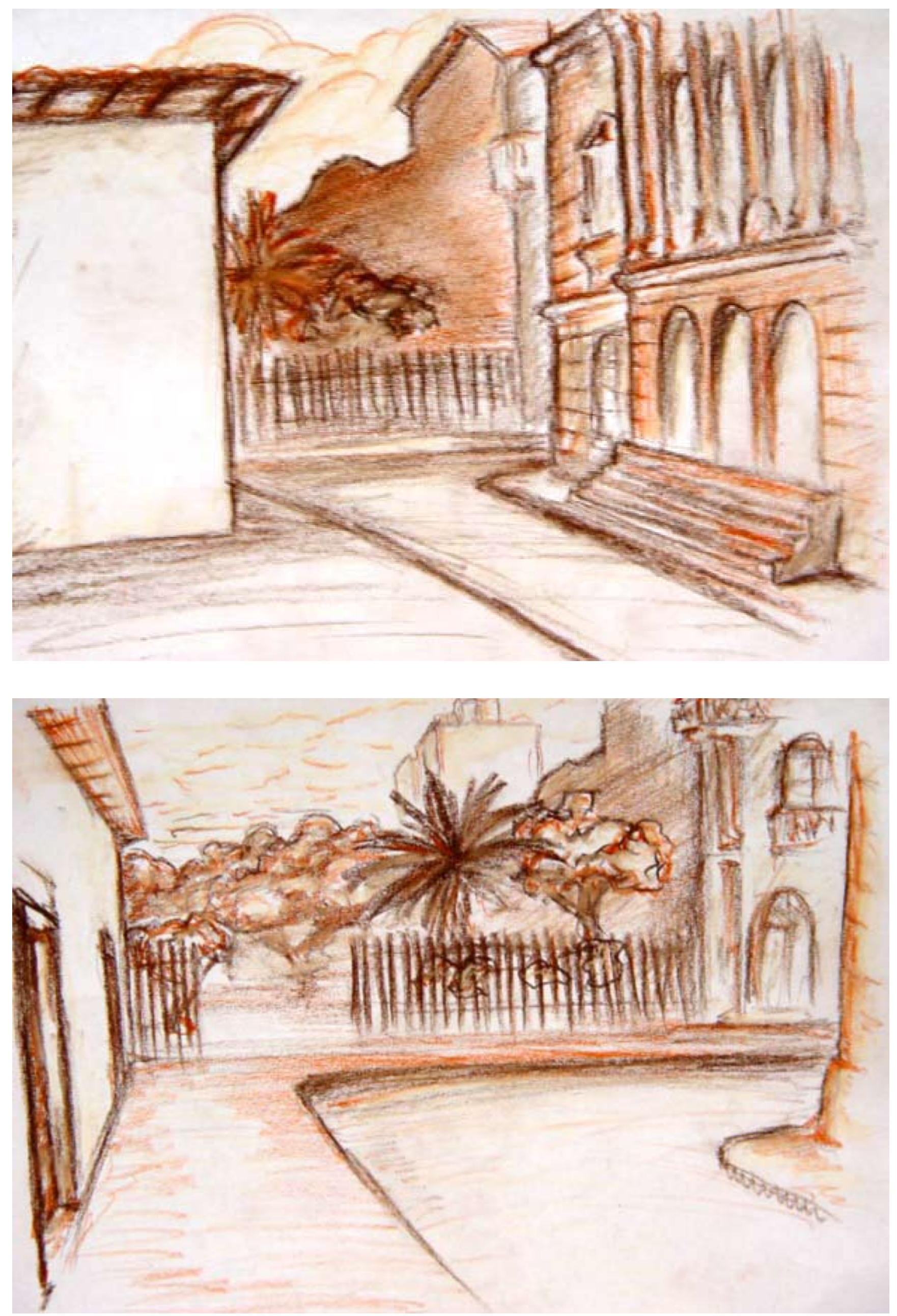

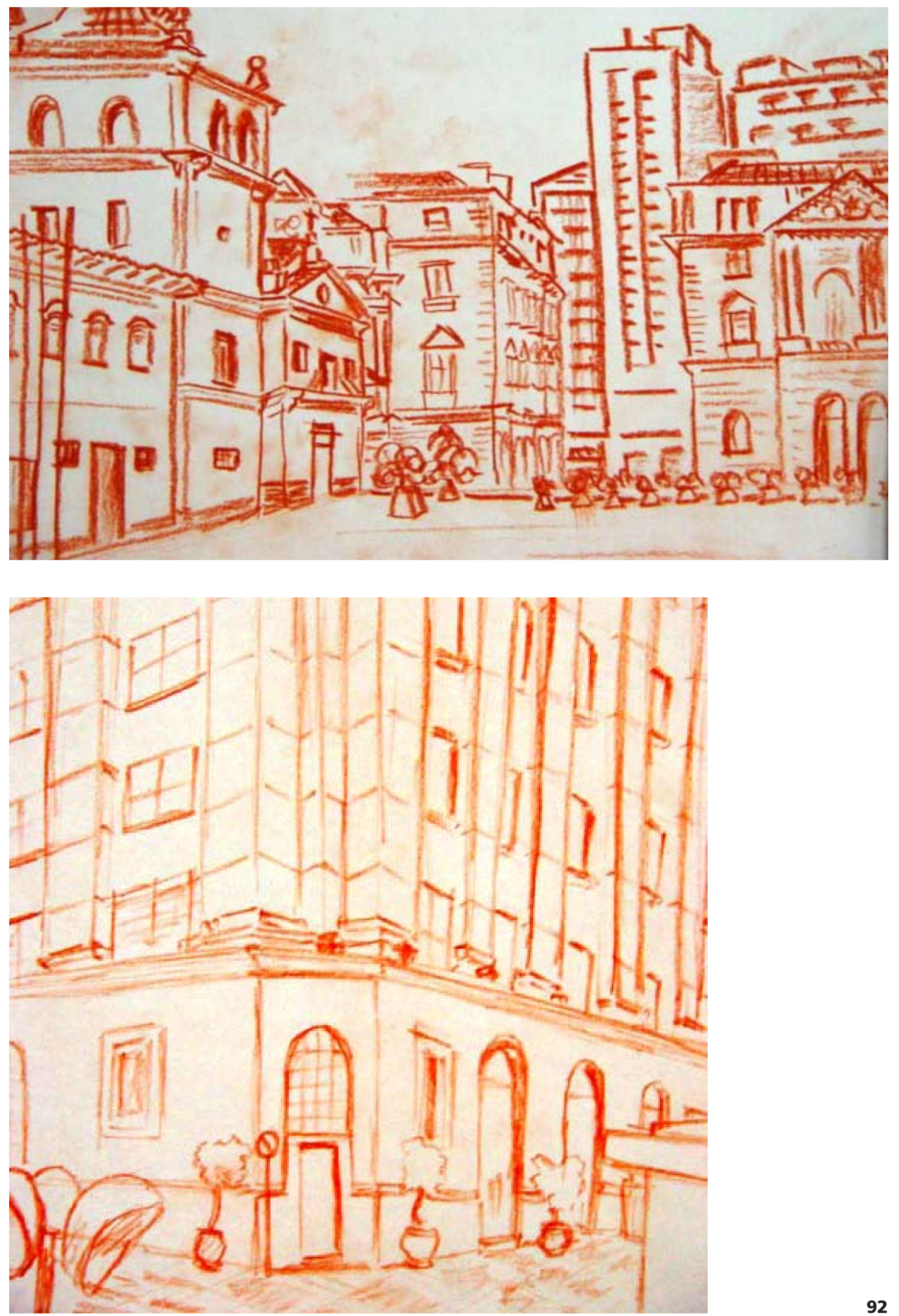
O exercício consta da criação de três prismas retos de base retangular, diferentes entre si, formando um único sólido; o aluno o desenhará em perspectivas sob diferentes ângulos, imaginando-se dentro do volume oco em diferentes escalas, e o representando através de desenho técnico.

\section{EXERCÍCIO 3}

Configuração Espacial e Volumétrica

\section{Objetivo}

Este exercício visa ampliar o repertório de tratamento da questão espacial e volumétrica como etapa preparatória ao exercício de concepção espacial de edificação procurando:

- Introduzir os alunos nas formas de investigar e produzir espaços, bem como nas maneiras de expressá-los.

- Ativar o potencial de criatividade, de racionalidade e de iniciativa com vistas à produção espacial.

\section{Material}

Grafite sobre papel-sulfite ou papel vegetal fino (papel-manteiga) A4 ou A3.

ETAPA 1 - MASSA, ESPAÇO, ESCALA, REPRESENTAÇÃO GRÁFICA

\section{Aula 1 (30/04)}

1.1 Massa / Representação gráfica: "Desenhos" 1

Imaginar e informar graficamente ("desenhar") a tridimensionalidade e a espacialidade de um sólido composto, resultante da justaposição de três prismas retos de base retangular, significativamente diferentes entre si, com a maior medida de até $18 \mathrm{~cm}$, como se estivesse à sua frente, apoiado pela base sobre a prancheta. 
Quantidade de vistas: em número necessário e suficiente para melhor informar o sólido obtido, no mínimo em duas direções opostas.

Observações:

- Para efeito deste "desenho", não será importante e nem será avaliado o aspecto de "composição", ou seja, a plasticidade do sólido composto obtido.

- Se julgado necessário e/ou conveniente, poderá ser utilizado uma representação gráfica ("desenho") da projeção do sólido sobre plano de base ("planta").

1.2 Massa / Escala / Representação gráfica: "Desenho" 2

Imaginar e informar graficamente ("desenhar") a tridimensionalidade e a espacialidade do sólido composto, agora aumentado 200 vezes, observado na mesma direção adotada para um dos "desenhos" do item 1.1, a uma distância equivalente à sua maior dimensão, e com altura de observação igual à altura do olho do observador em pé sobre o mesmo plano horizontal onde está apoiado o sólido. Quantidade de vistas: no mínimo 1.

1.3 Espaço / Representação gráfica: "Desenhos" 3

Considerar agora esse sólido composto aumentado 200 vezes completamente oco e com paredes de espessura desprezível; imaginar-se no seu interior e informar o seu espaço interno, observado de um ponto junto a uma das "paredes" (face lateral, vertical, do sólido) com a direção do olhar ortogonal à "parede" oposta, com altura de observação igual à altura do olho do observador em pé sobre o plano horizontal onde está apoiado o sólido.

Quantidade de vistas: em número necessário e suficiente para informar o interior do sólido, no mínimo em duas direções opostas, com ponto de observação junto às paredes. 
Observação:

Considerar inexistente a porção das "paredes" comuns (porção justaposta) aos dois sólidos.

\section{Aula $2(01 / 04)$}

\subsection{Discussão coletiva (14 h)}

No início da aula, cada equipe deverá ter uma seleção de dois conjuntos dos cinco "desenhos" discriminados acima, não necessariamente de mesmos autores: entregar um conjunto aos professores e afixar o outro no quadro-negro, em coluna, na ordem estabelecida no exercício, de cima para baixo, com as folhas alinhadas pela esquerda.

Aula expositiva: noções de representação técnica (projeção paralela -"desenho técnico") e perspectiva central.

Observação:

O material apresentado para discussão deverá ser recolhido pela equipe e deverá ser reapresentado para a discussão do dia 05.04 e, posteriormente, entregue junto com todos os outros "desenhos" para o professor responsável pela equipe.

\subsection{Representação gráfica técnica: "Desenho" 4 (15 h)}

Informar, de maneira necessária e suficiente, por meio de representação técnica (1 planta, 2 elevações, 1 corte transversal e 1 corte longitudinal) e com utilização obrigatória de instrumentos de desenho, a forma e as dimensões do sólido aumentado 200 vezes.

Imaginar o sólido composto completamente oco e, agora, com paredes de espessura igual a $40 \mathrm{~cm}$. 


\section{Aula $3(02 / 04)$}

\subsection{Massa / Espaço / Redesenho técnico 6}

Reelaborar as vistas obtidas nos itens 1.2 e 1.3, a partir de perspectiva central construída geometricamente utilizando os "desenhos" técnicos.

Construção geométrica da perspectiva

Vistas sem a construção geométrica

Importante:

Identificação - Com exceção das folhas padronizadas com margem e carimbo, todos as demais deverão ser identificadas na face frontal da folha, no canto superior esquerdo, com o nome completo e por extenso do(a) autor(a) grafado com letras de forma $\mathbf{5} \mathbf{~ m m}$ de altura em uma única linha.

\section{Entrega}

"Desenhos" e estudos desenvolvidos

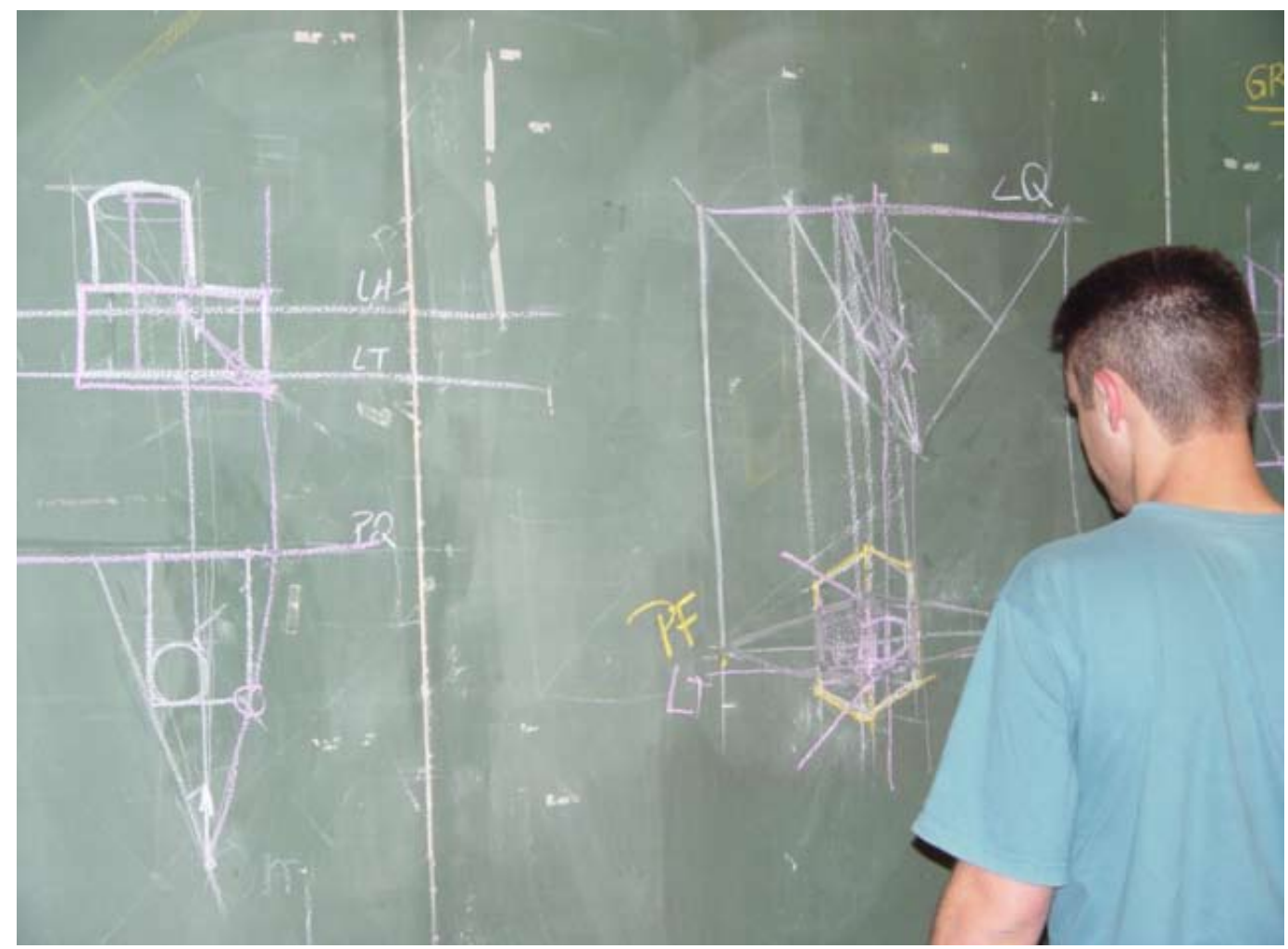




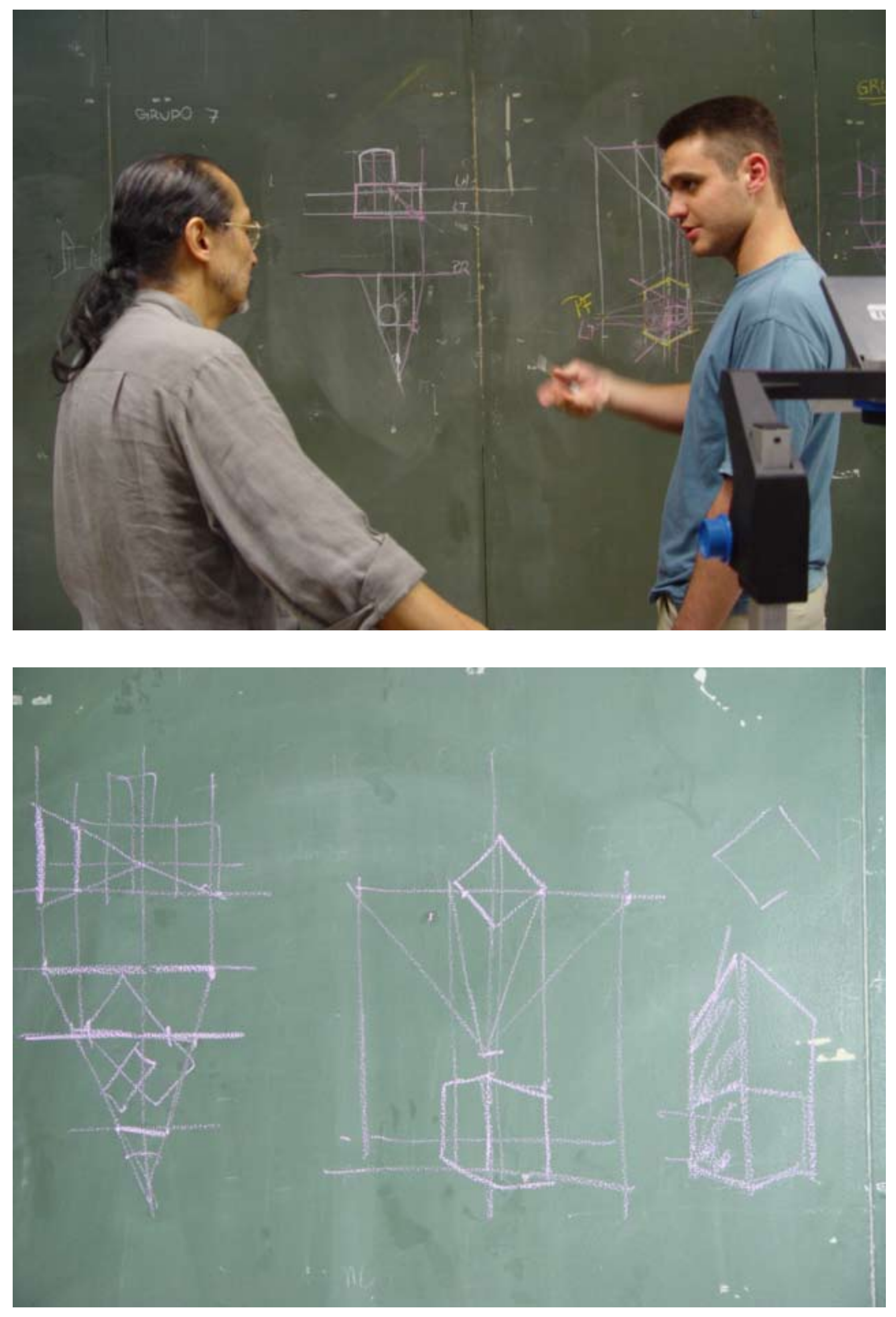



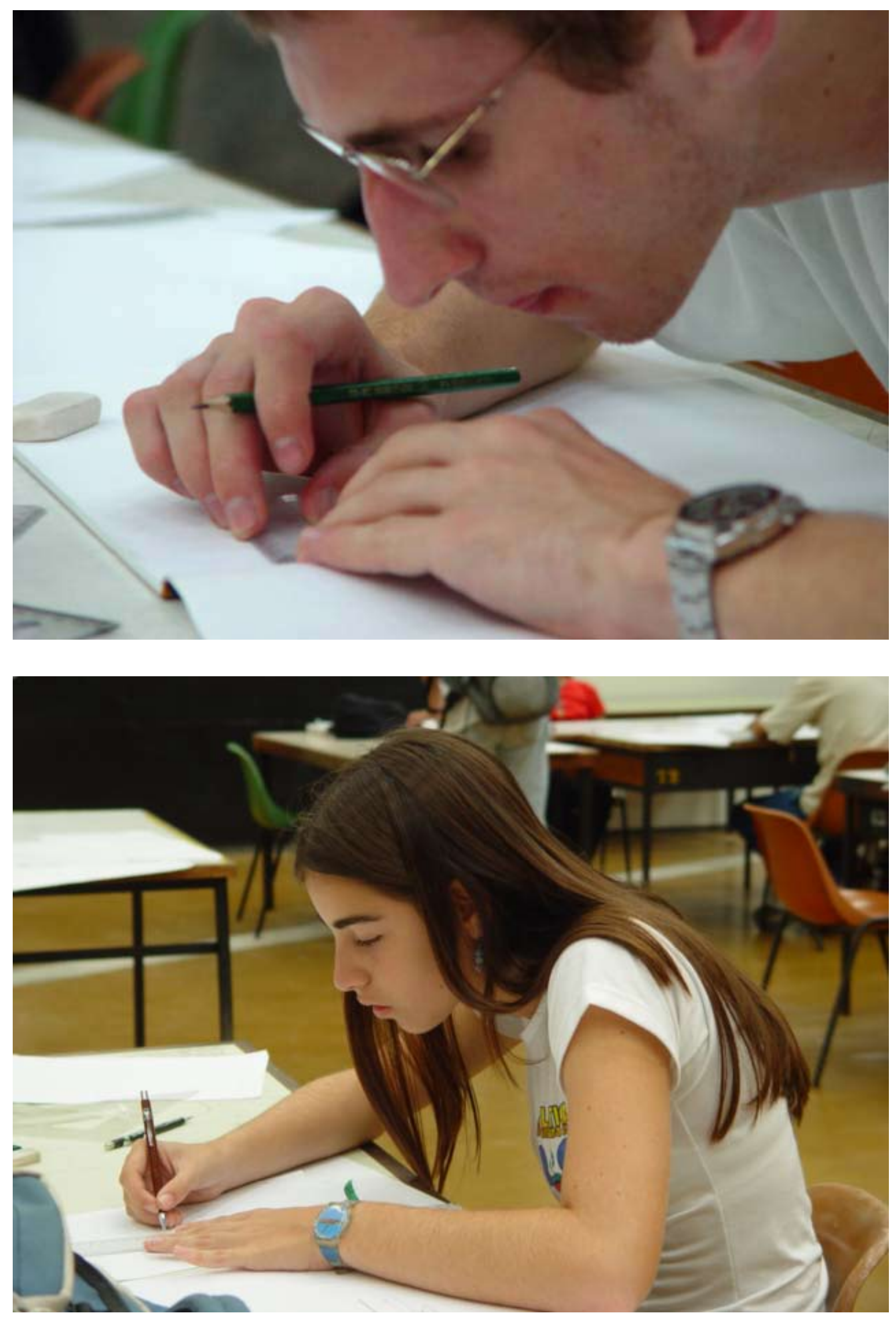


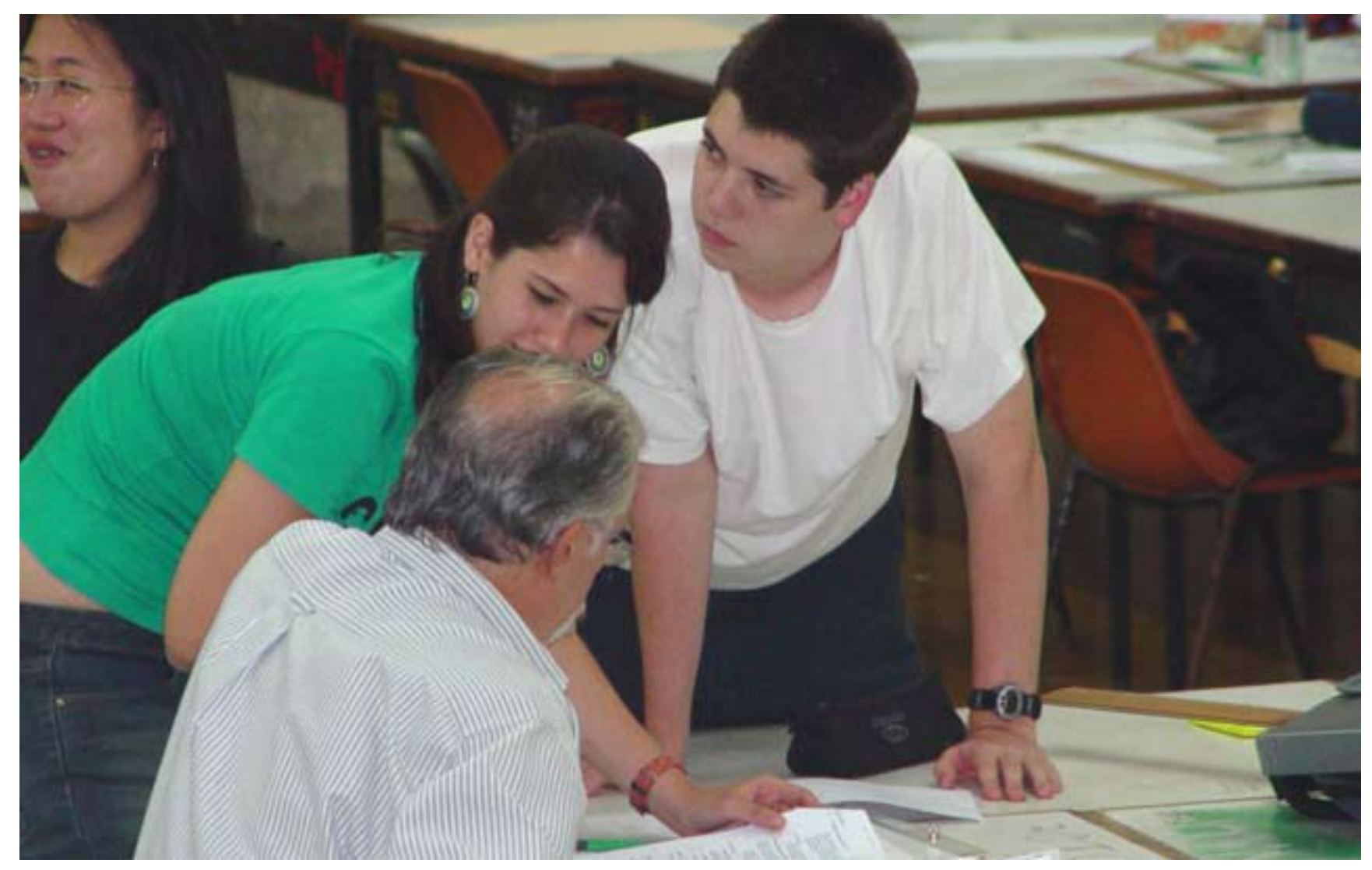

ETAPA 2 - VOLUMETRIA

A partir da projeção horizontal, contida em desenho anexo, na escala 1:200, o aluno deverá propor a volumetria de um conjunto arquitetônico. A volumetria do conjunto será resultante de uma das inúmeras possibilidades de interpretação tridimensional das linhas do desenho.

Na sua composição o aluno poderá suprimir as linhas que julgar dispensáveis para o seu estudo e deverá tomar como referências importantes a serem consideradas:

- Integração horizontal e vertical entre os vários espaços do modelo.

- $\quad$ Espaços penetráveis por pedestres (escala humana).

- Desenho harmonioso e equilibrado dos cheios e vazios.

- Noção de estabilidade do modelo.

- Os efeitos resultantes da luz e sombra.

O exercício deverá ser investigado através de modelo, em papel triplex branco, na 


\section{Entrega}

4 fotografias do modelo tridimensional (mínimo), coladas/impressas em papel opaco de tamanho A3.

\section{ETAPA 3 - VOLUMETRIA E EXPLORAÇÃO DO ESPAÇO CONSTRUÍDO}

A partir da discussão em ateliê e sala de aula, o modelo deve ser revisto, considerando o uso arquitetônico, integração dos espaços, estabilidade e os efeitos de luz e sombra.

\section{Entrega}

Complementando a investigação volumétrica através do modelo, deverão ser entregues desenhos das projeções horizontal e vertical, que possibilitem a devida compreensão do modelo. Utilizar técnica de claro e escuro (luz e sombra) explicitando a volumetria do modelo proposto. Desenhar em papel canson de tamanho A3, na escala 1:200.

- 5 desenhos de perspectiva externas e internas.

- 4 fotografias do modelo tridimensional (mínimo), coladas/impressas em papel opaco de tamanho A3.

\section{Calendário - Exercício 3}

\begin{tabular}{|c|l|l|}
\hline Dias & Etapas & Local \\
\hline $29 / 03$ & Discussão do Exercício 2 e apresentação do Exercício 3 & Sala 801 \\
\hline $30 / 03$ & Desenvolvimento da Etapa 1 - Exercício 3 (Aula 1) & Estúdio 1 \\
\hline $31 / 03$ & Desenvolvimento da Etapa 1 - Exercício 3 (Aula 1) & Estúdio 1 \\
\hline $01 / 04$ & $\begin{array}{l}\text { Discussão coletiva (itens 1.1, 1.2, e 1.3) } \\
\text { paralela - 'desenho técnico') e perspectiva central." } \\
\text { Desenvolvimento da Etapa 1 - Exercício 3 (Aula 2) }\end{array}$ & $\begin{array}{l}\text { Sala } 801 \\
\text { Estúdio 1 }\end{array}$ \\
\hline $02 / 04$ & $\begin{array}{l}\text { Desenvolvimento da Etapa 1 - Exercício 3 (Aula 3) } \\
\text { Dinoru - "Noç̃̃es de representação técnica (projeção }\end{array}$ & Estúdio 1 \\
\hline
\end{tabular}




\begin{tabular}{|c|c|c|}
\hline $\begin{array}{c}05 / 04 \text { a } \\
09 / 04\end{array}$ & Semana Santa - Não haverá aula & \\
\hline $12 / 03$ & Desenvolvimento do Exercício 1 & Caramelo \\
\hline $12 / 04$ & Discussão da Etapa 1 e apresentação da Etapa 2 & Sala 801 \\
\hline $13 / 04$ & $\begin{array}{l}\text { Entrega da Etapa } 1 \text { do Exercício } 3 \text { das } 9 \text { às } 11 \text { h30 (GDPR) } \\
\text { Desenvolvimento da Etapa } 2 \text { - Exercício } 3\end{array}$ & Estúdio 1 \\
\hline $14 / 04$ & Visita à Obra & \\
\hline $15 / 04$ & Desenvolvimento da Etapa 2 - Exercício 3 & Estúdio 1 \\
\hline $16 / 04$ & Desenvolvimento da Etapa 2 - Exercício 3 & Estúdio 1 \\
\hline $19 / 04$ & Discussão da Etapa 2 e apresentação da Etapa 3 & Sala 801 \\
\hline $20 / 04$ & $\begin{array}{l}\text { Entrega da Etapa } 2 \text { do Exercício } 3 \text { das } 9 \text { às } 11 \text { h30 (GDPR) } \\
\text { Desenvolvimento da Etapa } 3 \text { - Exercício } 3\end{array}$ & Estúdio 1 \\
\hline $21 / 04$ & Feriado & \\
\hline $22 / 04$ & Desenvolvimento da Etapa 3 - Exercício 3 & Estúdio 1 \\
\hline $23 / 04$ & Desenvolvimento da Etapa 3 - Exercício 3 & Estúdio 1 \\
\hline
\end{tabular}

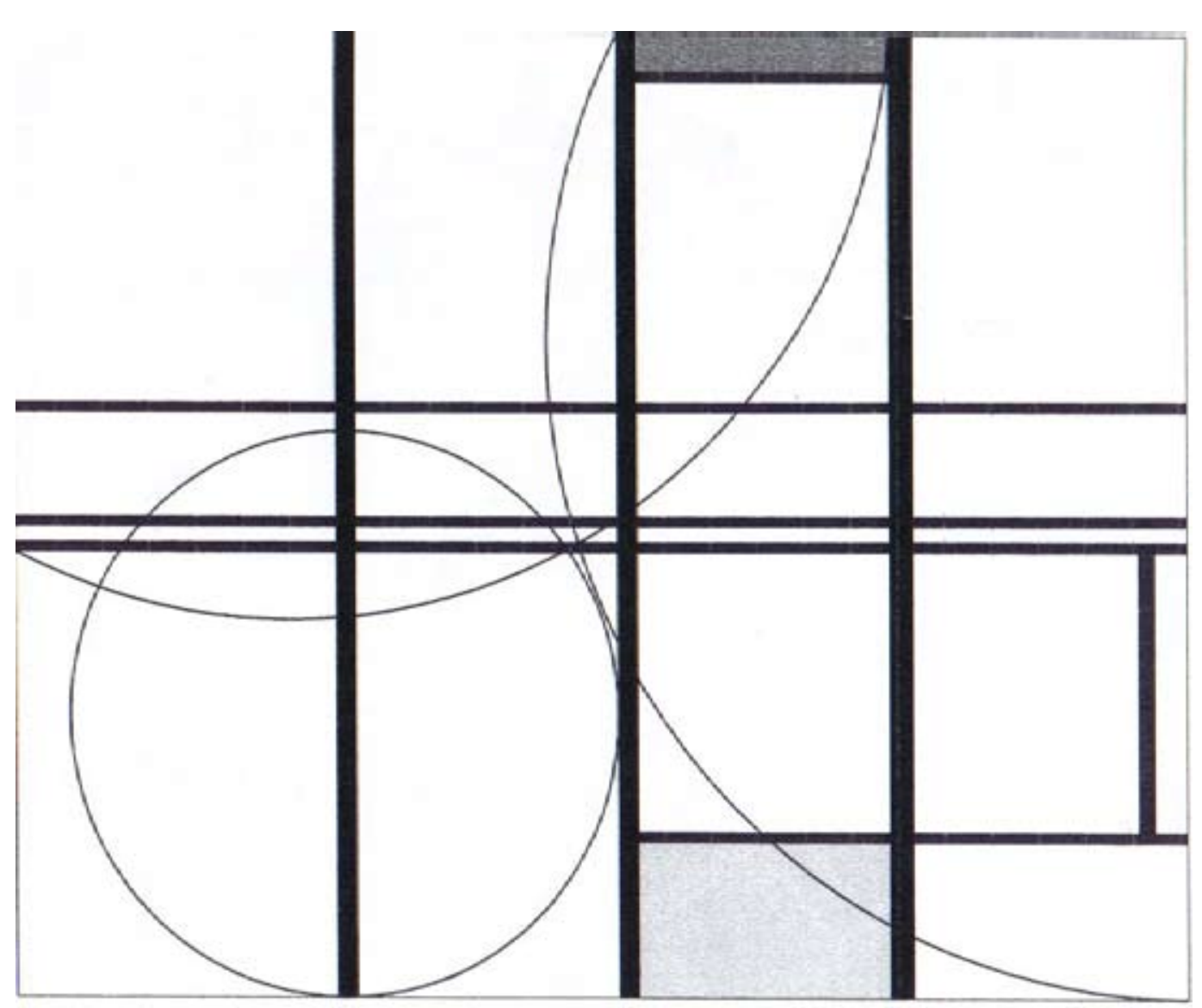



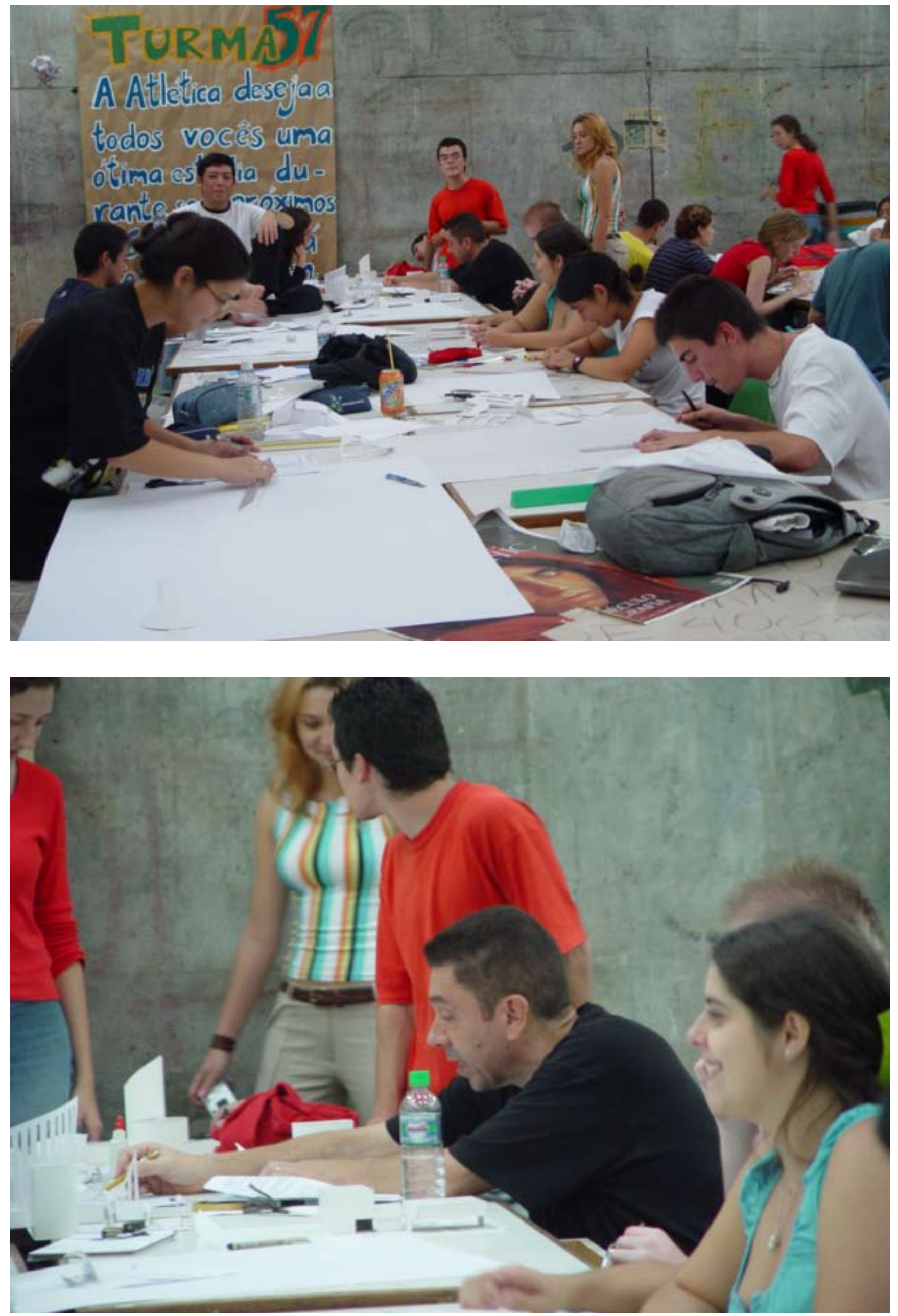

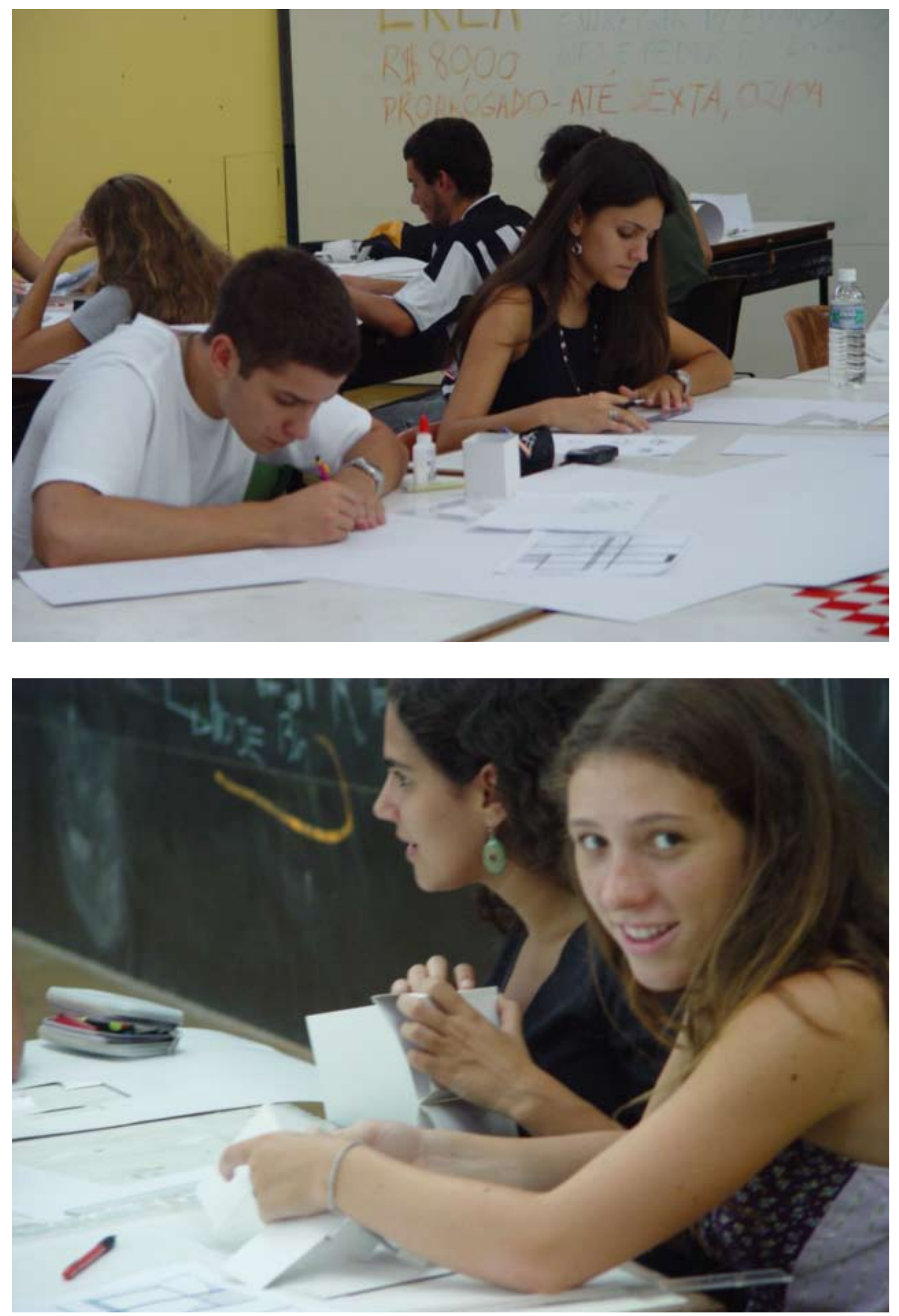

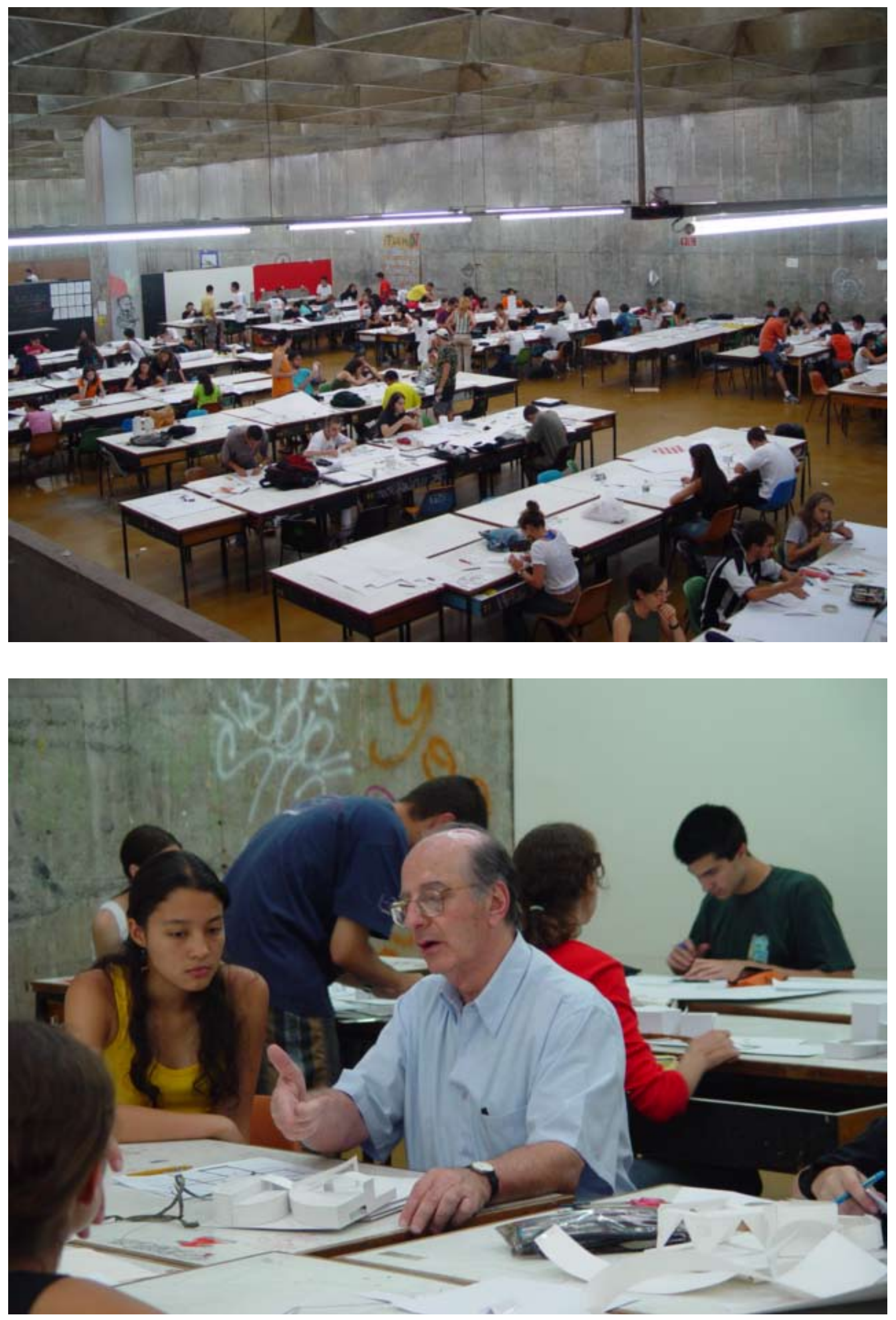

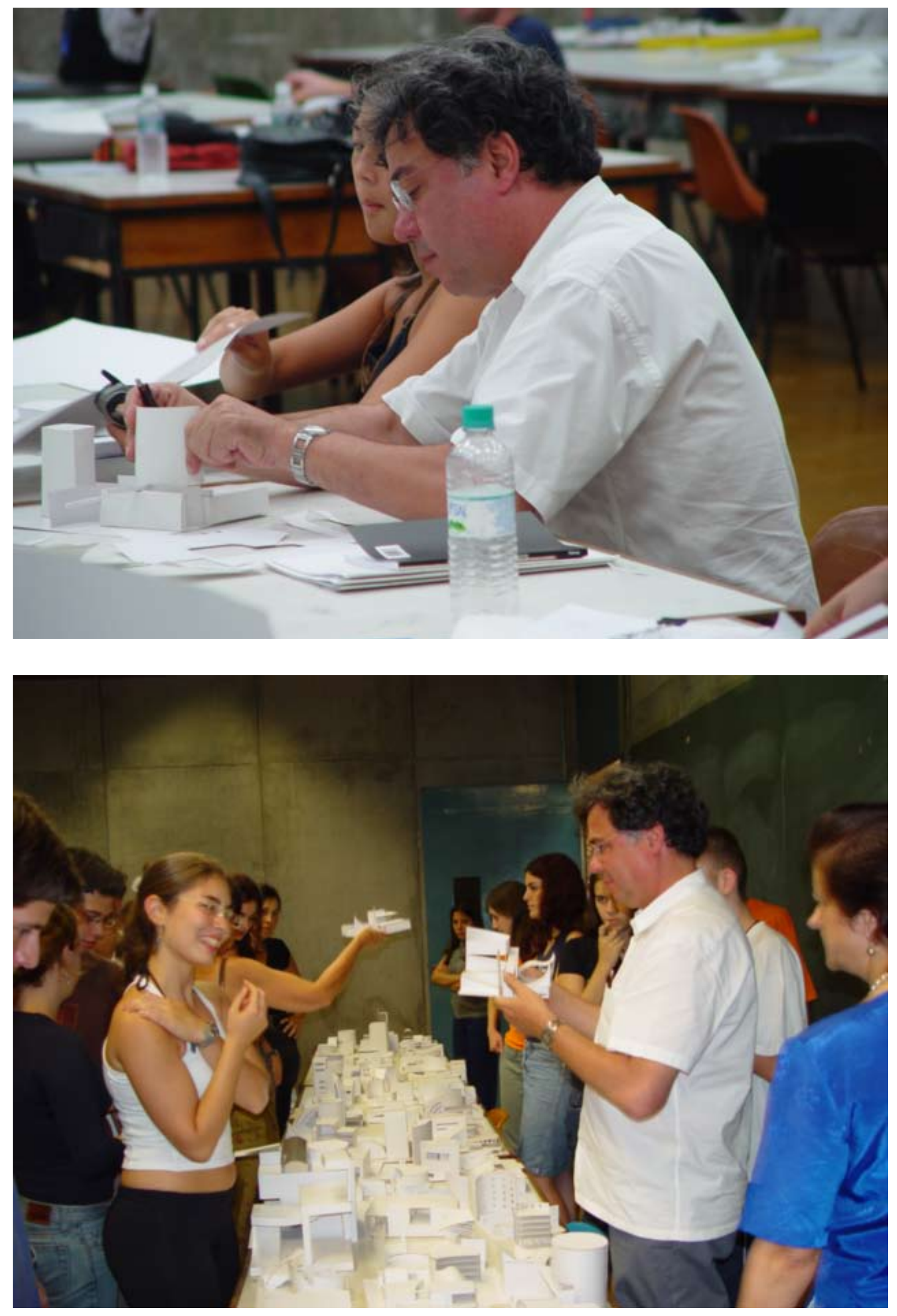

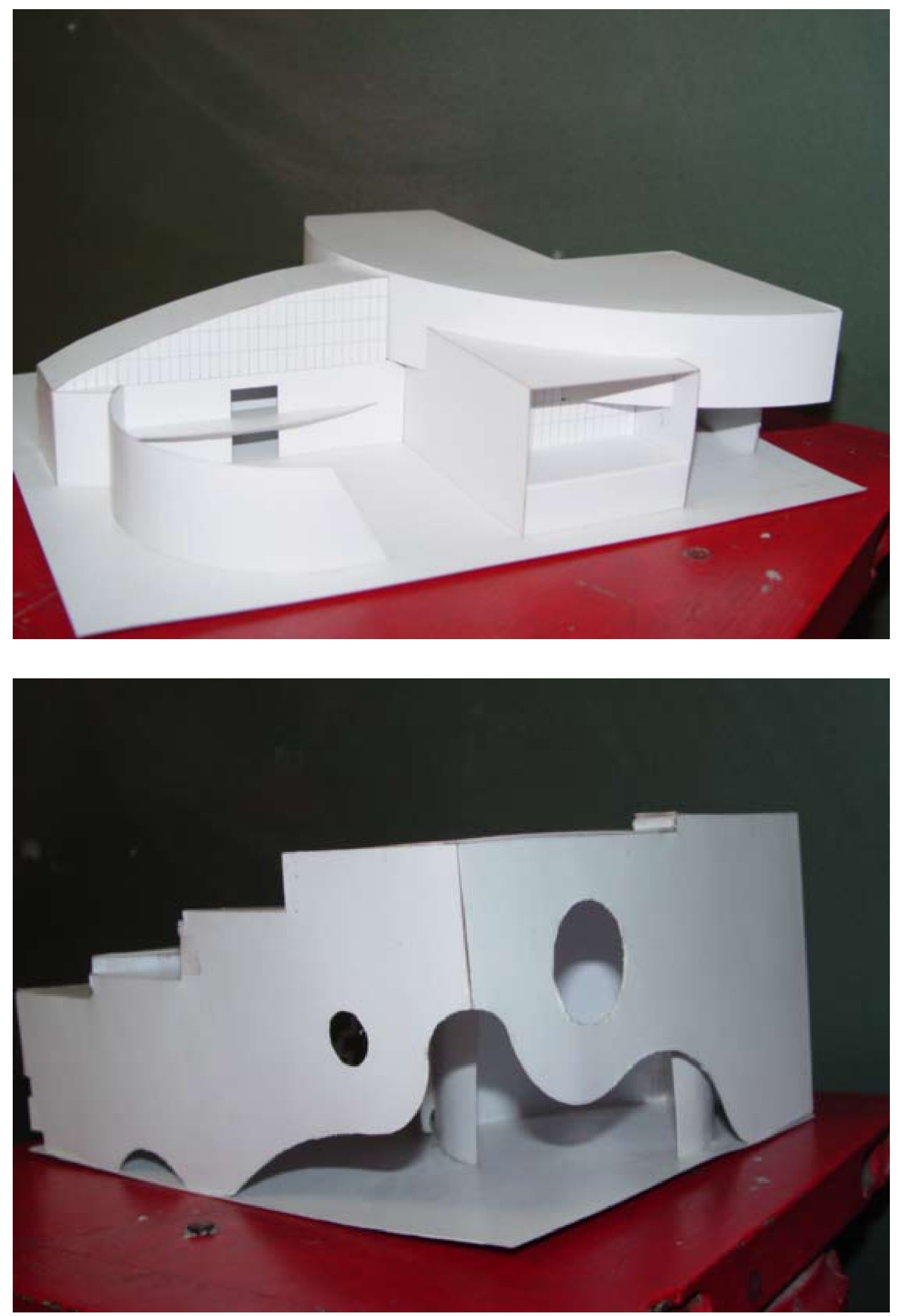

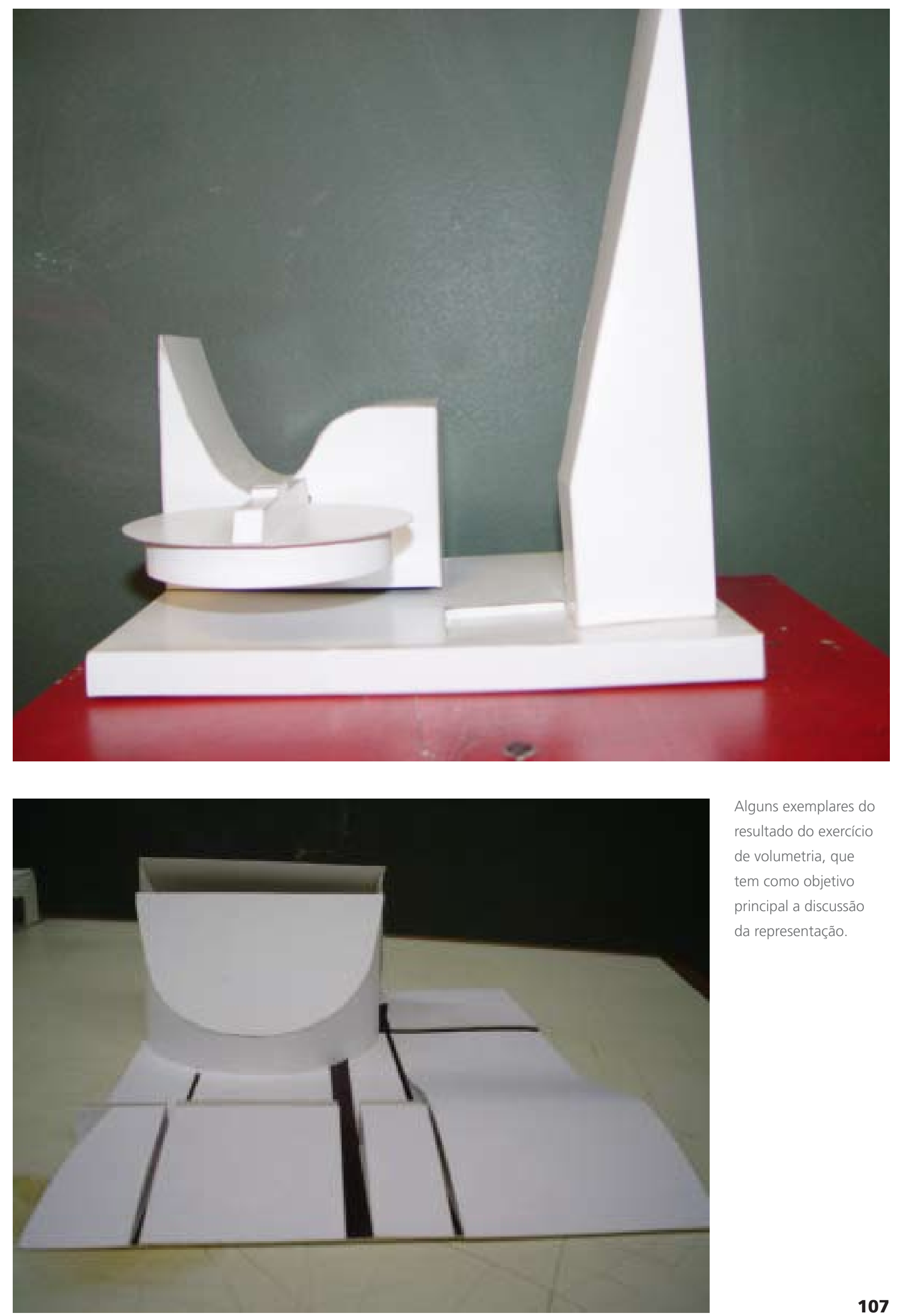

Alguns exemplares do resultado do exercício de volumetria, que tem como objetivo principal a discussão da representação. 

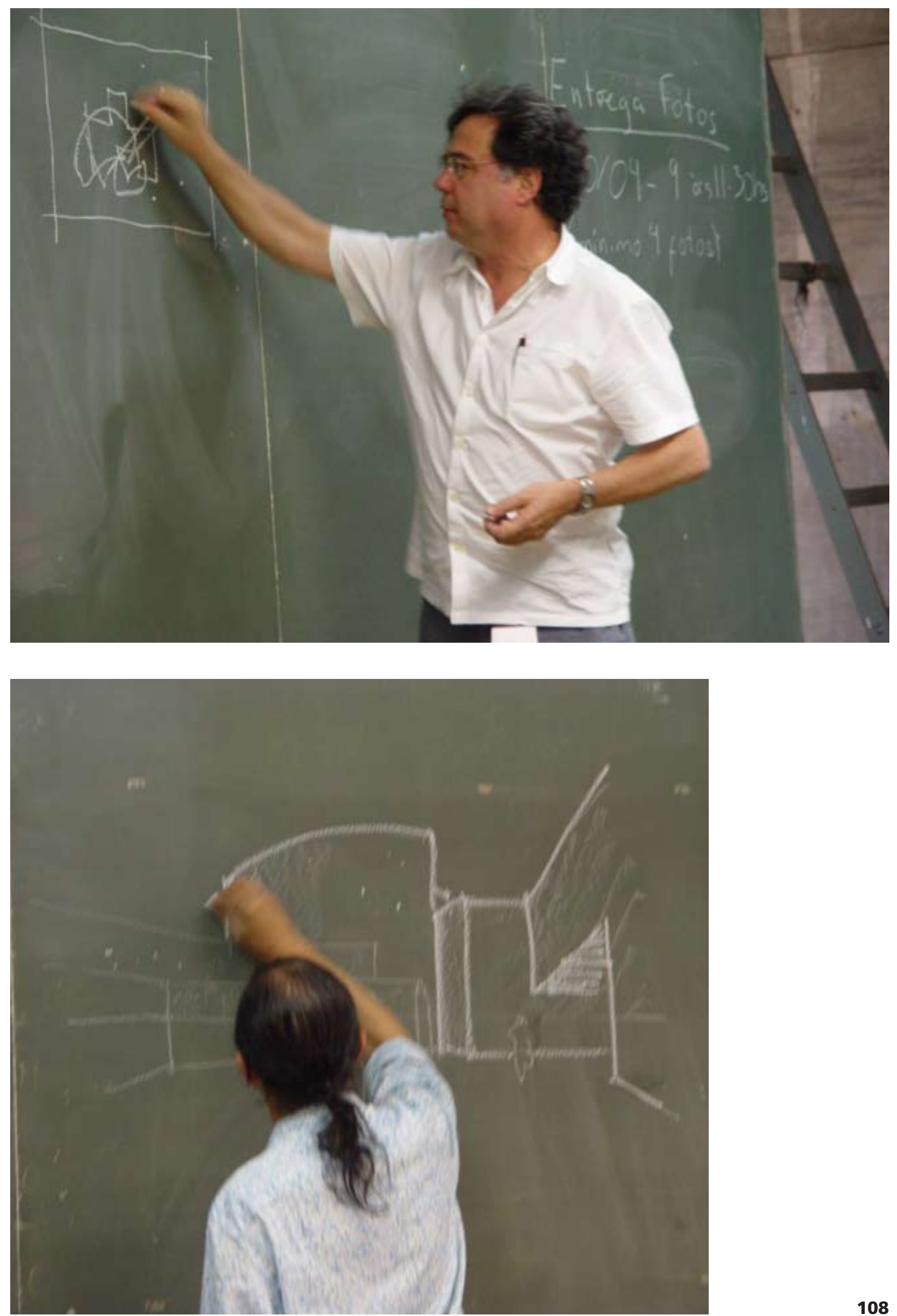

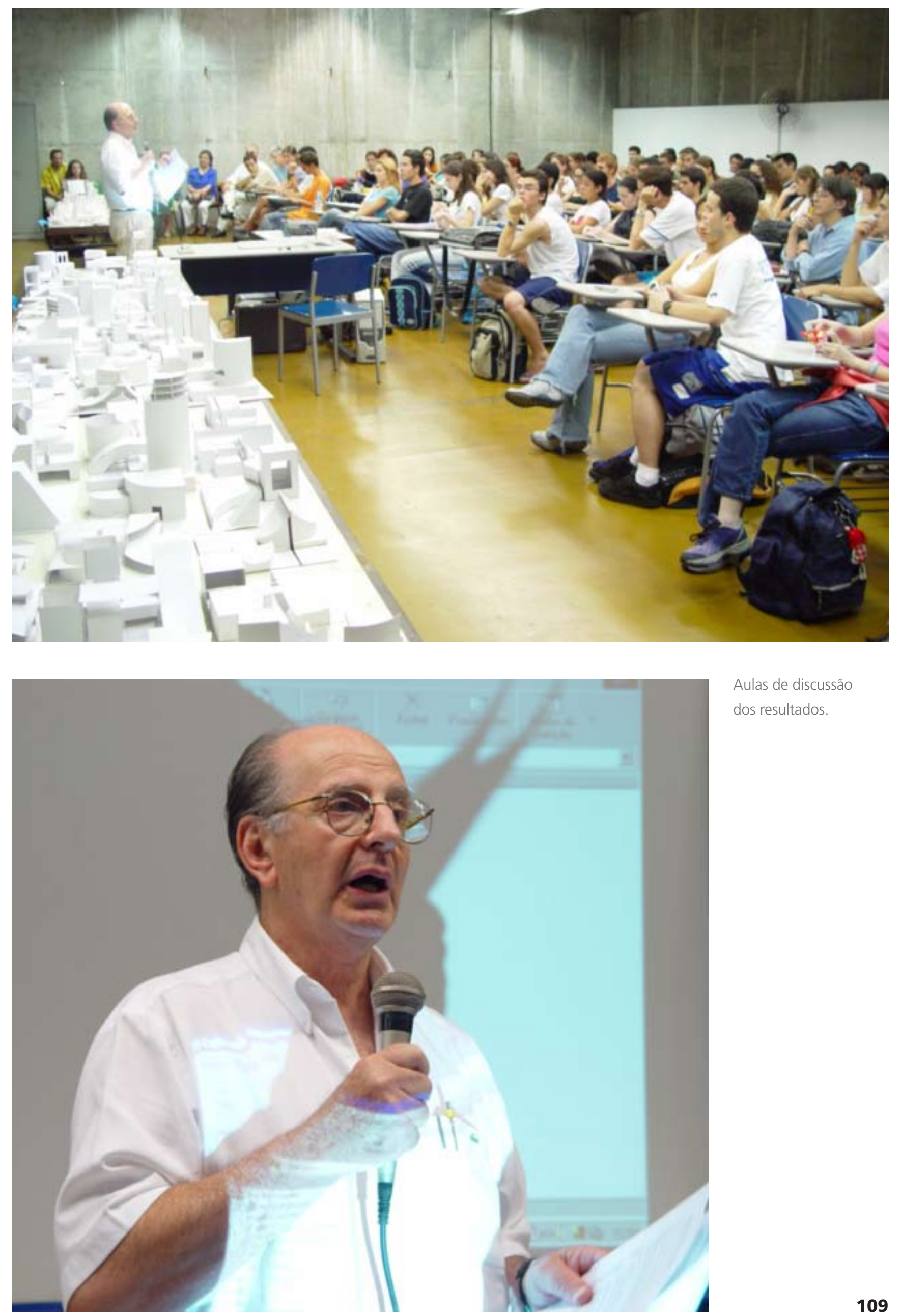

Aulas de discussão

dos resultados. 
A partir de terreno acidentado dado, os estudantes projetam um ateliê para um arquiteto.

\section{EXERCÍCIO 4}

Estúdio de Arquitetura - Concepção Espacial de Edificação e da sua Relação com o Entorno.

\section{Objetivo}

Exercitar com o aluno o processo de concepção nas principais etapas: estudo preliminar e anteprojeto, contendo noções de estabilidade, estrutura e iluminação natural.

\section{Programa da Edificação}

Em um terreno com orientação solar conforme planta anexa, o aluno deverá desenvolver o seguinte programa:

- Área coberta de $600 \mathrm{~m}^{2}$ com espaço de trabalho (300 a $\left.400 \mathrm{~m}^{2}\right)$ num único ambiente e com espaços para reunião, apresentação, recepção e secretaria, arquivos, sanitários e copa.

- Área descoberta para trabalho ao ar livre (única ou dividida).

- Área de paisagismo externo integrada à edificação, contendo arborização (árvores, arbustos, gramado, etc.), pisos pavimentados e com acessos apenas para pedestres.

- Via de acesso, circundante conforme planta de situação, de 4 m de largura.

Equipe de trabalho: 1 arquiteto coordenador, 9 arquitetos colaboradores, 5 estagiários de arquitetura, 5 funcionários de apoio (1 administrador, 1 secretária/ recepcionista, 2 serviços gerais, 1 limpeza) 
ETAPA 1 - LEITURA DO TERRENO

Elaborar um modelo tridimensional (em grupo, de cada mesa) para a compreensão da estrutura do terreno, bem como as suas relações com o meio ambiente e via de acesso.

\section{Entrega}

Cortes transversais e longitudinais (mínimo de 2) do terreno.

\section{ETAPA 2 - ESTUDO PRELIMINAR}

Elaborar o estudo de massas compondo os ambientes internos e externos, considerando:

- Acesso (s) às vias definidas pelo aluno.

- Definição dos ambientes de trabalho.

- Pé-direito livre, podendo ser único ou variável.

- Utilização do pavimento térreo, possibilitando o uso de, no máximo, dois mezaninos.

\section{Entrega}

Croquis, desenhos de implantação.

ETAPA 3 - DESENVOLVIMENTO - AVANÇO OU REVISÃO DO EXERCÍCIO

Com inclusão do partido estrutural.

Avanço com o modelo tridimensional estudando o partido estrutural e as condições de iluminação natural.

\section{Entrega}

Fotografias do modelo tridimensional (mínimo de 4) na escala 1:200, em pranchas A3. 
ETAPA 4 - ANTEPROJETO

Elaboração do modelo tridimensional, considerando o terreno no qual a edificação será implantada. Composição das projeções horizontais e verticais, além das perspectivas externas e internas.

\section{Entrega}

Síntese com avanço dos estudos anteriores.

Implantação com áreas externas e internas na escala 1:200.

Cortes longitudinal e transversal na escala 1:200.

Elevações (mínimo de 2) na escala 1:200.

Perspectivas externa e interna (uma de cada).

\section{Calendário - Exercício 4}

\begin{tabular}{|c|c|c|}
\hline Dias & Etapas & Local \\
\hline 26/04 & Discussão do Exercício 3 e apresentação do Exercício 4 & Sala 801 \\
\hline 27/04 & $\begin{array}{l}\text { Entrega da Etapa } 3 \text { do Exercício } 3 \text { das } 9 \text { às } 11 \text { h30 (GDPR) } \\
\text { Desenvolvimento da Etapa } 1\end{array}$ & Estúdio 1 \\
\hline 28/04 & $\begin{array}{l}\text { Aula Prof. Sant'Anna - "Experiências Contemporâneas na } \\
\text { Arquitetura" }\end{array}$ & \\
\hline 29/04 & $\begin{array}{l}\text { Entrega da Etapa } 1 \text { do Exercício } 4 \text { das } 9 \text { às } 11 \text { h30 (GDPR) } \\
\text { Desenvolvimento da Etapa } 2\end{array}$ & Estúdio 1 \\
\hline $30 / 04$ & Desenvolvimento da Etapa 2 & Estúdio 1 \\
\hline 03/05 & Discussão das Etapas 1 e 2 e apresentação da Etapa 3 & Sala 801 \\
\hline 04/05 & $\begin{array}{l}\text { Entrega da Etapa } 2 \text { do Exercício } 4 \text { das } 9 \text { às } 11 \text { h30 (GDPR) } \\
\text { Desenvolvimento da Etapa } 3\end{array}$ & Estúdio 1 \\
\hline 05/05 & 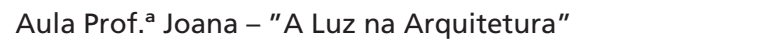 & Sala 801 \\
\hline 06/05 & Desenvolvimento da Etapa 3 & Estúdio 1 \\
\hline
\end{tabular}




\begin{tabular}{|c|l|l|}
\hline $07 / 05$ & Desenvolvimento da Etapa 3 & Estúdio 1 \\
\hline $10 / 05$ & $\begin{array}{l}\text { Entrega da Etapa 3 do Exercício 4 das 9 às 11h30 (GDPR) } \\
\text { Discussão da Etapa 3 e apresentação da Etapa 4 }\end{array}$ & Sala 801 \\
\hline $11 / 05$ & Desenvolvimento da Etapa 4 & Estúdio 1 \\
\hline $12 / 05$ & Aula Prof. Vladimir - "Arquitetura e Meio Ambiente" & Sala 801 \\
\hline $13 / 05$ & Desenvolvimento da Etapa 4 & Estúdio 1 \\
\hline $14 / 05$ & Desenvolvimento da Etapa 4 & Estúdio 1 \\
\hline $17 / 05$ & Desenvolvimento da Etapa 4 & Estúdio 1 \\
\hline $18 / 05$ & Desenvolvimento da Etapa 4 & Estúdio 1 \\
\hline $19 / 05$ & Desenvolvidio 1 \\
\hline $21 / 05$ & Desenvolvionto 1 \\
\hline
\end{tabular}

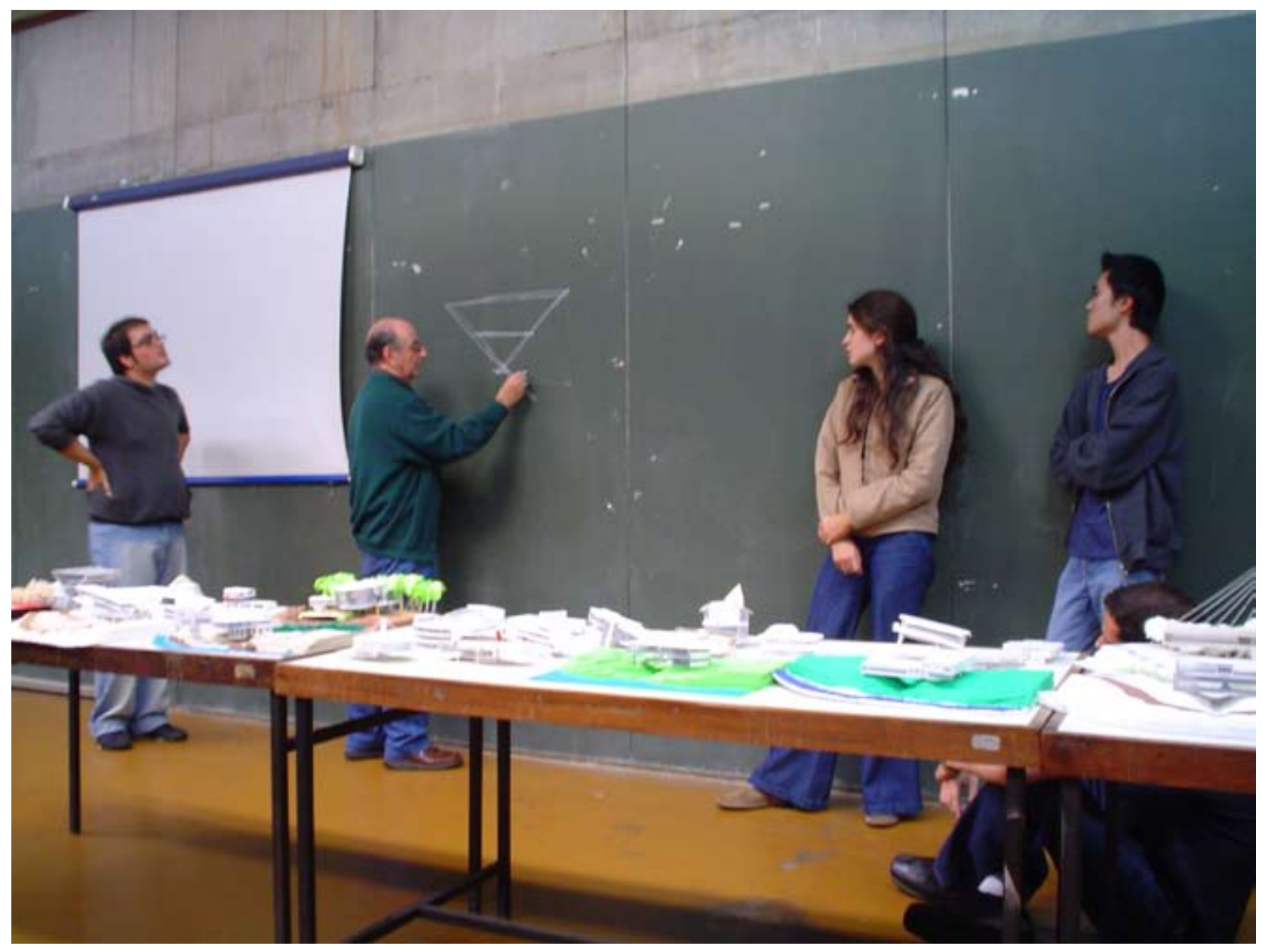



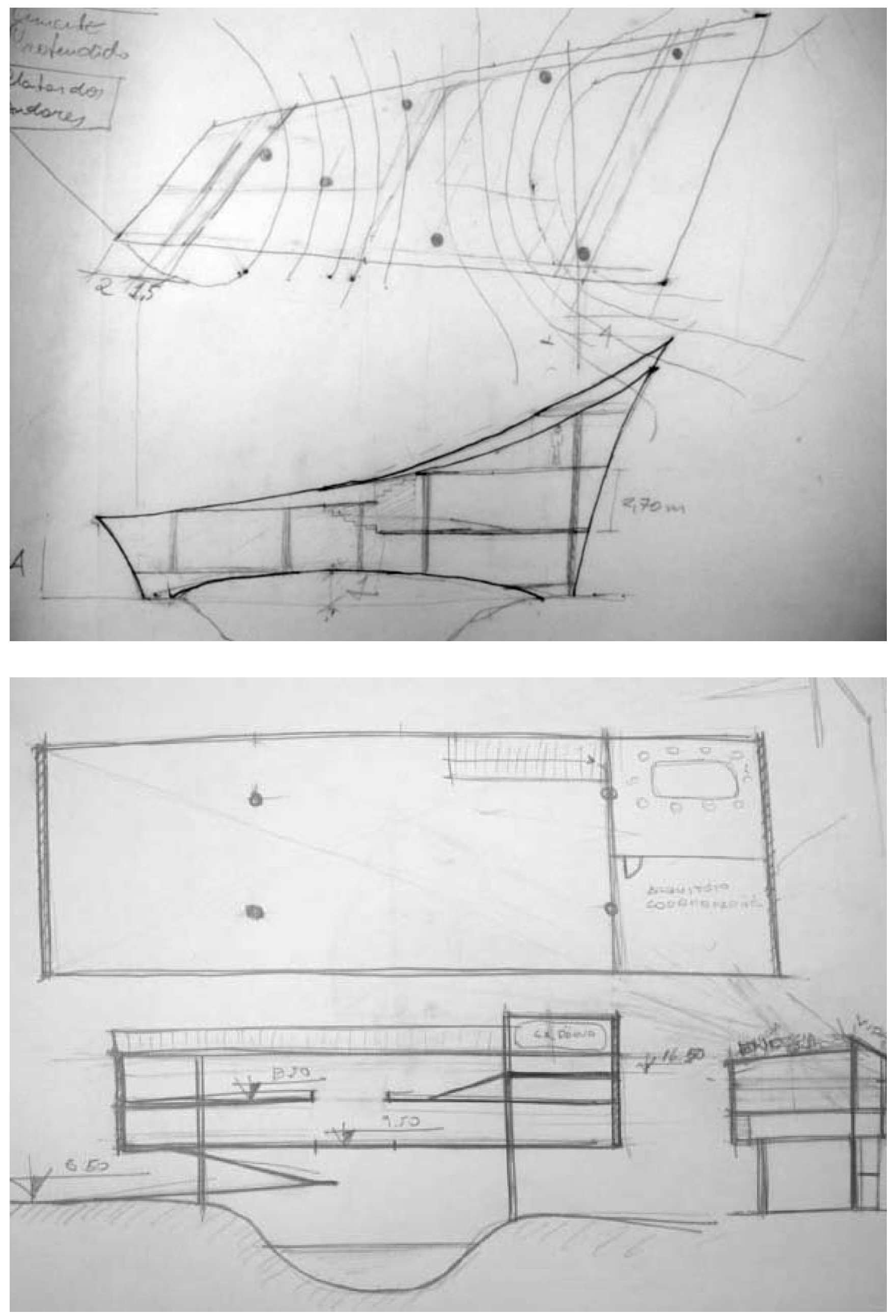

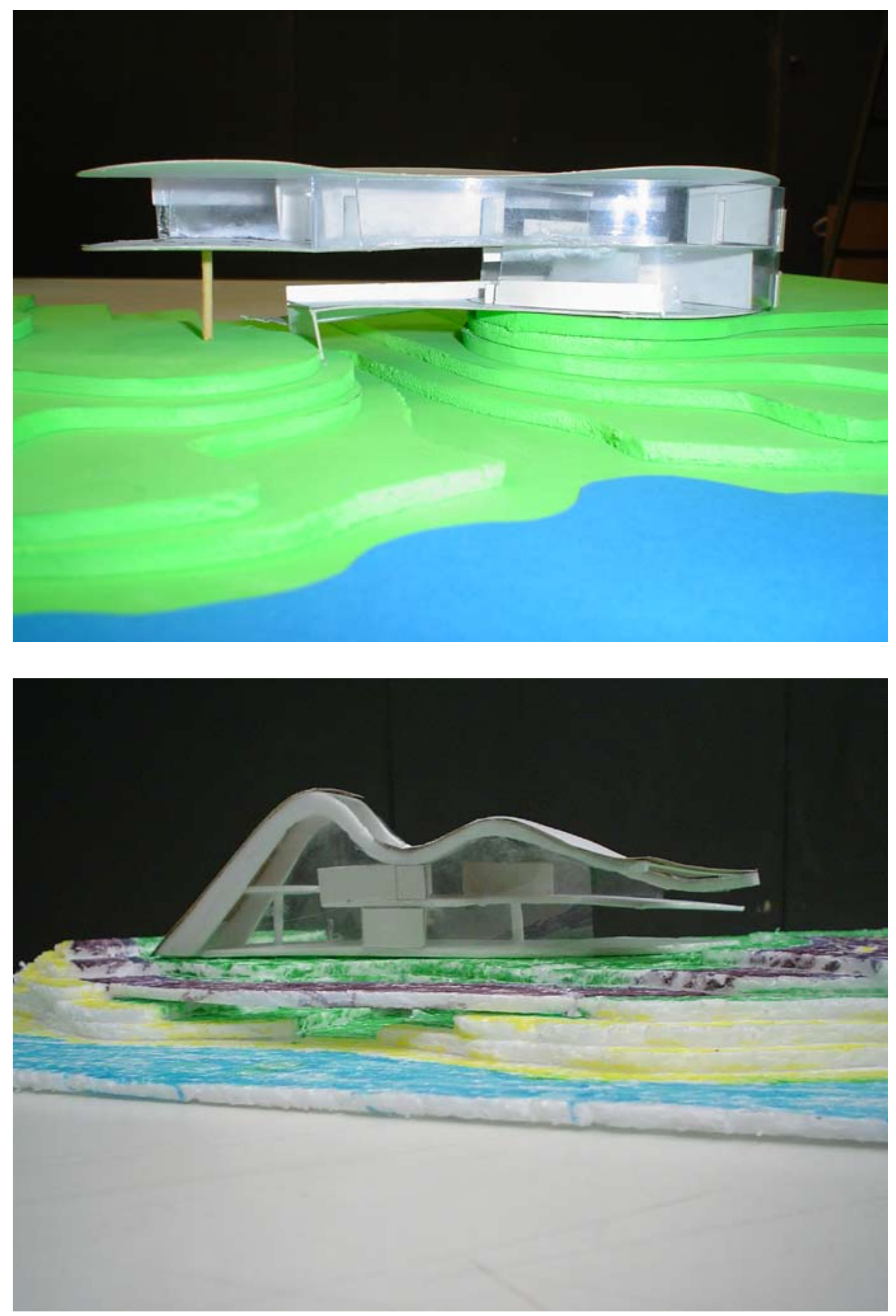

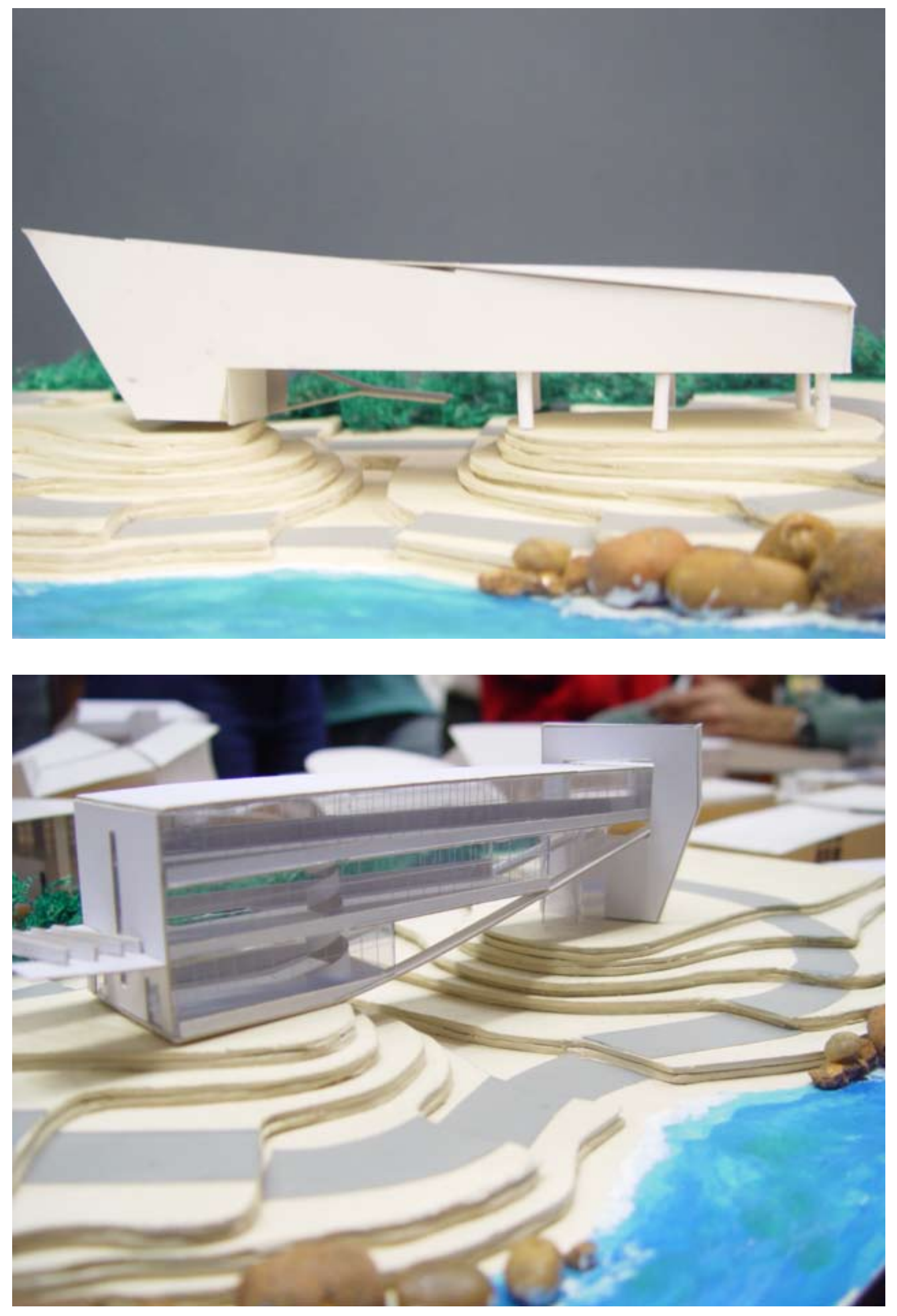

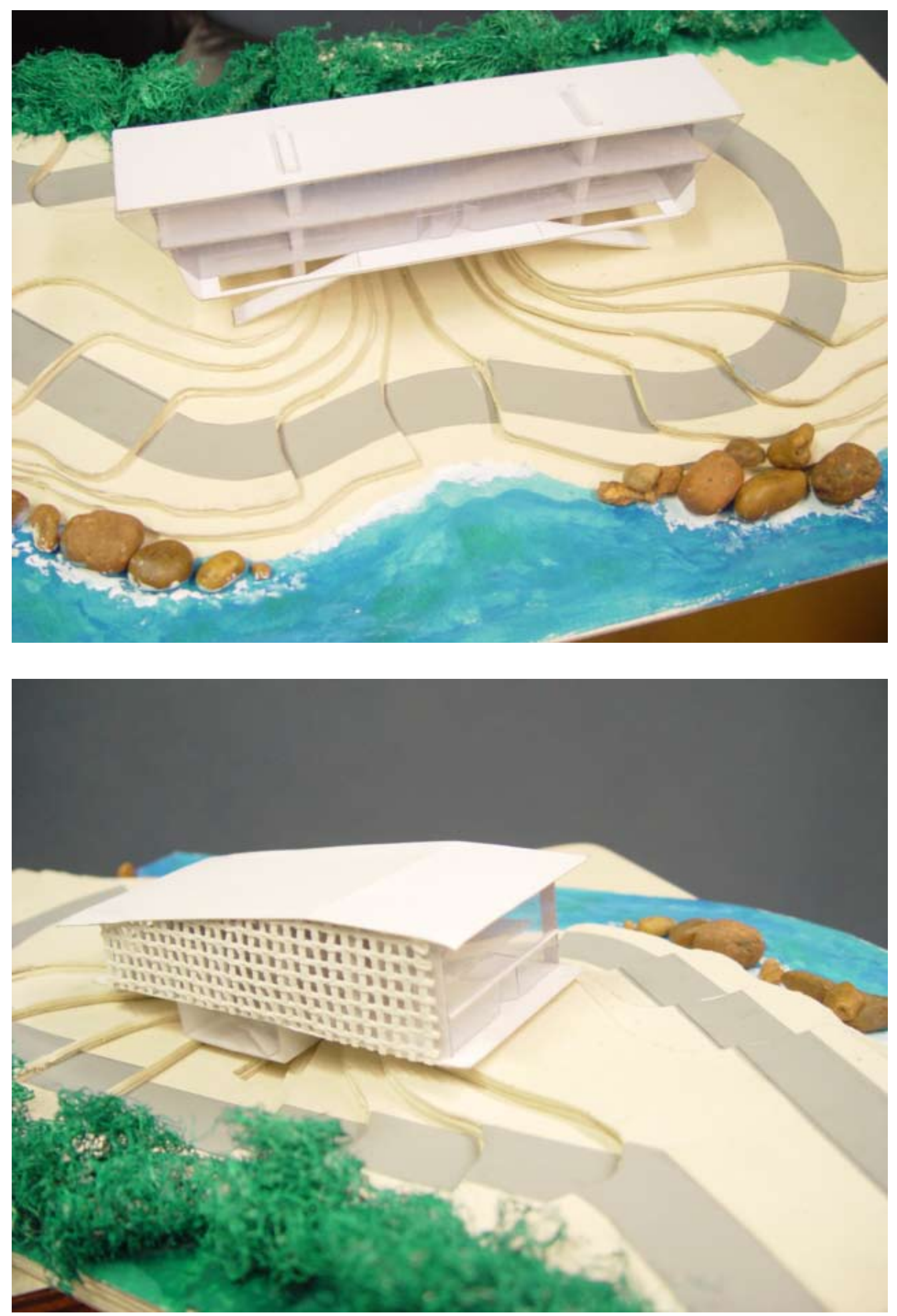

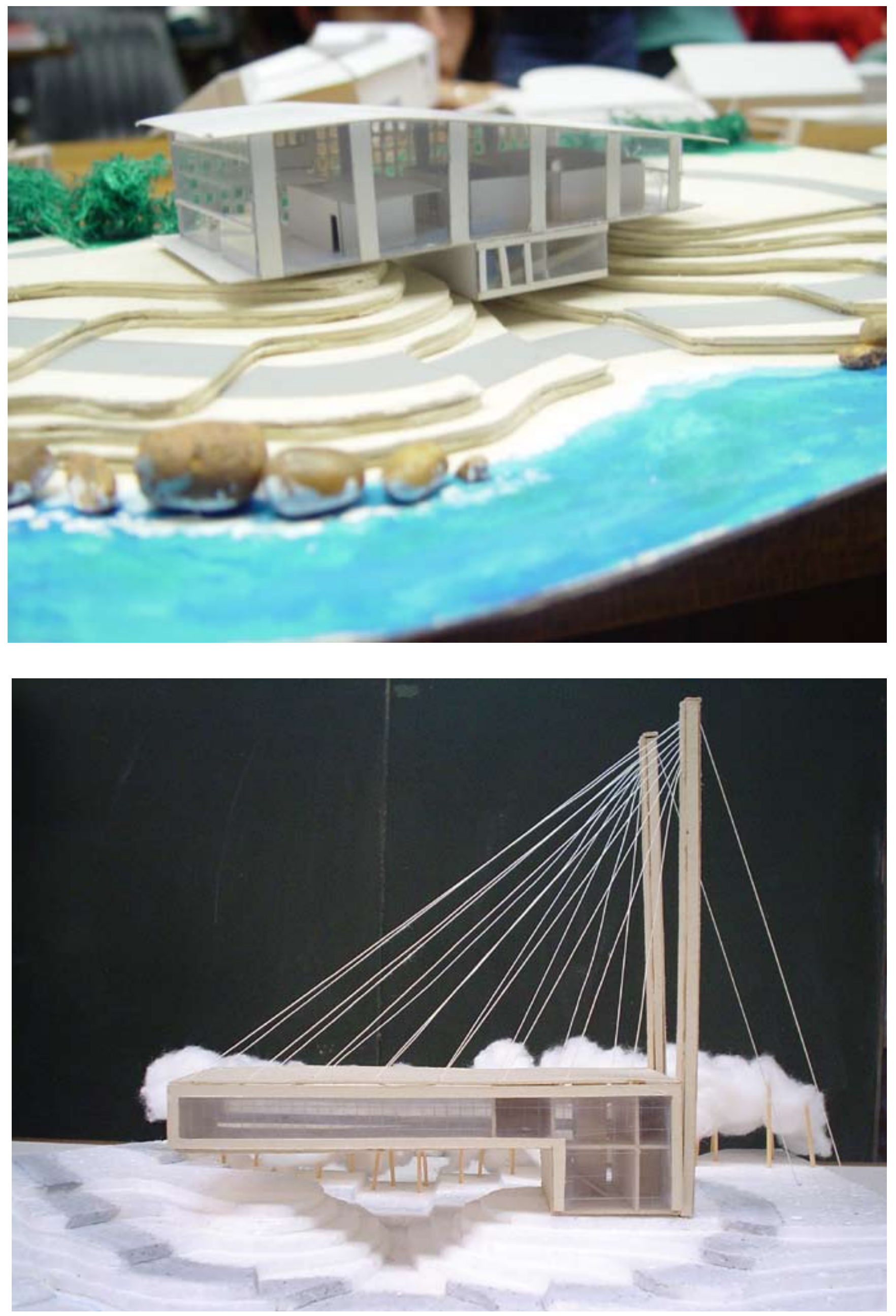
Exercício de leitura da cidade, em que cada grupo de alunos percorre um eixo importante da cidade e o retrata através de perfil desenhado.

\section{EXERCÍCIO 5}

Leitura e Interpretação do Espaço Urbano

\section{Objetivo}

Este exercício tem como objetivo:

- Sensibilizar os alunos com relação à diversidade da paisagem urbana.

- Fazê-los compreender a dinâmica da produção desta paisagem e das relações socioeconômicas e culturais que representa.

- Desenvolver técnicas de representação desta paisagem que explicitem as relações observadas.

- Compreender os principais elementos que constituem a estrutura e a dinâmica urbanas.

- Identificar os agentes produtores do espaço urbano.

- Conhecer os principais instrumentos urbanísticos de controle do desenvolvimento urbano.

\section{Desenvolvimento}

O exercício será desenvolvido em duas etapas. A primeira visa obter do aluno uma representação da imagem da cidade, através de uma leitura crítica que permita introduzi-lo na lógica da construção da cidade capitalista. A segunda tem como objetivo a análise da estrutura e dinâmica urbanas, pela identificação das relações e fluxos entre as diversas atividades desenvolvidas na cidade. 
ETAPA 1 - LEITURA DA CIDADE

Os alunos organizados em equipes, compondo duas mesas, farão uma leitura da cidade através do levantamento de 8 (oito) percursos radiais com origem no centro de São Paulo. Cada percurso será levantado e mapeado por duas equipes de alunos.

\section{Percursos}

- Sé-Jabaquara (Vergueiro, Domingos de Morais, Jabaquara)

- Sé-Rudge Ramos (Av. do Estado, Museu do Ipiranga, Anchieta)

- Sé-Largo Treze (Nove de Julho, Santo Amaro, Largo Treze)

- Sé-Capão Redondo (Augusta, Europa, Cidade Jardim, Morumbi, Giovanni Gronchi, Estrada do Campo Limpo)

- Sé-Granja Viana (Consolação, Rebouças, Eusébio Matoso, Raposo Tavares, até Granja Viana)

- Sé-Jaraguá (Anhagabaú, República, Memorial da América Latina, Lapa, Pirituba, Jaraguá)

- Sé-Cantareira (Santana, Tucuruvi, Cantareira/Horto)

- Sé-Itaquera (Brás,Tatuapé, Penha, Itaquera)

Os grupos deverão levantar o perfil longitudinal em ambos os lados da rota, registrando a massa edificada e a atividade urbana predominantes, os elementos construídos que se destacam na paisagem e os espaços abertos significativos, bem como a topografia existente, os acidentes geográficos encontrados e as obras de engenharia (pontes, viadutos, etc.). Esses registros serão feitos através de desenhos, fotos dos locais, croquis e anotações. A representação dessas informações deverá ser realizada em forma de rolo (A0 alongado), em papel-sulfite, 
contendo os perfis longitudinais das rotas de cada lado do percurso, rebatidos em relação a um eixo central imaginário, na escala horizontal de 1:5000. A escala vertical poderá ser de 1:500 ou aquela que o aluno considera mais adequada para expressar suas impressões.

\section{ETAPA 2 - DINÂMICA E ESTRUTURA URBANA}

Dentro das equipes já formadas, cada grupo de dois alunos deverá realizar um levantamento detalhado em quadras contíguas junto aos trechos dos percursos indicados abaixo:

- Sé-Jabaquara (imediações da Estação Paraíso)

- Sé-Rudge Ramos (imediações do Museu do Ipiranga)

- Sé-Largo Treze (imediações do Largo Treze)

- Sé-Capão Redondo (imediações da Rua Augusta com Oscar Freire)

- Sé-Granja Viana (imediações da Granja Viana)

- Sé-Jaraguá (imediações do Anhangabaú)

- Sé-Cantareira (imediações do Tucuruvi)

- Sé-Itaquera (imediações da estação Itaquera)

Na quadra os alunos devem observar e analisar a diversidade da topografia, vegetação, tipologia das edificações, uso das edificações, existência de espaços livres, sistema viário. A quadra deve ser representada:

- em planta na escala 1:2000 com o uso de cada edificação;

- em perspectiva axonométrica que permita visualizar as diferenças volumétricas do espaço construído (ocupação, verticalização, vazios urbanos, áreas livres). Na quadra, cada o aluno deverá realizar entrevistas com, no mínimo, 10 pessoas, conforme modelo de questionário anexo, visando estabelecer a relação desta área com a cidade, com relação às diversas atividades urbanas. Essas entrevistas procurarão 
conhecer qual a relação dessas pessoas com o local pesquisado, buscando conhecer como e quanto as pessoas se deslocam na cidade em busca de emprego e demais serviços (abastecimento, saúde, educação, lazer, etc.).

Essas entrevistas deverão ser reunidas dentro da mesma equipe de cada eixo levantado e tabuladas, resultando, assim, numa amostra significativa, capaz de mostrar a relação da área pesquisada com a cidade.

\section{Calendário - Exercício 5}

\begin{tabular}{|c|c|c|}
\hline Dias & Etapas & Local \\
\hline $24 / 05$ & Discussão do Exercício 3 e apresentação do Exercício 4 & Sala 801 \\
\hline $25 / 05$ & $\begin{array}{l}\text { Entrega da Etapa } 4 \text { do Exercício } 4 \text { das } 9 \text { às } 11 \text { h30 (GDPR) } \\
\text { Desenvolvimento da Etapa } 1 \text { (pesquisa de campo) }\end{array}$ & \\
\hline $26 / 05$ & Desenvolvimento da Etapa 1 (pesquisa de campo) & \\
\hline $27 / 05$ & Desenvolvimento da Etapa 2 (pesquisa de campo) & \\
\hline $28 / 05$ & Desenvolvimento da Etapa 2 (pesquisa de campo) & \\
\hline $31 / 05$ & Desenvolvimento da Etapa 1 (mapeamento) & Estúdio 1 \\
\hline $01 / 06$ & Desenvolvimento da Etapa 1 (mapeamento) & Estúdio 1 \\
\hline $02 / 06$ & Desenvolvimento da Etapa 1 (mapeamento) & Estúdio 1 \\
\hline 03/06 & Desenvolvimento da Etapa 1 (mapeamento) & Estúdio 1 \\
\hline $04 / 06$ & Desenvolvimento da Etapa 1 (mapeamento) & Estúdio 1 \\
\hline $07 / 06$ & Discussão da Etapa 1 & Sala 801 \\
\hline 08/06 & $\begin{array}{l}\text { Entrega da Etapa } 1 \text { do Exercício } 5 \text { das } 9 \text { às } 11 \text { h30 (GDPR) } \\
\text { Desenvolvimento da Etapa } 2 \text { (mapeamento/tabulação) }\end{array}$ & Estúdio 1 \\
\hline 09/06 & Aula Prof. ${ }^{a}$ Heliana - "Estrutura Urbana e Instrumentos Urbanísticos" & Sala 801 \\
\hline $10 / 06$ & Desenvolvimento da Etapa 2 (mapeamento/tabulação) & Estúdio 1 \\
\hline $11 / 06$ & Desenvolvimento da Etapa 2 (mapeamento/tabulação) & Estúdio 1 \\
\hline
\end{tabular}



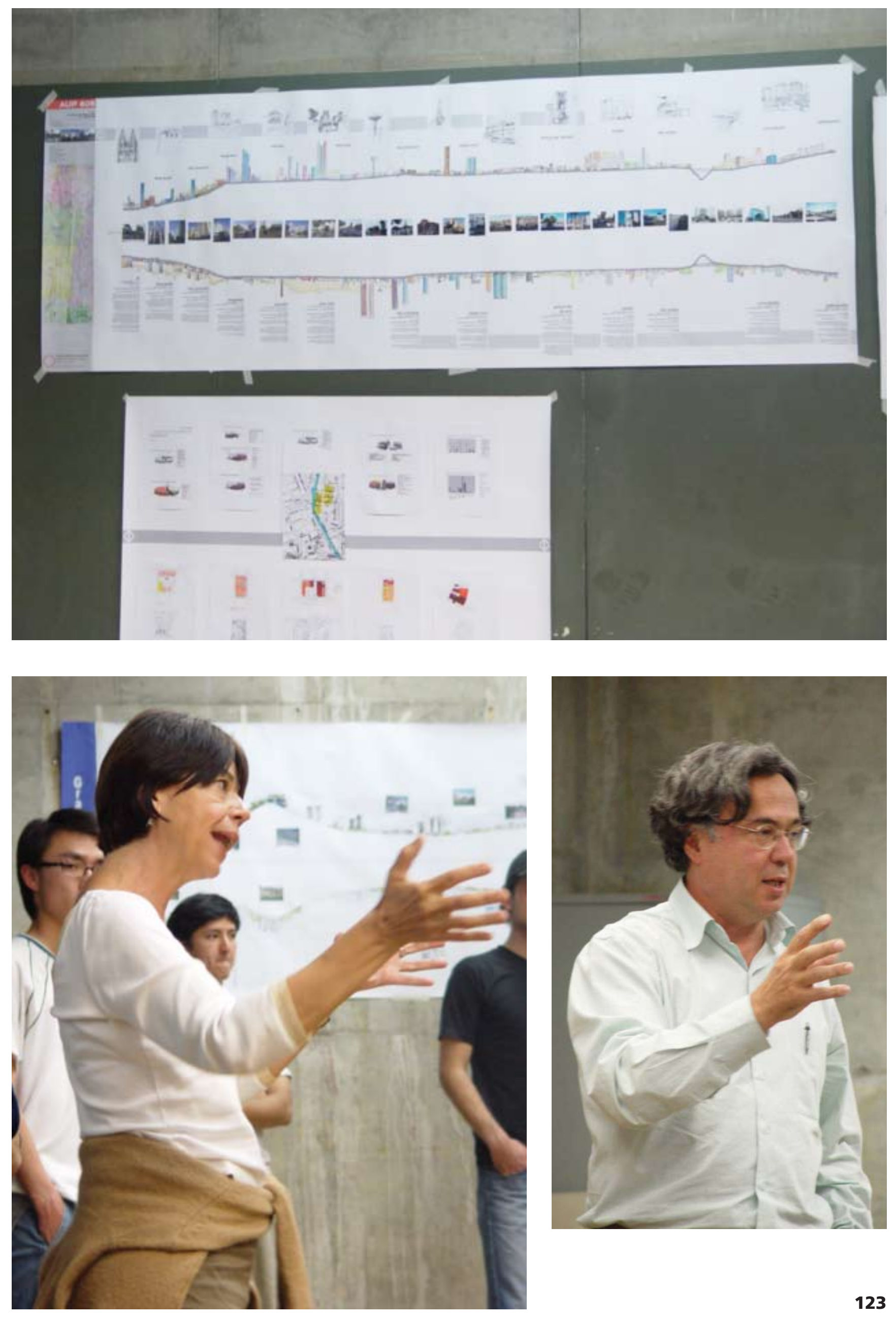

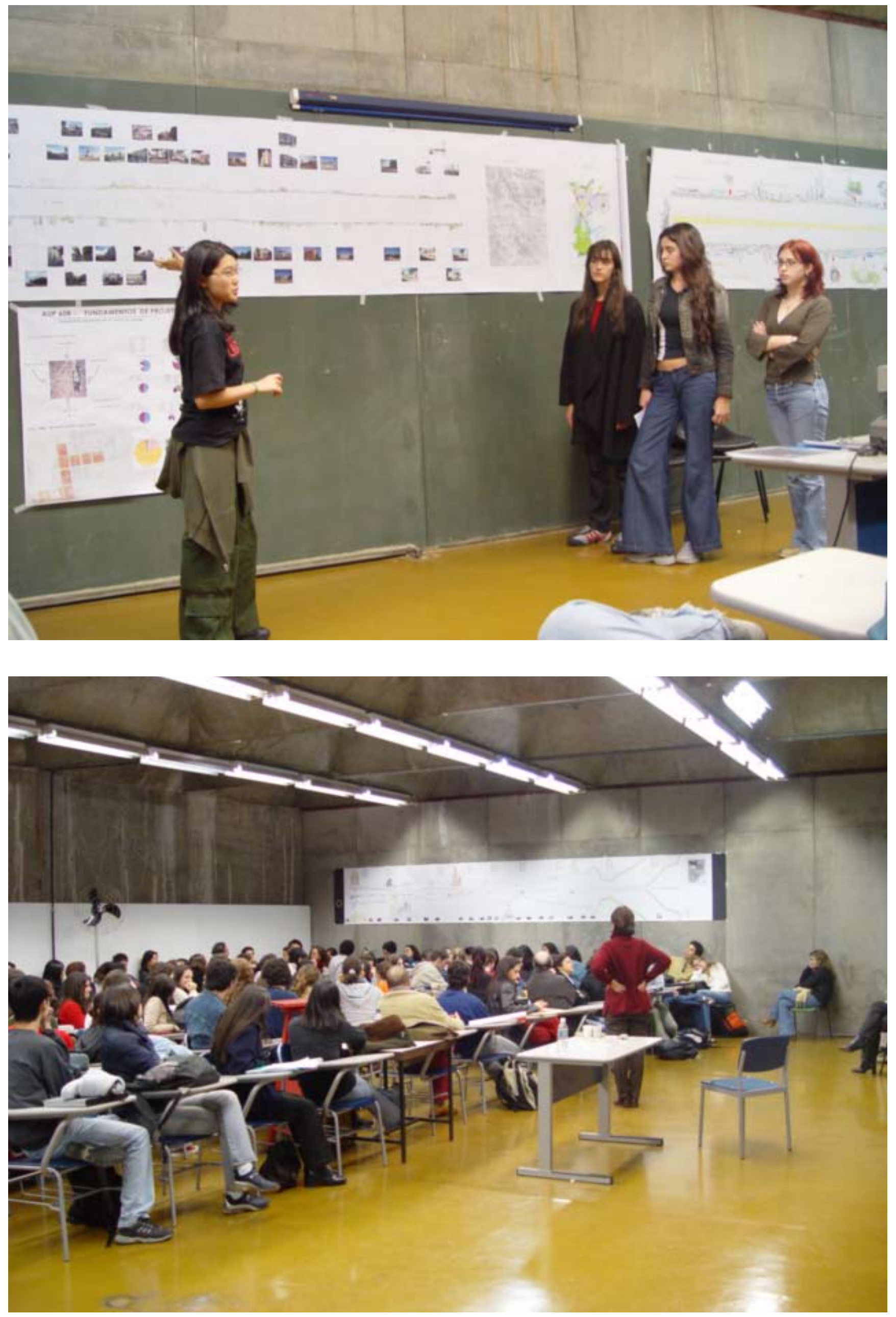
Exposição geral de todos os trabalhos realizados, com discussão em cada grupo sobre os resultados com o professor responsável.

\section{EXERCÍCIO 6}

Exposição dos Trabalhos Desenvolvidos

\section{Calendário - Exercício 6}

\begin{tabular}{|c|c|c|}
\hline Dias & Etapas & Local \\
\hline $14 / 06$ & Discussão do Exercício 5 e apresentação do Exercício 6 & Sala 801 \\
\hline $15 / 06$ & $\begin{array}{l}\text { Entrega das Etapas } 1 \text { e } 2 \text { do Exercício } 5 \text { das } 9 \text { às } 11 \text { h30 (GDPR) } \\
\text { Desenvolvimento do Exercício } 6\end{array}$ & Estúdio 1 \\
\hline $16 / 06$ & Aula Prof. ${ }^{a}$ Clice - "Programação Visual - Painéis" & Estúdio 1 \\
\hline $17 / 06$ & Desenvolvimento do Exercício 6 & Estúdio 1 \\
\hline $18 / 06$ & Desenvolvimento do Exercício 6 & Estúdio 1 \\
\hline $21 / 06$ & Montagem da Exposição & \\
\hline $22 / 06$ & Montagem da Exposição & \\
\hline $23 / 06$ & Montagem da Exposição & \\
\hline $24 / 06$ & Avaliação dos Trabalhos & \\
\hline $25 / 06$ & Avaliação dos Trabalhos & \\
\hline $28 / 06$ & Avaliação dos Trabalhos & \\
\hline $29 / 06$ & Avaliação dos Trabalhos & \\
\hline $30 / 06$ & Reunião dos Professores / Balanço do Curso & \\
\hline $01 / 07$ & Reunião dos Professores / Notas Finais & \\
\hline $02 / 07$ & Reunião dos Professores / Notas Finais & \\
\hline
\end{tabular}


Universidade de São Paulo

Faculdade de Arquitetura e Urbanismo

Departamento de Projeto

\section{AUP 608 - Fundamentos de Projeto}

Presença dos Docentes

Créditos: 12 (Aula), 4 (Trabalho) - Recuperação: Não haverá

A organização de turmas para efeito didático será definida pelos professores da disci-

plina, durante o semestre, podendo desconsiderar a lista oficial do Sistema Júpiter.

\begin{tabular}{|c|c|}
\hline Professores & Presença \\
\hline Siegbert Zanettini & $2^{a}$ e $5^{a}$ \\
\hline Maria Cristina da Silva Leme & $2^{a}$ e $5^{a}$ \\
\hline Anália Amorim & $2^{a}$ e $5^{a}$ \\
\hline Andreina Nigrielo & $2^{\mathrm{a}}$ e $6^{\mathrm{a}}$ \\
\hline Antonio Carlos Sant'Anna & $5^{\mathrm{a}}$ e $6^{\mathrm{a}}$ \\
\hline Vladimir Bartalini & $2^{\mathrm{a}}$ e $5^{\mathrm{a}}$ \\
\hline Clice de Toledo Sanjar Mazzilli & $2^{a}$ e $3^{a}$ \\
\hline Feres Lourenço Khoury & $2^{a}$ e $3^{a}$ \\
\hline Francisco Segnini & $2^{\mathrm{a}}$ e $6^{\mathrm{a}}$ \\
\hline Heliana Comin Vargas & $2^{a}$ e $3^{a}$ \\
\hline Joana Carla Soares Gonçalves & $2^{a}$ \\
\hline Klara Kaiser Mori & $2^{a}$ e $3^{a}$ \\
\hline Maria Assunção Ribeiro Franco & $2^{a}$ e $3^{a}$ \\
\hline
\end{tabular}




\begin{tabular}{|l|c|}
\hline Maria Cecilia Loschiavo dos Santos & $2^{\mathrm{a}}$ e $6^{\mathrm{a}}$ \\
\hline Minoru Naruto & $2^{\mathrm{a}}$ e $6^{\mathrm{a}}$ \\
\hline Rafael Perrone & $2^{\mathrm{a}}$ e $6^{\mathrm{a}}$ \\
\hline
\end{tabular}

\begin{tabular}{|l|c|}
\hline Monitores & Presença \\
\hline Camila Faccioni Mendes & $2^{\mathrm{a}}$ e $5^{\mathrm{a}}$ \\
\hline Almiro Blumenschein Cruz & $2^{\mathrm{a}}$ e $3^{\mathrm{a}}$ \\
\hline Antônio Takao Kanamaru & $2^{\mathrm{a}}$ e $3^{\mathrm{a}}$ \\
\hline Larissa Garcia Campagner & $2^{\mathrm{a}}$ e $5^{\mathrm{a}}$ \\
\hline Vera Lúcia Domshke & $2^{\mathrm{a}}$ e $6^{\mathrm{a}}$ \\
\hline Rodrigo Boufleur & $2^{\mathrm{a}}$ e $6^{\mathrm{a}}$ \\
\hline
\end{tabular}

Como monitora da disciplina AUP 608 - Fundamentos de Projeto, durante o primeiro semestre de 2004, participei da experiência de uma nova metodologia de ensino da arquitetura, cuja meta é não fragmentar em várias disciplinas os objetos de estudo. Os exercícios oferecidos aos alunos atingem os objetivos propostos: a orientação diversificada dos professores leva ao enriquecimento do aprendizado, por oferecer diferentes enfoques de um mesmo objeto de estudo. 


\subsection{FAUS - Universidade Católica de Santos: a integração horizontal no primeiro ano}

O Curso de Graduação da Faculdade de Arquitetura e Urbanismo da Universidade Católica de Santos - FAUS está entre os mais antigos do Estado de São Paulo. O ano 2000 marcou o início das comemorações de seu trigésimo aniversário. Nessa trajetória, a FAUS seguiu os princípios da formação generalista que permeou o pensamento da moderna arquitetura brasileira no século XX.

Foi em 1970, passados dois anos de sua criação, que a FAUS recebeu autorização para iniciar as atividades didáticas, incorporando-se às já existentes Faculdades Católicas de Santos, oferecendo setenta vagas no período vespertino, com vestibulares no início de cada ano. Devido à ampliação de seu corpo acadêmico (alunos e professores), novos espaços foram sendo necessários para o melhor desenvolvimento das atividades didáticas, ocupando o terceiro andar do Colégio Santista, na região central de Santos. Atualmente a FAUS tem sua sede própria na Avenida Conselheiro Nébias. O ano de 1976 foi promissor para a FAUS, trazendo conquistas marcadas não apenas pela inauguração da sede própria, mas também por seu reconhecimento pelo Conselho Federal de Educação e pelo aumento da oferta para 140 vagas, com a realização de dois vestibulares anuais.

A organização curricular da FAUS baseou-se na estrutura pedagógica que Vilanova Artigas criou para a FAUUSP, cujo modelo influenciou um grande número de cursos de arquitetura no país. As proveitosas reuniões com o Professor Vilanova Artigas estimularam a implantação na FAUS do mesmo sistema da FAUUSP, isto é, disciplinas organizadas em três departamentos representativos das áreas do conhecimento essenciais à formação profissional: Projeto, Tecnologia e História. Dentro do Departamento de Projeto criaram-se 
as disciplinas de Urbanismo, Edificação, Objeto e Mensagem, com o objetivo de estruturar as diversas categorias do projeto por meio de novas linguagens, alinhadas com o desenvolvimento industrial, atribuindo ao Trabalho de Graduação Interdisciplinar (TGI) a função integradora de todas essas atividades. Essa mesma estrutura de ensino segue vigente na Faculdade, sem alteração ao longo de seus trinta anos de existência.

A crise no ensino superior após o período militar, agravada por questões específicas das universidades privadas, como, por exemplo, o aumento do número de vagas, a queda da qualidade do ensino fundamental e médio e, principalmente, a mudança do perfil sociocultural do aluno ingressante na Faculdade de Arquitetura e Urbanismo da Universidade Católica de Santos, foram as motivações que levaram o grupo de professores dessa Faculdade a repensar o curso no ano de 2000. Nesse sentido reuniram-se tanto a direção quanto os chefes dos três departamentos da Faculdade de Arquitetura e Urbanismo, que assumiram o compromisso de elaborar propostas que visassem à melhoria e à excelência do ensino na FAUS, em conformidade com alterações que haviam sido aprovadas no Estatuto da Unisantos em junho de 2000.

Uma Comissão Plena foi constituída para o encaminhamento do processo de discussão, formada pelo diretor, vice-diretora, chefe do Departamento de Tecnologia, chefe do Departamento de Teoria de Arquitetura, chefe do Departamento de Projeto, um professor representando o Departamento de Tecnologia, outro de Teoria de Arquitetura, seis professores representantes das "seqüências" do Departamento de Projeto, bem como três alunos como representantes estudantis. Também integrava essa Comissão Plena um representante da NAP/Unisantos, que forneceu as diretrizes metodológicas para a elaboração do Projeto Político Pedagógico da Faculdade de Arquitetura e Urbanismo. Para a elaboração do do- 
cumento foi discutida a necessidade do aprofundamento das discussões sobre:

1. a participação do corpo docente e discente no processo de avaliação do ensino oferecido pela Faculdade de Arquitetura e Urbanismo;

2. informações sobre as estruturas didáticas e pedagógicas de diversas faculdades de Arquitetura e Urbanismo nacionais e internacionais;

3. a história da Faculdade de Arquitetura e Urbanismo da Unisantos;

4. diagnóstico da Faculdade de Arquitetura e Urbanismo, elaborado pelos departamento e pela representação estudantil;

5. a organização de palestras com profissionais que detinham experiências na elaboração de diretrizes curriculares e planos pedagógicos, de cursos de arquitetura e urbanismo.

Essas etapas do trabalho foram cumpridas e resultaram no documento "Comissão Projeto Pedagógico FAUS 2000", que reúne as seguintes propostas:

1. Características, objetivos e diretrizes do curso

2. Estrutura didática e pedagógica

3. Estrutura departamental

4. Integração vertical

5. Integração horizontal

6. Laboratórios e núcleo de estudos da cidade

A proposta sobre a integração horizontal presente no documento "Projeto Político Pedagógico“ foi posteriormente discutida em reuniões, e as diretrizes para sua implantação são as que seguem:

"2.4.2 As disciplinas são as unidades didáticas mínimas da estrutura pedagógica do ensino. A chamada integração horizontal pressupõe estabelecer algum tipo de vínculo didático e pedagógico entre as disciplinas.

2.4.3 Foi discutido que a integração deverá ter caráter flexível, ou seja, 
deverá ocorrer entre disciplinas que apresentem afinidades de conteúdos programáticos. A integração não deverá 'engessar' os objetivos e as ementas das disciplinas; ao contrário, visa ampliar as possibilidades de aproximação, reflexão e investigação científica das matérias do curso de arquitetura e urbanismo"...

"2.4.5 A integração entre as disciplinas de uma mesma etapa de curso poderá acontecer a partir de:

- Temas

- Problemáticas

- Objetivos

- Produtos comuns

2.4.6 A integração pode acontecer de forma variável nas etapas do curso e deverá pressupor ênfases diferenciadas das disciplinas de acordo com os temas, problemáticas, objetivos e produtos comuns escolhidos"...

Feitas as reuniões para estabelecer, a partir do primeiro ano, as diretrizes de implantação da integração horizontal, os professores das disciplinas oferecidas nesse ano conseguiram estabelecer atividades didáticas que se complementavam e buscavam um objetivo comum na formação do aluno. As demais etapas do curso não alcançaram o mesmo padrão de integração, mas foram realizadas reuniões e algumas atividades didáticas foram trabalhadas no sentido de integrar os conteúdos programáticos das disciplinas.

Outra reformulação curricular estabelecida como novo procedimento foi o da integração vertical, que constaria de um ateliê de projeto onde o TFG (Trabalho Final de Graduação) seria o trabalho a ser desenvolvido por cada equipe vertical formada por alunos do segundo ao quarto ano, tendo como coordenador o aluno do quinto ano cujo TFG seria desenvolvido pela equipe vertical. 
trumento, que é o ateliê vertical, porque, naquele momento, a estrutura da FAUS não oferecia subsídio para essa implantação. Em documentação anexa ao Projeto Político Pedagógico, um grupo de professores declara: "Não estamos convencidos da eficácia do ateliê vertical como elemento de integração vertical nesta estrutura atual vigente na FAUS". Como alternativa ao ateliê vertical, viável para a estrutura da FAUS naquele momento, foram sugeridas as disciplinas optativas, os concursos de projetos e viagens de estudos.

Essa proposta de ensino para a FAUS foi elaborada por um grupo de professores com o objetivo de viabilizar as diretrizes do Projeto Político Pedagógico em relação às integrações vertical e horizontal, e não só de colocar em prática no primeiro ano a sistematização da integração horizontal, como também de estendê-la para os demais anos. Essa proposta dos professores - apresentada na forma de esquema e reproduzida a seguir - foi colocada como anexo no Projeto Político Pedagógico. 


\section{Documentação Anexa}

Aprovaçöes Internas

\section{A. MODELO DE ENSINO / ESTRUTURAÇÃO DO CURSO}

Proposta desenvolvida pelos profs. Antonio Cláudio Pinto da Fonseca, Ana Claudia Ventura, José Cláudio Paneque, Vera Domsche e Carios Antunes, para a reestruturação do curso de arquitetura e urbanismo da Facuidade e Arquitetura e Urbanismo da Universidade Católica de Santos.

Questão Gerais-

1. Formação humanista, abrangente e generalista

2. Visão histórica näo segmentada

3. Percepção dos problemas reais e participação

4. Abordagem local e regional
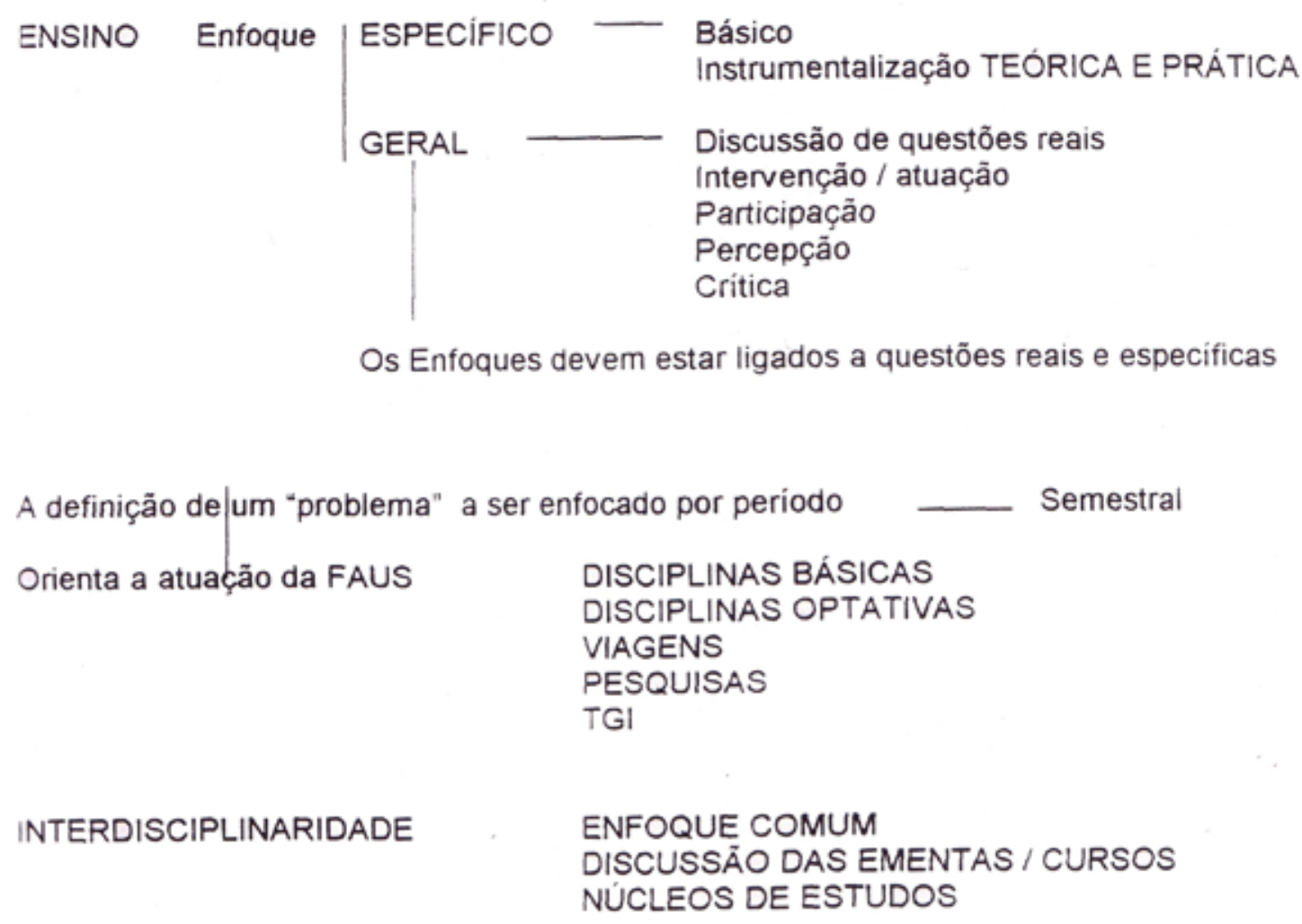
Trabalho de um periodo ou semestre

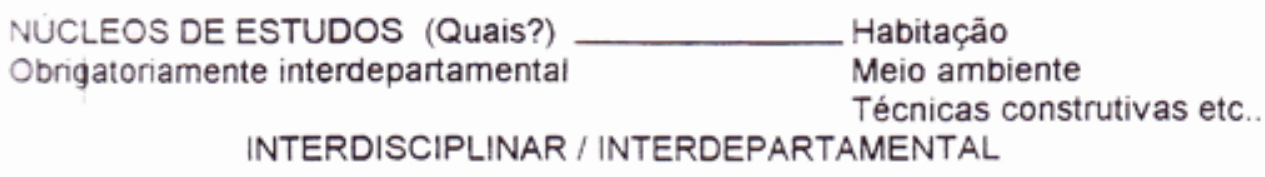

Não estamos convencidos da eficácia do "atelier vertical" como elemento de integração vertical.

INTEGRAÇÃO HORIZONTAL_ DISCIPLINAS OBRIGATÓRIAS - Um seminário de abertura para coordenar e ajustar os exercicios no inicio do semestre, visando diminuir a carga de trabalho braçal dos alunos. convergindo os exercicios de maneira integrada e outro seminánio de encerramento para avaliação e discussăo das estratégias adotadas.

DRIMEIRO ANO

projeto)
Visão Panorâmica em todas as Disciplinas

Trabaihos que enfoquem a cidade

Compreensåo dos problemas gerais

Percepção do espaço natural transformado

Participação em fases especificas nas disciplinas de outros anos

Apresentação do tema / trabalho

Viagens de estudo especifica

Seminários

Etc.

Visão panorâmica da História (História-sempre pelo viés da estética do

Ajudando a formar repertório ARTE / CULTURA / ARQUITETURA E URBANISMO /TECNOLOGIA

Avaliação conjunta e no mesmo dia. através de bancas de professores que não foram os responsáveis peio desenvolvimento do trabaino em avaliação, isto é os professores do segundo ano avaliam os alunos do quarto ano. por exempio. Esse esquema forçará a uma preparação muito maior das ementas. visto que a avaliação será feita sobre os itens constantes nas ementas. no tocante aos graus de exigència que se espera em cada final de semestre. $\bigcirc$ dia da avaliação será um dia 
de debates e comparaçōes. visto que os trabaihos estarảo simuitaneamente se tornando pubilicos.

OS ANOS SEQUENTES irão paulatinamente se integrando ao processo, a partir do primeiro ano. com as ènfases estabelecidas no quadro que encaminhamos adredemente a comissão organizadora.

Primeiro ano - ènfase na percepção

Segundo ano- ênfase na anàiise

Terceiro ano - ênfase na critica

Quarto ano - ènfase na sintese

O TFG. $\quad$ CONCLUI O PROCESSO, sugerimos a realização de rodizio obrigatório dos professores orientadores. fixando-se somente a comissảo coordenadora do TFG. formada por 3 protessores. 
Momentos ilustrativos das reuniões realizadas para as discussões do Projeto Político Pedagógico em 2000.
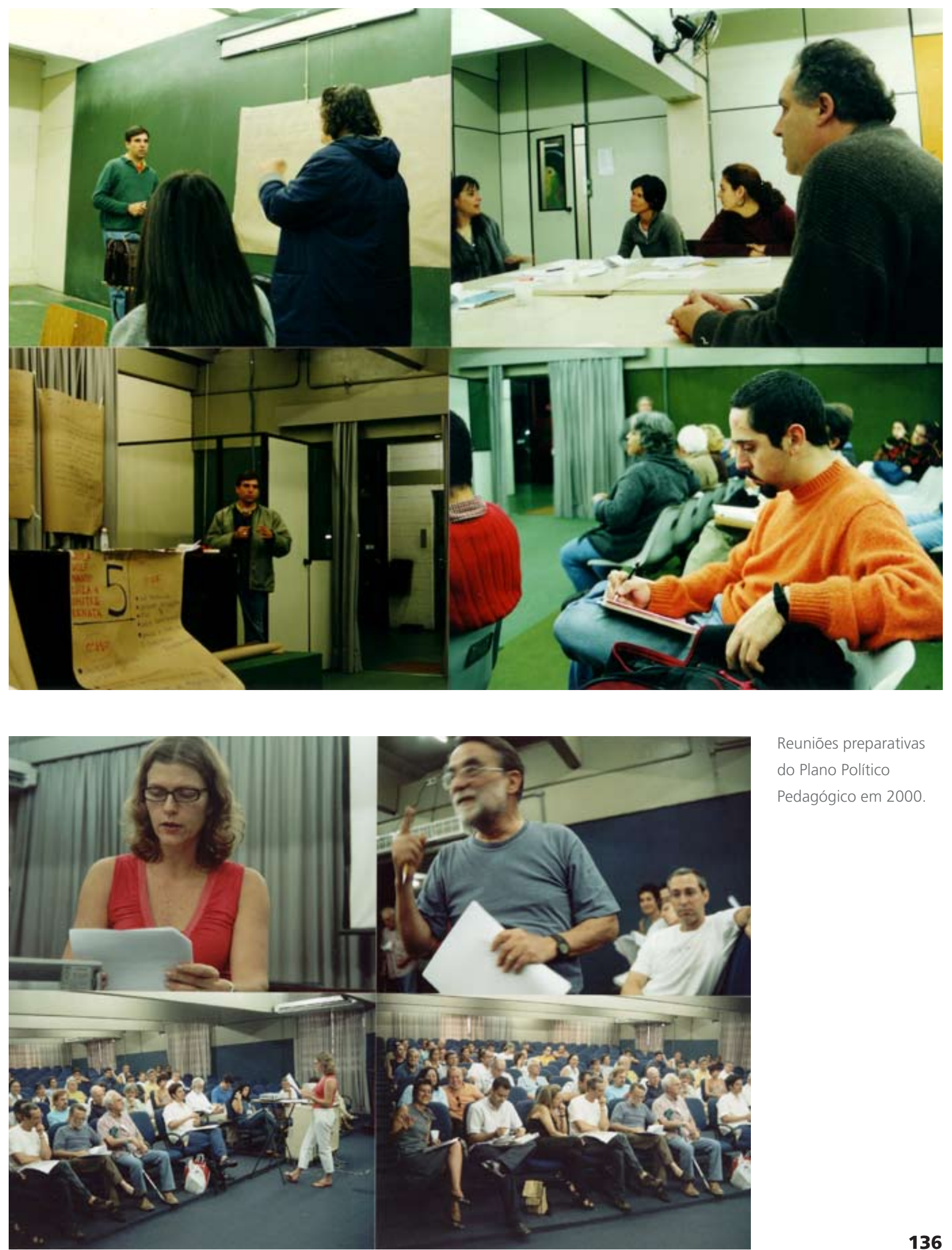

Reuniões preparativas do Plano Político

Pedagógico em 2000. 


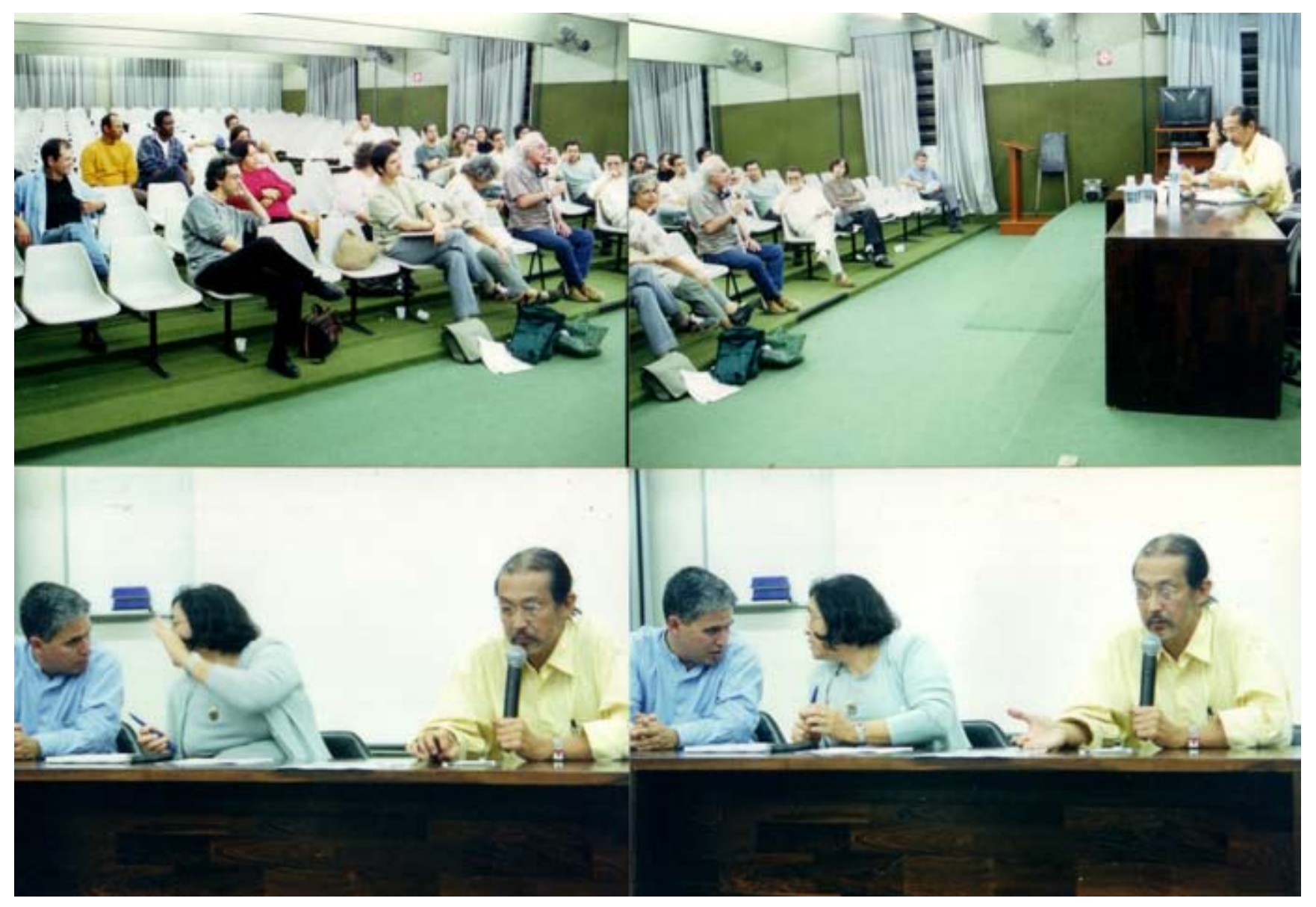

Depoimento de professores da FAU-Campinas e FAUUSP nas reuniões do Plano Político Pedagógico em 2000

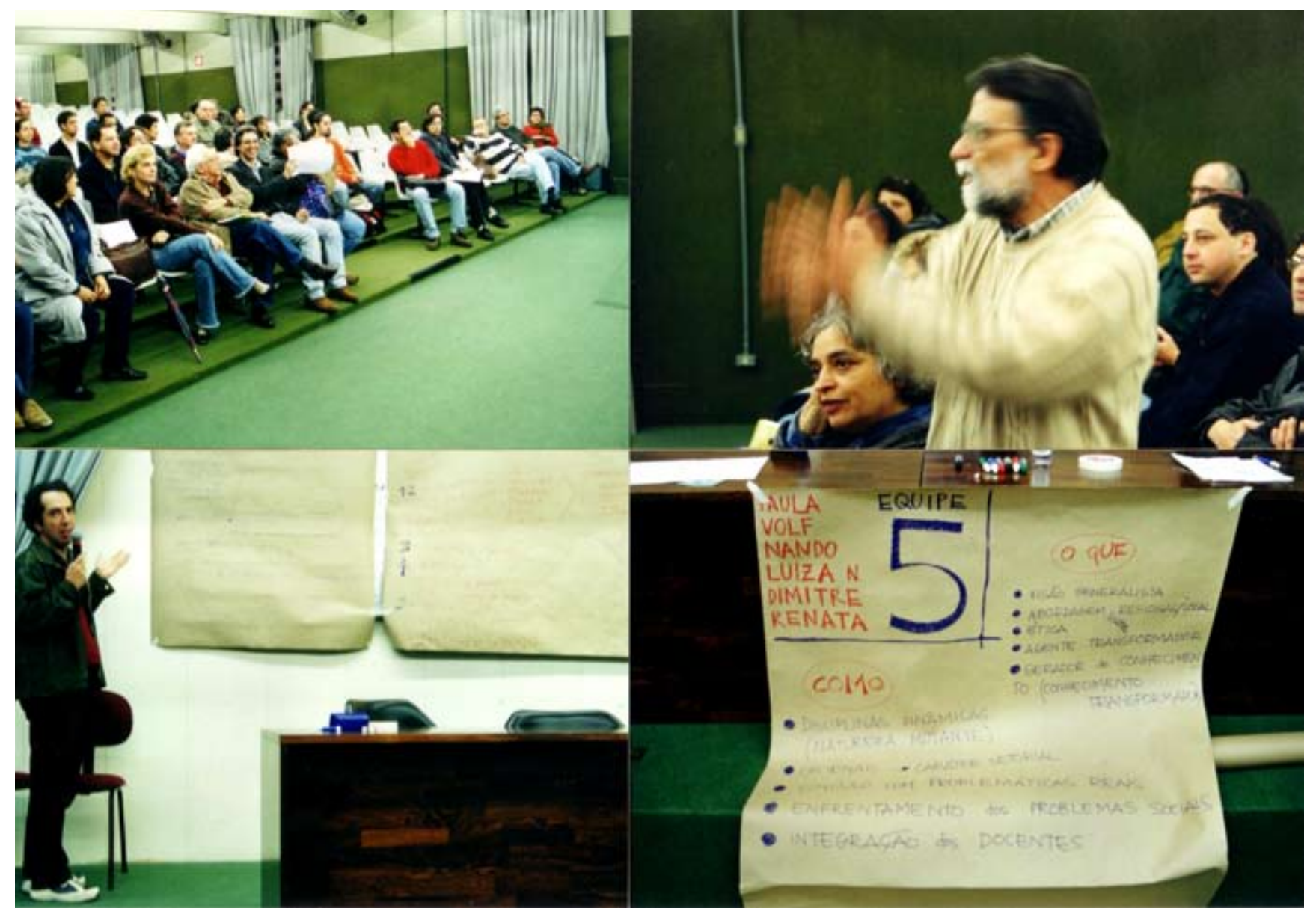




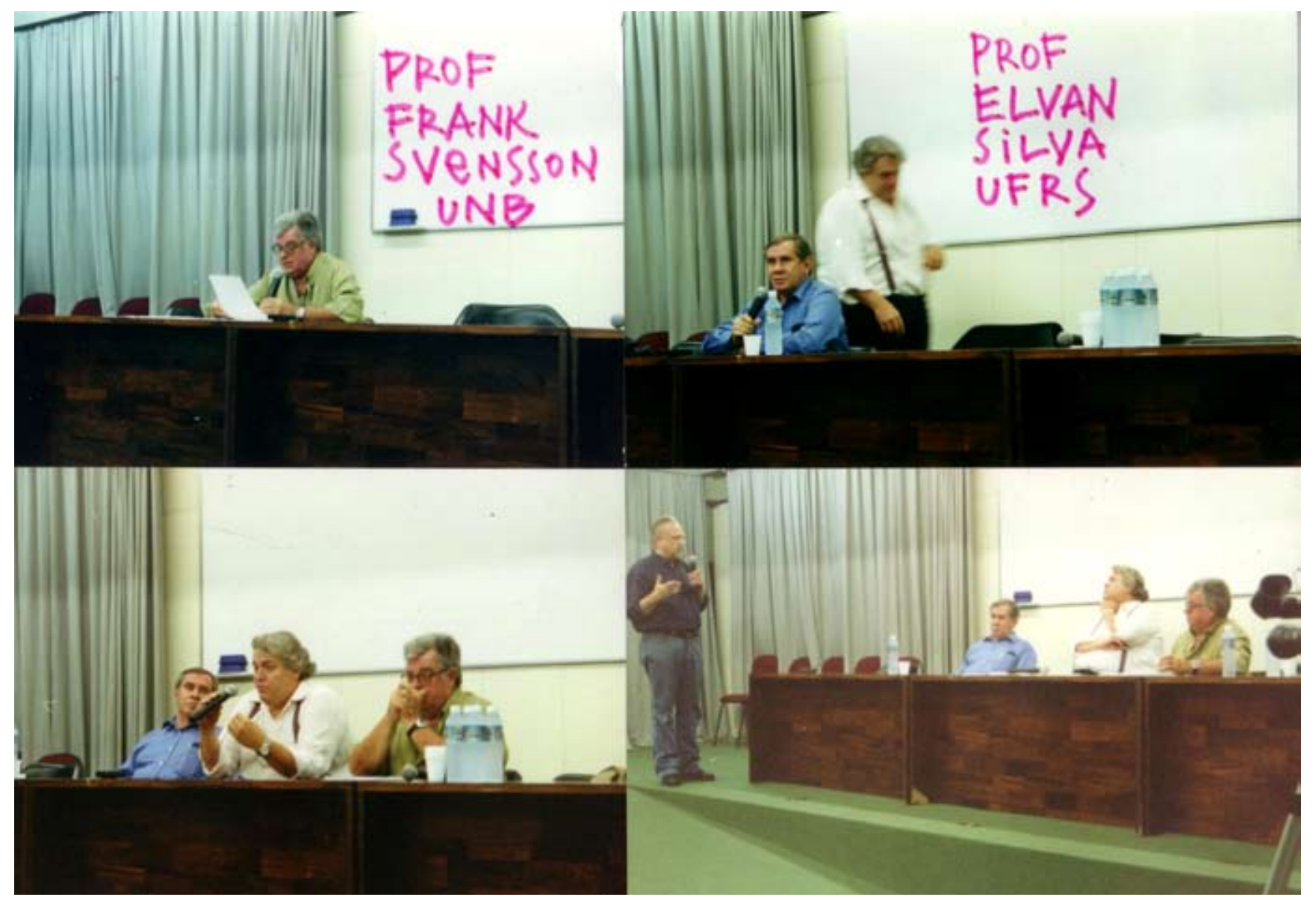

Depoimento de professores de outros estados nas reuniões do Plano Político Pedagógico em 2000.

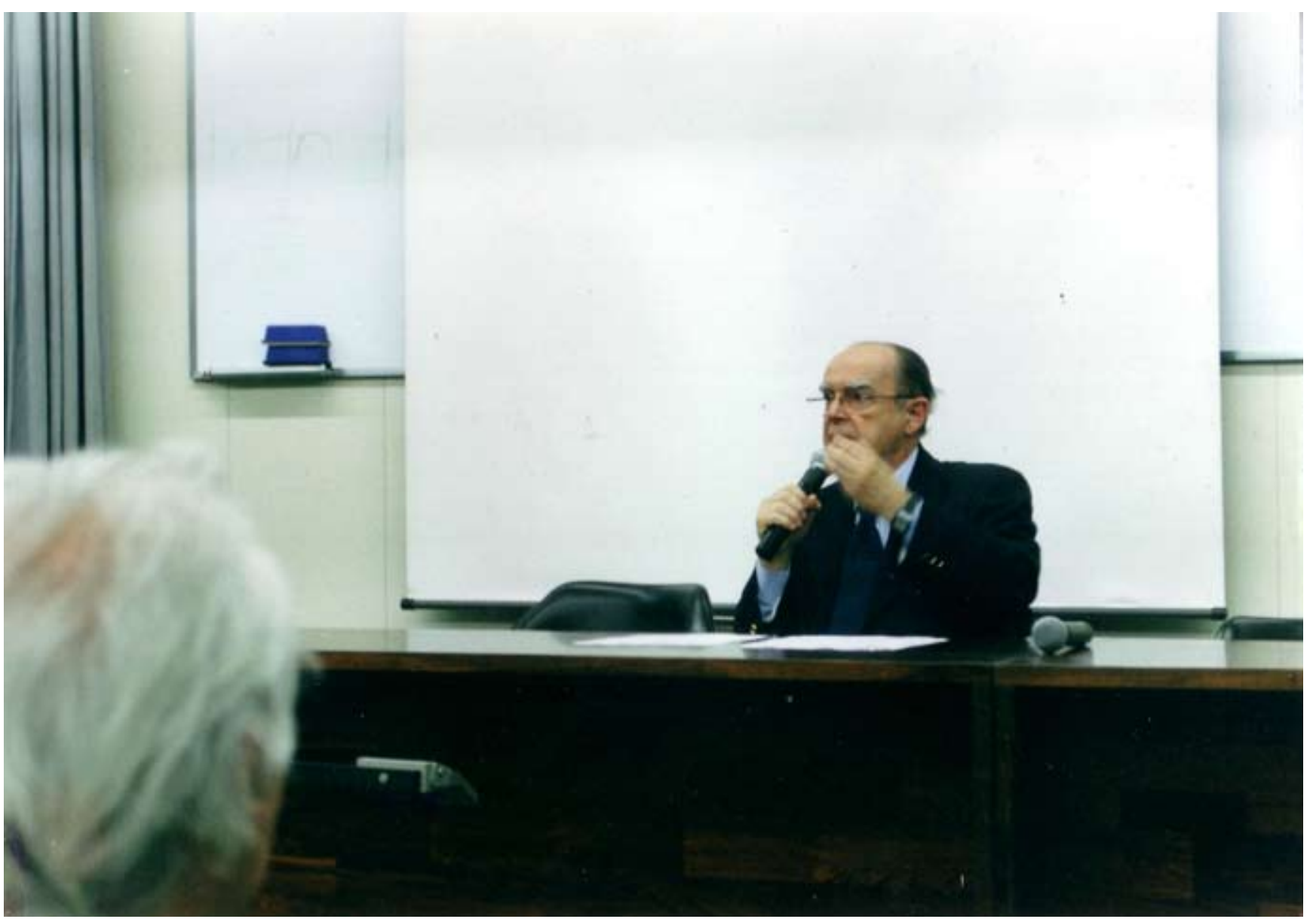




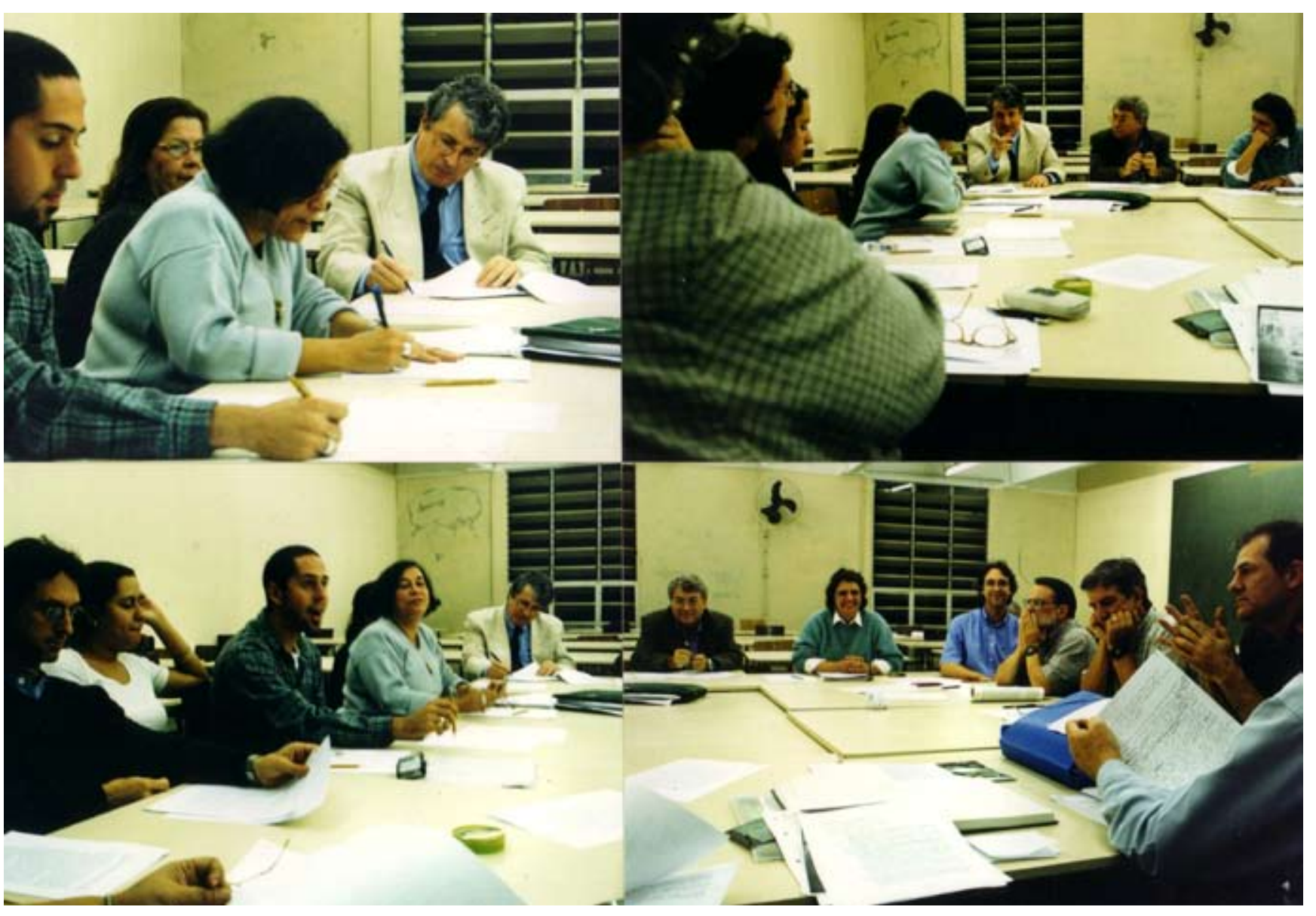

Alunos e Pró-Reitor Acadêmico participando das reuniões do Plano Político Pedagógico em 2000.

Inim $7 \mathrm{~F}$

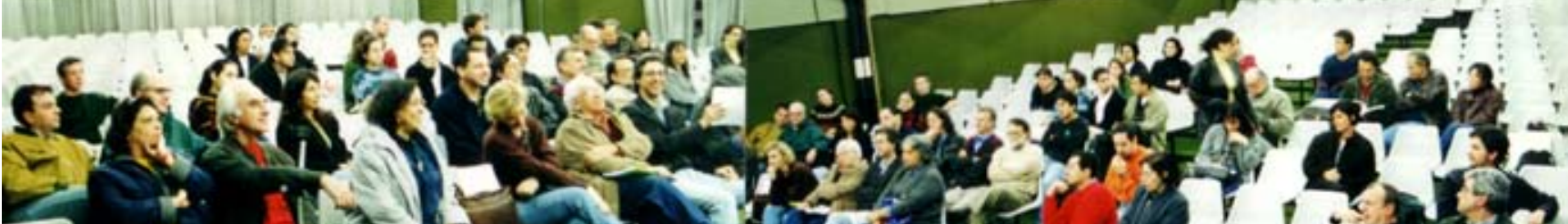

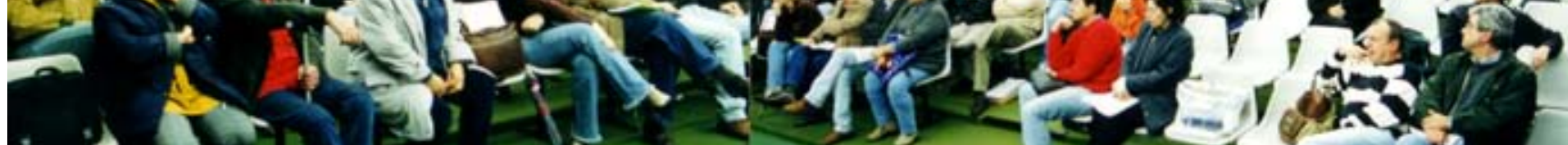

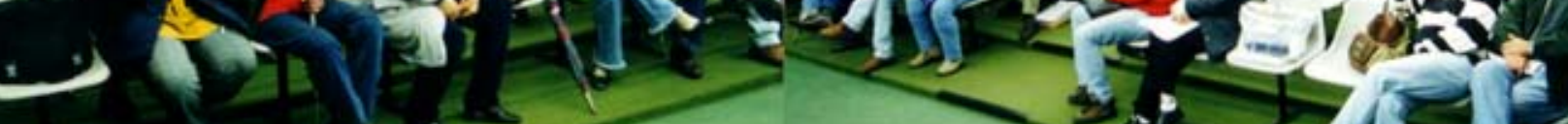

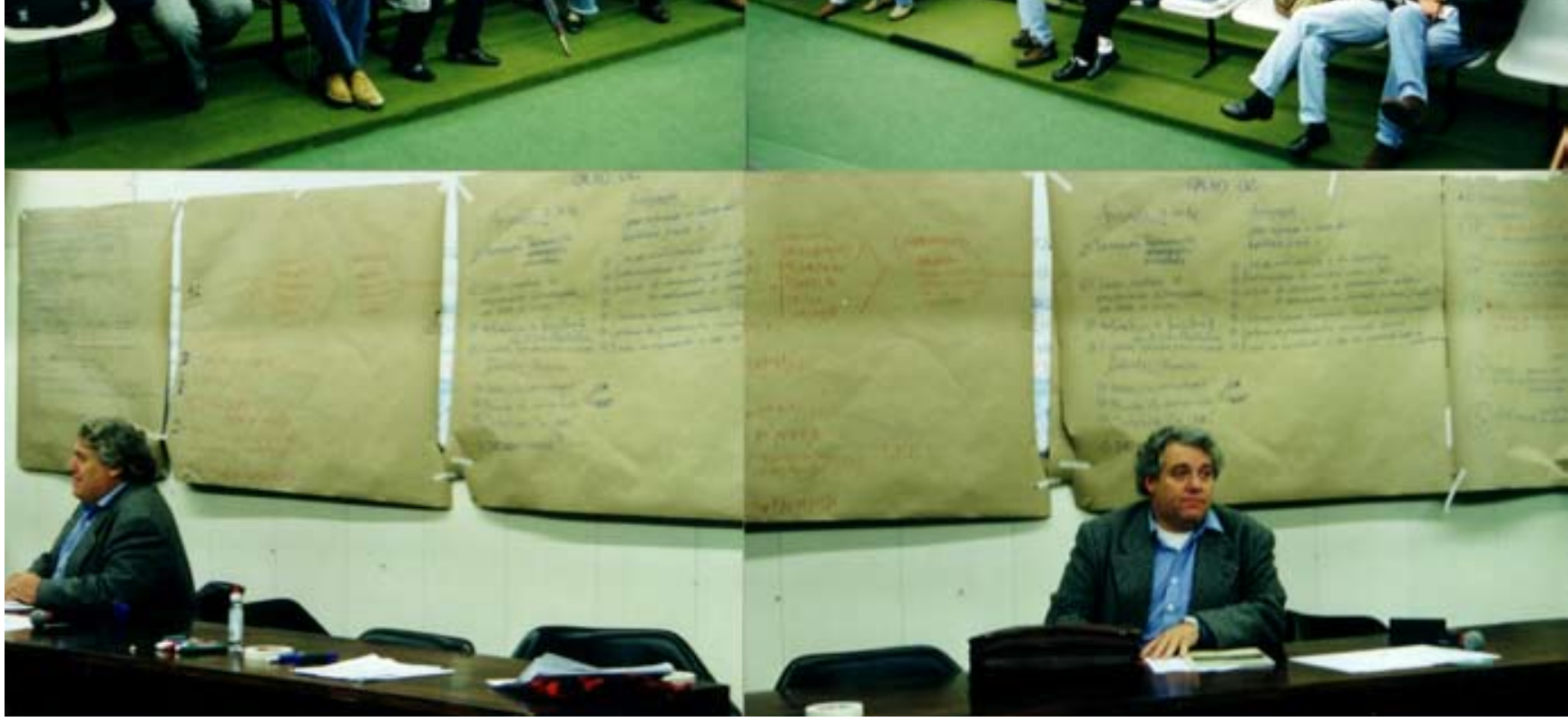


Minha experiência no ensino da arquitetura deu-se como professora da disciplina de Projeto Arquitetônico e como coordenadora da atividade de integração horizontal entre disciplinas no primeiro ano, cumprindo as metas do Plano Político Pedagógico no período entre os anos de 2001 e 2006.

A integração horizontal tinha a intenção de reunir as possíveis disciplinas que pudessem desenvolver seu conteúdo norteado por um tema comum, que seria organizado sob diferentes aspectos, de acordo com as especificidades de cada uma das disciplinas.

A coordenação encarregava-se do planejamento das reuniões dos professores antes do início do curso, quando era decidido o tema a ser trabalhado durante o ano; tratava-se de um seminário de abertura para coordenar e ajustar os exercícios no início do semestre, fazendo-os convergir de maneira integrada. Outras reuniões no decorrer do curso eram agendadas para avaliar os trabalhos e programar outras atividades. Os alunos eram solicitados a participar de algumas reuniões em que eram debatidos assuntos pertinentes a eles também. Por fim, ocorria um seminário de encerramento para avaliação e discussão das estratégias adotadas.

\section{Alunos e professores empenhados nos trabalhos relativos à integração} horizontal do primeiro ano.

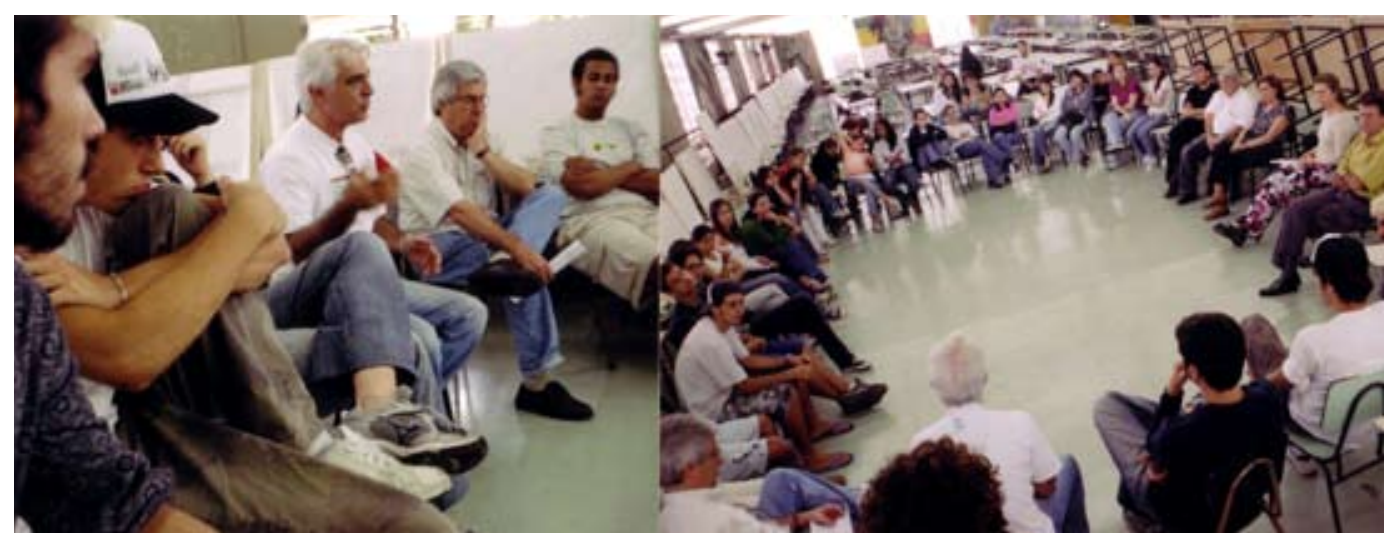

Reunião realizada com a participação dos alunos. 

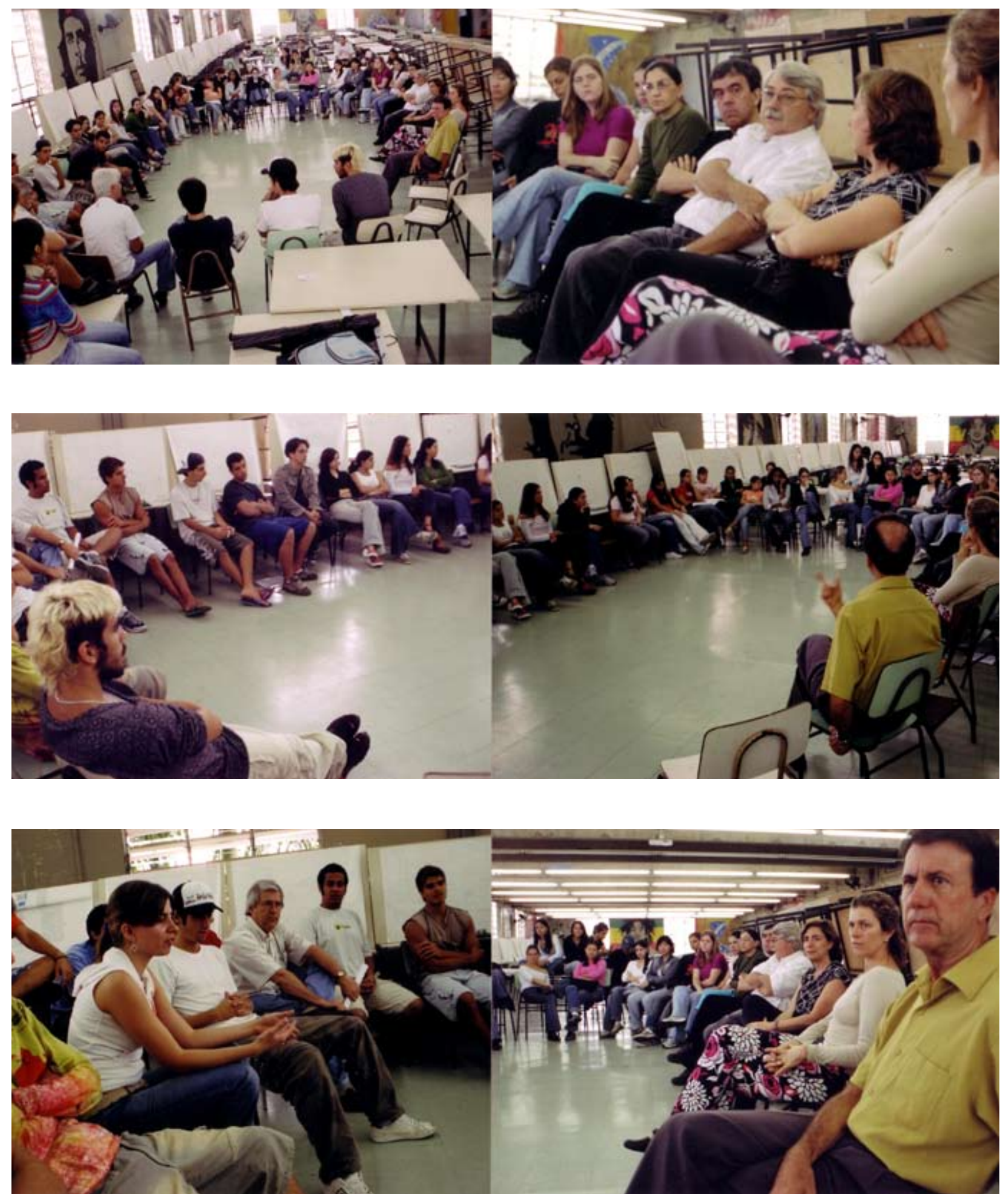

Reunião realizada

com a participação

dos alunos. 


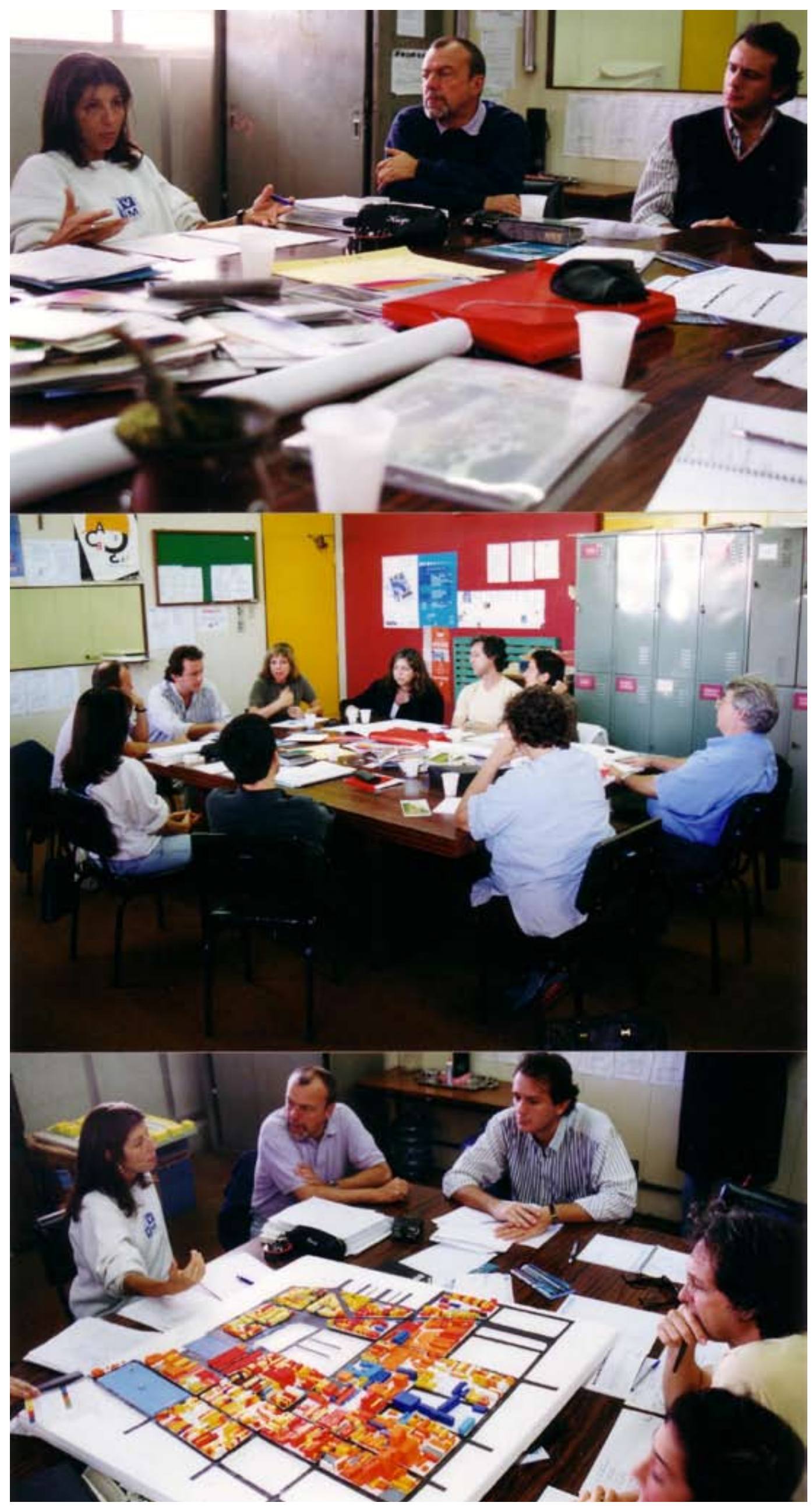

da integração horizontal. 


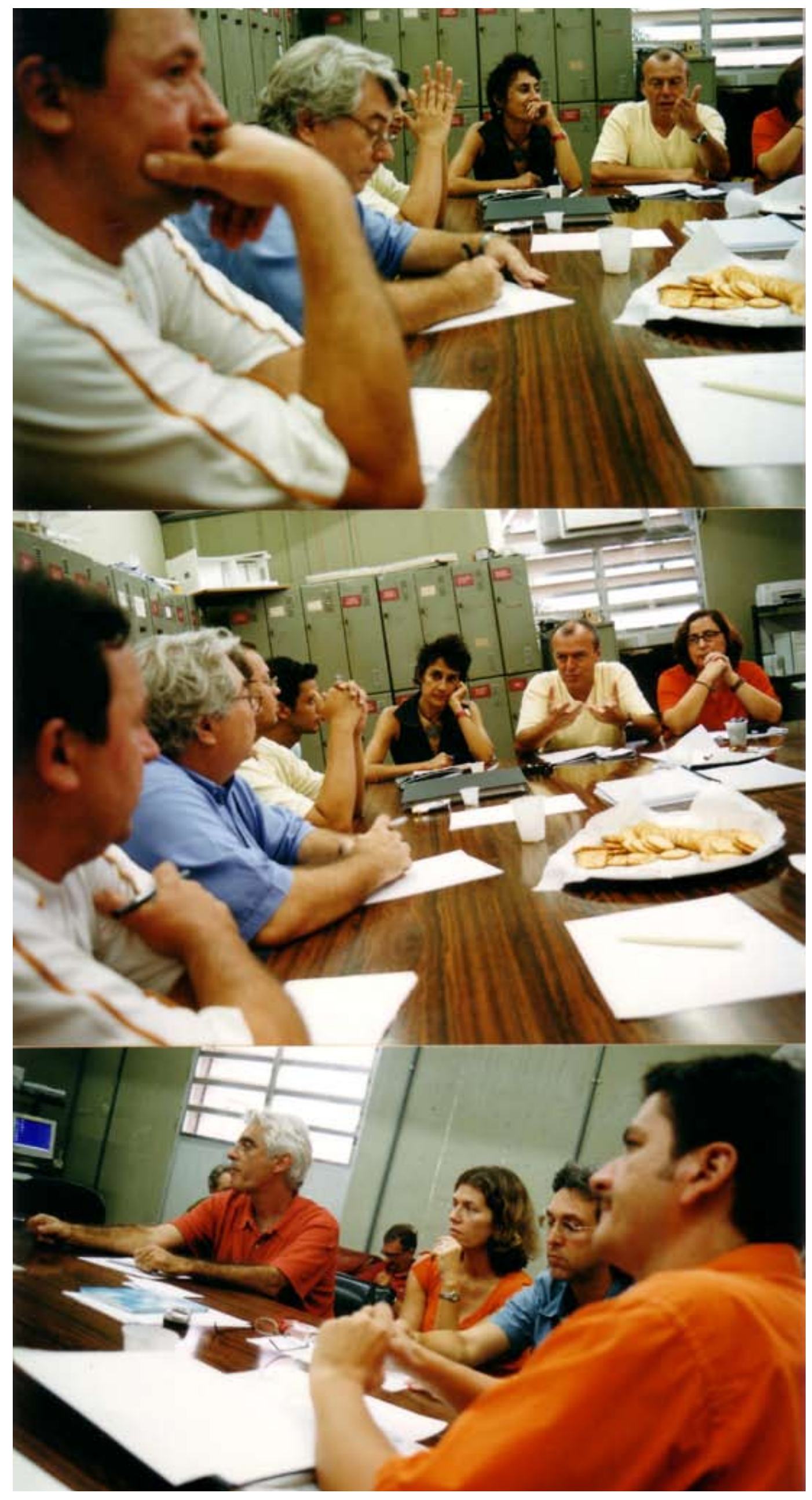

Reunião de professores

da integração horizontal. 
primeiro ano do curso, durante os anos de 2001 a 2006.

Uma carta gratificante enviada para os professores no início de 2006 pelos

alunos da FAUS do segundo ano permite afirmar que a integração horizontal

obteve sucesso nos trabalhos realizados no curso do primeiro ano de 2005.

\section{COMUNICADO}

Nob, alunos do $2^{\circ}$ Ano de Arquiteturat e Urbenismo de 2006 gostariamos de agradecer ìs pessoas que estiver.m envolvidas (profossores, direteria o reitoria) na realizacto das aulas expositivas que tivemos no ano de 2005, this aulas contribulram para 0 nosso entendimento do que of Arquitotura, pois vivenciamos a cidade, objeto de prinuipal tmportincia a nosesa profistas, adquirindo conhecimentos técicos, historicos, artisticos e socipis.

É importante tamberm destacer que as atividades e estudos realizados no Mente Serrat e na Vila de Parmapiacaba (Urbanismo, Plastica - Projeto de Arq), na Av. Ana Costa (Ubanismo e Teoria da Arq), na P'nacotec日 do Estado e no Teatro Municipal de Seo Punlo (Historia da Arte e P4́istica), nas pracas de Suntos (Plástica) e principalmente th visita a0 Rio da Janeiro (Projeto de Arq. e Plástica) foram do vital impertância para a rossa evoluçio ecademiea o profissionel, e percebemos igso nos trabalbos o projetos apresentedos em cimp de trmas coordenaios pelos professorss. B esta erolupipo também ví um

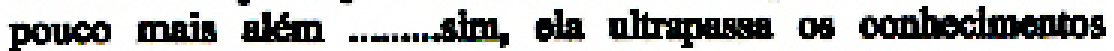
tonicos e evanca no campo social e tambim pedegdigico.

A relafilo alhmo-profeseor foi sentida por todas como uma grande unillo de barmonia, estimulendo debates o enriquecendo o nifel acadimico do curso e sociabilizando todos que se envolveram cem es questoes levantades.

Sendo assim quertemos pedir para que as aulas extra curriculares contimuem o sejam mais fieqlientes no segundo ano. Nos ahmos estamos comprometidos o cooperir com os professares e com a reitoria visando um grande desenvolvimento di faculdade, iromos organizar tambem oficinas diversas que complementem ainda mais a nossa formactio como profissionais e cidedilos.

Aqui vai o nosso PARABÉNS peln dintmica adotada reforente as aulas expositivas.

Agradecemos deside já a vossa colaboripáo. 
A integração horizontal organizava-se a partir da reunião de professores das disciplinas de primeiro ano, antes do início do ano letivo, com a intenção de escolher o tema a ser trabalhado no semestre. Cada professor apresentava a programação de sua disciplina de forma a se ajustar à programação das outras. A disciplina que não se adequasse às atividades em conjunto desenvolvia sua especificidade baseada no tema daquele ano. Um "calendário gigante" (anexo) era elaborado a cada semestre, para que todos os professores tivessem a noção exata do curso como um todo. Nesse calendário também constavam atividades coletivas como visitas, viagens, palestras, etc.

O tema Desenho nos anos de 2001 a 2006 foi o escolhido para nortear os trabalhos da integração horizontal no primeiro ano. O Desenho foi trabalhado sob diferentes enfoques, ou seja, como representação de uma idéia, como expressão da observação de uma paisagem, como livre expressão, como projeto.

Na disciplina de Projeto Arquitetônico esse tema foi desenvolvido como projeto baseado na representação de uma idéia, no sentido de desígnio, de desejo, como diz o professor Flávio Motta.

O primeiro exercício sobre o tema escolhido em nossa disciplina de Projeto Arquitetônico foi uma visita coletiva, no início do ano letivo, ao Pavilhão da OCA, no Ibirapuera, em São Paulo, onde acontecia uma exposição da obra do artista plástico Pablo Picasso. Os estudantes tiveram a oportunidade de entrar em contato com o cubismo e as questões de representação bi e tridimensional. A obra Bandolim sobre uma mesinha de centro, realizada em 1920, em Paris, foi escolhida para o desenvolvimento gramatical de execução de um objeto tridimensional em papel-cartão: uma escultura. Posteriormente, num trabalho conjunto das disciplinas de Projeto Arquitetônico e Plástica, foi proposta uma atividade de pintura a partir da observação do objeto 
tridimensional. Numa última etapa, os objetos foram pintados. Essa experiência incorpora uma reflexão da gramática de representação de Plástica à atividade de projeto, utilizando a pintura.

Nesse exercício a integração horizontal deu-se somente entre as disciplinas de Projeto Arquitetônico e Plástica. Os demais professores estiveram presentes na exposição com a intenção de focar a temática dentro de suas próprias disciplinas.

Programa do primeiro exercício distribuído aos alunos, em que se propõe a realização de objeto tridimensional em papel-cartão monocromático a partir do quadro de Picasso, cujas reproduções foram também distribuídas:

Faculdade de Arquitetura e Urbanismo Unisantos - Fau/Santos

\section{Projeto Arquitetônico I}

Professores Carlos Antunes, Denise Ruprecht, Ernesto Walter, Vera Lúcia Domschke

EXERCÍCIO I - PICASSO

\section{Objetivos}

O exercício visa:

1. Capacitar e valorizar linguagens de desenho e modelos como forma de prefigurar o espaço edificado.

2. Introduzir questões de proporção e composição volumétrica.

3. Introduzir questões de relação de escala. 


\section{Escopo e metodologia}

A partir de um objeto tridimensional (pintura) o aluno deverá recompô-lo em três dimensões (modelo).

Os elementos - planos e volumes - deverão ser escolhidos pelo aluno, entre os existentes na pintura, a partir dos quais deve organizar um "objeto arquitetônico" (tridimensional) estável segundo os seguintes princípios:

1. O "objeto" tem uma relação com a "pintura" na proporção de $1,0 \mathrm{~cm}=2,0 \mathrm{~cm}$.

2. Os planos podem ser organizados com plena liberdade, respeitando sua integridade, não podendo haver ruptura ou quebra.

3. O objeto deve apresentar estabilidade à compressão.

Pintura Pablo Picasso

Bandolim sobre uma mesinha de centro, 1920

Museu Picasso, Paris

TRABALHO FINAL

Modelo em papel-cartão monocromático

\section{Integração Horizontal com Plástica}

- Desenho de observação e pintura do modelo desenvolvido pelo aluno

- Pintura do modelo

\section{Processo}

Projeto Arquitetônico

Pintura

(bidimensional)
Modelo

(tridimensional)

\section{Plástica}

Pintura

(bidimensional) 
Fases do desenvolvimento do exercício proposto
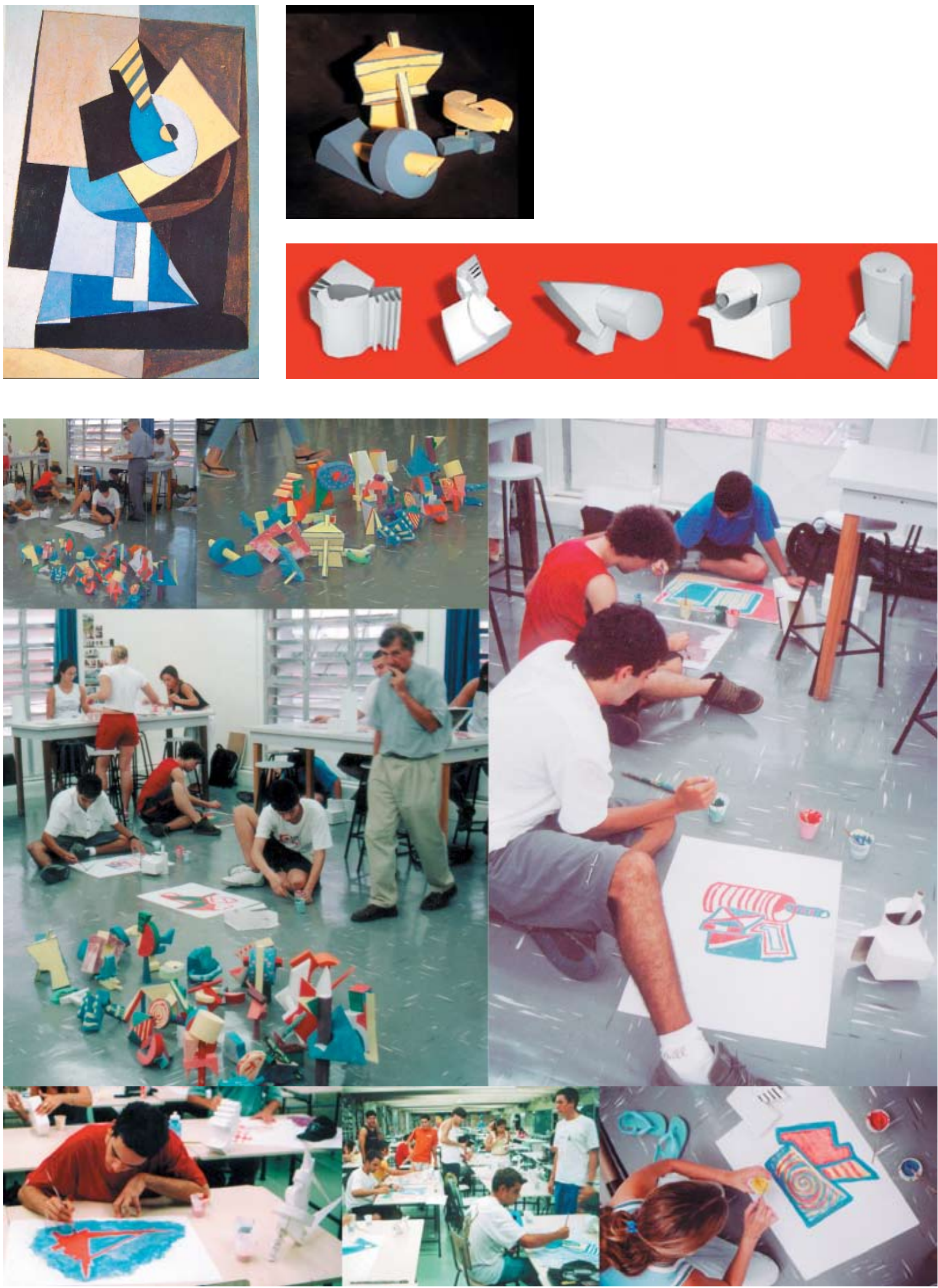

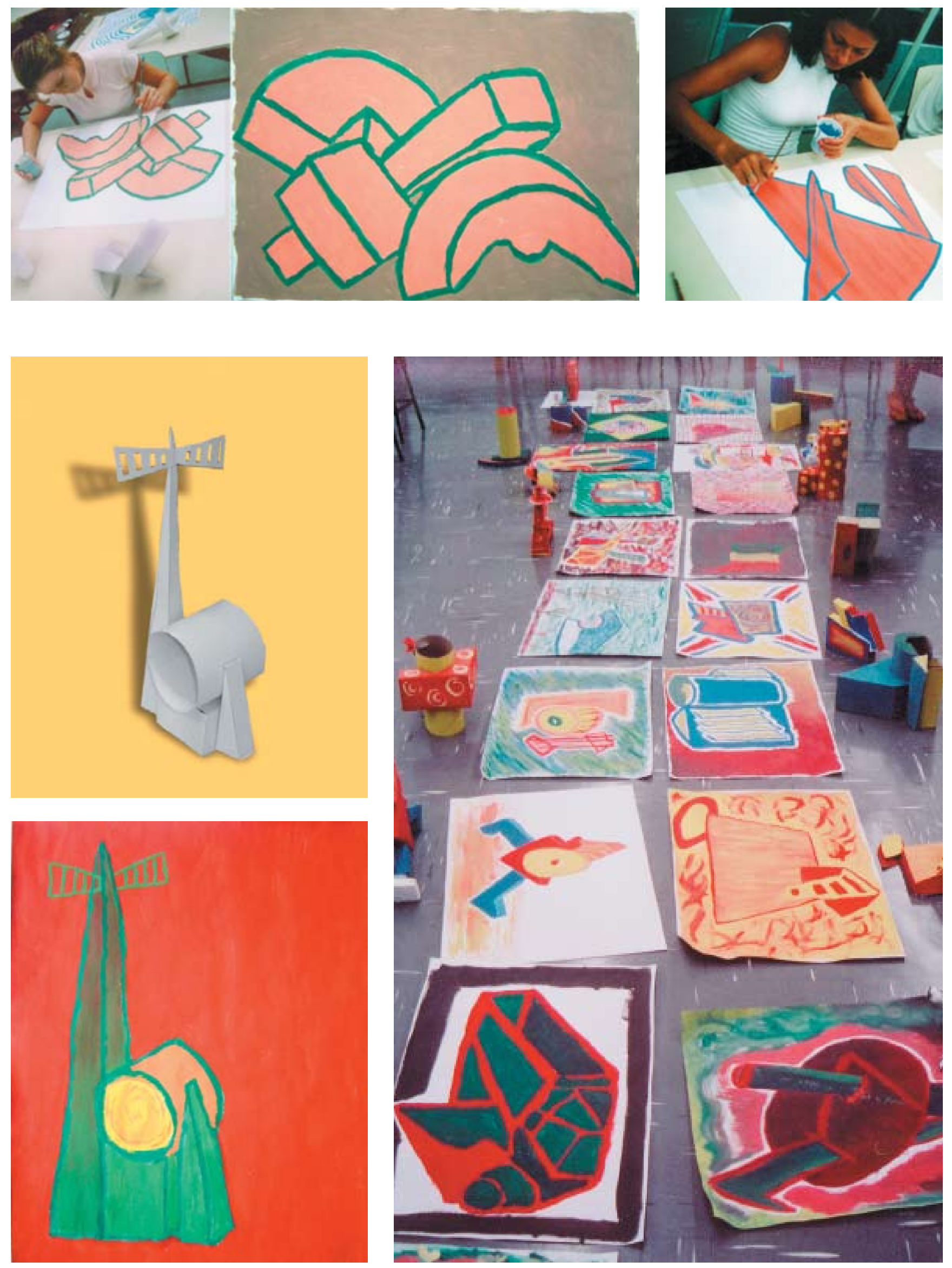

Resultado do exercício de integração de Projeto Arquitetônico e Plástica, 
Em outro semestre foi realizado exercício similar ao anterior - que tomou por base uma obra de Picasso -, a partir da pintura Natureza Morta, de 1920, de Le Corbusier. Reproduções desse quadro foram levadas ao ateliê para serem distribuídas aos alunos.

\section{Exemplares do exercício proposto}
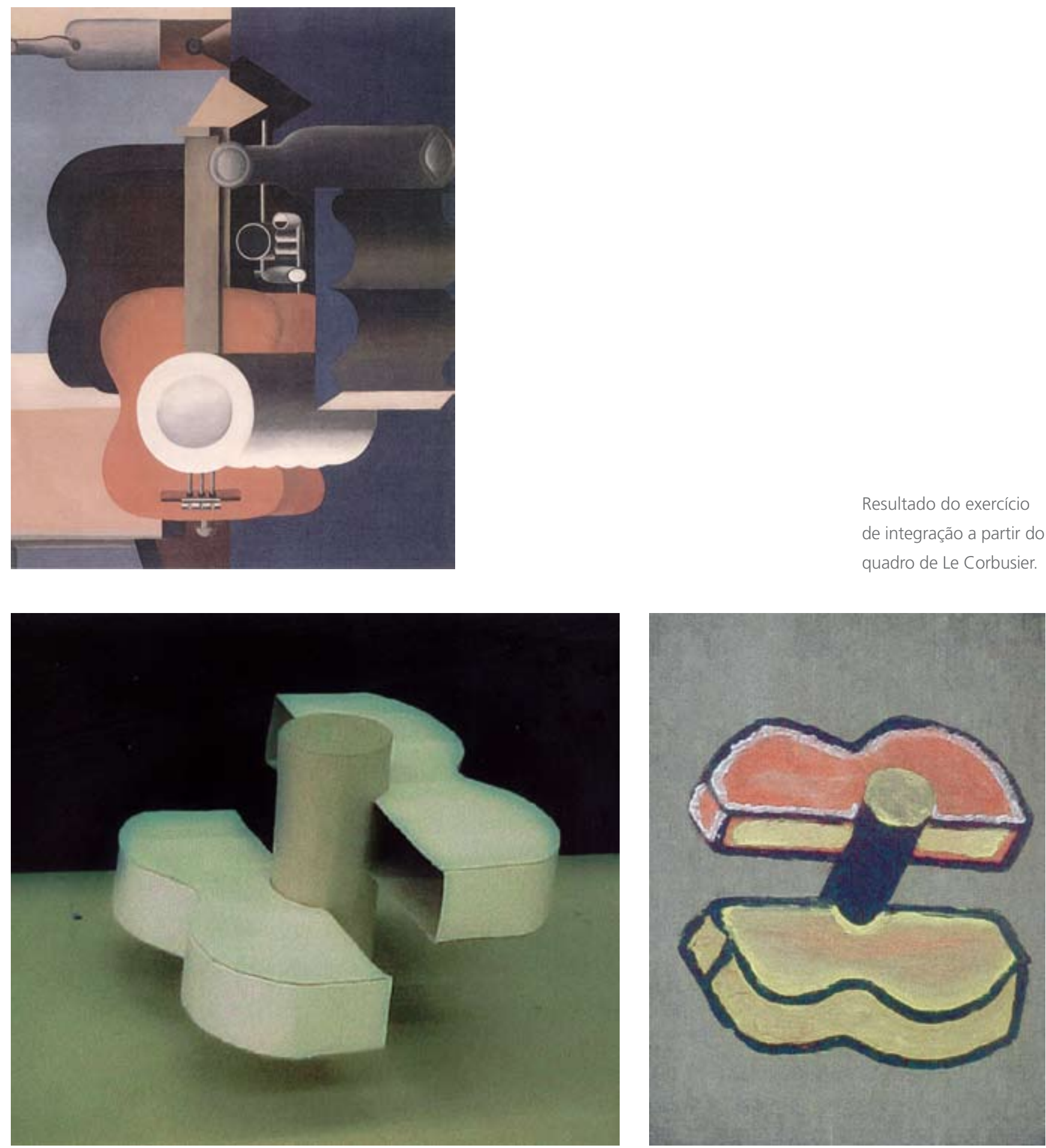

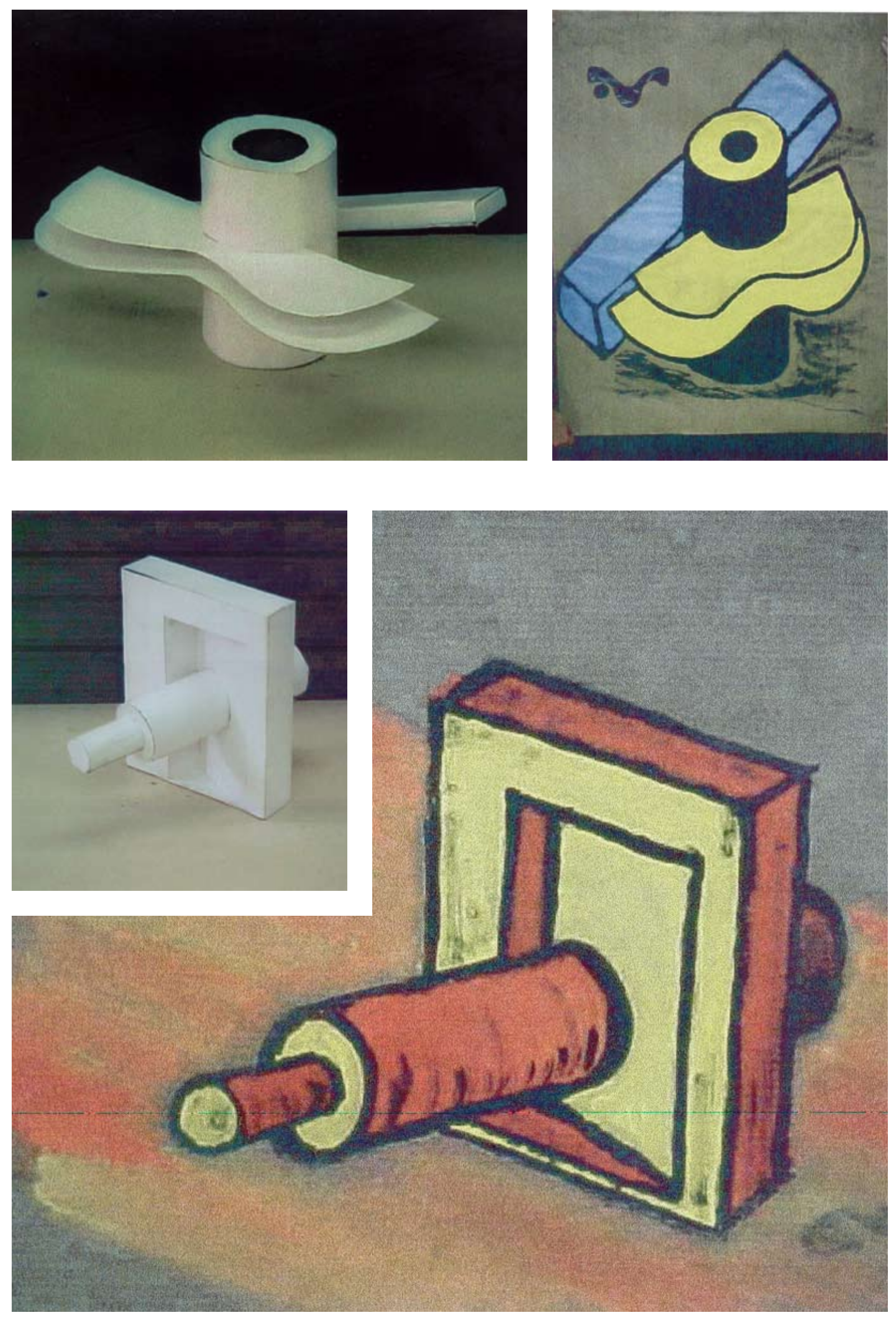
Uma visita à exposição "Modernismo Brasileiro: Propostas e Caminhos", na FAAP, em 2004, fez parte das atividades da integração horizontal daquele ano. Outro exercício similar ao descrito anteriormente foi realizado a partir da obra de Tarsila do Amaral, A Caipirinha, de 1923, óleo sobre tela, 60 x 41 cm, exposta na exposição.

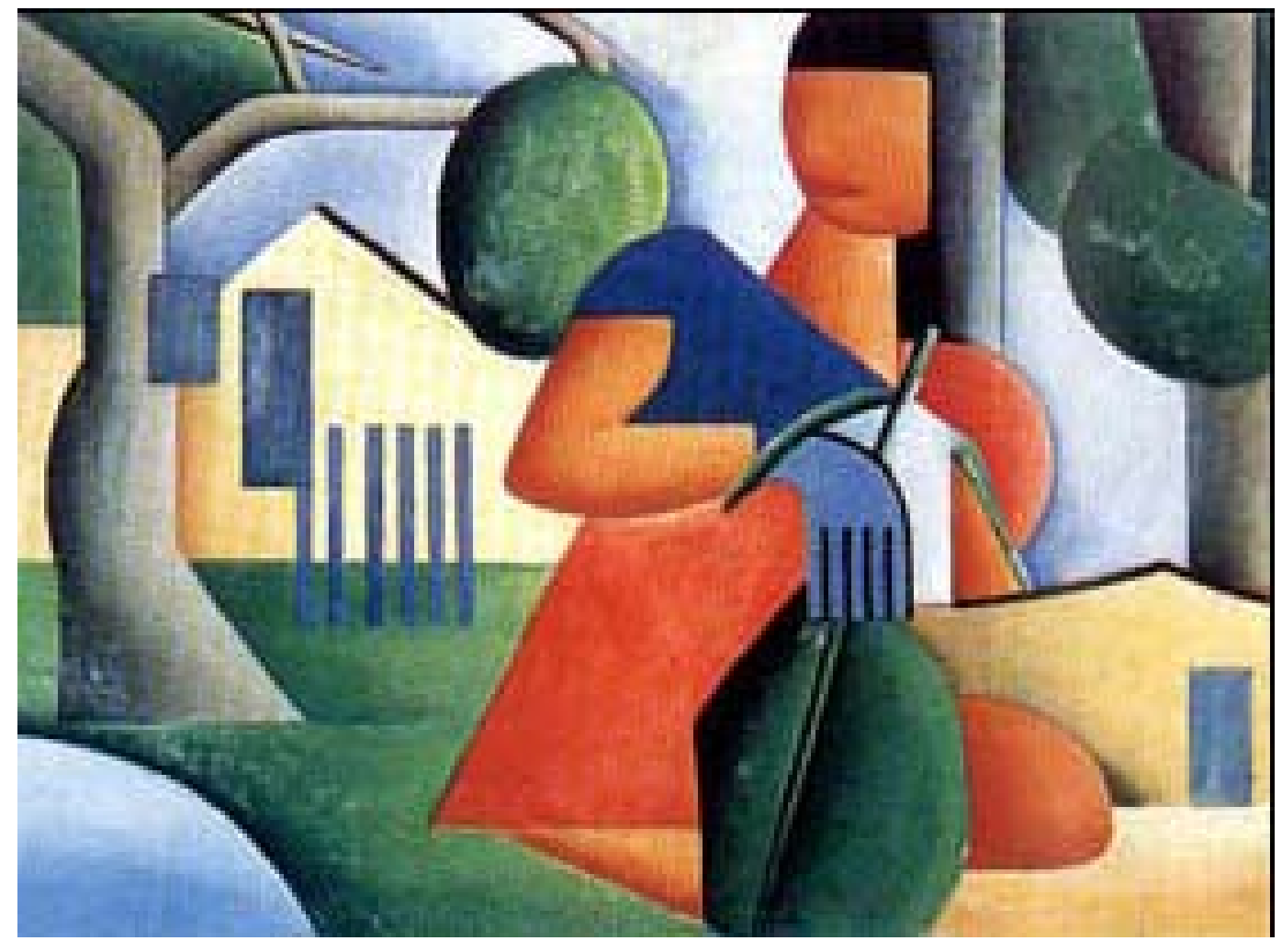

\section{Alunos trabalhando no exercício proposto}
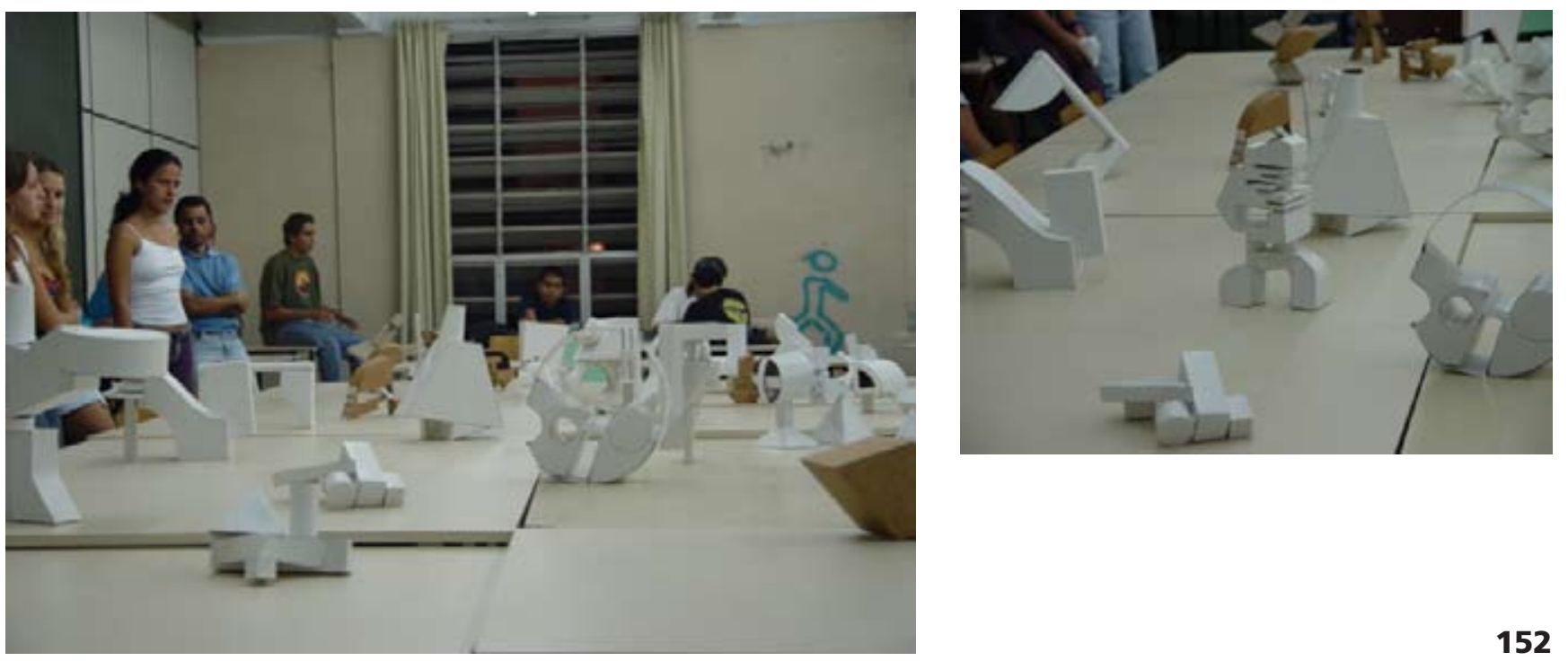

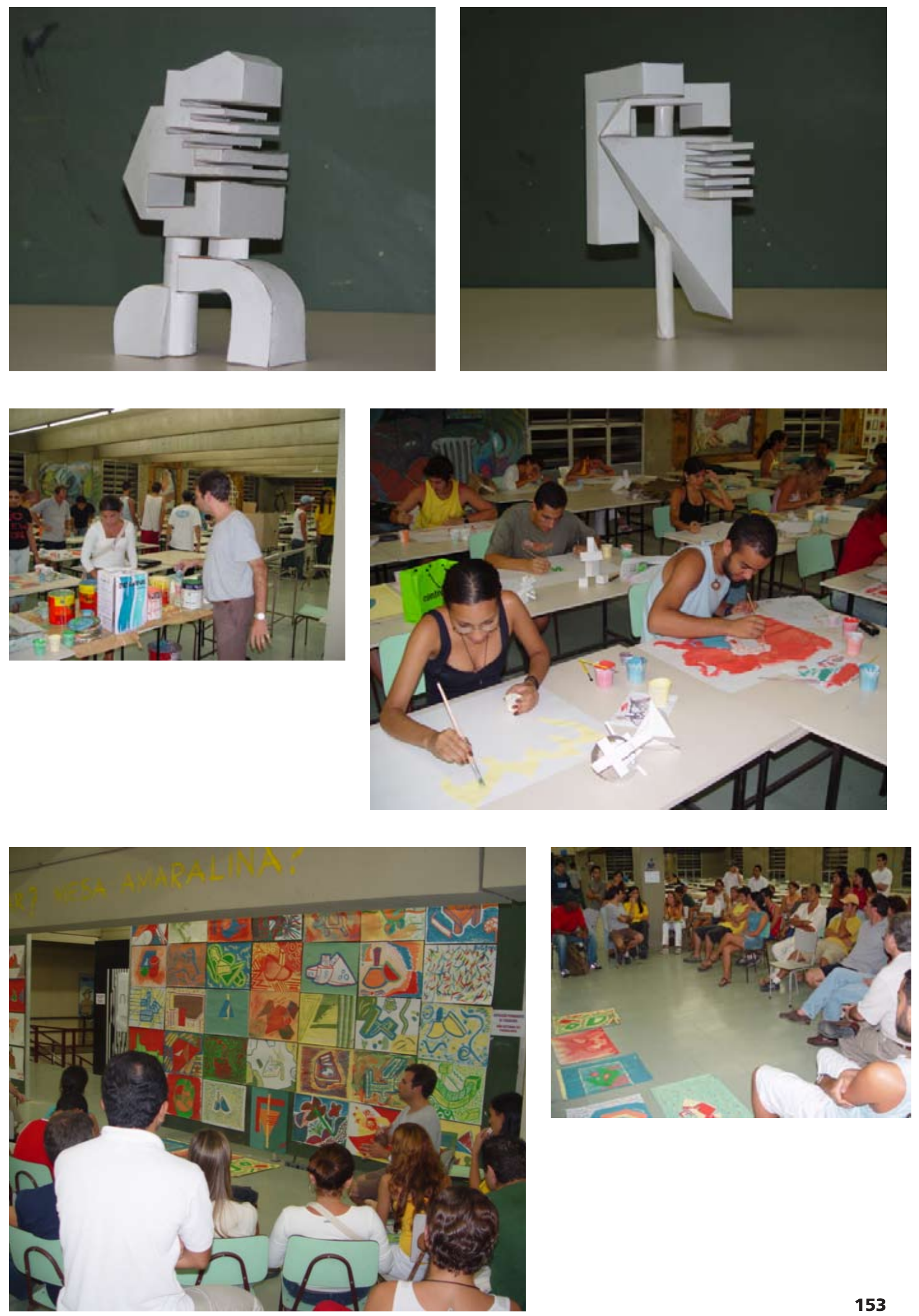

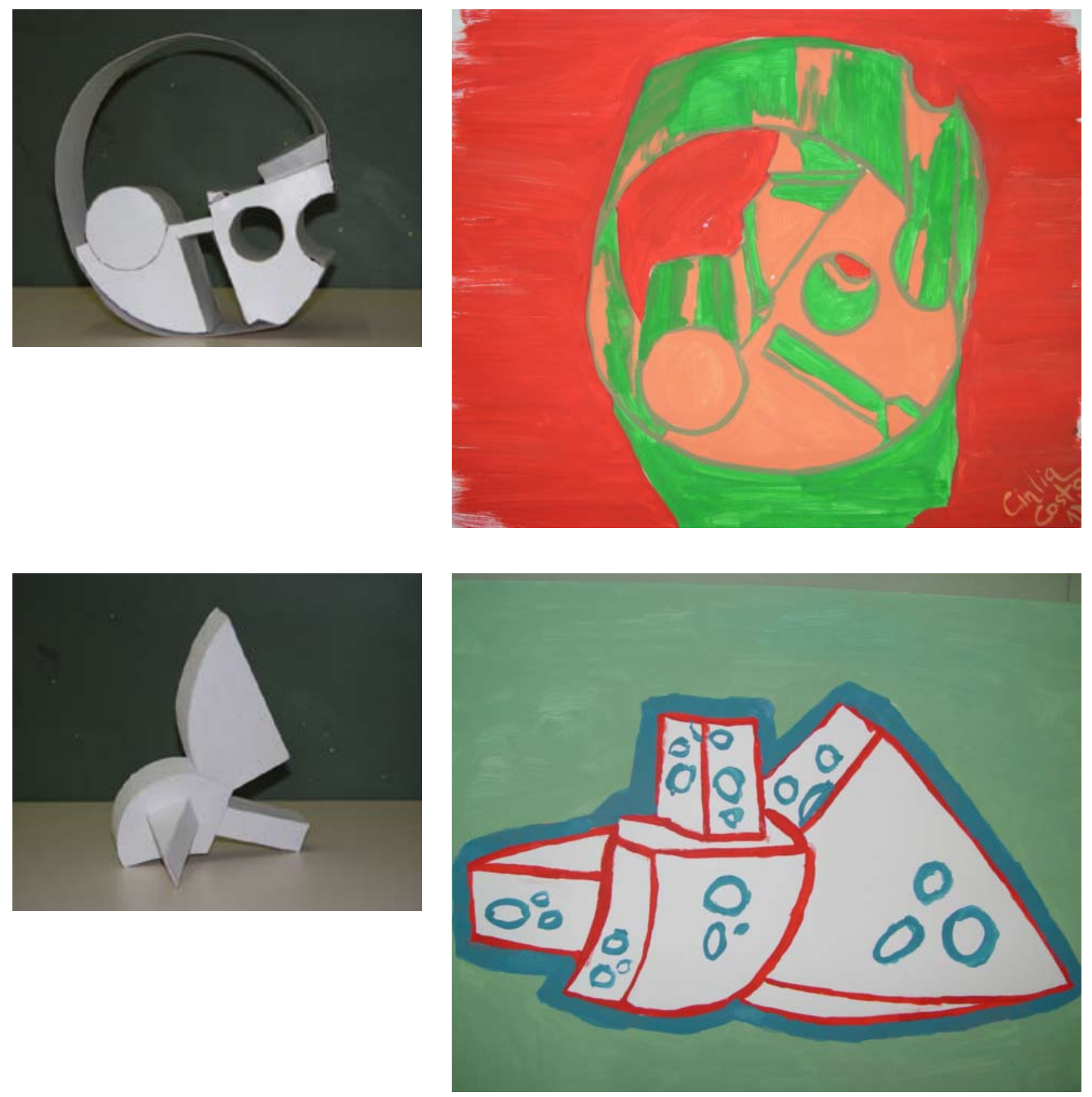

Com a intenção de introduzir no repertório dos alunos a prática da lei-

Resultado do exercício de integração de

Projeto Arquitetônico e Plástica a partir do do, dia em que todos estavam disponíveis. Esse evento foi acompanhado pequadro A Caipirinha de Tarsila do Amaral.

los professores das disciplinas de Projeto Arquitetônico, Urbanismo, Plástica e Teoria da Arquitetura, participantes das atividades da integração horizontal, proporcionando o apoio necessário para o desenvolvimento da prática de leitura, como desenhos de observação, explanações sobre a história da cidade e sobre o urbanismo de Santos. 

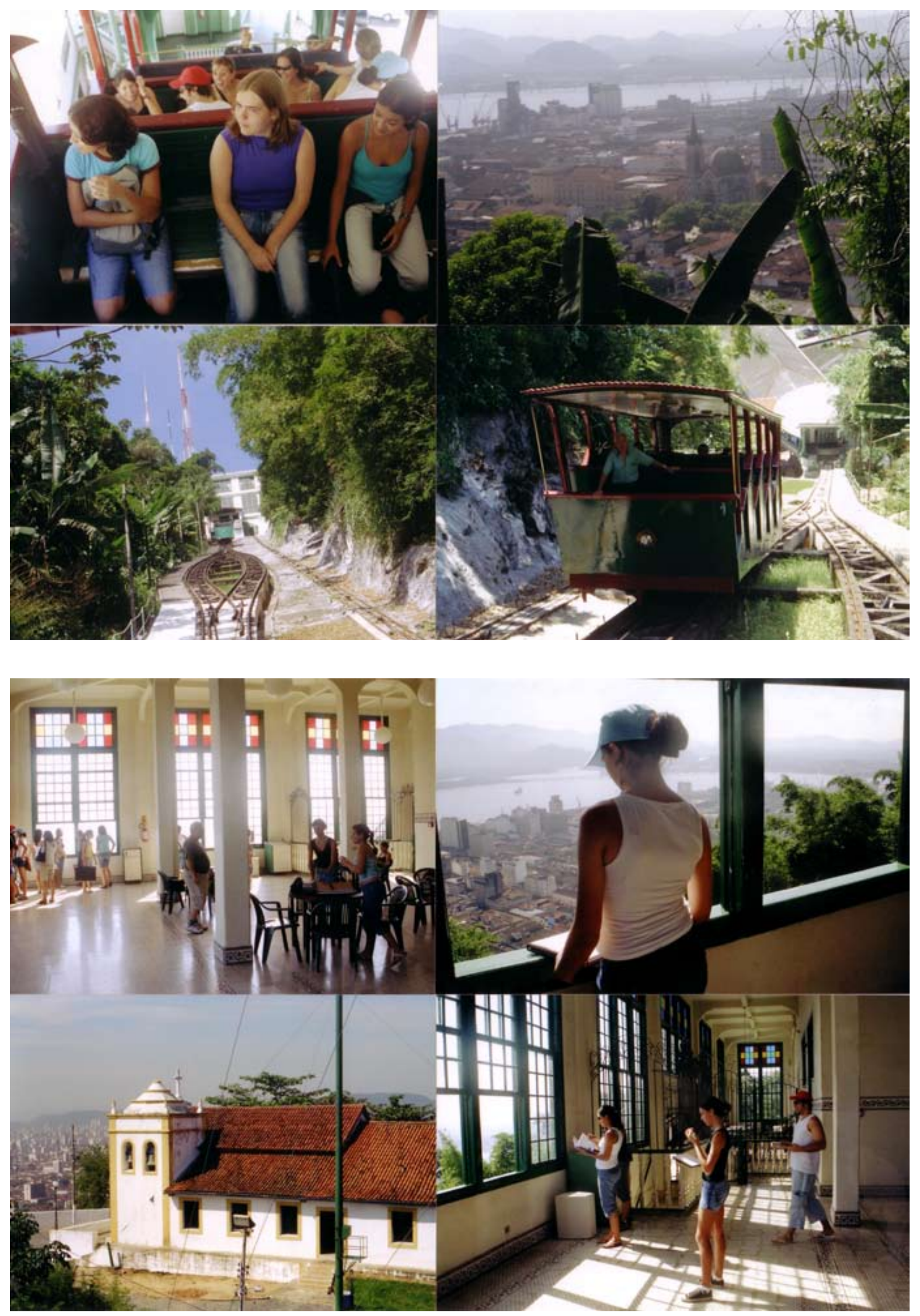

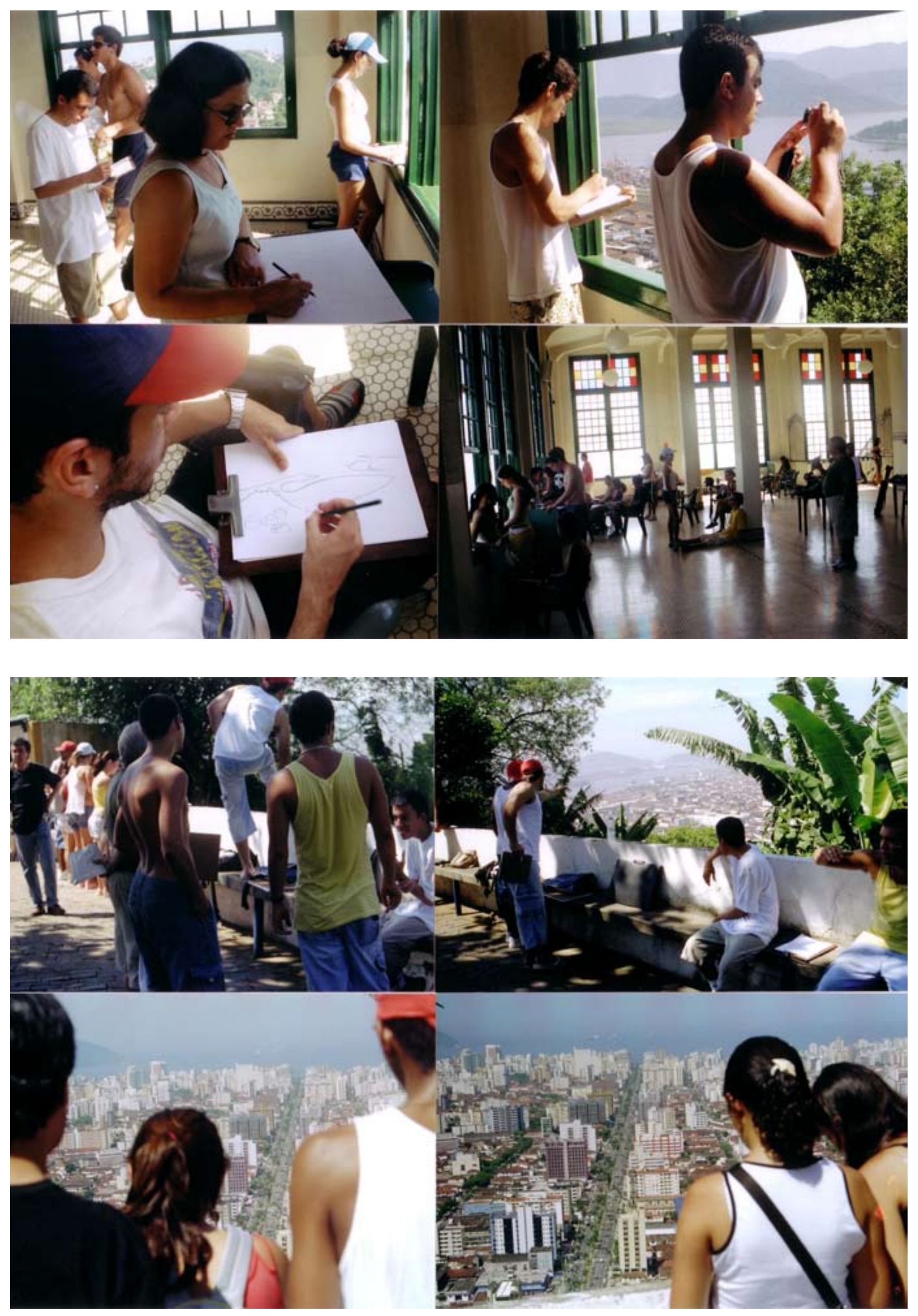

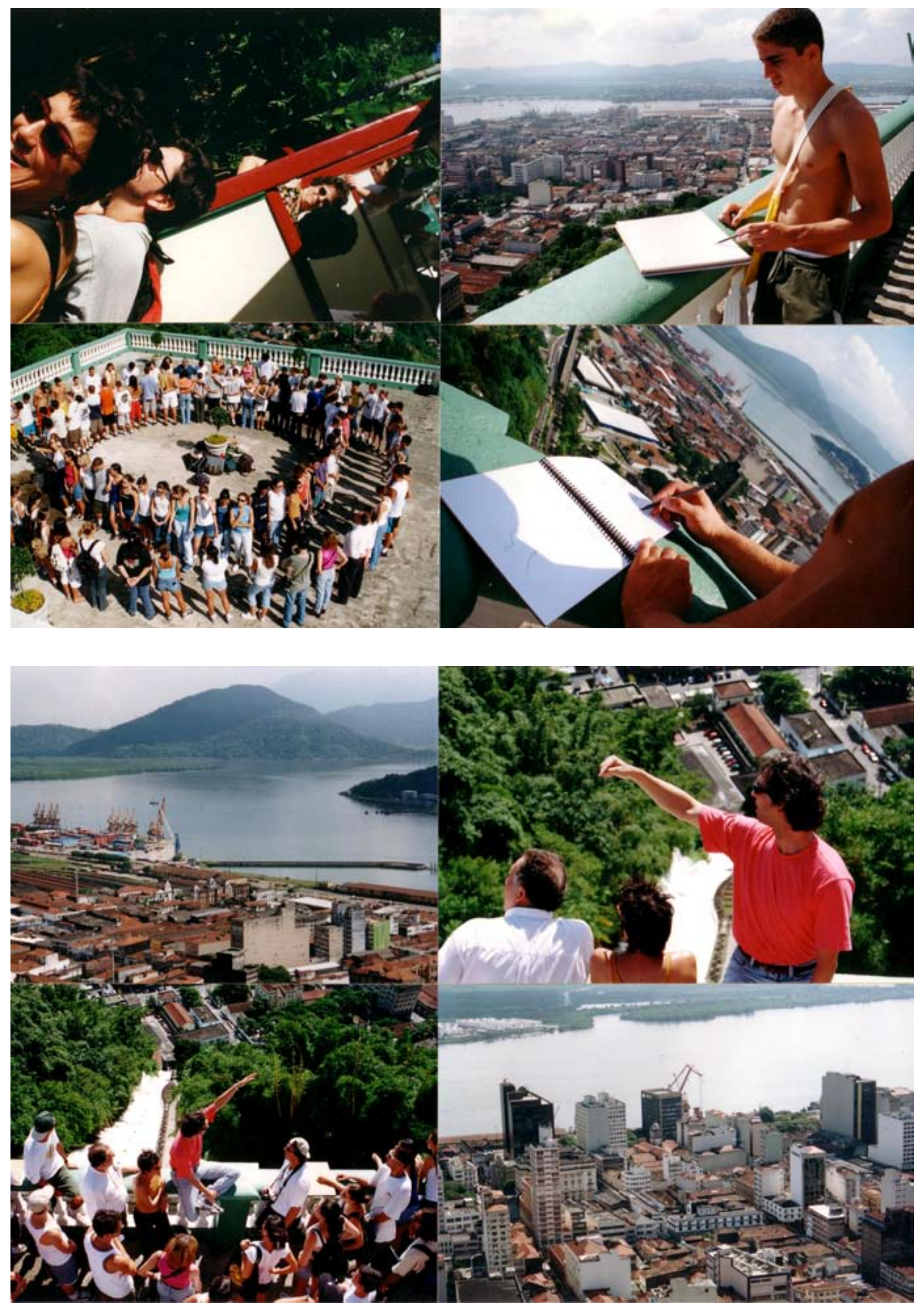
No mesmo dia, após a visão geral da cidade a partir do Monte Serrat, a área visitada pelos alunos foi a Bacia do Mercado. Essa área de Santos foi a escolhida para desenvolver o exercício proposto pelas disciplinas de Urbanismo, Projeto Arquitetônico, Plástica e Teoria da Arquitetura, envolvidas na atividade da integração horizontal.

Essa visita contou com a contribuição dos professores, de acordo com a especificidade de cada disciplina, e teve continuidade nos dias de suas aulas semanais, em que desenvolveram a leitura da Bacia do Mercado, de acordo com sua área de conhecimento.
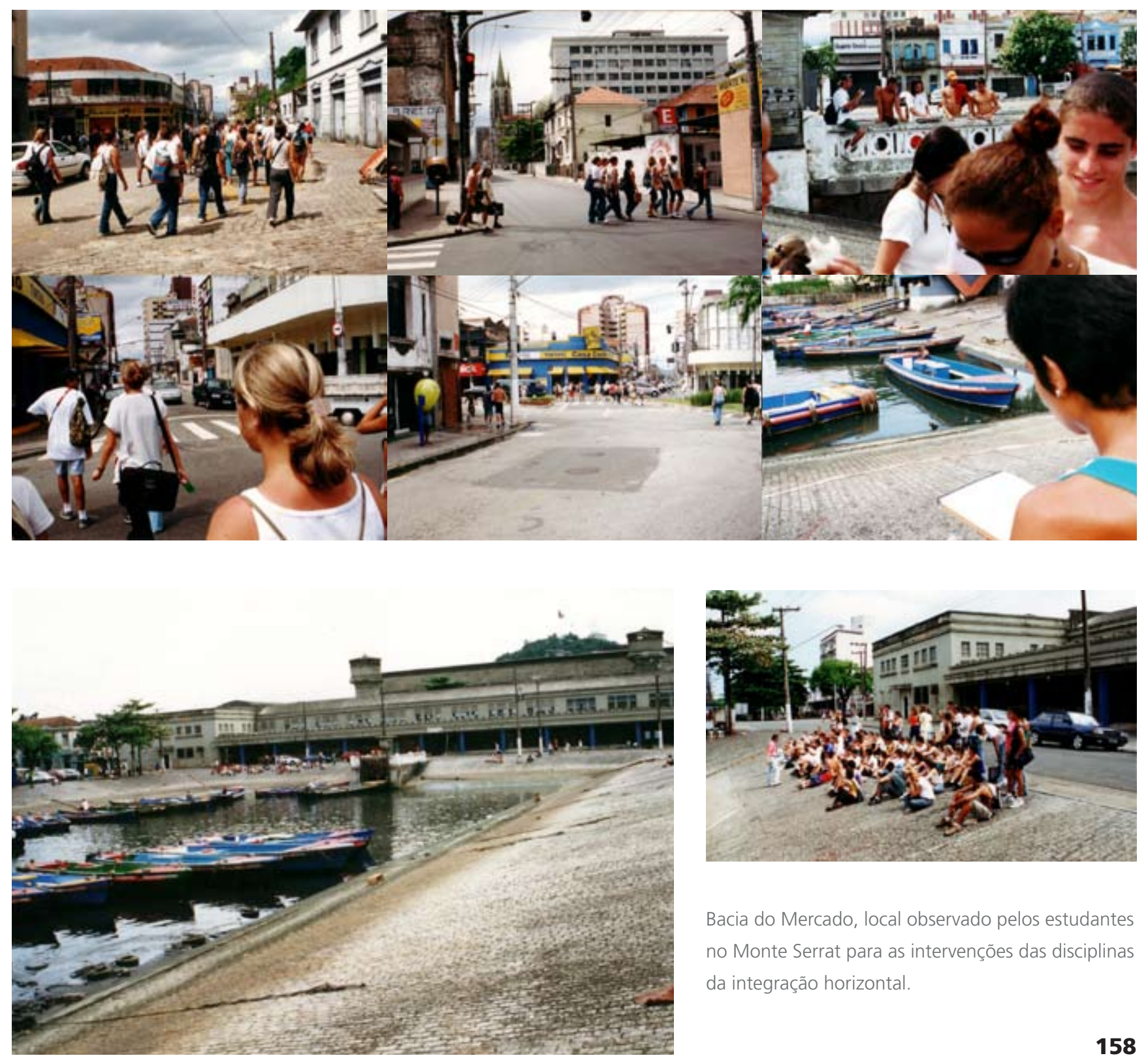

Bacia do Mercado, local observado pelos estudantes no Monte Serrat para as intervenções das disciplinas da integração horizontal. 
Nas semanas que se seguiram, a partir da visita realizada ao Monte Serrat e ao centro de Santos, as disciplinas de Urbanismo, Plástica e Teoria da Arquitetura aprofundaram a leitura da cidade por meio de suas especificidades (levantamentos, desenhos de observação, etc.). Ao mesmo tempo, a disciplina de Projeto Arquitetônico desenvolvia exercício de projeto gramatical. O exercício de Projeto Arquitetônico para a área de intervenção foi realizado após o término da leitura desse sítio. Uma maquete de todo o conjunto foi executada coletivamente pelos alunos, com suas intervenções projetuais, sob a coordenação da disciplina de Urbanismo e de Teoria da Arquitetura. A intervenção de Projeto Arquitetônico é individual e representada por modelo, fotografado na maquete geral.

Enquanto as demais disciplinas envolvidas na integração horizontal desenvolviam a leitura do sítio urbano a ser estudado, a disciplina de Projeto Arquitetônico elaborava exercício gramatical.

Esse trabalho discutiu a importância da representação de um objeto em três dimensões, composta pelas plantas, cortes e elevações. Volumes diversos são criados a partir de um desenho que acompanha o enunciado.

\section{Programa do exercício gramatical}

\section{Faculdade de Arquitetura de Santos - Fau/Santos}

\section{Projeto Arquitetônico I}

Professores Carlos Antunes, Denise Ruprecht, José Claudio Paneque, Vera Lúcia Domschke 


\section{Objetivos}

O exercício visa:

1. Capacitar e valorizar linguagens de desenho e modelos como forma de prefigurar o espaço edificado.

2. Introduzir questões de representação - desenho arquitetônico.

3. Introduzir as relações de tridimensionalidade e volumetria.

\section{Escopo e metodologia}

É apresentado o desenho de uma malha de $25 \times 25 \mathrm{~cm}$, que representa a vista superior de um volume, que deverá ser modelado pelo aluno com papelão monocromático.

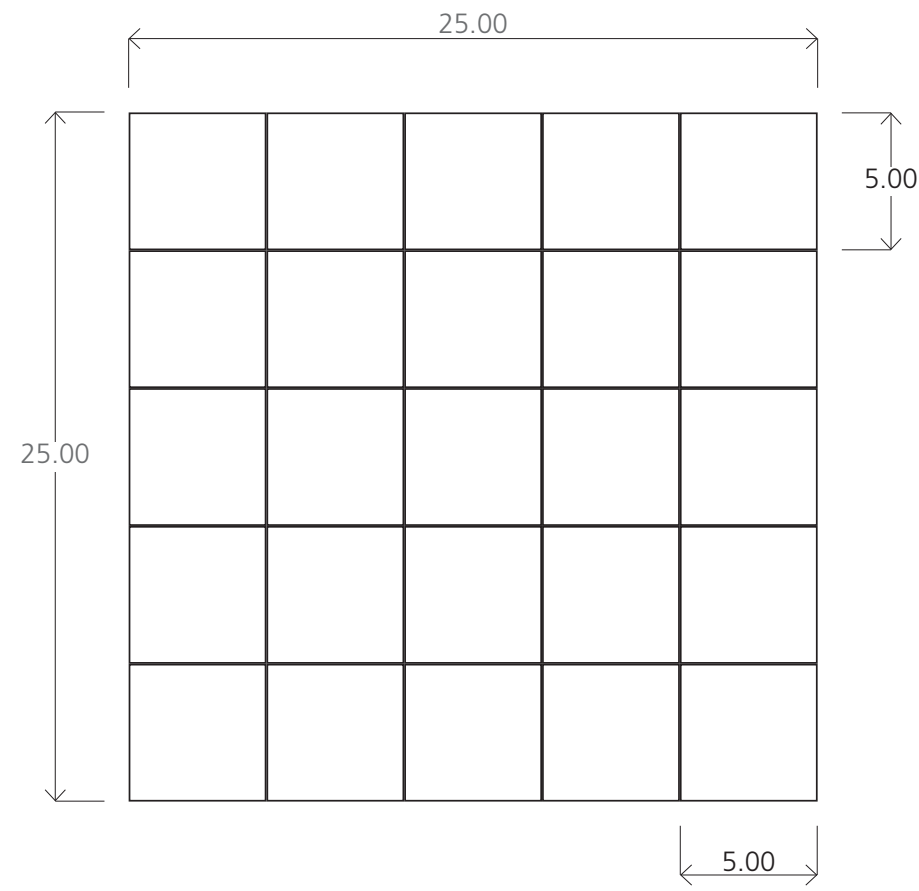

TRABALHO FINAL

1. Modelo na escala 1:100

2. Desenhos a lápis sobre papel-manteiga na escala 1:100:

A. Secção paralela ao plano de projeção horizontal

B. Dois cortes ortogonais entre si

C. Quatro elevações 
Os estudantes foram orientados a projetar um volume executando modelo em papel. Nesse exercício os alunos utilizaram o desenho como representação técnica de projeto e fizeram uso dos modelos executados para a representação.

\section{Exemplares do exercício gramatical proposto: Malha}

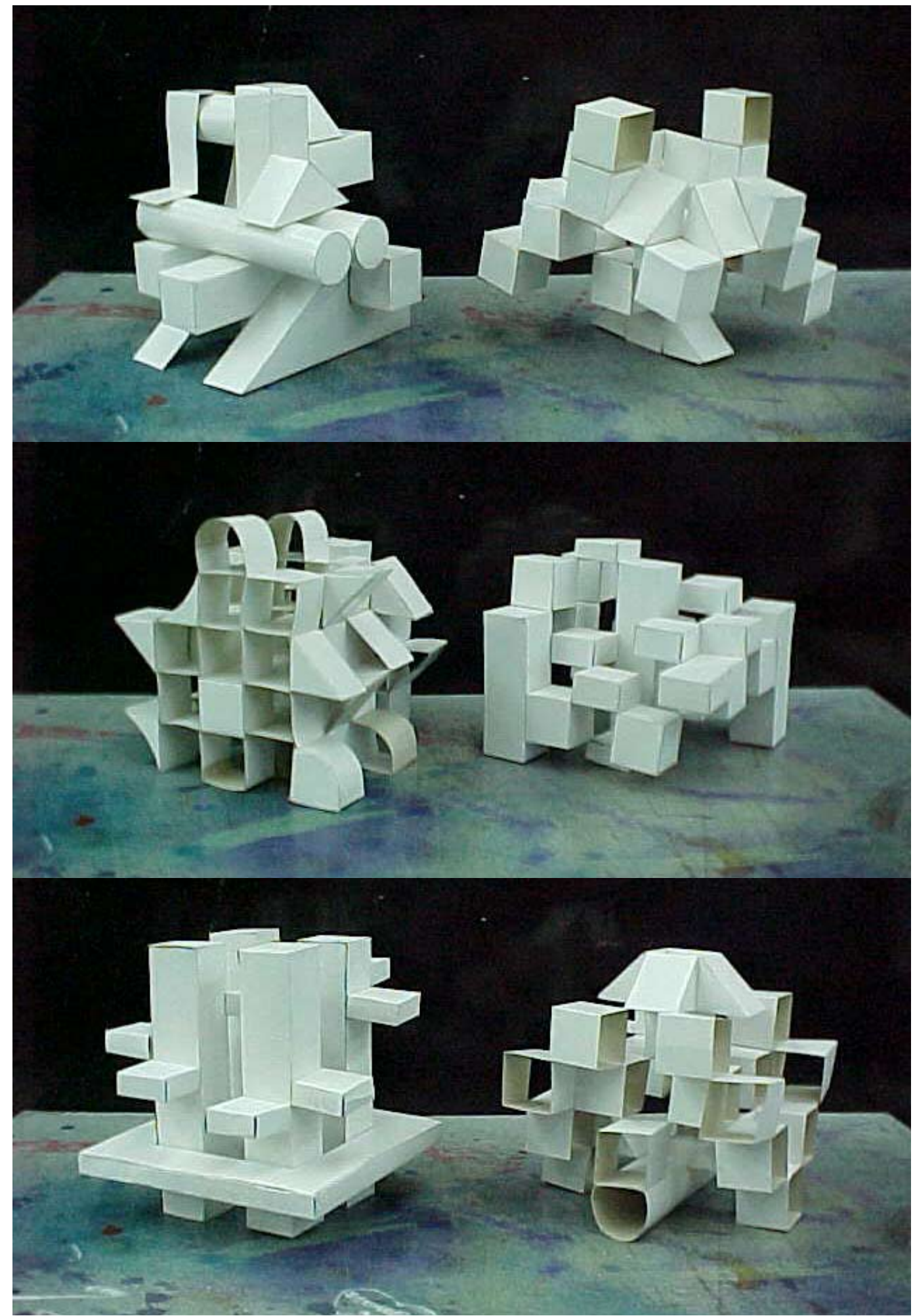




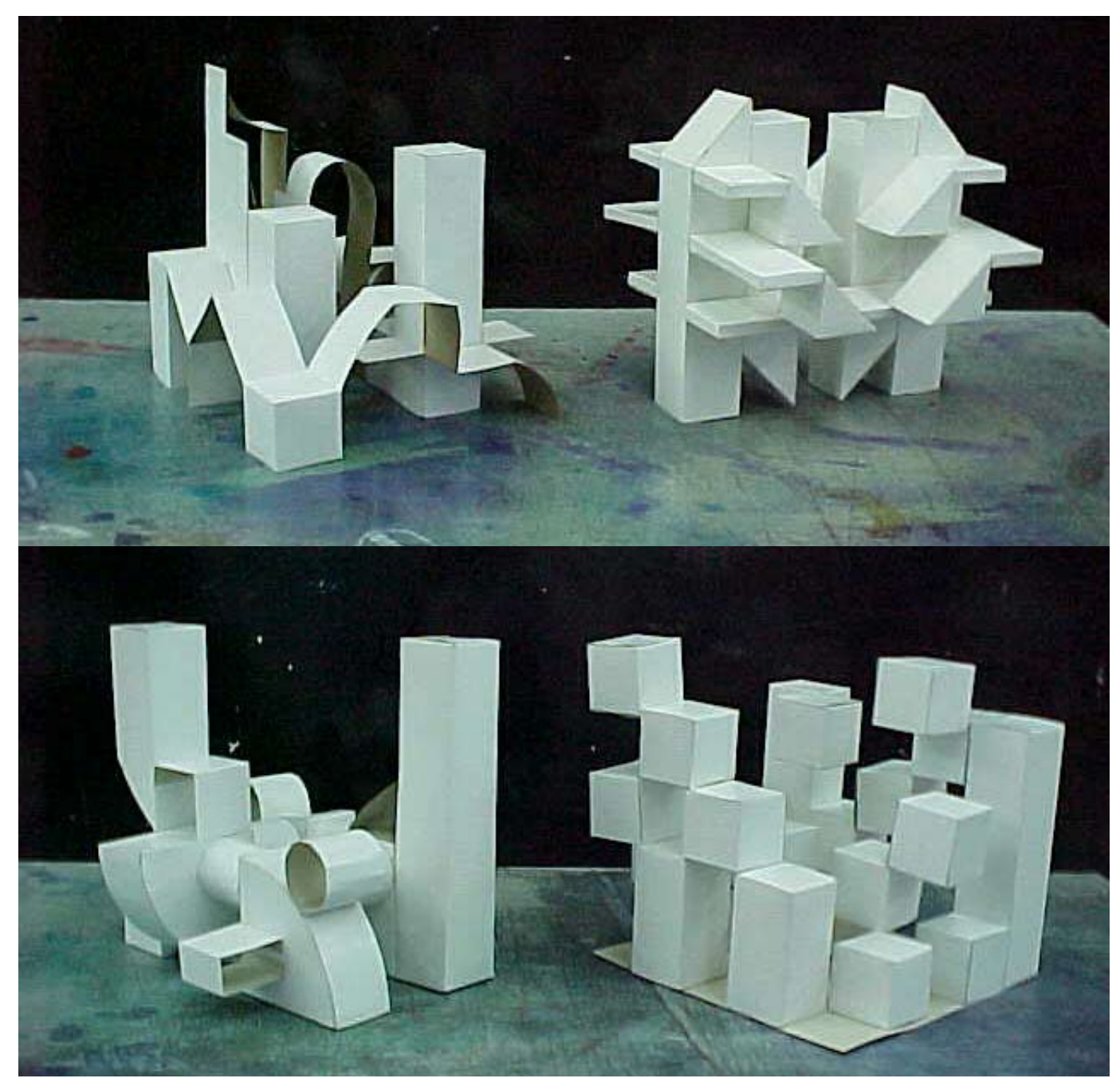

Resultado do exercício gramatical.

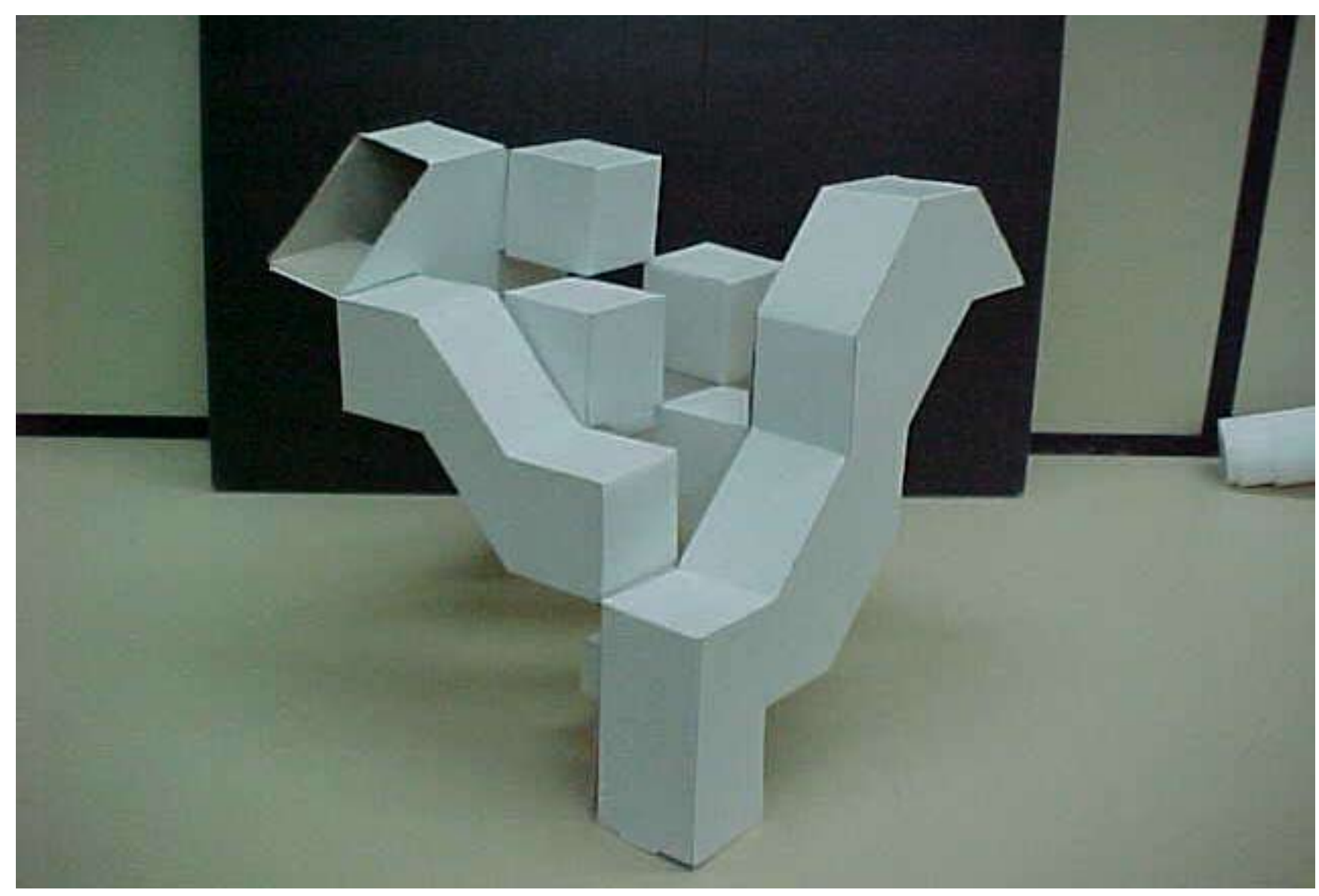


Após o término do exercício gramatical da disciplina de Projeto Arquitetônico, foi proposto aos alunos um exercício de intervenção na área da Bacia do Mercado, local que havia sido anteriormente objeto das leituras nas disciplinas de Urbanismo, Plástica e Teoria da Arquitetura. A intervenção propunha um volume a ser implantado em área livre ao lado da Bacia do Mercado, montado a partir de planos, os mesmos que compõem o Pavilhão de Barcelona, projetado pelo arquiteto Mies van der Rohe. Foram fornecidos desenhos do pavilhão na escala 1:200. Os alunos transformaram os desenhos para a escala 1:100, cortaram os planos e criaram um objeto tridimensional, considerando o entorno, a escala humana e a orientação solar. O uso da edificação projetada foi o de um pavilhão de exposições.

\section{Programa do exercício dos planos}

\section{Faculdade de Arquitetura de Santos Fau/Santos}

\section{Projeto Arquitetônico I}

Professores Carlos Antunes, Denise Ruprecht, José Claudio Paneque, Vera Lúcia Domschke

EXERCÍCIO III - OBJETO TRIDIMENSIONAL

\section{Objetivos}

O exercício visa:

1. A compreensão da tridimensionalidade do espaço arquitetônico e sua organização por meio de planos - horizontais, verticais, curvos, inclinados.

2. Introduzir o conceito de relações - escala humana.

3. Introduzir o conceito de estabilidade - lei da gravidade. 
4. Produzir repertório arquitetônico.

\section{Escopo e metodologia}

A partir dos planos dados - extraídos do projeto Pavilhão de Barcelona de Mies van der Rohe - o aluno deverá organizar um "objeto arquitetônico" (tridimensional) estável, segundo os seguintes princípios:

1. O objeto é uma representação do real.

2. O objeto tem uma relação com a escala humana na proporção de $1,0 \mathrm{~cm}=1,0 \mathrm{~m}$.

3. Os planos podem ser organizados com plena liberdade, respeitando sua integridade, não podendo haver ruptura ou quebra.

4. O objeto deve apresentar estabilidade à compressão.

5. O objeto deve permitir o percurso em seu interior - aberturas (cheios e vazios).

\section{TRABALHO FINAL}

Modelo em papel-cartão, monocromático, implantado na área da Bacia do Mercado em Santos.

\section{Integração Horizontal com Urbanismo, Plástica e Teoria da Arquitetura}

O objeto deverá ser implantado na área da Bacia do Mercado; a área será definida juntamente com os professores de Urbanismo. A avaliação de Projeto Arquitetônico levará em conta o objeto inserido no conjunto urbano. A disciplina de Urbanismo avaliará o projeto quanto a seu uso.

Será realizada visita de compreensão da área em relação à cidade e seu entorno, com participação dos professores de Projeto, Plástica, Urbanismo, História da Arte, Teoria da Arquitetura e Problemas do Homem Contemporâneo. 


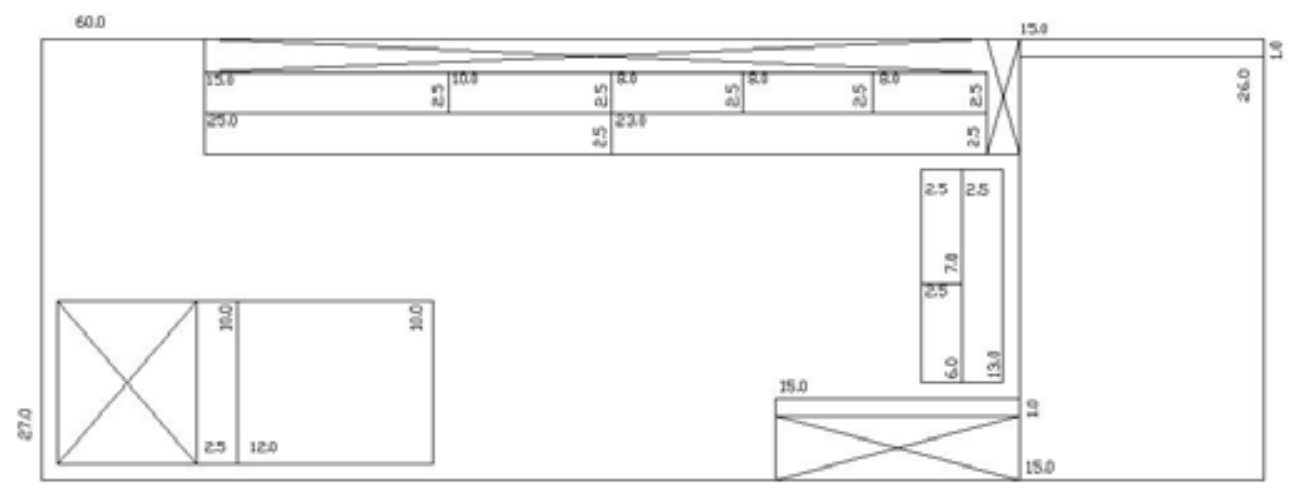

Desenhos fornecidos aos alunos na escala 1:200, usados na construção do Pavilhão de Barcelona, utilizados na construção deste exercício.
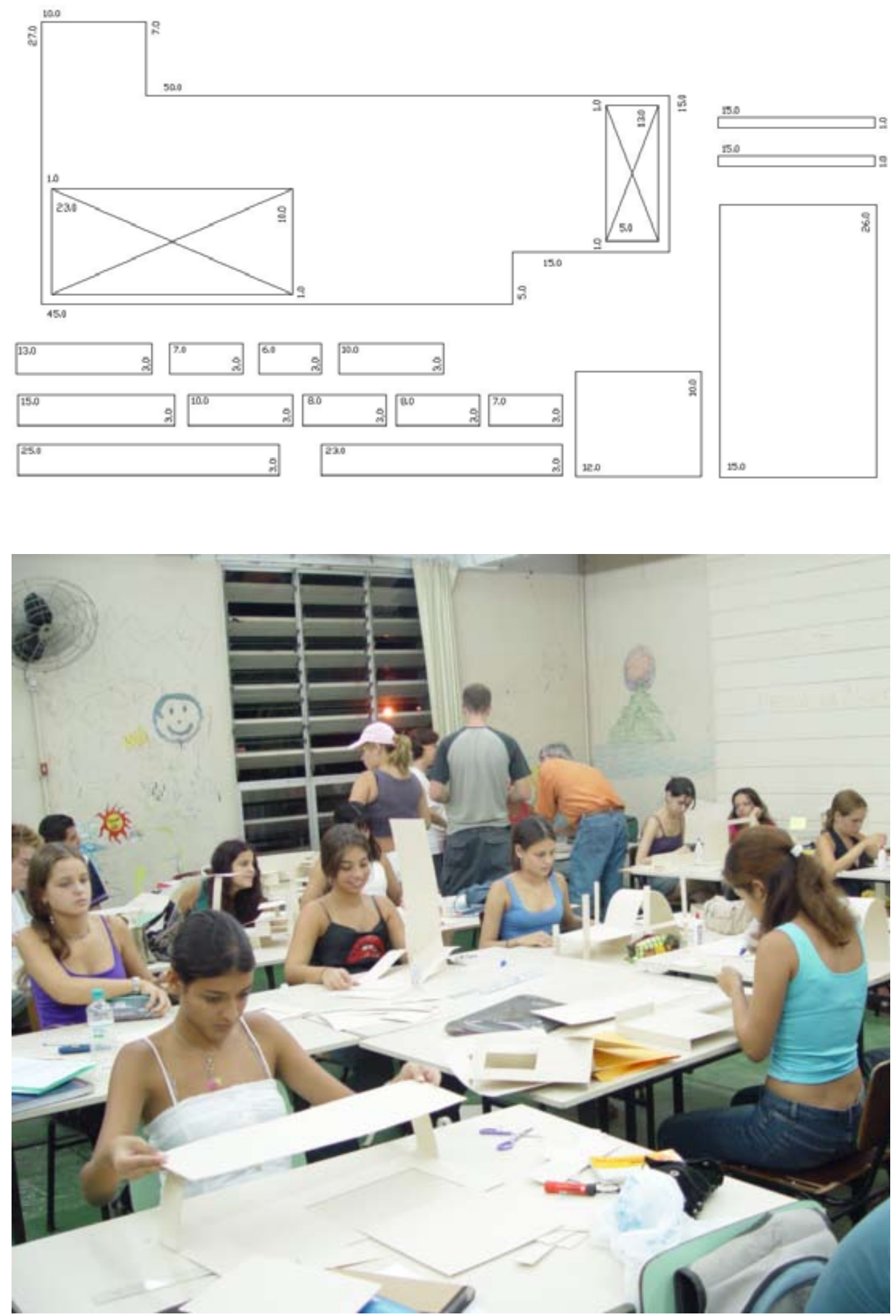

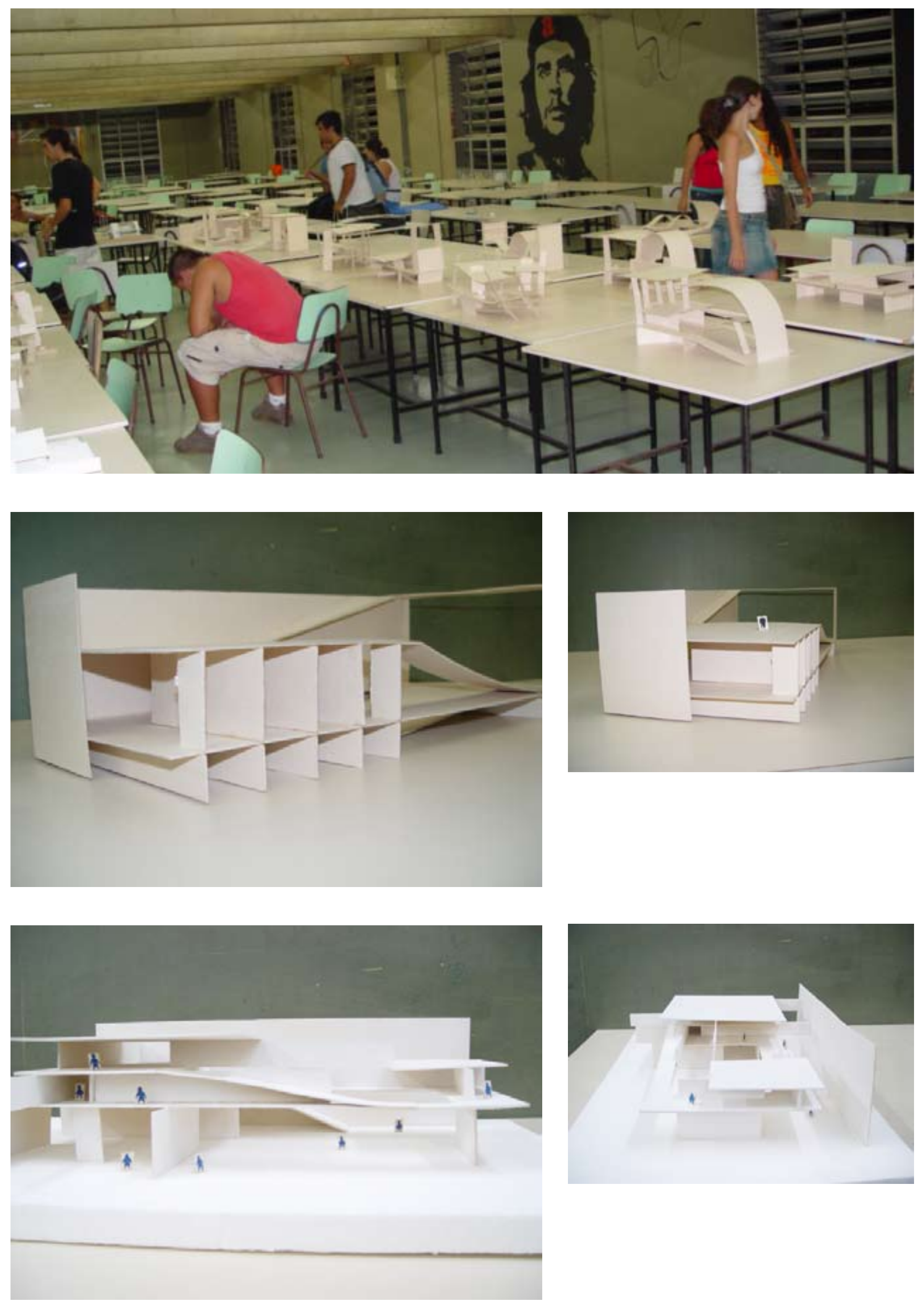
Esse mesmo exercício de leitura da Bacia do Mercado se repetiu com a Avenida Conselheiro Nébias e a Avenida Ana Costa.

Na Avenida Conselheiro Nébias, exercício similar de projeto foi realizado como atividade da integração horizontal com as disciplinas de Projeto Arquitetônico, Urbanismo, Plástica e Teoria da Arquitetura. A situação urbana do projeto era de um terreno entre dois edifícios altos, onde o estudante implantou uma galeria de arte.

\section{Programa do exercício}

\section{Faculdade de Arquitetura de Santos - Fau/Santos}

\section{Projeto Arquitetônico I}

Professores Carlos Antunes, Denise Ruprecht, José Claudio Paneque, Vera Lúcia Domschke

EXERCÍCIO IV - GALERIA DE ARTE

\section{Objetivos}

O exercício visa:

1. Desenvolvimento de um projeto arquitetônico simples.

2. Introdução de questões de espacialidade.

2.a Interna.

2.b Cheios e vazios.

2.c Acessibilidade.

2.d Circulação / escadas e rampas.

2.e Relação das aberturas para o exterior.

2.f Relação com o meio construído - espaço urbano. 
3. Incremento do repertório arquitetônico.

4. Representação do projeto.

\section{Escopo e metodologia}

Desenvolvimento de projeto arquitetônico, com programa simples, de uma galeria de arte a ser implantada na mesma área de intervenção do projeto desenvolvido por Urbanismo. Para o incremento do repertório arquitetônico foi realizada visita às seguintes obras em São Paulo:

- Estação da Luz

- Pinacoteca do Estado

- Mube

A visita foi feita em conjunto com os professores de Plástica.

TRABALHO FINAL

Desenhos e modelo do projeto e sua implantação.

As visitas à Galeria Fortes Villaça e ao Museu Brasileiro da Escultura em São Paulo foram acompanhadas pelos professores de Projeto Arquitetônico e tiveram como objetivo ilustrar o programa de espaços de exposição, objeto de estudo no projeto a ser realizado pelos estudantes.

Galeria Fortes Villaça na Vila Madalena, São Paulo.
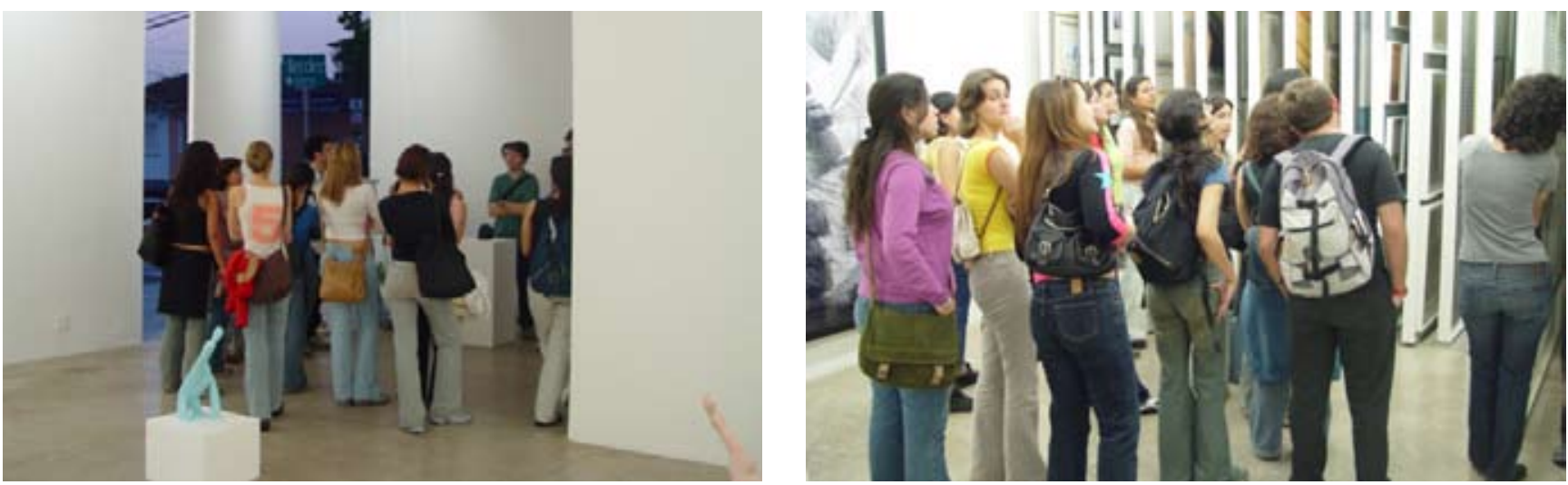

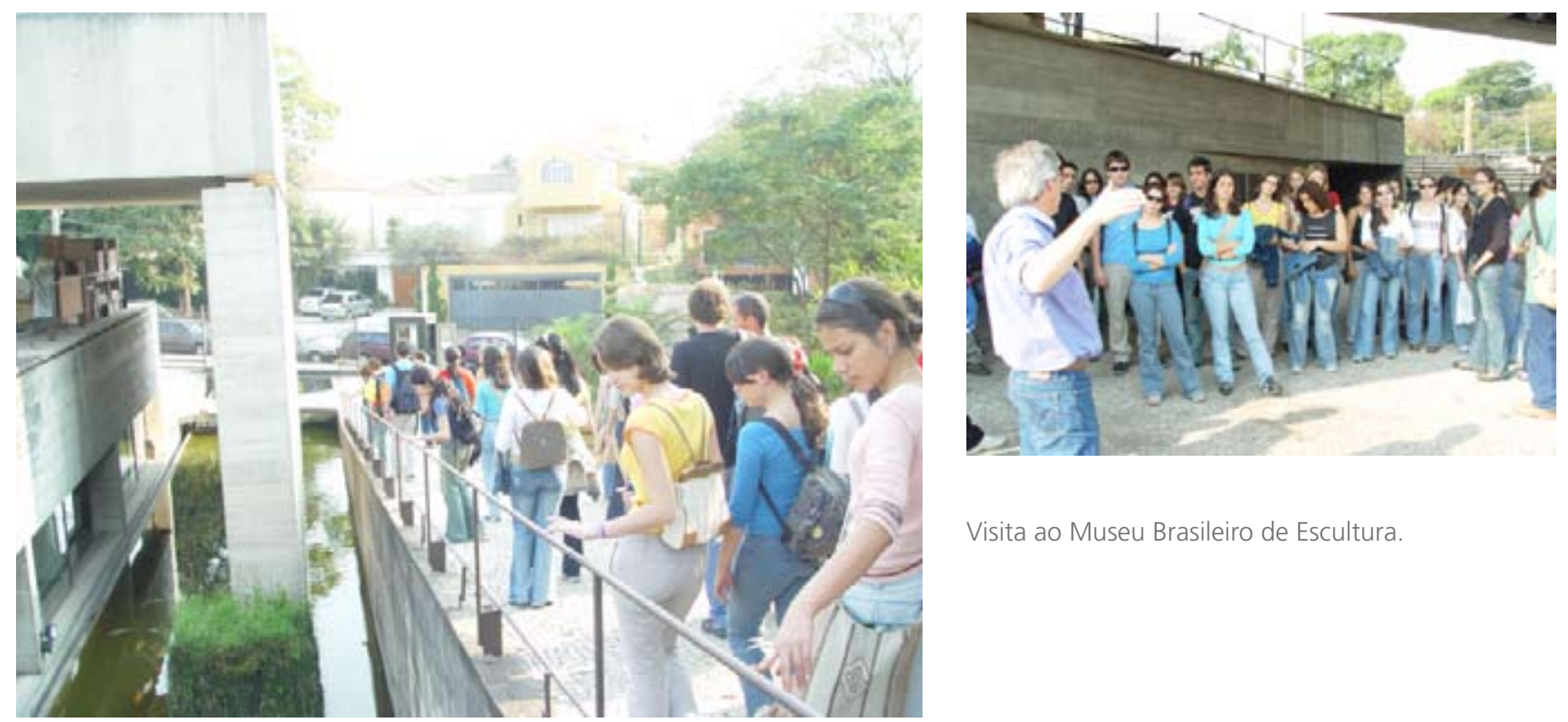

Visita ao Museu Brasileiro de Escultura.
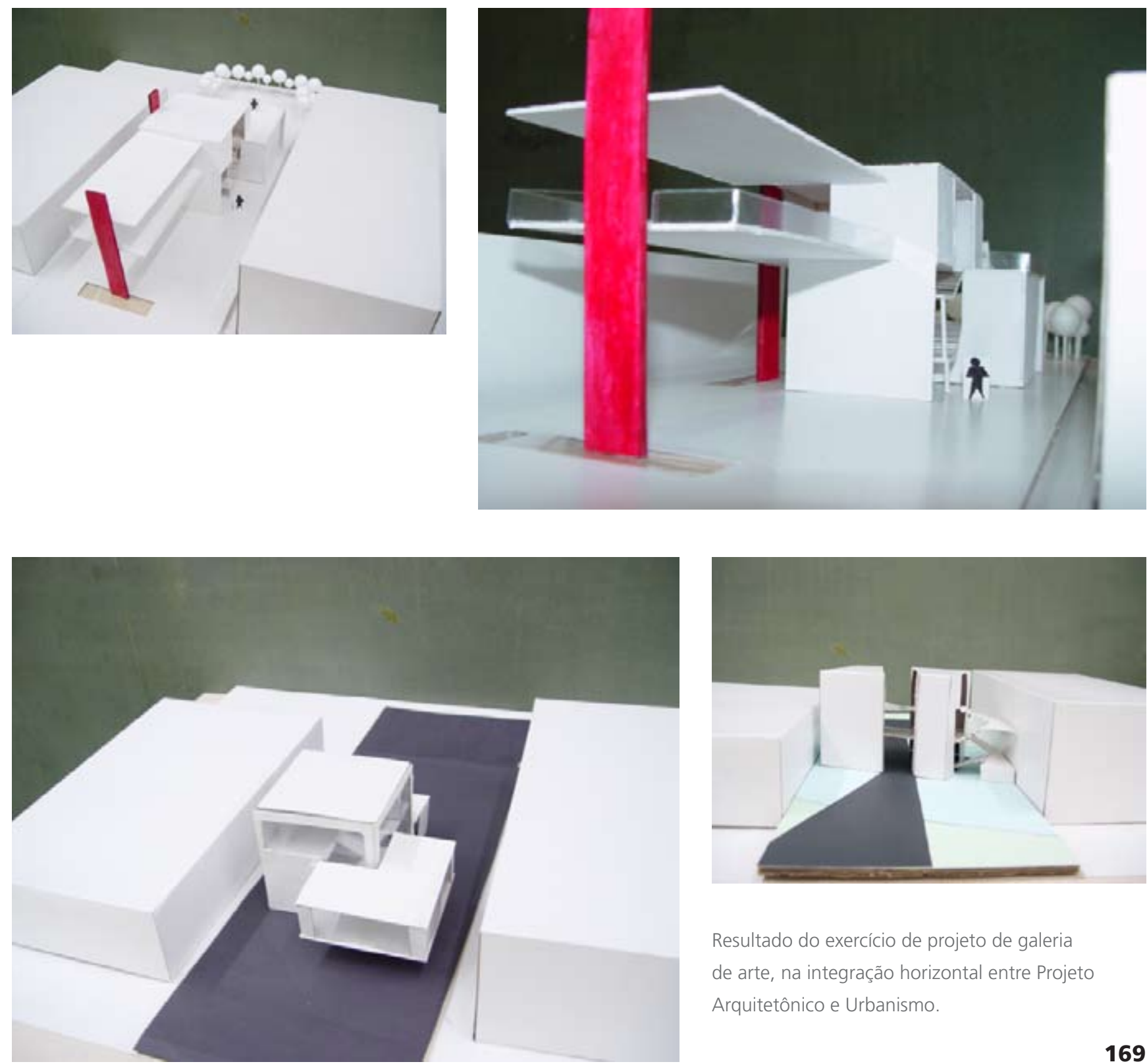

Resultado do exercício de projeto de galeria

de arte, na integração horizontal entre Projeto

Arquitetônico e Urbanismo. 
Exercício de integração horizontal de Projeto Arquitetônico e Topografia - Programa do exercício

Faculdade de Arquitetura de Santos - Fau/Santos, $1^{\circ}$ Semestre 2001

\section{Projeto Arquitetônico I}

Professores Carlos Antunes, Denise Ruprecht, José Claudio Paneque, Vera Lúcia Domschke

EXERCÍCIO V - CAPELA

\section{Objetivos}

O exercício visa:

1. Compreensão do espaço natural, corte, aterro, acessos, orientação, declividade e visuais.

2. Desenvolvimento de um projeto arquitetônico.

3. Incremento do repertório arquitetônico.

\section{Escopo e metodologia}

Primeira etapa

Os alunos, em equipes, deverão moldar um terreno com argila e, através de um experimento, marcar as curvas de nível do terreno.

Representar o terreno com as curvas de nível em escala 1:200 e construir, individualmente, modelo em papelão.

Segunda etapa

O aluno deverá desenvolver individualmente o projeto de um espaço ecumênico a ser implantado no terreno construído na primeira etapa do exercício. 

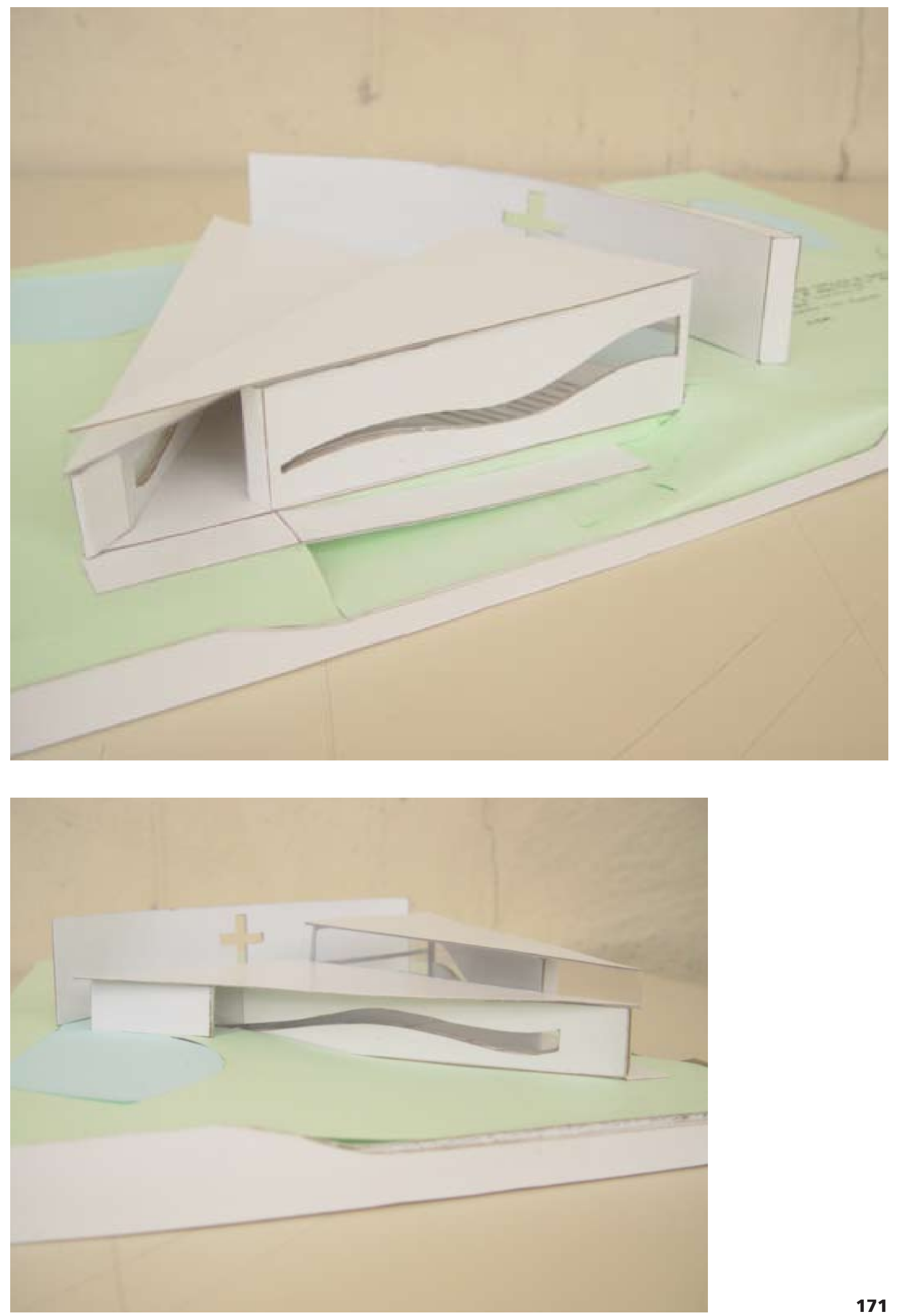

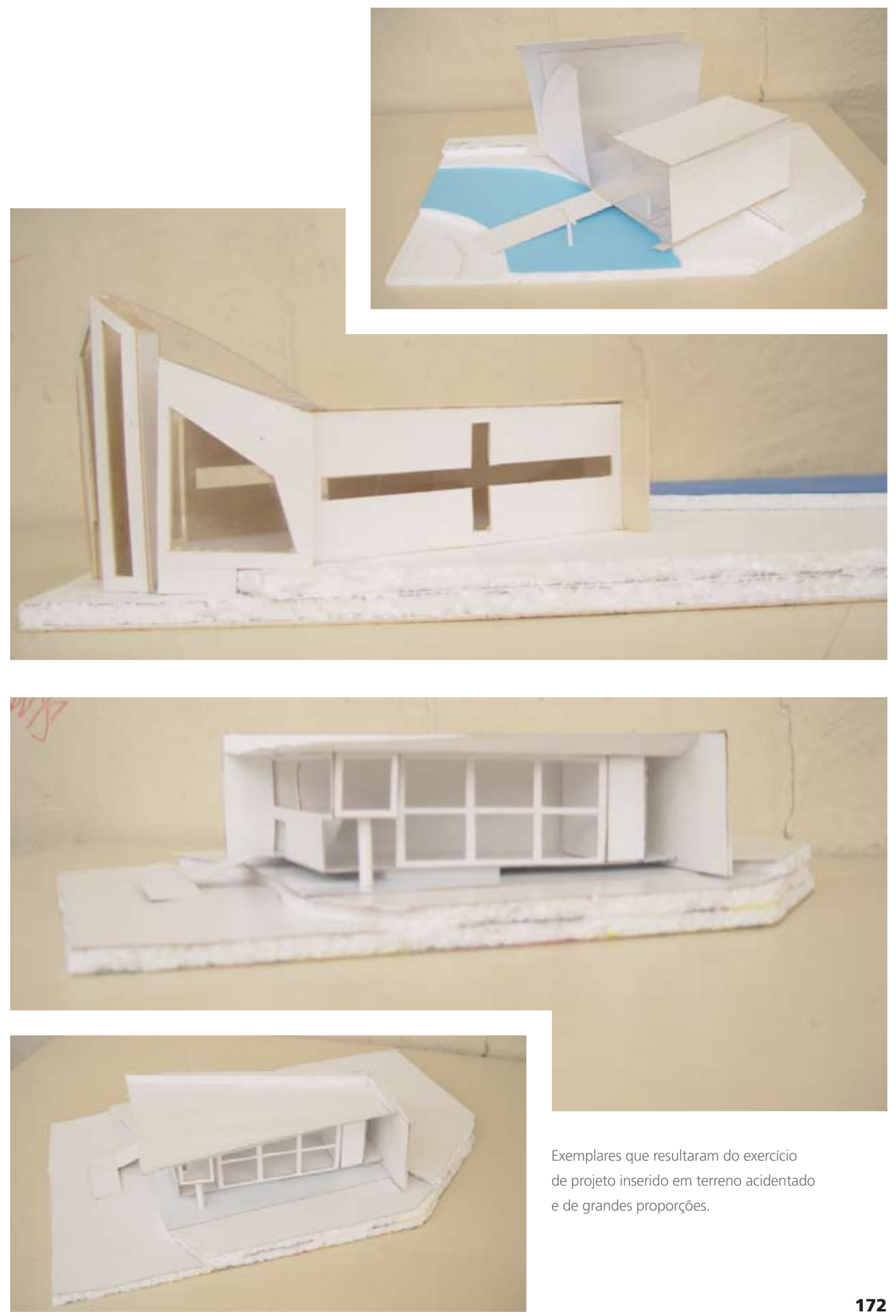

Exemplares que resultaram do exercício

de projeto inserido em terreno acidentado e de grandes proporções. 
Algumas atividades desenvolvidas no processo de integração horizontal variavam de ano para ano, mas as viagens estavam sempre incluídas e eram planejadas com roteiros detalhados. Os roteiros, oferecidos a todos os alunos, eram impressos em cadernos e continham informações de cada obra a ser visitada (plantas, cortes, fotos e texto explicativo), além de ter folhas para serem usadas pelo estudante para suas próprias anotações e desenhos. Constavam também da brochura informações complementares, como o roteiro de cada dia, dados sobre o hotel e sua localização, entre outras.

O Rio de Janeiro foi sempre escolhido como uma viagem de interesse para os alunos da integração horizontal do primeiro ano, pelo fato de se tratar de uma cidade litorânea, portuária e com diversas intervenções modernas, urbanísticas e de projeto, o que alimenta o repertório dos alunos para o projeto. A disciplina de Teoria da Arquitetura alterou o conteúdo de seu curso no primeiro ano, contemplando a arquitetura moderna, objeto dessa viagem.

A visita à exposição "Modernismo Brasileiro: Propostas e Caminhos", na FAAP, em 2004, serviu como introdução à viagem ao Rio de Janeiro, no segundo semestre, quando os alunos puderam entrar em contato com algumas obras arquitetônicas do modernismo brasileiro, que seriam visitadas posteriormente.

As mesmas leituras da cidade do Rio de Janeiro, a partir do Corcovado, e da cidade de Santos, a partir do Monte Serrat, foram atividades compreendidas na integração horizontal.

Durante a viagem, os alunos fizeram anotações e desenhos nos cadernos-roteiro, desenhos em cadernos tamanho A3 da disciplina de 
Plástica e desenhos coletivos em papéis de dimensões que comportam essa atividade, coordenados pelos professores de Plástica, Paulo Fernando von Poser e Giancarlo Latorraca, incentivadores das atividades de integração horizontal.

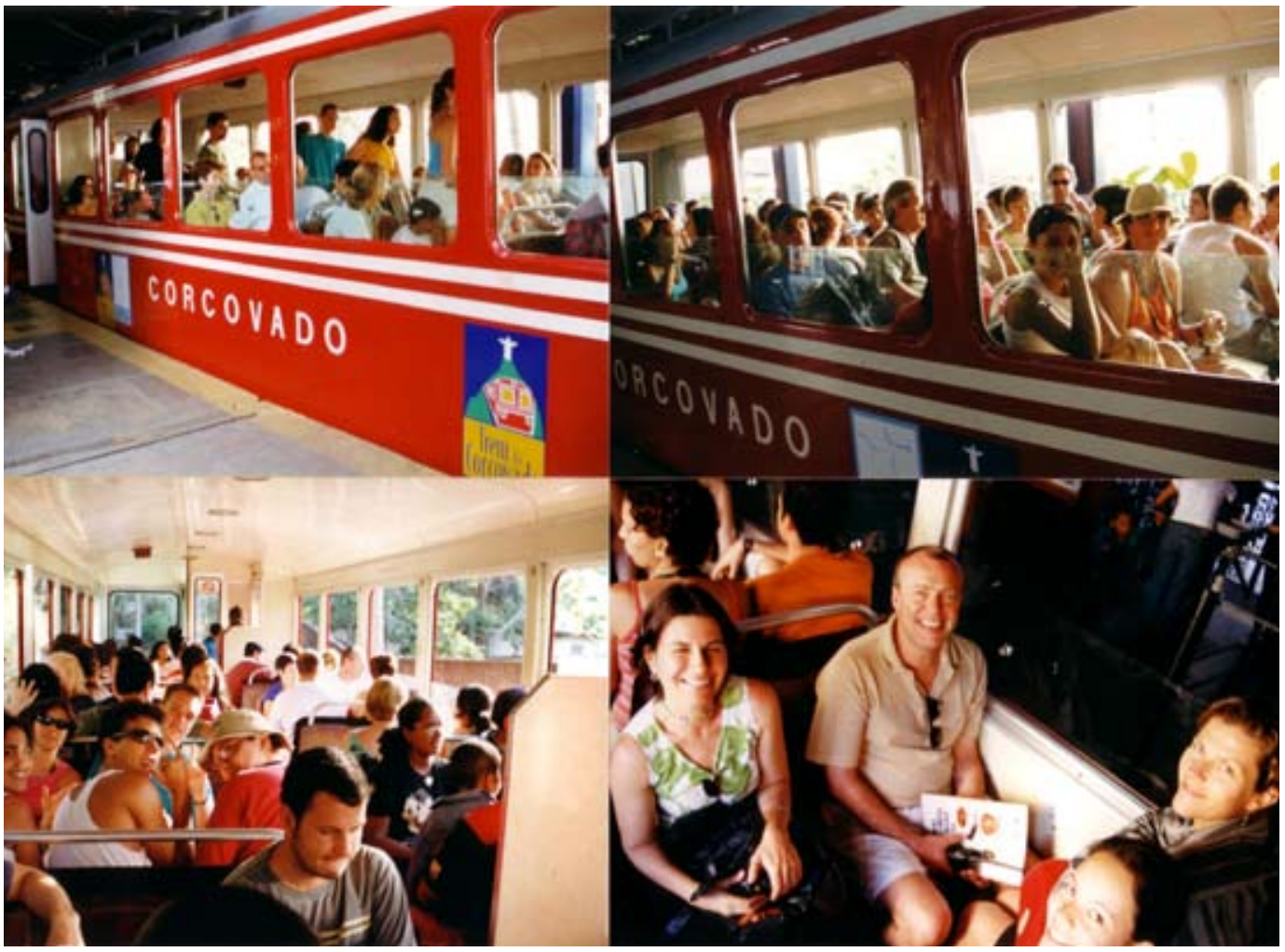

Visita ao Corcovado.

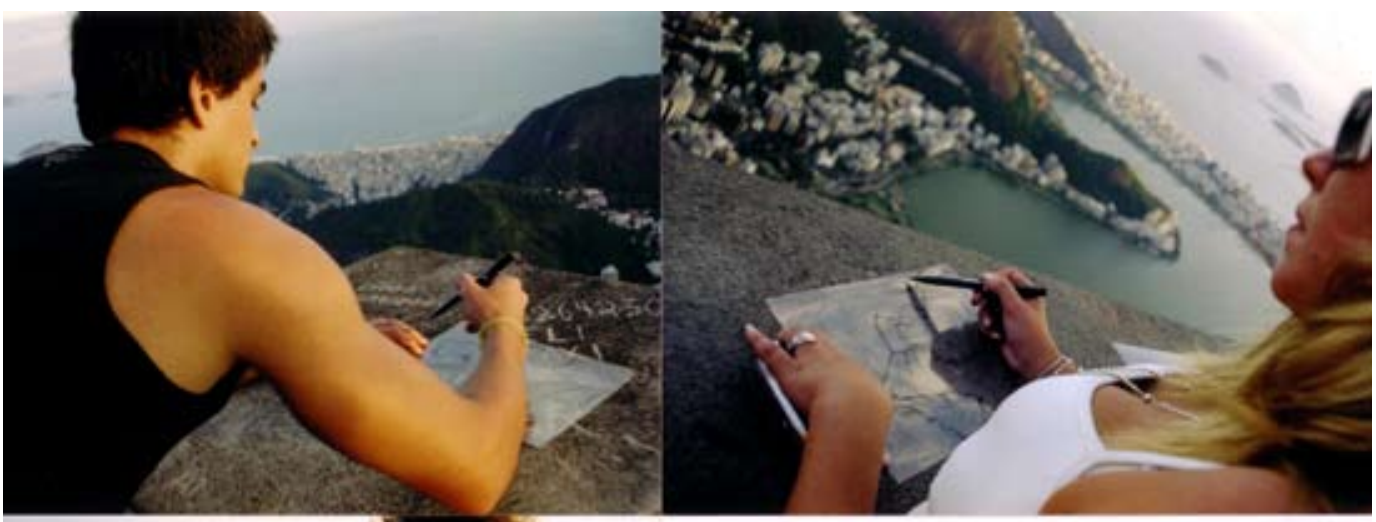

Alunos desenhando em folhas de acetato com canetas apropriadas.

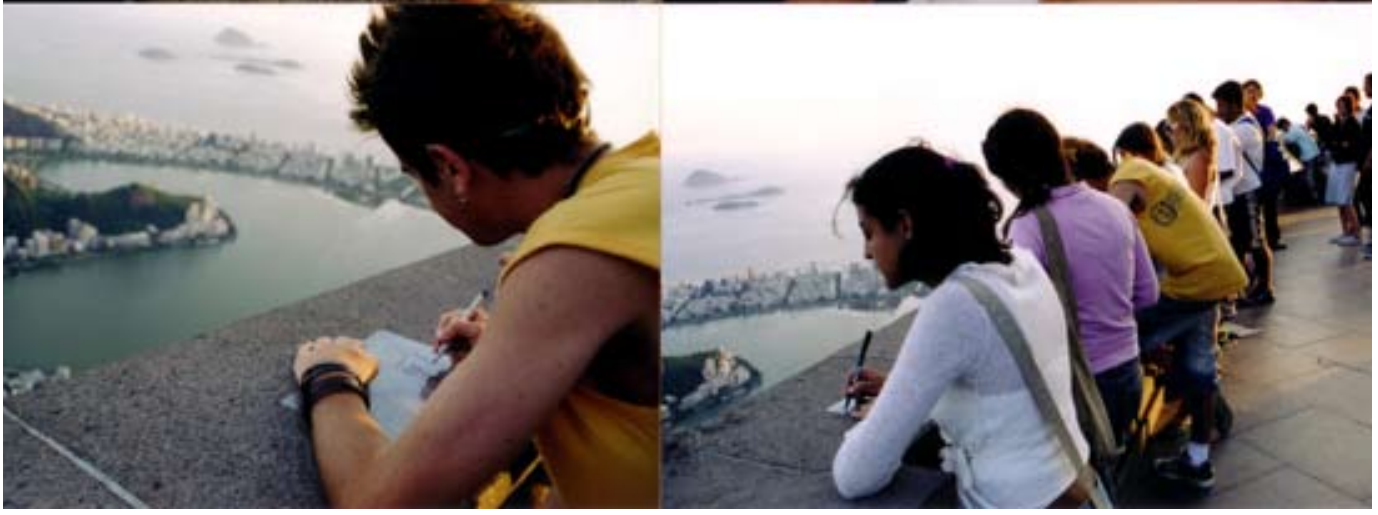




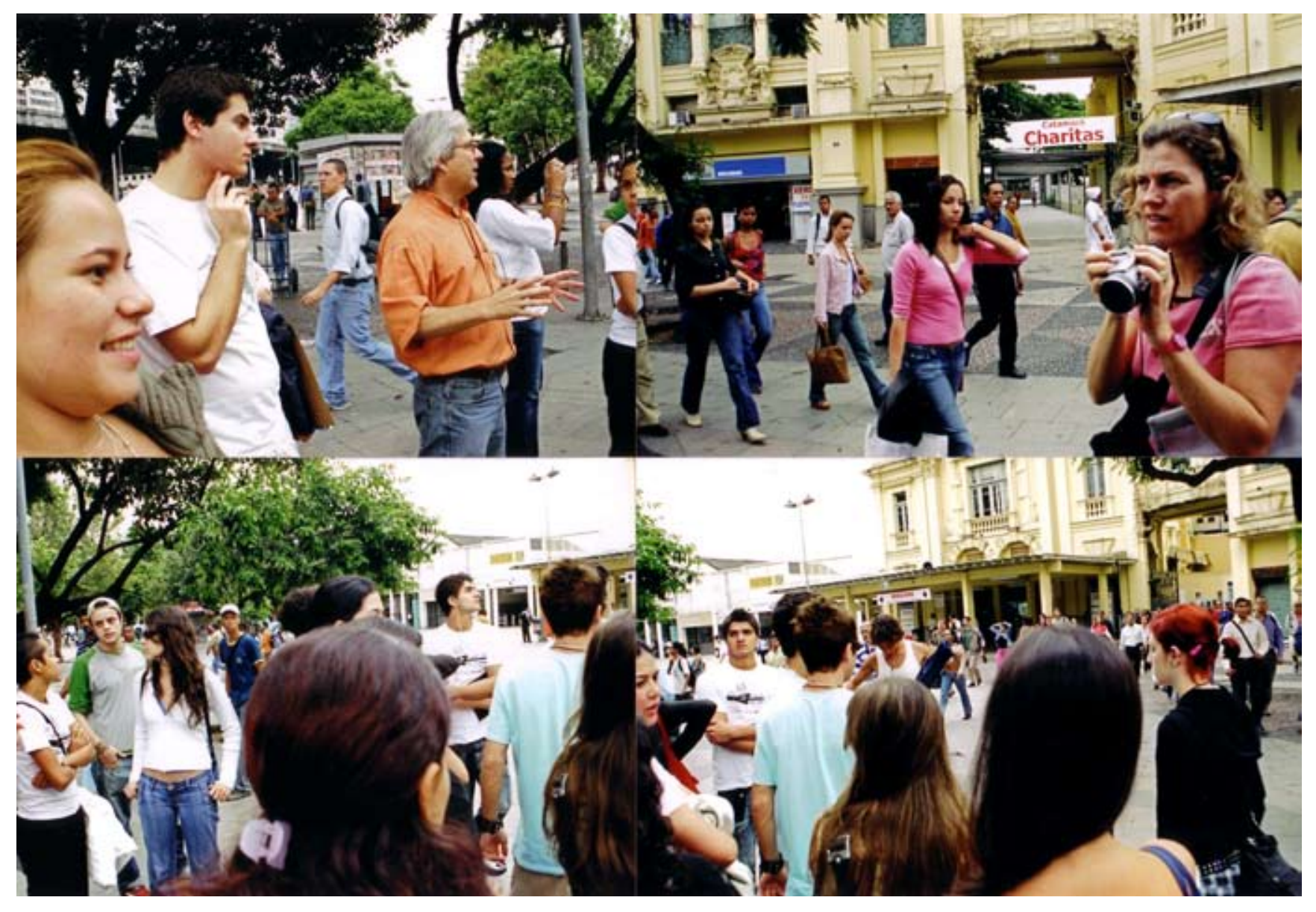

Visita ao centro do Rio de Janeiro.

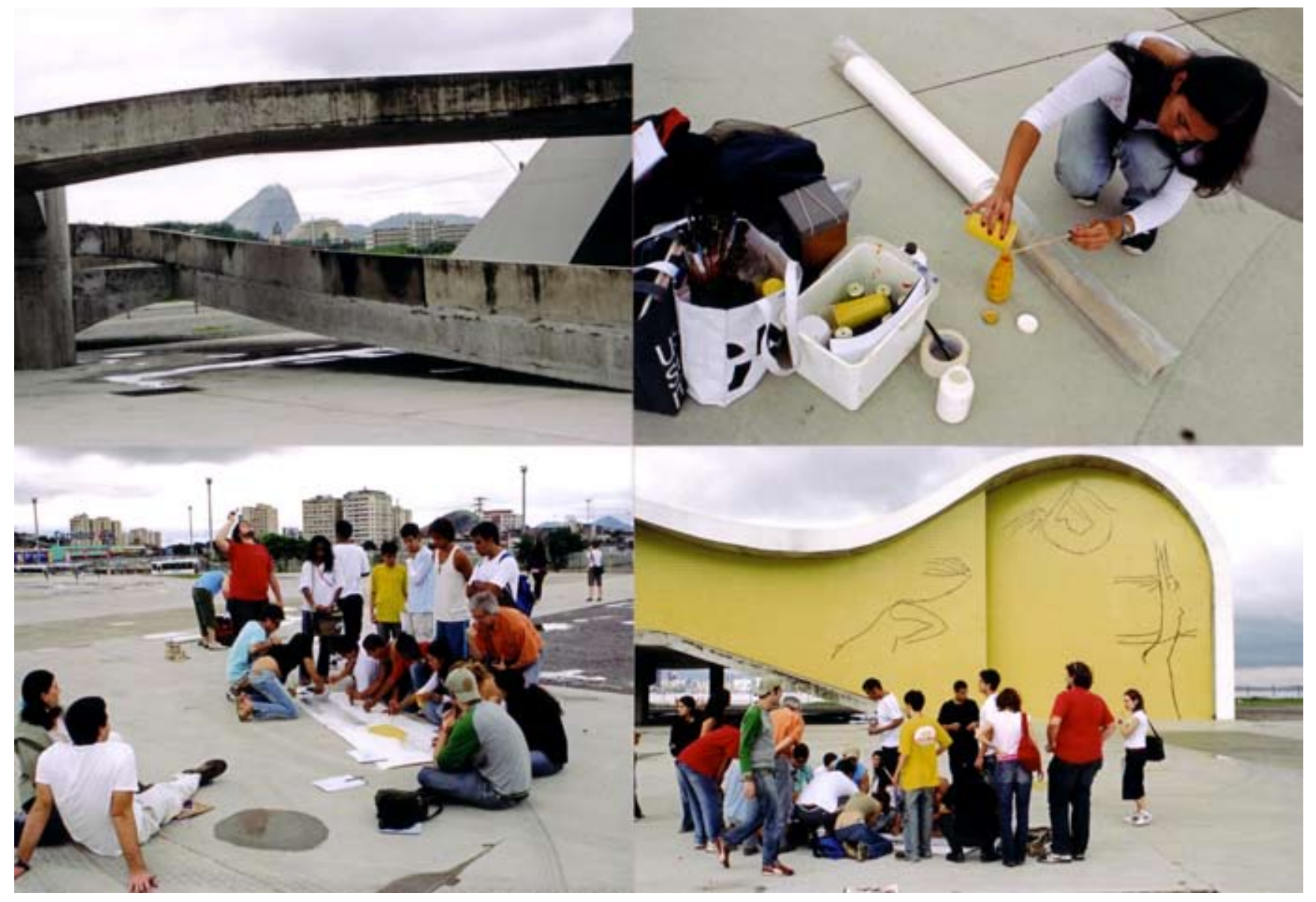



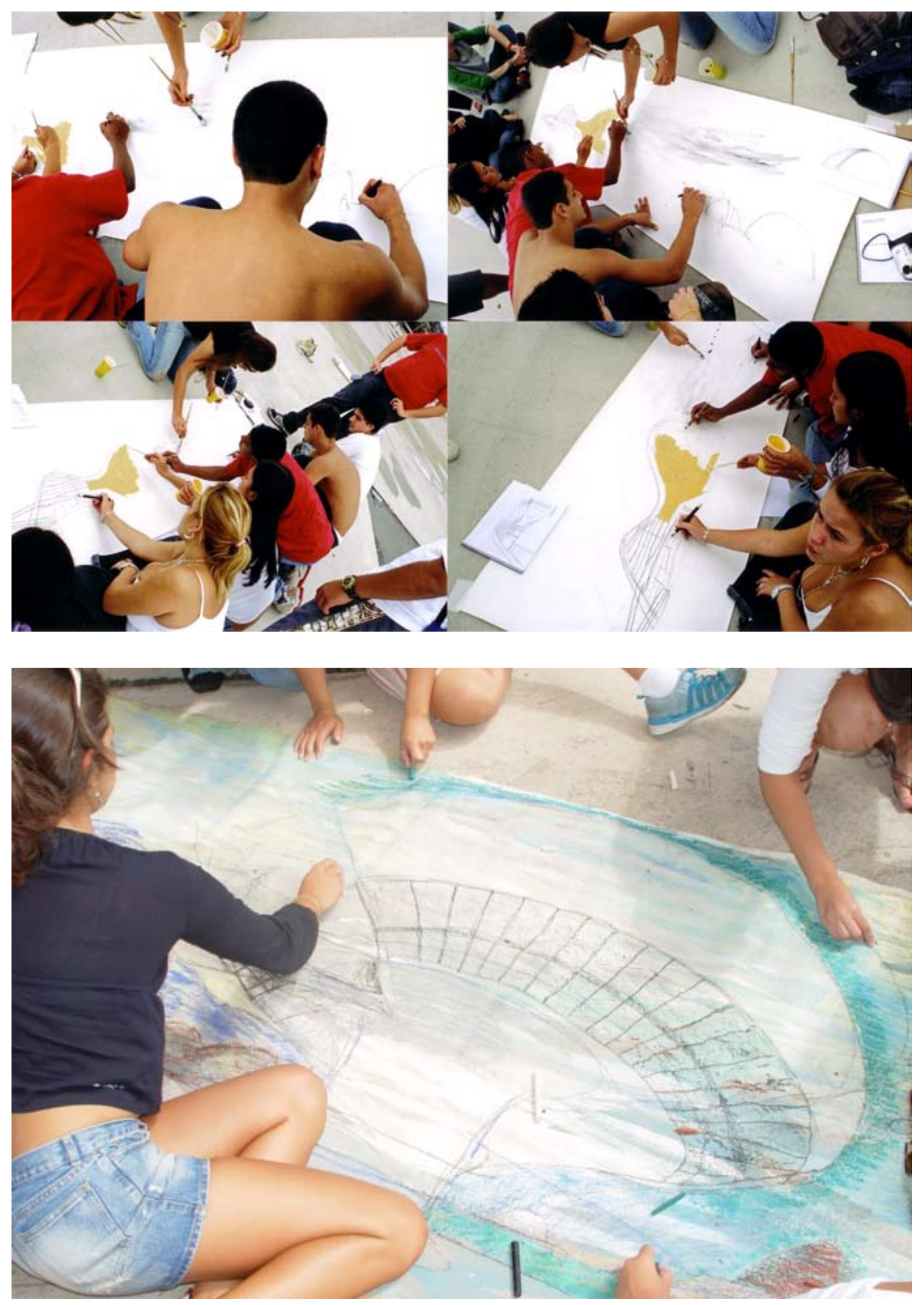

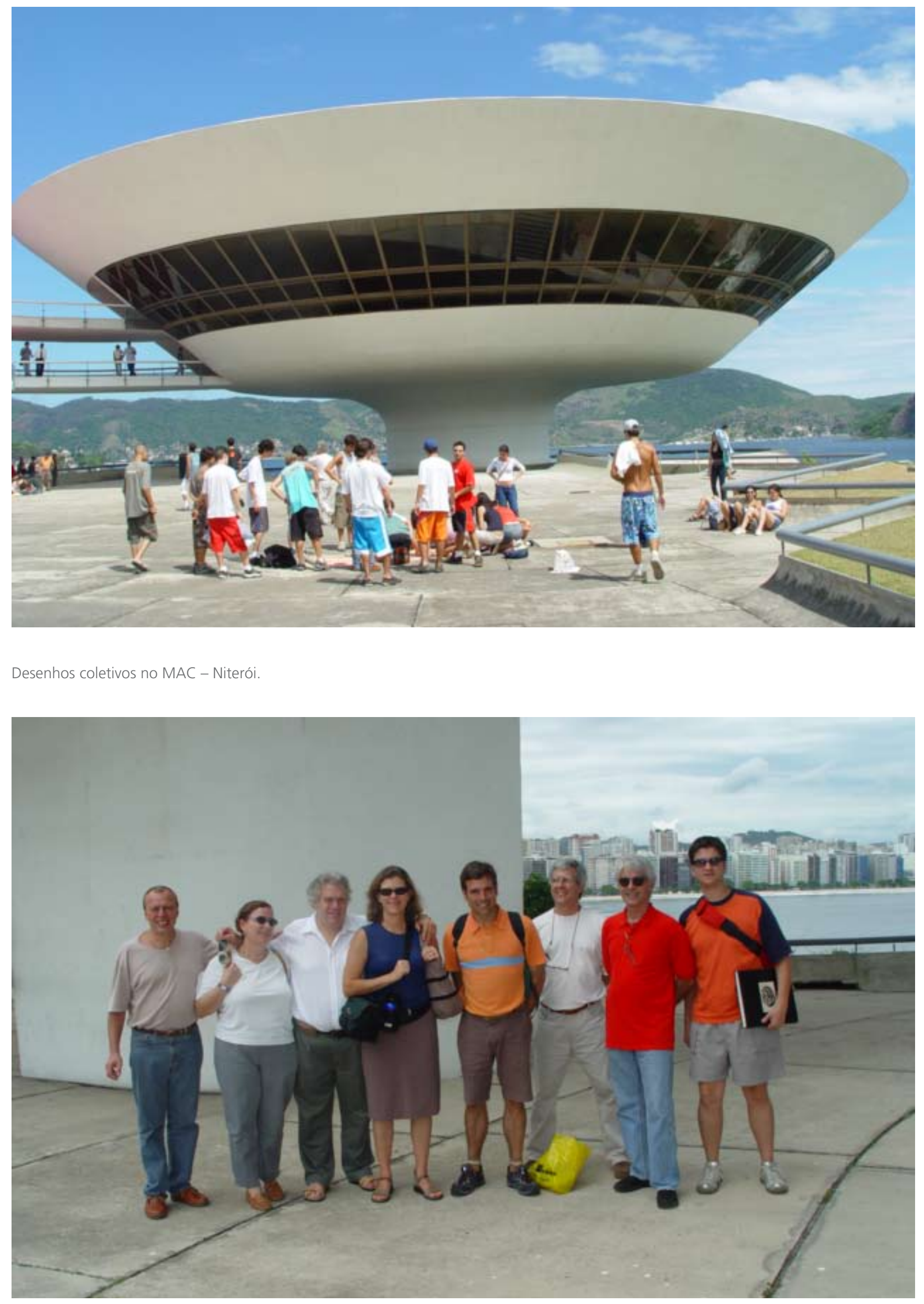

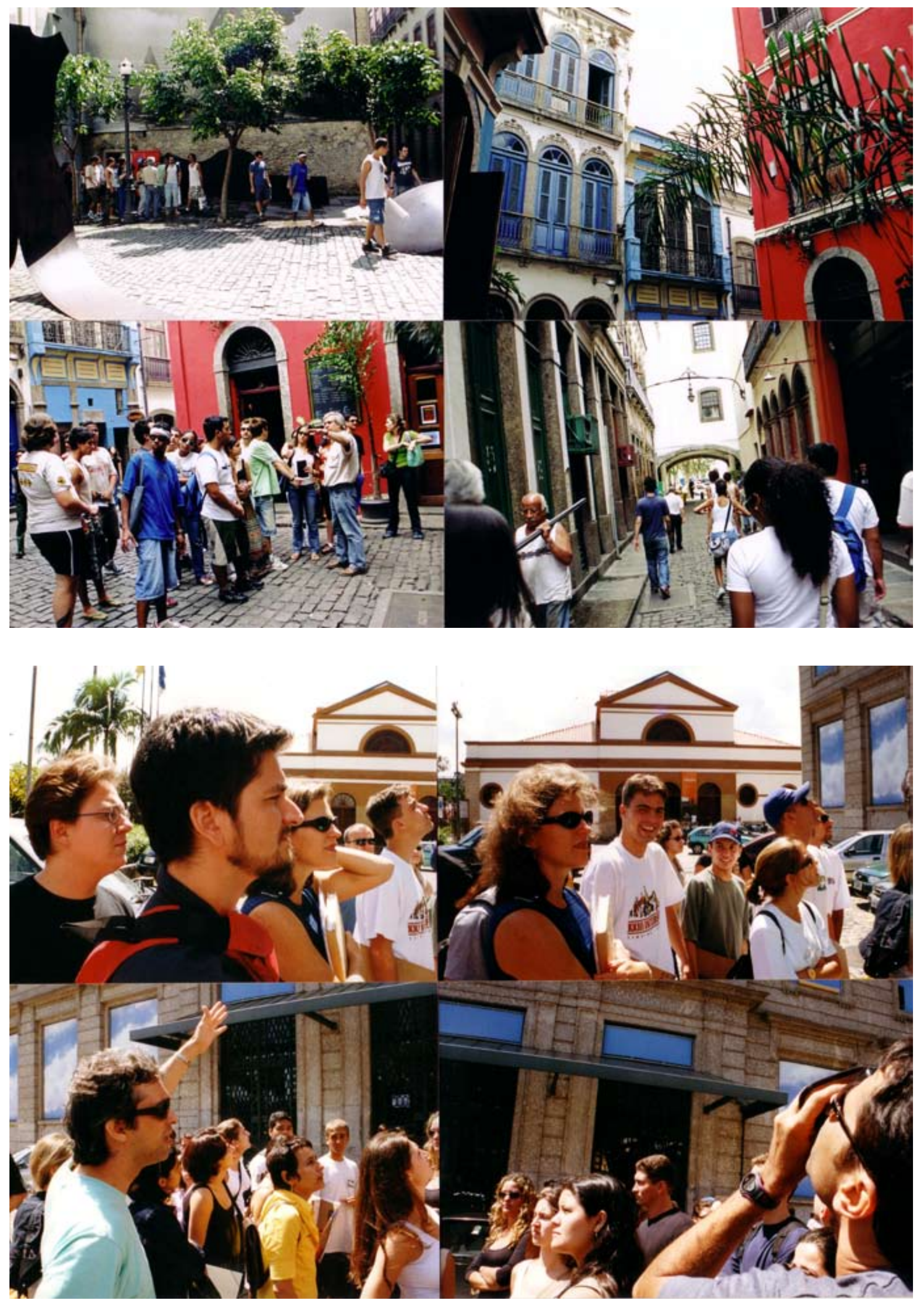

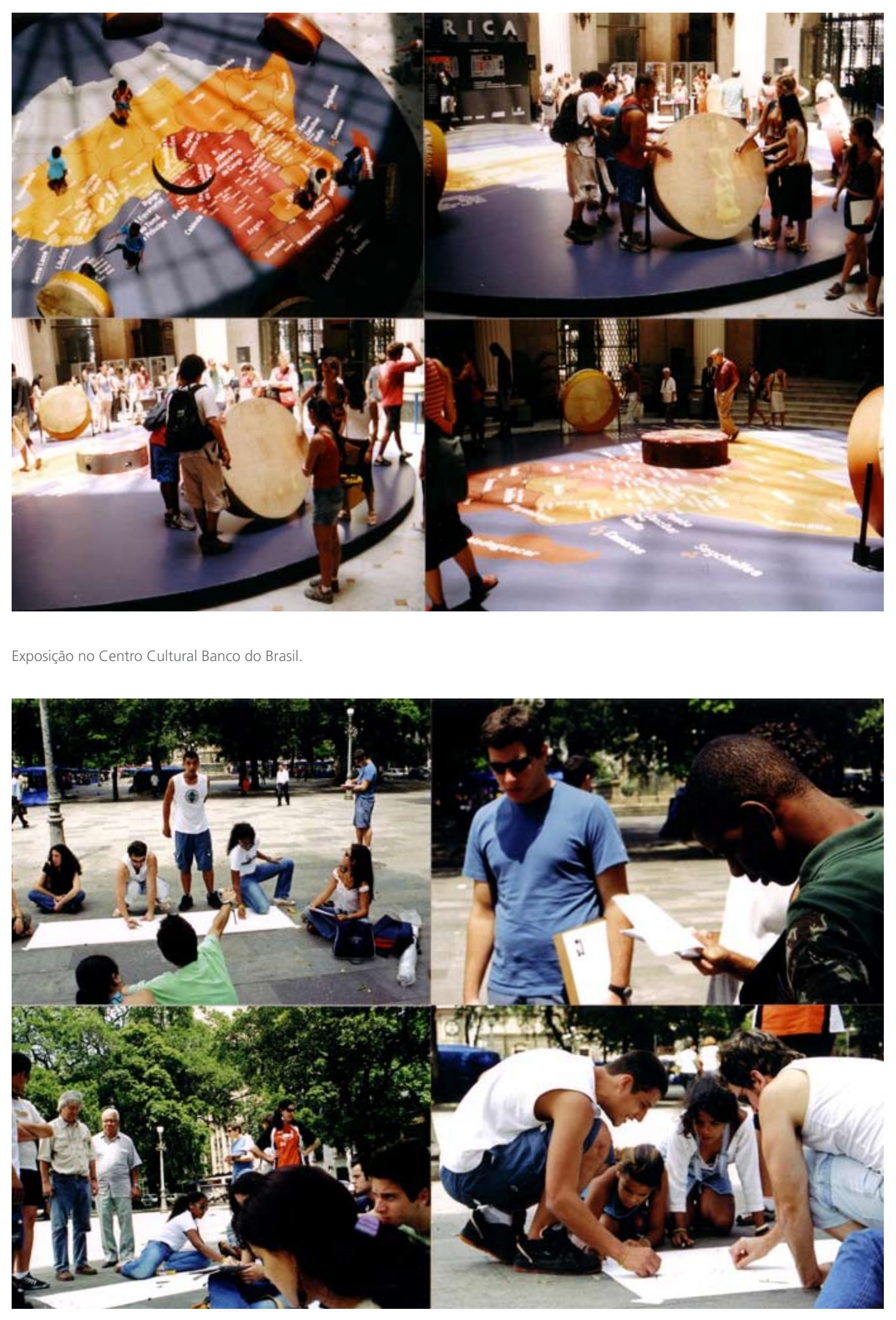

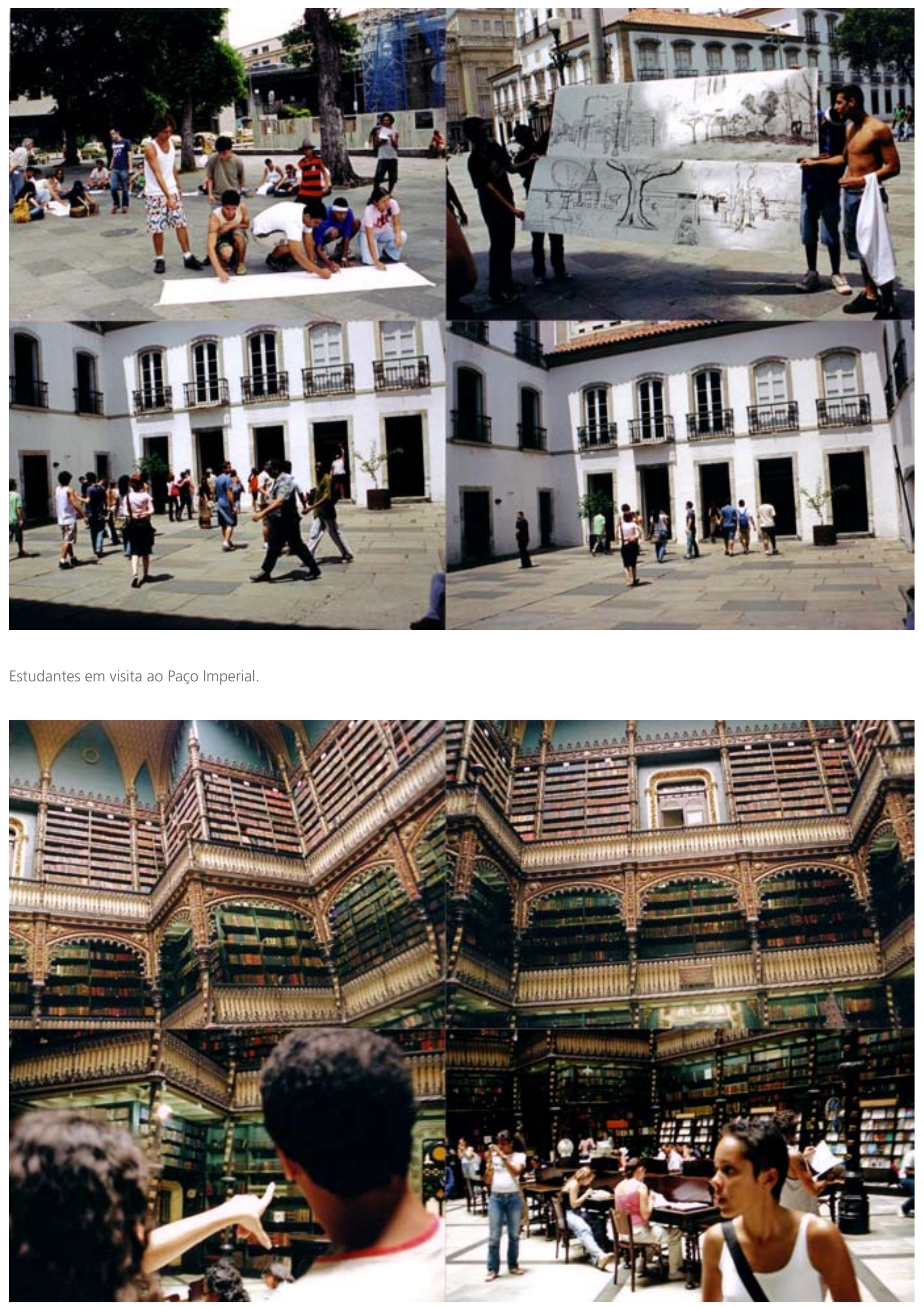

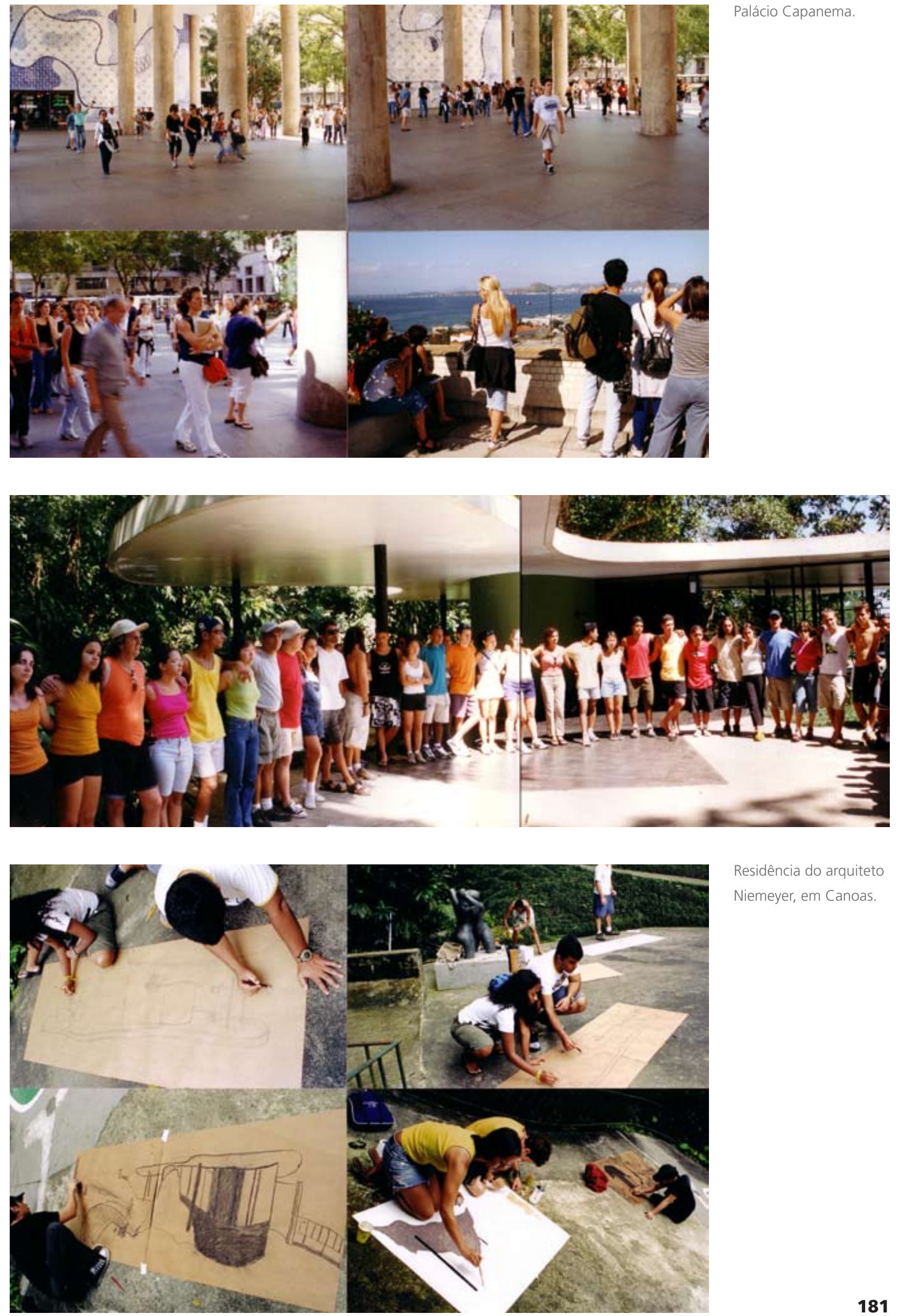

Residência do arquiteto Niemeyer, em Canoas. 


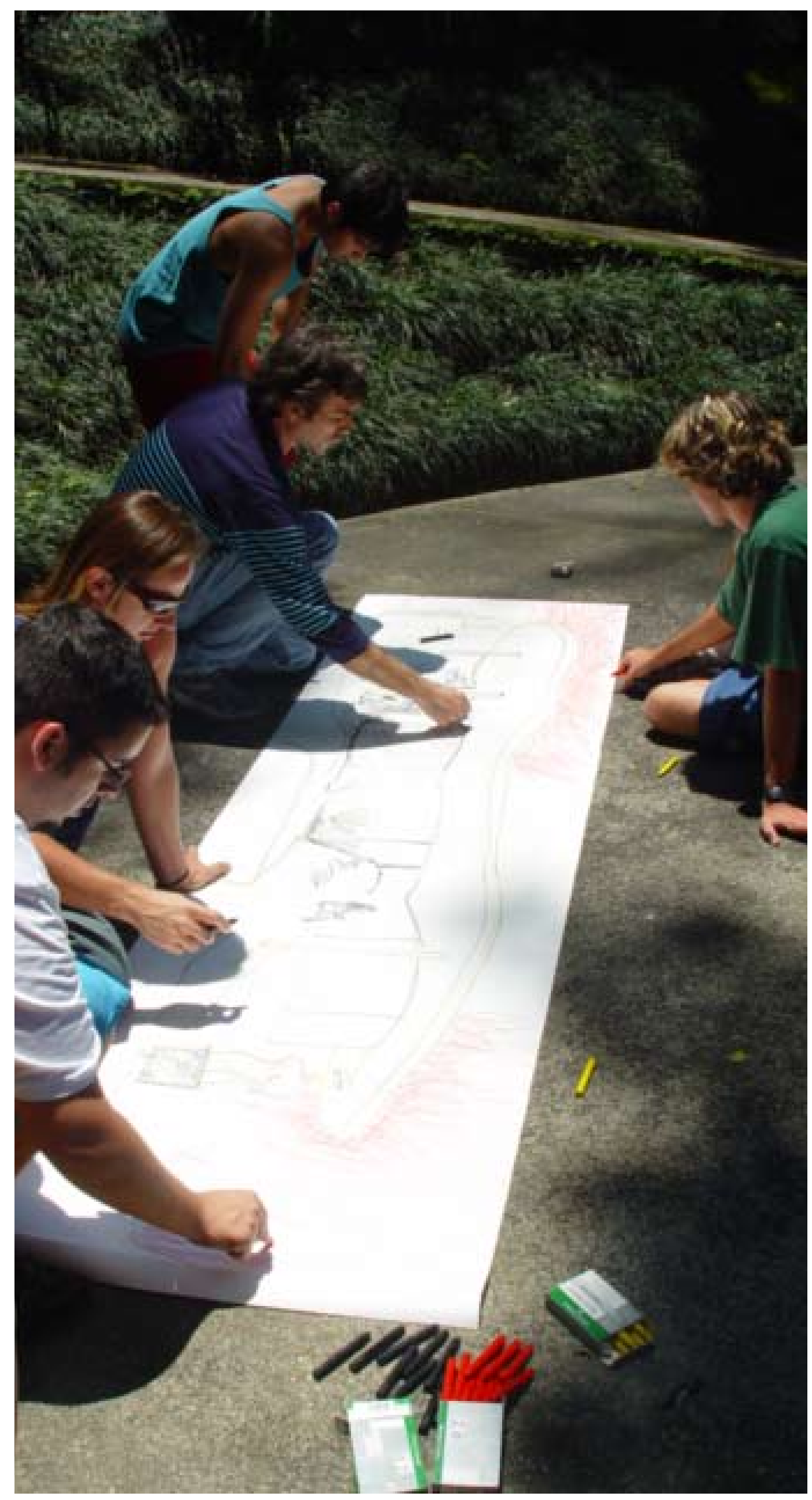




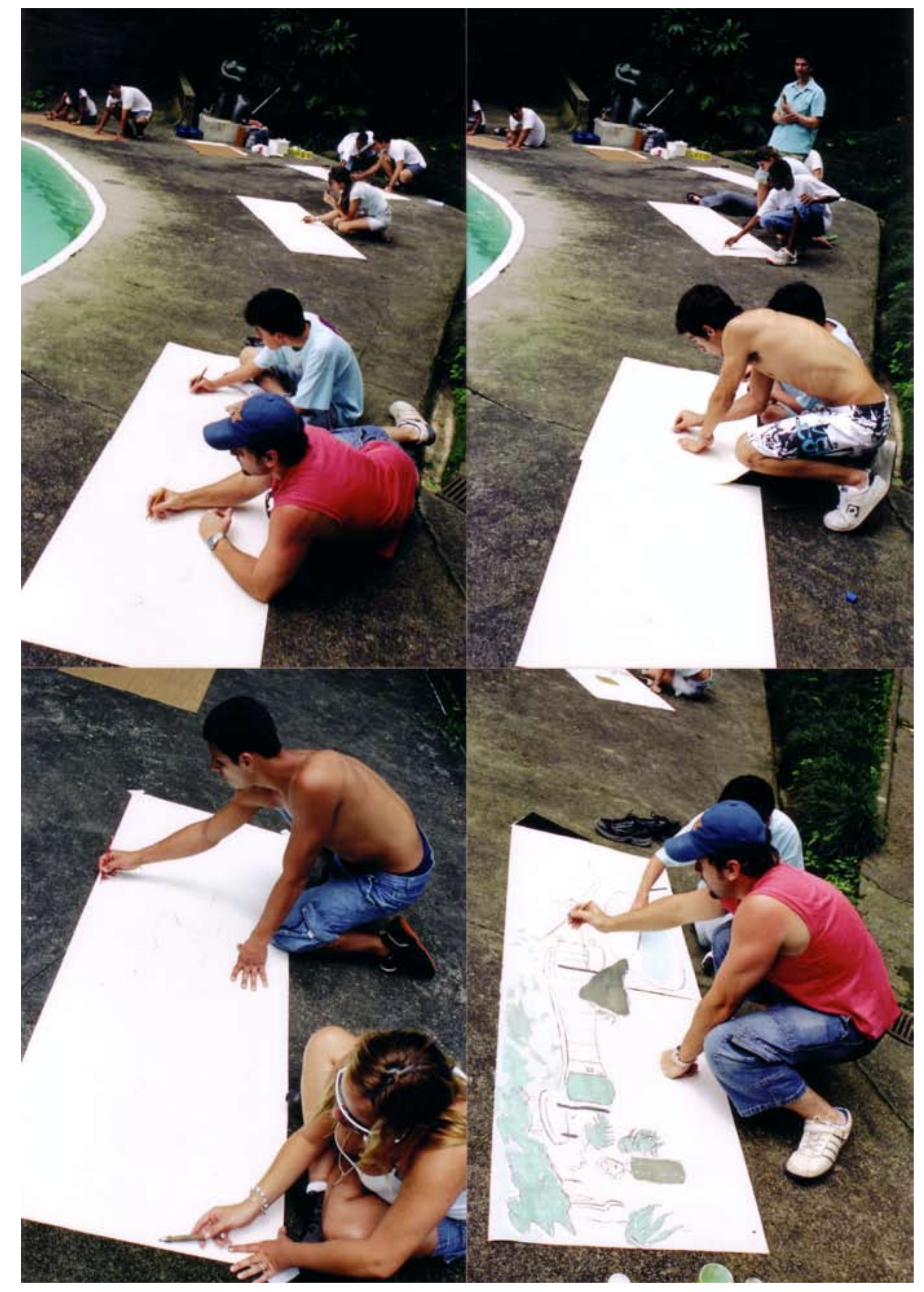



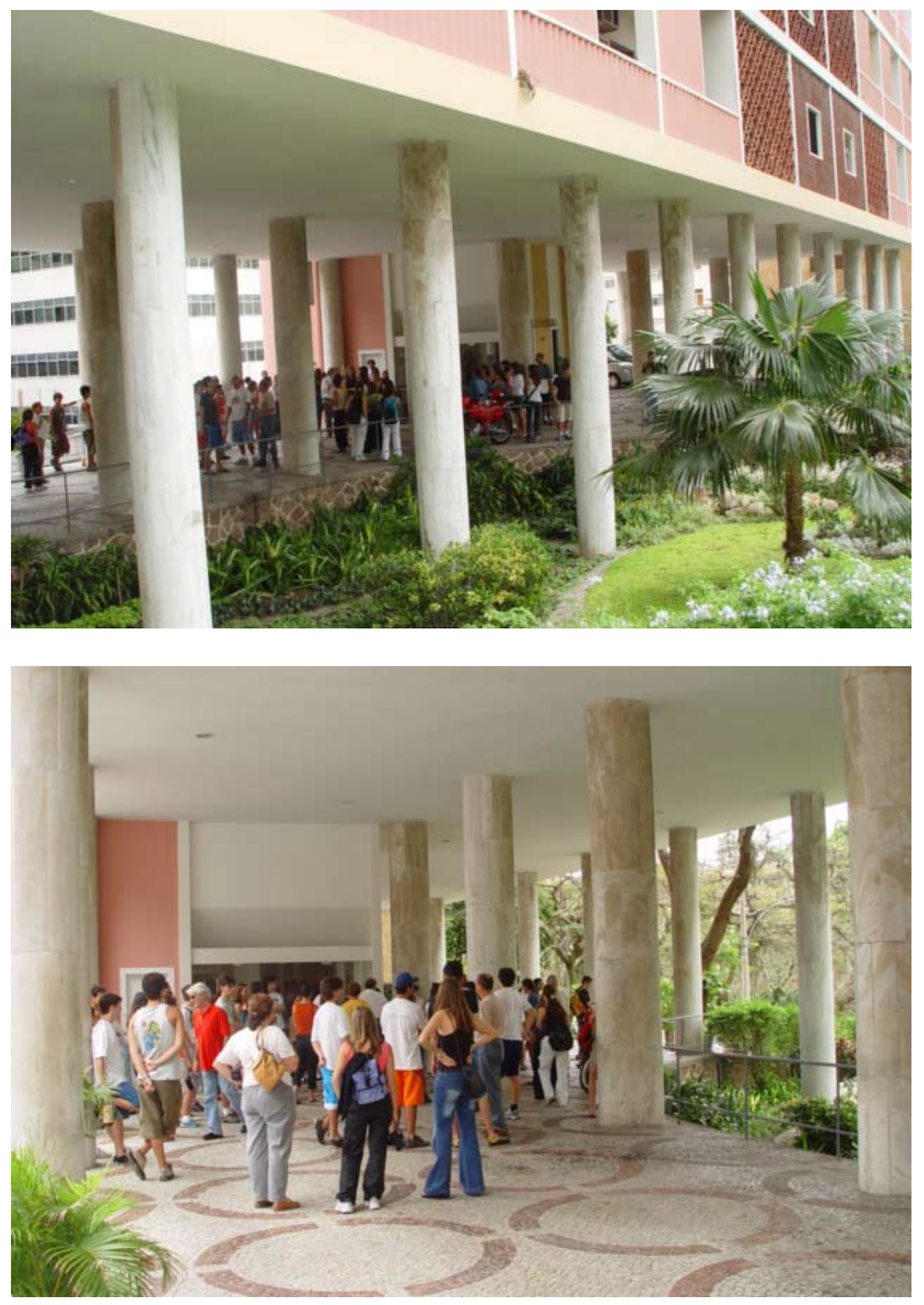


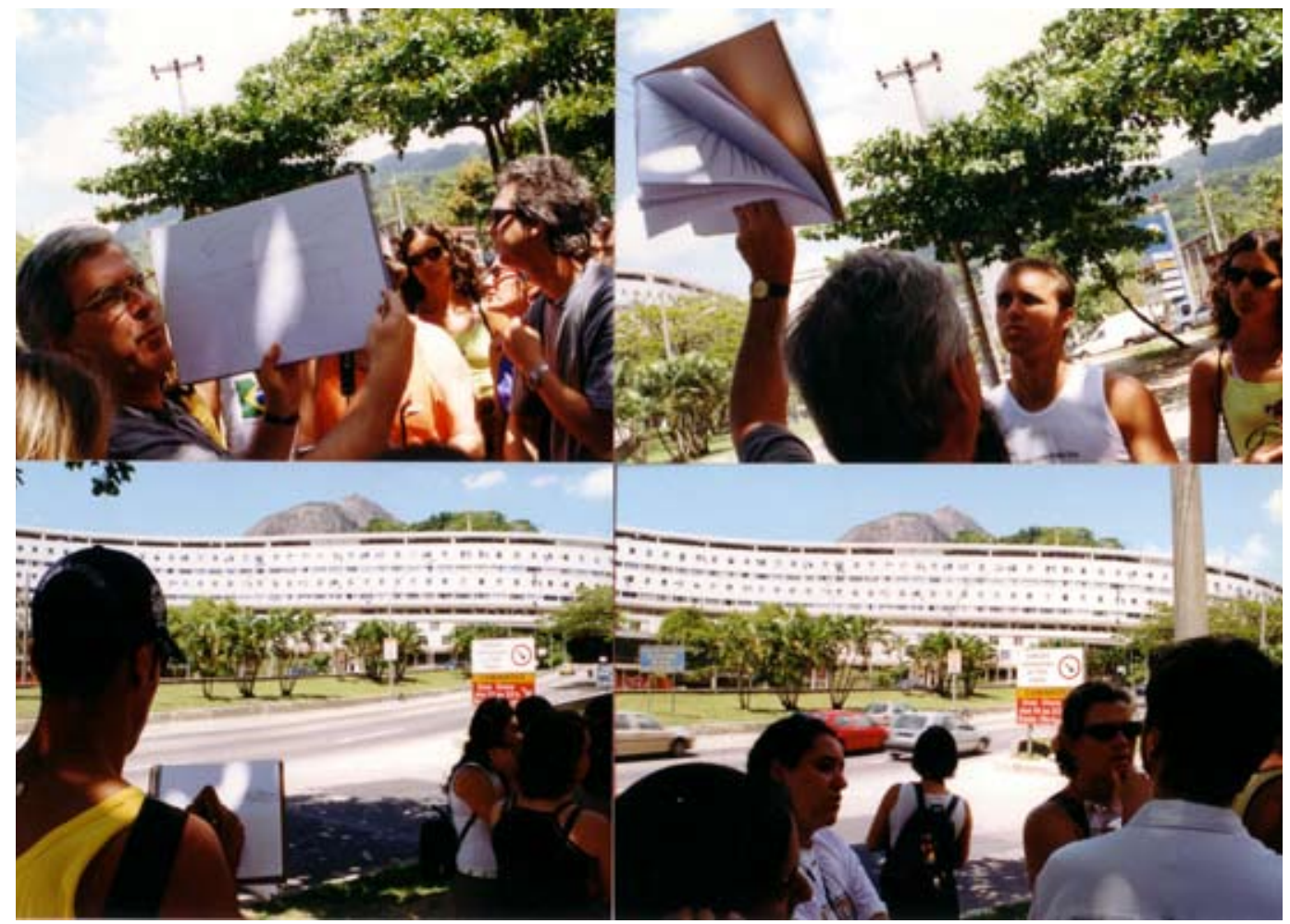

Conjunto Residencial

Marquês de São

Vicente, na Gávea.

A cidade de São Luís do Paraitinga foi escolhida como objeto de estudo, por se tratar de uma cidade histórica e de pequeno porte, tendo sido o trabaIho coordenado pela disciplina de Urbanismo. As viagens facilitam o contato dos estudantes com os poderes municipais: nas entrevistas com prefeito e vereadores eles vivenciam a relação que existe entre o poder público e a cons-

O Prefeito da cidade de São Luís do Paraitinga sendo entrevistado pelos professores de Urbanismo da FAUS trução das cidades.

Uma atividade de integração horizontal das disciplinas de Urbanismo e Projeto Arquitetônico é realizada pela implantação de projeto de edificação em local da intervenção da disciplina de Urbanismo.

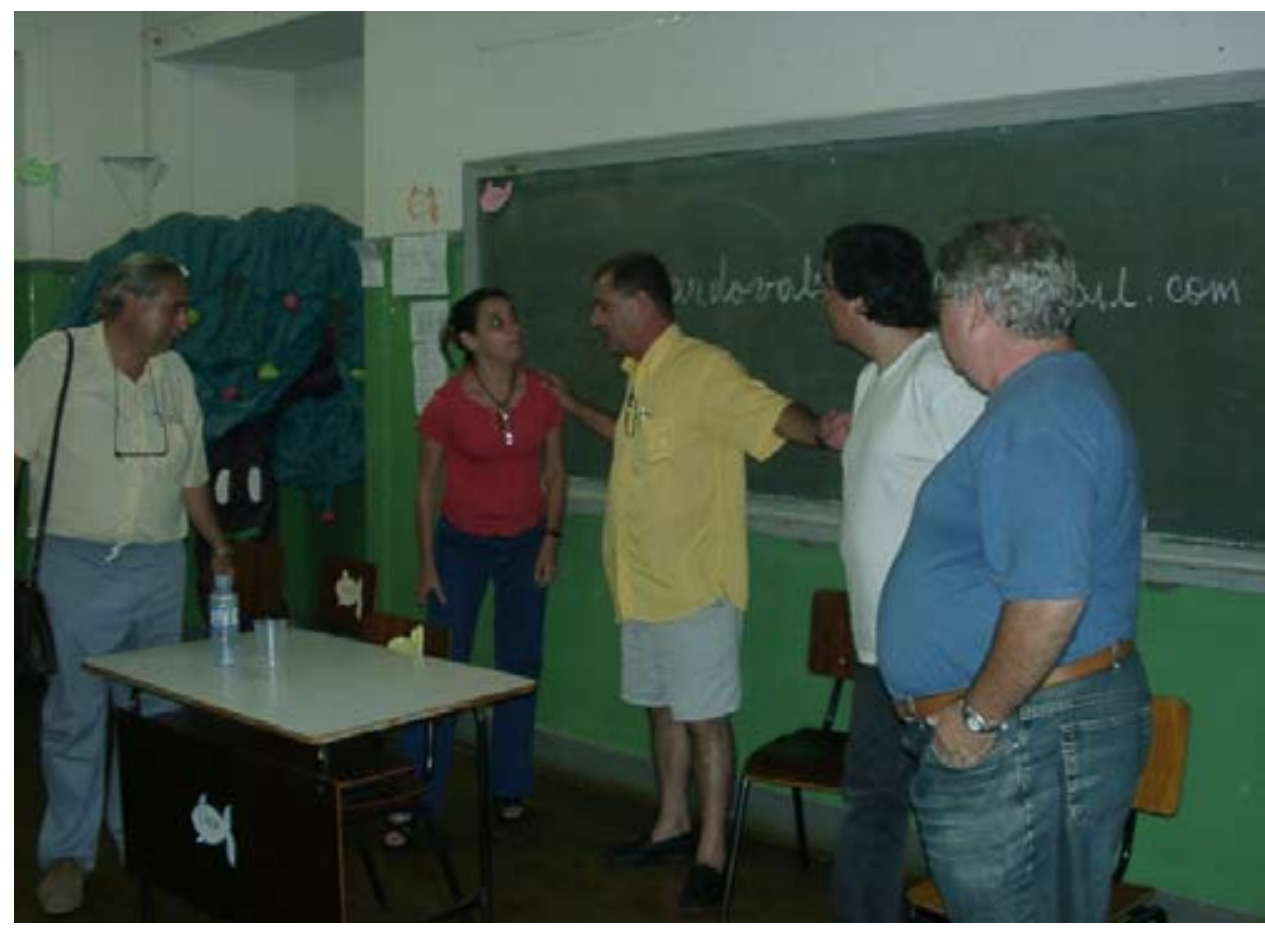




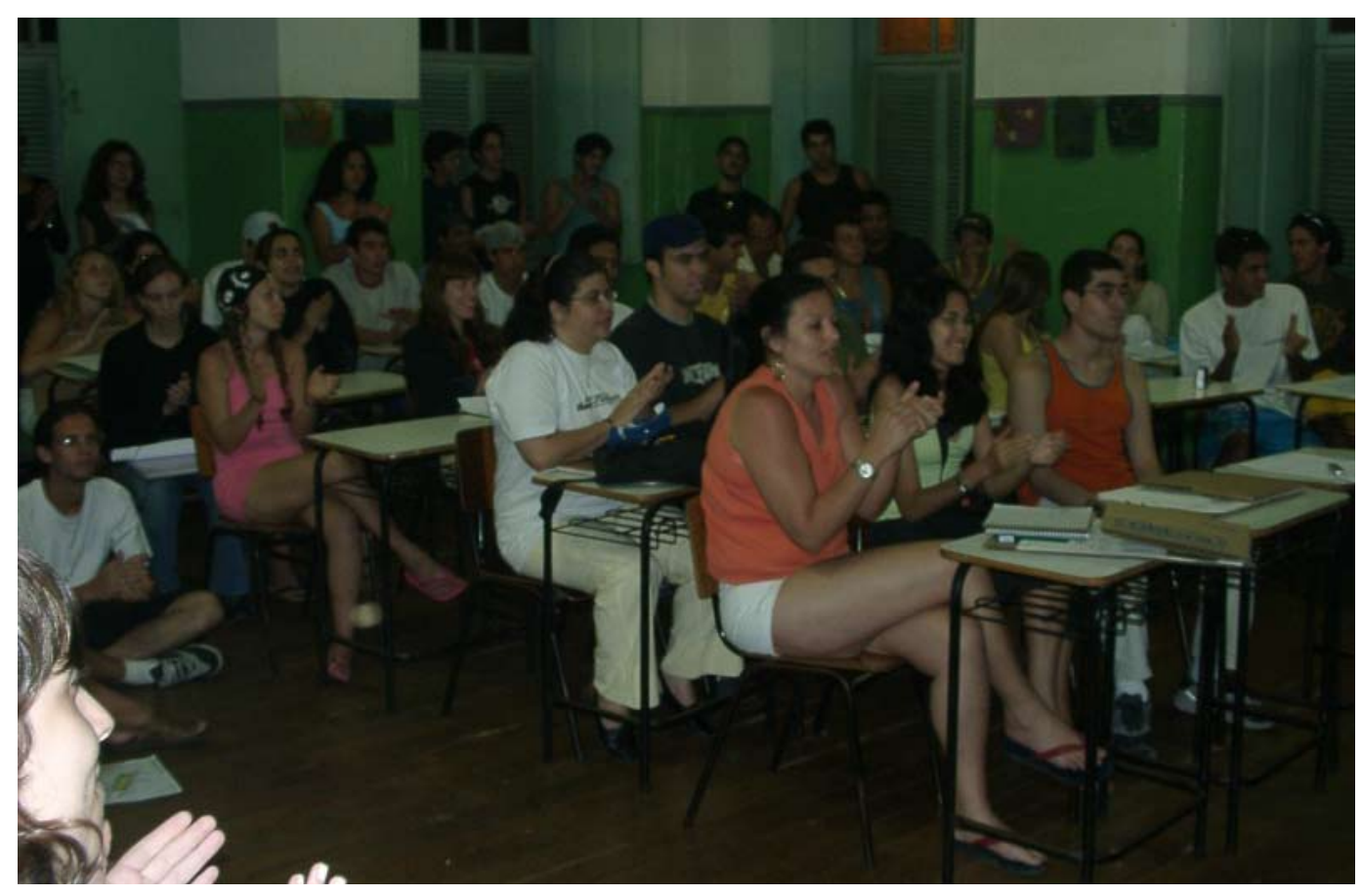

Em São Luís do

Paraitinga, o Prefeito

da cidade recebe

professores e alunos

da Unisantos, cedendo

para o encontro uma

das salas de aula da

escola municipal local.

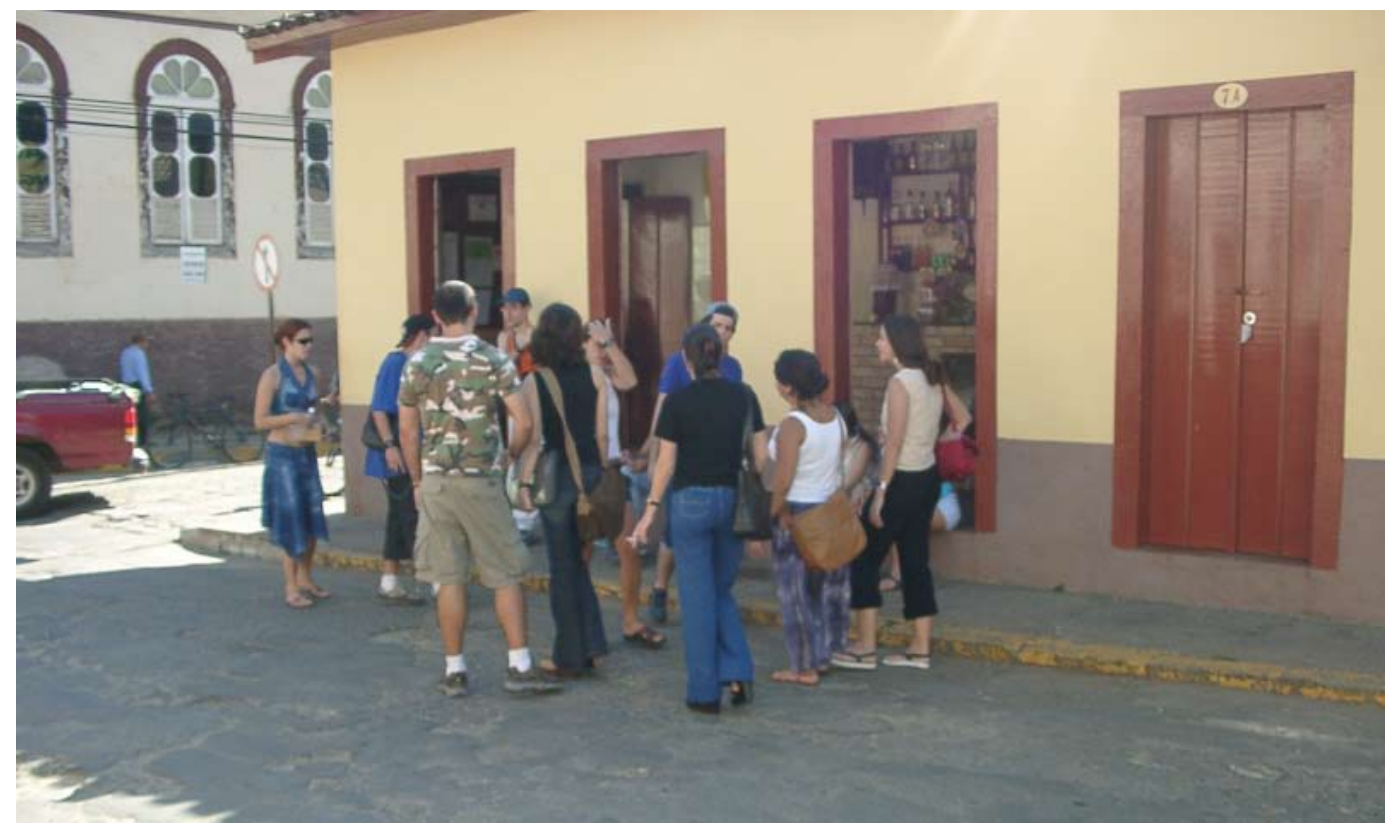

Alunos em visita à cidade de São Luís do Paraitinga.
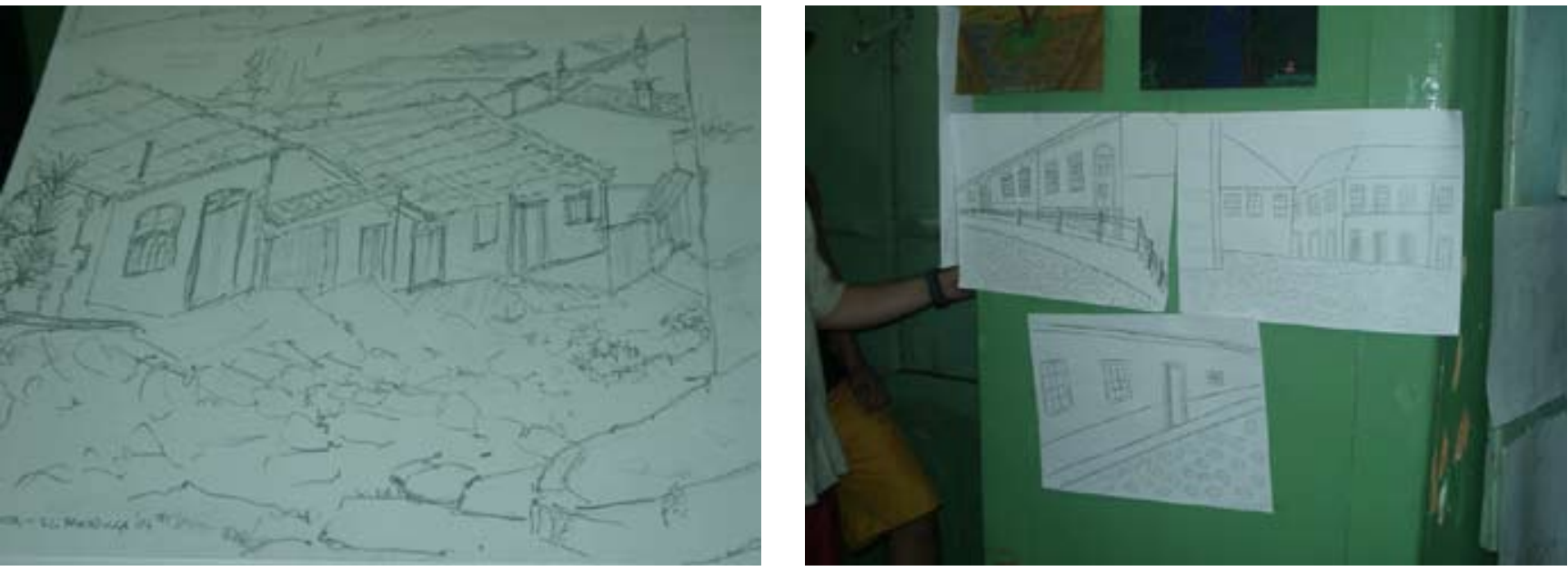
Com o mesmo objetivo foi programada uma outra visita, desta vez à cidade de Paranapiacaba, por apresentarem as duas cidades características semelhantes.

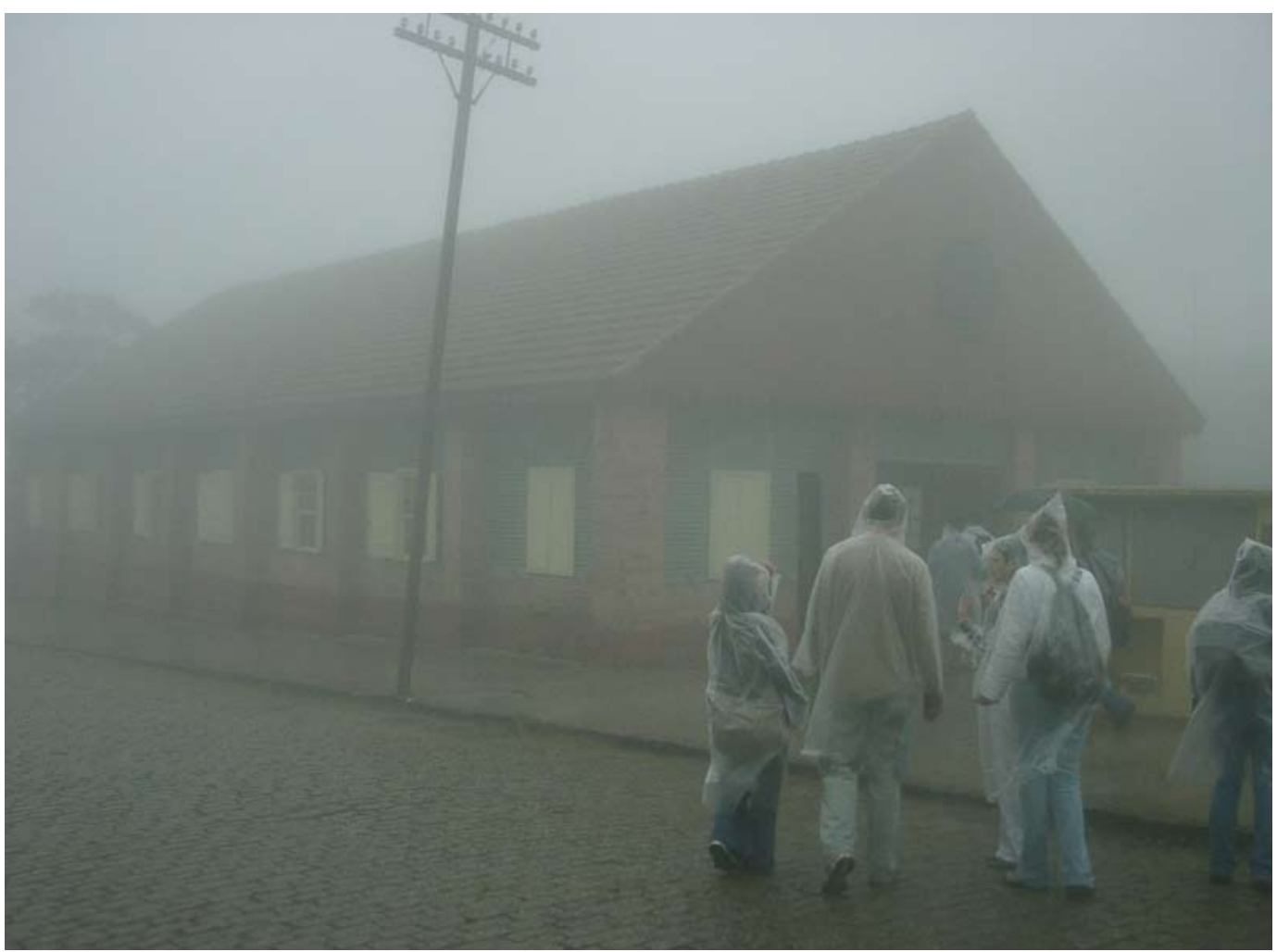

Estudantes em

visita à cidade de

Paranapiacaba.

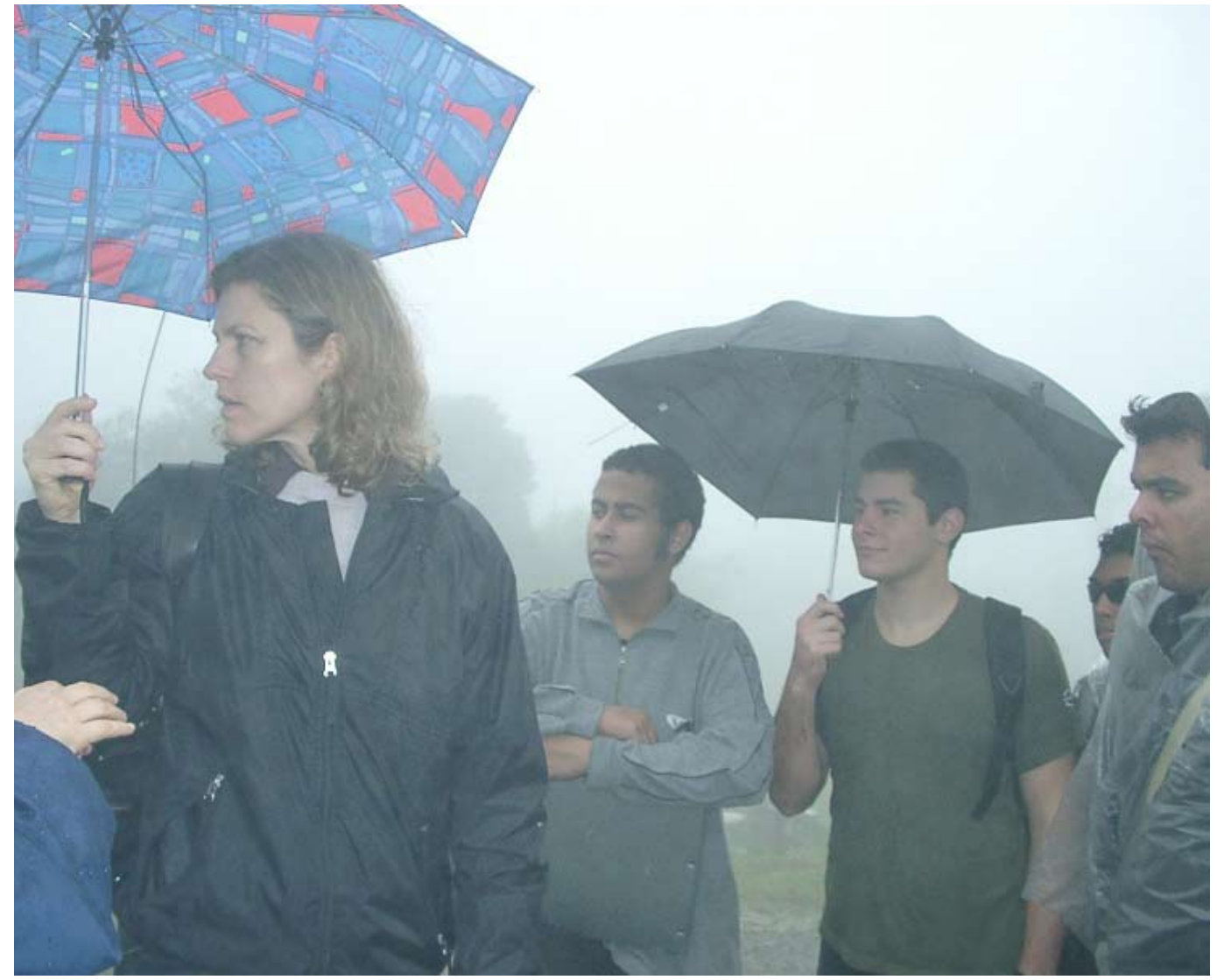

Visita dos alunos ao local de intervenção da disciplina de Projeto Arquitetônico. 


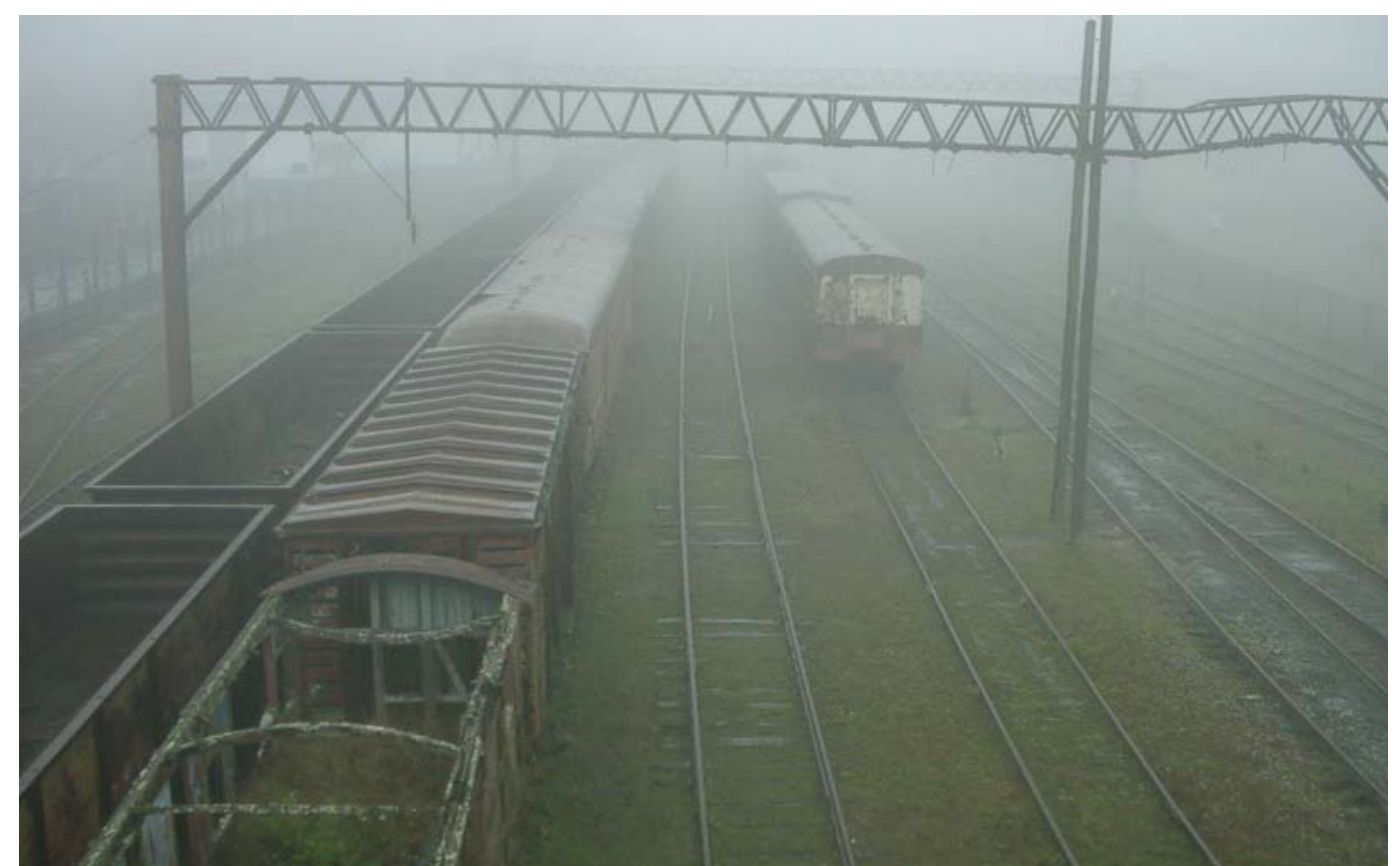

Visita dos estudantes ao local das intervenções de Urbanismo e Projeto Arquitetônico.

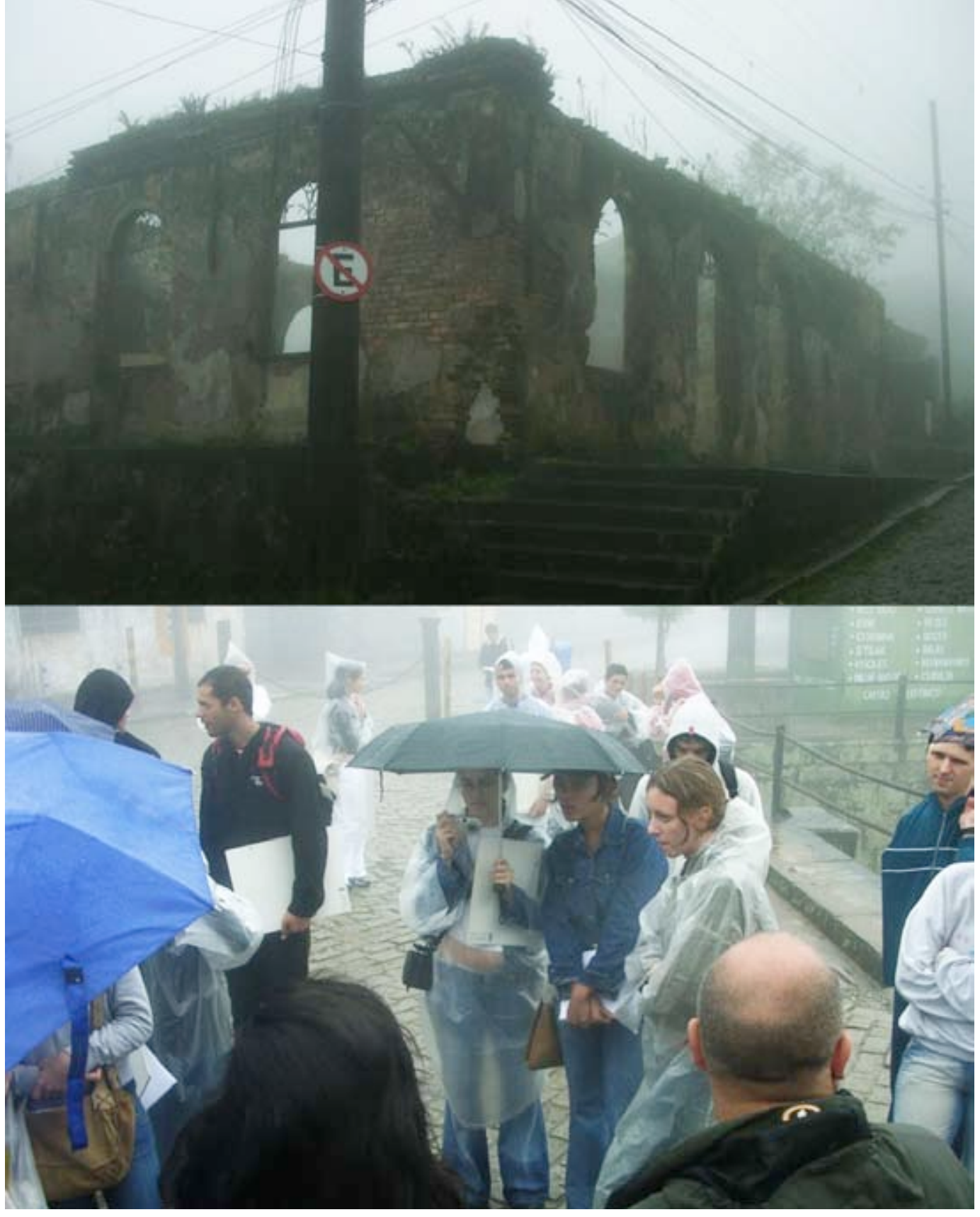


Em 2000 foi realizado, como atividade da Semana de Arquitetura, um ensaio do que seria a integração vertical proposta por um grupo de professores da FAUS para o Projeto Político Pedagógico. Com a participação dos arquitetos convidados Pablo Iglesias e Diego B. Inglez de Souza foi organizada uma oficina de projeto cujo objeto de estudo era a cidade de Santos.
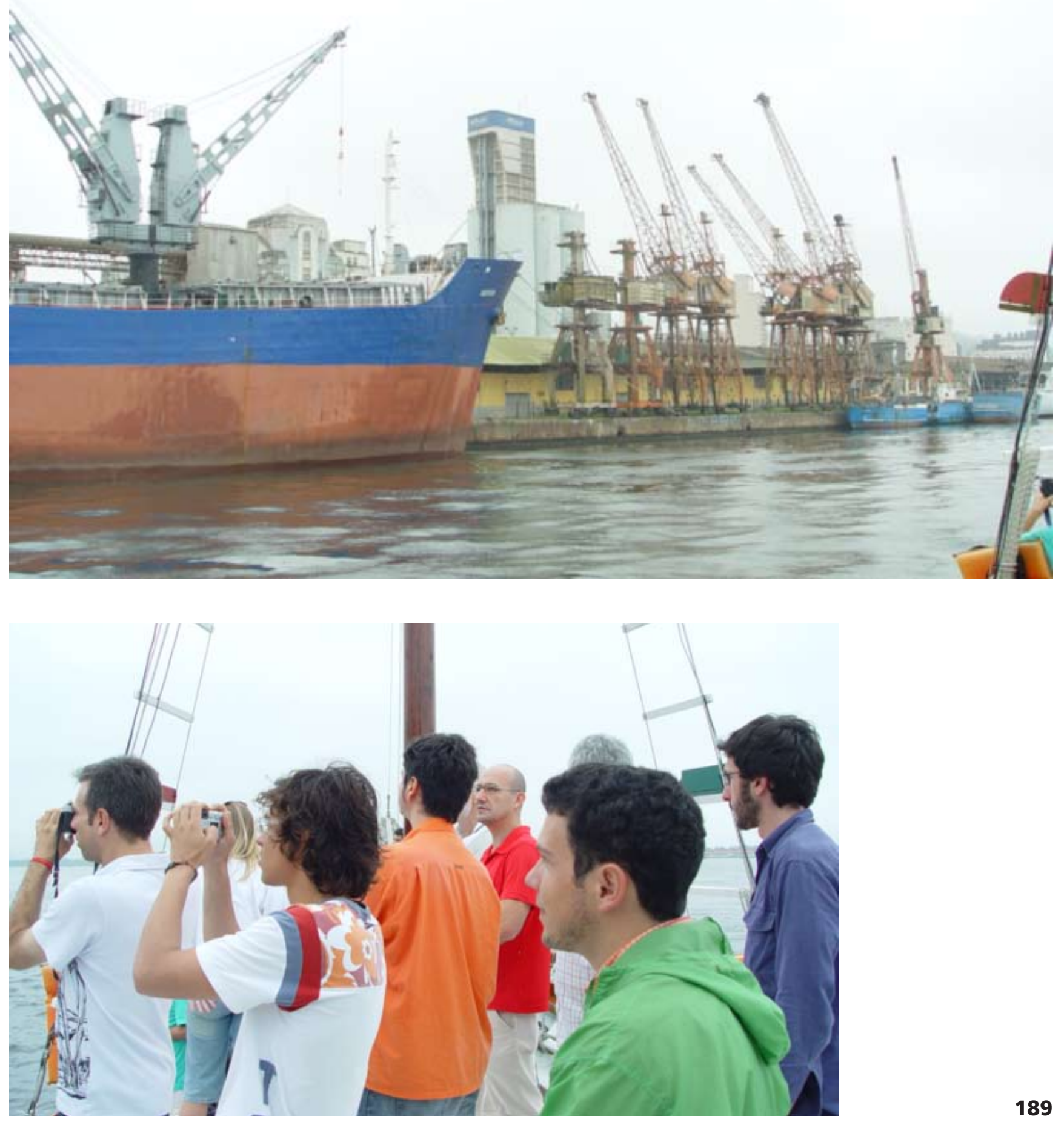

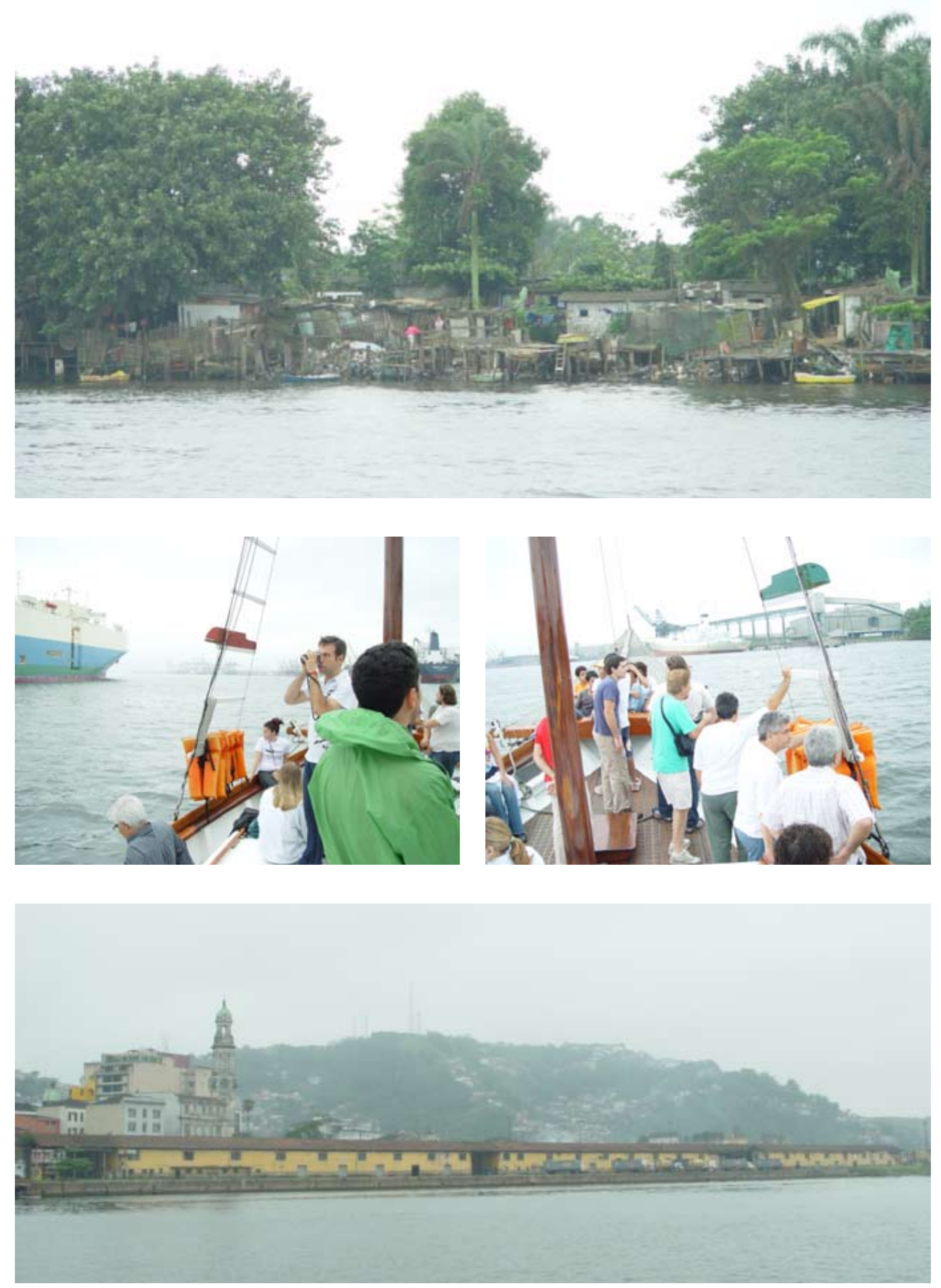
Como atividade da integração horizontal foram organizadas palestras com os professores Paulo Mendes da Rocha, João Filgueiras Lima e Aziz Nacib Ab'Sáber. As transcrições dessas palestras, apresentadas no Anexo, fizeram parte de um projeto de publicação que se propunha a criar o projeto gráfico dessas peças no Laboratório de Plástica da própria escola, com a participação dos alunos. Um minicurso com o maestro Gilberto Mendes sobre a relação entre arquitetura e música foi realizado e editado em DVD, e colocado na biblioteca da escola para consulta.
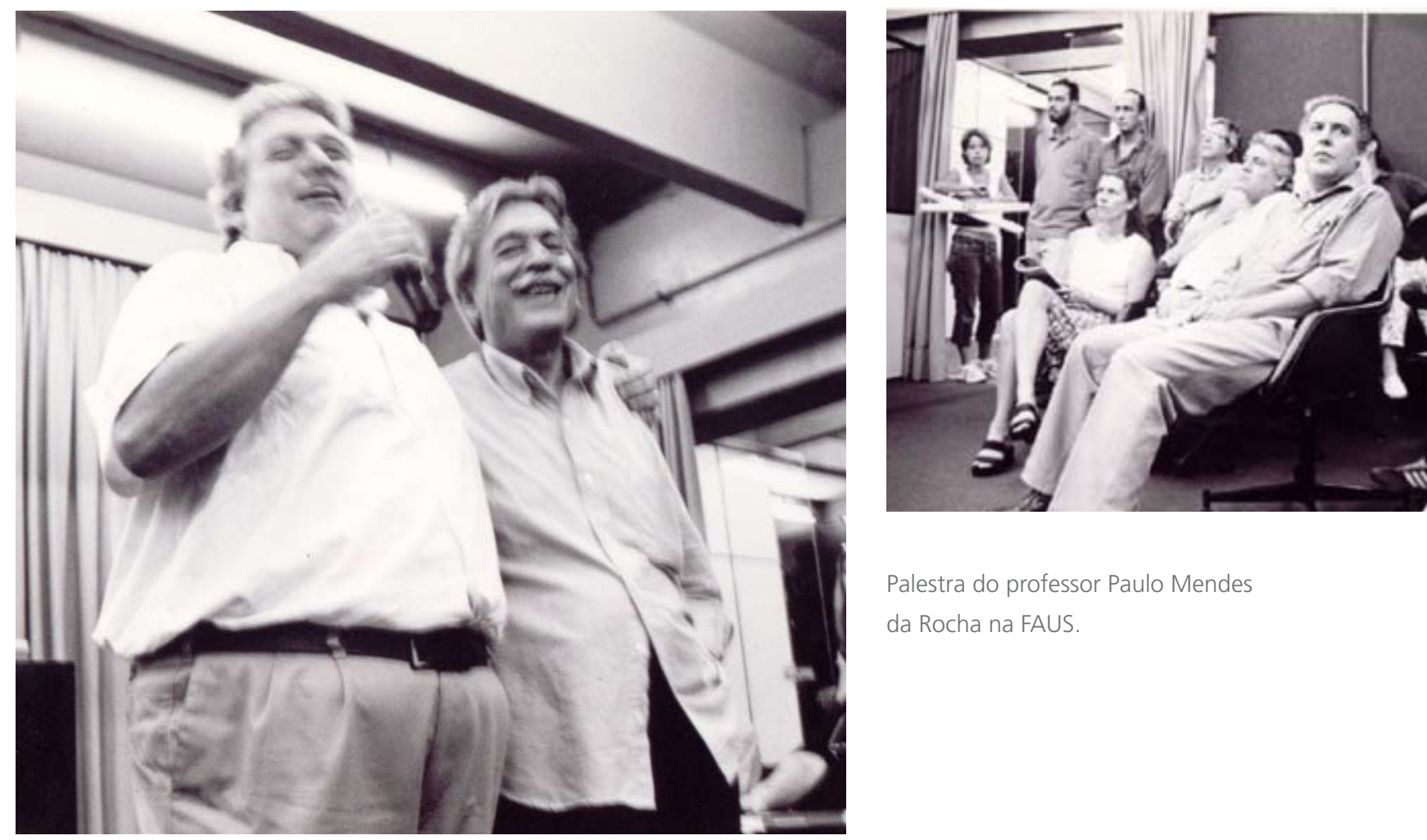

Palestra do professor Paulo Mendes da Rocha na FAUS.

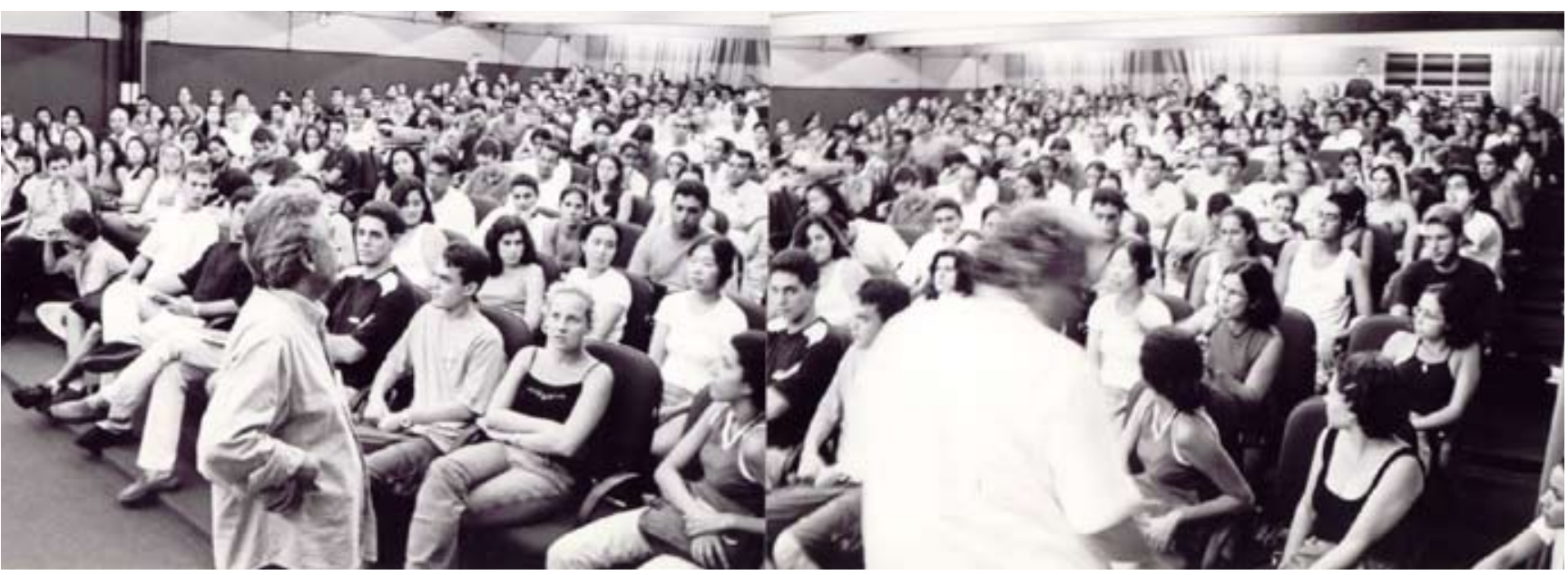



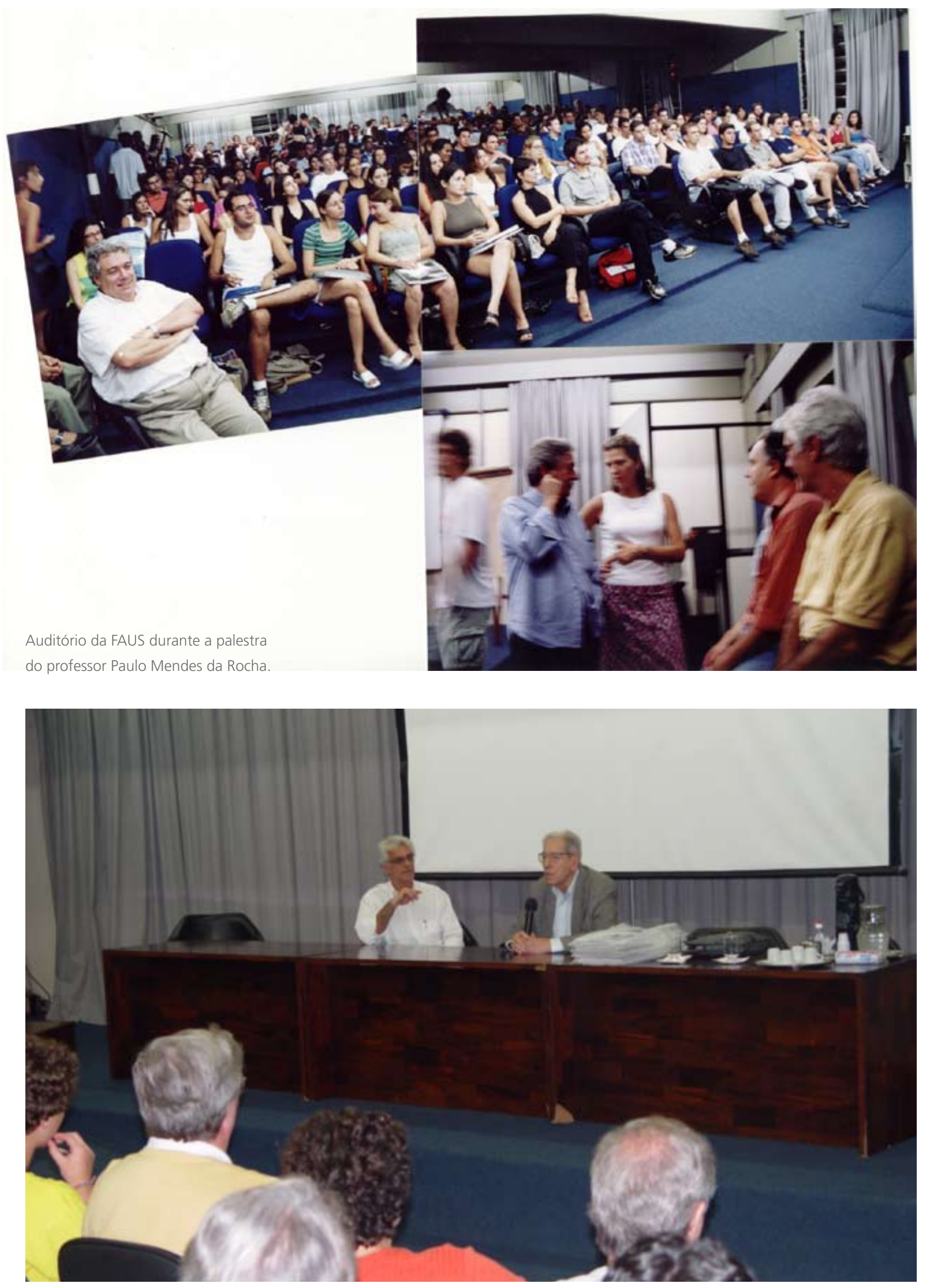


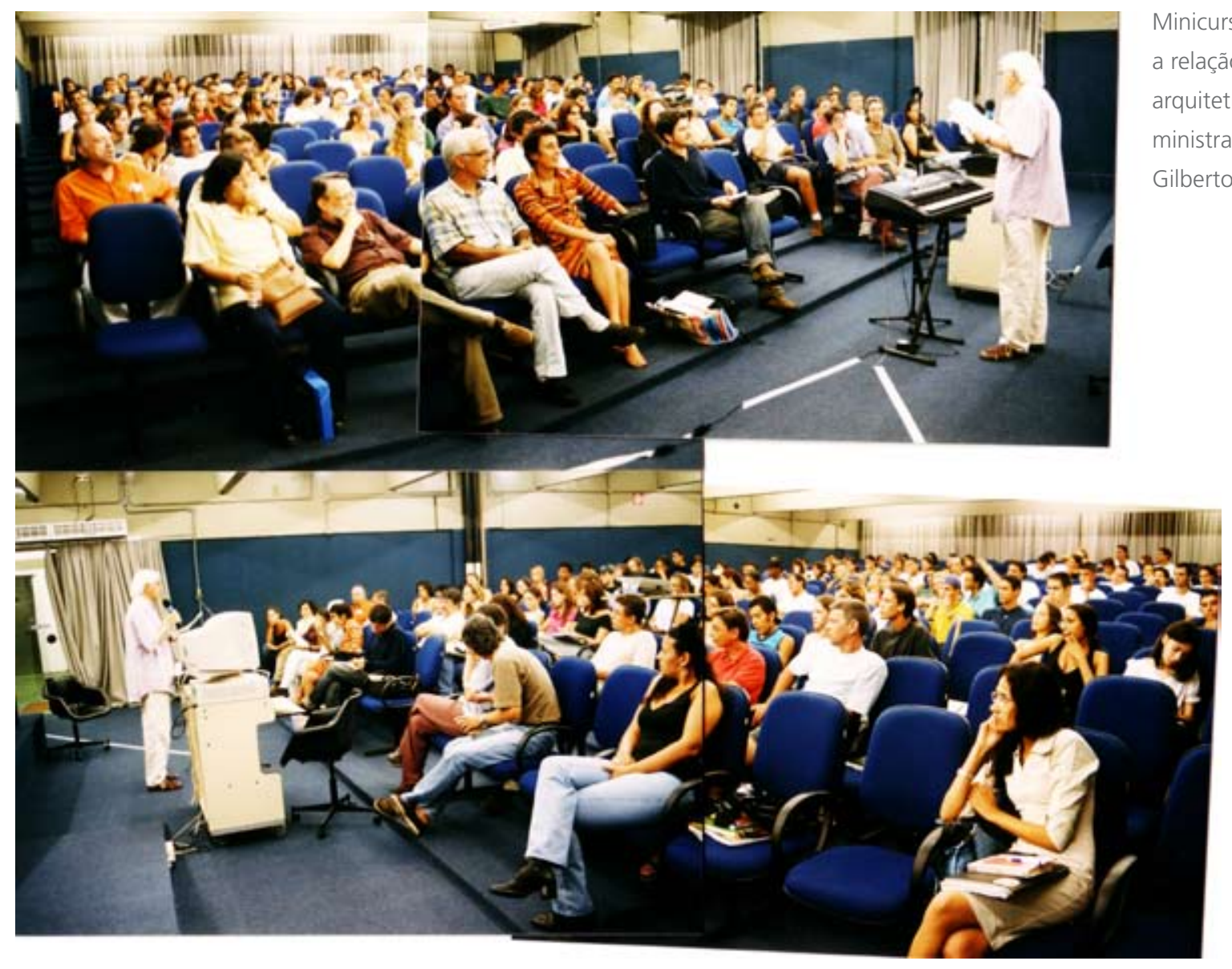

As exposições intermediárias com o intuito de verificar o andamento dos tra-

balhos da integração horizontal bem como a exposição final foram fundamentais

para que os alunos pudessem vivenciar o resultado dos trabalhos como um todo,

além de se prestarem para tornar público os resultados da integração horizontal.

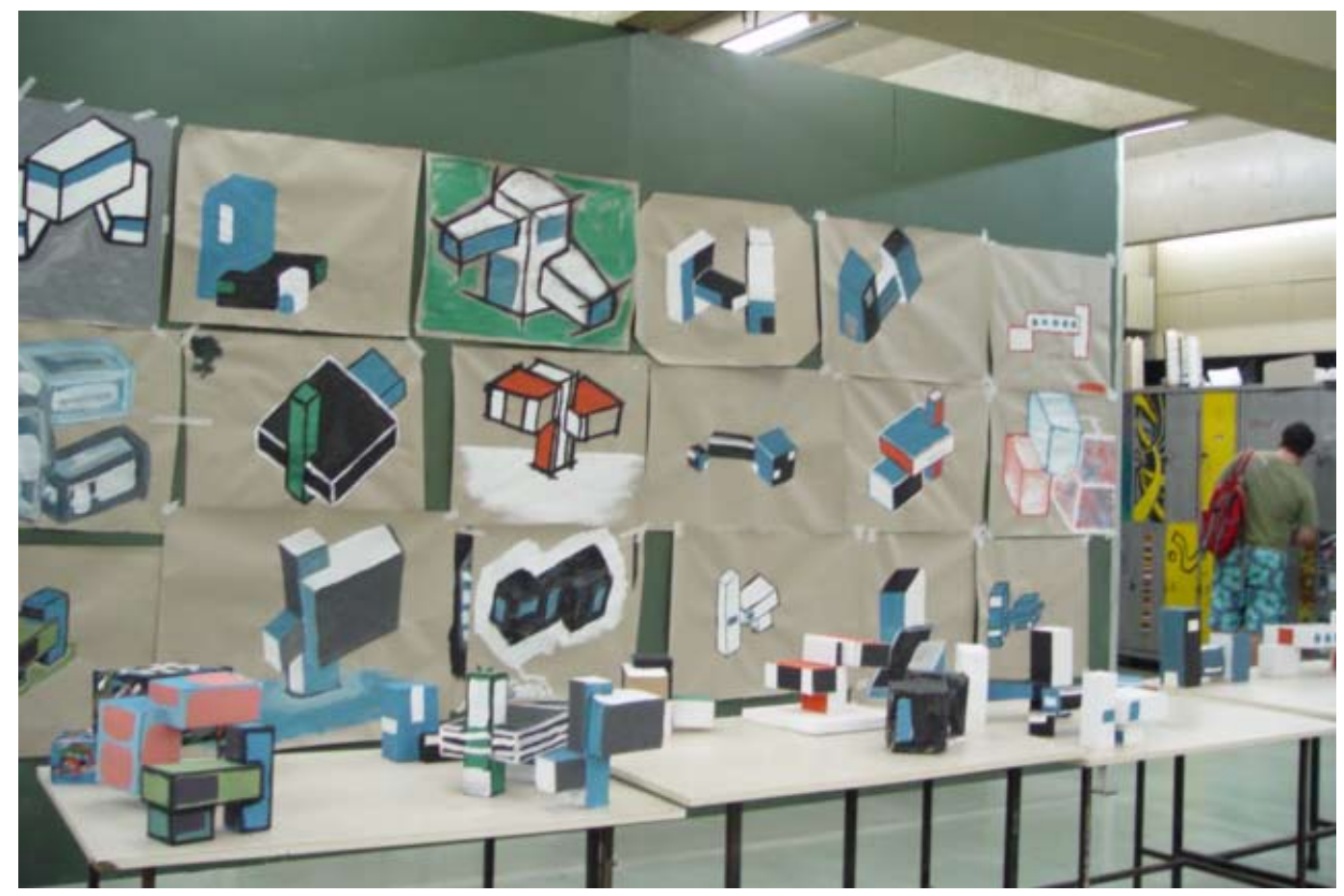

Exposição intermediária dos trabalhos finais

de um exercício de

integração horizontal. 

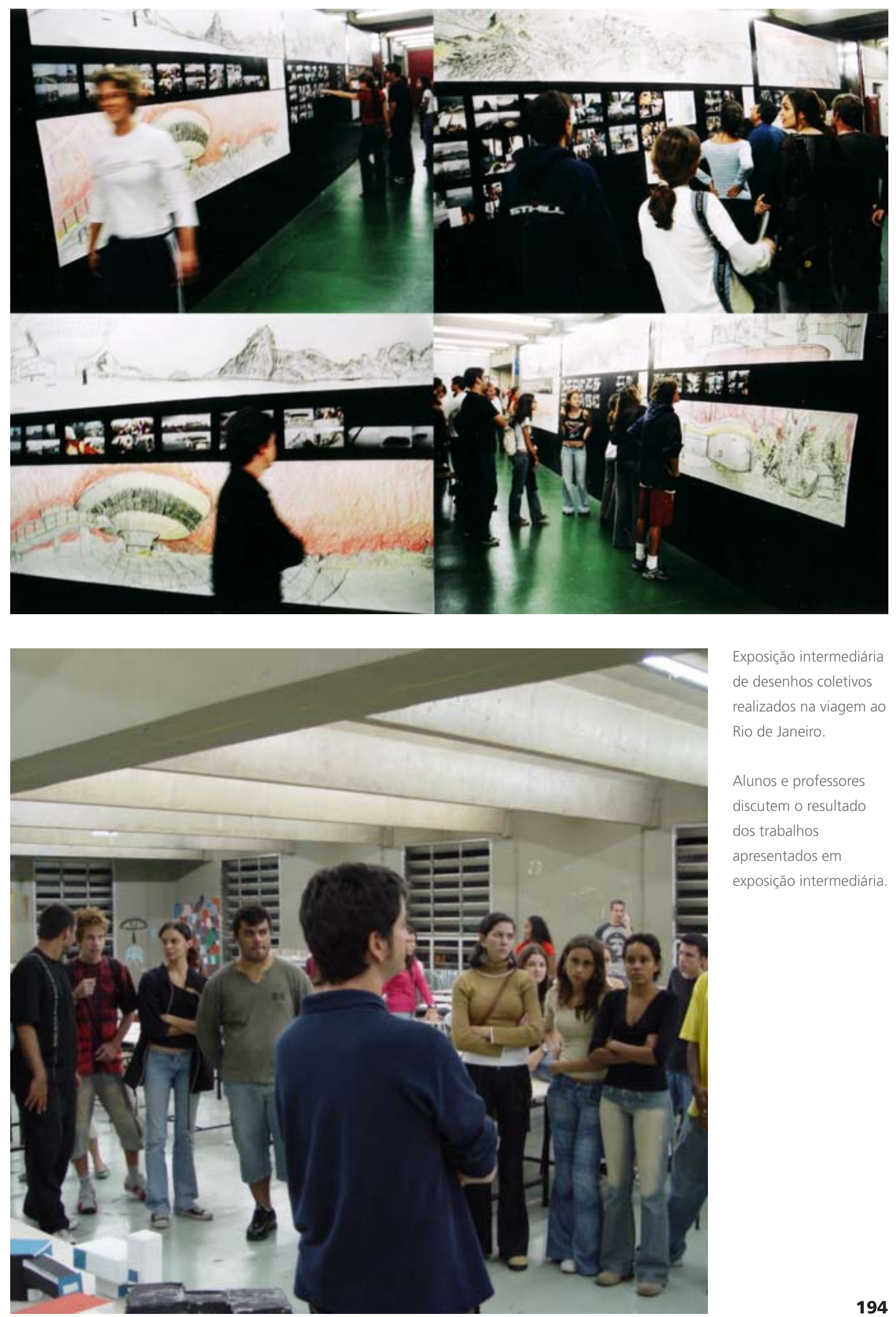

Exposição intermediária de desenhos coletivos realizados na viagem ao Rio de Janeiro.

Alunos e professores discutem o resultado dos trabalhos apresentados em exposição intermediária. 

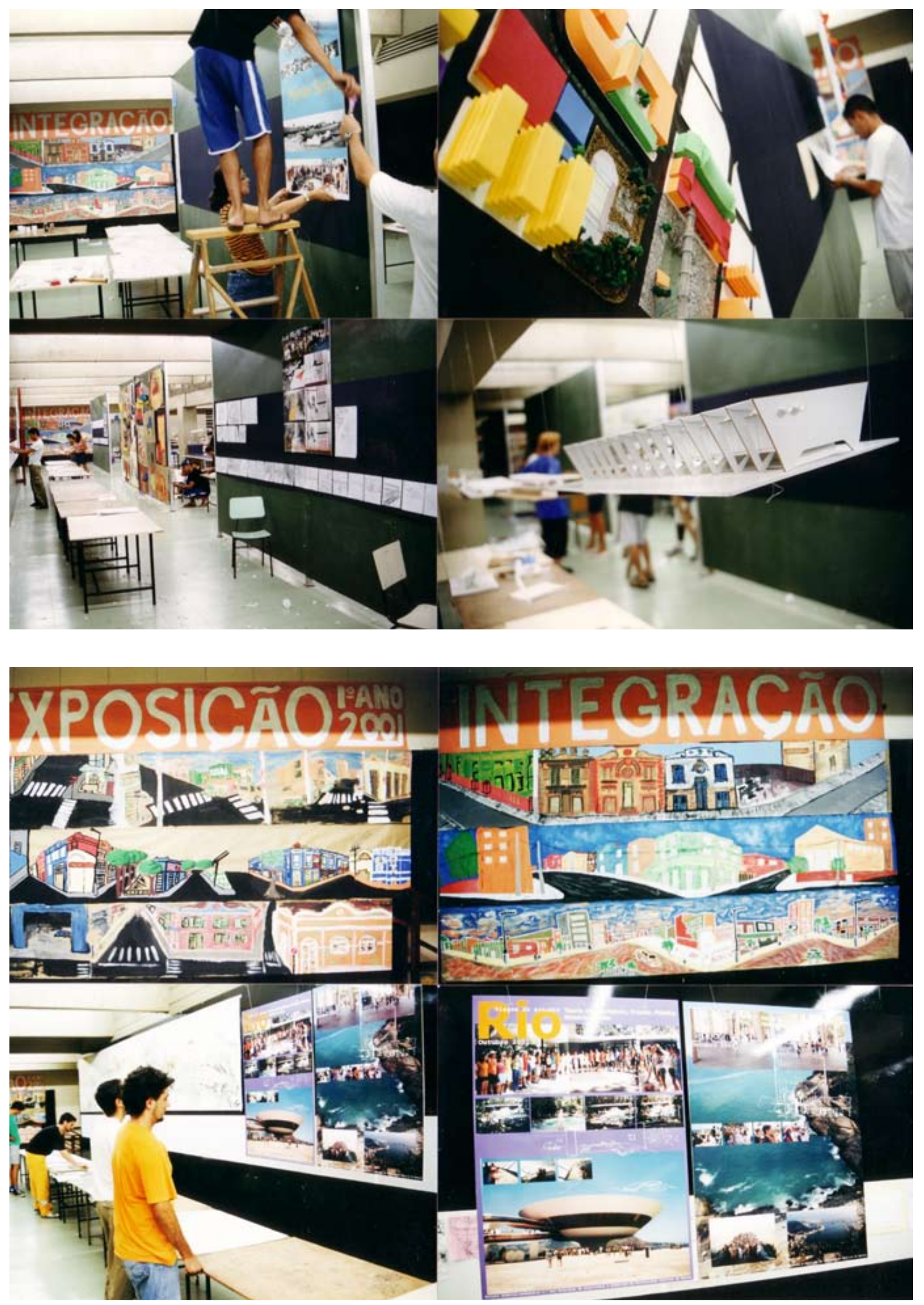

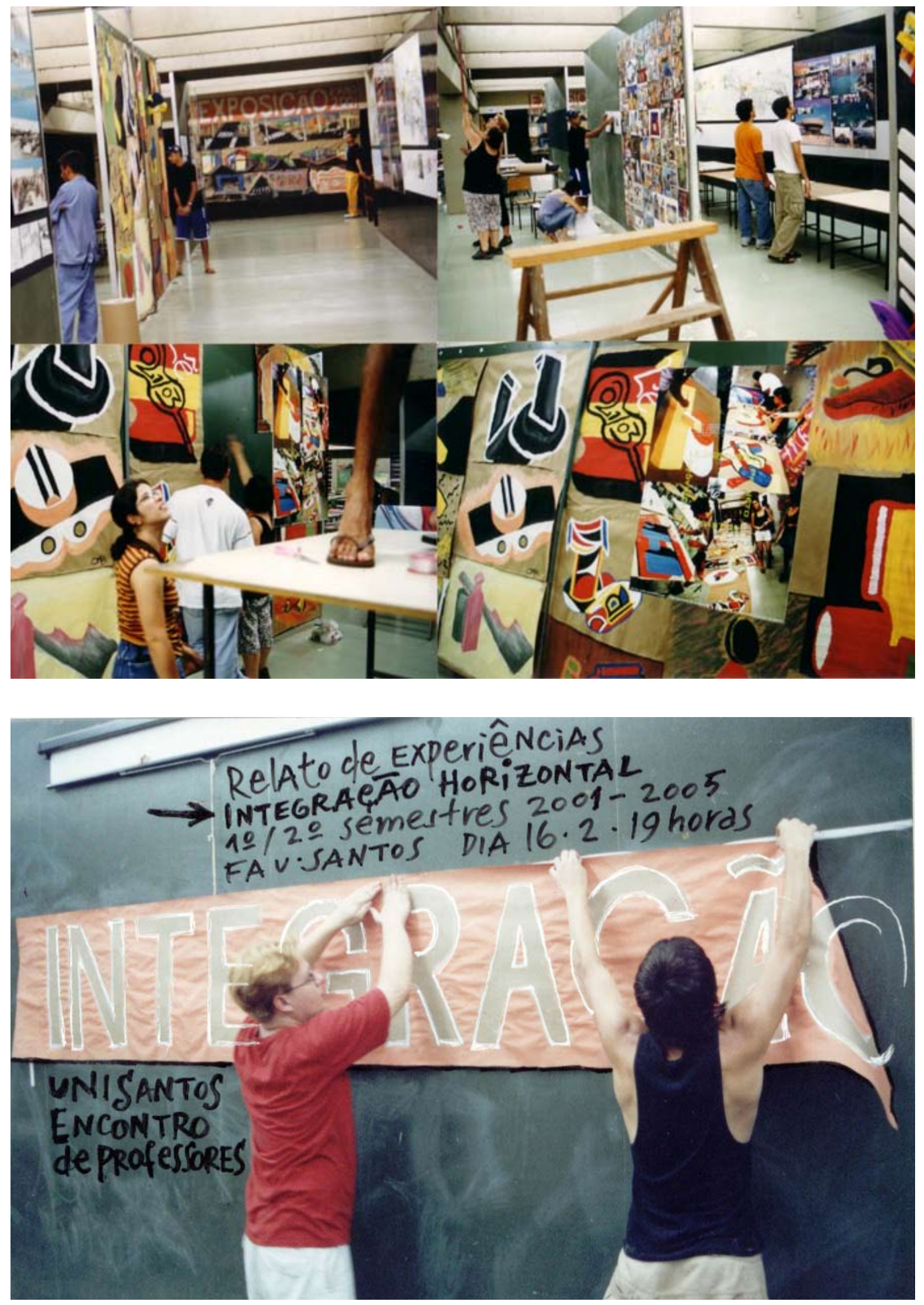


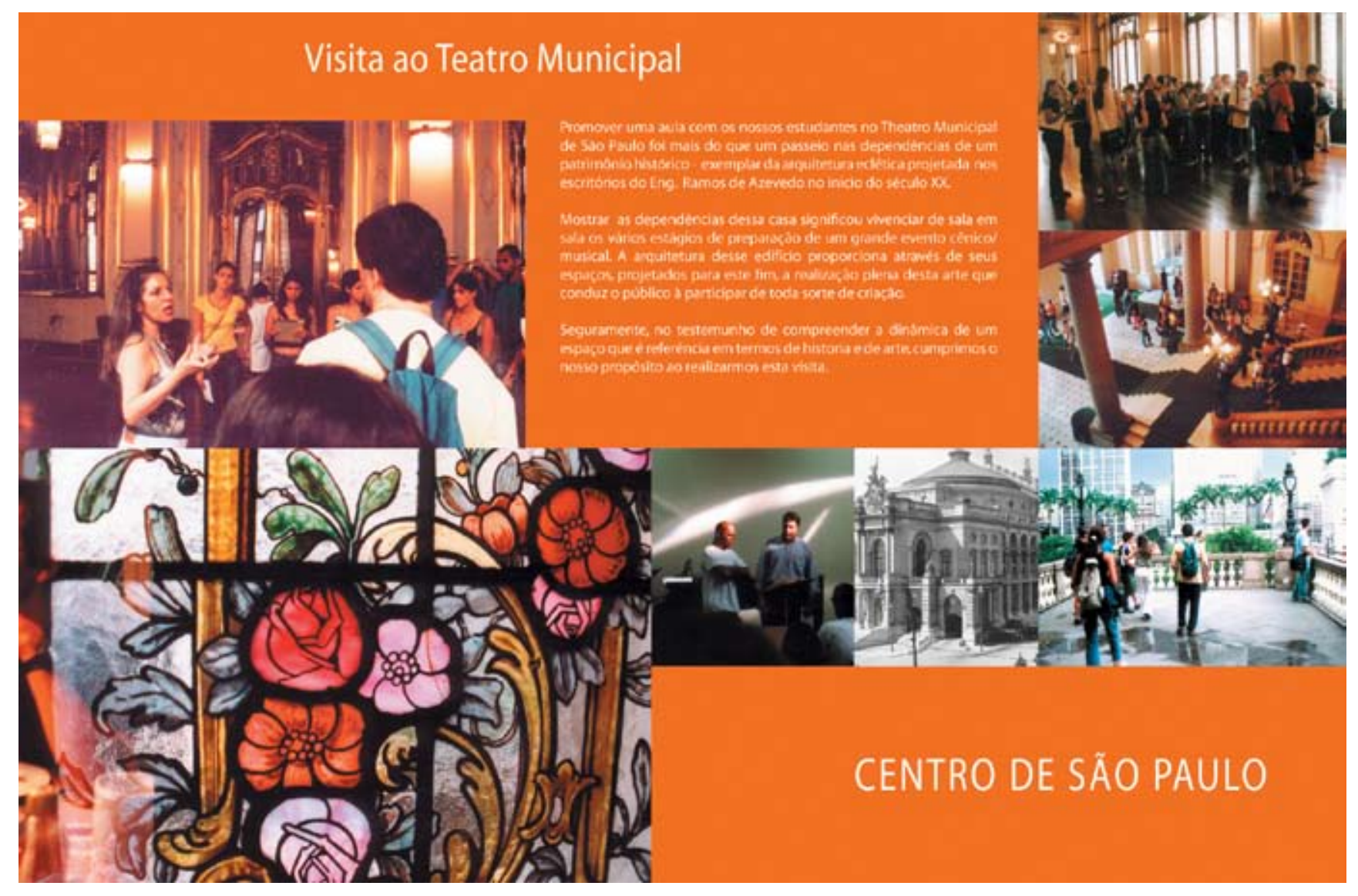

\section{PROJETO DE INTEGRAÇÃO HORIZONTAL}

Anhangabaú

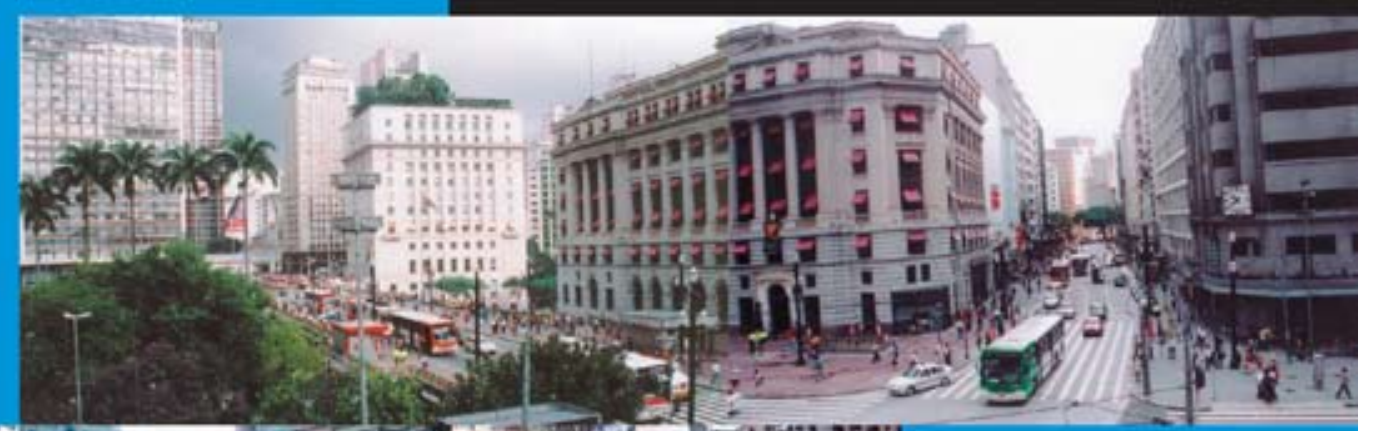

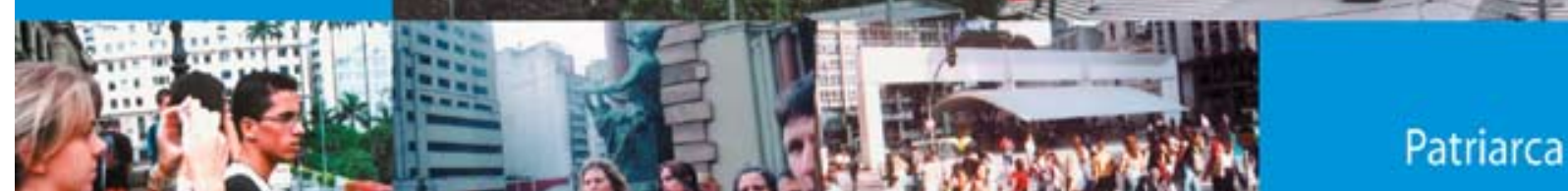

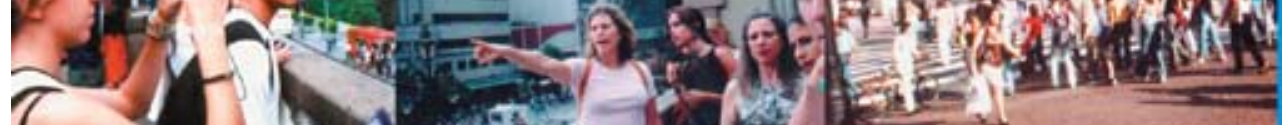

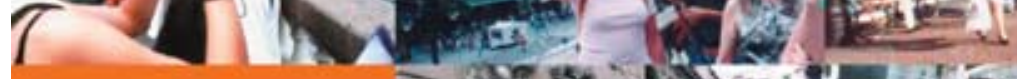

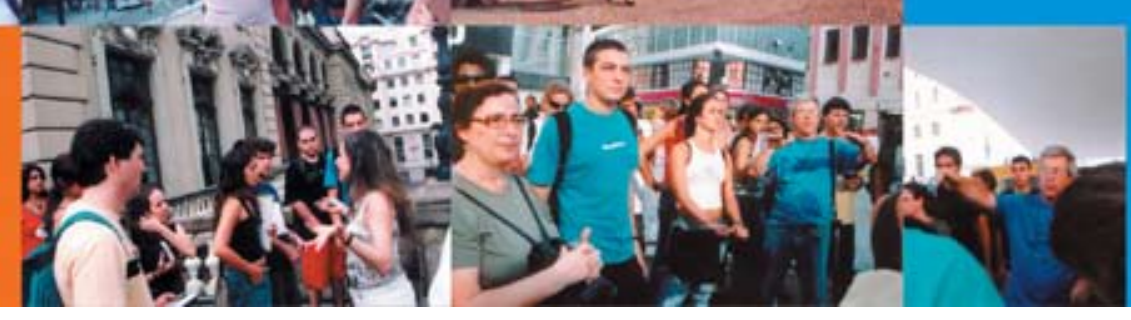




\section{ANO FAUS UNISANTOS}

Por quatro anos, o Curso de Arquitetura e Urbanismo vêm desenvolvendo a proposta de integracáo horizontal, nas disciplinss do primeiro ano. Fssa proposta decorre do modelo didático pedagógico implantado a partir de 2000, apos ampla discusstio entre professores e alunos.

Oobjetivodessa integraçắo éproporcionarao alunouma experiencia mais ampla eversatil das atribuiçóes profissionals do arquiteto e de seus objetos de trabalho, envolvendo as disciplinas, em discussbes abrangentes sobre a cidade arquitetura. historis e as artes. Muitas atividades resultaram em viagens de estudos, trabalhos e aulas em conjunto com as disciplinas, gerando uma nova abordagem didatica.
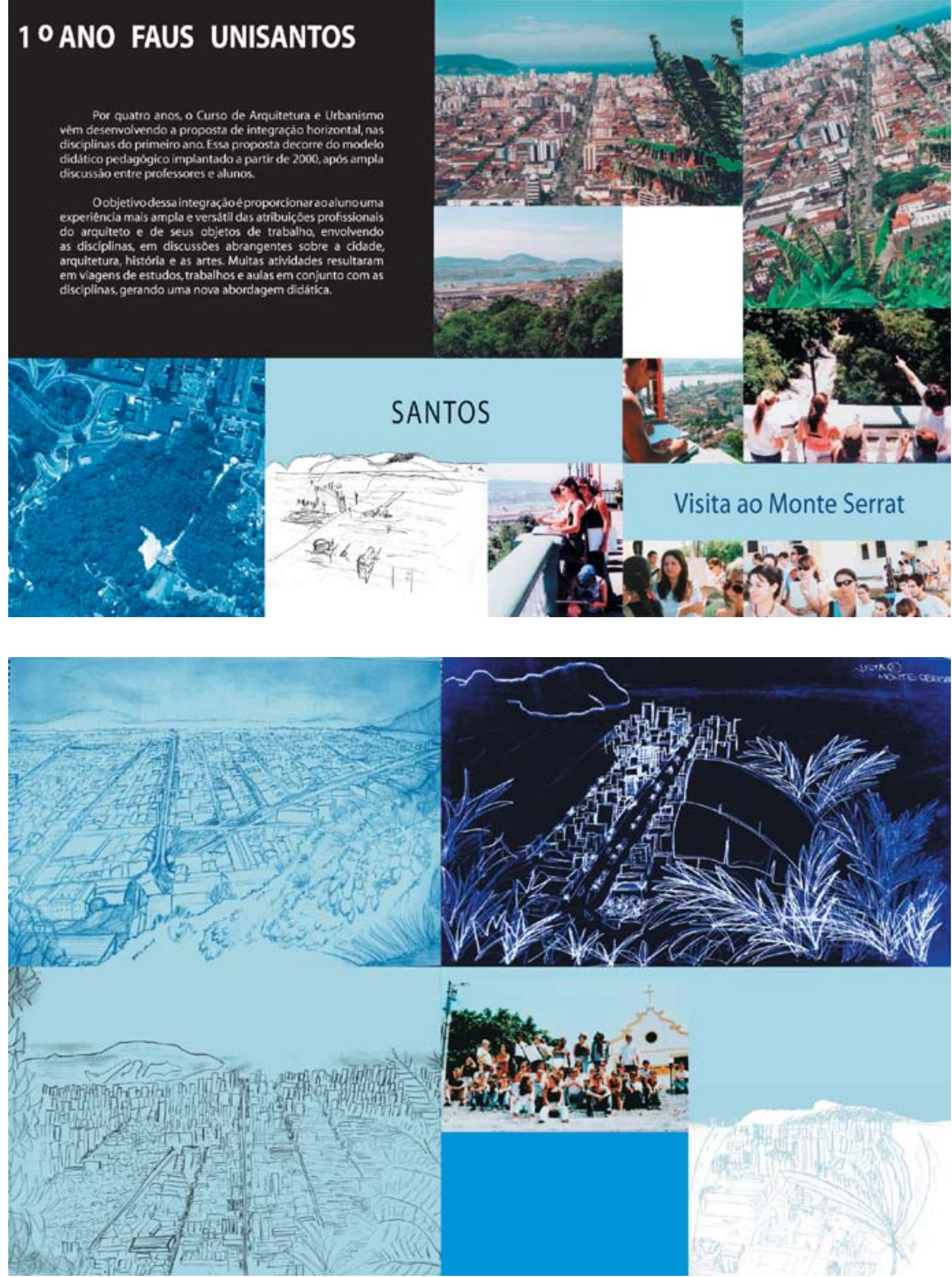


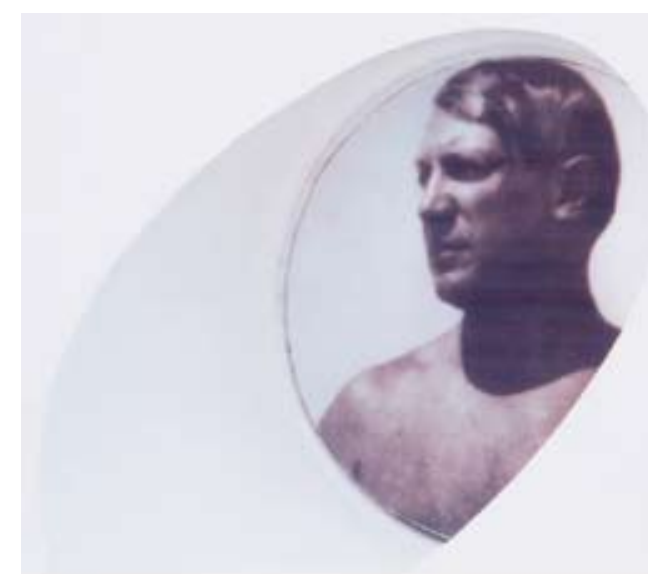

\section{PROJETO E PLÁSTICA}

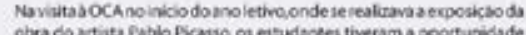

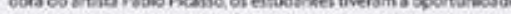

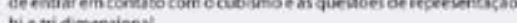
bie tridimensionat.

A obra "Bandolim sobee una mesinha de centro" maliasdis em 1920 em Fais foil escolhida para o deservolvimento do esercicio gramonicaldeenvin
umbe escultura.

Posteviomente inen teaballo coriurito das dsciplinas de Projets

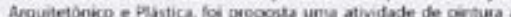
partir do objeto tridimexional. f numa utims etape es objetos tisdenensionas kram pintados.

Easo expecitincia incorpos uma reflecus da gramitica de pintura.
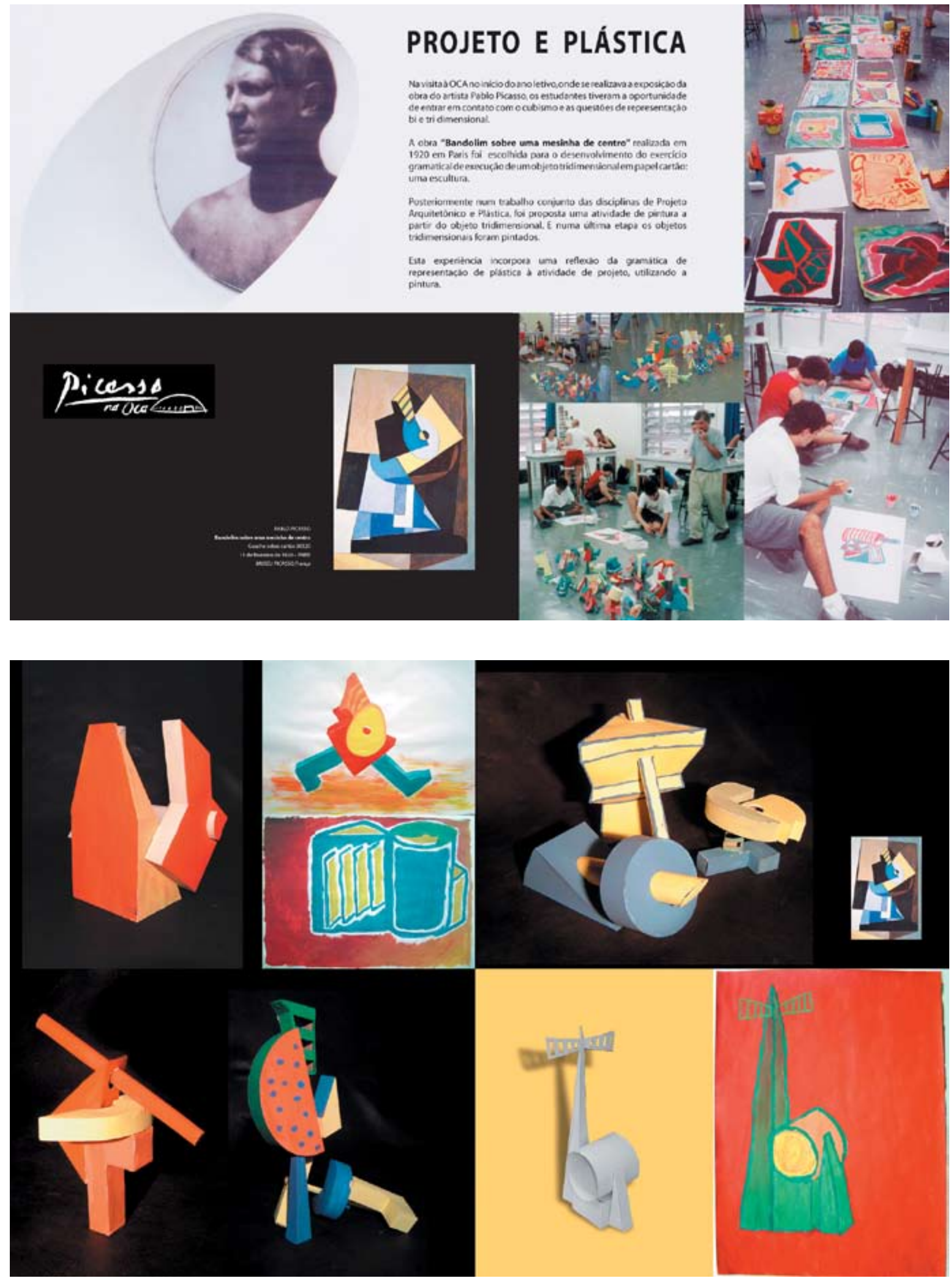

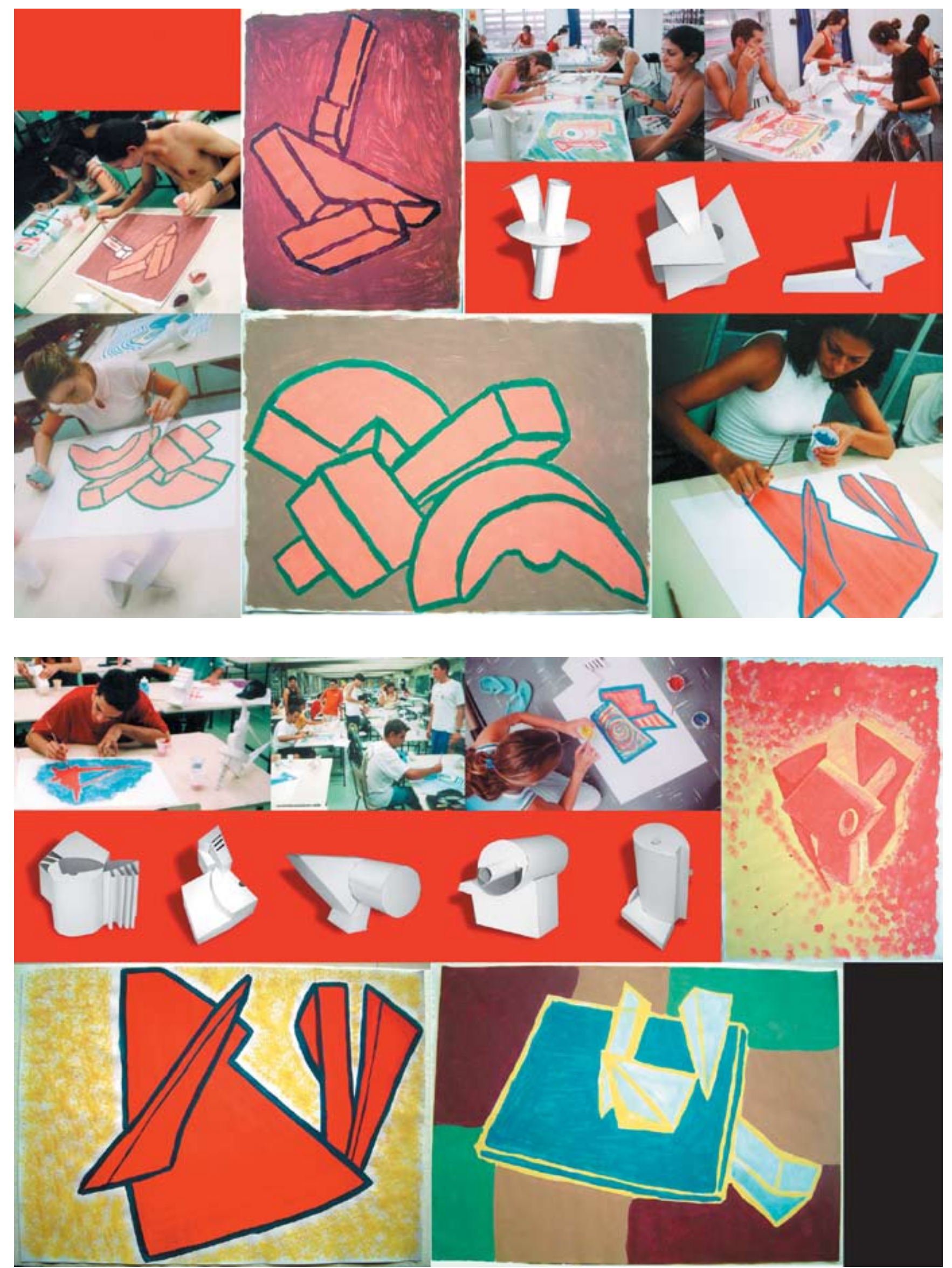


\section{TEORIA DA ARQUITETURA}

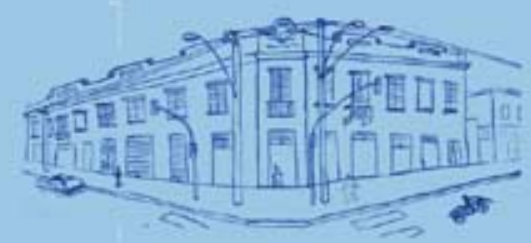

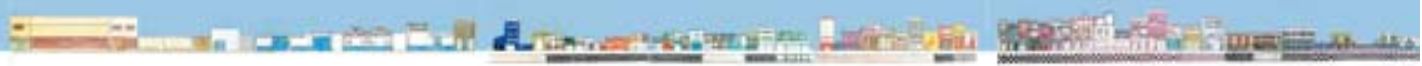
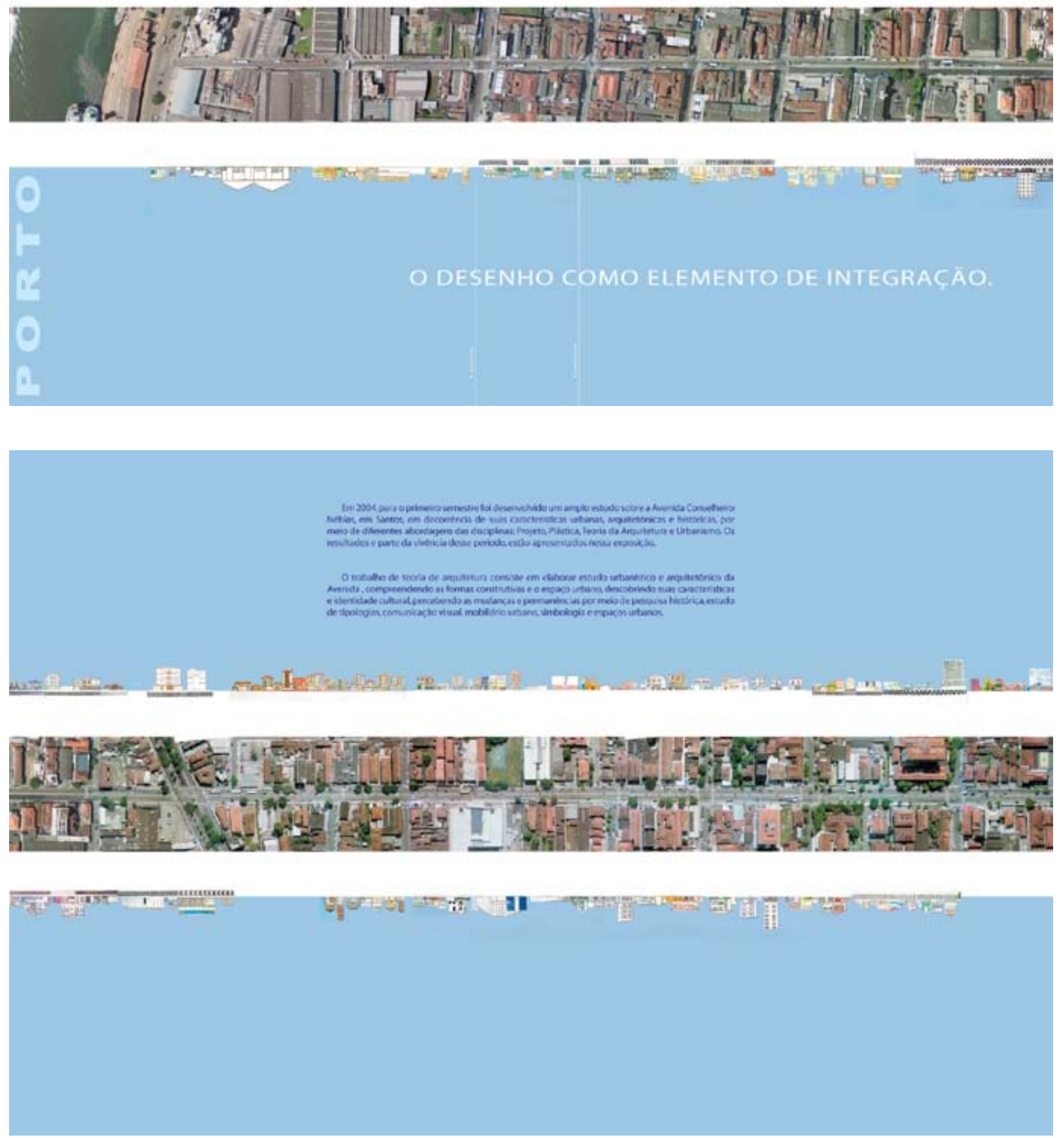

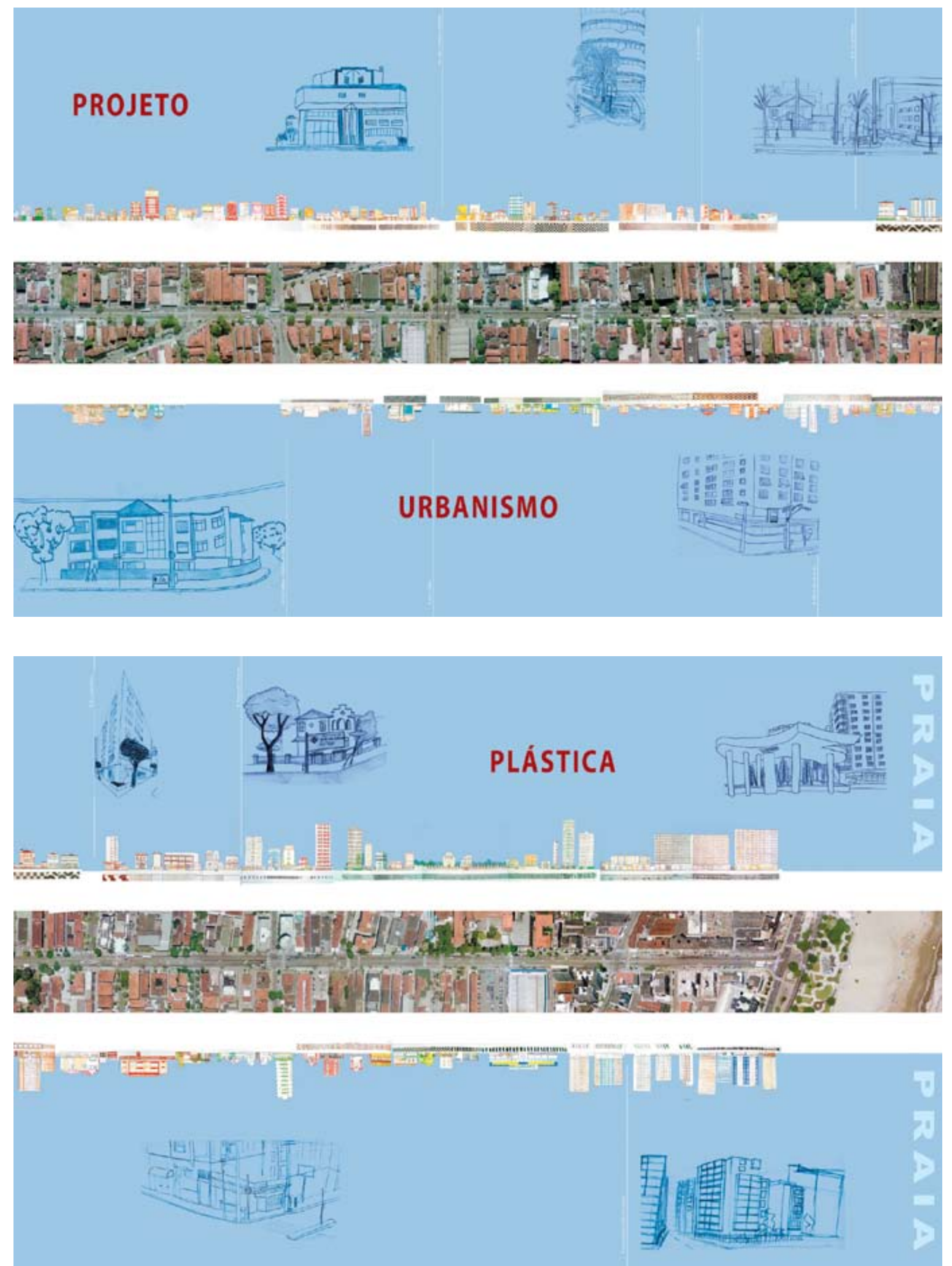

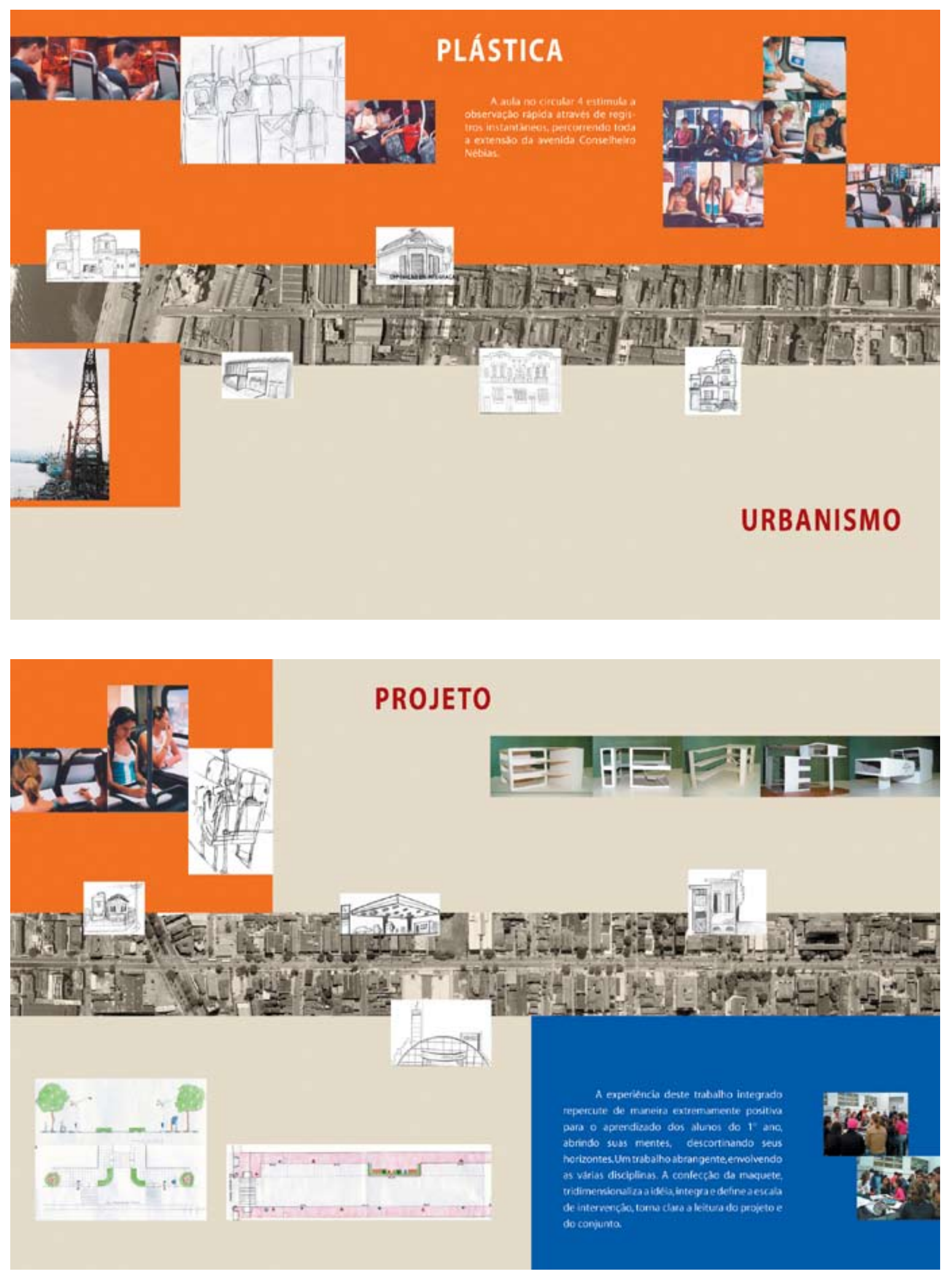


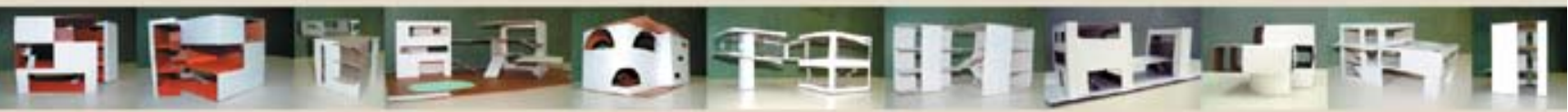

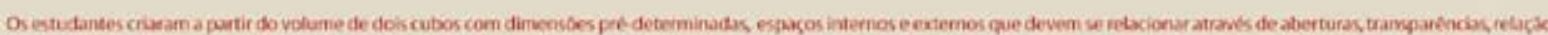

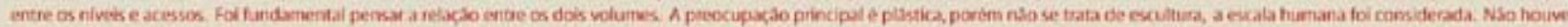

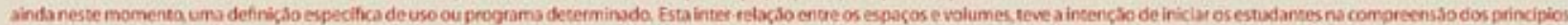
concetivils da arquisetura atraves da implantac so em um vaso a longo da Conselheiro Nebias

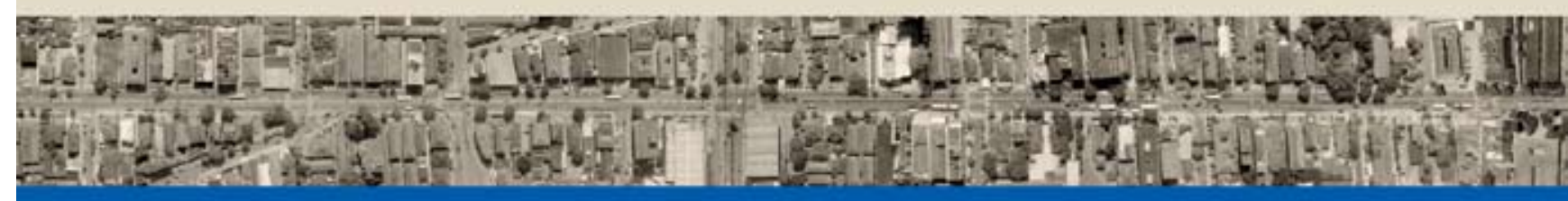

A MELHOR FORMA DE APRENDER É APRENDER FAZENDO, É APRENDER PRATICANDO.

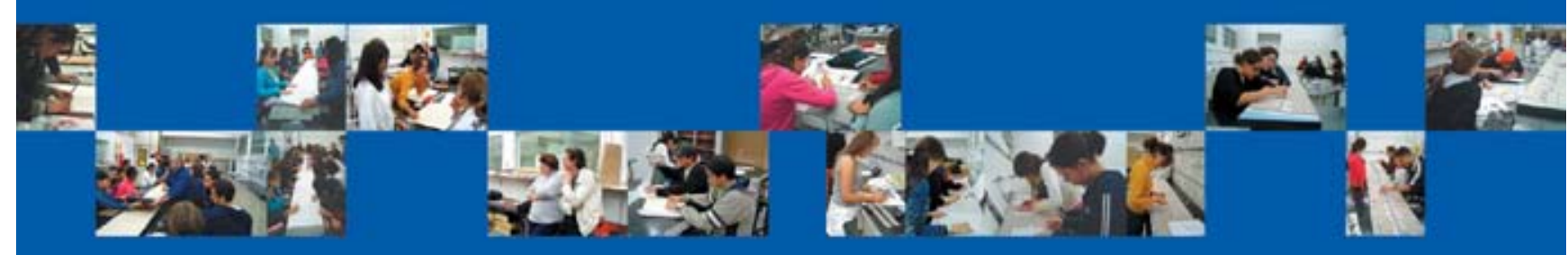

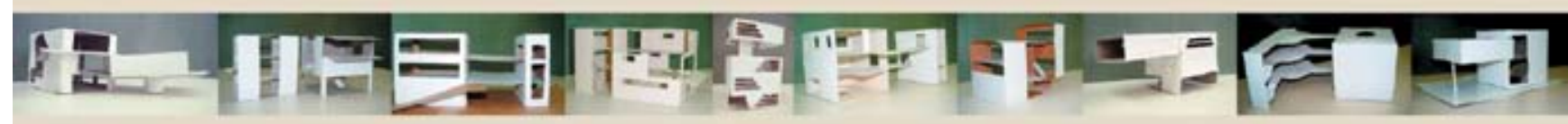

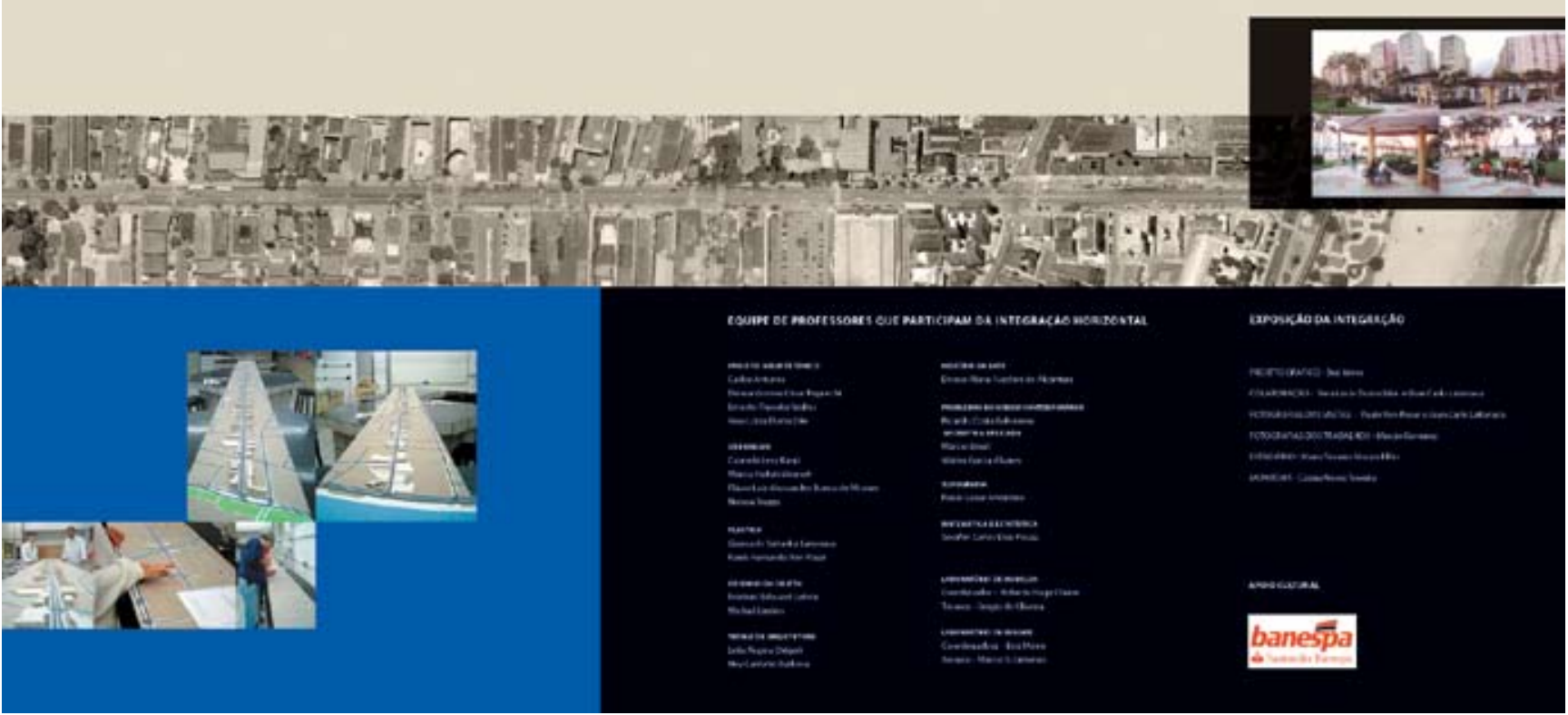


A integração horizontal, método pedagógico aplicado aos estudantes do primeiro ano de Arquitetura e Urbanismo, teve como objetivo proporcionar uma experiência mais ampla e versátil das atribuições profissionais do arquiteto e de seus objetos de trabalho, oferecendo a eles um envolvimento com as disciplinas em discussões abrangentes sobre a cidade, a arquitetura, a história e as artes. Muitas atividades resultaram em viagens de estudo, trabalhos e aulas em conjunto com as disciplinas, gerando uma nova didática.

O princípio regulador do aspecto didático da integração horizontal conduz claramente o ensino da arquitetura, não dando oportunidade a que cada estudante faça sua síntese isoladamente.

Professores-colegas participantes da implantação da integração horizontal na FAUS.

PROJETO ARQUITETÔNICO

Carlos Antunes

Denise Gomes Ruprecht

Ernesto Theodor Walter

José Cláudio Paneque

Paulo Eduardo Pignanelli

Antonio Cláudio Fonseca

Roberto Machado

Vera Lúcia Domschke 
PLÁSTICA

Paulo Fernando von Poser

Giancarlo Latorraca

Douglas Cajiani

URBANISMO

Carmela Levy Kanji

Márcia Halluli Menneh

Flávio Luiz Marcondes Bueno de Moraes

Nelson Trezza

\section{DESENHO DO OBJETO}

Frédéric Edouard Lebois

Michail Lieders

TEORIA DA ARQUITETURA

Leila Regina Diêgoli

Ney Caldatto Barbosa

HISTÓRIA DA ARTE

Denise Maria Fuschini de Alcântara

Luiza Jatobá

PROBLEMAS DO HOMEM CONTEMPORÂNEO

Ricardo Costa Galvanese 
GEOMETRIA APLICADA

Márcio Brasil

Walter Garcia Álvares

TOPOGRAFIA

Paulo César Ambrósio

MATEMÁTICA E ESTATIISTICA

Serafim Carlos Dias Pouza 


\subsection{Escola da Cidade - o estúdio vertical}

Desde 2005 participo como professora de projeto das atividades da Escola da Cidade: como tutora no estúdio vertical, como professora do $5^{\circ}$ ano - TFG, orientando o desenvolvimento da pesquisa e do projeto, e como professora de Projeto Arquitetônico no primeiro ano.

O processo didático do estúdio vertical vigente na escola consiste na integração dos alunos do $2^{\circ}$ ao $5^{\circ}$ ano e de professores de diferentes disciplinas, que trabalham juntos ao longo de períodos determinados. Os alunos se reúnem em grupos hierarquicamente organizados para o desenvolvimento de projetos, ou parte deles, ligados a um tema. Os grupos, compostos de cinco alunos, desenvolvem seu trabalho ao longo do ano e são acompanhados durante o desenvolvimento do trabalho por um professor-tutor para cada grupo. O professor-tutor é necessário durante a formação do curso para ser substituído por aluno do $5^{\circ}$ ano, que passará a coordenar o grupo. No processo de acompanhamento dos trabalhos há sempre um rodízio dos professores.

A característica principal de cada grupo de alunos - que garante a verticalidade da atividade - é que a composição do grupo é feita com um aluno de cada ano do curso. Dessa forma, todos os alunos pensam sobre uma determinada problemática dentro de um eixo temático e chegam a proposições objetivas a respeito dos problemas trabalhados.

O eixo temático é um tema ou problema levantado pelos professores e pesquisadores ligados à escola e deve organizar e definir as pesquisas e as realizações acadêmicas de todo o corpo discente e docente. 
Denominação

Regime Acadêmico

Vagas e Turmas

Número de Alunos por Turma

Duração

Bases Legais do Curso: Diretrizes Curriculares, pareceres e resoluções do CNE e das associações profissionais.

\section{Justificativa}

Objetivos Propostos para o Curso

Objetivos Gerais

Objetivos Específicos

\subsection{Relevância Social do Curso}

\section{INTRODUÇÃO HISTÓRICA}

A apresentação deste quadro histórico visa a salientar a extensão e profundidade dos desafios que se nos apresentam, como intelectuais - numa espécie de "cerzidura" da cultura arquitetônica brasileira -, de recondução da atividade ao campo dos debates nacionais conseqüentes e de sua interligação estratégica com o debate internacional atual sobre a transição histórica por que passa o mundo contemporâneo.

Há alguns anos um grupo de arquitetos, artistas, historiadores, filósofos e engenheiros vêm discutindo de modo contínuo, em suas obras e publicações, no ensino e em fóruns 
diversos, as bases conceituais da produção de Arquitetura e de arte no Brasil, tanto recente como passada. Esse grupo constatou a urgência de engendrar em novas formas os saberes gerados no salto tecnológico por que passamos com o exame da história, que novas abordagens, criadas pela cultura contemporânea, vêm permitindo.

Esse entendimento surgiu da compreensão de que vimos assistindo a um desmonte das instâncias que tradicionalmente abrigaram os debates teóricos de Arquitetura no Brasil - desde um passado recente, os anos de 1970 - o que acabou por originar a distância que todos pressentem entre os principais debates contemporâneos da Arquitetura e o atendimento às necessidades urbanas mais básicas do nosso país. Tornou-se evidente para esse grupo que tudo aqui vem sendo feito, tanto em relação às nossas cidades quanto à nossa natureza, de forma a conceber a discussão e o debate como formas de impedimento da ação, como se a reflexão nada devesse à realidade. Tal fato vem alimentando, nesses últimos vinte ou trinta anos, um processo perverso de formação de arquitetos e teóricos, que não só tem deformado o mercado de trabalho - por desviar a atenção da sociedade de suas principais questões - como tem limitado os horizontes criativos da Arquitetura à mera produção de objetos de apelo mercadológico e imediatista. Neste tempo histórico nossa urbanidade e nossas cidades vão se deteriorando a passos largos.

\section{UM QUADRO DE REFERÊNCIAS}

No Brasil dos últimos trinta anos vimos acompanhando um processo de desenvolvimento econômico e social que se constitui, em linhas firmes, por uma violenta concentração de renda, correlata a uma brutal concentração urbana, com a imposição de um modelo científico e tecnológico infensa à nossa necessidade material e um maciço desenvolvimento da indústria cultural alienante de nossas realidades socioculturais. 
visam adequar o Estado ao interesse da chamada "nova ordem econômica mundial" - de política social reconhecida como excludente.

Esse processo deu-se em conjunto com a gradual deterioração do modelo político e econômico anterior - imposto em 64/68 - ao longo dos anos de 1970, onde o crescimento econômico do país e o aumento do grau de complexidade das contradições de nossa sociedade colocaram o debate político sob novas condicionantes e demandas, que determinaram a superação do modelo anterior - ainda que mantida grande parte de sua estrutura. Tal quadro se manteve, em parte, devido a um paulatino isolamento da parte crítica da "inteligência" de sua influência na sociedade civil, tanto pelas contradições internas daquela, quanto pelo alijamento imposto por razões ideológicas, visto que, apesar de uma participação popular de fundo, essas passagens se deram todas intra-elites.

Em nosso país - como caracteristicamente agiram em processos semelhantes ao longo de sua história - as elites dirigentes procuraram acoplar as novas demandas sociais a sua consolidada estrutura de poder econômico - com o terço superior da pirâmide social de reduzida população e de renda mais que dobrada que os dois terços restantes - utilizando esse processo de reinserção mundial para solidificar e ampliar a diferença de acesso às condições básicas de existência entre nosso povo. Do relativo sucesso desses objetivos decorreu o quadro atual de problemas sociais que vimos se agravando a índices preocupantes, na última década, à medida mesma em que vem se completando a entrada do país na "nova ordem".

Durante esse período, no que afeta a cultura e a educação, assistimos ao sucesso da implantação de um modelo organizativo completo, constituindo uma quase totalidade dos horizontes existenciais da população. Para tanto, foram desenvolvidas ações específicas que tiraram partido de condições combinadas:

- Entre os anos 60 e os 90, a população do país triplicou, conformando ao longo dos anos 80 um quadro demográfico onde sessenta por cento da 
população estava abaixo dos trinta anos. Temos, hoje, cerca de dois terços da população inteiramente "crescida" no período.

- Concomitante a isso, estimulou-se um processo de migração populacional de escala nacional, do Nordeste, principalmente, para o Sudeste, e do campo para as cidades, trazendo para os centros urbanos uma enorme carga de demandas deslocadas: todo um universo agrário transplantado sem transição, para um novo contexto, despreparados cultural e materialmente, uns e outros, para tanto.

- Uma das intenções desse modelo foi o aumento das classes médias, como "camada de amortecimento" dos anseios populares, proletários ou lúmpen, caracterizando uma migração vertical de porte, em relação à sua duração no tempo.

- Para esse universo de deslocamentos foi criada toda uma indústria de bens de consumo, particularmente de não duráveis, enquanto se sonegavam soluções definitivas de infra-estrutura para bens duráveis e serviços públicos. A indústria da construção civil privada foi encarregada, quase exclusivamente e com sua ideologia liberal de não sofrer quaisquer restrições, de suprir as demandas de habitação, emprego de mão-de-obra, ordenação urbana, etc.

- Neste quadro realizou-se uma reforma do ensino que buscou aliar os propósitos de formação de mão-de-obra adequada ao modelo - baixa qualificação técnica/ baixa alfabetização nas camadas populares; qualificação tecno-especializada/cultural fragmentada nas classes médias - com os interesses do ensino privado. No ensino público a estrutura de ensino do país constitui-se de conservadoras formas cartoriais e burocratizantes - planos de carreira estreitamente vinculados à estrutura administrativa, sem discernimento objetivo entre progresso na carreira e grau de mérito, ou pertinência, da pesquisa acadêmica.

- Na senda do baixo investimento público, foi dada inteira ênfase ao ensino privado, que foi encarregado pelo Estado de suprir as demandas sociais 
estratégicas, substituindo-se um modelo de ensino universalizante e de ênfase humanística, por outro de caráter pragmático, especializado e tecnicista.

- Ao mesmo tempo, foi desenvolvida a rede nacional de telecomunicações, levando a todo o país a produção de uma potente indústria cultural de origem nos grandes centros metropolitanos. Rádios, TVs e imprensa de "variedades" passaram a ter como principal conteúdo a reprodução de um modelo de consumo de massa. Proporcionalmente, no período, o mercado editorial de livros teve sua presença drasticamente reduzida no perfil de consumo da população.

- Por fim, e mais grave, como decorrência direta da estrutura de poder imposta pelo modelo - a estratégia de segurança do Estado, aliada à gestão tecnocrática da economia -, renovou-se a estrutura historicamente oligárquica de nossa sociedade, gerando um processo de censura econômica - mais eficaz que a de idéias - baseado na cooptação pela corrupção e o compadrio, que se espraia hoje pela quase totalidade do nosso tecido de relações sociais. Vivemos também um desmonte dos contratos sociais e éticos que validam as formas institucionais de convivência e discussão das demandas sociais, culturais, políticas e econômicas.

E, destarte, dos quarenta milhões de crianças no ensino básico, temos somente cerca de quinze por cento chegando aos processos seletivos de terceiro grau, formando uma proporção de apenas cerca de cinco por cento da população brasileira com formação universitária. Como o país tem um déficit de cerca de seis milhões de habitações - e os correspondentes serviços públicos e infra-estrutura, suas cidades - há uma enorme urgência na área do ensino superior.

Compreende-se, assim, o contexto no qual vem se formando o alunado para sua tentativa de inserção nas camadas socioculturais superiores da sociedade, via ensino superior, e as decorrentes dificuldades desse ensino em transformá-los em indivíduos socialmente adultos e humanamente plenos. 
Esse quadro não se deu sem contradições. Tanto pelo setor intelectual, quanto por parte da classe política e empresarial, como da população em geral, as reações a esse modelo foram sendo lentamente articuladas em ações que ganharam relativa presença social, desde movimentos operários na crescente indústria, passando pela oposição politicamente negociada, ao debate e à reflexão em parte da imprensa e na universidade. Entre os intelectuais, esta oposição ainda sofreu um solapamento extra, devido a diferenças de enfoque geradas pelas contradições de pertencerem, estes, à peculiar condição sociocultural das elites brasileiras.

\section{A AÇÃO DOS ARQUITETOS}

No nosso campo em foco, a Arquitetura e o Urbanismo, foram realizadas diversas iniciativas na área institucional, em pesquisas, em projetos, na educação e mesmo na esfera propriamente política que, dado o quadro, se não puderam avançar em âmbito nacional, demonstram a tenacidade com que os arquitetos brasileiros vêm mantendo a sobrevivência de um quantum de qualidade na prática e no ensino de seu ofício.

Reunindo-se quase sempre em pequenos grupos que se articularam por entre as brechas deixadas na progressão do nosso modelo, mantendo a custo suas instituiç̧̃̃es profissionais e colocando, eventualmente, suas questões determinantes em debate, quase todas essas ações foram de curto sucesso no tempo, seja pela inadequação de meios, seja porque foram apropriadas pelo modelo vigente quando melhor sucedidas. Somente no final da década de 1990, com o paulatino estabelecimento institucional da democracia, puderam os arquitetos, associados a outros grupos, colocar na pauta política questões como os planos diretores das cidades.

Um exemplo conhecido de todos é o da instituição de ensino privada que se inaugura, ou se recupera, no "mercado", empregando na docência bons e reconhecidos 
profissionais da área, sustentando um grupo de reivindicações por melhores condições de ensino e pesquisa, até que estas entrem em conflito com seu projeto de gestão financeira: a partir desse momento, - em média recente girando ao redor de cinco anos -, o confronto se estabelece, levando ou à demissão desses profissionais, ou ao seu acomodamento a mínimas condições de trabalho, na esperança de sustentação de um mínimo de espaço conquistado.

Os exemplos paulistas são inúmeros e conhecidos: Santos, em 1970/1990, Taubaté, no mesmo período, São José dos Campos, Bauru, Belas-Artes, etc. Uma das mais recentes tentativas desse tipo foi experimentada em Moji das Cruzes, de 1992 a 1995, na Universidade Brás Cubas, em seu Departamento de Arquitetura e Urbanismo, onde se reuniu a maioria do grupo da Escola da Cidade.

Nesse contexto, aspectos das questões aqui levantadas, profundamente relacionados com o conhecimento específico da Arquitetura - políticas urbanas, recursos naturais, produção industrial, saúde pública, meio ambiente, infra-estrutura, políticas culturais, etc. - têm sido descuidadamente tratados, dada a circunstância dos próprios arquitetos, em sua maioria, terem perdido a capacidade de se articular aos demais segmentos profissionais e intelectuais, em debates e propostas conclusivos. O país cresceu e se fez mais complexo que nossa atual capacidade - como segmento profissional, artístico ou intelectual - de reconhecê-lo e compreendê-lo, o que está na base da difícil condição de trabalho dos arquitetos brasileiros, mormente a enorme necessidade do seu saber.

É nesse quadro de demandas históricas, sociais e materiais reprimidas, que a Associação de Ensino de Arquitetura e Urbanismo de São Paulo e a Escola da Cidade se apresentam como mais um espaço de debates e propostas para a sociedade brasileira. 


\subsection{Relevância na Região}

\section{FATORES DE INCLUSÃO SOCIAL E INCLUSÃO NO MERCADO DE TRABALHO}

A AEAUSP e a Escola da Cidade surgem dessa união de arquitetos, intelectuais, artistas e técnicos comprometidos com a melhoria da realidade brasileira. Esse grupo, embasado na sua experiência de ensino, na pesquisa teórica e aplicada e na prática profissional junto ao "mercado" e institucional, tem como desígnio fundamental a criação de um espaço privilegiado para a liberdade de reflexão e proposição, na forma de uma entidade civil sem fins lucrativos, de gestão democrática e financeiramente autônoma, de estrutura operacional moderna e não-burocrática, com ênfase na pesquisa interdisciplinar e dotada de meios materiais para o inter-relacionamento profundo e abrangente entre $\circ$ ensino, a pesquisa e a prática profissional, nas áreas de Arquitetura e Urbanismo.

Assim organizada, a Escola é a primeira experiência no ensino superior de Arquitetura brasileiro de criação de um tipo novo de instituição da sociedade civil, um instituto de investigação não só dos problemas urbanos, arquitetônicos e de apropriação do nosso território mas, principalmente, das suas possíveis e desejadas soluções. Um instituto de proposição, tanto quanto de análise, onde os membros são proprietários e executores, propositores e propiciadores, uma entidade do terceiro setor onde o principal interesse econômico está na satisfação das melhores condições para o desenvolvimento do ensino e da pesquisa, e assim compreendido como um modelo que pode ser replicável nas demais regiões do Estado e do Brasil, possibilitando a outros grupos de educadores e intelectuais um novo caminho de realização de seu papel social, artístico e intelectual.

É sabido que do total anual de produção da construção civil do Estado de São Paulo, a participação de arquitetos-projetistas gira em torno de três a cinco por cento desse montante. Associado a esse dado, temos carências urbanas em habitação, 
infra-estrutura e serviços públicos que segregam da plena fruição da vida urbana cerca de metade de sua população.

Este quadro não tem mudado ao longo dos últimos vinte anos anos, mesmo com o grande aumento no número de faculdades de Arquitetura no período, principalmente no setor privado, pois as características organizacionais e didáticas dos mesmos têm dificultado a formação de quadros capacitados a responder eficazmente a essas demandas, pelas razões expostas acima.

Frente a este quadro, e pelo exposto anteriormente, a AEAUSP foi configurada como um Instituto de Investigação sobre o Desenho do Ambiente, organizado em Núcleos complementares à Escola - Aplicação, Pesquisa, Tecnologia, Formação Continuada e Comunicação (explicitados adiante) - que a complementam e informam, num caminho de mão dupla, para a ampliação de seu escopo e ação social, a criação de oportunidades de aplicação social do conhecimento produzido, a prática de ensaios profissionais pelo alunado e o aprofundamento e difusão de questões levantadas na produção acadêmica. Essa conformação institucional é fundamental para o sucesso da Escola no seu posicionamento estratégico frente às demandas da sociedade, visando a, mais que simplesmente colocar o aluno no "mercado", ampliar o espaço de inserção da Arquitetura e do Urbanismo na realidade por meio da proposição de programas e propostas para governos e instituições da sociedade civil.

\section{CONCEITUAÇÃO DIDÁTICO-PEDAGÓGICA}

O cerne da conceituação pedagógica da Escola da Cidade é apoiado na existência de alguns elementos peculiares ao ensino da Arquitetura, aqui compreendida contemporaneamente, como um "processo de reflexão propositiva sobre os estabelecimentos humanos e respectivos espaços habitáveis e seus suportes materiais e imateriais". 
do espaço edificável/habitável, abrindo mão do exercício das atuais práticas da comunicação visual e desenho do objeto/industrial, posto que estas adquiriram, hoje, complexidade e autonomia próprias. Assim também, o conjunto das disciplinas de História e Planejamento passam a ser integrados ao corpo de suportes dessa prática acima definida, deixando de se configurar, como hoje em dia, em semidepartamentos auto-suficientes, pois entende-se que tanto a historiografia e historiologia da Arquitetura fazem parte do corpo de conhecimento histórico geral, como os diversos níveis de planejamentos são hoje, a partir do desenvolvimento da questão do meio ambiente, parte de um maior e mais abrangente, desenho do ambiente.

Assim as aulas de Estúdio são o centro nevrálgico do processo de ensino por seu caráter experimental, propositivo e de síntese. Experimental por ser uma investigação orquestrada em meios e fins pelo Desenho (intenção/Artigas, 68); Propositivo, pela característica dessas experiências serem, sempre, ensaios de modalidades de avanço para além do presente, de exercícios de ampliação do real; e Síntese, pelo concatenamento dos diversos saberes componentes do campo de conhecimento da Arquitetura em novas relações que os inquiram, nas suas imbricações com a realidade.

A fragmentação dos saberes em matérias estanques acaba colocando-as como a conformação de um campo demasiadamente específico do saber, em que estas se dispõem, cada uma por si mesma, à completa cobertura desse campo, isolada e exclusivamente, dificultando a compreensão pelo alunado de nosso tempo de como fazer transposições de interpretação de um campo a outro, entendendo os processos de imbricação mútua desses campos, para melhor percebê-los nas suas especificidades dentro da realidade. Essa fragmentação, além do mais, é perfeitamente condizente com a da cultura de massas.

A atividade acadêmica universitária pode falhar em sua competência precípua de total instrumentação técnica e prática do alunado, determinada que está por uma abordagem necessariamente universalizante e humanista, de caráter conceitual, 
porém ideológica, da diversidade do conhecimento. Busca-se que ele se aparelhe criticamente para a apropriação dos elementos essenciais estruturadores da realidade (a história, a ciência, a técnica, a estética, a economia, etc.), o que se associa à necessidade de desenvolver procedimentos de aprendizagem para a incorporação e a elaboração desses conhecimentos e à necessidade de desenvolver nele seu potencial inventivo a partir deles. A entrada na graduação universitária revela-se como apenas o começo do percurso intelectual e instrumental do indivíduo no complexo âmbito de conhecimentos que o mundo atual requer para sua plena fruição.

Compreendidas as condições de seu ingresso, é preciso que se definam as condições de sua saída, o perfil aproximado de arquiteto urbanista desejável dentro da condição atual das práticas arquitetônicas. Sabe-se que o formando terá um amplo leque de atividades tanto na iniciativa privada como no Estado, sem que, entretanto, Ihe seja possível vislumbrar nesse momento todo o seu potencial de desenvolvimento em tais atividades. Tal questão coloca para o curso a necessidade de propiciar aberturas para as diversas possibilidades de prática profissional. Assim o formando deverá sair da faculdade com uma visão articulada da amplitude de determinantes e condicionantes da realidade, para que possa situar-se mais prontamente em relação a ela, buscando de modo mais eficaz sua inserção particular, sua conduta de desenvolvimento futuro em relação à mesma e a compreensão dos meios concretos necessários para sua efetivação.

É, portanto, nosso objetivo pedagógico entregar à sociedade arquitetos com plena capacidade de apreender a aprender a partir de um nível básico de conhecimentos, que Ihes permita situar-se no universo das atividades de Arquitetura e Urbanismo. Pois parte considerável do seu conhecimento instrumental será posteriormente desenvolvida em suas diversas práticas, num processo que será intimamente dependente da sua capacidade crítica de lidar com elas. 
Com isso podem se estabelecer procedimentos que visem a capacitá-lo a conceber o seu próprio processo de aquisição de conhecimento e, acima de tudo, projetá-lo, ou seja, compreender sua própria condição em cada instante e ampliá-la, transformála conscientemente. Sabemos que vocações, talentos ou potenciais individuais ou de grupos aflorarão no processo educativo, se não definindo, ao menos indicando perfis de atuação. Mas sabemos, também, que tanto pela diversidade apontada anteriormente, como pela faixa etária característica do alunado universitário (final da adolescência, passagem para a vida adulta), é necessário pensar seu preparo a partir de uma média comum de possibilidades de desenvolvimento na realidade. O que nos conduz a conceber o processo inicial desse desenvolvimento como um processo "matricial", gênese de uma gama maior de possibilidades. Portanto, um processo que desenvolva no aluno sua apreensão do processo próprio da aprendizagem e da invenção. Essa hipótese nos conduz a uma concepção de curso onde se desenvolverá, preponderantemente, uma visão de conjunto, ou seja, parte-se de um grupo elementar de conhecimentos (em vez de uma ampla gama, porém superficial e atomizada, como usualmente ocorre), para que sejam ampliados organicamente, conforme a resposta da turma em cada etapa.

A compreensão desses fundamentos sugere uma estrutura de curso diferente das atuais. Para tanto, o curso deverá dar ênfase à integração interdisciplinar (via ConseIho de Graduação), onde as matérias, reagrupadas em linhas disciplinares sem perda de sua autonomia de conteúdos, deverão buscar, a partir de objetivos comuns entre si ano a ano, tematizando de modo conjunto seus programas, de tal forma que a seqüência natural de conteúdos de cada uma se dê, mas integradamente às demais. Desse modo se definirão grupos essenciais de conhecimentos a serem transmitidos, aptidões básicas a serem desenvolvidas, ferramental principal a ser incorporado, coerentes a cada etapa do curso, onde serão embasados os fundamentos de um conjunto 
de saberes condicionados reciprocamente. Tal trabalho exercitará continuamente a compreensão pelo alunado da relação mútua dos saberes e suas diversas escalas de condicionamento das realidades.

Isto também requererá uma contínua troca de informações por parte do corpo docente de cada ano, dada a concatenação do programa em torno de elementos básicos. As aulas tratarão, então, de esquemas comuns de abordagens dos conteúdos, de temáticas gerais a essas abordagens, de âmbitos mais homogêneos dos conhecimentos implícitos nestas, sem, no entanto, impedir que a diversidade de visões sobre esses conteúdos aflore no processo (dada à diversidade própria do corpo docente).

Também será necessário que o formato das aulas se modifique, deixando a rígida divisão aula expositiva/aula propositiva para uma mescla das duas estratégias. Isso porque, dentro da atual diversidade de matérias, se elegerão as principais e as complementares - dentro dos objetivos gerais de formação no curso - fazendo com que algumas aulas passem a ser dadas, por vezes, conjunta e complementarmente. As aulas terão assim, aproximadamente, as feições das atuais aulas de estúdio, com dois, três, quatro professores em diálogo, mas mantendo seu cerne de aulas expositivas que aprofundem e/ou ampliem os aspectos necessários.

Serão, assim, cursos de caráter propositivo, com geração contínua de produtos que reflitam a absorção e a elaboração dos conteúdos (pesquisas, seminários, projetos, objetos etc., em torno de questões comuns). Deste modo, a partir da prévia definição temática, as linhas disciplinares poderão definir dois momentos de trato com a turma: um, em conjunto, com produto final comum, e um próprio, com desenvolvimento paralelo ou complementar, e produtos idem, porém relacionados àquele objetivo definido, fruto da temática da etapa.

Será, portanto, necessária uma prática de avaliação comum da etapa (e da turma), resolvendo o problema atual de disparidade estrutural de tratamento dessa questão. 
A definição de objetivos comuns induz a uma maior transparência nos critérios de avaliação, pois aqueles serão os paradigmas destes, e sendo ambos apresentados de antemão ao alunado, como procedimento didático, tornam-se ferramenta poderosa na explicitação das inteligências por trás dos trabalhos acadêmicos. É este processo de avaliação que permitirá que o curso possa se auto-avaliar continuamente, propondo um processo didático-pedagógico auto-reflexivo.

Pretende-se assim, particularmente no âmbito pedagógico, que elementos primordiais da Arquitetura e do Urbanismo sejam abordados de modo confluente, vistos por várias áreas de saber, juntas, buscando sínteses entre si.

\section{ESTRUTURA CURRICULAR E DINÂMICA DO ENSINO/ APRENDIZAGEM}

A partir destes princípios gerais foi elaborada uma estrutura de curso para a Escola da Cidade que busca realizar ao máximo os objetivos acadêmicos e sociais que pautam a sua criação. Tal estrutura compõe-se de algumas noções e práticas que organizam a vida acadêmica da Escola, propondo uma composição dos tempos e uma disposição das matérias particular e orgânica.

Seus elementos organizadores básicos são: o eixo temático de cada ano, o estúdio vertical, os seminários das quartas-feiras, em conjunto com as matérias próprias do curso de Arquitetura. Passemos à descrição da estrutura e da organização do curso, através da qual explicaremos cada um destes pontos de forma detalhada.

O curso de Arquitetura e Urbanismo da Escola da Cidade será realizado em período equivalente ao integral, com os alunos participando de atividades curriculares no $1^{\circ}$ e $2^{\circ}$ períodos à tarde. À noite a Escola será ocupada por cursos livres, que compõem parte das atividades de extensão universitária da Escola. $01^{\circ}$ e o $2^{\circ}$ períodos curriculares são chamados de $1^{\circ}$ e $2^{\circ}$ Tempo, têm funções diferenciadas e estão organizados de forma a desenvolver o projeto mais amplo da Escola: 
Durante $\circ 1^{\circ}$ Tempo os alunos devem assistir às aulas e orientações teóricas e/ou específicas por ano, que os habilitarão para o desenvolvimento dos projetos a serem realizados pela Escola. No $2^{\circ}$ Tempo os alunos participarão do espaço de pesquisa e de trabalho coletivo que chamamos de estúdio vertical. Estes dois tipos de atividades são integradas na vida acadêmica dos alunos, e também dos professores, pelo projeto geral de pesquisa que orientará a cada ano letivo, que chamamos de Eixo Temático. O Eixo Temático é um tema ou problema, levantado anteriormente pelos professores e pesquisadores ligados à Escola, que deve organizar e definir as pesquisas e as realizações acadêmicas de todo o corpo discente e docente da Escola. Trata-se de uma questão real, - ligada à vida da cidade ou do país, e ao estado atual do pensamento arquitetônico e urbanístico -, que deve inspirar os estudos e projetos acadêmicos que serão realizados no período de um ano letivo. Este tema embasa as discussões internas da Escola, sem congelá-las em proposições estanques, buscando o debate plural entre as várias posições ou matérias, que permita a elaboração de soluções amplas e adensadas para o problema proposto. A cada ano letivo se deverá eleger uma questão para compor o eixo temático que estará em discussão ao longo de todo o trabaIho a ser realizado, e por todas as turmas da Escola.

Ao final deste trabalho unificado de um ano em torno de um problema concreto eleito como eixo temático a Escola da Cidade como um todo - incluindo aí alunos e professores - deverá apresentar publicamente os resultados teóricos e as proposições objetivas que se pôde construir a respeito do problema eleito.

O momento privilegiado de trabalho a respeito do eixo temático do ano será o Estúdio Vertical, que ocorrerá todos os dias no período da tarde de funcionamento da Escola. Passamos a descrevê-lo.

O Estúdio Vertical é um momento de integração acadêmica dos alunos dos vários anos da Escola, e de professores de diferentes matérias que trabalharão juntos ao 
longo de períodos determinados. Ele consiste da reunião dos alunos em grupos hierarquicamente organizados para o desenvolvimento de projetos ou de partes de um projeto mais amplo, ligado ao eixo temático. Tais grupos serão compostos de cinco alunos, configurando o que podemos chamar de um "escritório", que desenvolverá seu trabalho ao longo do ano. A característica principal de cada "escritório" de alunos, e que garante a verticalidade da atividade, é que sua composição será feita com um aluno de cada ano do curso.

Desta forma, no $2^{\circ}$ Tempo teremos grupos de trabalho equivalentes a escritórios, que estarão desenvolvendo os problemas e as soluções do eixo temático do ano; cada grupo será composto de cinco alunos, sendo que um deles pertencerá ao primeiro ano da Escola, outro ao segundo, outro ao terceiro, outro ao quarto, e o último, um coordenador, ao quinto ano (enquanto desenvolve seu TFG). Garante-se assim uma integração ampla de todo o corpo discente nas atividades programadas da Escola, e um espírito acadêmico vivo e compartilhado entre o alunado.

O Estúdio Vertical coletivo do $2^{\circ}$ Tempo também integrará diferentes matérias e professores em suas atividades. Cada dia da semana o estúdio será dirigido por um grupo de professores pré-determinado, em geral ligados às áreas de projeto e Urbanismo; porém a cada dia da semana estes professores e alunos que trabalham no estúdio vertical receberão a visita de professores das matérias desenvolvidas no $1^{\circ}$ Tempo (onde se concentram as áreas de História, Tecnologia, Desenho, bem como Projeto e Urbanismo), Tais professores funcionam no $2^{\circ}$ Tempo como "orientadores/interlocutores" do trabalho que está sendo desenvolvido pelos grupos. Desta forma garante-se uma integração acadêmica maior entre as matérias, com um necessário efeito de troca multidisciplinar. Garante-se ainda o envolvimento do maior número possível de professores da Escola ao redor da discussão e das soluções para o eixo temático, soluções que têm caráterização propositiva e pública. 
Além destas três dimensões organizadoras do dia a dia de trabalho que são o Eixo Temático, o Estúdio Vertical e as Matérias Específicas, há uma quarta atividade estruturante do funcionamento da vida acadêmica da Escola da Cidade, que se trata dos Seminários das quartas-feiras.

Os Seminários das quartas-feiras, a serem realizados no período da tarde, são momentos em que a Escola convida profissionais e pesquisadores que tenham algo a dizer ou a ensinar a respeito do eixo temático que está sendo desenvolvido. Também poderão ser convidados arquitetos, artistas e intelectuais cujas idéias despertem o interesse da comunidade acadêmica da Escola, para ministrar seminários. A programação destas quartas feiras será feita por um grupo de professores inteiramente responsável por esta atividade a partir do interesse do corpo discente e docente da Escola. As datas vagas destes seminários, que não forem preenchidas com convidados externos, serão preenchidas com a apresentação dos trabalhos e das pesquisas dos próprios professores da Escola, de forma a divulgar os interesses e os resultados aprofundados do trabalho de cada professor, buscando a criação de um ambiente acadêmico vivo e informado. Por fim, uma quarta-feira de cada mês será reservada à discussão livre entre alunos e professores a respeito do funcionamento e das questões que envolvem a própria Instituição, configurando-se como um fórum interno.

As atividades dos seminários de quarta-feira abrem a Escola para a interlocução com outros pensadores e instituições, de forma a testar as hipóteses de trabalho que estarão sendo gestadas internamente, e a evitar a alienação em um conjunto de idéias que se cristalizem pela própria dinâmica institucional. Ao mesmo tempo permite que o trabalho realizado na Escola, e o pensamento de seus membros, seja exposto através destas reuniões acadêmicas mais amplas. Desta forma mantém a vida intelectual da Escola aberta ao novo e em contato permanente com as realidades externas à instituição. Esta atividade é curricular e obrigatória para os alunos da Escola. Os 
seminários também serão divulgados publicamente, de forma a serem abertos à comunidade, e configurando-se como espaço de extensão universitária.

Passamos a resumir os pontos constitutivos da estrutura acadêmica da Escola da Cidade: "Período integral" (quantidade de horas-aula equivalente, dividida em 2 períodos vespertinos). Busca garantir uma formação ampla e aprofundada com todos os problemas que implicam o trabalho de projetar e desenvolver proposições espaciais, ambientais e urbanas em nossa realidade.

Primeiro Tempo/Específico: aulas expositivas/ específicas e matérias regulares. Busca aparelhar os alunos criticamente para o desenvolvimento das pesquisas e projetos a serem realizados pela Escola.

Segundo Tempo/Estúdio Vertical. Integra todos os alunos do curso em grupos verticais de trabalho. Integra professores de diferentes matérias na discussão e no desenvolvimento dos trabalhos. Tem a tarefa de chegar a proposições objetivas a respeito dos problemas trabalhados.

Eixo temático. Orienta a pesquisa de toda a Escola. Permite que a Escola contate realidades reais para desenvolver seu trabalho. Potencializa o trabalho coletivo e organiza a produção real que pode ser divulgada posteriormente.

Seminários das quartas-feiras (v. Seminários). Mantêm a Escola aberta para proposições de interesse e que não sejam produzidas internamente. Mantém a discussão das produções internas viva e exposta ao crivo externo. Cumpre a função de extensão universitária ao serem abertos a toda a comunidade.

As visitas, pesquisa de campo e viagens (v. Escola Itinerante e Núcleos), serão programadas como parte da dinâmica de ensino, sendo que as visitas e as pesquisas de campo estão entendidas como uma atividade ligada à uma disciplina ou um conjunto delas, abordando uma temática comum, como parte dos convênios regulares a serem feitos com universidades, centros de desenvolvimento tecnológicos e instituições de interesse 
acadêmico. As viagens são programações de cunho didático e formador, com sentido de ampliação do conhecimento, sem vínculo estrito com as áreas de estudo regular. As pesquisas bibliográficas e iconográficas (v. Biblioteca), serão conseqüência natural e direta das demandas formuladas nos eixos temáticos, e da relação com os institutos de pesquisa, como as organizações técnicas, das pesquisas de campo e dos convênios.

A pratica projetual nos estúdios, com a característica básica do exercício propositivo de projetos, deverá agregar juntamente com as matérias de suporte técnico, as condições para a formação dos programas de pesquisa e reconhecimento dos processos construtivos. Os convênios com os institutos tecnológicos e entidades das áreas de construção civil são a base para a efetivação desta atividade curricular.

As verificações laboratorias (v. Laboratórios) estão amparadas no Laboratório de Modelos e Ensaios, como parte da dinâmica do programa de atividades desenhadas pelos projetos, nos estúdios e nas matérias de tecnologia e desenho na experimentação de modelos.

O TFG

Objetivos

Introdução e ideário

A proposta educacional, ancorada na discussão dos eixos temáticos de ensino entre o $2^{\circ} \mathrm{e}$ o $5^{\circ}$ ano, por ocasião da elaboração do trabalho final de graduação, deve buscar definir em termos muito precisos a natureza da arquitetura enquanto carreira, a condição do arquiteto e sua inserção e contribuição, enquanto intelectual, no plano do conhecimento. Como poucos campos da atividade humana, o objeto da arquitetura e, portanto, o resultado do trabalho nesse campo, se estende desde o simbólico, cerimonial, monumental até o plano do objeto utilitário e funcional. Sua jurisdição se estende do poético ao prático 
sempre externando dois sistemas diferentes de valores, um advindo das artes e outro da ciência e da tecnologia. Isto confronta o arquiteto com problemas que lhe são únicos. No plano subjetivo uma abordagem no campo das artes, a criação, a manipulação da ordem formal. As buscas visando a solução das questões de forma e conteúdo extraindo desse trabalho uma resposta de alto valor estético que considere os signos e os significados que instruem o repertório do autor em conformidade com os seres humanos e os processos sociais que não necessariamente exigem respostas carregadas de requerimentos e referências estéticas, mas certamente de exigências ambientais. Arquitetura não requer espectadores, como muitas formas de arte, mas sim, se expõe a participantes, à imersão experimental. $\mathrm{O}$ ambiente edificado deve atender às pessoas e aos processos a que se destina e, por conseguinte, contemplar, propor o espaço continente. Com isso afirmamos que pouco interessa a manipulação dos continentes para fins puramente formais. O ensino pretende enfrentar as contradições, descartando abordagens que tratem as questões do ambiente construído como organismos vivos, naturais. Há que estabelecer uma crítica para propor uma resposta objetiva (com termos de repertório cultural) a um dado problema ou condição. Tais problemas sempre foram inerentes a produção arquitetônica, mas no presente estes se expõem de uma forma aguda, tal o desenvolvimento da ciência e da tecnologia, pôr um lado e a ampliação das contradições encontradas nas razões históricas, nas questões sociais e econômicas advindas dos processos de desenvolvimento industrial.

\section{Orientação didática}

A experiência de orientar e contribuir para o processo da conceituação, concepção das teses e propostas dos alunos é o aspecto mais interessante da responsabilidade didática, pois não se pretende enquadrar ou "amestrar" as pretensões ou suas formas de representação ou expressão. Ao orientador cabe conduzir o futuro arquiteto numa trilha de crescente interesse, valorização e concretização do objeto de 
estudo, num clima de avaliação permanente das dificuldades específicas das temáticas e das diversas formas de entendê-las e superá-las, estabelecendo-se metas bem claras e cada vez mais ambiciosas buscando assegurar conteúdos às pesquisas elaboradas. Nesse processo, sempre, procurar-se-á o apoio e o concurso do conjunto de professores envolvidos com o TFG, demais professores da escola e de especialistas ou profissionais, externos ao âmbito da escola, que se dediquem aos temas abordados. Permite avaliar o desempenho do futuro profissional no que se refere ao seu "talento", ou dom, ou criatividade. A exigência do "talento" existente na área e considerada na avaliação não deve ser exacerbada em detrimento da avaliação do domínio de conhecimentos essenciais e da capacidade de resolver problemas, sem os quais não se exercita com responsabilidade técnica-social, a profissão. O exercício ético da profissão deve ser visto com exigência de uma determinada criatividade, de uma estética e de um saber técnico, próprio de arquitetos e urbanistas e que constituem a identidade disciplinar frente a si próprio, à sua categoria e à sociedade à qual pertence.

Conteúdo Programático:

\begin{tabular}{|c|c|c|c|c|c|c|}
\hline \multicolumn{7}{|c|}{ Conteúdos Nacionais } \\
\hline \multicolumn{7}{|c|}{ Eixo temático } \\
\hline $\begin{array}{c}\text { Ambiente \& } \\
\text { Natureza }\end{array}$ & $\begin{array}{c}\text { Paisagem: } \\
\text { Atuação } \\
\text { Interferência } \\
\text { Modificação }\end{array}$ & $\begin{array}{l}\text { Projeto } \\
\text { Urbano } \\
\text { Desenho } \\
\text { Urbano }\end{array}$ & $\begin{array}{c}\text { Atuação } \\
\text { no espaço } \\
\text { edificado } \\
\text { Projeto do } \\
\text { edifício }\end{array}$ & $\begin{array}{l}\text { História } \\
\text { Cultura } \\
\text { Sociedade }\end{array}$ & $\begin{array}{l}\text { Técnica e } \\
\text { Tecnologia } \\
\text { A arte de } \\
\text { construir }\end{array}$ & $\begin{array}{l}\text { O desenho } \\
\text { Linguagem } \\
\text { do arquiteto }\end{array}$ \\
\hline \multicolumn{7}{|c|}{ O sítio de atuação / O espaço do Projeto } \\
\hline \multicolumn{7}{|c|}{ Tutoria e Orientação } \\
\hline abalho Fi & Graduaç & & & & & \\
\hline
\end{tabular}




\section{METODOLOGIA}

- Abordagem, concepção e metas

O Trabalho Final de Graduação consiste no desenvolvimento, por parte do estudante do último ano, de um projeto arquitetônico que contemple a escala da edificação e a escala da cidade a partir de propostas de trabalho formulado sobre tema de sua livre escolha, atendendo ao seu interesse próprio, que busque e alcance incorporar conhecimento e estabelecer discussões voltadas para temáticas com ênfase nas questões da natureza, do ambiente - tomado como o conjunto das condições da natureza, já modificadas pela presença humana - da paisagem, do urbanismo enquanto projeto e desenho da cidade, projeto do edifício, do campo da historia da arte e da arquitetura, da técnica e tecnologia, com conteúdo social, enfim, assuntos aos quais o aluno tenha se dedicado nos quatro anos de anteriores de estudo do currículo de formação e aprendizado profissional.

Nesse sentido o conjunto dos professores sugere que os alunos procurem dirigir o tema a ser estudado, de forma a permitir seu desenvolvimento enquanto proposta, configurando-o em um ou mais de um dos campos de estudo constantes do conteúdo programático, preferencialmente, mas não exclusivamente, na cidade de São Paulo e sua região metropolitana, perfeitamente determinados e delimitados. Podem ser discutidos e considerados temas mais amplos, de escala nacional, ou em outros locais e situações, desde que aceitos em conjunto, pelo corpo de professores orientadores do TFG.

Enfatiza-se que a temática abordada deve considerar, dentro das diversidades permitidas, temáticas de interesse social efetivamente relacionadas com a realidade brasileira (numa perspectiva histórica - social), seus problemas emergentes e de que forma, como futuros arquitetos, se pode contribuir, atuando sobre esses processos culturais, através da atividade criadora, no campo da arquitetura. 
- Considerações sobre o trabalho de estúdio

É certo que todos os trabalhos de projeto desenvolver-se-ão em torno do estúdio. Entende-se por projeto uma proposta cultural como manifestação de soberania. A compreensão deste princípio, desde a década de 50 do século XX, no Brasil, não foi, nem tem sido, de fácil assimilação, inclusive pela nossa própria categoria. Contém em si a idéia de emancipação de nossa cultura técnica e artística, da continuidade temporal de nossa nacionalidade. Busca-se a descolonização da consciência dos arquitetos dentro da cultura na qual exercitam seu ofício. Nossa escola deve educar seus alunos de forma a que estes conheçam a fundo as questões brasileiras para que possam cogitar sobre estas. Outra questão é não se furtar de buscar um trabalho de síntese. “Como, a partir dos recursos modernos de análise, as informações sobre determinada questão se multiplicam, vivem alguns arquitetos a fazer propaganda de um trabalho de equipe em que desaparecem, inibem-se e furtam-se de assumirem a responsabilidade de enfrentar a síntese em obra projetada que as sofisticadas informações complicam deveras. Confundem-se as informações dos planejamentos com os projetos. A posição colonizada que se caracteriza pelo 'não sabemos' atribui a outros setores da cultura responsabilidades nossas... também se atribui a estrangeiros na constante procura de liderança metropolitana... há uma crítica de colonizados empregada a denegrir os nossos melhores resultados". ${ }^{36}$

O perfil do arquiteto a formar deve ser o mais variado possível, de personalidade multifacetada e baseado no mais amplo sistema de informações de forma a poder contarmos, futuramente, com arquitetos nos mais variados ramos de atividades sociais, formando-os para desempenharem as mais variadas missões.

Educar os alunos na compreensão e convicção de que o desenho é a forma de

${ }^{36}$ J.B. Vilanova ARTIGAS, Contribuição para o relatório sobre ensino de Arquitetura. UIA-UNESCO IAB/ SP, 1971 
expressão e linguagem das pesquisas mais profundas e de síntese, as mais complexas.

"Exato como os recursos da ciência". ${ }^{37}$

Finalmente deve-se evitar eleger temas inéditos ou pouco estudados e explorados. Jamais "criar" sem experiência, afinal "a única ciência da arte é a História". ${ }^{38}$ Por outro lado, lembrar que o TFG não é aprendizado, apenas.

\section{AVALIAÇÕES}

Devem ocorrer, ao longo do processo anual de orientação, quatro avaliações e uma Banca Avaliatória Final, de acordo com normas do MEC, que outorgará ao graduando o título de Arquiteto e Urbanista. Os critérios que estabelecem as avaliações consideram os ditames do Regulamento do TFG da Escola da Cidade.

- Avaliações Bimestrais

Avaliação 1

Procedida pelo professor orientador, e pelo professor da cadeira "Metodologia \& Conteúdos do Discurso e da Linguagem", instrumento de suporte metodológico e de compreensão da linguagem e do discurso do trabalho em progresso. Eventualmente solicitar-se-á o concurso auxiliar de professores das áreas de concentração de História, Tecnologia e Desenho e do Coordenador do TFG.

Será avaliada a capacidade do aluno de expor, enfrentar e desenvolver na sua área ou linha de pesquisa temática pretendida ou buscada:

O problema proposto

Relevância da pesquisa na área e temática propostos.

Objetivos teóricos e práticos

\footnotetext{
37 Idem, ib. 
Objeto de conhecimento

Objeto de estudo e sua abrangência

\section{- Avaliação 2}

Procedida por cada professor orientador, o coordenador do programa da "escola itinerante" e, se convocado, o coordenador do TFG. Inclui-se nesta avaliação ponderação sobre relatórios de avanço do trabalho durante o período e o processo de pesquisa ao longo do calendário bimestral das atividades:

Escola Itinerante

Tutoria Estúdio Vertical

Seminários da Cultura Brasileira.

Será avaliada a capacidade do aluno de expor, enfrentar e desenvolver na sua área ou linha de pesquisa pretendida, buscada:

Objeto de estudo e sua delimitação

Hipóteses

Metodologia de pesquisa e as ações que testam as hipóteses

Produtos parciais e produtos finais esperados

Ensaios exploratórios e estudos preliminares desenvolvidos através da linguagem do desenho, principalmente.

- Avaliação 3

Procedida pelo professor orientador em conjunto com outro professor do corpo de orientadores do TFG. Inclui-se nesta avaliação ponderação sobre relatórios de avanço do trabalho durante o período e o processo de pesquisa ao longo do calendário bimestral das atividades:

Escola Itinerante

Tutoria Estúdio Vertical

Seminários da Cultura Brasileira. 
Verificar-se-á ainda em nível de Estudo Preliminar, em escala adequada, de menor módulo que o da avaliação 2, os conteúdos que compreendem :

Qualidades da proposta no que contempla a cidade, a vizinhança do sítio objeto de estudo, a permeabilidade desta e sua continuidade e as articulações e elos espaciais propostos.

Qualidades da proposta no que contempla o trinômio : Implantação, Circulação e Estrutura, verificando-se a coerência desse todo com o Programa proposto pelo aluno.

Qualidade da Representação Gráfica

Planos de Massa, Volumes, Cheios e Vazios, Percursos, Funcionalidades.

Resultado

Nesta etapa será julgada a condição do trabalho, sua coerência geral, particularidades que merecem maior aprofundamento por parte do autor e se o todo possui qualidades que justifiquem sua continuidade. Na ocasião poderá ser emitido comunicado sucinto por escrito, sobre esta etapa avaliatória para conhecimento e anuência do aluno, ponderando sobre a conveniência do prosseguimento dos trabalhos.

Os critérios sugeridos para a avaliação são:

Implantação e Circulação

Verificar se o plano geral está correto e a circulação vertical, horizontal e suas hierarquias.

Peso do item 3

Programa e Áreas

Verificar se a proposição está contemplada e o dimensionamento é apropriado

Peso do item 1

Estrutura

Verificar examinar se partido estrutural e seus conceitos de suporte estão definidos ou esboçados. Se estes se apresentam explicitados de forma ingênua ou se estes são ausentes orientar novamente o aluno com forte ênfase nestas questões (retomando- 
se aulas já ministradas se for possível). Examinar condições de estabilidade e dimensionamento das proposituras. Eventualmente encaminhar o aluno para orientação específica e precisa dos professores as cadeiras do curso de Técnicas.

Peso do item 3

Funcionalidade

Considerando programa e tema, verificar se o todo está contemplado ou atendido, se apresenta pequenas omissões ou erros evidentes.

Peso do item 1

Apresentação e Precisão dos desenhos

Verificar qualidade da leitura do trabalho apresentado e se a representação pelo desenho é correta e suficiente ou os desenhos são ingênuos ou mesmo insuficientes e inadequados. Eventualmente encaminhar o aluno para orientação específica e precisa dos professores as cadeiras do curso de Desenho.

Peso do item 2

Os pesos dos itens acima são apenas orientativos, podendo ser revistos e readequados pelos orientadores e avaliadores envolvidos com esta etapa em função das abordagens desenvolvidas e metas pretendidas.

- Avaliação 4 - Qualificação

Procedida conjuntamente por três professores um do corpo do TFG, outro do estúdio vertical, com a participação do orientador responsável pelo desenvolvimento do trabalho do aluno. Verificar-se-á, em nível de anteprojeto, em escala adequada, de menor módulo que o da avaliação 3, os conteúdos da avaliação anterior com ênfase na coerência, clareza das conclusões e méritos do todo, para ser submetido a Banca Avaliatória do TFG. Tal avaliação também será considerada para qualificação, pelo Coordenador do TFG e pelo professor da atividade Razões do 
emitido comunicado sucinto por escrito, sobre esta avaliação bimestral final e qualificatória, para conhecimento e anuência do aluno, ponderando sobre a oportunidade de seu trabalho ser defendido face à Banca Avaliatória de Conclusão de Curso.

Ficha avaliatória da qualificação:

\begin{tabular}{|c|c|c|}
\hline Conteúdos Avaliados & Orientações e Comentários & Notas/Pesos \\
\hline \multicolumn{3}{|l|}{ Ambiente } \\
\hline \multicolumn{3}{|l|}{ Cidade } \\
\hline \multicolumn{3}{|l|}{ Implantação } \\
\hline \multicolumn{3}{|l|}{ Espaços } \\
\hline \multicolumn{3}{|l|}{ Públicos \& Privados } \\
\hline \multicolumn{3}{|l|}{ Circulações\& } \\
\hline \multicolumn{3}{|l|}{ Permeabilidade } \\
\hline \multicolumn{3}{|l|}{ Estrutura } \\
\hline \multicolumn{3}{|l|}{ Concepção } \\
\hline \multicolumn{3}{|l|}{ Ordem e Lógica } \\
\hline \multicolumn{3}{|l|}{ Estabilidade } \\
\hline \multicolumn{3}{|l|}{ Volumes } \\
\hline \multicolumn{3}{|l|}{ Cheios e Vazios } \\
\hline \multicolumn{3}{|l|}{ Funções ordenadas } \\
\hline \multicolumn{3}{|l|}{ Programa adequado } \\
\hline \multicolumn{3}{|l|}{ Desenhos } \\
\hline \multicolumn{3}{|l|}{ Expressão Representação } \\
\hline \multicolumn{3}{|l|}{ Leitura } \\
\hline \multicolumn{3}{|l|}{ Textos / Memoriais } \\
\hline \multicolumn{3}{|l|}{ Coerência } \\
\hline \multicolumn{3}{|l|}{ Conjunto } \\
\hline \multicolumn{3}{|l|}{ Leitura e compreensão da } \\
\hline & & \\
\hline \multicolumn{3}{|l|}{ Observações } \\
\hline \multicolumn{3}{|l|}{ Comentários } \\
\hline Recomendações & & \\
\hline
\end{tabular}




\section{- Avaliação Final}

Banca Avaliatória de Conclusão de Curso.

Os critérios mínimos de avaliação dos trabalhos apresentados, além daqueles que poderão ser livremente aplicados pelos Professores Convidados na análise e avaliação final dos trabalhos, são os que seguem:

Atualidade de conceitos e teorias utilizados no desenvolvimento da proposta;

Metodologia empregada no trabalho;

Conteúdo e qualidade dos elementos apresentados;

Coerência da proposta apresentada;

Fundamentação conceitual do trabalho;

Linguagem adequada;

Organização e apresentação do trabalho.

Os documentos comprobatórios da realização das bancas é composto por uma ficha de avaliação do aluno (a ser preenchida pelo prof. orientador e em seguida encaminhada, à secretaria, ao final da sessão), duas vias da ata da sessão, sendo uma a ser entregue devidamente preenchida ao aluno e a outra via encaminhada à secretaria ao final dessa sessão. Recomenda-se consultar sempre o regulamento do TFG.

Serão entregues certificados de participação a todos os membros convidados da Banca. Os alunos depositarão os produtos finais de seu trabalho junto a Coordenação do TFG, conforme calendário e ordenações do regulamento do TFG 2007.

Transcrevemos abaixo, com adequações do texto original pelo coordenador do TFG 2007, o Regulamento do TFG propugnado pela Comissão de Arquitetura e Urbanismo do Ministério da Educação - no que diz respeito às Bancas Finais de Avaliação:

Artigo 32 - A avaliação do Trabalho Final de Graduação apresentado pelo graduando será pública e feita perante Banca Examinadora composta por três membros da Comissão de Avaliação aprovada pelo Conselho Departamental. 
$\S 1^{\circ}$ - A Banca Avaliatória será composta pelo Professor Orientador, que presidirá seus trabalhos, por um Professor Convidado pertencente ao quadro docente da Escola da Cidade e, finalmente, por um Professor Arquiteto não pertencente ao quadro docente da Escola da Cidade, que tenha identidade com o tema a ser apresentado.

(..)

$\S 4^{\circ}$ - A ausência de um dos membros da Banca Examinadora na sessão pública de avaliação implicará no agendamento de nova data para sua realização, dentro dos prazos previstos no Programa de Atividades do TFG.

$\S 5^{\circ}$ - A avaliação final consistirá na argüição oral dos aspectos que forem particularmente relevantes com base no Trabalho Final apresentado pelo graduando e em sua exposição para a Banca Avaliatória.

$\S 6^{\circ}$ - Após a apresentação do Trabalho pelo examinando e sua argüição pelos membros da Banca Examinadora esta, em sessão secreta, se manifestará por escrito, elaborando ata com a avaliação e justificativa de cada um de seus integrantes, em duas vias, sendo uma via entregue ao examinando e outra encaminhada à Coordenação.

$\S 7^{\circ}$ - A Ata da sessão de avaliação, subscrita pelos membros da Banca Examinadora, será documento oficial da Escola da Cidade e será considerada como Certificado de Conclusão do TFG - Trabalho Final de Graduação.

\section{CORPO DE PROFESSORES}

Coordenador TFG

Responsável Escola Itinerante

Estúdio

- Professores Orientadores

Álvaro Luís Puntoni

Anália Amorim
Prof. Julio Camargo Artigas

Prof. Ruben Otero 
Celso Pazzanese

Guilherme Mendes da Rocha

Guilherme L. Motta

Fábio Rago Valentim

José Armênio B. Cruz

Newton Massafumi

Paulo Brazil E. Sant'Ana

Pedro Rivaben Sales

Ricardo Caruana

Ruben Otero

Vera Lúcia Domschke

- Metodologia - Conteúdos do Discurso e da Linguagem

Diana Micheline Cohen

- Razões do Construir - Conteúdos Históricos e Sociais da Técnica

Pedro Paulo de Mello Saraiva

- Prática e Exercício Profissional

Marcos Valentim

Marina Grinover

Renato Cymbalista

Versão final 2 de abril de 2007

Programa da Escola Itinerante no $5^{\circ}$. Ano

\section{CONTEÚDOS}

Dentre as atividades do primeiro semestre no sentido de construir o Trabalho Final de Graduação é parte da programação de pesquisas iniciais buscando objetivar o 
projeto a ser submetido à banca avaliatória, o deslocamento do aluno de forma que permita incorporar-se a uma instituição que já possua vínculo pedagógico com a Escola da Cidade, na intenção de integrar-se por tempo determinado a um ou mais processos de conhecimento ou mesmo de reconhecimento de projetos implantados ou em execução, sobre temática pertinente ao seu pretendido escopo de trabalho. As atividades do aluno na instituição que irá recepcioná-lo deverá ser ordenada e programada antecipadamente, já com o concurso do professor orientador, no primeiro bimestre letivo do ano de Formação, O orientador também deverá manter contato com professor ou responsável, membro da instituição que recepcionará o aluno a fim de acompanhar as atividades do orientado e o progresso das tarefas avançadas na itinerância programada.

Este deslocamento é obrigatório, sendo conteúdo curricular programado na agenda da escola e deve ser cumprido num prazo mínimo de quarenta e cinco dias e num prazo máximo de noventa dias. O processo de acompanhamento e orientação do aluno procederse-á por meio da elaboração de "relatórios de avanço" quinzenais, do processo de aprendizado, sendo que estes devem ser encaminhados para a sede da Escola, ao professor orientador, de preferência por meio da rede mundial de computadores, que procederá à sua avaliação e responderá da mesma forma, enviando a orientação sobre os itens e conteúdos a serem explorados e procurados, no ambiente de estudo elegido.

Os relatórios consubstanciarão um dialogo que agreguem conteúdos e conhecimento arquitetônico entre Escola, Instituição e aluno, o professor orientador será o receptor desse diálogo e seu comentarista / avaliador conclusivo, procedendo a avaliação pedagógica da itinerância. A conclusão desse deslocamento que busca agregar conteúdos e experiências ao TFG em progresso, deve ocorrer antes da terceira avaliação bimestral e o relatório final dos seus resultados, elaborado pelo professor orientador, será quesito considerado nessa avaliação bimestral e deve habilitá-lo a prosseguir seus estudos. 


\section{FORMAS DE DESLOCAMENTO}

O local sede do deslocamento pode ser um ou mais de um, se justificado, em território brasileiro ou no exterior e os estudos vinculados ao TFG e as relações entre este e os objetos de estudo programados, claramente relacionados. Os processos de enriquecimento do saber e embasamento do trabalho, por parte do aluno, devem ser claramente estabelecidos de forma inicial e serão aprofundados ao longo da vivência didática pedagógica então em curso.

\section{AS INSTITUIÇÕES}

A Escola reconhece, desde que submetido à sua anuência, qualquer instituição pessoa jurídica ou física, como instituição capacitada a receber o alunado. Assim desde determinado estúdio individual de arquiteto a uma grande empresa estabelecida no mercado, organizações não governamentais, empresas e autarquias públicas, Secretarias de Estado, Municipais, Estaduais ou Federais e, primordialmente, Escolas de Arquitetura Centros Universitários e Universidades. O aluno poderá realizar, excepcionalmente, sua pesquisa de forma autônoma, visitando sítios, instituições ou empreendimentos, desde que sua proposta de aprendizado seja submetida antecipadamente à coordenação do TFG.

\section{CONTATOS EXISTENTES}

Até o presente momento os contatos estabelecidos entre a direção da Escola, ou seus professores e entidades de interesse para intercambio são as seguintes:

- Universidades

Ritter dos Reis, Porto Alegre, Brasil

Universidade de Lisboa, Portugal 
Universidade de la República, Montevidéu, Uruguai

Universidad de los Andes, Bogotá, Colômbia

Università degli Studi, Nápoles, Itália

University of Florida, Geinsville, FL, EUA

Instituto Politécnico de Monterrey, México

- Instituições

Casa Vilanova Artigas em Curitiba, Paraná

Centro Técnico Rede Sara-CTRS, Salvador, Bahia

Secretarias de Estado

Secretaria de Planejamento de Sobral, Ceará

- Estúdios, Escritórios, Empresas

Architekt Mathias E. Frey Basel, Suíça

Gladys Architects, Amsterdã, Holanda

\section{Estúdio Vertical como instrumento didático}

O que destaca e particulariza o plano e as atividades de trabalho em estúdio como prática didática são as atividades e exercícios acadêmicos elaborados no decorrer dos dois cursos (temas) semestrais do Estúdio Vertical. Os exercícios e temas desenvolvidos constituem-se no motivo e na ação de atividade principal da escola, pelo fato de envolver alunos do $2^{\circ}$ ao $5^{\circ}$ ano com um tema projetual comum de discussão e aprendizado. Cabe destacar que a diversidade de abordagens ao longo da semana didática através das aulas 
expositivas específicas da formação do arquiteto, os seminários sobre cultura brasileira - conforme explicitado nas páginas 217 e seguintes - procuram confluir para as aulas do Estúdio, exercidas por um conjunto variado e distinto, composto por grupos de professores orientadores, um tutor e por mais três professores arquitetos, pelo menos, apoiados, em ocasiões específicas, previamente agendadas, por professores das áreas de técnica e história. Essa condição de trabalho pedagógico pretende contribuir amplamente para as discussões sobre os temas desenvolvidos e sua compreensão pelos orientados. Eles são absorvidos na medida da capacidade de síntese de cada aluno - por certo desigual, pois envolve o repertório de conhecimento arquitetônico de cada um, que também é desigual por conta do tempo de educação em arquitetura vivenciado na escola e que independe do tempo de inclusão, pois decorre do grau de interesse do alunado.

A condição de trabalho em equipe, tanto por parte dos alunos como na orientação dos professores do estúdio, é o esforço que se busca na consolidação dos exercícios em progresso, visando ordenar as questões de método de abordagem dos temas, tratados como problemas, e as atividades de orientar suas interpretações e concepções no âmbito da realidade brasileira, temática constante dos trabalhos.

Os produtos elaborados refletem a capacitação e a dedicação dos grupos de trabalho do corpo discente que concebem soluções com méritos distintos. Os projetos demonstram qualidades e submetidos à avaliação didática - considerando-se metas e méritos previamente acordados e didaticamente explicitados e comparando os diferentes produtos didáticos elaborados - espelham a capacitação de cada grupo, tanto no que diz respeito ao conhecimento como na sua capacidade de estabelecer soluções 
e conclusões, de forma a contemplar as questões solicitadas pelo projeto. É patente que não ocorre uma homogeneidade no plano dos resultados projetuais, que variam da solução medíocre até a de destaque enquanto síntese, conceituação e concepção final. Essa é a grande questão a ser construída pelos professores e alunos no decorrer de um período de pelo menos cinco anos de exercícios, nos quais os alunos são orientados e instruídos de forma conjunta em função de temáticas variadas. Trata-se de um processo de interpretações e consolidação de métodos por certo variados, se não diferentes, de concepção arquitetônica, apoiados na proposta didática de formação de arquitetos no estúdio de projetos, em sua capacitação para o exercício do ofício e em sua capacitação intelectual ao longo de sua vida de prática profissional (ver página 219 e seguintes).

Na tutoria que exerci em 2005 no Estúdio Vertical verifiquei que a didática utilizada na Escola da Cidade reunindo todos os alunos para pensar uma mesma temática, compondo grupos hierarquicamente organizados, foram momentos muito ricos para o amadurecimento mais rápido dos alunos para enfrentar as demandas universitárias, como a crítica e a pesquisa.

Há um bom relacionamento entre todos os alunos da Escola, não havendo, portanto, formação de grupos fechados, o que é uma conseqüência do trabalho desenvolvido no Estúdio Vertical.

O eixo temático desenvolvido nessa ocasião foi o de habitação, cujo programa está anexo. 


\section{Lares Periféricos}

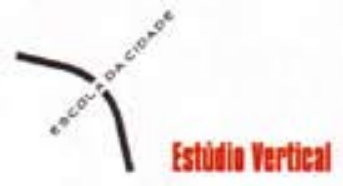

O exercicio será desenvolvido em 4 módulos, com aproximadamente 30 dias cada um.

Concluindo cada um dos três primeiros módulos a Equipe tem avaliaçóes feitas por seu orientador. A avaliaçấo final será objeto de banca formada por três professores, o orientador, um professor do EV e um professor do primeiro tempo.

Os cronogramas deverão ser estritamente seguidos.

Abordagem pótico-conceitual do Morar; Bibliografia e arquiteturas exemplares; Programa para três casas;

Materiais de construçắ e técnicas construtivas para a habitação.

O exercício desenvolver-se-á numa área lindeira à adutora da Sabesp em Sapopemba.

Objetivo Geral: desenvolver projeto de arquitetura a partir de uma premissa dada.

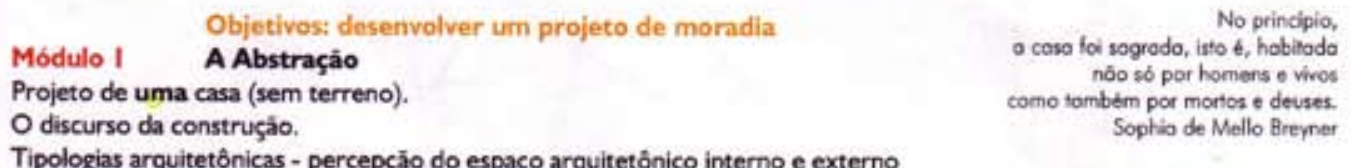

Hábitos do morar.

O que é uma moradia contemporainea?

Tecnologia: Processo Construtivo e Partido Estrutural.

I:50

Apresentaçâo ao Orientador.

planta, corte, elevachio + maquete

AVALIAÇÁO I- Nota Individual $(0$ a 10)

Objetivos: adequar as casas ao terreno

Módulo 2 A Inter-açáo

A partir do projeto anterior, projetar três casas adequando-as à topografia.

Implantaçáo e topografia. A orientaçáo e as aberturas da casa.

0 discurso do bairro. A cidade perto.

1:50 e 1:100 Apresentaçắo ao Orientador. plantas, 2 cortes, elovaçóes + maquetes

AVALIACCĀO 2- Nota Individual (0 a 10)

Objetivos: adequar a moradia à cidade de forma critica Apresentaçăo do entorno imediato do terreno $(500 \times 500 \mathrm{~m})$.

Módulo 3 A Vizinhança

Revisão dos projetos anteriores.

Implantar as casas na quadra de Sapopemba. Constituiçáo de uma

"freguesia". Diálogo entre esses objetos arquitetônicos e a cidade real.

I:200

A cidade longe. As vias de conexảo. Os equipamentos de uso público.

Habitabilidade.

Inter-relacionar a "freguesia" à cidade circundante.

O desenho da cidade próxima: a calçada, o ponto de ônibus, o mercado ou

a escola. Sempre, a casa como construçáo.

I:25 e 1:50 Apresentaçấo aos Orientadores (3).

implantaçio geral, plantan, cortes, nlevaçōer + maquutes AVALIAÇÁO 3- Nota Equipe ( 0 a 10)

\section{Módulo 4 A Construçáo}

Revisáo do projeto anterior.

Conjunto edificado.

Como a habitaçăo vira cidade?

Verticalização da soluçảo horizontal?

Da unidade ao conjunto.

I: $10,1: 25$ e $1: 50$ Banca

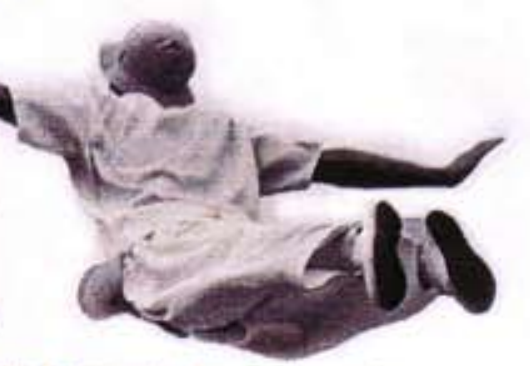

Objetivos: entender a habitaçào e os meios de sua produção

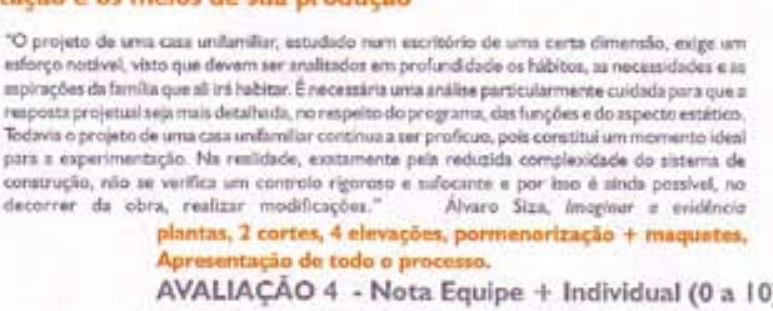

desenhar em follhas de papel manteiga $50 \times 70 \mathrm{~cm}$

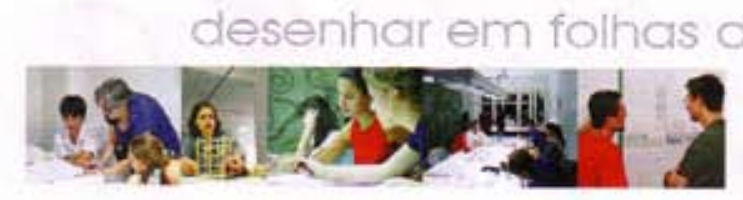




\section{Conclusão}

Não é nova a preocupação com a fragmentação do ensino que ocorre nas faculdades de arquitetura e urbanismo: a integração insuficiente dos conhecimentos teóricos e técnicos do aluno, necessários à formação do arquiteto. Já em 1977 pude vivenciar a experiência no nível interdisciplinar no Departamento de Projeto, como aluna do primeiro ano da FAUUSP.

Essa experiência integrou duas disciplinas do Departamento de Projeto, a AUP 100 - Introdução ao Projeto e AUP 400 - Meios de Expressão e Representação (Introdução ao Desenho Industrial). A integração se fez pelo contato direto dos estudantes com três vilas da periferia de São Paulo, onde convivemos mais proximamente com as populações que estavam se estabelecendo na região, com problemas de loteamento clandestino, não-atendimento das necessidades básicas em infra-estrutura e não-atendimento das necessidades básicas de vida comunitária e até mesmo individual. Essa vivência nos mostrou qual a população mais carente de soluções arquitetônicas e urbanísticas. Apesar da complexidade do tema e do objetivo de ensinar a elaboração de projetos referentes a ele, essas disciplinas foram adequadas para o nível de vivência e de conhecimento dos alunos do $1^{\circ}$ ano, mas nem por isso o ensino foi necessariamente limitado ou menos complexo. Tendo em vista o fato de não ser vasta a formação teórica e abstrata dos alunos nessa fase de sua formação, foi necessário maior controle do complexo de variáveis com que trabalhávamos. Essas variáveis, que dependem da bagagem cultural e vivência que os alunos trazem consigo, levam à possibilidade de criação de novas soluções (fixação de determinadas combinações de variáveis).

O conceito de ensino é o esclarecimento e entendimento das contradições existentes na realidade em que qualquer solução só é relativa e, em parte, 
modificadora dessas contradições. Isso levou os estudantes a perceber que uma proposta nunca é a solução ou eliminação de uma contradição. Assim, durante nosso curso, nunca houve a frustração provocada pela relatividade das soluções apresentadas, pois a relatividade era pressuposto fundamental para a discussão e entendimento das contradições existentes na realidade.

O exercício foi desenvolvido em equipes. Nossa equipe estabeleceu a variável do programa, extraída das entrevistas realizadas com os moradores da região: a construção de uma padaria. Outra variável, que era demanda do programa do curso, foi a tecnologia alternativa para a construção da padaria - a taipa de solo cimento. Para isso, desenvolvemos o projeto da forma e construímos um protótipo a partir de modelos e ensaios de laboratório.

Atualmente as disciplinas do primeiro semestre do primeiro ano do Departamento de Projeto da FAUUSP foram fundidas em uma única disciplina, a AUP 608 - Fundamentos de Projeto, que trouxe uma mudança conceitual. A fragmentação do ensino da Arquitetura em diversas disciplinas se transformou em uma única disciplina, com os diferentes enfoques convergindo para um mesmo objeto de estudo.

Uma solução diferente para esse mesmo problema, o da fragmentação do ensino, foi realizada na FAU da Universidade Católica de Santos, com a integração horizontal. Uma mesma temática é abordada por todas as disciplinas sob diferentes enfoques, de acordo com as especificidades de cada uma delas.

Portanto, nesta forma de integração, o princípio regulador do aspecto didático não permite que cada estudante elabore sua síntese isoladamente, mas há uma condução clara na proposta de ensino para que o aluno perceba a inter-relação entre as disciplinas. A integração horizontal proporciona ao estudante uma experiência mais ampla e versátil das atribuições profissionais 
do arquiteto e de seus objetos de trabalho, envolvendo as disciplinas em discussões abrangentes sobre a cidade, a arquitetura, a história e as artes. Muitas atividades resultaram em viagens de estudos, trabalhos e aulas em conjunto com as disciplinas, gerando uma nova abordagem didática.

É possível que o ateliê da integração vertical na FAUS tenha sido colocado em prática de forma acanhada, pelo fato de não ter a escola estrutura de suporte para incorporá-lo.

Essa questão permeou a história da escola a partir do debate realizado no ano de 2000 sobre o Projeto Político Pedagógico. O resultado da discussão sobre a implantação do ateliê vertical não reverteu em sua real aplicação na estruturação do curso. A fragmentação que, como já vimos, é mal endêmico nas escolas de arquitetura, em Santos configurou-se de modo mais abrangente. O modo de superação dessa dificuldade bifurcou-se em duas teses, se não opostas, pelo menos conflitantes naquele momento. Numa posição sólida, porque amparada em experiência realmente vivenciada e com forte apoio no meio estudantil, a proposta organizada pelo professor Paulo Bastos resultava numa reestruturação da escola a partir da montagem de uma estrutura verticalizada, em que alunos de vários anos constituiriam estúdios de trabalho em comum, superando, desse modo, a mencionada fragmentação. Entretanto, outro grupo de professores tentava, de modo organizado e competente, superar essa mesma dificuldade através de uma estrutura horizontalizada, em que a integração se fazia pelo arranjo e equilíbrio entre as diversas disciplinas.

Essas tentativas, apoiadas pela diretoria da escola em várias gestões consecutivas, encontraram um grupo de professores entusiasmados com a idéia. A experiência foi muito produtiva, mas não conseguiu superar o conflito entre as tendências da própria escola. De modo que, assim que a experiência 
perdeu o apoio direto da direção, ela se esvaiu, resultando no que nenhum dos grupos desejava: a ausência absoluta de um projeto de restauro da fragmentação pedagógica da escola.

A integração horizontal foi bem recebida pelos estudantes. Contudo, como alunos do $1^{\circ}$ ano, tinham pouca familiaridade com os problemas da escola, não sendo, naquele momento, capazes de perceber que o exercício proposto tinha a intenção de evitar a fragmentação estrutural do curso. O que não se percebeu na época foi que a coexistência de duas propostas consistentes - a integração horizontal e o ateliê vertical - era um ganho de qualidade e não um conflito. As dificuldades reais para a implantação desses modelos pedagógicos estavam na estrutura da própria escola, que naquele momento apresentava uma mudança importante no perfil do aluno que nela ingressava, na baixa renda e no nível de formação de seus estudantes, etc... De certo modo, a escola se alterava como um todo, e as propostas passaram a estar cada vez mais distantes do quadro real que a conjuntura apresentava.

A Escola da Cidade foi estruturada em função do estúdio vertical, para se opor à fragmentação dos saberes em matérias estanques. Sua prática é fundamental, porém seus ajustes são previsíveis.

Embora sua aplicação seja a ideal na formação dos alunos, não deixa de apresentar alguns desajustes, que, certamente, podem ser corrigidos com o tempo.

A integração horizontal, eliminando a fragmentação do ensino, conduz o aluno à síntese da problemática que diz respeito ao ofício de arquiteto. 0 estúdio vertical, concentrando o estudo numa temática que envolve alunos de todos os anos, capacita o estudante a uma abordagem abrangente dos problemas da cidade. 


\section{Bibliografia}

\section{Livros}

ARGAN, Gian. C. El concepto del espacio arquitetónico: del barroco a nuestros dias. Buenos Aires: Nueva Visión, 1966.

Progetto e destino. Milano, Il Saggiatore, 1968.

Walter Gropius e a Bauhaus. 2. ed. Lisboa: Presença, 1990.

ARTIGAS, João B.V. O encontro de especialistas sobre o ensino de arquitetura. In: Caminhos da Arquitetura. São Paulo: Lech, 1981.

- Rumos para o ensino da arquitetura. In: Caminhos da arquitetura. São Paulo: Lech, 1981.

A função social do arquiteto. São Paulo: Nobel, 1989.

BIERMANN, Verônica et al. Teoria da arquitetura: do Renascimento aos nossos dias. Colônia: Taschen GmbH, 2003.

BOULLÉE, Étienne-L. Architecture. Essai sur l'art. Paris: Hermann, 1968 (Miroirs de l'Art).

COLLINS, Peter. Los ideales de la arquitectura moderna: su evolución (1750-1950). trad. I. Solá Morales R. Barcelona: Gustavo Gili, 1970 (Arquitectura y crítica).

CORREA, Charles. Learning from Ekayala. In: POLLAK, Martha. Education of the architect. Cambridge: MIT Press, 1997.

COSTA, Lúcio. A arte e a educação. In: Leituras de arquitetura contemporânea. São Paulo: Faculdade de Arquitetura e Urbanismo da Universidade de São Paulo, v. 1, 1962.

. Lúcio Costa: sobre arquitetura. Porto Alegre: Centro dos Estudantes Universitários de Arquitetura, 1962.

DE FEO, Vittorio. Arquitetura construtivista - URSS 1917-1936. São Paulo: Worldwhitewall Ed., 2005.

DURAND, Jean-N.L. Précis of the lectures on architecture. Los Angeles: Getty Research Institute, 2000. 
FICHER, Sylvia. Os arquitetos da Poli: ensino e profissão em São Paulo. São Paulo: Fapesp/Editora da Universidade de São Paulo, 2005.

FRAMPTON, Kenneth. Historia crítica de la arquitectura moderna. Barcelona, Espanha: Gustavo Gili, 1987.

FRÉART, Roland, S.C. Parallèle de l'architecture antique avec la moderne. Paris: L'imprimerie d'Edme Martin, 1650 (ed. fac-símile: Genève: Minkoff Reprint, 1973).

GAILLARD, Christian. In:VVAA. Espaces des sciences humaines - questions d'enseignement en architecture. Paris: Institut de I'Environnement, 1972.

GOROVITZ, Matheus. Os riscos do projeto: contribuição à análise do juízo estético na arquitetura. São Paulo: UNB/Nobel, 1993.

GRAEFF, Edgar A. Arte e técnica na formação do arquiteto. São Paulo: Nobel/Fundação Artigas, 1990.

Três categorias artísticas na arquitetura. Porto Alegre: Centro dos Estudantes Universitários de Engenharia, s. d.

GROPIUS, Walter. Programm des Staatlichen Bauhauses. Weimar, 1919.

. Scope of total architecture. New York: Harper \& Brothers, 1955.

Bauhaus: novarquitetura. 2. ed. São Paulo: Perspectiva. 1972.

HERBERT BAYER, Ise; GROPIUS, Walter. Bauhaus: 1919-1928. New York: Museum of Modern Art, 1938.

HERTZBERGER, Herman. Lições de arquitetura. São Paulo: Martins Fontes, 1999. Space and the architect. Rotterdam: 010 Publishers, 2000.

ITTEN, Johannes. Design and form. Revised edition. The basic course at the Bauhaus and later. London: John Wiley \& Sons, Inc. and Thames and Hudson Ltd., 1975.

KAUFMANN, Emil. Tres arquitectos revolucionarios: Boullée, Ledoux y Lequeu. trad. X. Blanquer et al. Barcelona: Gustavo Gili, 1980 (Biblioteca de Arquitectura).

LAUGIER, Marc-A. Essai sur l'architecture. Paris: Duchesne Libraire, 1755 (ed. fac-símile. - Bruxelles: Pierre Mardaga, 1979). 
LE CORBUSIER. Précisions sur un état présent de I'urbanisme. Paris: Éditions Vincent, Fréal \& Cie, 1960.

MAHFUZ, Edson da Cunha. Ensaio sobre a razão compositiva: uma investigação sobre a natureza das relações entre as partes e o todo na composição arquitetônica. Viçosa: UFU, Belo Horizonte: AP Cultural, 1995. 176 p.

MARTSON FITCH, James. Architecture and the esthetics of plenty. New York: Columbia University, 1961.

NERVI, Pier Luigi. Costruire corretamente. Milano: Ulrico Hoepli, 1965.

OLIVEIRA CAVALCANTI, Nireu. Arquitetos e engenheiros: sonho de entidade desde 1789. Rio de Janeiro: Crea-RJ, 2007.

POLIÃO, Marco Vitrúvio. Da arquitetura. São Paulo: Hucitec: Annablume, 2002.

RYKWERT, Joseph. Los primeros modernos: los arquitectos del siglo XVIII. trad. J. Beramendi. Barcelona: Gustavo Gili, 1982 (Biblioteca de arquitetura).

SEVERINO, Joaquim Severino. Metodologia do trabalho científico. São Paulo: Editora Cortez, 2002.

TAFURI, Manfredo et al. Constructivismo ruso. Barcelona: Ediciones Del Serbal, 1994.

VITRÚVIO. Tratado de arquitectura. Tradução de M. Justino Maciel. Lisboa: Cambridge University Press, 2006.

WICK, Rainer. A pedagogia da Bauhaus. São Paulo: Martins Fontes, 1989.

\section{Teses/Dissertações}

ALBUQUERQUE, Roberto P. Uma escola de arquitetura - FAUUSP: edifícios e ensino. 2004. 415 p. Dissertação (Mestrado). Faculdade de Arquitetura e Urbanismo da Universidade de São Paulo. São Paulo.

ARTIGAS, Júlio Camargo. O sonho do morar coletivo: ideologia e projetos modelares. 2007. 294 p. Dissertação (Mestrado). Faculdade de Arquitetura e Urbanismo da Universidade Presbiteriana Mackenzie. São Paulo.

AZEVEDO TEIXEIRA, Kátia A. Ensino de projeto: integração de conteúdos. 2005. 223 p. Tese (Doutorado). Faculdade de Arquitetura e Urbanismo da Universidade de São Paulo, São Paulo. 
BARDI, Lina B. Contribuição propedêutica ao ensino da teoria da arquitetura. 1957. 95 p. Tese apresentada ao Concurso da Cadeira de Teoria de Arquitetura. FAUUSP. São Paulo.

BAROSSI, Antônio C. Ensino de projeto na FAUUSP. 2005. Tese (Doutorado). Volumes 1 e 2. Faculdade de Arquitetura e Urbanismo da Universidade de São Paulo. São Paulo.

CALDANA JÚNIOR, Valter L. Projeto de arquitetura: caminhos. 2005. Tese (Doutorado). Faculdade de Arquitetura e Urbanismo da Universidade de São Paulo. São Paulo.

CONTIER, Luiz Augusto. Ensino de arquitetura: aspectos e reflexões sobre sua organização. 2001. 340 p. Dissertação (Mestrado). FAUUSP. São Paulo.

FICHER, Sylvia. Ensino e profissão: o curso de engenheiro-arquiteto da Escola Politécnica de São Paulo. 1989. 787 p. Tese (Doutorado). Faculdade de Filosofia, Letras e Ciências Humanas da Universidade de São Paulo. São Paulo.

GOUVEIA, Anna Paula Silva. O croqui do arquiteto e o ensino do desenho. 1998. Tese (Doutorado). Faculdade de Arquitetura e Urbanismo da Universidade de São Paulo. São Paulo.

HERKENHOFF, Heloisa Lima. Ensino de projeto arquitetônico: caracterização e análise de um suposto modelo, segundo alguns procedimentos didáticos. 1997. 185 p. Dissertação (Mestrado). Universidade de São Paulo, Faculdade de Arquitetura e Urbanismo. São Paulo.

KATAKURA, Paula. O ensino de projeto de arquitetura. 2003. 298 p. Dissertação (Mestrado). Faculdade de Arquitetura e Urbanismo da Universidade de São Paulo, São Paulo.

NARUTO, Minoru. Repensar a formação do arquiteto. 2006. 129 p. Tese (Doutorado). Faculdade de Arquitetura e Urbanismo da Universidade de São Paulo. São Paulo.

NOVITA FORTIS, Sérgio. A formação do arquiteto na Faculdade de Arquitetura e Urbanismo da Unisantos: trajetória, organização curricular e condições de funcionamento no período de 1970 a 2003. 2004. Dissertação (Mestrado). Unisantos. Santos.

MERLIN, José Roberto. Ensino e prática de projeto. São Paulo, 2004. Tese (doutorado). Faculdade de Arquitetura e Urbanismo da Universidade de São Paulo. São Paulo.

PETRACCO, Francisco. Arquitetura: desenho, estrutura \& ritmo. 2005. Tese (Doutorado). Faculdade de Arquitetura e Urbanismo da Universidade de São Paulo. São Paulo. 
PUNTONI, Geraldo Vespaziano. Ensino de desenho: um treinamento da habilidade de fazer desenhos. 1992. Dissertação (Mestrado). Faculdade de Arquitetura e Urbanismo da Universidade de São Paulo. São Paulo.

O desenho técnico e o ato criador do arquiteto. 1997. Tese (Doutorado). FAUUSP. São Paulo.

RIBEIRO DOS SANTOS JUNIOR, Wilson. O currículo mínimo no ensino de arquitetura e urbanismo no Brasil: 1969-1994. 2001. 203 p. Tese (Doutorado). Faculdade de Arquitetura e Urbanismo da Universidade de São Paulo. São Paulo.

STOCKLER E BREIA, Maria Teresa de. A transição de ensino de arquitetura beaux arts para o ensino da arquitetura moderna na Faculdade de Arquitetura Mackenzie - 1947-1965. 2005. 488 p. Tese (Doutorado). Faculdade de Arquitetura e Urbanismo da Universidade de São Paulo. São Paulo.

VIDIGAL, Emerson J. Um estudo sobre o ensino de projeto de arquitetura em Curitiba. 2004. 145 p. Dissertação (Mestrado). Faculdade de Arquitetura e Urbanismo da Universidade de São Paulo. São Paulo.

YURGEL, Marlene. As aventuras de um arquiteto no reino da fantasia da geometria. 1999. Texto sistematizado apresentado à Faculdade de Arquitetura e Urbanismo da Universidade de São Paulo para Concurso de Livre-Docência junto ao Departamento de História e Arquitetura e Estética do Projeto. São Paulo.

\section{Publicações/Folhetos}

ALMEIDA, Elvira et al. Atelier no $1^{\circ}$ Ano. Projeto de Edificações, Desenho Industrial. $1977 / 2^{\circ}$ semestre. Faculdade de Arquitetura e Urbanismo da Universidade de São Paulo, 1978. Edição 500 exemplares.

ANDRADE, Luciana et al. Arquitetura e ensino: reflexões para uma reforma curricular. Faculdade de Arquitetura e Urbanismo da Universidade Federal do Rio de Janeiro - Coordenação de Extensão, 2003.

ANDRADE, Mário. Do desenho. In: Sobre o desenho. São Paulo: Centro de Estudos Brasileiros do Grêmio da Faculdade de Arquitetura e Urbanismo da USP, 1975.

ARTIGAS, João B.V. O desenho. In: Sobre o desenho. São Paulo: Centro de Estudos Brasileiros do Grêmio da Faculdade de Arquitetura e Urbanismo da USP, 1975. 
AZEVEDO, Ricardo M. de. Ensino de arquitetura. Belo Horizonte: XII Congresso Brasileiro de Arquitetos Vilanova Artigas, 1985.

CORONA, Eduardo. I Encontro de professores de história da arquitetura e teorização. Salvador, 1975.

DAHER, Luiz Carlos. Sobre o desejo - digo, o desenho - do arquiteto. In: SEGALL, Museu Lasar. A linguagem do arquiteto: O Croqui. São Paulo: Museu Lasar Segall, 1984.

DESENHO INDUSTRIAL E COMUNICAÇÃO VISUAL. Exposição e debates. São Paulo: Faculdade de Arquitetura e Urbanismo da Universidade de São Paulo, 1970.

DIAS SILVA, Hélio. O projeto pedagógico do curso de Arquitetura e Urbanismo. In: Cadernos da ABEA n. 15, Rio de Janeiro: ABEA, 1995.

FAGGIN, C.A.M. Ateliê na formação do arquiteto: uma análise critica do documento apresentado. São Paulo: FAUUSP. Sinopses, n.n. esp., p. 130-32, 1993.

GOMES, José C. Reflexões sobre o ensino do urbanismo. São Paulo: Faculdade de Arquitetura e Urbanismo da Universidade de São Paulo, 1971.

GUEDES SOBRINHO, J.M. Ajuste conceitual da formação do arquiteto. São Paulo: FAUUSP. Sinopses, n. 19, p. 50-2, jun. 1993.

KATINSKY, Júlio R. Ensinar - aprender: por uma educação criadora. In: VVAA, Contribuição ao ensino de arquitetura e urbanismo. Brasília, Instituto Nacional de Estudos e Pesquisas Educacionais, 1999. Org. GOUVEIA, L.A. de Campos e outros. . Considerações sobre o ensino do desenho técnico. São Paulo: FAUUSP. Boletim Técnico, p. 5-48, n. 6, 1992.

LEFÈVRE, Rodrigo B. Notas de um estudo sobre objetivos do ensino da arquitetura e meios para atingi-los em trabalho de projeto. São Paulo: Faculdade de Arquitetura e Urbanismo da Universidade de São Paulo, s/d.

LEMOS, Carlos A.C. Estudo da história na formação do arquiteto. São Paulo: FAUUSP. Seminário "O Estudo da História na Formação do Arquiteto". Revista Pós, n. esp., 1995.

MACEDO, Silvio Soares. Exercícios gramaticais como instrumento de aprendizado. Rio de Janeiro: UFRJ/Fundação Universitária José Bonifácio, 1998. Encontro de Ensino de Paisagismo em Escolas de Arquitetura, 1. Anais. Rio de Janeiro: UFRJ/Fundação Universitária José Bonifácio, 1998. 
MILLAN, Carlos J. O ateliê na formação do arquiteto. Relatório apresentado pelo Prof. Carlos J. Millan, Coordenador do Grupo de Estudo do Ateliê. Serviço de Documentação, Setor de Publicações. São Paulo: FAUUSP, 1962.

MOTTA, Flávio. Desenho e emancipação. In: Sobre o desenho. São Paulo: Centro de Estudos Brasileiros do Grêmio da Faculdade de Arquitetura e Urbanismo da USP, 1975.

PROJETO POLÍTICO PEDAGÓGICO. Relatório final das atividades do ano 2000. Santos: Faculdade de Arquitetura e Urbanismo da Universidade Católica de Santos, 2000.

ROCHA, Paulo Archias Mendes da. Engendrando o humano (Entrevista a Luiz Carlos Junqueira Filho e Roberto Kehdy). 1998. In: Ide, n. 31, 2. sem. 1998.

RONCONI, Reginaldo Luiz Nunes. Canteiro experimental, mais uma possibilidade para a paixão. São Paulo: FAUUSP. Informativo FAUUSP, n. 2, jul. 1999.

SÃO PAULO. Instituto de Arquitetos do Brasil. Relatório do encontro de especialistas sobre o ensino da arquitetura. Zurich: Unesco, 1970.

UNIVERSIDADE DE SÃO PAULO. FACULDADE DE ARQUITETURA E URBANISMO. GRÊMIO. Textos sobre o ensino de arquitetura /Grêmio da Faculdade de Arquitetura e Urbanismo. São Paulo; GFAU, 1956. 1 v. $30 \mathrm{~cm}$.

VARGAS, Heliana C. Da experiência da disciplina inicial: fundamentos de projeto. In: FAUUSP. Reflexões sobre o ensino em arquitetura e urbanismo no Departamento de Projeto FAUUSP. São Paulo: Faculdade de Arquitetura e Urbanismo da Universidade de São Paulo, 2005-2006.

ZANETTINI, Siegbert. Ensino de projeto na área de edificação. São Paulo: Faculdade de Arquitetura e Urbanismo da Universidade de São Paulo, 1980.

\section{Artigos}

COMAS, C. E. In: COMAS, C. E. (Org.). Projeto Arquitetônico: Disciplina em Crise, Disciplina em Renovação. Projeto, São Paulo, p. 94, 1986.

KATINSKY, Júlio R. Por uma educação criadora [Encarte]. Caramelo, São Paulo, n. 9, p. 239, 1997. . O projeto de edifício como exercício escolar. Caramelo, São Paulo, n. 10, p. 26-38, 1998. 
MAHFUZ, Edson da Cunha. Nada provém do nada. Ensaio e pesquisa. Projeto, São Paulo, n. 69, 1984.

. Os conceitos de polifuncionalidade, autonomia e contextualismo e suas conseqüências para o ensino de projeto arquitetônico. Projeto Arquitetônico: disciplina em crise, disciplina em transformação. Projeto, São Paulo, 1986.

ROCHA, P.A.M. Construir a imaginação. [Depoimento]. Arquitetura e Urbanismo, São Paulo, n. 68, out./nov. 1996.

SAWAYA, Sílvio. O exercício de antever. Arquitetura e Urbanismo, São Paulo, n. 5, 1986.

\section{Internet}

CAMPOMORI, Maurício J. L. O ensino do projeto de arquitetura: multidisciplinaridade, interdisciplinaridade e transdisciplinaridade. Disponível em <http://www.arq. ufmg.br/mauricio/transdic.html>

\section{Imagem/Vídeo}

<http://upload.wikimedia.org/wikipedia/commons/thumb/d/d4/Reliance_Building_ (Burnham_Hotel)_-Chicago,_Illinois.JPG/220px-Reliance_Building_(Burnham_ Hotel)_-Chicago,_lllinois.JPG>

NIEMEYER, Oscar. A vida é um sopro.

\section{Entrevista}

Entrevista com o Arquiteto Júlio Camargo Artigas sobre os croquis do arquiteto, realizada em junho de 2004 na Faculdade de Arquitetura e Urbanismo do Mackenzie pelo professor Fausto P. de Oliveira em pesquisa sobre o croqui. 
Anexos 


\section{Palestras na Universidade Católica de Santos²}

\section{Prof. Aziz Ab'Saber}

Cláudio Abdala (coordenador do Curso de AU - Unisantos): É uma honra para nós termos a presença do professor e geógrafo Aziz Ab'Saber para proferir a aula magna nesse ano de 2004. É um prazer também porque, ter a oportunidade de ouvir o professor, é um privilégio de que, tenho certeza, os alunos aqui presentes e os professores saberão aproveitar. O professor é um homem com vastíssimo trabalho em sua área e em todos os âmbitos que extrapolam geografia. É um profissional de renome internacional, foi professor da Universidade de São Paulo e continua trabalhando no Instituto de Estudos Avançados da Universidade de São Paulo, na Sociedade Brasileira para o Progresso da Ciência, no CONDEPHAAT e em outras instituições de altíssima qualidade e eficiência. $O$ professor Aziz Ab'Saber, após a sua palestra, vai conversar conosco. Portanto, tenho a honra de chamar o professor para ocupar junto conosco esta mesa.

Aziz___ Eu queria dizer, em primeiro lugar, que eu tenho uma satisfação imensa de estar entre vocês jovens e entre meus colegas professores que trabalharam muito para implantar uma Faculdade de Arquitetura e Urbanismo na cidade de Santos. Como é sabido demorou muito para que a cidade de Santos tivesse Universidade, e nós sempre fizemos um esforço imaginário no sentido de que Santos pudesse ter uma Universidade como é a UNESP, como é a UNICAMP, como é a USP, mas foram as faculdades aqui instaladas que corrigiram esta deficiência. Mas antes de falar sobre os assuntos que me trazem aqui, eu queria contar um pouquinho para vocês da minha história pessoal em relação à cidade de Santos. Eu tive a felicidade de sair da minha terrinha, São Luís de Paraitinga, com seis anos, para morar em Caçapava. Felicidade no sentido de conhecer o mundo, não de sair da minha cidade que é muito querida. Caçapava era um lugar que tinha estrada de ferro o que facilitava a vida do meu pai para ele vir a São Paulo fazer suas compras, porque ele era um pequeno comerciante da porta do mercado de São Luís de Paraitinga. Quando nós estávamos para mudar de lá , o meu pai junto com alguns fazendeiros amigos que ficavam na porta de minha casa, lendo o Estado de São Paulo (que meu pai assinava em nome do Aziz, em meu nome, e por isso talvez eu seja um dos mais antigos assinantes do jornal Estado de São Paulo) organizaram um excursão para ver o mar. Imaginem vocês a dificuldade que nós tínhamos nas décadas de 1920, 1930 de conhecer uma cidade costeira, uma cidade litorânea. E então com uma tropa de cavalos, os mais idosos, os adultos foram pra Santos, e eu com seis anos, meus dois irmãos, um com quatro e outro com três anos, eles nos botaram dentro de uma jaca, para poder atravessar a noite úmida e chuvosa das matas que estavam no reverso da Serra do Mar. E foi assim que eu cheguei cá embaixo, saí da jaca e comecei a conhecer o mar, a costa, a praia e a paisagem da região de Ubatuba. Mas parece que estava definido que por caminhos

\footnotetext{
${ }^{1}$ Transcrição de Rosa Camargo Artigas
} 
transversos eu ia conhecer Santos. No ano de 1935, depois de cinco anos morando em Caçapava, eu tinha 11 anos apenas, uma parente minha que gostava muito de mim, irmã da minha mãe, resolveu vir pra Santos, pra conhecer a cidade onde moravam parentes do marido dela. E lá o Aziz, com 11 anos, ainda muito pequeno, veio parar em Santos e pela primeira vez vi uma praia mais urbanizada, com uma longa série de mansos e pousadas, hoteizinhos e um ou outro grande hotel. E nunca mais eu deixei de lembrar de Santos. A terceira vez foi quando eu estava no ginásio, fizeram uma reunião inter-colegial na cidade de Santos, aqui na beira da avenida da praia. E lá vinha meu irmão e eu que estivemos alguns dias aqui, ainda com muita pobreza, sem dinheiro nem para os lanches. Mas fomos ao campo de futebol, que hoje é famoso por causa do Santos Futebol Clube. Fui chegando em Santos. Mais tarde, como pesquisador, tive que tratar do problema das duas ilhas, a ilha de Santo Amaro e a ilha de Santos, e certas ilhotas e tômbolos da região de Santos. Dediquei-me mais ao estudo da Baixada, da Serra do Mar, das duas ilhas que têm o topo plano, quase plano, depois tem vertentes íngremes, depois tem patamares, depois cai para os manguezais e para as planícies. E eu tive que fazer um trabalho sobre a gênese da Baixada Santista e tratei da planície de mangues, tratei de certas ilhotas de areia que estão no meio da planície do mangue e que tem uma vegetação diferente daquela que predomina nos grandes espaços de manguezais. Também passei a pensar um pouco na forma de ocupação que foi muito complexa em função das dificuldades que os mais pobres que vieram trabalhar nas usinas em Cubatão etc, têm para conseguir seu pedacinho e terra. E assim foi indo meu conhecimento sobre a Baixada Santista. Mas hoje eu não vim aqui para fazer recordações, eu vim para conversar com vocês sobre assuntos que interessam para os que estudam o espaço geográfico e os que estudam os espaços produzidos pelo homem sobre as heranças produzidas pela natureza.

A primeira coisa de que eu gostaria de tratar é a problemática que nós enfrentamos no presente momento no Brasil e que dificulta a vida na universidade. Os governos estão dando muito mais atenção às ONGs do que às universidades, do que o trabalho que se faz com muita solidariedade cultural e interdisciplinaridade nas faculdades de arquitetura e urbanismo, nas escolas politécnicas, na geografia, na história, na ciências sociais. Isso me causa profundo aborrecimento. Como é que um jovem que pediu votos para os intelectuais, que fez reuniões intelectuais no Rio de Janeiro para poder ganhar a confiança deles, de repente, se volta apenas às ONGs? É uma coisa séria. Bom, mais do que isso num repente muito desagradável, as ONGs conseguiram convencer o Ministério do Meio Ambiente da sua importância e transformaram-se de Organizações Não Governamentais em Governamentais. Estão lá dentro do Ministério do Meio Ambiente. E isso me deixa muito triste. E pra completar, alguns atos falhos do meu amigo Lula (não sei se ele continua a ser meu amigo porque eu sou amigo dele, mas não sou do governo dele nem do partido dele mais) se sucedem. Um dia desses, quando saiu o Pinguelli Rosa, ele disse: eu não quero acadêmicos no meu governo, porque acadêmico não dá voto. $\mathrm{E}$ eu fico perguntando se um presidente depois que se instala tem que falar assim ou ele se instalou e nos primeiros meses já está pensando na reeleição, isso é um absurdo! Outra coisa que aconteceu mais grave ainda, um ato falho verbal do próprio Lula, é que ele declarou uma vez na televisão que a Amazônia não pode ser intocável, mesmo porque lá moram 20 milhões de brasileiros, então tem que tocar na Amazônia sim. Bom, essa frase é perigosa. Não há conecção entre a população amazônica que hoje em grande parte, 
uns $60 \%$, está morando em cidades e a população que vive nas selvas, nas beiras do igarapés, nas beiradas dos rios, em vilazinhas, em agrupamentos mais simples. Então, eu fiquei muito triste, o problema não é dizer que ela deve ser intocada, o problema é saber como ela está sendo tocada. E vocês não podem imaginar que desastre que é a ocupação da Amazônia, depois que se fizeram estradas sem prever os impactos ambientais, sem nenhuma acuidade governamental para saber como fazer com que as estradas pudessem ser bem aproveitadas, mas não continuassem a ser caminhos de devastação. A devastação é fantástica. Ao longo da estrada vão se fazendo ramais para chegar até certos pontos onde o terreno é muito barato, vendido por proprietários muito simples a preço aviltados. Então, ao longo da estrada começa a haver destruição dos dois lados, em faixas de quinhentos metros a quatro quilômetros de largura. Depois fazem os sub-ramais. Ao longo dos sub-ramais, de trezentos a quinhentos metros, tem as "espinhelas de peixe", que são como quarteirões no meio da floresta vendidos para incautos que moram muito longe, que não tem nem condições de chegar lá para poder fazer sua pequena fazenda ou pequeno sítio. É um desastre. Os mais ricos fazem um linhão bem distante, até os confins e abrem um espaço enorme para fazer uma fazenda agropecuária, pensando que não há ninguém para controlar seu trabalho. Eles devastam tudo e colocam pastagem. Pagam uma miséria para as pessoas, em alojamentos simplórios que estão sujeitos a doenças tropicais, por causa dos insetos, etc. E a mesma coisa acontece nas beiras dos rios. A classificação de rios na Amazônia distingue igarapé, riozinho, rio e Pará. Pará é o riomar. Ao longo desses diversos riozinhos que chegam às cidades maiores, dá-se o mesmo: devastação de um quilômetro, quinhentos metros e etc. e a instalação da agropecuária. Os mais pobres entram pelos igarapés e também devastam, no mesmo esquema dos mais ricos. É um desastre o que está acontecendo na Amazônia. Eu estou desesperado com isso. Esse assunto está na minha cabeça. Há poucos meses, esse pessoal das ONGs, que foi para o Ministério do Meio Ambiente, resolveu fazer um cômodo projeto de alugar as florestas nacionais para terceiros, para empresas. Ou concedê-las para ONGs estrangeiras. Esse assunto é um assunto extremamente delicado. Não podendo controlar as formas de devastação dos fazendeiros agropecuários, eles resolveram iniciar uma privatização das florestas nacionais com ONGs estrangeiras, o que é mais grave. Mandaram um cidadão oferecer as florestas nacionais para as ONGs estrangeiras por 30 a 60 anos. Daqui a 60 anos, o Lula não estará mais no governo, talvez nem na vida e todos nós também não, e provavelmente as ONGs estrangeiras iriam pedir que um tribunal internacional dissesse se elas têm direito ou não de permanecer pelo muito que elas fizeram. E quanto ao aluguel para empresas, eles estão pensando em deixar as empresas entrarem para retirar árvores de espécies bem adequadas à exportação, tanto para o Brasil-sul, quanto para a China, para o Japão, e as pessoas vão ter o direito de entrar pela floresta adentro, cortando árvores de mogno, de castanheiro. Isso é extremamente grave, porque as pessoas que quiseram fazer este cômodo projeto, não sabem que para entrar na floresta e encontrar uma árvore, que ela pode estar a quinhentos ou a cinqüenta metros da estrada principal, mas que também pode estar a sete ou oito quilômetros porque, na estrutura dos ecossistemas florestais, não existe uma equidade na distribuição das espécies. Então tem que fazer uma trilha, levar um mateiro da própria Amazônia que vai reconhecendo as árvores e fazendo as trilhas. Depois que encontrar as árvores tem que cortar e então vai um grupo de homens com moto-serra. Para poder trazer as árvores para a estrada, tem que fazer 
um caminho, um caminho de cá, outro de lá, porque está muito disperso. Um desastre ! Aí, na televisão perguntaram para o senhor João Paulo Capobianco se ele já tinha pesquisado na Amazônia. "Não", ele disse, -"eu estive em Macapá . Em Macapá, sim, eu sei. Ele esteve em uma reunião ambientalista a convite do João Alberto Capeberibe, governador do Estado do Amapá. Capobianco é o fundador de uma ONG que fez a vida recebendo rios de dinheiro durante a Rio- Eco 92 e não é confiável. Bom, sobre esse assunto eu não vou prosseguir. Se vocês quiserem pedir alguns dados depois, vocês me peçam.

O segundo assunto que eu trouxe para falar pra vocês é a questão da posição que alguns de vocês possam ter mais tarde na vida. Os estudantes de amanhã serão os homens que estarão nas empresas, estarão na administração pública, serão profissionais da construção civil, serão profissionais dos mais diferentes tipos. E nesse sentido, eu queria deixar na cabeça de vocês que nós temos que imaginar que esse país precisa de gente que pense no nacional, no regional e no setorial. O nacional é muito complexo, porque também depende do internacional. Então as viagens do Lula para diversas partes do mundo serão aprovadas. Só que convém viajar menos, pra poder administrar mais o regional e o setorial, senão não adianta andar pelo mundo. O nacional também pressupõe a Constituição, pressupõe assuntos que dizem respeito ao todo, ao espaço total do território; pressupõe as infra-estruturas que não são importantes só para um lugar, redes viárias interligadoras para o transporte de produto, etc. E o regional no Brasil é mais complexo. Não há curso neste país que não precise diferenciar o nacional, regional, e o setorial e que não trate bem do regional. Por que nós temos regiões muito amplas, aparentemente muito homogêneas. A Amazônia tem 4 milhões e $200 \mathrm{mil} \mathrm{km}^{2}$ de área, dos quais 2 milhões e 800 mil com florestas contínuas. Depois tem umas transições nas suas bordas pro lado da Roraima, pro lado do Maranhão, pro lado de Goiás, pro lado de Tocantins e também pro lado da Rondônia. Então não é uma região comum: 4 milhões e 200 mil km², se comparado com alguns países que tem menos de $100 \mathrm{~km}^{2}$, conclui-se que se precisa muito mais conhecimento. As faculdades de arquitetura têm que ter um centro se estudos do regional, porque ninguém sabe onde vocês vão parar. Vocês poderão trabalhar em Santos, mas poderão estar trabalhando em São Gabriel da Cachoeira e em Macapá. Já encontrei paisagistas paulistas trabalhando perto da Fortaleza de São José, perto de Macapá. Nós temos que conhecer o Brasil. Para conhecer bem o Brasil precisa ter um curso bom de Geografia regional, mas dentro de certas óticas sobre as quais vou conversar um pouco com vocês. O setorial é grave, porque se o governante tem pouca noção do nacional, conhece mal o regional e não sabe nada do setorial, ele está desgraçado e o país com ele. O setorial envolve saúde pública, educação, saneamento básico, o complexo educacional que vai do primário ao curso superior, às universidades, indústrias, comércio, comunicações terrestres, comunicação eletrônica, comunicação por rádio, televisão, por meios digitais, por internet, etc, que é a única coisa mais globalizada que existe, mesmo porque a globalização que o primeiro mundo pretende dentro de um país, como o Brasil, é uma globalização financeira e burocrática. Através da força de pressão financeira pode-se enquadrar qualquer país. E burocraticamente colocamos, sem que ninguém saiba, um mundo de gente. $E$, além disso, atrás de nós, tem a força bélica. Não precisa mais fazer como se fez com a Índia. Na Índia houve uma colonização bélica e burocrática e enquadraram um país de velhíssimas tradições. Agora, não precisa mais do bélico. Bélico fica para trás, só para garantir o interesse deles se não der a 
colonização financeira e burocrática. Nós estamos nessa fase e temos que ter olhos. $\mathrm{O}$ caso da Amazônia é gravíssimo. Nos EUA não há quem não fale sobre a Amazônia, sem nunca ter ido para lá. Porque eles sabem que os recursos amazônicos são de uma importância fundamental para um país que tem tecnologias muito variadas. E eles estão de olho nos recursos da floresta, em termos de sua biodiversidade que é aproveitável para fármacos, em termos da madeira, em termos de uma porção de coisas. E nos recursos hídricos. Como a Amazônia tem um só e grande sistema hidrográfico que vem desde os Andes e das Guianas, e vem do Brasil central e desemboca lá no Golfo Marajoara, evidentemente que os recursos hídricos são absolutamente avantajados. Não dá, por exemplo, para comparar os recursos hídricos do Amazonas com o Nilo. O Nilo passa por um deserto, é estreito na parte da bacia, maior na parte superior. Mas o Amazonas é um volume fantástico de água doce. $\mathrm{E}$ a água doce está se acabando no mundo. Voltando ao problema da educação: a situação para nós é grave. Pessoas que ainda não se dedicaram a estudos aprofundados de nada, que não tem sentido de interdisciplinaridade, para ganhar um emprego dentro de uma época e uma conjuntura em que o emprego é muito difícil, eu reconheço, elas organizam as ONGs. E há uma briga entre as universidades e as ONGs. E o governo adota o ponto de vista das ONGs. Gravíssimo.

A terceira parte do que vou abordar, diz respeito a um assunto de interesse direto do arquiteto e do urbanista. É a questão do projeto com a natureza. Descendo a serra do mar, hoje, passando por diversos pontos, pelos manguezais, pelas ilhotas de areia que têm jundus, uma vegetação adaptada a conviver com a areia, na zona costeira de São Paulo e que o índio soube reconhecer bem, que chega até os morros de Santos, eu me vejo na obrigação de repensar a questão do desenho com a natureza. Vocês têm a obrigação de ler o livro "Design with nature" de lan L. Mac Harg. E ler também Garret Eckbo, o maior paisagista americano do fim do século XX. Ele esteve em São Paulo dando um curso de pós-graduação na FAU da rua Maranhão, para os arquitetos e urbanistas. E eu tive a felicidade de assistir as aulas dele. Acompanhei um pouquinho depois os conhecimentos sobre a obra dele. Ele tem um livro chamado The world with I see , ["O mundo que eu vejo"] que é muito importante para os paisagistas. Tem também outro livro do qual eu vou falar para vocês, um livro sobre uma penitenciária rural que acabou ficando próxima de uma cidade média dos EUA, e que não podia mais permanecer naquele lugar. Os líderes culturais da cidade achavam que aquela penitenciária deveria ser rebocada para outro lugar. Liberados os espaços, depois que saíram os presos, saiu o diretor, saíram os funcionários, não sabiam o quê fazer com os prédios que estão numa certa paisagem. Então as lideranças locais chamaram Garret Eckbo para explicar o que se podia fazer. $O$ paisagista, arquiteto de alta importância, Garret Eckbo, disse: - "Eu vou primeiro dar uma olhada, uma nova olhada na penitenciária e nos seus entornos e depois eu venho falar com vocês. Esse é um assunto importante pra vocês. Nunca fale daquilo que vocês não viram. Bom, o Garret voltou e fez uma planificação extraordinária. Ele disse para o grupo da cidade que era composto por administradores e empresários: - Se vocês querem que eu e minha equipe trabalhemos, em primeiro lugar, criem uma comissão de recursos, e por um ou dois anos, não mexam um tostão nos fundos acumulados. Em segundo lugar, criem uma comissão de cartografação que vai fazer a cartografia da região da penitenciária e de seu entorno imediato. Depois uma comissão de estudos sobre o espaço total, tal como ele é, os prédios, as ruelas, as pontezinhas, os lugares onde trabalhavam os presos 
da zona rural, o estado de degradação ou não da natureza na zona rural, do seu entorno, etc. Cada um desses grupos vai me trazer o que aprendeu na sua área, como mapeou convencionalmente, como mapeou a geomorfologicamente, a fitogeografia da região, a hidrologia, quais as observações que têm feito para isso. Vão fazer o contato com as outras comissões. A segunda comissão, é a comissão do espaço total e sua visualidade. Olhar, a partir da última prateleira dos edifícios, a paisagem em diversos setores e diversos ângulos. Descer para a planície, e da planície olhar os prédios e o relevo das colinas e o estado delas. É uma comissão de visualização paisagística, tal como a paisagem está hoje. E o terceiro grupo é aquele que em função desses conhecimentos, cartografação, visualização, vai elaborar um projeto baseado na função entre arquitetura, ou urbanismo e a funcionalidade, passível de ser trabalhada." Essa proposta ficou no meu coração também porque é lógico o que ele fez, e o pessoal aceitou e ele trabalhou nisso. Quero dizer que isto é uma fórmula pra gente pensar: do conhecimento à inspiração. Sem isso não há arquiteto, sem isso não há urbanista, sem isso não há planejador, etc. Não vou sobrecarregar mais vocês sobre esse terceiro item, mas ele me inspira a falar sobre um quarto.

Vocês estão cansados?Olha, eu não quero amolar vocês. Tanto que eu trouxe um livro que eu admiro profundamente. Vocês já viram que quando eu admiro, admiro mesmo. Então eu trouxe um vídeo chamado Povo Brasileiro que tem dez matrizes, são dois cassetes. Cada matriz diz respeito a um fato da história do povo brasileiro. É a matriz tupi, que nos interessa porque aqui estiveram os tupis antes da chegada dos portugueses. Depois tem a matriz lusa, depois tem a matriz afro, depois tem a matriz crioula, e as outras eu não sei, porque não deu para eu ver todo o vídeo. São dez matrizes. Então eu solicitei para a casa a possibilidade de que, depois que eu terminar essas palavras, as vezes, um pouco explosivas e críticas, se passasse pelo menos a matriz lusa, que é um momento da história desse vídeo. O Darcy Ribeiro estava vivo ainda, ele tinha uma fundação chamada Darcy Ribeiro e uma moça extremamente inteligente chamada Isa Grispun Ferraz, que trabalhou intensamente na feitura dessas matrizes. Foram a Portugal, foram para a África, foi uma Odisséia.Então pelo menos uma matriz de 20 minutos eu queria que passassem para vocês porque assim ameniza um pouquinho essas críticas que de vez em quando eu faço. Vocês já viram que tenho grande contato com arquitetos e urbanistas da USP, de outros lugares. De vez em quando alguém lá de São Carlos pede pra eu ir até São Luís de Paraitinga, para nós vermos o sítio e a localização da cidadezinha onde eu nasci. Eu vou, e apesar de saber que o prefeito mandou fechar a praça, pra cortar as árvores mais altas e pôr umas arvorezinhas muito baixas lá. Isso é típico de véspera de eleição. Nós temos que mostrar serviço, então vamos destampar a cobertura do Mercadão que era a coisa fundamental na história de São Luís e vamos pôr um tabuado em torno da praça e trabalhar para fazer um novo paisagismo na pracinha em frente da igreja.

Mas voltando, o quarto assunto é o seguinte é a questão do conceito de espaço total. Quando a gente diz, é preciso pensar no regional fica muito amplo, o regional é a Amazônia, é o nordeste seco, é o Brasil tropical atlântico, é o domínio do cerrado, é o domínio dos planaltos de araucárias, é o domínio das pradarias mistas, etc, e suas áreas de contato. Entre um e outro tem sempre um contato de $A$ e $B$ e às vezes entre três, tem um contato $A, B, C$, muito complexo. Às vezes tem uma planície muito especial por causa de fatos paleo-geomorfológicos, como é o pantanal que está no contato entre o cerrado, o charco e a Amazônia, então precisamos estudar tanto as áreas nucleares dos domínios 
- domínio das terras baixas florestais da Amazônia - domínio das colinas recobertas por caatingas e dotadas de drenagens intermitentes sazonarias do nordeste seco, e assim por diante. Mas ao mesmo tempo tenho que estudar as interfaces entre esses domínios que formam um mosaico no conjunto do país. E, além disso, dentro da profissão, nós temos que estudar o espaço total de cada fragmento do território para o qual, como profissionais fomos chamados para trabalhar ou como administradores tivemos que pensar no destino daquele fragmento do território. $E$ aí então vem esse conceito de espaço total. $\mathrm{O}$ professor Milton Santos trouxe esse conceito numa conferência que ele fez na FAU USP e dizia: "O espaço total é aquele que está presente hoje e que é o resultado de uma história . Eu peguei esse conceito, achei muito importante profissionalmente falando, cientificamente falando e, sobretudo pensando no futuro dos espaços estatais de hoje e transformei em um senso ecológico. Então é espaço total, vamos fazer uma didática aqui: suponhamos que todos os componentes que estão aqui são do espaço total. E são dados de uma história social, econômica, política, etc e de uma história de atividades, de uma atividade humana. Quais são os componentes do espaço total? Os componentes do espaço são de três faixas: os ecossistemas naturais remanescentes, quando eles existem e não é sempre que existem; a agricultura comercial que acabou arrasando muitos desses ecossistemas em certos espaços totais regionais; e depois destes componentes vem os agroecossistemas, que são os sistemas rurais, e, por fim, vem o sistema urbano. O ecossistema urbano distribuído sobre o espaço total, sobretudo no meio das áreas de agro-ecossistemas. E com uma complexidade que não tem tamanho. Quando eu penso no ecossistema urbano da cidade da grande São Paulo, eu fico desesperado. Porque cresceu demais, foi limitado por algumas pequenas atitudes que nós tomamos como o tombamento da Serra da Cantareira, da área do Jaraguá, esse entorno, apesar de que o Silvio Santos já entrou um pouco por lá. A Serra do Morro Grande, um maciço do Bonília, ficava entre Sto. André e Mauá, derruíram tudo. Não tem mais nada de ecossistemas naturais. E o maciço de Itapeti, entre Mogi das Cruzes e o Vale do Parateí, praticamente está sendo tomado: querem fazer pousadas, querem fazer bingos, querem fazer loteamento, então apesar de estar tombado, ninguém gerencia o tombamento. Eu estava falando com um colega que pertence ao CONDEPHAAT : ou o CONDEPHAAT dá a volta por cima e volta a controlar os espaços naturais que foram tombados ou ele ficará no arquivo morto da história. É minha opinião. Esse conjunto de componentes do espaço total muda de região para região. Na região de Ribeirão Preto, que tem solos muito bons, a cidade é extraordinária. Mas a cidade não está entrando muito na zona rural tanto quanto possível, porque de repente, aquele solo rico, de terras roxas, oxisolo dos mais ricos da face da Terra, passaram seu suporte ecológico para a cana-de-açúcar. Então, passou do ciclo do café para o ciclo da cana, mas tem entrado a soja, que é o grande invasor dos espaços. Em cada setor do interior de São Paulo, um fragmento do território terá ecossistemas naturais, às vezes não terá agro-ecossistemas e terá a cidade querendo entrar no campo. Esse é um problema muito sério. Talvez daquelas partes de solo mais ricos do Brasil, no norte do Paraná, Ribeirão Preto, Sertãozinho, estejam invadido menos o campo, porque a força do solo é muito grande. Mas lá em Maringá, em Londrina, eu assisti pela primeira vez, a cidade está caminhando horizontalmente na direção dos campos. Não tem outro jeito, porque é o outro ecossistema que existe na zona rural. Mas na medida que houve a decadência do ciclo do café, muitas famílias que herdaram fazenda, estão loteando essas fazendas e 
loteiam por saltação, então depois de loteados e vendidos aí então eles querem emendar com a cidade. $\mathrm{E}$ isso faz com que, no espaço total em dinâmica na região, nós estejamos tendo um crescimento horizontal pelas pontas das ruas da própria cidade, um crescimento por saltação na zona do campo e um crescimento verticalizado que é importante para o profissional de arquitetura. Mas atenção, somando os três, é o caos! Então o Aziz está trabalhando hoje no problema da aldeia global! Este problema partiu de dois conceitos que eu tenho: o de espaço total como fragmento de território e que deve ser cumprido tal como está e, ao mesmo tempo, do problema da gestão do futuro. Como é que vai ser o futuro? Esta cidade está crescendo na horizontal, crescendo na vertical, crescendo por saltação no campo. Das saltações se reúne ao conjunto. Mas essa cidade é um ecossistema complexo, e a outra ali a 20,30 ou 40km, não interessa, outra lá, outra lá, se todas elas crescerem na horizontal, na vertical, e por saltação o que vai ser o mundo depois de 50, 100, 500, 1000, 10.000 anos. Vai se formar aldeia total em alguns lugares. E aí os governantes que se sucederam e deixaram acontecer tudo isso, vão dizer: "Bem, a cidade é mais importante que o campo. Só que tem que se produzir alimentos e tem que ter exportação. No momento estamos vivendo o ciclo da soja. Depois do café, o mais importante que aconteceu foi o ciclo da soja. E por isso mesmo precisa de mais espaços rurais produtores. Então eles vão dizer: “Não. Não estou pensando em mil anos depois de nós. Se não se pode emendar todas as cidades, tem a Amazônia nós vamos plantar lá. Só que lá, eles estão destruindo gradualmente todos os espaços possíveis como já aconteceu no sul do Pará. Então a situação é dramática para o futuro. Eu tenho medo do futuro dos meus filhos, e netos dos meus netos, e bisnetos, e etc. Bom, uma vez eu falei essas coisas para um candidato à presidência da República, e ele disse: Esse tipo de assunto não interessa aqui. Temos que pensar na minha gestão só por quatro anos. Esse é o problema. Um governador da Amazônia um dia, há cinco ou seis anos atrás, não poucos anos depois da ECO-RIO 92, declarou de público, na hora que deram para ele o parlatório : Em primeiro lugar eu quero dizer à vocês que eu sou contra os ambientalistas, que estão atrapalhando a vida dos projetos e em segundo lugar, eu quero dizer que, os que vierem depois de nós, que aceitem o mundo que nós deixamos da mesma maneira que nós recebemos o mundo que outros nos deixaram". Não há frase mais antiética que esta. Parece que não houve universidades, que não se desenvolveu o ambientalismo, que ninguém pensou interdisciplinarmente nos fatos do mundo e vamos deixar o mundo caótico que a gente está vendo, que está sendo produzido, para o futuro e eles que recebam assim. Eu acho extremamente grave e nós temos que nos centrarmos nisso: o mundo que nós queremos deixar para os outros, tem que ser um mundo repensado em sua organização humana de espaços sobrepostas à natureza. Tem que ser repensado no nível da sua estruturação econômica e social. Tem que ser pensado para se evitar a aldeia global em territórios que tenham os solos muito bons e que por isso mesmo perderam esse solo em termos de produtividade. E tem que ser pensado também no destino dos ricos e pobres dos futuros tempos. Os ricos vãovão se alimentar de umas capsulazinhas e não vão precisar de produtos tradicionais das lavouras. Mas os pobres vão sofrer muito por falta de alimentos, por dificuldade de preço e etc. Os supermercados atuais, em São Paulo, estão dizendo que nunca houve um desenvolvimento tão grande porque aumentou um porcentual de compras, mas eles não falam que eles elevaram os preços de todas as mercadorias, que interessam à classe média, pobre e à pequena burguesia. Eu estou atento para essas coisas. 
A ética como futuro é tão importante quanto à ética com o presente, mesmo porque o presente é passageiro, daqui a pouco eu estou bem lá longe e vocês estarão em suas casas, já é passado. Por isso que eu sou muito sentimental. Acho que as pessoas têm que se lembrar, quando fazem uma reunião como essa, porque a gente poderá nunca mais estar juntos. Por isso mesmo, nós temos que estar juntos por outros processos, pelos escritos, pelas mensagens escritas ou televisivas ou qualquer que seja. Mas voltando: o conceito de espaço total fica muito complicado na hora de estudar os ecossistemas urbanos. Vários autores, vários ecólogos tentaram mostrar o que é o ecossistema urbano, e sempre fica muito falho. É uma acumulação de gente em pequeno espaço. Na área agrícola se vende espaço por hectares de alqueires, na área urbana por $\mathrm{m}^{2}$. Algumas áreas do corpo central se valorizam muito e por isso mesmo, as pessoas vendem os prédios mais antigos para poder ceder lugar para a verticalização. Mas as cidades dependem do campo, dependem do campo que está longe, e dependem do mundo que está muito mais longe delas. Então, temos um outro tipo de consideração que mostra um pouco melhor o problema da ecologia humana, que é muito mal conduzida em nosso país. Normalmente, depois desse assunto, eu deveria tratar do metabolismo urbano. Lembrando que a cidade tem um metabolismo agigantado, nós temos aquele metabolismo que a gente não gosta de falar em sala de aula: entrada, fluxos e saídas. Mas a cidade tem a mesma coisa e nunca foi tratado nesse nível. Ela tem entradas que os americanos que fizeram o conceito de metabolismo urbano chamaram de in up, depois eles têm os fluxos, slow ups (fluxos internos) e depois tem o how up (dejetações). E esse sistema de pensar a cidade é importante parte do problema de uma racionalização do ecossistema urbano. O que entra na cidade? Didaticamente isso é fantástico. Eu perguntava para os alunos: $\mathrm{O}$ que entra nas cidades, sem o que ela não pode viver, porque ela depende de coisas que estão de fora? Daí um alunozinho virou e disse: "Professor, eu sei. Comida, feijão, arroz, tem que vir do campo." Digo, nota 10. O outro virou e disse, "eu sou filho de uma pessoa que trabalha na Eletropaulo, entra energia, sem o que também grandes cidades não teriam existido". Muito bem, nota 10. Depois foi indo, um deles disse assim: "entram umas coisas que vem de lugares que eu não sei onde estão. Vem de Taiwan da China e é vendido a $R \$ 1,99$ na porta da loja." Aí eu virei pra ele e disse assim: então, você lá na sua escola, vai pegar o Atlas e vai pedir ao seu professor dizer onde está o Taiwan e o que grande país que é a China. Então tem valor. Mas por último eu perguntei: - "o que mais que entra na cidade?" Aí foi aquele silêncio. Aí uma professorinha inteligente virou e disse: "professor, eu sou lá do nordeste, lá do Ceará, entra muita gente que vem lá de fora para cá e vai ficando e não sai." Eu digo, nota mil. Quer dizer a grande cidade é a sedutora. Nós usamos sedutor só pra termos de gênero. Mas a cidade, ela própria no seu conjunto, é sedutora. Ela tem o dia, ela tem a noite, ela tem estrutura de lazer, no passado cinemas ( agora cinema está dentro de casa, pela televisão) e tudo isso é chamariz para pessoas que vem disputar um lugar dentro dessa selva complicada que é a grande cidade. E então o que entra é muita coisa, e tudo isso que entra, o que faz em relação ao que já está por dentro? Mistura-se com os fluxos internos. Então tem um fluxo de entrada, tem um conjunto de entrada, caminhões, treminhões. Eu estava olhando hoje a estrada que vem para cá, véspera de um feriado já começa a se movimentar, mas viemos até mais cedo com a Professora Vera Domscke por causa da dificuldade que poderia ter com o trânsito. Lá na cidade, na Avenida dos Bandeirantes, desde além da banda do aeroporto até a cidade, não 
tinha um espaço entre dois carros que fosse maior do que 1,5 metro. Então vejam vocês que é grave o problema das entradas, mas fica muito mais grave depois que entra, porque aí já tem os fluxos internos da cidade: os ônibus, os microônibus, os carros, os veículos, pouco metrô, etc. É uma coisa extraordinária a junção dos fluxos que entram com os fluxos que já estão. Começamos a falar em ecologia urbana. $E$ as pessoas têm que trabaIhar, têm que ir para as escolas; outros têm que ir para o comércio, têm que ir para o lazer e precisa de um sistema de circulação. E o sistema de circulação nos países de terceiro mundo, em geral, é muito pobre. O fato de ter custado muito para formar o metrô de São Paulo foi uma tragédia, porque poderia se ter evitado aquelas fantásticas formas de aquisição de veículos para todo mundo. O mais pobre dos paulistanos tem vontade de comprar seu veiculozinho, nem que seja de dez ou quinze anos atrás, e tenta usá-los. Os mais ricos importam veículos mais bem acabados e velozes e andam com uma velocidade fantástica nas estradas, desrespeitando todos os sistemas de tráfegos. Eu vejo isso na Raposo Tavares que é a rodovia que eu preciso usar pra chegar à minha casa. Então é muito complicado. Mas depois vêm os problemas ligados ao que é dejetado de dentro do metabolismo urbano. O que se dejeta: gases em particulados dos carros e das fábricas, águas servidas dos edifícios todos e de todos os bairros; os esgotos, os efluentes industriais, os efluentes domésticos. Por fim, o mais grave: o lixo criado pela cidade. Aquilo que é utilizado parcialmente e tem restos, escombros.Onde depositá-los quando a cidade global daqui a 500 mil anos estiver muito emendada? Essa emenda que nós chamamos conurbação já está acontecendo. Nas praias, na Praia Grande, já aconteceu uma conurbação muito ampla; em Bertioga há outra conurbação e só o litoral norte poderia talvez, ter ainda uma série de diferenciações. Mas um dia desses, passei antes de Ubatuba e vi dois prédios inclinados, uma coisa triste, da área politécnica, arquitetônica, urbanística e de distúrbios geotécnicos. E pra isso vocês tem que trabalhar muito na Escola de Arquitetura e Urbanismo para entender que o formato do prédio, a construção do prédio com estrutura, não é tudo. Tem que pensar na funcionalidade e etc, mas também tem que pensar no problema do solo, que vai receber aquele peso fantástico. Foi o que aconteceu de errado lá no Rio, com o Sérgio Naya. Ele não pensou nem na estrutura e nem no solo e o edifício caiu, matou gente e o governo não sabe como vender as coisas do Naya pra poder pagar as pessoas e também pagar a si próprio. Um desastre. Então o nosso trabalho é sério. Eu sempre lembro de uma coisa. Alguém me explicou: "Aziz arquitetura é assim, e a escultura é assim. A escultura se faz da periferia pro centro da massa e a arquitetura é de dentro pra fora". $\mathrm{O}$ "dentro" principal começa com uma compreensão de subsolo. Como é que era o subsolo da região de Santos na parte das planícies?

Vou terminar por aqui, mas vou contar a vocês uma historinha que diz respeito a minha pessoa. Por conhecimentos gerais do mundo, se sabe que entre 23 mil e 13 mil anos atrás o oceano estava muito mais baixo, menos de 95 a $100 \mathrm{~m}$. Então por entre os morros de hoje da região de Santos, passavam rios que iam até 30,50km dentro da plataforma. Lá na própria cidade do Guarujá, município do Guarujá, existem alguns sinais de rios que iam para o mar por muito quilômetros. E um canal fluvial que não tinha águas salinas estava entre o Itapanhaú e a llha de Sto. Amaro, que é o atual canal de Bertioga, talvez com dois rios, um que ia para o norte e outro que ia para o sul. Quando o mar desceu, eles fizeram uma erosão regressiva e talharam vales fundos. Pois bem, depois de um certo tempo mudou o clima, mudaram as coisas e o mar subiu, subiu e parou um 
pouquinho de subir, e no fim ficou mais $3 \mathrm{~m}$. Hoje eu fiquei com uma vontade enorme, se estivesse com máquina e com luz do dia, de fotografar o ponto onde chegava uma lâmina de água, encostando na Serra do mar, dos esporões baixos das serras do mar. A Professora Vera viu meu interesse por aquilo, e ela vai me mandar uma foto que ela disse que tirou de lá. Pois bem, então o que é hoje a baixada eram vales muito cruzados, porque dois maciços ficaram separados da serra do mar: o de Sto.Amaro e do de São Vicente, Monte Serrat e Santa Terezinha e Vales Fundos indo para o mar. Quando o mar sobe, ele passa por entre os intervãos, entre as ilhas, entra pelos vales de Bertioga, tanto pelo norte, quanto pelo sul e sobra mais $\underline{x}$ de metros com águas vivas, semi-salinas até perto da base da serra do mar, em Cubatão, Piaçaguera, etc. Nessa ocasião formaram-se alguns areiais no meio dessa baixada alagada pelo mar, e esses areiais depois resultaram num solo diferente do mangue. O mangue foi formado de mais de 3 metros e meio, e ainda contando as oscilações de maré. O mar começou a descer num ponto, desceu bem mais não muitos metros, subiu um pouco, desceu mais, três vezes. E a baixada virou um lago, e as massas de areia viraram ilhotas rasas. E a partir dos segmentos fininhos que passaram a existir em grandes massas, porque a serra do mar ficou muito tropicalizada, as florestas se estenderam, as rochas se decompuseram, os solos se formaram e saiu muito material fininho pelos rios e estes foram pressionados pelas marés e foram sendo espraiados pelas áreas que hoje tem mangues, e sobraram apenas uns restinhos de areia que tem uma vegetação diferente da do mangue. Estou falando tudo isso a vocês, porque qualquer planejamento exige o conhecimento do espaço total.

Então, o Aziz estudando com pessoas muito importantes de Strassburg, soube que houve um clima muito seco aqui no Brasil. No passado, há 110 anos, Luiz de Agazis pensou que existiu um período glacial que abrangeu o Brasil. Então ele imaginava o Pão de Açúcar cheio de gelo, e saindo dos morros que hoje tem floresta. Mas naquele tempo não devia saber que o chão era pedregoso. Foi esse chão pedregoso que definiu, depois para cientistas que vieram, em 1956, ao Brasil, que chão pedregoso é de um clima seco e não tinha havido glaciação como estava nos livros de Agazis e de Hart, e de outros. Então o mar, desceu com correntes frias até a Bahia, com dificuldades para a penetração de ventos úmidos e a atomização da umidade lá do lado do Chile, que a gente diz que tem desiertos nublados, e aqui houve semi-desertos nublados nessa região toda. Nessa altura as florestas se reduziram, ficaram nos lugares mais úmidos na testa superior da serra do mar, e outros lugares.Depois de doze mil anos até seis mil e cinco mil e quinhentos anos, quando o mar esteve a mais de 3,5m, é houve a retropicalização. E é bom que quem mora em Santos saiba disso. E também saiba que na conjuntura atual do país é preciso pensar nas infra-estruturas dos transportes marítimos nos portos. Vocês que daqui pra diante vão ser profissionais, pensem que não é só na construção da casa, nem na feitura de avenidas radiais, é sobretudo num ideário de uma rede de metrôs. Não sei porquê não fizeram uma rede de metrôs que saísse da zona norte perto da Casa Verde e que viesse até o Hospital das Clínicas ou Vila Madalena e chegasse até a Cidade Universitária. O mias belo trecho de metrô que eu já vi na minha vida foi em Boston. Eu quis o metrô que sai de Boston, cruza um rio até chegar à porta da Cidade Universitária. Mas lá foi outro mundo. Eles pensaram mais inteligentemente e tinham muito mais recursos. Nós podemos pensar magnificamente e os recursos faltam. E depois que criam problema é muito difícil resolver. Depois que se instala uma favela num terreno vago, pertencente a particulares 
ou ao estado, é muito difícil eliminar aquela favela. Porque é anti-social. Depois que se fazem poucas linhas de metrô e é se obrigado a se utilizar o automóvel, as fábricas de veículos não querem deixar de produzir e aí então começa ser muito séria a concorrência. - Vale a pena pensar interdisciplinarmente em todos os fatos da natureza: na devastação da Amazônia em progressão, na aldeia global e nos indícios de conurbações parciais. Pensar que todo o projeto nosso vai ser dirigido para o espaço total do presente que contém todos esses componentes que eu falei. Não há projeto que não seja dirigido para um lugar ou uma área, e por isso mesmo, nós temos que conhecer a área como um todo, a fim de que o nosso paisagismo não seja apenas o de um jardim de uma casa de rico ou um trecho que sobrou entre ruas pra fazer uma pequena praça. Queria dizer a vocês que eu estou me preocupando com as periferias pobres de São Paulo, onde existem os maiores problemas sócio-econômicos, sócio-culturais e que não estão sendo possíveis de serem resolvidos com facilidade porque existe o problema do emprego. Fome Zero é uma expressão eleitoreira. Alimentação, nutrição, mais empregos, mais cidadania é o que nós precisamos sempre. Queria contar a vocês que, um dia desses, estive em Marabá e tinha uma cavalgada de fazendeiros amazônicos. Fazendeiros que dominaram os espaços comprados por preços aviltadíssimos de gente do passado. Eles dizem o seguinte: - "a propriedade é minha e eu faço com ela o que eu quiser e quando eu quiser. Vou deixar o tempo que eu quiser pra poder fazer alguma coisa. E na cavalgada de Marabá, fiquei impressionado. Eu tinha que fazer uma conferência num bairro de além de Itacaiuna. Marabá fica entre o Tocantins e o Itacaiuna e eu tinha que passar a ponte pra chegar lá no lugar onde ia ser feita a palestra. E me avisaram: vai às cinco horas porque vai ter uma cavalgada. Eu pensei que era brincadeira e fui as nove. E aí começaram a passar os fazendeiros. Cada fazendeiro de cada fazenda de agropecuária, completamente insensíveis ao futuro, totalmente insensíveis, tinha uma bandeira, ou duas. Depois, atrás dele, alguns cavalos muito bonitos, e vinha a senhora dele e as filhas. Depois os filhos menores, em cavalinhos menores e depois um ou outro capataz. Outros e mais cavalos começaram a passar: Mil e quinhentos! Só pra assustar aqueles que pensam na reforma agrária. A cidade inteira de Marabá ficou silenciosa. Só ficaram uns coitados de uns ciclistas que pararam pra olhar aquele mundo de cavaleiros sem ter idéia do que aquilo significava.

Um dia, eu fui fazer uma visita em uma periferia e resolvi fazer um sopão pra poder ter a possibilidade de entrevistar as pessoas. O sopão foi feito com menos de dez reais: couve, bastante cebola, bastante tomate, bastante alho e um pouco de caldo Maggi e, como ficou um pouco rala e eu botei um pouco de fubá mimoso. Ficou muito bom. Fez-se uma fila dos meninos de até 10 anos e depois vieram os adolescentes que jogavam bola de manhã à noite, no sábado e no domingo. Saíam de manhã, sem tomar café e iam jogar bola até meio-dia. No meio-dia não tinha banho pra tomar, não tinha comida pra comer, ficavam na porta de um barzinho de periferia, um comprava um refrigerante e dividiam. E depois de meio-dia voltavam a jogar bola e depois à noite voltavam para casa, não tendo banho para tomar, nem roupa para trocar, nem comida para comer. Então eu pedi pra uma menininha que estava na fila, para ela buscar pratos. Me deu na cabeça de fazer isso ocasionalmente, então eles foram buscar os pratos em casa e uma colher. E a gente foi dando sopão e a menininha entrava na fila de novo, mas na fila atrás dos pequenos, e vinha e tomava outro prato. Ela percebeu que eu vi, então ela virou pra mim e disse: "professor, hoje não vamos precisar comer lá em casa, 
porque já comemos bem aqui, eu, vou perto da minha mãe que certamente vai entrar na fila. Mas tem uma coisa professor lá em casa, não tem nada pra fazer comida." Desculpe de ter que tratar de coisas tão tristes. Mas é para que, um dia, elas sejam mais alegres. Um abraço pra todos vocês. Abdala bom eu queria, antes de mais nada, agradecer o professor Aziz Ab'Saber e franquear a palavra aos presentes que quiserem fazer uso dela. Lembrando da condição especial dessas situações, lembrando que esta aula de urbanismo, urbanidade, cidadania e postura política frente à vida para entender de que grandeza possa se revestir o espaço de uma escola. Portanto, muito feliz pela palestra proferida pelo professor Aziz Ab'Saber eu abro a palavra aos presentes.

Pergunta: Eu gostaria que o prof. elucidasse mais sobre a termo-elétrica que vai ser instalada aqui na refinaria. Se não fosse a ação das ONGs, a gente iria confiar em quem? No grande monopólio? Na ALCA que vem aí?

Aziz __ Olha eu vou situar apenas as ONGs. Eu fiz uma tipologia das ONGs e publiquei num livro feito pelo Sesc, em que eu dizia o seguinte: existem ONGs grandes em que, certamente, o chefe da ONG é dinheirista. Receberam os rios de dinheiro que queriam ganhar. Para poder fazer alguma coisa de interessante pegavam parte desse dinheiro e alugavam pessoas da universidade para escreverem pequenos trechos para eles. Então fizeram: mapeamento da vegetação do Brasil, mas nunca fizeram nada em planejamento a serviço do país. E, no entanto, pioraram sempre, dizendo que a sua ONG resolveria o problema do país. Estão lá dentro do governo. Vamos ver se resolve não é? Depois existem ONGs especializadas. Tem umas que cuidam da praia, outras que cuidam do lixo, da rua etc. São muito importantes porque criam uma permanente campanha contra fatos errados no meio ambiente e no metabolismo urbano. E depois tem algumas ONGs que são predatórias. Se vocês soubessem o número de pessoas que às vezes me pergunta: "prof. Aziz estou querendo organizar uma ONG, o senhor fica no nosso conseIho?" Agora questão da usina termo-elétrica aqui em Cubatão: como eu mostrei no Sesc de Santos, as coisas estão muito complicadas. Fui o primeiro falar com os engenheiros da Petrobrás, lá em Cubatão e eles me mostraram uma coisa que eu utilizei pra argumentar contra eles próprios. Mostraram a pluma: vem os ventos de nordeste, vem os ventos leste, os do sudoeste e empurram a pluma pra dentro da Serra do Mar. Não pode passar a Serra, porque ela bloqueia, sobe, e ao subir entra um pouco no planalto . E aí eu queria saber qual a altura que chegava os gases particulados e me disseram que acharam a altura de 1.100 à 1.300 ms. Como Paranapiacaba está a 780 ms. e seus arredores a 1.100 m., é evidente que entra reverso continental da Serra do Mar. E eu aí então disse a ele.: "Agora, vão fazer mais uma coisa que joga mais gases para o ar. É perigoso."

Eu estou com os funcionários da Petrobrás, que do ponto de vista de precaução, é uma concentração grande de poluição/área por elevação. Não me lembro bem o nome. É isso que eu posso dizer a você. Eu não sou favorável à termo-elétrica ali. Agora, surge um problema. Se ali não é favorável, onde colocá-la? E aí tem o problema do espaço total. Ou eu conheço o espaço total para achar um lugar que pode pôr a usina, ou então está tudo perdido. Uma outra termo-elétrica foi colocada próximo a Jundiaí. O povo reclamou muito e com razão. Então nós temos problema nessa passagem, nesse desdobramento de fontes energéticas. É só isso que eu posso responder pra você.

Pergunta: E a dragagem? A dragagem de Piaçaguera e do Porto de Santos?

Aziz __ Olhe, eu não conheço em detalhes os problemas das dragagens. Eu só 
sei dizer que a poluição que vai pra dentro do estuário é muito grande, e a pesca está extremamente prejudicada. Os pescadores foram expulsos da frente das ilhas, pra ceder lugar para as construções magníficas de verticalização. Problema de pobreza, jogada pra retroterra. Então a questão maior é estudar o que está na frente das ilhas, de Santos, São Vicente, Guarujá e depois passar a estudar socialmente, pensando na pobreza das pessoas que foram abrigadas nos piores espaços, nos ares de mangues, à beira de gamboas e mais para dentro nos sopés da Serra. A poluição é grande e os organismos de saneamento sabem disso.

Pergunta: Professor, há alguns anos atrás, o senhor escreveu a respeito da proposta do Engenho dos Erasmos.

Aziz __ Eu trouxe esse problema do Engenho dos Erasmos pra falar pra vocês, mas eu confesso que a palestra já estava um pouco longa. Desde há muito tempo vi que os historiadores ficavam falando sempre dos Engenhos dos Erasmos e não sabiam nem localizar. Nos geógrafos temos que entender do sítio, dos componentes do espaço total e da localização. Então eu vim pro engenho dos Erasmos a convite de um arquiteto meu amigo, prof. Júlio Katinsky e estudei o conjuntozinho do espaço do entorno do engenho dos Erasmos. Pra mim não interessava apenas ver as paredes, as ruínas. Interessava ver porque eles escolheram aquele lugar. E eu fui muito feliz nisso. Porque sai um riozinho que vem de uma vila que está suspensa lá nos altos do Maciço de Santa Terezinha, e aquele riozinho cai abruptamente em cachoeira e escorre até a base do lugar onde foi implantado o engenho. E esse rio vai chegando próximo da baixada e ficou bem claro pra mim que os canaviais, que foram a base da possibilidade de ter um engenho para fazer rapadura, açúcar preto, etc, foram plantados na planície de piemonts do morro. Foi todo esse conjunto, o rio que sai em cachoeira, que desce, que se espraia, e que forma um aluvião rico, que serviu para o engenho. $O$ engenho não é outra coisa senão o espaço de plantação da cana mais a sede de trabalho para a produção. Então eu fiz um trabalho que está publicado na revista da USP, em que eu falo até uma coisa de alto interesse pra vocês. Eu estudei toda a região, o entorno, da estrada da Gramalheira dá pra ver todo o conjunto. Chama-se estrada da Gramalheira, e tem dois patamares, provavelmente terraços geomorfológicos, que sobraram. O primeiro à direita do riozinho, não tem nome, eu chamei de ribeirão dos Erasmos, o segundo é onde estão as ruínas. $\mathrm{E}$ eu propus o seguinte: que a Secretaria da Cultura da prefeitura cuidasse. Que cuidasse do lugar onde tem a cachoeirinha lá em cima, saindo 220 m, e não deixasse, no entorno, produzir casas carentes, porque a tendência era ficar em cima da cachoeira com um vão embaixo da casa. Ao lado já tem uma assim, e tudo o que eu escrevi não foi aceito por ninguém, ninguém reparou e deixaram uma organização social importante ter a sua esquina quase na frente do começo da cachoeirinha. E lá embaixo eu tinha sugerido, como são dois patamares, um com as ruínas, e outro devastado, que antes de chegar nos aluviões, que hoje tem bananais e não mais cana de açúcar, que aí se estabelecesse alguma coisa complementar da universidade. Talvez até da escola de vocês, da faculdade, pra fazer um centro cultural, um ponto de turismo em que as pessoas saíssem para um passeio turístico, histórico, eco-geográfico, da fortaleza da Bertioga até o porto de Santos, do Porto de Santos até o Monte Serrat, e do Monte Serrat até o morro de Santa Terezinha e o engenho dos Erasmos. E que fosse uma escola de paisagismo, já diretamente sobre a recordação do passado do engenho dos Erasmos. Enfim, só a história não basta é preciso 
conhecer o espaço em que a história se desenvolveu e por isso atendi o professsor Katinsky e fui lá repensar o problema do engenho dos Erasmos.

Pergunta: __ O senhor, lembrou muito bem, o prof. Milton Santos. Sabia que a geografia é a ciência do espaço, no entanto a geografia não é ensinada com esse olhar nas escolas. Poderia comentar sobre isto?

Aziz _ Para um país do tamanho do Brasil, com o mosaico de áreas importantes com duas megas regiões florestais Amazonas e Mata Atlântica, sendo que da Mata Atlântica sobrou 6\%. Por isso que eu sou contra essas ONGs que dizem S.O.S Mata Atlântica. Eles que fizessem o que eu fiz. Tombassem a Serra do Mar e para depois se fazer o tombamento legal. Eu comecei um tombamento provisório e depois eles fizeram o tombamento final. Só que hoje não existe gerenciamento. Um dia desses, lá em Ubatuba, eu vi um vídeo que dizia: "nós de Ubatuba temos nosso parque municipal da Serra do Mar". Como se fosse só deles e do município, quando ela é tombada de alto abaixo, dos piemonts aos Saltos. O tombamento da Serra do Mar está perigando por falta de gerenciamento e por falta também de esclarecimento dos governantes. Eles acham que é coisa simples ter a Serra do Mar, utilizada talvez por gente que vai subindo, fazendo condomínios. A situação é muito grave, e eu acho que na questão educacional - considerando o fato de se continuar se ensinando uma geografia limitadora, só decorativa e que não coloca as coisas frente aos alunos - precisa haver alguns acréscimos. E vocês, parecem que viram esses vídeos (O Povo Brasileiro), que nos sugerem que, para poder dar mais conhecimentos aos alunos, nós temos que usar outras estratégias, incluindo estratégias bem avançadas no caso da tecnologia como é o caso desses vídeos. Esse vídeo, por exemplo, fala na parte do tupi, da pré-história, da agressividade dos grupos humanos. Florestan Fernandes falou que houve um papel social da guerra entre os tupinambás daqui da nossa região entre Santos, São Vicente, Praia Grande, Bertioga etc. E agora os americanos descobriram que não é só o papel social da guerra. É o papel ecológico da guerra, através do que os grupos que falavam o tupi queriam um espaço mais produtivo do que os outros e aí começaram os conflitos. É o papel social e ecológico da guerra. E a gente precisa saber certas coisas da pré-história. Continua havendo um papel social e ecológico baseado no capitalismo selvagem que quer comprar tudo e fazer do jeito deles, do jeito que dê mais dinheiro. Então minha resposta para a parte educacional é que ela começa dentro da universidade com uma produção de coisas que sirvam para completar essa falta de capacidade da geografia no Brasil de poder ser mais conjuntural, mais visualizável e mais séria em relação às questões das desigualdades sociais e regionais. Não dizer apenas como é dito em São Paulo por gente ilustrada: lá na Amazônia é assim. Meu Deus! Numa área de 4 milhões e 200 mil km² como é que eu vou dizer que lá na Amazônia é assim, seria a mesma coisa que eu dissesse assim: lá em São Paulo é assim , sem me lembrar dos diversos circuitos econômicos e sociais de S.Paulo, da Av. Paulista até as periferias do Jardim Ângela, ou da zona leste. Então a gente tem que saber as coisas com mais cuidado e uma das maneiras de começar saber isso é fazer coisas que mostrem a realidade, conjunturalmente, além das aulas formais.. Eu passei esse vídeo em Sorocaba, na Faculdade de Sorocaba. Foi a primeira vez que eu vi um vídeo aplaudido no fim da passagem. Isso mostra que temos que ter algumas estratégias para completar a nossa geografia, mesmo que os professores do primário e secundário não conheçam todo o Brasil. E os próprios alunos da universidade ainda não puderam se organizar 
para fazer viagens pelo Brasil afora pra ver as realidades de todas as áreas. Lá na USP, os geógrafos, desde que eu trabalhei lá, faziam excursões para conhecer o Brasil, só que naquela época não se podia ir até a Amazônia. Não tinha a estrada Belém Brasília, não tinha outras estradas que vão até Cuiabá e depois vão para a região de Manaus. Então temos que arranjar estratégias para a região de Manaus. Temos que arranjar estratégias para conhecer melhor o país e exigir que as pessoas que estão no topo da sociedade, mais ricos, empresários e a pequena burguesia também pensem no Brasil no seu conjunto. E a melhor maneira de pensar o Brasil no seu conjunto é que a mocidade, filhos de todas as classes sociais, aprendam mais e exijam mais em relação ao conhecimento.

Abdala muito obrigado professor.

\section{Prof. João Filgueiras Lima - Lelé}

Cláudio Abdala (Coordenador do Curso de AU - Unisantos): Hoje estamos encerrando a nossa Semana de Arquitetura com um fecho especialíssimo porque contamos com a presença do professor, do arquiteto, João Figueiras Lima, que vai nos dar oportunidade de tomarmos contato com sua obra que é do maior significado no cenário da arquitetura brasileira. A ele devo nossos agradecimentos especiais em função de seu esforço de nos fazer essa visita. Nessa circunstância especial encaminho a ele os agradecimentos da Faculdade de Arquitetura e Urbanismo de Santos pelo privilégio que é de ter esta oportunidade de tomar maior contato com a obra e a presença do arquiteto, que é uma das figuras mais importantes do nosso cenário de arquitetura moderna brasileira. Quero também agradecer a presença da professora Anália Amorim, diretora da faculdade de arquitetura, da Escola da Cidade que veio acompanhando o professor João Filgueiras Lima, e também o empenho da professora Vera Domschke em viabilizar esta palestra, além da presença do professor Júlio Artigas que abrilhantará este momento, conduzindo a mesa do debate.

Júlio Artigas - Boa noite, colegas, professores, agradáveis e simpáticos alunos da FAU-Santos, sempre educados e bondosos para conosco, seus professores. Quero chamar a atenção para o fato de que esta faculdade de arquitetura é um espaço privilegiado. Privilegiado pelo fato de que, há mais de 30 anos, ensina às gerações de arquitetos os assuntos, os métiers, as questões relativas ao plano do conhecimento humanista que é o espaço cultural e a área de conhecimento da arquitetura, que se nós imaginarmos, tem quase a idade do homem civilizado, pelo menos 100 mil anos de vida cotidiana. Nesses anos todos que a escola existe nós tivemos a felicidade de poder contar, em determinados momentos, com a presença sempre constante do Osvaldo Correia Gonçalves, que é o mentor desta escola. Sua presença ainda existe entre nós. Osvaldo é sempre um anjo, um condutor das nossas querelas, nossas discussões, de nossas vivências. Pudemos contar duas vezes com a visita de Vilanova Artigas nesta escola. Pudemos contar, recentemente, com Paulo Mendes da Rocha. Mas esta semana da arquitetura 
em particular trouxe para esta escola um elenco digno da arquitetura do séc. XX nesse limiar do séc. XX I que nós estamos a construir. Participaram os arquitetos e professores João Valter Toscano, Pedro Paulo Melo Saraiva, que na minha opinião é o maior professor de arquitetura do Brasil neste momento, e também do Alberto Xavier que fez uma palestra incrível sobre a história da arquitetura do Brasil, além do Décio Tozzi, do Eduardo Longo, e do Yopanan Rebello, ex professor desta escola. Bem, e para encerrar esta semana, recebemos hoje, sem dúvida nenhuma, um herói da raça: João Figueiras Lima é um representante do saber, da cultura e da invenção do povo brasileiro. Conheço o Lelé desde meus 12 anos, em Brasília 1962, mas fui conhecer de fato, reencontrá-lo, em 1968, já sob a ditadura militar. Nessa época ele estava realizando a primeira obra dele que eu vi, a Disbrave (Distribuidora Brasileira de Veículos) e uma agência da Volkswagem, muito bonita, com uma solução estrutural que até hoje prezo.

Mas vamos falar um pouco de seu currículo. João Figueiras Lima nasceu no Rio de Janeiro em 1932. Freqüentou a Academia de Agulhas Negras, escola militar, e fugiu dela. Formou-se na Faculdade Nacional de Arquitetura, Universidade Federal do Rio de Janeiro, em 1955. Em 1957, foi convidado para trabalhar com Oscar Niemeyer na construção de Brasília. Lá ele militou até 1978, junto com Oscar Niemeyer. Em seguida, saindo de Brasília foi para a Bahia e TrabaIhou como Coordenador Técnico do Escritório de Projetos de Pré-moldados da RENURB, Companhia de Renovação Urbana da Prefeitura de Salvador, desenvolvendo projetos que visavam recuperar as áreas da periferia da cidade, que precisavam de drenagem. O Lelé também é um músico excelente. Toca Chopin, como poucos. Participou do trio "Dodô e Osmar", o trio elétrico. Ele toca piano, teclado, com o Osmar que trabalhava na RENURB e era um funcionário muito inventivo. Devemos muitas soluções de arquitetura do Lelé, ao Osmar, que é arquiteto também. Mas depois desse período na Bahia, em 1983, Lelé contribuiu com governo Leonel Brizola, no Rio de Janeiro, o primeiro governo democrático eleito que teve que derrotar, nessa eleição, não só os outros candidatos ao governo, como também a Rede Globo. E lá, Lelé realizou os CIEPS - Centros Integrados de Educação Pública, fez as fábricas de escola, das creches, que nós conhecemos e que foram implantadas no governo Brizola, pelo Darcy Ribeiro que era o vicegovernador do Estado do Rio nessa época. Em 1988 desenvolveu projeto semeIhante para o governo Federal (os CIACs - Centros Integrados de Apoio à Criança e ao Adolescente). Depois foi convidado para trabalhar novamente em Salvador, na Bahia, onde ele está desde 1989 até hoje. Na Bahia, ele desenvolveu os projetos da Rede Sarah de hospitais, que hoje, pra vocês terem uma idéia, já são 45 unidades espalhadas pelo Brasil. Produziu também escolas, creches e igrejas. Nossa escola, que é católica, teve a felicidade, a benção de ter o professor Décio Tozzi que mostrou o projeto dele no Ceará para a segunda visita do Papa e hoje temos o Lelé que fez o espaço da igreja do Papa, em Salvador. Lelé já realizou mais de cem obras até hoje, o que é algo espantoso, acho que não tem arquiteto que tenha produzido mais de cem projetos construídos com a qualidade das obras dele. São mais de mil obras realizadas, considerando que as pré-fabricações e suas repetições permitem uma ampliação do universo das obras. Mas não se 
esqueçam que cada obra é uma nova invenção. Bom, isto é o que eu tinha de dizer de meu grande amigo Filgueiras Lima. Queria reforçar a importância da presença dele neste momento, neste auditório, porque ela dá uma condição especial para o recinto, pro espaço desta escola, que há mais de 30 anos vem formando consciência de cidadãos que vão se dedicar à nobre, profícua e humanista profissão de arquiteto. Antes de tudo, Lelé é um profissional social e vai mostrar como essa condição pode ser levada às últimas conseqüências. Com vocês, a palavra, o saber, e a experiência brasileira de João Figueiras da Lima, um herói da raça.

João Filgueiras Lima - Lelé - Estou muito feliz em participar desta série de eventos com vocês. São todos arquitetos muito importantes que nós sabemos reconhecer, e não é somente apresentação do Julio que me comove, que é feita de uma forma tão simples e não há quase nenhum reparo a fazer. O único reparo que eu faria é que eu fugi da escola militar, mas depois fui recuperado e aí saí direitinho pela porta da frente. Não tive que ser desertor, porque seria uma tragédia. Mas cheguei a fugir, de forma que ele não mentiu nem um pouquinho. Mas, realmente estou muito feliz de estar aqui com vocês, de participar desta série de eventos. Eu gostaria de ter trazido alguma coisa um pouco diferente, mas vocês devem imaginar que eu vim fazer uma palestra em São Paulo e trouxe quatro carrosséis de slides. Tinha sido inicialmente convidado pelo Zanettini, para fazer uma palestra sobre a tecnologia da "argamassa armada", que faz parte do currículo que ele e a Professora Anália Amorim desenvolvem na FAUUSP e então abordo nesta palestra uma parte grande alusiva à argamassa armada. O restante do trabalho que eu gostaria de mostrar um pouco meIhor para vocês ficou um pouco comprimido, mas dá para nós conversarmos. 0 título da palestra ou por outra, a proposta da palestra, era eu falar sobre a adequação tecnológica e foi assim que procurei inserir a tecnologia da argamassa armada dentro desse contexto. De forma que nós vamos falar sobre a adequação tecnológica. A rigor, o que eu gostaria de mostrar é que, nessas experiências todas que nós tivemos no decorrer desses anos, pudemos experimentar várias tecnologias, cada uma com suas disponibilidades, com suas características próprias, daí a nossa oportunidade de optar por uma ou outra. Por exemplo, o Julio citou a igreja do Papa. Foi uma opção feita a partir de uma disponibilidade de mão-de-obra. É isso que vou tentar mostrar pra vocês aqui: na verdade, quando um arquiteto enfrenta um problema de arquitetura, ele tem que encontrar seu caminho, às vezes, de acordo com as disponibilidades concretas.

\section{COMEÇAM AS IMAGENS}

1. Índios do Xingu

Eu até gostaria de iniciar mostrando como os nossos antepassados, que foram os donos desta terra, faziam umas casas muito bonitas, que são as casas dos Xavantes. Lembro que Darcy Ribeiro, que foi muito meu amigo, tinha uma verdadeira adoração por estas casas e aprendi muito com ele, inclusive como se constroem essas casas. Acho que pra mim foi uma lição inesquecível. Não esqueço jamais de como os índios conseguem elaborar um espaço tão correto, tão apropriado para a vida deles, de uma forma tão inteligente. Quero começar 
falando da tecnologia da construção e da adequação tecnológica exatamente com a casa dos índios do Xingu. Essas grandes malocas que os índios construíam em torno de uma clareira - eram várias malocas em uma distribuição em círculo com uma maloca central que era a área social deles e um grande espaço de habitação coletiva - eram adequadas ao clima por meio de alguns processos de ventilação que nós usamos ainda hoje, aproveitando o grande pé direito para haver uma convecção do ar, quer dizer, para o ar subir, ser extraído por cima nessas peças de xelio.(sheds?). Algumas tribos usavam a grande cumeeira que atravessa, como um ornamento deixando expostas as raízes para mostrar a ligação que havia com a terra. Existe, então, todo um processo simbólico na construção e ao mesmo tempo aspectos funcionais tão corretos que eu gostaria de começar nossa palestra a partir disso. Por exemplo, a questão dos ventos. Numa barraca dessas, com oito metros, o principal inimigo estrutural era o vento, devido á altura. Então toda a concepção da forma não só fica muito apropriada a se defender do vento, mas além disto, eles colocavam na cumeeira peças de contraventamento, quer dizer, duas peças em curva, em xis, pra resolver melhor essa resistência ao vento. Outro aspecto muito inteligente é que eles desencurvavam estas peças, que eram relativamente finas, porque, na medida que se curvam as peças, se cria uma tensão no sentido oposto. A mesma força que eles liberam de um lado, ao contrário do que eles faziam no ar, sabiam utilizar também. Então, é o mesmo princípio do outro lado: comprimem na direção oposta, criando uma força na direção oposta ao lado em que o vento atuar. É um processo bastante intuitivo, bastante instintivo mas que eles já dominavam completamente. Por outro lado, a construção geométrica, a forma geométrica de construir, era um processo já sedimentado culturalmente. Por isso é que eles construíam sempre igual e passavam de geração para geração e chegaram ao apuro de construção. Esse processo cultural não podia prescindir de uma organização já geométrica do espaço para que todas as pessoas soubessem fazer igual a mesma casa. E quando a gente vai às tribos do Xingu, todas as casas são iguais. É um processo com uma força cultural imensa. A marcação, essas peças são fincadas na forma da maloca e depois estabelecida uma ligação com as outras mais fortes de forma que, a partir daí, eles iam curvando as peças do telhado que eram amarradas com embira nas peças da cobertura e depois cobriam com palha. Esse primeiro exemplo que nós demos, foi de uma arquitetura bem organizada, embora feita de uma forma intuitiva, funcionando perfeitamente para o clima do lugar.

Seqüência de imagens das malocas dos índios do Xingu.

2. casa Aluísio Campos da Paz.

Vamos mostrar um exemplo, quase oposto, de uma arquitetura caótica que não tem condição nem de se desenhar, porque nós optamos, nessa época em meados dos anos 1960 lá em Brasília, por fazer essa construção simplificada, em pedra. Na verdade esse sítio fica bem próximo do lago e é um sítio com uma construção morfológica bastante peculiar em Brasília, alem da flora do cerrado, que era muito exuberante. Nossa idéia era incorporar a construção completamente a essa topografia, evitando danificar a flora existente, 
recuperando a vegetação, mantendo toda essa área cheia de pedras, usando as pedras do local para fazer uma espécie de gruta. Disse que é uma construção caótica, porque ela não tem nenhuma regra estabelecida, fomos procurar o melhor sítio, pra danificarmos o mínimo da paisagem, para organizar um espaço em que se pudesse dormir e ao mesmo tempo tivesse a parte de serviços e cozinha, ocupando de uma forma mais inteligente possível a topografia. Claro que no decorrer da obra tinha uma pedra imensa que não foi possível remover, então a incorporamos também. Mas o que é importante ressaltar é que é uma construção extremamente simplificada. Há uma laje de concreto em cima e a planta, eu não sei bem como é, e ninguém sabe porque aquilo foi feito de uma forma espontânea, no local. A piscina, que fica numa área adjacente, foi adaptada ao terreno. Em cima da pedra nós fizemos um furo para colocar uma lanterna de luz. O dono dessa casa é o médico Aluísio Campos da Paz.

\section{Casa do Nivaldo}

Vamos passar dessa tecnologia a uma outra mais organizada, de tijolos que é uma tecnologia dos assírios, que vocês sabem perfeitamente que é mais antiga do que a arquitetura romana; precedeu a arquitetura romana e, muito embora os romanos tenham sido os mestres dos arcos, os assírios já os faziam em tijolos. É uma tecnologia de quatro mil anos. Mas a razão de nós termos usado essa tecnologia era que, naquela oportunidade o dono da casa, que era um pernambucano, queria manter toda a família reunida e quis fazer uma casa enorme.Nós dispúnhamos de um mestre de obras, o Tião, agregado da família do proprietário, que era um hábil construtor de abóbadas. Ele falava um espanhol muito difícil, mas a gente conseguiu se entender e, na medida que eu fui conversando com ele, o projeto foi surgindo, justamente pra que ele participasse efetivamente da obra. O Nivaldo (seria o proprietário? Sobrenome) ficou muito feliz com isso. Ele acompanhava toda a construção e a casa levou cinco anos para ser construída. O conceito da casa é quase o de uma igreja porque você tem as naves laterais - onde ficam os quartos e as áreas de serviços - e no final um grande espaço que ao mesmo tempo incorporava as áreas de estar com o ambiente de água, onde havia incidência de luz muito forte. O restante da casa, no entanto, era sombreada e o espaço central tem uma parte ajardinada.

\section{Igreja do Papa em Salvador}

Eu tinha feito um projeto pra visita do Papa, que era um projeto bem simples, um telhado inclinado, com incidência de luz zenital até pra ficar uma coisa menos acintosa diante da pobreza da região dos alagados. Essa é uma área, uma espécie de uma colina que existe em Salvador e o entorno dela tem toda essa pobreza das palafitas dos alagados. Então nós tínhamos imaginado uma coisa mais simples. O local foi escolhido para o Papa inaugurar, propositalmente por ser uma área muito pobre. Mas o Arcebispo não concordou com o projeto, achava muito simples e aí por uma coincidência dessas, o mesmo Tião das abóbadas tinha me convidado para o casamento da filha dele, em Brasília. Brincando com ele falei: 
- Tião você não quer fazer uma igreja em Salvador para o Papa inaugurar? Ele disse - Ah, vou fazer.

- Mas o problema é que você tem que fazer em cinco meses, porque a visita do Papa já está marcada.

Achei aquilo um disparate porque não imaginei que aquele artífice, detaIhista, cuidadoso, fazendo cada junta de tijolo, se propusesse a enfrentar uma maluquice dessa, de fazer a igreja em cinco meses. Mostrei para ele o projeto como era, sentamos juntos e fomos fazendo o projeto. Fizemos uma grande abóbada. A conversa tinha sido no sábado e na segunda-feira ele já estava lá para trabalhar. Ele mesmo selecionou o pessoal que ia trabalhar, falando o espanhol difícil de se entender - que depois percebi que era catalão. Não sei como ele conseguiu falar em baiano. Sei que ele juntou uma porção de pedreiros e a igreja foi feita no prazo. Acho isso fantástico: uma pessoa que era acostumada a trabalhar tão solitariamente, de repente, aceitar a proposta e fazer a igreja, toda fora de prumo, toda torta, mas que afinal de contas o Papa pôde inaugurar. Ficou em pé. Havia umas peculiaridades: nós quisemos defender essa árvore, uma mangueira, e isso foi um desastre ! Fizemos um enrocamento de tijolos pra defender a raiz da mangueira porque tivemos que cortar um pouco a colina para implantar a igreja. Mas aí, o que aconteceu: os meninos vão colher as mangas e apedrejam um vitral muito bonito que o Athos Bulcão produziu. Esse vitral foi completamente destruído por causa da mangueira que nós tentamos salvar. Queria chamar a atenção também para este tirante que é uma herança cultural muito forte que temos que resguardar, é a herança das construções dos mouros. Acho que houve duas tendências muito diferentes, distintas na arquitetura européia que foram absorvidas pela arquitetura portuguesa e pela arquitetura espanhola: uma tendência do uso do tirante que chegou até nós, que a arquitetura ocidental, a arquitetura gótica, abnegava de todas as formas. Mas o tirante é pra se combater esse último empuxo que essa abóbada oferece.

\section{Igreja de concreto em Salvador}

Saindo um pouco da arquitetura do tijolo, vamos entrar na de concreto. Visto com a sua plasticidade, o concreto usado como ninguém melhor do que o Oscar Niemeyer conseguiu se exprimir no nosso país. É até humilhante mostrar o uso da plasticidade concreto com esse exemplo. Exemplo melhor seria uma obra do Oscar Niemeyer. Mas de qualquer maneira vamos mostrar. Acho que essa igreja só poderia ser concebida em concreto armado porque a proposta realmente envolvia todo um aspecto do espaço externo que não permitiria outra solução. Primeiro que a nossa intenção foi manter toda a vegetação intacta e toda a topografia existente inclusive, porque é lógico que à medida que você muda a topografia você destrói as raízes das árvores. Pra isso foi criado um receptáculo rigoroso no cume da colina e esse receptáculo foi inserido na estrutura, protegido por pedra. Houve uma intenção simbólica de usar muitos apelos à arquitetura religiosa da Bahia. Acho que a concepção dessa igreja é barroca no sentido do desenho, das intenções, respeitando a tradição baiana. O espaço da nave principal foi organizado segundo uma elipse que se transforma depois, 
com pétalas, em um helicóide ascendente, com essas pétalas aumentando de tamanho à medida que se aproximam do topo. Só o concreto armado permite uma concepção desse tipo, a gente tem a forma que é como se fosse a estrutura de uma folha. Você tem na área principal onde existem as tensões de equilíbrio, não as tensões na área do centro de gravidade, mas aquelas da área principal das tensões. No centro fica um pilar e este pilar está fortemente engastado nessas nervuras que formam o conjunto da folha. É uma concepção bastante orgânica. Eu conheci muito o Joaquim Cardoso, que foi o calculista que trabalhou com o Oscar Niemeyer. O Joaquim Cardoso concebia sempre a estrutura de uma forma orgânica. Costumava dizer: - Olha, a estrutura é como se fosse uma raiz. Ela tem que procurar seus apoios, procurar suas resistências ao trabalho mecânico de uma forma orgânica. Ele defendia sempre essa tese. Esse exemplo aqui se enquadra muito bem na visão que Joaquim Cardoso tinha do comportamento da estrutura. Aqui também havia a idéia de respeitar o efeito dos tetos dourados, de criar entre cada pétala uma incidência de luz com vidros âmbar, que dourassem o concreto. Havia todo um simbolismo também que queríamos respeitar. No entorno da igreja foram usadas as pedras da maneira que os portugueses faziam nas fortificações e nos arrimos que eles criaram na cidade.

\section{Casa no lago em Brasília}

Ainda sobre o uso do concreto vou falar agora de uma casa em Brasília que também é um exemplo característico em que temos uma grande viga que trabalha na cobertura. Uma viga que chamamos de pórtico, com engaste bastante forte e que transmite os esforços para o pilar. Com o balanço também engastado, forma um conjunto estrutural no qual se pendura todo o pavimento onde se desenvolve a parte mais importante da casa. Por que uma estrutura tão inusitada, tão estranha? Isso resultou principalmente de um desejo do proprietário que queria um mirante que garantisse a vista do lago, porque ele não queria cortar um pomar que tinha. Inicialmente eu disse para ele:

- Olha, se você tem dinheiro, levanta toda a casa e garanta a vista. Com um mirante você vai subir um dia por semana para ver o lago e ele não vai mais fazer parte da sua vida. É preciso dominar o lago diariamente para que você amanheça vendo a vista que você não quer perder. Então levantamos a casa e criamos um elevador. Como aqui era uma orientação norte, elas (elas quem?) ultrapassam muito o limite da casa pra criar uma proteção natural quanto à orientação norte. Não imagino essa estrutura, da forma como foi concebida sem o uso do concreto armado. Só o concreto armado poderia nos proporcionar todos os engastes necessários: uma viga engastada e o pavimento todo pendurado. Os serviços estão num pavimento abaixo completamente solto e têm azulejos do Athos Bulcão.

\section{Edifício não identificado (autarquia)}

Este outro edifício (qual?) tem também uma concepção que só o concreto armado poderia proporcionar. Ela está muito forjada numa experiência de Le Corbusier em Marselha, que vocês devem conhecer, que é o 
uso da viga de transição. Nós temos um grande ligamento, que ocupa um pé direito inteiro, fazendo a transição para os pilares debaixo do apoio que vem dos pavimentos superiores. Então temos uma viga que chamamos de viga de transição. No pavimento da biblioteca, que tinha uma parte de varanda e o resto era todo fechado, se fez também, não só a transição da estrutura, mas a transição das instalações, inclusive do ar-condicionado. Por que o uso dessa viga de transição? Esse espaço, que é destinado ao setor de autarquia, estava muito comprometido com as dificuldades de circulação para veículos e também com a relação que ele tinha com o sistema viário, muito próximo. 0 edifício, com esta empena descendo, ia ficar uma coisa lamentável. Nosso desejo também foi promover uma certa respiração para esse urbanismo a rigor estava bastante prejudicado devido ao sistema viário.

7. Edifício em Brasília que o Julio falou no começo.

Indo um pouquinho mais adiante, e mudando a concepção do uso do concreto, neste caso ele está voltado para pré-fabricação. O desenho vai mudando e começa a ter os elementos repetitivos. Essa foi uma experiência que nós fizemos lá no lago (?) depois do golpe militar. O Julio falou deste projeto pós-golpe. A idéia da pré-fabricação fica muito presente na medida em que você tem todas as peças independentes. São estruturalmente independentes e ao mesmo tempo são repetitivas, pra você ter a economia de escala, que é um dos princípios da pré-fabricação. Este prédio foi produzido em várias etapas. Cada molde desses tem 24 m, num pilar central. O comportamento desta estrutura só é possível com o uso concreto armado para se ter todos estes engastes e permitir a estrutura esta forma. Esses prédios me acompanham o resto da vida. Porque a cada reforma sou chamado para restaurar. Fizemos uma reforma em argamassa armada que eu vou mostrar um pouco melhor depois.

\section{Pré fabricação na Universidade de Brasília.}

Já avançando um pouco na exposição da pré-fabricação, vamos ver a primeira experiência de pré-fabricação que fizemos na Universidade de Brasília. O primeiro prédio realizado com pré-fabricação total ainda estava muito inspirado na tecnologia da madeira. Nós estávamos iniciando as experiências nesse período na Universidade de Brasília, em 1962, com pré-fabricado, de maneira que nós transferimos muitas das tecnologias da madeira - a viga fixada com parafuso, soluções muito propícias à tecnologia da madeira - que eu acho que não exprimem bem as possibilidades do concreto. Acho um projeto equivocado. Vou dizer depois porquê. Para resolver problema do contraventamento nós tivemos que criar peças que são os apoios das escadas, fundidas no local. Essa é uma pré-fabricação em canteiro e todas as peças que foram produzidas ao lado são também protendidas. Os cabos utilizados são um recurso para reduzir os custos na montagem da retirada das formas. Usamos todas as disponibilidades tecnológicas da época, mas a concepção do projeto continuo achando que é equivocada. 


\section{Hospital de Tabatinga (?)}

Este é um projeto elaborado com posturas posteriores. Nós continuamos a falar nos pré-fabricados, no uso do concreto, mas já incluindo uma segunda etapa, a etapa de concretagem à qual estes componentes todos são ligados. Este é um hospital em Brasília de 1967 ou 1968. A intenção deste projeto foi o de criar uma forma diferente de atender os pacientes do hospital, criando terraços para que eles pudessem participar dos banhos de sol. É ao mesmo tempo um projeto bastante flexível porque pode crescer, poder readaptar seus espaços, usufruindo também de elementos de iluminação natural a partir de sheds. Esses sheds são péssimos, mas enfim houve a intenção. A construção também obedecia a um critério de economia. O setor da pré-fabricação é ao lado e aqui se tem umas posturas posteriores em que se fez uma concretagem de segunda fase de forma que o sistema ficava monolítico.

\section{Centro administrativo da Bahia (?)}

Agora falaremos da pré-fabricação na qual essa segunda etapa é levada às últimas conseqüências, usando tecnologia pesada. O porquê desta solução: quando nós fomos convocados para fazer o centro administrativo da Bahia, o projeto inicial do Dr. Lúcio Costa, estabelecia que o sistema viário e as construções deviam ficar sempre nas encostas, protegendo as áreas de vegetação que seriam os vales. Isso foi em respeito a uma tradição em toda a implantação. Na Bahia os vales não eram ocupados. Só mais tarde foram usados para se fazerem avenidas de vale. Mas antes, nos vales, tinha horta e coisas que mantinham sempre um espaço verde. Por isso que Bahia sempre foi muito bonita. Hoje está enfeando. A Bahia ainda tem áreas de respiração verde, graças a esses critérios de implantar os prédios nas cumeadas. O problema a ser enfrentado era sério porque, naquela época, as construções eram muito mais delicadas, faziam-se os arrimos, se curvavam as plataformas, mas isto sem a tecnologia de hoje, principalmente a de movimento de terra. Os primeiros prédios começaram a ser feitos e o Dr. Lucio ficou assustadíssimo, disse: - "Estão desvirtuando tudo! Por que começaram a fazer aterros?" E aí o aterro se debruçava através das encostas dos vales e tudo estava sendo destruído. Do enfrentamento desse problema é que surgiu a concepção deste projeto: os prédios são completamente soltos das (meias) encostas para respeitar os vales e preservar a vegetação. Foram criadas plataformas de transição que depois suportavam os pavimentos. A rigor nós não estávamos propondo um projeto, e sim propondo uma forma de construir: os cinco prédios são modelos. Tínhamos a área administrativa e alguns prédios, como os auditórios, que excepcionalmente podiam se debruçar nas encostas. Os serviços todos ficavam voltados na direção das áreas de estacionamento. Embaixo as garagens dos prédios e depois o sistema de circulação vertical, escadas, rampas. É um modelo e a partir dele desenvolvemos uma maquete muito rigorosa de todo o centro pra poder implantar os prédios em cada topografia com sua respectiva curva. A construção, a parte feita no local, se resumia simplesmente a esses grandes pilares com essa viga central que é uma grande viga de transição que transmite todas as cargas para a plataforma. A Anália Amorim estava chamando 
a atenção na exposição que eu fiz em São Paulo, que a questão da pré-fabricação era complicada de resolver por causa das curvas. Então, nessa época nem tinha computador direito, e nós tivemos que desenvolver um programa de computador para estabelecer esses módulos para resolver o problema dessas curvas. Criamos uma curva com três caixas de 2 (?) do outro lado que nos proporcionavam a adaptação para formar varias curvas que acompanhavam sempre a topografia.

Quero chamar a atenção de vocês para a montagem porque, às vezes, é necessário fazer um escoramento que acaba prejudicando muito a paisagem. Isso que vocês estão vendo não é apenas uma torre metálica que é só para servir para o direcionamento da peça, mas a rigor, não tem nada escorado. Essa peça era montada apenas com uma solda que os soldadores já estão esperando, e depois esse sistema todo consolidado através de uma concretagem de segunda fase. (aqui ou se elimina a frase ou se coloca a imagem correspondente e o trecho como legenda)

11. Edifícios da Camargo Correia (e Silva?) em Brasília / Terminal de ônibus/ Estação

Essa industrialização de que falei ainda é um pouco precária porque parte das peças é executada no local. Neste outro caso, dois prédios da companhia Camargo - Correia e Silva (?) em Brasília, não. Aqui nós já tínhamos a pré-fabricação contando com processos mais disciplinados.

Ainda falando no pré-fabricado, existe uma outra expressão do pré-fabricado em concreto, que é a pré-fabricação pesada, que se usa especificamente em obras de viadutos, em obras de artes, em rodovias. Essa obra não deixa de ser um exemplo, porque ela a rigor é uma estação de passageiros, mas tinha que ter comportamentos para resistir à carga dos ônibus. Então é um exemplo de fabricação com vigas bem pesadas. A nossa concepção era a de um sistema todo pendurado porque se pretendia conseguir uma ausência total de pilares. Fizemos somente as escadas porque esta via que é uma via de vale, ela tem um cul de sac no final onde todos os ônibus tinham que contornar e retornar. Tinha que haver ausência total de pilares para se conseguir esse prodígio: os ônibus fazerem a curva no fundo.(Concepção estrutural) A concepção é uma estrutura em concreto, com tirantes protendidos que vão pendurando todo o sistema auxiliados por rótulas. A grande estrutura, para permitir toda a pré-moldagem, foi essa estrutura básica destas torres. Elas têm alturas diferentes, porque de um lado tinha dois tirantes e as outras uma linha de tirantes só. (só com imagem). Nesse espaço onde os passageiros se distribuem, pode-se ver os tirantes, bem fininhos, isto realmente foi o resultado deste comportamento estrutural, porque nós precisávamos ter o pavimento de baixo completamente livre. (mais imagens do canteiro).Outra coisa que eu queria mostrar na pré-fabricação pesada que se usa muito em viadutos é uma certa higiene na obra. Por exemplo, uma coisa pesada desta, pra você montar se não tivesse a pré-fabricação, este era um escoramento incrível, caríssimo. Então aqui ela, a peça, já é montada com o auxílio dos tirantes. O guindaste segurando e os tirantes já sendo esticados lá. Eles próprios que servem para a montagem. Eliminam-se todos os escoramentos. O viaduto principal 
envolve um vão de 100 metros. Aqui todos os ônibus faziam as curvas e nos tínhamos o problema mais sério do VLT (Veículos leves sobre trilhos (?)) que entrava pelo pavimento inferior, no terceiro pavimento. Fizemos o sistema intermodal: Tínhamos embaixo o VLT, no pavimento intermediário, os ônibus, e em cima os passageiros, subindo a pé a cumeada por meio de escadas rolantes. Houve nesta estação um problema que eu gostaria de relatar para vocês verem os riscos que a gente enfrenta com essas tecnologias. Nessa época - hoje esta tecnologia dos tirantes está bem dominada com a proteção dos cabos - mas nessa época ainda não estava e a única possibilidade que tínhamos para proteger os tirantes da oxidação era através de bainhas de nata de cimento. Isso foi feito graças a uma exigência que houve na aprovação no projeto de contar com a possibilidade de que, mesmo tendo dois cabos rompidos, a estrutura permaneceria estável. Nós conseguimos uma proteção adicional porque eles erraram na proteção. Quando eles colocaram a proteção de nata dentro dessas bainhas, eles não compactaram bem e o topo ficou sem nata. Então os cabos oxidaram e só se percebeu isso vinte anos depois, quando o primeiro cabo estourou. Graças àquela medida de segurança foi possível ir retirando os cabos e substituindo tudo por uma tecnologia mais moderna que dispensa a proteção de nata de cimento contra oxidação.

\section{Argamassa Armada}

Vamos falar sobre a argamassa armada. Falamos do concreto, passamos para o concreto pré-fabricado, com rigor pro concreto pesado e agora vamos falar da argamassa armada. A argamassa armada não deixa de ser um concreto mais sofisticado, porque ela exige uma condição de execução mais cuidadosa. A argamassa armada é uma tecnologia existe há muitos anos. Quem desenvolveu muito essa tecnologia na Europa foi o conhecido engenheiro Pier -Luigi Nervi . Ele produziu muitas obras com a argamassa armada que ele chamava de ferro-cimento porque havia uma quantidade muito maior de cimento e de ferro na composição do material.

\section{Drenagem em Salvador}

Nós usamos a tecnologia da argamassa armada em Salvador. O que queríamos resolver era o problema da drenagem num fundo de vale, porque as calhas dos rios, que antigamente eram bem situadas nos centros dos vales, foram assoreadas e as águas passaram a se distribuir em torno das casas. O material todo era um solo muito difícil de se trabalhar, sem nenhuma resistência pra mecânica, pra execução de qualquer obra de engenharia e, além do mais, ficava comprimido entre habitações. Então desenvolvemos uma tecnologia prevendo uma sensibilidade maior para poder implantar os canais nos vales. Era preciso, fundamentalmente, que as peças pré-fabricadas pudessem ser manipuladas, transportadas à mão e montadas com um sistema a seco, um sistema de cunha. Existe um comportamento bem diferente da argamassa armada que se assemelha, aproximadamente, a um material homogêneo com espessuras muito pequenas, dois centímetros. A tela (de aço) participa do processo, porque evita o fissuramento, e há outras medidas que nós temos que tomar ainda por causa dos efeitos de 
retração na cura. Usamos sempre a cura d'água. ${ }^{2}$ As escavações dos canais, eram muito mais complexas porque era necessário escorar as casas também, tudo através de processo manual. Não há como entrar uma máquina nessas condições. Tudo isso tinha que ser feito de uma forma cuidada pra você evitar que as construções caíssem. São construções muito precárias. Ao mesmo tempo nós tínhamos de resolver os vales, as encostas e a solução foi a construção de escadarias com drenos, os quais foram construídos antes das escadarias e montados manualmente. Para vocês terem uma idéia, nesse local, no vale do Camarugipe a escala de projeto era de 250 quilômetros de escadarias. Era esse o nosso projeto. Nós tínhamos obtido financiamento do Banco Interamericano ( de Desenvolvimento ) porque o prefeito de Salvador, Mário Kertz, era muito hábil e conseguiu sensibilizar o presidente do Banco exibindo o protótipo que fizemos. E conseguiu o dinheiro pra fazer a obra.. Infelizmente o Mário teve que sair da prefeitura e essa tecnologia foi transferida para o comando da iniciativa privada que não teve os mesmos cuidados que a gente tinha. 0 problema é que, numa área pobre como essa, não se pode atuar pensando no lucro. Tem-se que agir pensando em resolver problemas que são completamente diferentes. Se uma casa dessas começa a cair, não se pode esquecer que existe uma família morando lá dentro. Você tem que escorar. E os custos são incompatíveis com os lucros das empresas privadas. Esse é um exemplo bem claro de que não se pode pensar em atuar numa área como essa, de baixa renda, pensando em lucrar. Para cobrir os custos eventuais de acidentes tem-se que criar tantos custos adicionais que acaba tornando o sistema proibitivo.

Ao mesmo tempo tínhamos que fazer os arrimos para garantir as encostas. Aqui vocês vêem um conjunto de/com (?) meia drenagem, os arrimos, esse conjunto de intervenções é o que foi restituindo a garantia de estabilidade dessas encostas. (imagem).

\section{Abadiana}

Essa experiência foi em Abadiana, que sucedeu ao período da RENURB. Foi uma coisa muito romântica. Quando houve a abertura política nós nos juntamos entorno de um grupo de frades dominicanos e fomos convocados, cada um na sua área específica, para fazer um programa de recuperação numa cidade muito pequena que se chama Abadiana. O município é grande, não é pequeno não. Mas era uma área muito pobre, e a comunidade tinha muito mais necessidade de médico do que de arquiteto. Mas enfim, eu tinha que fazer minha parte lá..E eu tratei do saneamento básico, da reurbanização, de criar um pequeno plano diretor, fazer um diagnóstico para poder atuar lá. Uma das indicações que nós tínhamos para a recuperação econômica do município seria atuar justamente na área da construção civil, porque aí tem um rio, o Corumbá, que abastecia de areia

\footnotetext{
2 Nota da edição. Para fazer um texto bem claro, seria necessário explicar algumas tecnologias às quais o autor se refere. Pensamos que estudantes de arquitetura que não tiveram a oportunidade de assistir à palestra - e por isso sua publicação - deveriam poder ter acesso aos meios técnicos aos quais o arquiteto se refere.
} 
toda a construção de Brasília. Tinha também uma vila muito boa onde a gente pretendia desenvolver atividades de cerâmica também. Também tinha cimento perto porque toda aquela região é calcária.Tinha uma fábrica de cimento a 30 $\mathrm{km}$ de distância. Com isso, desenvolver uma tecnologia na área da construção civil para a recuperação econômica do município, era possível. O primeiro problema que surgiu foi o de uma ponte. Com a degradação das matas ciliares, os leitos dos rios foram aumentando e ao mesmo tempo a falta de aroeira para conseguir fazer ponte de madeira foi criando problemas muito sérios de distribuição das estradas vicinais de acesso ao município. Nós desenvolvemos, então, essa tecnologia de pontes em argamassa armada. Todo o pessoal foi treinado; não tinha nenhum engenheiro, o agrônomo nos ajudava, tudo era improvisado.

Eu tinha que ser peão também, tinha que dar o exemplo. Realmente nunca me senti com tanta responsabilidade na minha vida quanto nessa experiência. Uma coisa completamente louca porque as pessoas não sabem nada, então ficam confiando que vai haver um milagre da construção porque tem um engenheiro que sabe. Mas na verdade eu não sabia nada também, tive que aprender. Foi uma experiência de vida...o rio enchia, uma confusão mas afinal conseguimos fazer a ponte. Mas acho que foi muito bom que criou uma certa motivação, não só para a população, que de repente conseguiu uma resposta para a ponte que era um problema crucial para ela, mas também houve uma convocação geral da Universidade de Goiás que passou a financiar o nosso pequenino empreendimento. Pra vocês terem uma idéia essa ponte foi construída com a venda de um carro Chevrolet, porque cada prefeito tinha um Chevrolet que o governo de Goiás tinha dado. Ele vendeu o dele pra construir a ponte. Ainda havia esse compromisso financeiro porque não tinha um tostão a mais. Se a ponte não fosse montada com o Chevrolet, eu teria que e explicar depois para o prefeito como eu tinha acabado com o dinheiro dele sem fazer nada. Então resolvemos ampliar nossa experiência pra fazer escolas também, já que havíamos feito escolas de madeira, uma coisa muito precária então resolvemos fazer escolas também de argamassa armada. Todo o processo é sempre aquele, usando mão-de-obra em grande escala, todas as peças transportadas manualmente. Eram módulos que iam se justapondo e formando os espaços para cada tipo de escola, que tinha sempre uma organização diferente. As pequeninas escolas rurais apenas com poucos módulos. Também só tínhamos um caminhão para transportar. Nessa área não tinha luz, e tivemos que transportar vigas e umas tesouras que nós tínhamos criado, equipamento para montagem apenas com uma talha para segurá-las. Um sistema muito improvisado. Mas isso não quer dizer que a tecnologia tinha sido renegada a um programa secundário, pelo contrário, eu acho que essas peças em argamassa armada estão muito bem feitas. Havia precariedade de mão-de-obra de montagem, mas nem por isso a escola passou a ser uma coisa precária. Infelizmente, embora para mim tenha sido uma experiência muito rica, terminou aí.

\section{CIEPS}

Em seguida o Brizola ganhou a eleição no Rio de Janeiro e o Darcy Ribeiro era o vice-governador. Ele resolveu criar as fábricas de escolas. Nós fizemos escolas 
em quantidade. sempre usando a mão-de-obra em grande escala também. Era uma época de desemprego, então nós não queríamos abrir mão da mãode-obra e tudo foi feito manualmente. Você vê a quantidade de gente incrível que ocupava aí a fábrica. Inicialmente os painéis eram feitos de madeira, depois passamos a fazer em metal sempre com desenhos de Athos Bulcão, e as escolas tinham sempre a mesma forma possível. Possível que eu digo é devido ao espaço e às vezes, devido à topografia. Mas tinham formam as mais variadas dependendo do espaço que a gente ocupava. Algumas eram escolas com uma casa de criança adicional. Tivemos também que treinar as crianças porque naquela época já havia todo o tráfico de drogas no Rio de Janeiro, não era assim como hoje, mas já havia. Então pra implantar, por exemplo, nessas escolas a Casa da Criança, nós tínhamos que discutir com os traficantes. Recentemente eu estive na favela para ver outro programa que eu estou desenvolvendo e achei engraçado que tivemos que falar com o traficante chefe. Ele ficava calado, via, olhava, e aí no final um sujeito fez um discurso e o traficante falou: autorizado. Foi a única coisa que ele falou. Era igualzinho nessa época. Me lembro que a primeira escola que nós fizemos foi no Morro do Borel, um lugar chamado Chácara do Céu. O sujeito disse para o nosso engenheiro, que era um sujeito muito cioso, muito sério: - olha, primeiro prepara aqui nosso campo de futebol. O engenheiro disse: - Ah, isso não. O cara pegou o revólver e pôs na cara do engenheiro. O dia inteiro o cara andou atrás dele com o revólver apontado. Era um menino de 23 anos, tinha um olho verde outro azul, eu nunca mais me esqueci desse traficante. Logo depois ele foi morto por outros traficantes. - Mas aí o engenheiro me ligou apavorado na hora do almoço. Eu disse: - faz o campo de futebol deles, você ficou maluco? Você vai receber um tiro na cabeça, faz o campo de futebol depois a gente vê como é que é. Esse convívio tinha que ser assim. Depois de autorizado a gente podia fazer o que a gente queria. O que aconteceu logo nessa primeira chácara, quando nós fomos inaugurar a casinha da criança e a escola, é que houve um tiroteio e mataram uma porção de traficantes. Quando as professoras subiram tinha oito corpos espalhados pelo meio da rua. Elas nem subiram, ficaram ali mesmo, voltaram e nunca mais quiseram subir. Eram professoras com uma formação melhor e não estavam acostumadas com a vida pesada da favela. Nós tivemos que passar a treinar as professoras. Então nós montamos uma casinha da criança na própria fábrica com uma professora que acompanhava a parte pedagógica. Mas a escola da criança era um programa especial porque era uma pré-escola. Nós fizemos noventa pré-escolas lá nessas áreas. Houve o caso de um traficante que deu a metade de um campinho para nós fazermos uma casa da criança. Quando o programa tinha um auditório, uma coisa maior, usávamos um sistema de treliças de argamassa armada que, no entanto, é uma solução equivocada, porque cria áreas de tensões muito fortes e a maneira pra você juntar depois uma segunda concretagem é muito difícil. De qualquer maneira tentamos fazer pra provar que éramos burros. O mobiliário também era produzido lá na fábrica. Havia ainda a questão do saneamento básico que foi uma coisa mais complicada, porque os canais eram 
de 4 metros a 4 metros e meio e tivemos toda aquela experiência do fio. Mudamos então completamente a tecnologia para produzir peças que pudessem ser montadas manualmente.

Fizemos também abrigos que se comportam muito bem com a argamassa armada, com uma viga de torsão.

\section{6 - Escolas em Salvador/ Centro Histórico}

Bom, depois disto nós voltamos para Salvador, com o prefeito Mario Kertz desta vez eleito. Da outra vez, tinha sido nomeado pelo Antonio Carlos MagaIhães que também o desnomeou e por isso nossa experiência foi curta porque quando ele foi demitido nós também fomos. Essa segunda experiência foi mais duradoura. Mas quando ele foi embora também acabou. Nós construímos muitas escolas, sempre com essa tecnologia em dois pavimentos e em áreas muito pobres. As escolas às vezes tinham pátio interno, então a organização do espaço era variada. A proposta era a mesma: de carregar os elementos manualmente e criar muitos empregos.Dessa vez resolvemos de uma forma mais inteligente os auditórios com arcos metálicos e os sanitários públicos vinham completamente prontos.Participamos também de um projeto da recuperação do centro histórico, feita com peças e argamassa armada, no qual minha participação foi muito mais como colaborador da Lina Bo Bardi. A Lina era uma pessoa muito criativa, então o que ela imaginou que ocorreria no centro histórico era o seguinte: Se você tem casarões de três ou quatro pavimentos os quais foram se apoiando uns nos outros, quando se destrói um, eles perdem a estabilidade, então tem que recuperar esta estabilidade. Os desenhos que nós fizemos eram uma montagem de argamassa armada, na qual, depois nós introduzimos só o cimento para formar suportes de peso para recuperar a estabilidade dos prédios. Produzimos também muitos bancos de argamassa armada e os lixo-dutos. Fizemos os lixo-dutos de argamassa armada para o sujeito jogar o lixo e evitar que esse lixo ficasse depositado ao longo das encostas e uma proteção que a gente chamava de proteção contra coco, porque realmente, eles jogavam coco e se o coco caísse quicando podia matar um outro sujeito lá embaixo. Nós tomamos um susto, a primeira vez que vimos, porque vinha aquele coco que parecia um torpedo.

\section{CIACs}

A experiência dos CIACS foi malograda. Fizemos só duas unidades: uma no Rio e outra em Brasília. Foram protótipos. Mas de qualquer maneira, foi uma experiência que nos proporcionou muito desenvolvimento tecnológico na área da argamassa armada. Foi malograda por uma questão política. Mas nós ficamos com um vocabulário enorme e com coisas produzidas com bastante cuidado no âmbito de isolamento térmico, acústico, por exemplo. A solução da treliça foi substituída por um arco, também em argamassa armada, uma forma muito mais fácil e inteligente de resolver o problema. Sheds, pestanas... nós desenvolvemos um vocabulário da ordem de 200 e tantas peças. Aqui por exemplo vemos montagem da viga dividida ao meio, a viga do ginásio montada em cima de um escoramento. A biblioteca, sempre com sheds para iluminação natural.(imagem). 


\section{Prefeitura de Salvador}

Vamos falar de uma arquitetura mais industrializada que resulta do casamento do aço com a argamassa armada. O primeiro exemplo aí é um prédio em Salvador. Ele foi feito quase como um prédio provisório. Eu o chamava de prédio transitório para abrigar a prefeitura, que o prefeito Mário Kertz eleito, queria governar do centro da cidade e com muita razão porque a presença da prefeitura era importante para a revitalização do centro, reintegrando todas as secretarias na área do centro da cidade. E então nossa proposta foi fazer um prédio de construção rápida. Ele foi montado em 12 dias, foi construído em 4 meses desde o projeto, mas mesmo sendo uma construção provisória foi muito hostilizada pelos baianos, porque eles acham que é um prédio moderno que não pode conviver com a arquitetura histórica. Isso eu acho é que é uma visão equivocada. O edifício tem que respeitar a volumetria, os espaços urbanos, isso foi feito com muito critério. A rigor ele dialoga, ele está bem no eixo do palácio do Rio Branco o qual não é um exemplo de boa arquitetura. É um prédio horrível. O que nós pretendíamos era valorizar outro, que é uma construção tipicamente portuguesa, que aliás nós vamos encontrar alguns muito semelhantes em Macau. As ruínas estão lá, igualzinho! Eu tomei um susto quando eu vi esse prédio lá em Macau. Mas realmente é um prédio bonito, é um prédio que tem a dignidade muito grande da arquitetura colonial. ( precisa imagem ou pelo menos identificar que prédio é esse do qual ele fala). Mas o que importa é a questão tecnológica. Na verdade nós queríamos fazer um prédio solto para respeitar uma conquista da população, de poder usar esse espaço onde antes era uma biblioteca que foi desmontada e que era um edifício implantado no chão. Nós liberamos completamente o nível do chão. Essa biblioteca foi feita na década de 1910, foi demolida depois.A fachada da Igreja da Misericórdia que fica ao lado não foi feita para ser exibida e a presença do prédio não a prejudicava, portanto. Vocês vêem que propositadamente o ar condicionado é completamente solto em cima, isto tudo pra facilitar uma montagem, com prazo muito curto, porque o que atrapalha às vezes na montagem de um prédio é integrar todos os serviços como ar-condicionado, instalações, etc. É preciso criar uma independência muito grande desses serviços para poder cumprir um cronograma um pouco mais flexível e até mais rigoroso em termos de prazo.

\section{Passarelas}

Bom o outro exemplo dessa área da industrialização são as passarelas. O que nossa pretendíamos com as passarelas? Viabilizar a implantação do transporte coletivo, porque nós trabalhávamos o transporte coletivo numa pista de segregação. Mais tarde o ônibus articulado seria substituído pelo VLT, o que infelizmente não aconteceu. Agora fizeram metrô, que é uma coisa absurda, mas a nossa proposta era fazer o VLT entrar no pavimento inferior, na estação da Lapa, como ponto final. E as passarelas, a função primordial delas era reintegrar as comunidades que tinham sido separadas pela avenida do Vale, uma avenida de alta velocidade que fez com que as pessoas não pudessem mais conviver umas com as outras. Essas comunidades, antes, eram integradas através dos Vales, tinham 
hortas etc., e com as avenidas do Vale isso tudo se perdeu. Com as passarelas se reintegravam essas comunidades que estavam divididas pela avenida do Vale. O processo de produção é um processo bastante simples, a gente tem os apoios que permitem a articulação em vários sentidos além de receber vários setores de treliça, as treliças metálicas e o resto dos componentes em argamassa armada. Aí nós fizemos muitas passarelas por ai afora, mas depois criaram uma fábrica em Florianópolis. Mas vocês estão vendo, por exemplo, as articulações então funcionam para se criar o nivelamento e as integrações em qualquer direção.

\section{Rede Sara}

Vamos passar então a parte final que é essa experiência que eu gostaria de ter mostrado com mais detalhe porque eu acho que é a mais atual, mas infelizmente ela foi comprimida um porque o nosso tempo é limitado. Tratase da experiência da Rede Sara que começou em 1976, quando nós fizemos o primeiro hospital da Rede Sara em Brasília, que seria o centro de referência de um sistema na área do aparelho locomotor. Então a concepção que já vem do hospital de Taguatinga, é uma concepção de hospital que poder crescer através de um eixo principal. Então os excretores (?) (é meio esquisito isso aqui de repente) cresciam de uma forma orgânica conforme uma árvore que cresce seus ramos e suas raízes. Nós tínhamos esse critério, quer dizer, ao mesmo tempo que a infra-estrutura crescia para dar suporte às tecnologias, nós tínhamos também os setores independentes crescendo a partir de ramificações consecutivas. A outra questão importante era o uso do espaço externo do sol para os pacientes poderem participar sempre de banhos de sol que, além de resolver problemas psicológicos de contato com a natureza, resolvia também o problema de assepsia. O primeiro exemplo foi Brasília, com esse prédio, que é feito com a tecnologia do concreto armado. Isso foi em 1976. Como é um espaço urbano muito comprimido, tivemos que criar de uma forma artificial esses grandes terraços para os pacientes serem removidos sistematicamente. Tivemos também que criar um desenho de uma cama-maca para poder tornar os pacientes muito mais móveis do que eram nos outros hospitais convencionais. É claro que hoje a Rede Sara é uma coisa gigantesca, o nosso primeiro projeto já cresceu quase três vezes a sua área inicial. A outra tônica eram os espaços coletivos, as esperas, integrados com os espaços mais amenos, com jardins, etc. Os primeiros prédios que nós fizemos foram projetados ainda com a tecnologia da argamassa armada. Então temos um em São Luís e outro em Salvador. Eles foram criados a partir daquelas experiências das escolas em Salvador, que era a FAEC (?). que Infelizmente foi fechada por problemas políticos e ficamos sem poder executar esses prédios. O Sara de São Luís foi feito adaptando, não fomos nós que fizemos, foi o pessoal de lá mesmo, com uma adaptação para concreto, mas isso não deu certo e a solução é muito precária, foi muito mal construído. A nossa fábrica é composta de uma série de oficinas separadas. Elas têm uma certa autonomia, uma independência. Mas elas se integram todas no mesmo sistema construtivo. Nós temos uma oficina de serralheria pesada, uma outra oficina para montar os equipamentos. 
As fôrmas ficam abrigadas num depósito embaixo do pavimento. Hoje nós temos uma quantidade enorme de moldes metálicos que respondem a uma infinidade de peças. A argamassa armada já tem um o enfoque é completamente diferente, tem um nível de automação muito grande. A mão-de-obra incide numa escala pequena porque osso objetivo é diferente, não era como das outras vezes de dar emprego para muita gente. A parte da injeção de plástico, é uma parte muito importante para o nosso uso. Há uma parte para pintura com decapagem, pintura eletrostática a pó, com forno para aquecimento da peça. A peça sai pronta em 40 minutos, 30 minutos, para a montagem. Qual é a importância da injeção de plástico? Agora nós usamos também a injeção de plástico às vezes para componentes de arquitetura de construção como, por exemplo, os engates móveis para peças, brises, sistema de articulação. Fazemos muitas coisas, mas principalmente atendemos a área de equipamentos. Sem injeção de plástico nós não poderíamos fazer os equipamentos que fazemos para os hospitais. Também montamos uma pequena oficina em Brasília, mais voltada para equipamentos ortopédicos, para a área cirúrgica. Os hospitais do Nordeste foram feitos com sistema de ventilação natural. Então se têm túneis de ventilação que são ao mesmo tempo galerias e sistemas de fundações. $O$ ar penetra através das galerias e é injetado em ventiladores para aumentar a velocidade. São voltados para a direção do vento dominante e os sheds extraem o ar quente. Os edifícios têm esse sistema de ventilação vertical sempre com a extração dos sheds que ao mesmo tempo ele serve para a iluminação também. Tem-se uma galeria para cada linha de pilares porque os pilares se apóiam também num mesmo sistema de fundação. A construção da super estrutura metálica com viga de chapa dobrada e treliças. Os componentes, outros, quase sempre de argamassa armada. (Imagens). No caso específico de Salvador, tivemos que desenvolver também uma tecnologia para criar os patamares para a implantação do hospital. A tecnologia da terra armada, que é uma tecnologia francesa, foi adaptada para a execução da argamassa armada. Não pudemos usar os componentes porque isso é patenteado, então tivemos que inventar fitas específicas para nós. Essas peças têm esses engates onde as fitas são fixadas com pinos e elas depois são incorporadas no aterro. Então à medida que se vai aterrando, isso tudo vai funcionando como um grande bloco de terra, daí o porquê de se chamar terra armada. O hospital funciona com equipamentos móveis. Tudo é móvel, o próprio paciente é extremamente móvel. Tem um posto em que ele fica permanente lá na sua enfermaria. A enfermaria é sempre com controle visual, mas é extremamente móvel. Todos os espaços são adaptados ao uso desse sistema móvel: um paciente tetraplégico pode penetrar na piscina sempre com rampas, e os espaços internos sempre são usados como solários, áreas para lazer e convívio. Tivemos que estudar também veículos específicos para transporte dos pacientes principalmente porque, esses hospitais que a inicialmente eram hospitais ortopédicos, tiveram um crescimento de demanda muito grande com o aumento de acidentes e da violência urbana que produzem lesados medulares. Nossos hospitais são adaptados para tratamento do lesado medular, paraplégico e tetraplégico. São pacientes que têm dificuldade total de locomoção. Eles vivem em cadeiras de rodas ou em macas. As camas-macas são 
também veículos especiais para transportar os pacientes. A linguagem dessa arquitetura é a mesma; temos sempre os mesmos elementos construtivos que vão sendo organizados nos espaços de forma diferente. No hospital de Fortaleza, bem melhor resolvido, inclusive como ventilação e conforto ambiental, havia um bosque de árvores frutíferas, mangueiras, que tivemos que preservar e confinamos um pouco o edifício do hospital, apesar do terreno ser muito grande. Com isso tivemos que verticalizar as enfermarias. Mas o sistema de ventilação está mais sofisticado. Existe nebulização uma permanente que reduz a temperatura em 3 a $4 C^{\circ}$, antes de entrar nas galerias, e ao mesmo tempo as galerias são muito melhor distribuídas do que no hospital de Salvador. O espaço central é o espaço mais importante do hospital: serve de convívio, abriga as piscinas e fica integrado com a fisioterapia. É um espaço que também se integra aos pavimentos. Então quando há algum evento lá embaixo os pacientes podem participar a partir dos andares. A construção foi toda industrializada em argamassa armada e aço. As lajes em argamassa armada, as caixas de ventilação vertical também são em argamassa armada. Os pés direitos no Sara de Fortaleza são muito mais altos e, portanto, a circulação vertical é muito mais forte. Em cada pilar há uma galeria. Aqui também nós colocamos os sheds no centro do vão ao invés de ficar no outro extremo e com isso nós aumentamos bastante a altura dos sheds e criamos uma ventilação mais forte. Esse concreto de fundação aqui, ele envolve uma questão muito simples, que você quando faz um corte tira a terra, tira peso então você tira o peso correspondente ao peso da estrutura que vai lá, esse sistema, isso aqui, funciona como radie(?) nessas calhas de argamassa. São encaixadas as peças depois isso é concretado, no fundo então você tem a parte debaixo funcionado como radie(?) e a própria galeria funcionando como infra-estrutura. (imagem). Este é o projeto do Rio Grande do Norte. A idéia era criar um grande espaço com uma lona, só para área de reabilitação. O hospital fica um pouco afastado por causa do salitre que prejudica muito os equipamentos. Então o hospital fica afastado e ganhamos esse terreno à beira do mar onde nós pretendemos criar um grande espaço com essa cobertura em lona para fazer a reabilitação.

O centro de reabilitação de Brasília é enorme. Tem áreas de leito, áreas de ambulatório, áreas de fisioterapia, reabilitação infantil e um centro de estudos para conferências e biblioteca em cima. O centro de reabilitação infantil foi concebido como se fosse um circo. Você tem uma área central para as atividades coletivas e os apoios nas áreas adjacentes. Tem um grande ventilador em cima que extrai o ar quente que sobe, então isso funciona como uma grande clarabóia em policarbonato. Ventilação sempre se faz através desse sistema de convecção. $O$ ar quente sobe e é extraído por cima. Para vocês terem uma idéia, por exemplo, as telhas todas são produzidas pela fábrica. É completamente inviável se pensar nessa construção se não for industrializado. Nós produzimos as telhas, as telhas são trapezoidais. É um sistema complicado de se fazer artesanalmente. Tem um painel do ___ (?)___ ( seria do Athos Bulcão? É preciso confirmar) muito bonito porque é móvel, vai adquirindo formas diferentes. Os auditórios também, sempre com uma área plana do lado para os pacientes poderem participar dos eventos. É auditório e ao mesmo tempo ele é palco, pode fazer espetáculo de teatro, 
orquestra, etc. As piscinas sempre com rampas. No projeto de Belém do Pará a dificuldade de construção foi muito grande porque esses terrenos são muito instáveis, na foz do rio Amazonas. Só matéria orgânica e foi muito caro o sistema de fundação que nós tivemos que adotar. $\mathrm{O}$ terreno fica todo inundado quando a maré enfia, tínhamos que trabalhar com a maré baixa para recuperar o terreno. Vocês estão vendo aqui, por exemplo: recuperação na área do Igarapé. Tem que esperar a maré baixar para poder atuar. A piscina teve até uma particularidade, porque a não se podiam fazer as estacas, conforme o resto do hospital, então nós fizemos com uma tecnologia de argamassa armada. Não tem nenhuma novidade. Nós estamos fazendo os aterros e a maré vinha e levava o aterro. Quando a piscina ficou pronta ela começou a andar, a maré foi levando, então a gente esperou ela parar. Nós não fizemos nem a pavimentação definitiva. Tem que esperar ela parar definitivamente pra gente poder acabar. Esse hospital é em Macapá...é engraçado essa questão de clima. Você tem duas cidades tão próximas: Belém do Pará e Macapá, a mesma situação. Era de se supor até que Macapá fosse pior, porque Macapá fica exatamente em cima do Equador. Existe até um time de futebol que chama "Norte-Sul". Tem um campo de futebol que a linha do Equador divide ao meio. É o norte contra o sul.

Júlio Artigas - O projeto desse estádio é do Vilanova Artigas.

Lelé - O esgoto da piscina, esgoto da pia no hemisfério sul é um, no hemisfério norte ao contrário. Cada pia tem sua peculiaridade: minha pia do norte, minha pia do sul. É engraçado. Estava tão preocupado com Macapá pela questão do clima. E Macapá tem um clima bem melhor que Belém. É menos úmido, a ventilação é maior. Então nós aumentamos bastante o pé direito e criamos várias peças de ventilação, como esses cobogós metálicos largos, todo o hospital pintado de branco pra refletir bem o calor e está funcionando muito bem, melhor do que em Belém. Fizemos também muitas obras na sede, que foi crescendo, crescendo, passarelas. Fizemos obras através de convênios, por exemplo, ITCU (?), fizemos oito prédios pra eles, em Belo Horizonte, Salvador, Sergipe, Rio Grande do norte.

Em Cuiabá se vê que a questão da industrialização não cria uma limitação tão grande de linguagem. É possível você fazer com as mesma peças, é lógico, nós temos vários padrões de forro, vários padrões estruturais, mas a estrutura metálica permite uma flexibilidade muito grande. Você pode organizar espaços bastante diferentes. Apesar desse prédios terem o mesmo princípio de industrialização são completamente diferentes até como concepção. O edifício de Natal, é completamente solto do chão com o auditório é pendurado. Estas treliças recebem todas cargas. Em Cuiabá faz muito calor e a ventilação é natural ou com ar condicionado e tem um jardim interno que tem alguns elementos do Athos Bulcão. Em dois desses prédios as cobras, jibóias gigantes, entram pelo muro do Athos vão conviver lá dentro. Estão pressionando pra fechar o painel por causa das jibóias. Isso é um pouquinho do Brasil. No Piauí, em Teresina, o prédio é o rei das jibóias. É jibóia todo dia, 
e o sujeito reclama que essa jibóia entra pelo painel do Athos. Você sabe que antigamente os armazéns tinham jibóias pra comer os ratos. Era jibóia mesmo, não era gato não, depois é que virou gato.

\section{Pequenas prefeituras/posto fiscal e passarelas}

Fizemos várias umas vinte prefeiturinhas, posto fiscal pra passagem de caminhão, com passarelas industrializadas de argamassa armada com o mesmo princípio de montar rapidamente. Construíamos de madrugada numa hora que praticamente não tinha tráfego pra montagem dos vãos, das treliças. Depois toda a montagem posterior à mão, não necessita de guindaste. Então com isso se viabiliza uma obra muito mais higiênica para o uso da cidade. Então você vê duas coisas que parecem antagônicas, mas que não são. Há necessidade de você ter esse sistema manual e não usar o guindaste pra montar esse sistema, porque tinha que usar um guindaste, com lança muito grande, muito pesado que iria atrapalhar o trânsito.

\section{São José do Ribamar}

Em São José do Ribamar, uma cidade perto de São Luís do Maranhão, existe romaria todo o ano em louvor de São José. Fomos convocados pra fazer uma espécie de palco que anualmente serve para as consagrações religiosas de São José. Deixamos o palco bem a beira-mar, dialogando com uma capelinha pequena. Mas o que eu queria chamar a atenção é para a questão da construção. Nesse caso, montamos toda a estrutura com um balanço de vinte metros. Recentemente eu fiz, com um amigo meu, uma cobertura grande pra uma piscina de dez metros de balanço com um tirante atrás e com um parafuso fomos regulando a ponta, pra ficar uma linha certa. Porque para se transmitir bem a idéia do balanço, é preciso se vá afinando para que fique muito delgado na ponta.

\section{3. casa Salvador}

Numa casa em Salvador onde estou agora, a pontinha do balanço tem três centímetros. (não dá pra saber se lê mostrou a imagem. Se não mostrou, pode-se juntar ao parágrafo anterior).

\section{Tribunal eleitoral de Salvador}

Este é o Tribunal Eleitoral em Salvador. A intenção foi voltar esses grandes capturadores de ar na direção do vento. Não tem galerias, como também não tem os hospitais, e ao mesmo tempo cria jardins entre cada área administrativa. É um prédio grande, tem 15 mil metros de área construída e nosso plano era de montar em quatro meses. Depois, por questão de um atraso financeiro, nós tivemos que fazer em seis meses, o que correspondeu também a um sobre preço. Para você usar um sistema industrializado, o cronograma da construção tem que ser justo, aquele que for mais econômico. Se forem muito grandes as despesas indiretas começam a pesar e o preço começa a subir. Então a construção industrializada requer um planejamento prévio e um rigor enorme do cronograma de execução da obra. 


\section{Hospitais no Rio de Janeiro}

Dois hospitais no Rio de Janeiro: um é um centro de reabilitação que fica numa ilha, a ilha da Pombeba, e o hospital propriamente dito fica a uma distância de uns $3 \mathrm{~km}$ da ilha. Também fica na beira da lagoa (Rodrigo de Freitas?). Esse projeto foi muito condicionado à manutenção de uma vegetação de mangue que foi toda retirada, uma vegetação de restinga muito comum no Rio de Janeiro. Tem muito algodoeiro da praia que a gente recuperou. A ilha estava muito degradada, tinham feito lá uma área de produção de asfalto para a cidade. O edifício tem ar-condicionado e os sheds que servem para iluminação. Todo o sistema de ar-condicionado pode ser removido e a ventilação e a iluminação naturais continuam mantidas. Tudo funciona com motor, então se pode transformar, imediatamente, em um sistema aberto. Usamos muito sistema aberto, não só por uma questão de economia, mas principalmente por uma questão de proteção contra assepsia. Nos hospitais o grande inimigo se chama infecção hospitalar, são as bactérias que criam resistência muito grande aos antibióticos. Então, na medida em que a gente abre o ambiente, essas bactérias convivem com outras também e elas perdem um pouco a força. É importante manter o hospital aberto, para combater infecção hospitalar sempre que preciso, mesmo nos ambientes com ar-condicionado se cria a oportunidade permanecerem abertos para a renovação no ar. No hospital propriamente foi mais complicado. É um hospital enorme, com cinqüenta mil metros quadrados de construção e além do mais é preciso prever uma flexibilidade considerando as novas tecnologias. Eles tem de ser mutáveis, pra isso é preciso que as instalações mudem também. Essa flexibilidade é muito importante. Ficamos, portanto, condicionados à linha dos sheds. Nesse hospital, que representa um aprimoramento maior da rede, nós resolvemos criar uma independência total, para que os pavimentos pudessem segundo a necessidade. Então, criamos um grande espaço com ventilação natural, mas com os tetos completamente autônomos: temos aqui ventilação fixa, e ao esmo tempo um outro sistema de cobertura embaixo que mantém esse grande colchão de ar com uma área de sombreamento. Ao mesmo tempo nós temos aqui as galerias, um entrepiso onde ficam as unidades fancoils (não sei se é isso e o que é isso, se é que é isso) que podem injetar esse ar laranja que está entrando aqui que é extraído pelos sheds através da cobertura. Criamos um sistema hermético para o ar-condicionado, que injeta a água gelada no ventilador e fecha os sheds. Na montagem, por exemplo, o pavimento que é embaixo é composto de estruturas muito baratas. O teto, com essas unidades móveis: quando se monta o pavimento, já se monta em cima do piso cerâmico pronto que é um piso de policarbonato pra poder ter flexibilidade. Como já disse, o espaço é completamente mutável, inclusive com a cobertura de cada um deles. O ar-condicionado é todo injetado por cima. Vou falar os equipamentos: os bancos novos para o transporte ficar mais fácil, é dividido ao meio. Uma mesa de aerodinâmica; elevadores, nós produzimos os elevadores também. 
Produzimos todos os carrinhos, essa cama-maca que é do Rio de Janeiro, é a nova cama-maca que é toda controlada eletronicamente. Tem um sistema que é privilégio da enfermeira, que tem uma chave.

Tudo e feito ( os equipamentos ?) plástico injetado. Sem isso a gente não podia ter todos os rodízios todos os sistemas. O plástico é que permite essa articulação. Sem uma indústria de plástico, é impossível a gente fazer essa cama-maca. Ela se comporta dentro da mesma linha de produção, quase como uma cadeira de rodas, tem uma mobilidade muito grande. Nós estamos pensando em colocar um motorzinho para acionamento, para facilitar a enfermeira empurrar. O motorzinho diminui o peso. Mas ela fica praticamente uma cadeira de rodas.

26. Recuperação da área central de Ribeirão Preto.

Para resolver um problema de recuperação da área central de Ribeirão Preto propusemos um viaduto. Existe uma intenção quase simbólica de colocar esse mastro bem em cima de Ribeirão Preto, e ao mesmo tempo, criar uma forma de interligação das cumeadas de uma lado e de outro, através desse viaduto, não só para pedestres, como também para veículos. Criamos, mesmo tempo, um terminal de ônibus na parte de baixo, terminal para ônibus urbanos para retirar a antiga rodoviária, transformando-a num centro cultural. É muito interessante esse viaduto. São viadutos atirantados que acabam criando uma porção de pilares. Mas este viaduto é completamente engastado na rocha basáltica, então esse projeto seria impossível se propor se não tivesse uma rocha muito sólida embaixo. Essa é a fábrica que nós montamos em Ribeirão Preto e que agora existe um plano de recuperá-la, porque ela foi feita quando o prefeito era Antônio Palocci. Depois ele saiu, o novo prefeito não sabia como usá-la e ela acabou fechando a fábrica. Nós queremos recuperá-la para um programa do governo na área federal, para produzir bases de apoio para cultura.

Essa fábrica usava também argamassa armada, como a fábrica do Sara, com alguns componentes diferentes, como o sistema de ventilação, mas basicamente o mesmo sistema.

É um programa do Ministério da Cultura que vai criar prédios diferentes para cada região. Na cidade de São Paulo vão ter oito, e no Rio de Janeiro também. A ventilação também é cruzada, vocês estão vendo que existem essas (?) para a entrada e saída do ar.Tem um auditório, que é uma sala de espetáculo com uma parte de multimídia.

\section{Centro cultural na Rocinha}

Este é o projeto para a Rocinha, no Rio de Janeiro. Tem um palco para o ministro chegar lá e cantar, porque é o Gilberto Gil. Pelo menos nas inaugurações. Se ele canta até na ONU, pode cantar aí também. Mas o prédio tem uma área para suporte e comércio e também um restaurante do "Fome Zero". Então o prédio está virando uma colcha de retalhos, quer dizer, uma sopa de pedras, cada vez acrescentam uma coisinha não sei onde é que vai parar.

Lélé ___ Na verdade a proposta é fazer um restaurante muito econômico. Parece que eles já têm recurso para isso. Falta alguma agilidade administrativa. 
28. Castelo - Garcia D'Avila - recuperação.

É uma área em Salvador que é um Forte, o Castelo - Garcia D'Avila, que está sendo recuperado. Houve uma recuperação de uma parte da igreja, mas o resto ia ficar em ruína. Então nós fomos convocados para criar um espaço onde se pudessem organizar espetáculos, e ao mesmo tempo fosse local em que as pessoas pudessem ficar avistando o mar, que fica no lado oposto e também ter também um espaço pra tomar um refrigerante, um lanche rápido no bar embaixo. Mas a idéia é mudar o piso e à medida que o piso vai sendo rebatido, surgem as cadeiras e os degraus do auditório. Tem também uma cobertura retrátil. De repente fez-se um auditório com 500 lugares com o palco no interior da área. É uma maneira de se preservar também a partir de uma concepção tecnológica complicada, mas o CDR'S (?) está perfeitamente habilitado. Esse projeto está completamente concluído sob o ponto de vista de montagem. A estrutura é metálica, mas a cobertura é de lona.

\section{Perguntas e respostas}

Júlio Artigas - A palavra está aberta para os presentes. Alguém quer fazer uma pergunta, levanta a mão, vem falar aqui no microfone para a gravação. Identifiquem-se por favor.

Nilma, arquiteta formada pela FAU. Trabalho na área hospitalar. Eu queria saber se a fábrica do "Sara" comercializa o material, os equipamentos, ou só fabrica para a rede Sara?

Lelé___ Infelizmente é só para a rede Sara. Eu acho um equívoco, a legislação é tão complicada, e agora nos últimos seis anos, ela se tornou tão rigorosa, que a gente não pode mais nem fazer mais convênios com outras instituições sem fins lucrativos. Porque o Sara pressupõe que não pode ter lucro. É uma associação sem fins lucrativos.

José Luís, estudante do terceiro ano da Uni-Santos. Eu queria saber, diante do poder das construtoras, empreiteiras que financiam as campanhas políticas e tem muito lobby para tomar conta, como o senhor lida com isso?

Lelé___ com muita dificuldade, porque realmente a pressão é muito forte. Eu mostrei um exemplo pra vocês na época do Collor. Naquela ocasião a proposta foi até de conivência com a iniciativa privada. As fábricas seriam entregues, as próprias empresas, as grandes empresas foram relacionadas, mas era um obra social que nós pressupúnhamos um custo baixo de construção. Orçamos naquela época de cerca de 190 dólares o metro quadrado de cada Ciac. Houve uma pressão muito grande das companhias construtoras para aumentar o preço, claro, a partir dessa necessidade de financiar campanhas políticas. Para se ter uma idéia, quando nós retiramos esse projeto, até porque já envolvia uma corrupção muito grande do PC Faria, que originou a queda do Collor, o projeto já tinha mudado para poder subir o preço que tinha chegado à 500 dólares o metro quadrado. 
Você vê de 190 a 500 dólares o metro quadrado. Então realmente é difícil lidar com isso, até porque está generalizado. As construtora financiam as campanhas. Por outro lado acho que nós incomodávamos por causa dos custos. Criamos referências. O Tribunal de Contas, que está inventando hoje não se pode fazer convênios. É de uma imensa ingratidão porque criamos vários parâmetros. Eu estava conversando com o Julio na viagem, que esses restaurantes baratos tiveram um custo baixo para poder realizar, mas a gente sabe que, se nós chegarmos a um custo abaixo de 500 reais o metro quadrado a coisa tem que ser exprimida. Sabemos perfeitamente que isso vai incomodar a iniciativa privada, não pelo fato de a gente estar roubando o quinhão deles, mesmo porque a nossa produção é pequeníssima comparada com a demanda que existe no país, mas porque cria um referencial: se nós fazemos por menos de 500 reais, eles têm que fazer também. Isso incomoda iniciativa privada .

Luís. Eu queria que o senhor colocasse como nós podemos ver a qualidade de criação, não só de projetos, mas a viabilização tecnológica desse projetos feitos no Brasil, inclusive feitos com tecnologia absolutamente viável. Como é que o senhor vê as contratações que têm sido feitas atualmente no Brasil de arquitetos estrangeiros para desenvolver projetos grandiosos.

Lelé____Estamos falando de uma outra arquitetura. Eu acho que você está se referindo principalmente ao museu Gugenheim no Rio de Janeiro. Uma coisa que incomoda a todos. Incomoda não só pelo alto custo do projeto, mas a proposta de estar fazendo museu, museu, museu, onde é que a gente vai parar não é? Eu acho que não há acervo pra tanto museu. O Gugenheim é uma simples lavagem de dinheiro, a gente sabe. Se você for à Bilbao vai ver que não tem acervo nenhum. Não tem acervo porque o acervo todo é móvel, então isso aí virou uma lavagem de dinheiro no sentido mais restrito da palavra. Mas eu acho que tem espaço para tudo. Mas a gente tinha que procurar uma construção mais viável, mais econômica. Não vejo o porquê, por exemplo, prescindir da iluminação natural. São coisas que estão aí para se usar. Então se está abusando muito ao copiar uma linguagem dos países nórdicos, que nem sempre, ou por outra, quase nunca, se aplica ao nosso clima. Nós temos que criar nossa linguagem. Eu acho que esses prédios que mostrei, sem nenhuma pretensão, é apenas uma tentativa que nós fazemos de criar uma arquitetura que responde melhor às nossas necessidades não só de termos econômicos, mas inclusive de conforto ambiental, de espaço de arquitetura, porque é isso que nós temos que fazer. A arquitetura européia hoje está muito ligada ao turismo, à promoção, à mídia. Ela produz grandes discursos, você vê as obras de arquitetos importantes como Santiago Calatrava. Tudo muito dirigido para uma coisa, até colonialista, são de grandes eloqüências, é turismo, não é? Eu acho que a gente tem que procurar responder aos nossos anseios, nossas demandas, de uma forma muito mais lógica para nós. Claro não sou contra. Se tiver que fazer um museu, que ser feito um museu. Nós somos profissionais. Estamos aí para isso. Não sou contra a arquitetura grande e eloqüente, só acho que ela não pode ocupar o espaço inteiro. São grandes expressões da arquitetura. Nós temos grandes mestres, a arquitetura de Oscar Niemayer, importantíssima 
para nossa cultura como foi também a arquitetura do Vilanova Artigas. Eu acho devemos muito a todos esses arquitetos. É o caso do pai do Julio que fez uma arquitetura muito forte e muito ligada com nossas necessidades. Gosto muito, imensamente do trabalho de Artigas, mas eu acho que também há espaço para discurso grande, eloqüente. Não estou criticando não. Eu acho que sim, há espaço. O Niemeyer faz isso muito bem, não precisamos do Calatrava porque já temos quem faça isso. Não sou contra também trazer de fora se o projeto for bom. Não há nenhum preconceito. Agora, não podemos fazer um Guggenheim no Rio de Janeiro daquela forma extorsiva, que vocês sabem como é que foi. Lógico que eu sou contra isso. Acho que nenhum arquiteto brasileiro é a favor daquela proposta do Rio de Janeiro, que felizmente gorou.

Marcelo. Queria saber o que é que o inspirou para essas formas? Eu sou estudante do terceiro ano desta faculdade. Aluno do professor Júlio. E eu queria saber o que inspirou essas formas que são tão peculiares na arquitetura que o senhor desenvolve por toda a carreira.

Lelé___ Cada tecnologia, cada proposta, requer uma forma que está muito mais ligada ao seu conteúdo. No fundo a forma está muito ligada ao conteúdo que a gente pretende ter da arquitetura. No caso que eu mostrei inicialmente da cabana dos índios, das malocas, aquela expressão arquitetônica que acho extremamente bela está muito ligada à concepção daquele espaço que os índios queriam ter coletivamente. E eu acho que eu tento fazer é a cabana dos índios, que é de ter sempre um espaço que possa responder às necessidades de funcionamento. Se os sheds(?) tem uma curvinha para que a aerodinâmica seja mais bem resolvida para entrar luz, isso também está muito ligado ao aspecto funcional. Há sempre uma intenção: por exemplo, na igreja você vê uma concepção barroca. Mas acho o desenho tem que estar ligado a um conteúdo. É uma coisa profundamente triste se a gente fizer um prédio de trás para frente, ou de fora para dentro. Eu acho muito ruim, muito feio, eu acho que um prédio tem que ser feito na sua totalidade, e não de fora para dentro, pra gente ver por fora e não ver o que tem dentro.

Mário, estudante do TFG, quinto do ano daqui da FAU Santos. O que dá para perceber é o senhor é um mestre da pré-fabricação que está sempre utilizando e estudando muito essas tecnologias. Gostaria de saber como que essa tecnologia poderia ser usada na habitação popular, respeitando todos os contextos de onde estaria inserida. Só queria uma opinião de alguém que eu admiro. Obrigado.

Lelé___ A questão de fabricação é sempre economia de escala. É a base da indústria. Você não pode fazer um carro á mão, separado do conceito de economia que é o conceito da industrialização, da economia de escala. Então, economia de escala é ter que reproduzir muitas vezes. Quanto mais você reproduz, tem um processo de industrialização, mais complexo, mais integrado para reduzir os custos. Torna a construção não só mais econômica, mas com uma qualidade melhor também. Enfim, a gente pode fazer a habitação popular. Agora, eu acho que quando você, por exemplo, fabrica um automóvel, você tem uma demanda e tem um poder aquisitivo para compra desse automóvel. No caso da habitação 
é difícil porque a população dessa habitação popular que você está falando não tem poder aquisitivo para adquirir. Isso é quase sempre convencionado pelo governo, é uma coisa paternalista, porque o sujeito que ganha um salário de indigência primeiro tem que comer e quando você dá uma casa pra ele, ele come a casa, ou por outra, ele vende a casa para poder comer. Então eu acho que é um problema difícil. Agora, a resposta tecnológica existe. Existe uma condição decente, eu não mostrei aqui, mas em outra oportunidade, posso mostrar uma casa pré-fabricada em argamassa armada. Mas esse tipo de usuário que você está se referindo, quando você diz casa popular, ele não tem dinheiro pra ter casa. Então dentro da estrutura capitalista, isto é impossível, porque ele primeiro tem que ganhar seu dinheiro, para depois ter acesso à casa.

Ricardo, aluno do quinto ano da FAU-Santos. Eu gostaria de saber quanto ao futuro das técnicas que poderão vir, ou materiais, se o senhor tem alguma idéia, que possa falar alguma coisa.

Lelé____ Claro que a gente vê o uso do aço que incorpora técnicas muito novas. O aço não é uma coisa nova. Você viu, por exemplo, a tecnologia da chapa dobrada, por exemplo. Há trinta ou quarenta anos você tinha um perfil siderúrgico que era uma forma, uma viga " $\mathrm{T}$ " que se adquiria no mercado. As soldas eram muito difíceis. Hoje as soldas estão bem desenvolvidas. A Usiminas, que é um fabricante de perfis, já manda os perfis soldados, não vende mais os perfis produzidos como antigamente, por processo siderúrgico. Acho que a indústria do aço tem muito que evoluir na proteção contra oxidação. Hoje já existem aços especiais. No meu entender, a forma mais indicada para o desenvolvimento de edifícios, a matéria-prima mais indicada seria o aço no qual se sente um cabedal enorme. O concreto está praticamente esgotado. Mesmo os concretos leves, essa coisa da argamassa armada acho que hoje se introduzem agregados de alta resistência. Tem-se concreto de altíssima resistência de maior qualidade também, mas isso são pequenas contribuições que, no entanto, não abre assim um horizonte para essa tecnologia do cimento. Os plásticos, eles vêm aí com uma força enorme. Aliás, uma observação que eu gostaria de fazer: quando vocês forem ao Guggenheim de Bilbao, vocês vão ver que o comportamento daquelas treliças, toda a arte estrutural é muito primitiva, não tem nenhuma contribuição especial ali na estrutura daquele prédio. É só um espaço muito diferente, inusitado.

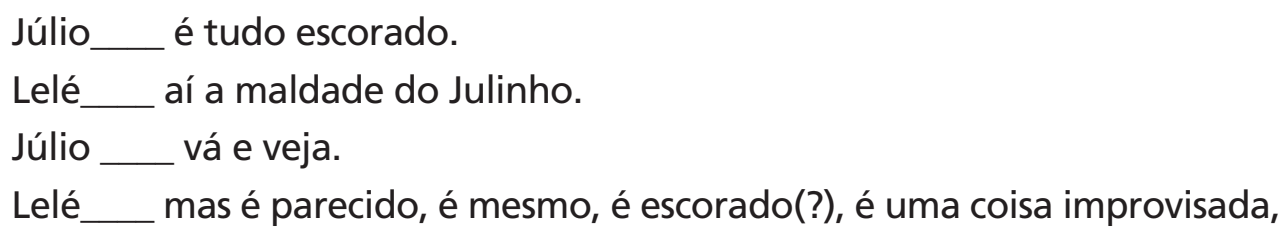
não vejo aí nenhuma contribuição para a industrialização da construção, não. É um super discurso grandiloqüente, com uma forma absolutamente inusitada, mas isto tem sido uma maneira deles imporem sua hegemonia cultural no mundo moderno através da arquitetura. Mas eu acho que não é por aí, não vejo assim nada espetacular que possa acontecer. Essas matérias-primas que nós temos aí são as que são usadas por eles, nesses super discursos. O Calatrava continua usando concreto. Os moldes de concreto que ele usa são de aço revestido de madeira 
para dar textura. Então é uma construção super cuidada e não estou negando valor. Ele é um engenheiro fantástico, um arquiteto fantástico, o discurso é perfeito, mas eu estou dizendo: não há nenhuma contribuição especial em termos de matéria-prima e proposta estrutural que seja nova dessas que a gente não conheça. Existe uma preocupação de fazer o inusitado. Eu acho muito bonito, não estou discutindo a beleza. Calatrava na arquitetura e não na tecnologia. $\mathrm{Na}$ arquitetura continuo achando que ele é um arquiteto excepcional.

Júlio___ vou passar a palavra ao querido diretor Abdala e comunicar aos fãs do Lelé se coordenem de um certo jeito e venham tirar fotografia com ele. Quem quiser tirar fotografia, fica bonitinho aí no canto. Moças têm a preferência.

Abdala__ Primeiro vou fazer uma observação, como professor e arquiteto, queria que vocês tivessem clara a demonstração de coerência da produção, do trabalho desse arquiteto, desse cidadão que é o Lelé. A clareza demonstrada pela objetividade, pela coerência e pela competência, porque às vezes essas três coisas não se juntam. Essa competência expressa no desenho que é o assunto que falamos nesta escola, que é a arquitetura, se expressa de uma maneira belíssima, de uma maneira ímpar, de uma maneira brasileira, de uma maneira que interpreta todos os anseios os quais se colocam na obra consolidada, correta e mais do que isso, generosa. Estou muito satisfeito e, falando em generosidade, quero agradecer ao Lelé a generosidade da visita, e tenho certeza que falo pelo conjunto de alunos e professores. Na presença do Júlio vou dar ao Lelé um presente, um livro do Vilanova Artigas como lembrança dessa sua visita na escola. Muito obrigado professor. Muito obrigada.

\section{Prof. Paulo Mendes da Rocha}

Formado pela Universidade Mackenzie em 1954, Professor Titular da Faculdade de Arquitetura e Urbanismo da USP

Sem dúvida nenhuma um dos maiores artistas do Brasil, o Prof. Paulo vai falar o que ele quiser. (Júlio Artigas)

Como é de praxe agradeço este convite imensamente, cumprimento voces todos com muito carinho, porque são estudantes, são o simbolo supremo do futuro e da esperança e de tudo que possa imaginar que se saiba na medida em que as coisas possam continuar, a vida é uma sucessão.

Cumprimento muito particularmente meu ilustre querido amigo, diretor desta Faculdade, Júlio Artigas, Cláudio Abdala com quem eu tive o prazer de trabalhar de uma forma extraordinária. O que é muito difícil de uma maneira em geral, o nosso trabalho na interlocução, no caso digamos com o governo, na ocasião em que Cláudio era Secretario de Planejamento da Prefeitura e eu acredito que por ele convidado para estudar o novo aquário de Santos, que foi muito interessante. Tudo que se desencadeou a partir disso, amparado o que já é uma questão do que eu poderia dizer a vocês bastante importante, a idéia do amparo 
e da consciência política sobre as questões da transformação da cidade, tudo isso, que nessa ocasião se revelou então de modo muito particularmente favorável a um desenvolvimento de um trabalho delicado muito extraordinário $A$ instalação de um aquário em Santos, a questão da implantação urbana e tudo isso.

Cumprimento meus colegas todos em particular, Vera e todos os que estão aqui, Maria Helena Flynn, a minha querida amiga de muitos anos.

Bem, o que me ocorreu dizer a vocês, solidário com os professores desta escola, cujo a idéia eu acho fundamental, é recebê-los no curso de arquitetura. Antes de mais nada que era necessário sempre distinguir aquilo que é necessariamente cotidiano e banal na nossa vida, principalmente na vida estudantil, de uma idéia que permanentemente deveria nos alimentar de que, entretanto, trata-se de algo fundante no gênero humano a idéia de escola, aprender e transmitir conhecimento, é muito difícil. Por outro lado, é a mais fundamental das razões, talvez da nossa existência no universo termos nos acostumados depois, mas inventado ninguém sabe bem quando, a estabelecer uma concomitância na idéia de consciência e linguagem, ou seja, adquirida consciência sobre qualquer coisa que venha ser e só podia ser diante da natureza, descobrir, inventar e engendrar linguagens capazes de transmitir ao outro na maior profundidade possível esse conhecimento, como se nós tivéssemos nessa consciência estabelecido primordialmente a consciência sobre a necessidade de construirmos a nossa existência no planeta. Talvez o homem não esteja extinto até hoje enquanto espécie por isso, por essa razão, de transmissão do conhecimento e uma consciência sobre o que vem a ser conhecimento. No âmbito disso, dessa questão ou desse quadro, a arquitetura assume uma posição muito interessante porque inexoravelmente ela é ligada enquanto universo de conhecimento à construção do habitat humano, como quem diz, a natureza ela mesma, para nós não tem virtude nenhuma. A natureza produz desastres da natureza, é adversa, a natureza é fria ou quente, a natureza é na medida inclusive cada vez que sabemos mais sobre mecânica celeste, o que somos e quem somos no universo. É uma situação, nós perante a natureza trágica; o mundo não é estável, o planeta não é o que é. Não será sempre coisas assim que estão ligadas a nossa existência particular, a nossa experiência particular, enquanto americanos de uma maneira muito recente, particularmente aventurosa e extraordinária quais tenham sido as navegações ao mesmo tempo em que Galileu dizia que nos éramos um planeta desamparado no universo. Coisas tão extraordinárias como novidades no conhecimento humano, a ponto de um homem deste tipo, Galileu, ser mandado queimar em fogueira, porque contrariava todos os dogmas, etc., etc., etc... Ou seja, nós americanos de um modo em geral, somos detentores de uma experiência onde se comprova com a nossa própria existência num verdadeiro planeta novo em relação ao mundo europeu a dimensão do universo e a nossa necessidade de instalarmo-nos nesta natureza de maneira engenhosa e construída, como quem constrói uma natureza habitável, que é uma outra natureza no planeta. A experiência americana deveria ser a consciência nossa sobre essa experiência deveria ser, e é por isso, talvez, que de maneira muito frágil ainda eu acho, há esse reconhecimento. É tida como muito importante a experiência americana de um modo geral diante do conhecimento, 
particularmente arquitetura. O prestígio da arquitetura brasileira por outro lado dentro da América é muito grande no mundo. Na minha opinião, por essa razão de termos nós, mesmo que não nativos diante do quadro dos horrores do colonialismo, entretanto uma consciência nós temos, exibimos com nossa arquitetura sobre a idéia de transformações da natureza para que aquilo que lá estava como pura e simples natureza "in natura" possa se transformar num lugar habitável, que se chama na sua integridade e complexidade maior cidade, o homem hoje só pode viver numa cidade, não há outro modo de se viver e não por destino trágico ou por inconveniência, mas por sublime realização, apesar de todos os desastres e desencontros, em contradição, de um alto ideal que sempre acompanhou a nossa existência de vivermos juntos e construirmos um recinto onde isso seja possível na sua maior e plena dimensão. Nessa medida ou com esse tipo de idéia, as cidades a beira mar, as cidades portuárias, assumem particularmente um interesse muito grande, por que para nós, nessa escola, pra vocês, a cidade de Santos, uma escola na cidade de Santos obriga-se na minha opinião, a voltar delicada e agudamente o seu olhar sobre este tipo de situação, porque na história se voces concordarem ou pensarem, os recintos onde estão os portos de um modo em geral, são os recintos mais impróprios para que se faça ali uma cidade, são recintos onde a natureza na sua escabrosa conformação geológica instável, e depósitos, deposições de aluviões que vem das alturas das serras e da águas, são regiões de conflito entre o mar poderoso na sua dinâmica natural, e esse território que é mutável, mangues, regiões inundáveis, inundadas e coisas assim. A idéia do porto, entretanto, surge quando o mundo começou a ser navegado, mas surge há milhares de anos já atrás de maneira incipiente, de todos os modos que nós sabemos da história, como um desejo de comunicação através das navegações e de transportes de mercadorias, de estabelecimentos de riqueza material, de troca e tudo isso, encontro entre os homens, os portos. Portanto, essa beira, essa fralda da terra e do mar inóspito passava já, sempre foi desejabilíssima como lugar para se habitar e exigia esses lugares uma intervenção enérgica de obras de grande engenho que já editavam a possibilidade das maravilhas das construções e das obras de engenharia e do sucesso dos engenhos humanos naquilo que é uma transformação da natureza e mais que isso, uma reinterpretação da natureza, do ponto de vista do senso comum, porque os navegantes, os engenheiros, os homens artesãos de todas as épocas já sabiam disso, mas para se ver todo o mundo uma espécie de exibição inexorável, como é possível e como é necessário e como é engenhoso o homem para transformar o que seria uma geomorfologia em coisa possível de se habitar porque seriam esses lugares inabitáveis.

Nessa cidade particularmente a obra fundamental no sentido da palavra e mais extraordinária, seria interessante nós assumirmos por mais que possa ser contraditório e anti-canônico, e anti-acadêmico a obra mais notável de arquitetura seria a intervenção feita pelo projeto básico fundamental de (o homem que fez os canais) de Saturnino de Brito.

Saturnino de Brito representou no Brasil um tipo de conhecimento que no mundo inteiro você encontra seria o Sr. Freseneu na França, com o estabelecimento dos canais navegáveis com portas e engenhos. Engenhosidades 
e aplicação de conhecimento capazes de organizar um território inóspito em território sadio e possível para que se estabeleça vida humana. Essa transformação de território é que para mim devia ser o enfoque básico de uma escola de arquitetura, a dragagem das zonas inóspitas inundáveis, o estabelecimento dos canais, as comportas que regulam esses canais, a interlocução entre as águas que vem do interior e as águas que vem do mar, na elevação dos níveis de maré, das chuvas que vem de dentro, uma dimensão extraordinária

A consciência sobre essa transformação do território do ponto de vista da habitabilidade, assume um interesse além desses exemplos indiscutíveis, quais sejam, configurar o alinhamento correto do confronto da terra com o mar, das muralhas de cais nos enrocamentos, aterros e os planos, onde não havia possibilidade de se estabelecer as construções, as casas, etc...

E principalmente a posição do homem na idéia de uma escolha fundamental de recintos e lugares perante a natureza, a geografia, a mecânica dos solos, etc..

Aqui faremos a cidade, aqui será o porto. Essa capacidade de um olhar sobre o universo, e no caso o território que permite a nós escolher os lugares, sabendo que ali com determinados intervenções nós podemos transformar tudo no que chamamos espaços habitáveis, que depois chegará as casas, os edifícios comerciais, as instalações industriais, os armazéns, a possibilidade de atracar um navio com algum calado junto a essa cidade que eliminou essa paulatina profundidade que obriga o navio a ficar longe, chegar na praia com escaleres, etc

Atracação de um navio no recinto urbano é um fenômeno extraordinário que deveria ser comemorado diariamente. Um navio de bandeira estrangeira que transporta uma verdadeira nação inteira, com costumes, regras de navegação, sabedorias dentro do recinto de uma cidade com mercadorias e tudo isso. Uma idéia de que estamos providenciando a vida dia a dia, portanto uma cidade que rejeita, como se fosse lixo, parte doente da cidade. O cais do porto que rejeita a vida, inclusive urbana, na sua interlocução sistemática, com aqueles navegantes que vem e se divertem, coisas do tipo. Uma cidade festiva naturalmente, que rejeita essa realidade formal e principalmente mais que isso, de caráter humanístico do encontro das pessoas com essa possibilidade extraordinária de ser porto de mar. É uma cidade que já nasceu para ser, ou melhor, é uma cidade que possui uma degenerescência que nós teremos que assumir a responsabilidade, digamos de caráter literário, intelectual, político, principalmente de retomar o rumo do não desastre e do sucesso.

O interessante desse discurso todo é trazer essas imagens, que são mais ou menos, digamos, indiscutíveis para o âmbito da arquitetura do dia-a-dia, digamos assim, como que um edifício não pode ser visto como coisa isolada e como que as construções organizam o espaço naquilo que é um território e coisas desse tipo, essa é a fundamental posição que uma escola de arquitetura deverá adotar, que já implica necessariamente no estabelecimento de uma sistemática visão e plano crítico em relação as coisas que se faz.

A arquitetura que tem se demandado de um modo em geral a nós, os profissionais, ela já contém o germe da degenerescência. A arquitetura que já presume que seja ela o produto, o prédio, o edifício, seja o que for, instrumento 
ou produto de mercado ou negócio puro e simplesmente, que não se preocupa com a realização e a reconfiguração do território na medida em que se edifica e se construa, é uma arquitetura que já está destinada ao desastre.

É interessante considerar por aí, que mesmo então, uma certa arquitetura dita, pode ser instrumento do desastre da cidade. É fácil fazer um edifício que prejudica a cidade, é fácil imaginar, deveria ser para nós um deleite, digamos assim, o prazer de nosso conhecimento, da nossa especulação como que as edificações reconfiguram o território solidárias, digamos como conseqüências daquelas primordiais transformações tão importantes e indispensáveis vistas particularmente em cidades portuárias e beira mar.

Entre nós, algumas obras são notáveis e quem já viu eu repetir isso peço que me desculpem, mas, para quem esta nesta escola que nunca talvez tenha atentado, é preciso entender o valor e o vigor, o poder dessas transformações com uma memória, um exemplo ou outro.

Eu vou contar para vocês, por exemplo o seguinte, fazê-los lembrar. No Rio de Janeiro havia um morro, um pouco raro naquele lugar, porque só feito de terra. No Rio é muito comum afloramento rochoso e coisa do tipo. É o morro do Castelo, é chamado morro do Castelo junto à avenida Rio Branco, avenida principal do Rio em direção ao mar do lado esquerdo, de quem de costas para o porto; praça XV olha para onde está hoje o museu de arte para a baía, para a laguna Flamengo. Esse morro além de vários inconvenientes no plano urbanístico da cidade que causava, lá pelas tantas, foi objeto de uma especulação em torno também de uma necessidade da construção de um heliporto na cidade do Rio de Janeiro, contando no caso feliz daquela cidade na sua implantação com a possibilidade de aproximação dos aviões pelo mar, o que faz com que as dificuldades de um heliporto no meio de uma grande cidade, com prédios, etc.., seja ponto possível de ser contornado, ou seja, o Rio viu-se feliz se pudesse ter um heliporto no centro da cidade, o que de fato é uma maravilha hoje o heliporto Santos Dumont do Rio de Janeiro. Pois bem, o heliporto Santos Dumont do Rio de Janeiro foi construído assim, onde se queria que o heliporto ficasse, foi construído num retângulo adequado com muralhas de cais, que se chama enroncamento de pedra britada que faz uma contenção naquela área dentro do mar. O morro do Castelo que estaria a 2 ou $3 \mathrm{~km}$ dali, foi programado pela engenharia desmontado a jato d'água, ou seja, estabeleceu-se um desmonte hidráulico que transforma a terra do morro num fluído, numa suspensão de terra e água, um novo fluído, um trabalho belíssimo de mecânica de solos, mecânica dos fluídos, cujo fluído agora pode ser transportado por tubulações. Foi estabelecida uma tubulação e essa lama foi jogada naquela ensecadeira, ela expulsou a água do mar e desapareceu constituindo uma grande esplanada para reurbanização belíssima chamada mesma Esplanada do Castelo no Rio de Janeiro, e surgiu um novo território retangular perfeito, plano horizontal nas dimensões adequadas chamada de heliporto Santos Dumont. Isso é uma maravilha de exemplo de uma transformação feita pela nossa engenharia muito recentemente, etc... Portanto é o que eu quero dizer, é que essas são possibilidades reais de transformar o lugar naquilo que nós queremos para torná-lo 
habitável. Do ponto de vista, ah será, você arruma pra mim, desculpe são oito ou qualquer coisa assim do MUBE, depois tem dois da baía de Montevidéu, dois do Tietê, e quatro ou cinco de Vitória, que é fácil distinguir, eu trouxe uns slides, não sei se vale a pena passar, talvez seja interessante.

E então, pra ilustrar o que eu estou dizendo gostaria de mostrar alguns exemplos e projetos que eu andei estudando, onde esta questão da transformação aparece em dois ou três momentos de uma maneira muito interessante, do meu ponto de vista. Um desses exemplos é de como esse edifício que pode se tornar um inimigo da cidade, por outro lado pode assumir uma configuração outra, de caráter sadio e altamente imaginativo do ponto de vista da invenção, digamos um edifício, vamos imaginar que é isso que nós queremos fazer, não se trata de eu fazer um auto-elogio, como quem diz, os senhores dirão depois que aquilo é uma droga, mas o que eu quero dizer é o que se pretendia que fosse algo belíssimo e que amparasse toda a visão de espacialidade nova, que o edifício é capaz de fazer, enquanto ele um instrumento virtuoso em si, ou seja, uma sucessão de lajes, elevadores, que é uma máquina extraordinária que permite você colocar um edifício vertical, o que quer dizer, produzir tanto de área útil de uma certa qualidade, seja habitação, no caso seriam escritórios, instalações inclusive de edifícios institucionais, tipo capitânias dos portos, central de mercado de café, aduana e também escritórios quaisquer. Isso na cidade de Vitória, no porto de Vitória, numa área que é a entrada da baía de Vitória, cujo porto está lá no fundo, numa região onde até lá pouco tempo o território é original, com todas essas dificuldades de manguezais, alagamentos, etc e não edificante que seria como se fosse aqui, e eu vou descrever pra vocês, e o tapete azul, as águas, os navios entram do oceano aberto até o fundo da cidade velha onde está o porto, e essa área muito recentemente foi retificada com o mesmo tipo de técnica com que foi feito o aeroporto Santos Dumont. Uma muralha adequada e calculada, e um aterro de tal modo que se faz uma esplanada horizontal e a frente do mar fica absolutamente urbana, possível de edificações etc...

Como essa área é uma extensão da própria cidade da área central, da cidade de Vitória, imaginava-se, até hoje urbanizar essa área como uma extensão da área central.

$\mathrm{Na}$ entrada do porto, num canal de 500 ou 600 metros a $4 \mathrm{Km}$, depois ele estreita mais adiante, que é a entrada onde entram os grandes navios, etc. De uma maneira disciplinada, porque navegam no canal, no talvez desse. Bem, nesse lugar se tratava de urbanizar, como se faz normalmente, uma série de ruas, talvez de loteamentos, e destinar terrenos para aqueles edifícios cujas capitânias dos portos, etc. por programa, 2500 ou 3000 metros, iam constituir uma série de palacetes com certeza ordinários, não se sabe bem como se fazer isso, como inventar essas besteiras, uma provocação ao imaginário, uma imaginação do arquiteto, uma verdadeira idiotia, na medida em que uma empresa hoje trabalha num belo andar de qualquer prédio e não precisa ter um palacete que possa exprimir o que possa ser o café, a capitânia dos portos, ou seja, uma exacerbação de uma linguagem inútil no caso para exprimir fúteis imagens que se transformam muito rápido no tempo, um pouco desligada da magnitude do trabalho em rela- 
ção aos navios, as descargas das mercadorias, o transporte, a alegria das crianças, a vida simples das casas, etc.. Ficam esses monstrengos, que seriam os palácios senhoriais do passado, agora para representar empresinhas ou coisas assim. Principalmente no caso, diante da magnitude de tudo isso, seja da grande paisagem e mesmo da monumentalidade dos espetáculos dos navios e do trabalho diante desses pequenos palacetes, pequenos naturalmente porque os programas eram de $2500 \mathrm{~m}^{2}$ ou coisas do tipo. Então eu imaginei o seguinte, se não era possível constituir um belíssimo jardim com habitações principalmente e comércio que se estendesse essa cidade. E que essas instituições, inclusive os escritórios, numa certa medida, fossem instalados em edifícios padrão, um tipo de edifício que podia se repetir em 2 ou 3 vezes, com mil metros por andar de tal sorte que a capitânias dos portos seriam dois andares, o instituto do café seriam quatro andares, coisas desse tipo. Que com elevadores privativos você pudesse atingir de tal sorte que, esses edifícios pudessem conviver com as entradas dos navios de uma forma muito especial. E o que foi feito foi o seguinte, nesse cais, eu não sei se precisa desenhar, eu acho que eu podia mostrar na mesa, tava muito melhor. Nesse cais, o mar esta lá, e o mar está aqui, diante dos navios que entram aqui e se não era possível construir esses edifícios de tal sorte que os andares pudessem conviver a ponto de você escolher justamente a cota, tal seria a capitânia dos portos que passa rente aos castelos de comando dos navios e coisas desse tipo. Se não seria interessante considerar que se o terreno original era esse, e se a maré está aqui, esse pequeno aterro não assegura fundações para um prédio acima de 4 ou 5 andares que não sejam tubulões pneumáticos, que tanto faz você fazer aqui, ou como fazer aqui no mar, é a mesma coisa. Se não seria interessante construir com essa técnica então esses edifícios aqui no mar de tal sorte que se pudesse criar entre o edifício e a costa um canaleto, um pequeno canal, suficiente para as pequenas embarcações que navegam para a ilha do Príncipe. Há uma intensa navegação de passageiros na baía, que podiam atracar nesse cais e que se eu fizesse isso, seria mais interessante eu fazer esse prédio como se fosse duas torres em concreto armado com esses tubulões, afastadas de 30 metros de tal sorte que eu pudesse montar pelo mar, com equipamento naval, que é conhecido como técnica e tecnologia da população que mora lá, de estaleiros, caldereiros, pelo mar como estruturas metálicas que depois se fariam como lajes evitando os canteiros prejudiciais à vida da cidade. Que essas cábrias, guinchos e guindastes flutuantes trouxessem dos estaleiros as estruturas metálicas capazes de vencer esse vão de 30 metros entre uma placa de concreto e outra, cujas abrigariam todos os elevadores, de tal sorte que esse, esse, esse é capitânia dos portos, esse daqui, etc assim. De tal sorte, que eu pudesse ter essa exclusividade deste ou daquele empreendimento ou tarefa. Eu quero dizer as virtudes que começam a surgir desse tipo de posição técnicas e espaciais da cidade. Se não seria o caso de se fazer como se tem feito no mundo todo, toda essa área uma garagem pública de tal sorte que o cais ficasse no nível das garagens. Se não era o caso de se imaginar que esses esgotos, águas e mesmo a entrada, não se poderia fazer pelo mar, deveria se fazer numa cota, de tal sorte que ia obrigar o serviço do prédio como a saída, a construção de um pavilhão em terra, que seria um pavilhão cristalino 
para jornais, cafés e bares e com escada rolante, a recepção do prédio aqui e você passa para esses prédios, se não seria possível imaginar um, dois ou três prédios interligados, quantos você precisasse, e se daí não surgiria uma urbanização da área extremamente interessante mais inventiva e liberta da inexorável condição do palacete do loteamento, etc...etc...etc... Eu quero com isso dizer que, quem sugere essas novas, você vê que o desenho não é pra guardar, quem sugere essas novas espacialidades é uma consideração das virtudes de tudo o que se faz , cais, navegação, além de uma visão exclusiva de arquitetura de modelos e coisas de revista, coisas que parecem que já estão feitas e exauridas...

A aproximação se faz até com a rigorosa matemática, porque 30 por 30 não dá 1000, mas em todo caso. E numa cota absolutamente, eu vou dizer um detalhe desses porque eu gosto muito disso, se numa certa cota absolutamente extraordinária não seria possível construir entre um pequeno espaço de 10 ou 12 metros pelos 30, que só tem acesso daqui pra cá, junto aos navios e junto a essas águas onde naturalmente devem estar lá, freqüentando tudo isso, aqueles mesmos caranguejos e moluscos que estavam aqui nestas pedras naturais antes, agora nessa construção de concreto armado belíssima feita pelo homem. Se isso não seria uma verdadeira maravilha, passar noites aqui pra ver, porque os navios inclusive entre outras virtudes possuem essa de não ter horário, o navio por razões de suas máquinas, por razões do giro da terra, entram no porto às 04:00hs da manhã, saem do porto à $1 \mathrm{~h}$ da madrugada e coisas do tipo. Portanto há uma vida ligada ao universo e ao mundo que deve animar uma cidade portuária, além da idiotice de deixar que as áreas portuárias degenerem como áreas de lixo e de porcárias digamos assim, ou rejeitadas pela vida urbana diária e passe a se desejar sempre, não se sabe bem o que no idealismo que não se leva a nada. O lado habitacional exclusivamente habitacional, com casas que ninguém sabe bem onde é. $E$ que acaba resultando, que uma cidade como em Santos tem alguns palacetes, se bem que muito bem construídos, mas normandos, mas estilo isso ou estilo aquilo. São formas absurdas da existência, tudo isso leva perante a natureza, você ter que considerar que altura assumiria esse edifício, uns 30 ou 20 andares, essa altura seria sem dúvida nenhuma obrigatoriamente para nós, referida as montanhas e as paisagens do lugar com certeza num certo equilibrio entre tudo isso, natureza - construção, que seria no caso, as construções a nossa verdadeira natureza, a natureza que interessa o homem, possível de ser habitada. Eu vou mostrar duas ou três imagens de uma maquete que foi feito disso, para a ilha de Vitória, etc.. Eu vou mostrar também, não sei o horário se esta demorando muito. Outro projeto com estas considerações que eu gosto muito de mostrar e que eu fiz, eu tive a possibilidade de fazer, eu quero dizer, fazer é discutir muito com grupos grandes, particularmente nesse projeto, porque foi feito num seminário internacional que se repete sempre, que é muito notável ...até a escola podia fazer um contato com a Escola Federal de Arquitetura de Montevidéu, é uma escola de arquitetura extraordinária sobre vários aspectos, que organiza seminários assim, convida cinco ou seis arquitetos que acha que deve convidar de várias partes do mundo e que põe a disposição vinte alunos, quatro professores e um ateliê por uma semana, todos com o mesmo tema, depois debate aquilo tudo, inclusive vem, convidam 
pessoas de fora do país também para discutir projetos e comentar, é riquíssima a situação, portanto, eu posso mostrar isso sem escrúpulos de vaidade porque é um trabalho coletivo, feito pelos professores e alunos de lá muito interessante, na minha opinião, sobre o que estamos conversando das transformações, vejam vocês. A baía de Montevidéu tem um canto muito especial principalmente por ser na América Latina, a saída da bacia do Prata, ou seja, a navegação todo o interior do continente mútuo brasileiro deságua, descarrega, flui e navega essa baía de Montevidéu forçosamente, porque é uma baía enquanto porto abrigado muito melhor que o porto de Buenos Aires por razões de reposição de material, de correntes, etc... O porto de Buenos Aires é naturalmente assoreado, exigem trabalhos de drenagens, dragagens sistemáticos mais do que o Porto de Montevidéu.

A baía de Montevidéu por outro lado, é constituída é um recinto mais ou menos circular, e a cidade está em volta dessa baía, aqui há um leve morrote, tudo isso é muito horizontal por exemplo, forçosamente e aqui há um famoso, importante da região, um riacho que deságua na baía e um outro aqui assim. E aqui uma pequena, ganhado do mar com equipamentos de petróleo e nesse recinto há muito anos, já foi construído o porto da cidade e um píer que protege do assoreamento este porto que é dragado, e a baía, uma pequena ilha aqui, é toda ela e antes de mais nada, pra arquitetos, vocês já deviam estar perguntando que tamanho tem isso, a escala é muito interessante porque se vocês considerarem que a avenida Paulista tem $2 \mathrm{Km}$ e meio, é justamente um diâmetro de um círculo imaginário aqui, essa baía tem dois, três quilômetros, é algo que você vê assim, e a cidade luta aflitivamente com a atração dessas águas e a dificuldade de enfrentar isso com planejamento urbano, digamos comum, ou seja, sempre se quer circundar a baía, e isso cria problemas de tráfego muito grandes, como nós sabemos que acontece em toda a avenida beira mar e coisas do tipo, não se sabe o que fazer. A cidade fica em vez de acessível a essas águas tão atraentes, os espaços da cidade em vez de acessíveis ficam tolhidos por essas avenidas de contorno e coisas do tipo. Estudando isso, o tema era esse, a baía como em toda, surgiu a seguinte idéia, primeiro se isso é dragável, o melhor aproveitamento para fazer o porto progredir é construir o porto do outro lado também, uma vez que a dragagem pode servir a um todo de área de píer. E se há esse problema de circundar a baía e há tração das águas e se há uma espécie de ameaça do futuro, a circunstância de que a baia toda é muito rasa, e muito rasa quer dizer, dois metros de calado, um metro e meio, muito rasa uma espécie de água inútil, água que tende "apodriste" como eles mesmo dizem, água que tende a ser poluída, enfim uma ameaça de aterrar tudo isso como algo inútil. Fizemos o seguinte projeto, com aquele técnica, nós retificamos essa frente da baía e urbanizamos, imaginamos que a cidade nessa região dirija-se a essa nova frente que é uma esplanada, inclusive como cais de atracação para a baía. Que se mantenha parque por aqui, mas que se retifique essa outra frente da parte de equipamentos técnicos e que se construa esse porto novo, esse cais e que se ligue pelo lado de lá ou por aqui. E que fique com isso, se estabeleça um tipo fácil de embarcação que navegue em dois metros, qualquer batelão de passageiros, para a navegação de 
passageiros dois metros de água é de uma virtude imensa com a possibilidade de navegação, tem algo a ver com o plano do Kenzo Tange para a baia de Tóquio. A baía de Tóquio também é muito rasa, não serve para navios de setenta mil toneladas, mas para a navegação de passageiros é uma maravilha e que se passe a navegar de um lado para outro, como quem diz, os meninos desse bairro para ir para a escola e coisas do tipo. E que se transforme essa ilha com a mesma técnica, num teatro para que se possa ouvir a orquestra e possa tocar no seio dessa baía transformada agora numa praça quadrada de água e que tudo se transforme, desse modo, em algo que isso passe a ser uma verdadeira cidade, agora com as luzes refletidas nessas águas e com virtudes que começam a aparecer dessas águas, aparentemente inútil, extraordinária a ponto de se imaginar esse teatro assim, uma vez corrigido o relevo dessa ilha com as muralhas, o aplainamento disso na água e atracação dos navios de passageiros dos barcos, que é o único acesso para esse teatro. Esse teatro podia ser feito assim, como os navios possuem grandes espaços abaixo da linha do mar com a sua platéia rebaixada e essas áreas como áreas de praças muito bonitas. E que pudesse ter uma cobertura feita por fora, com flutuantes, cuja estrutura metálica de cobertura se apoiasse nesses flutuantes e que esses flutuantes podiam ser feitos, dois a dois, de tal sorte que motorizados pudessem se afastar e em noites de lua, isso pudesse se abrir, e o teatro se tornar um teatro de ar livre. E tudo isso passa a ser uma maravilha com as virtudes da mecânica dos fluidos e com a técnica da navegação. Uma arquitetura que é tirada para outros espaços, outros ideários e outro universo imaginativo daquele do corriqueiro e amargo modo com que temos visto se desenvolver a arquitetura, quadra por quadra, da mesma quadra que existia na cidade antiga. Casa do loteamento do período colonial tirado para que ali se faça um prédio vertical, como quem diz, verticalizar a cidade, a floresta de concreto armado, o desastre da cidade, a desmoronização da inteligência, e do saber da arquitetura através de uma visão errática da interpretação das coisas. A construção é que transforma a natureza inóspita em algo belíssimo, que é o novo espaço do homem no universo. É interessante notar que essa visão toda da espacialidade e da inconveniência ou conveniência do edifício, e a possibilidade do edifício ser visto não como uma coisa isolada em si, objeto, mas como um instrumento de transformador do lugar, pode ser levado a um simples edifício. E com isso eu vou mostrar alguns slides de um pequeno museu que eu fiz, que todos já conhecem, mas para que se veja que também um edifício, pode ser inventado de tal sorte, que ele transforme todo o recinto além da sua exclusiva estrita condição de área coberta, tanto disso, tanto daquilo, vestíbulo, salão, essas coisas. Numa situação inclusive, onde havia uma provocação porque muito particular quanto a tudo isso, no espaço, enquanto que se demandava é que se fizesse um edifício museu de escultura e onde surge naturalmente a idéia de que o espaço para exposições ao ar livre é muito importante para um museu de escultura.

E que a constituição de um espaço, de uma espacialidade museológica num conjunto construído chamado, ou tido como, ou visto, ou usado, e que possa ser usado como espaço ao ar livre nos leva a condição de considerar se esse espaço será o quintal do fundo, ou o recuo lateral, ou o jardim da frente, que outra al- 
ternativa há, ou um pátio interno e eu queria chamar a atenção então de vocês que muitas vezes faz-se ou imagina-se um projeto, não porque você queira fazer isso ou queira fazer aquilo, mas principalmente porque não quer fazer o que foi o caso, ou o que é muito forte como argumento nesse projeto, por isso vou mostrar que eu não quis de jeito nenhum reproduzir um jardinzinho da casa, do palacete que estava ali em volta, daquele bairro, muito menos um quintal que tem uma herança de fundo de coisa que não se deseja mostrar e principalmente os recuos laterais que são uma grande besteira na partição e no desastre do recorte e do retalhamento dos espaços urbanos que não se vê nesses projetos que eu estou mostrando como no edifício. Não há o que sobre que não tenha virtude, como no caso, da distância do edifício até o costão, ser meticulosamente estudado a ponto de poder passar um pequeno vapor de passageiros, etc. É um desencadeamento de circunstâncias intrigantes e voltadas contra eles, e não queria fazer no caso do museu muito principalmente o pátio interno pela sua herança de passado colonial de convento, de coisa escondida e de horrores que se passam e que ninguém vê, isto que se chama o claustro, etc.

Coisas que no passado tiveram a sua razão, coisas que como patrimônio conservado pode ter alguma graça, mas que não tem sentido reproduzir como quem não tem imaginação para outras formas. Então nos levou a inventar uma sucessão de espaços entre os quais a relação do que é dentro ou do que é fora, se tornou intrigante e mais ou menos inusual, não é nada que tenha paradigmas e cartilhas, principalmente tipologias vistas antes. Uma advertência interessante talvez também trazer para vocês, que nem sempre pode se encontrar exemplos e modelos com a facilidade com que se imagina e se existirem esses modelos, nem sempre é importuno simplesmente copiá-los. Esses slides a gente podia passar, não sei. Enquanto passam, eu posso continuar comentando para lembrar do que eu já disse. Bem, você pode por favor, passar como se você estivesse folheando uma revista, e vira isso quando quiser. Tá muito bem, mas a navegação é um outro, isto é para ficar parado. Deixa eu tirar aqui. Tá ótimo. Estas são vistas, aqui tá bem, essas são vistas do museu que não tem ordem e vocês vêem, digamos, uma espacialidade arquitetônica, (risos), uma espacialidade arquitetônica que se está fora e está dentro, como vocês conhecem isto, etc., pode passar depressa. É, mas está voltando, bom, de fato, eu não trouxe plantas e coisas assim que pudesse explicar tudo isso, eu não me importo que a primeira vista não se entenda muito. Um belo dia vocês vão ver isto, mas de qualquer maneira, para mostrar como uma construção pode ser intrigante em relação a sua espacialidade no que diz respeito ao que está dentro e ao que está fora. Muito particularmente nesse caso, porque como eu já disse, museu de escultura presume uma parte, uma disposição de lugares, de recintos de exibição ao ar livre para grandes peças, etc...E esse ar livre me parecia que não podia ser aquilo que sobrou da construção. Como costumam ser os quintais, os jardins, isso que eu quis dizer, talvez não tenha dito muito bem e naturalmente uma outra possibilidade que é o famoso pátio interno, que eu imaginei no caso, que eu assumi como espaço execrável de um passado que não está nos interessando. Pode, pode, assim entre assim o museu por aqui, o jardim está em nível porque há um desnível no terreno que é uma 
esquina, e isso aparece como um edifício que não aparecia por lá e o que é aqui uma parte do jardim, é teto do que está lá dentro. O museu é semi-subterrâneo nos seus recintos internos e está ao ar livre, essa peça foi feita para marcar o lugar, e em vez de, como se costuma dizer, aquilo que pode aparecer no jardim, na história da arquitetura, sejam lódias, coretos, pérgolas, marquises de abrigo de entrada, e coisas assim. De fato, se estiver chovendo um carro pode girar aqui, ficar em baixo disso e abrigar quem vai entrar no museu e coisas assim. E marca o lugar de algum modo, marca de uma maneira também pensada, de tal modo que essa viga é perpendicular à avenida, que é uma coisa importante e a altura em relação a parte mais alta que ela cobre, é a altura de uma casa como quem diz, a razão é assumir agora essa viga que tem essas características todas arquitetônicas, também como uma régua de medida de escalas, uma vez que essa altura é a altura da minha casa e eu posso avaliar se uma coisa é grande ou pequena, etc... Agora você pode passar tudo. E assim se sucedem esses espaços entre jardins, áreas internas e áreas externas como um passeio para quem vai ver uma eventual exposição. Que esse museu é um museu que não presume, não pretende, jamais possuir um acervo, coisa muito boa porque um acervo de esculturas é muito complicado e pode ao mesmo tempo possuir um belíssimo acervo para estudo de documentação eletrônica e coisas assim, de toda a arquitetura do mundo e se dispor à exposições temporárias do maior brilho, da maior magnitude que queira imaginar. Pode passar assim como se fosse uma revista. Ele é constituído de três recintos iguais enquanto há vão em um dos recintos; desce escadarias por fora, porque embaixo o pé direito é reduzido, são as áreas justamente de apoio do museu, e tudo isso cria uma situação arquitetônica digamos assim, fora da inexorável estrutura de paredes e telhados e coisas assim. Pode passar, pode passar, é interessante essa foto você vê que a sombra denuncia o trabalho feito no território, enquanto que a peça principal mantém-se serena e horizontal, são elogios digamos de virtudes fundamentais da arquitetura, na minha opinião, muito além dos aspectos decorativos e supérfluos com que a arquitetura às vezes foi decorada em passagens históricas, muito significativas, mas cujos momentos históricos já não são da nossa época, digamos, coerentes com a nossa época, capaz de comover a nossa época, aliás aqui há um exemplo muito interessante sem querer, que aparece um telhado normando de um dos palacetes desse jardim América, uma besteira enorme. Pode passar tudo hem, pode passar, a viga tem 60 metros de vão, o que é uma bobagem, uma brincadeira, porque não tem carga nenhuma, só para peso próprio, é quase uma exibição de construção, ela é muito simples, muito delicada, feita com quatro vigas verdadeiramente, e cascas que envolvem e é apoiada com juntas de tal modo que protendida, é uma peça rígida e apóia-se de modo esostático para absorver, para não transmitir aos pilares os brutais esforços da dilatação dessa peça com 60 metros e coisas do tipo, assim também é uma técnica vulgar na construção, pode passar...Há resíduos internos que surgem então de uma maneira imprevisível, digamos, em relação daquilo que é sempre uma fachada que já denuncia o que esta lá dentro. Você pode passar rapidamente, só vou mostrar que há recintos internos vulgares, quase comuns a qualquer museu, (pode passar), auditórios, e que não há nenhuma incompati- 
bilidade nem nada contraditório entre uma certa aparente liberdade fantasiosa na organização espacial visível, primeira chegada diante disso e aquilo que se espera numa casa comum, auditório isso e aquilo. (Pode passar tudo), bem, esse projeto é um que eu não comentei, e vou passar muito depressa, são três slides só, mas também é uma cidade fluvial, porto fluvial no rio Tietê que agora é navegável, uma novidade do território paulista, extraordinário do ponto de vista de transformações no trabalho, na economia, etc.. Uma marinhagem no sertão. Essa navegação não se fará a não ser que um ou dois pólos primordiais sejam construídos para amparar essa mesma navegação, quanto à técnicas de navegação, abastecimento, coisas assim e mesmo porto fundamental. Isso não existe também, o porto sem as ferrovias, e como o estado de São Paulo historicamente foi organizado na sua economia, com uma ferrovia ao norte e uma ferrovia ao sul, se você, e o leito do Tietê, sempre abandonado como área, aquela simplesmente da natureza imprópria à vida, com inundações, pragas, etc.. Agora tratado com a engenharia na sucessão de barragens que foi feita, o canal do Tietê impossível de navegar até o rio Paraná e sair naquela bacia de Montevidéu, como de fato as águas lá saem, as mesmas. Pra fazer uma cidade portuária primordial, nós imaginamos que se num eixo transverso ele ligasse a ferrovia do norte com a ferrovia do sul, ferrovia de cima que vai até a Bolívia, e ao Pacífico, já, já. Nós podíamos estabelecer um novo sistema de transporte que amparasse o porto e que sustentasse uma nova cidade já criada, com área industrial, área habitacional, metrô, etc... Como uma instalação inteligente depois de um momento do passado em que as coisas se faziam de um modo colonial, como se sabe, nós não podemos começar construir de novo, como se fosse uma colônia, mas nós temos que editar uma cidade absolutamente moderna desde o começo, (você pode passar essas fotos rapidamente). Esse é o croqui, você pode passar outras, essa é uma maquete disso que está aí, é uma cidade muito simples que se desenvolve com uma linha de metrô e liga lá com a parte portuária e o aeroporto. Esse é um porto avançado da Escola Politécnica, imaginou-se pra tudo que é da hidráulica era se tratado aqui, são estádios, isso aqui são 10 km, aqui estão os escritórios, os edifícios comerciais, os bairros residências, a parte recreativa junto ao rio. É interessante considerar isso aqui, que é uma espécie de Vale do Anhangabaú feito com água, uma albufeira, ou seja, uma área inundada de marcha a ré contra um riacho que vem pra cá. Portanto se a cidade passar horizontal, essas fraldas junto da água podem constituir um porto de passageiros no coração da cidade, e esses jardins para museus, edifícios institucionais como uma variante do eixo principal da cidade, algo muito espetacular do ponto de vista paisagístico, já no caso assumindo um ar de jardim urbano. (Pode passar tudo) Bem, esse é o porto de Vitória, (pode passar bem rápido), essas são maquetes da cidade, eis a entrada do porto. Os três edifícios, é só uma visão geral, (você pode passar tudo uma atrás da outra). E assim fica essa nova esplanada, os navios entram aqui nesse estrangulamento, e é necessário passar muito perto dessa nova frente com os prédios, a idéia era essa. E essa é a ilha de Vitória,etc. Lá no fundo está o novo porto de grande tonelagem, chamado porto do Tubarão para navios de até 500 mil toneladas, e o porto da cidade aquele antigo que eu falava, está aqui e essa é a cidade 
velha que não aparece aqui nesta imagem, mas isso aqui tem 800 metros, um quilometro e meio. São distâncias muito cômodas, muito urbanas do ponto de vista de densidade da vida da cidade. Pode passar e pode passar porque são imagens da mesma coisa, como se vê ai está tudo. Essa aí é a bacia de Montevidéu, essa é a carta original apesar de exígua de dados, o perfil é rigoroso, geográfico. Essa é a pequena ilha que eu falei, a distância aqui são 2,5 quilômetros, 3 quilômetros, esse é o mar aberto e aqui é a bacia do Prata. Essas águas, se há poluição aqui, a pior parte depende de nós, através do rio Tietê e do rio Paraná, nós poluímos essas águas. Esse é o bairro do Serrito, essa é a parte velha da cidade com o porto, aqui aparece mal o píer de sustentação dessas águas.

Esse é o croqui do que se faria então, e a outra é da maquete da praça quadrada de águas, eu queria chamar a atenção de vocês que a idéia do quadrado, ou do retangular perfeito é uma idéia sublime do ponto de vista, ou a figura é sublime não a idéia, porque sendo retangular perfeita, eis a obra do homem não há absolutamente nada perfeitamente reto ou perfeitamente horizontal na superfície do planeta. Um campo de futebol é uma obra primorosa, de engenharia, pelo fato de ser horizontal. E essa idéia da praça quadrada de água, pra todos os bairros se dirigem essas frentes mais do que circundar e naturalmente que esses ganhados do mar necessários para a retificação serão novos espaços, como aqueles de Vitória que deveriam ser enquanto frente dos bairros para algo espetacular que a própria cidade. Os recintos destinados aos cafés, bares, restaurantes, hotéis quem sabe escolas e coisas do tipo. E isso é tudo.

Se alguém quiser colocar alguma questão, fizer alguma pergunta ao nosso simpático conferencista, faça agora por favor, a palavra esta aberta. Só que tem que falar aqui, pois está gravando. Sem pergunta não tem autógrafo.

Eu queria saber só, sobre o Rio de Janeiro...

O aeroporto Santos Dumont é uma obra à parte, é em si, o aterro do Flamengo o aterro do Botafogo, e principalmente o aterro de Copacabana que talvez vocês não tenham sabido disso, mas Copacabana possuía uma calçada de um metro e meio com um famoso desenho que era uma beleza, a areia e naturalmente para dentro uma pista larga, nem sei se havia duas mãos, duas mãos com certeza, mas uma pista única e as casas. Foi ganhado 150 ou 120 metros, quase 200 metros de areia em Copacabana. Foi feita a duplicação da pista e a calçada alargada, etc., até o Leme. Esse aterro de Copacabana é uma das obras mais extraordinárias talvez feitas no continente americano porque naturalmente a Holanda possui obras no mar que são fantásticas para não falar de quase todos os paises europeus, mas aqui na América, hein, mas na América eu tenho certeza que nada foi feito com tal magnitude ou tal monumentalidade quanto o aterro de Copacabana e também do Flamengo. Aquele aterro foi feito com a dragagem do porto do Rio de Janeiro, por incrível que pareça apesar de toda a poluição é superficial digamos, apesar de tudo em relação ao fundo do mar da baía. O território, as areias da baía são branquíssimas, puríssimas são aquelas que tem em Copacabana, e o trabalho de aterro desse depósito de material retirado não sei se isso se chama aterro, do canal com a dragagem 
do canal é um trabalho fantástico, eu assisti isso em torno dos anos 40 , se eu não me engano depois da guerra nos anos 50, assisti várias operações porque durou de 2 a 3 anos, havia dragas inclusive contratadas na Holanda, uma delas chamava-se "Symmaster" eu não me esqueço, essas dragas chegavam na arrebentação como se fosse um, como se chama isso, que os meninos fazem nas ondas é o "surf", mas uma draga imensa, você ouvia o urro das máquinas e você dizia "vai encalhar" e ela ficava a poder dos motores, se sustentando naquela arrebentação. Aí os motores dobravam de ruído, de barulho e você via a água toda espumando, como espuma de cerveja amarela que era areia em suspensão, porque a areia era expulsa por máquinas também emulsionadas por água e o mar ficava todo amarelo em volta e ao mesmo tempo a draga flutuava, porque livrava-se daquela carga e ao mesmo tempo começava a dar a ré, como se diz em linguagem naval, e saía para fora. Uma maravilha de controle, etc, de máquina, e já vinha outra e outra e a praia ia crescendo e deu naquilo. Porque nós podemos transformar desde que tenhamos projetos né, transformar como e o quê, muito bom depois foram feitos jardins, etc.,

Minha pergunta é em relação ao ensino. É, você bem sabe que a política atual de ensino secundarista no Brasil tem sido de aumentar cada vez mais os cursos e hoje em dia existem vários cursos de arquitetura abrindo, acho que já chega a 150, uma situação bem diferente de anos atrás, quando só se tinha a FAU, Mackenzie. Como professor titular da USP como você vê essa abertura dos cursos e que conselho você daria com relação a formação do arquiteto na atual conjuntura?

Bom eu vou aproveitar já que o tema é ensino e especialmente no nosso caso que é um ensino específico aqui dentro da escola, a gente trabalha basicamente no primeiro ano, com a questão do desenho. E semana passada com a Vera, professora de projeto, fiquei sabendo que tem escolas de arquitetura que estão ai, que não tem mais exame de desenho para você entrar na escola, eu fiquei surpreso, não tem mais linguagem da arquitetura para você prestar vestibular, você presta vestibular de odontologia, de arquitetura, é tudo a mesma coisa. Então eu acho que complementa um pouco a questão que o Felipe levantou. Se você quiser...

Bem vocês tem que admitir que eu estou diante de tudo isso, essas transformações, os números de escolas, tão perplexo quanto vocês. É muito difícil você prever o que será o mundo, mas de um modo geral, é melhor dizer que quanto mais escolas, principalmente em países de analfabetos existirem é melhor, mas eu não sei se escolas profissionalizantes que entregam diploma não estão muito submetidas a uma visão mercantilista, de vender este diploma e isso naturalmente que vai ser um desastre, já aconteceu isso em grande parte com a medicina, já aconteceu principalmente com o direito, na advocacia os cursos jurídicos, eu me lembro já na minha época, você dizia mas aquele cara é um advogado de Niterói, havia uma escola de advocacia em Niterói que era uma coisa horrorosa. Isso sempre existiu, fica muito difícil você controlar, o que me parece mais interessante quanto uma perspectiva de reorientação de tudo isso para sucesso futuro em 
vez de desastre, é pensar no curso secundário, de tal forma que o plano crítico, nenhum menino vai ser bobo de entrar numa escola de arquitetura, e dizer eh eh eh eh o que é isso aí, eu me lembro de uma vez, eu tinha um amigo, agora eu vou contar a história, vou contar até o fim. Eu tinha muitos amigos médicos, estudante de medicina e não sei porque razão e uma vez eles me arrastaram para ver uma conferência de um oftalmologista italiano de fora, não sei, mas era estrangeiro, tinha tradução, muito importante, porque depois nós iríamos não sei aonde, mas que seria muito bonita a conferência. E havia um mito na faculdade de um famoso oftalmologista que tinha uma clínica aqui na rua Bahia, como chamava, não, não ali todo mundo sabia, Bussaka, A Bussaka, o famoso Bussaka era médico italiano, era conhecido por ser um gênio e um grande oftalmologista. E eu fui a conferência, e assisti esta cena, o auditório era muito em pé assim, e tinha uma portinha lá no fundo, ia dar no terceiro andar da faculdade, e lá pelas tantas a portinha rangeu no meio da conferência do estrangeiro e Bussaka entrou e eles diziam; Esse é o Bussaka! entrou e se sentou lá em cima. E o cara continuou a conferência dele, o estrangeiro, lá pelas tantas ele tinha umas projeções de ampliações de microscópio eletrônico, já coisas fantásticas, lá pelas tantas, o Bussaka lá atrás, que já tinha sido esquecido nessa altura, estava todo mundo olhando, levantou e falou assim:

- Ei que donde o Sr. aprendeu anatomia? e foi embora.

Tava tudo errado o que o cara tava dizendo, e ele só falou isso, "que donde o Sr. aprendeu anatomia?", como quem diz, isso aí não é nem a pupila,você tá mostrando é fotografia de orelha. E acabou a conferência, os estudantes todos perceberam que ele tinha razão, enfim...

Portanto o plano crítico possa vir a corrigir isso. Eu tenho muitas vezes pensado ultimamente, isso que eu queria dizer, que você vê o curso secundário, principalmente eu já fiz isso há quase um século, porque vocês precisam ver também, eu nasci em 1928, quer dizer, eu fiz o curso secundário nos anos 30, 35, é um século, e então, matemática, geografia, história, será que hoje o urbanismo não é algo que seria a geografia contemporânea, não como uma substituição para se esquecer a outra, um desdobramento da geografia, um aprofundamento, porque se nós imaginarmos esse conhecimento que esta aí agora, e se imaginássemos por outro lado que a idéia de conhecimento seja cumulativa, como uma questão quantitativa, nós estamos condenados a uma ignorância imensa, porque a cabeça não mudou nada. Tem gente que usa o chapéu do bisavô, o nosso cérebro não progrediu propriamente do ponto de vista da capacidade de armazenar conhecimentos, portanto o que nós temos que imaginar como conhecimento, não é uma soma, é uma transformação. Hoje é impossível você imaginar a arquitetura sem uma visão de antropologia, de geografia, sem dúvida nenhuma de filosofia, de lingüística, não é o modo de você estudar só arquitetura como arquitetura; isso é arquitetura, como? Um prédio, isso pode ser um desastre, como tem sido muitos deles. Do modo que são colocados, etc., etc., etc. Eu não vou repetir o que eu já disse. Portanto o nosso espírito crítico, dos meninos que serão educados já de outro modo. Hoje qualquer garoto pode saber fundamentalmente no que 
consiste a idéia de código genético e tudo isso, porque seria um absurdo você só aprender depois do quê, é imediatamente, que o raciocínio que configura o universo é em grande parte matemático, é claro, você não pode pensar que um escritor primeiro ele raciocina com asneiras, com a imaginação delirante, depois vai ver como consegue escrever aquilo, como se as palavras fossem de grande dificuldade. É o contrário: - são os instrumentos da construção do raciocínio. O cara raciocina já escrevendo um discurso. E arquitetura é sem dúvida um discurso também, portanto conhecer construção é conhecer tudo. Se você não souber como se faz uma coisa, como é que você pode imaginar a coisa? Portanto, a tendência nessa proliferação de cursos nessa rapidez com que se pretende ensinar isso e aquilo, seja direito, medicina, do modo que ainda era, inclusive, só pode degenerar; nós temos que transformar o curso de tal sorte que seja muito fácil ver tudo com clareza. Outra coisa é que a visão profissionalizante, eu acho que é uma visão também decadente; você estuda para um diploma, para ganhar dinheiro; pode não ser, você pode estudar por puro prazer. O saber das coisas né, como, chamemos de idiota porque existe né, passeando na floresta amazônica e um grande botânico, acho que o botânico goza mais naquilo do que o outro que não sabe nem do que ele tá vendo. Portanto estamos sempre diante de toda a história e de todo conhecimento. É um raciocínio interessante você considerar o seguinte - o que é o conhecimento e o que é história - não é nada. Só existe entre nós os vivos, ao mesmo tempo, se desaparecer o gênero humano não existe nada disso, nós que inventamos tudo isso e portanto é para sair já sabendo, quem demora para aprender não aprende nunca, então eu tenho a impressão que nós temos que mudar os patamares do começo da coisa, daquilo que é chamado de começo e tem que começar no curso secundário, sem dúvida nenhuma. Acho difícil um menino começar hoje um curso de arquitetura, eles não sabem nada, não tem nenhuma iniciação ao universo das artes, não sabem o que nós chamamos de arte, o que é ultrapassagem possível na imaginação daquilo que seria dedutível para as ciências exatas, etc. Porque nós estamos no limiar de uma era que não vai ser mais possível distinguir "ciência" e "arte", me parece uma bobagem, quanto à questão do desenho, eu acho que posso mudar de opinião até hoje mesmo ainda, mas tenho a impressão que teria que ser obrigatório sim um teste de desenho, porque como ele vem de onde nós estamos, nós não nos transformamos da noite para o dia, exprime-se com essa abstração que é chamada desenho, que não é uma escrita com palavras, não é nada diante de uma provocação qualquer, um tema e um desenho eu acho fundamental, porque o menino que não sabe desenhar ou não tem a idéia de que pode desenhar como recurso para dizer o "indizível" tá perdido, acho que sempre é um teste, bom, por outro lado eu acho que você pode dizer isso, tudo bem mas quem julga o desenho, para dizer esse sim esse não, esse é que é o problema, não é? Como você avalia o desenho, a idéia de avaliação. Se nós pudéssemos nos libertar de tudo isso, né concursos, vestibulares, prêmios, se você soubesse, muitos sabem, você sabe, mas como é horrível receber um prêmio né, você se sente alijado assim, eu tô frito, já me premiaram, você foi 
reduzido a boi, boi que ganhou o prêmio, boi gordo, boi de raça, 10 Prêmio. Mais perguntas inclusive sobre pecuária.

Professor, me fascina muito o processo de criação, concepção de um projeto, você é um profissional já consagrado, premiado, queira ou não. Eu gostaria que explicasse principalmente para os alunos como que é o processo de concepção de criação de um projeto, definição de um partido, principalmente em cima desses projetos que você explicou. Esses projetos que você explicou é de uma maneira muito lógica, muito dedutiva e me parece muito fácil, muito claro, muito cristalino. E na verdade, ás vezes, os artistas tem um processo de criação que é muito doloroso. Ás vezes alguns colocam isso de uma maneira até um pouco sobrenatural, a forma de criação ou de uma maneira muito lógica ou muito racional, como que é a sua?

Bem em primeira instância...

Só querendo complementar a questão do Prof. Ney. Eu queria saber também nesse processo de criação, por ser hoje o grande nome contemporâneo da arquitetura brasileira. Como você lida com essa, uma espécie de responsabilidade de ser a grande cara da arquitetura brasileira, pra fora, principalmente na Europa que tem uma arquitetura que já hoje é bastante, completamente diferente da nossa. Então como lidar com essa responsabilidade?

Bem, são perguntas caroço de abacate. Mas acontece o seguinte: Primeiro, talvez por uma questão de política individual, você não viva desse modo, eu não sei de nada do que você falou, eu não ando como se eu fosse isso ou aquilo, ao contrário. Quer dizer, eu procuro, e o processo de criação eu não sei o que é, mas de tudo o que você disse, o que eu acho que precisava ser comentado de qualquer maneira é o sobrenatural que você falou. Olha, se você imaginar os índios nossos aqui, acho que outros também, mas os nossos é muito comentado, a aborduna do índio, ele levanta aquilo, e é no meio da sinagoga que ele bate e arrebenta o crânio. Então, imagine um de nós, imediatamente após uma abordunada, com os intestinos para fora, misturados sangue e o que comeu no almoço, etc.

Se você pode ver isso, há possibilidade de qualquer coisa sobrenatural. Nós somos a natureza, nós somos uns viventes no planeta, nós somos macacos que providenciamos o nosso desenvolvimento em grande parte, por isso estamos aqui até hoje com essa idéia de formação da consciência e da linguagem, não há nada sobrenatural, você faz um trabalho como se fosse um carpinteiro, você sabe, a única coisa que eu poderia te dizer sobre este aspecto um tanto escandaloso ou escabroso da idéia da criação, eu não vejo que ninguém possa criar coisa nenhuma. Como é que pode criar? você não cria nada, você transforma; não, mas nós temos uma experiência, você tem que se louvar na história, nós! eu não quis dizer eu, que eu não me chamo de nós, nós do gênero humano. Se você imaginar aquilo que eu disse da natureza que não serve pra nada, então você pega uma pedra, larga e ela cai, é um estafermo, a força da gravidade é um trambolho, se cair no pé então, você não tem 
dúvida. Agora o camarada faz assim, matuta aquele troço, pega a pedra, taIha com uma certa geometria, usa a mesma força da gravidade como quem diz para ela, olha aqui, você vem a ser adverso, eu vou transformá-la numa virtude, e empilha de um modo que faz um arco, porque cortou a pedra numa certa maneira geométrica. Ele contrariou a natureza e realizou um abrigo que não existia, ele que procurava gruta para se abrigar, e fico imaginando rapidamente que aquilo como revolução pode ser transformado, como num sólido que é um domus, etc, etc, etc, e constrói as catedrais e coisas assim. Portanto, nós estamos aqui para transformar natureza, e temos uma grande experiência, eu não me louvo em mim mesmo, eu me louvo nos outros que já me antecederam. Há milhões e milhões de anos foi muito mais difícil viver nas primeiras épocas da humanidade, com certeza, sem saber o que era o raio, sem saber o que era o fogo, do que hoje que nós sabemos tudo, o que é mais difícil do que antes, hoje, é ter a condição de viver sabendo tanto, vendo tanta miséria, nós nunca fomos tão infames, o gênero humano, como é hoje o gênero humano que vê as crianças morrendo de fome, que aceitam o colonialismo como nós não somos capazes de indignar na dimensão que deveríamos, diante da Europa, diante de um falso conhecimento, diante do mercado que esta aí nos oprimindo, diante da farsa do dinheiro, que você recebe pelo rádio a notícia de que o outro caiu na bolsa e cai tudo aqui, isso é uma besteira que não tem tamanho, nós temos que ser senhores do nosso território, senhores da nossa produção, responsáveis pela fome dos nossos meninos, plantar mandioca que precisamos, dar um jeito de uma revolução, de uma resistência em relação a isso. Nós temos que reagir contra especulação imobiliária, nós temos que escarnecer dos empresários com as porcarias dos prédios que fazem, parecem gaveteiros abertos. Umas idiotices que não tem tamanho, nós temos que exigir do serviço público que transforme a cidade de acordo com que nós queremos. Nós temos por outro lado, que fazer com que esse pensamento não seja um pensamento autoritário, mas seja o pensamento da maioria do povo, educando o povo, portanto, ensinando os meninos na escola que nós é que construímos a cidade, a cidade não é um dado dado.

Mais perguntas...

Professor eu gostaria de saber a respeito do projeto de Montevidéu e sobre o seu discurso que obviamente nos remete ao antropocentrismo, e todos os primordiamentos modernos. Como você encara os novos conceitos de ecologia, de ecologia urbana e a respeito das novas teorias, a teoria de Gaia, basicamente fala sobre chover em Pequim e ter repercussão em Nova York por exemplo, e como você defende seu projeto, de você fazer com que o relevo natural seja totalmente transformado e como você prevê a ecologia, todo mundo fala que as coisas são imprevisíveis e que é a teoria do caos. Por exemplo, a repercussão que isso vai ter na natureza daqui pra frente?

Se você toca a natureza você pode estar ferrado, é isso que você quer dizer. Que nós somos a natureza então, eu tenho razão, trate-se de respeitá- 
la. Não é verdade. Não se pode construir, não se pode desmontar um morro e fazer um porto porque isso é contra a natureza. Eu não vejo assim, porque o que está em pauta é uma visão política sobre as ações humanas. Você não pode pretender a ignorância pra se salvar na natureza. Nós não podemos imaginar regredir no tempo histórico, no tempo que se passou para nos coadunarmos com a natureza, ao contrário, o que nós sabemos hoje é que abandonados da natureza não duramos 15 dias, na nossa querida floresta amazônica, se fosse possível isolá-la por 15 dias um avião que caiu, por 10 dias talvez por cinco dias, você morreria comido por formigas, lagartixas, pouco a pouco, formigas demoram para comer. Não é para se fazer anedota, eu estou falando sério, você morreria de febre, de desespero, você poderia morrer de angústia de não encontrar os seus amigos, nunca mais talvez, você poderia morrer de tristeza, de desespero, nós fomos já um homem civilizado e temos que estabelecer uma justa política para tocar a natureza, cuja inexoravelmente terá que ser tocada pelas nossas mãos, pelo nosso trabalho. Ela em si não serve para o nosso habitat, já não serve mais, nós evoluímos a um ponto que só podemos ter uma natureza construída por nós, eis a delicadeza. Existe uma consciência mundial cada vez maior sobre essa questão de ecologia, chamada de ecologia, porque é muito vago, você tem que ampará-la absolutamente, você tem que saber se esta construção colabora com a movimentação da natureza nas suas forças inexoráveis, ou se é contrária e é justamente isso que eu estava falando quando crítico o tirar uma casinha e fazer um prédio, etc,etc,etc, Você não pode reproduzir o processo exploratório da terra, lotear, construir casas, depois construir prédios em cima da casa, sem providenciar novas maneiras, por isso que eu iniciei tudo mencionando o Saturnino de Brito, falei em Freseneu, porque essa regularização das águas, da feitura dos canais, que essa é uma forma absolutamente coerente com a natureza com relação ao futuro e a vida. As obras que eu imagino são obras que justamente poderiam estar depois, eternamente lá. Não contrariam absolutamente a natureza, um exemplo mais dramático se você quiser e mais inexorável, a ilustração de tudo que nós estamos dizendo é a coisa neste século, que pode ser mesmo a medida desse século, a teoria dos Quanta, o Sr. Max Plunk, e a possibilidade de descobrir que há uma energia imensa que configura a matéria que pode ser desencadeada essa energia atômica para iluminar cidades ou construir a bomba. É uma decisão política, não quer dizer que o cientista que fez a bomba, ao contrário, os maiores e mais dos filósofos, pensadores, teatrólogos, como Brecht, por exemplo, como DureMarx, escreveram belíssimas peças de teatros, textos sobre esse desastre, esse desgosto imenso produzido no gênero humano sobre esse desvirtuamento da descoberta científica, existe uma peça de DureMarx chamada "Os físicos" que vocês deveriam ler na escola de arquitetura, em que se imaginam os físicos todos no mesmo manicômio, loucos, com um diálogo maravilhoso. Porque os de verdade nomeados pelos seus dons e Brecht escreveu "Galileu, Galilei" que é uma peça belíssima, sobre a saga toda do Galileu preso pela inquisição ameaçada, ser queimado na fogueira por ter tido desaforo de dizer que a terra girava, etc. Por outro lado, 
de fato quem comprovou, escarneceu do dogma, não foi tanto o próprio Galileu que não tinha força para isso, o que ele podia fazer fez, anunciou, e disse foi Colombo, porque naqueles feitos que estavam aí há bilhões de anos, que nunca, que foram só vendo naqueles ventos levantada uma vela, que não havia também o tecido ,que já foi outra obra do homem, talvez no Egito tenha nascido, eu não sei. Um pano colocado contra o vento, amarrado em algo que flutua nas águas, por causa do atrito, etc, mecânica dos fluídos, leva você a horizontes que podem comprovar que o mundo de fato, então nós estamos diante da natureza para confrontá-la docemente, ao contrário, não ignorá-la a ponto de submetermos a voltarmos a andar de quatro patas, comendo com a boca direto o capim do chão, ao contrário. Nós somos a natureza, nós somos a parte inteligente da natureza, como que pode se negar. A parte inteligente da natureza que engendra códigos fragilíssimos se você pensar que todas as sinfonias do mundo foram escritas com sete notas musicais, se você pensar que existe 25 letras no alfabeto, que com estas mesmas 25 letras tudo o que Shakespeare escreveu, escreveu com elas, como Graciliano Ramos, como Alberto Moravia, como em várias línguas, 25 letras cabem na palma da mão. Se você imaginar 09 algarismos, toda a Matemática que descreve a mecânica celeste, etc. Nós não somos arrogantes, ao contrário, nós somos muito inteligentes, que com pouca coisa você consegue codificar o som que existe por si na natureza, nos ventos, nas frestas codificar em notas e fazer uma sinfonia que é o próprio elogio da natureza, ao contrário, tudo o que nós fazemos é o supremo elogio da natureza, por isso é que somos nós mesmos capazes de execrar aquilo que pode ser aberrante e errático - isso não; isso sim.

De onde você tira inspirações para os seus projetos? da natureza de algum lugar?

Eu não tiro inspiração nenhuma com os meus projetos, eu não faço, mas eu não digo isso eu não tiro, acho que nenhum corpo de vocês vão conseguir fazer nada tendo inspirações, ninguém tem inspiração. Ele falou que há projetos que a pessoa se inspira em árvores, que mais podia ser, etc. Não vejo a menor possibilidade de você se inspirar numa árvore e fazer um projeto. $\mathrm{O}$ Grupo Paulistano que eu fiz não tem nada que ver com árvores, eis o respeito pela natureza, uma árvore é uma árvore. A flexibilidade de uma árvore que é alimentada diariamente pela seiva, etc,etc, Você não consegue reproduzir de jeito nenhum, ao contrário, a natureza pode escarnecer de nós. Eu odeio a natureza se você quer saber, quer dizer, você não pode fazer uma árvore, você tem que calcular o momento de inércia, as forças cortantes e fazer uma viga que é uma porcaria e se possível não fazê-la de madeira porque a nossa madeira não é boa e nós precisamos preservar as florestas. Essas coisas que se diz que nós podemos produzir madeira para usar, entre nós não é muito verdade nos trópicos, porque o crescimento não é homogêneo é muito diferente uma árvore digamos brasileira, venezuelana de uma árvore da Suécia dos países frios, são perfeitas no desenvolvimento das fibras, etc. Não vejo necessidade, ao contrário, quer dizer tão logo não usamos mais madeira, só usamos isso e aquilo, fibras e coisas assim, não podemos. 


\section{Programa FAUS Primeiro Ano}

\begin{tabular}{|c|c|c|c|c|c|c|c|c|c|}
\hline & Proieto Averitedonico & Uitoniamo & Deserho Cbieto & Rosico & Des. Ava/Geometio & Teoria Aeq & Hat. Avq. & Prob. Homen Cont. & Topogrdio \\
\hline \multicolumn{10}{|l|}{ MARCO } \\
\hline \multicolumn{10}{|l|}{2} \\
\hline cun 3 & $\begin{array}{l}\text { aula tesnica score a rebacato } \\
\text { arte/arq. }\end{array}$ & & & & & & & & \\
\hline 4 & & & & 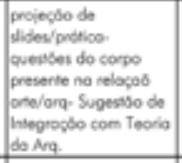 & & 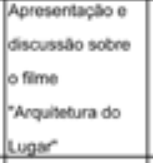 & & & \\
\hline \multicolumn{10}{|l|}{5} \\
\hline Ses.6 & & 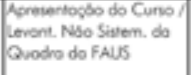 & & & & & & & \\
\hline \multirow{2}{*}{\multicolumn{10}{|c|}{$\frac{8}{9}$}} \\
\hline \multirow{2}{*}{\multicolumn{4}{|c|}{$\begin{array}{cl}9 \\
\text { OuA } 10 & \text { Vagem SP. } \\
\end{array}$}} & & & & & & \\
\hline & $\begin{array}{l}\text { Vagem SP. } \\
\text { PantarcamunicipalPicasso }\end{array}$ & & & & & & & & \\
\hline 11 & & & & 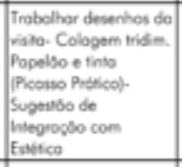 & & $\begin{array}{l}\text { Aula expositiva: } \\
\text { conoetos scbore } \\
\text { ansuibetura e } \\
\text { opologias }\end{array}$ & & & \\
\hline \multicolumn{10}{|l|}{12} \\
\hline SNE 13 & & $\begin{array}{l}\text { Eive Cons, Nebias - } \\
\text { Lehnos Sersoniois do } \\
\text { Poisogem. Parte 1t Prolo } \\
\text { Centro } \\
\end{array}$ & & & & & & & \\
\hline & 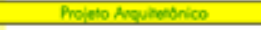 & Uitonilymo & Dewerho Cbiento & PGorico & Der Avg/Geometio & Teori Arg. & Hipt, Avg. & Prob, Homem Cont, & Togogrofo \\
\hline \multicolumn{10}{|l|}{$\frac{\text { MAECO }}{15}$} \\
\hline \multicolumn{10}{|l|}{$\frac{15}{16}$} \\
\hline \multicolumn{10}{|c|}{$\begin{array}{l}\text { QuA } 17 \text { Exl- Montapem de volume a } \\
\text { partis so pintuaa }\end{array}$} \\
\hline T19 & & & & 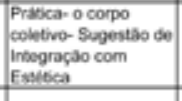 & & $\begin{array}{l}\text { Aulo exposiova: } \\
\text { pistoris urbans de } \\
\text { Sartes }\end{array}$ & & & \\
\hline SAb 20 & & $\begin{array}{l}\text { Eico Cons. Notias - } \\
\text { Lehouras Sensoriais da } \\
\text { Paisagem- Parte 2: } \\
\text { Porto-Cortero } \\
\end{array}$ & & & & & & & \\
\hline \multicolumn{10}{|l|}{$\frac{22}{23}$} \\
\hline \multicolumn{9}{|c|}{$\begin{array}{l}23 \\
\text { CUA } 24 \text { Acomeanhamenbo emerc. I }\end{array}$} & \\
\hline$\frac{25}{26}$ & & & & Modelo Vivo & & $\begin{array}{l}\text { Trabalho com o } \\
\text { sexeso "A imagem } \\
\text { da didade" de } \\
\text { Kevin Lyench }\end{array}$ & & & \\
\hline 30127 & visita so Mont Serras/ Desenho & $\begin{array}{l}\text { visiba ao Mont Serral } \\
\text { Dessenho }\end{array}$ & & & & & & & \\
\hline \multicolumn{10}{|l|}{$\frac{28}{30}$} \\
\hline \multicolumn{10}{|c|}{$\begin{array}{l}\text { Qun } 31 \text { Avalaçato exencicio V Integraçlo } \\
\text { ecm Plastica }\end{array}$} \\
\hline Anc & & & & $\begin{array}{l}\text { O Mont Sertax a parsir } \\
\text { da Praca da } \\
\text { Peetehura }\end{array}$ & & \multicolumn{3}{|c|}{ 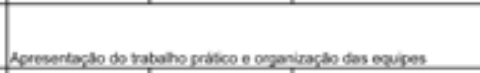 } & \\
\hline \multicolumn{10}{|l|}{2} \\
\hline \multicolumn{10}{|c|}{ Des. Ava/Geometio } \\
\hline ses 3 & & 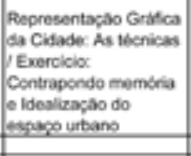 & & & & & & & \\
\hline \multicolumn{10}{|l|}{$\frac{5}{6}$} \\
\hline \multicolumn{10}{|c|}{ 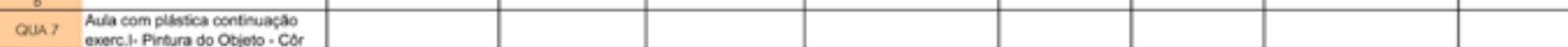 } \\
\hline $\begin{array}{r}\frac{8}{9} \\
\text { SAB } 10 \\
12\end{array}$ & F & E & a & Retrabahar o Obipto & A & b & o & & \\
\hline$\frac{12}{13}$ & & & & & & & & & \\
\hline QUA 14 & $\begin{array}{l}\text { Aula Magna Pol Toscano- } \\
\text { Sugestao Convidar Tamberm } \\
\text { prot Odlies }\end{array}$ & & & & & & & & \\
\hline 15 & & & & $\begin{array}{l}\text { Aula conjunta TA I } \\
\text { Chevear } 4\end{array}$ & & \begin{tabular}{|l|} 
Levantamento de \\
Campo na \\
Conseheivo \\
Nebias - aula \\
conjurta com \\
Pisstica I \\
\end{tabular} & & & \\
\hline SNo 17 & & $\begin{array}{l}\text { Uso e Oougaçio do } \\
\text { Solo Urbano ao Longo } \\
\text { do Eawo da Conseheivo } \\
\text { Nubias }\end{array}$ & & & & & & & \\
\hline$\frac{18}{20}$ & & 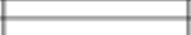 & & & & & & & \\
\hline Q0421 & $F$ & 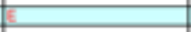 & 8 & & $\vec{a}$ & to & 을 & & \\
\hline
\end{tabular}




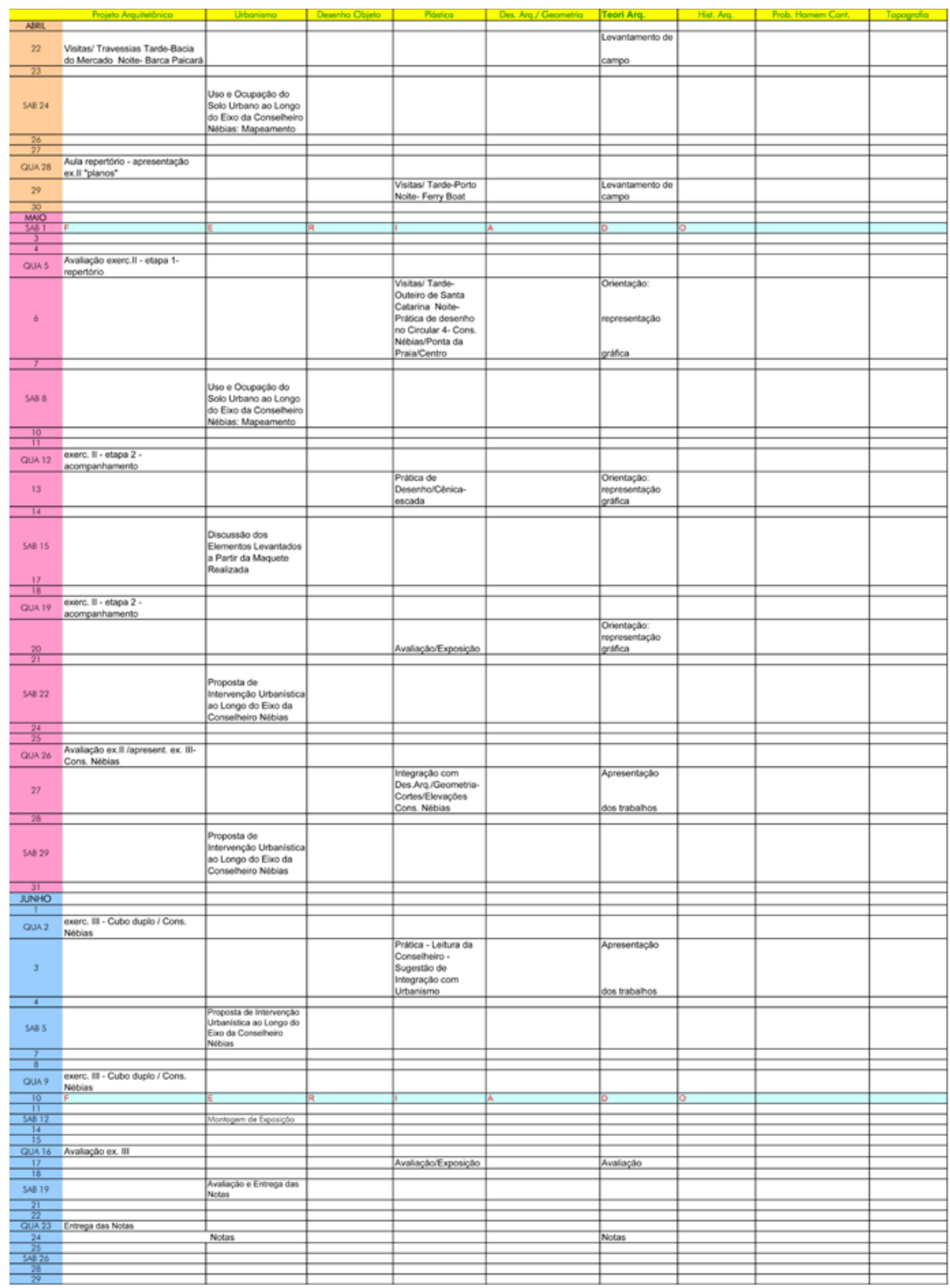




\section{Roteiro da viagem de estudos ao Rio de Janeiro}

\section{0 a 24 de outubro de 2004}

\subsection{0 - Quarta-feira}

Saída da Escola às 23:00.

\subsection{0 - Quinta-Feira}

Chegada ao Rio de Janeiro e visita à Cidade Universitária e à Faculdade de Arquitetura e Urbanismo.

Palestra com professor da Faculdade de Arquitetura e Urbanismo da UFRJ.

Almoço

Acomodação no Hotel do SESC / Copacabana

17:00 - saída com o ônibus para visita ao Pão de Açúcar - levar 1 kg de alimento não perecível por pessoa para desconto de $50 \%$ (deverá ser pago somente $\mathrm{R} \$ 15,00$ por pessoa) / produção de desenhos.

\subsection{0 - Sexta-Feira}

Saída as 9:00 - tomar barca em frente à Praça XV para Niterói.

10:00 - Visita ao Caminho do Mar em Niterói, com acompanhamento do Eng. ${ }^{\circ}$ Milton.

12:00 - Retorno com a barca e caminhada até o Largo da Carioca.

Almoço no centro.

15:00 - Visita ao Ministério da Educação e Cultura - MEC 1936: Lúcio Costa, O. Niemeyer, Affonso E. Reidy, Carlos Leão, Jorge Machado Moreira, Ernani Vasconcelos - produção de desenhos/visita à cobertura/terraço e auditório.

Após esta visita, caminhada até o MAM.

Obras a serem destacados durante as caminhadas:

- Praça XV, Arco do Telles, Paço Imperial, Casa França Brasil, Centro Cultural Banco do Brasil;

- Ed. Maison de France 1955 - Jaques Pilon;

- Ed. Associação Brasileira de Imprensa ABI 1936 - Marcelo e Milton Roberto;

- Ed. Instituto de Resseguros do Brasil 1941 - MMM Roberto;

- Museu de Arte Moderna do Rio de Janeiro - Affonso Eduardo Reidy;

- Urbanização do Parque do Flamengo 1962 - Affonso E. Reidy e Burle Marx (paisagismo). 


\subsection{0 - Sábado}

Saída às 9:00 com visita a:

- Conj. Residencial Marquês de São Vicente 1952 (Gávea) - Affonso Eduardo Reidy

- Casa das Canoas 1953 - O. Niemeyer

- Hospital Sulamérica 1952 - O. Niemeyer, Helio Uchoa, R. Burle Marx (paisagismo) Almoço

- Corcovado (vista do Rio de Janeiro) (desconto de 50\% na subida ao Corcovado com o trenzinho para os alunos e professores da Unisantos - agendado para a tarde $-\mathrm{R} \$ 15,00 \mathrm{p} /$ pessoa)

- Parque Guinle 1948/1954 - projetos de Lúcio Costa e projetos de MM Roberto

\subsection{0 - Domingo}

Saída às 10:00 com visita ao:

- Museu de Arte Moderna de Niterói 1989 - O. Niemeyer - produção de desenhos Almoço no Bob's da Serra

Regresso a São Paulo

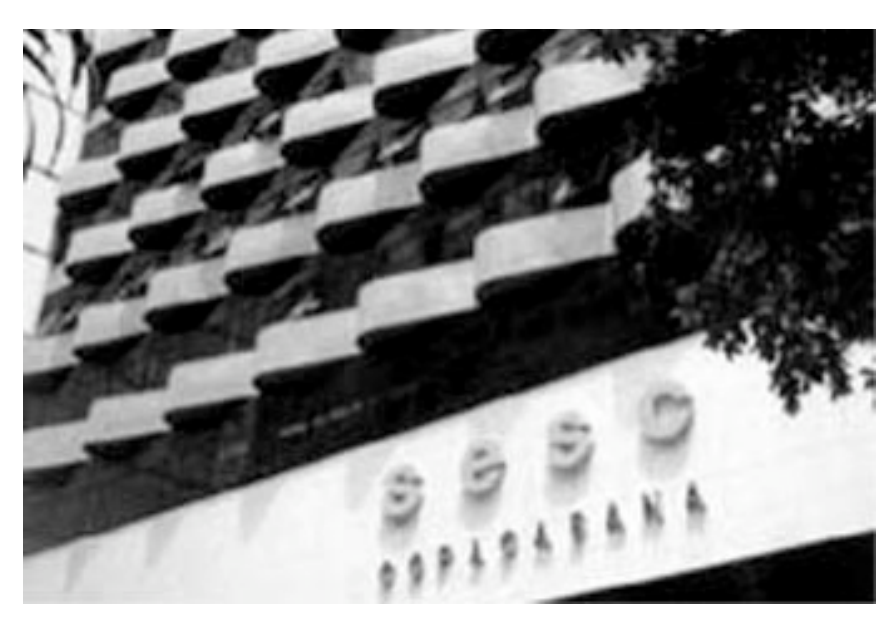

SESC Copacabana

Rua Domingos Ferreira, 160

Copacabana - Rio de Janeiro

CEP 22050-010

Tel: (21) 25481088 
Lista de imagens 
Os elementos da arquitetura. Do livro: Vitrúvio. Tratado de arquitetura - Livro I.

Tradução de M. Justino Maciel. Lisboa: Cambridge University Press, 2006. Imagem página 56.

Tijolos. Do livro: Vitrúvio. Tratado de arquitetura - Livro III.

Tradução de M. Justino Maciel. Lisboa: Cambridge University Press, 2006. Imagem página 100.

Homo bene figuratus. Do livro: Vitrúvio. Tratado de arquitetura - Livro III.

Tradução de M. Justino Maciel. Lisboa: Cambridge University Press, 2006. Imagem página 127.

Origens estruturais dos genera e seus ornamenta. Do livro: Vitrúvio. Tratado de arquitetura - Livro IV.

Tradução de M. Justino Maciel. Lisboa: Cambridge University Press, 2006. Imagem página 163.

A basílica. Do livro: Vitrúvio. Tratado de arquitetura - Livro I.

Tradução de M. Justino Maciel. Lisboa: Cambridge University Press, 2006. Imagem página 205.

Tipos (genera) de átrios (cavaedia). Do livro: Vitrúvio. Tratado de arquitetura - Livro VI. Tradução de M. Justino Maciel. Lisboa: Cambridge University Press, 2006. Imagem página 245.

Estilos de pintura mural. Do livro: Vitrúvio. Tratado de arquitetura - Livro VII.

Tradução de M. Justino Maciel. Lisboa: Cambridge University Press, 2006. Imagem página 289.

Nivelamento com a ajuda do coróbata. Do livro: Vitrúvio. Tratado de arquitetura Livro VIII.

Tradução de M. Justino Maciel. Lisboa: Cambridge University Press, 2006. Imagem página 319.

Movimento planetário. Do livro: Vitrúvio. Tratado de arquitetura - Livro IX.

Tradução de M. Justino Maciel. Lisboa: Cambridge University Press, 2006. Imagem página 354.

Guindastes para cargas mais pesadas. Do livro: Vitrúvio. Tratado de arquitetura - Livro X. Tradução de M. Justino Maciel. Lisboa: Cambridge University Press, 2006. Imagem página 403.

Do livro: Précis of the lectures on architecture, Jean-Nicolas-Louis Durand. Plate 1 Part I.

Do livro: Précis of the lectures on architecture, Jean-Nicolas-Louis Durand. Plate 3 Part I.

Do livro: Précis of the lectures on architecture, Jean-Nicolas-Louis Durand. Plate 10 Part I. 
Do livro: Précis of the lectures on architecture, Jean-Nicolas-Louis Durand. Plate 1 Part II.

Do livro: Précis of the lectures on architecture, Jean-Nicolas-Louis Durand. Plate 4 Part II.

Do livro: Précis of the lectures on architecture, Jean-Nicolas-Louis Durand. Plate 17 Part II.

Do livro: Précis of the lectures on architecture, Jean-Nicolas-Louis Durand. Plate 4 Part III.

Do livro: Précis of the lectures on architecture, Jean-Nicolas-Louis Durand. Plate 8 Part III.

Do livro: Précis of the lectures on architecture, Jean-Nicolas-Louis Durand. Plate 16 Part III.

Do livro: Précis of the lectures on architecture, Jean-Nicolas-Louis Durand. Plate 21 of Graphic Portion.

Do livro: Précis of the lectures on architecture, Jean-Nicolas-Louis Durand. Plate 27 of Graphic Portion.

Palácio de Cristal, 1851, Joseph Paxton. Do livro: Architecture and the esthetics of plenty, James Marston Fitch, página 16.

Schlesinger \& Meyer Building, 1899 - Louis Sullivan. Do livro: Architecture and the esthetics of plenty, James Marston Fitch, página 16.

Cité industrielle, 1903. Do livro: Architecture and the esthetics of plenty, James Marston Fitch, página 17.

Edifício Ministério de Educação e Saúde. Do livro: Lúcio Costa. Registro de uma vivência, página 127.

Lake Shore Drive Apartments, Mies Van der Rohe, Chicago, 1952. Do livro: Mies Van der Rohe at work, página 52.

Edifício Reliance, Burnham e Root, 1890-1895.

Fonte: http://upload.wikimedia.org/wikipedia/commons/thumb/d/d4/Reliance_Building_(Burnham_Hotel)_-_Chicago,_Illinois.JPG/220px-Reliance_Building_(Burnham_ Hotel)_-_Chicago,_Illinois.JPG; acesso em 12/11/2007.

Edifício Bauhaus

Fonte: http://pt.wikipedia.org/wiki/Bauhaus; acesso em 12/11/2007.

Aula de Modelo vivo da Disciplina AUP-608 no salão caramelo da FAUUSP - Fotos de Candinha, páginas 82, 83 e 84 .

Desenhos elaborados pelos alunos de AUP-608, Exercício 2 - Fotos de Vera Lúcia Domschke, páginas 89,90,91 e 92. 
Exercício 3 de AUP-608 - Fotos de Vera Lucia Domschke, páginas 96, 97, 98 e 99; 102, 103, 104, 105, 106, 107, 108 e 109.

Exercício 4 de AUP-608 - Fotos de Vera Lucia Domschke, páginas 113,114, 115, 116, 117 e 118.

Exercício 5 de AUP-608 - Fotos de Vera Lucia Domschke, páginas 123 e 124.

Discussão do Projeto Político Pedagógico na FAUS - Fotos de Paulo Fernando von Poser, páginas 136, 137, 138 e 139.

Reuniões preparatórias para a integração horizontal no $1^{\circ}$ ano da FAUS - Fotos de Paulo Fernando Von Poser, páginas 140, 141, 142 e 143.

Exercício I da integração horizontal no $1^{\circ}$ ano na FAUS, quadro de Picasso - Fotos de Paulo Fernando Von Poser, páginas 148 e 149.

Exercício I da integração horizontal no $1^{\circ}$ ano na FAUS, quadro Le Corbusier - Fotos de Carlos Antunes, páginas 150, 151.

Exercício I da integração horizontal no $1^{\circ}$ ano na FAUS, quadro Tarsila do Amaral Fotos de Vera Lúcia Domschke, páginas 152, 153 e 154.

Monte Serrat e Centro da cidade de Santos - visita com os estudantes do $1^{\circ}$ ano Fotos de Paulo Fernando Von Poser, páginas 155, 156, 157 e 158.

Exercício II da integração horizontal no $1^{\circ}$ ano na FAUS - Fotos de Carlos Antunes, páginas 161 e 162.

Exercício III da integração horizontal no $1^{\circ}$ ano na FAUS - Fotos de Vera Lúcia Domschke, páginas 165 e 166.

Exercício IV da integração horizontal no $1^{\circ}$ ano na FAUS - Fotos de Vera Lúcia Domschke, páginas 168 e 169.

Exercício $V$ da integração horizontal no $1^{\circ}$ ano na FAUS- Fotos de Vera Lúcia Domschke, páginas 171 e 172.

Viagem ao Rio de Janeiro com os alunos do $1^{\circ}$ ano da FAUS - Fotos de Paulo Fernando von Poser, páginas 174, 175, 176, 177, 178, 179, 180, 181, 182, 183, 184 e 185.

Viagem São Luiz do Paraitinga com os alunos do $1^{\circ}$ ano da FAUS - Fotos de Nelson Trezza, páginas 185 e 186.

Paranapiacaba - visita com os estudantes do $1^{\circ}$ ano da FAUS - Fotos de Nelson Trezza, páginas 187 e 188.

Canal de Santos - visita com os estudantes da FAUS durante Semana de Arquitetura - Fotos de Paulo Fernando von Poser, páginas 189 e 190. 
Palestra com o Prof. Paulo Mendes da Rocha na FAUS - Fotos de Paulo Fernando von Poser, páginas 191 e 192.

Palestra com o Prof. Aziz Ab'Saber na FAUS - Fotos de Paulo Fernando von Poser, página 192.

Palestras com o maestro Gilberto Mendes na FAUS - Fotos de Paulo Fernando von Poser, página 193.

Exposição temporária dos trabalhos dos alunos na FAUS - Fotos de Vera Lúcia Domschke, página 193.

Exposição temporária dos trabalhos dos alunos na FAUS - Fotos de Paulo Fernando von Poser e Vera Lúcia Domschke, página 194.

Exposição final dos trabalhos dos alunos na FAUS - Fotos de Paulo Fernando von Poser, página 195 e 196.

Exposição final dos trabalhos dos alunos do $1^{\circ}$ ano na FAUS - Projeto Gráfico da exposição: Prof. ${ }^{a}$ Beá Meira, páginas 197 a 204. 